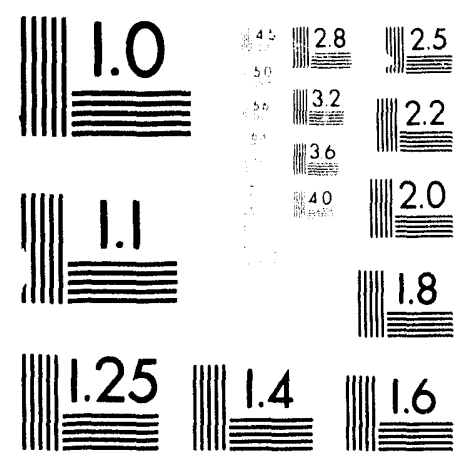



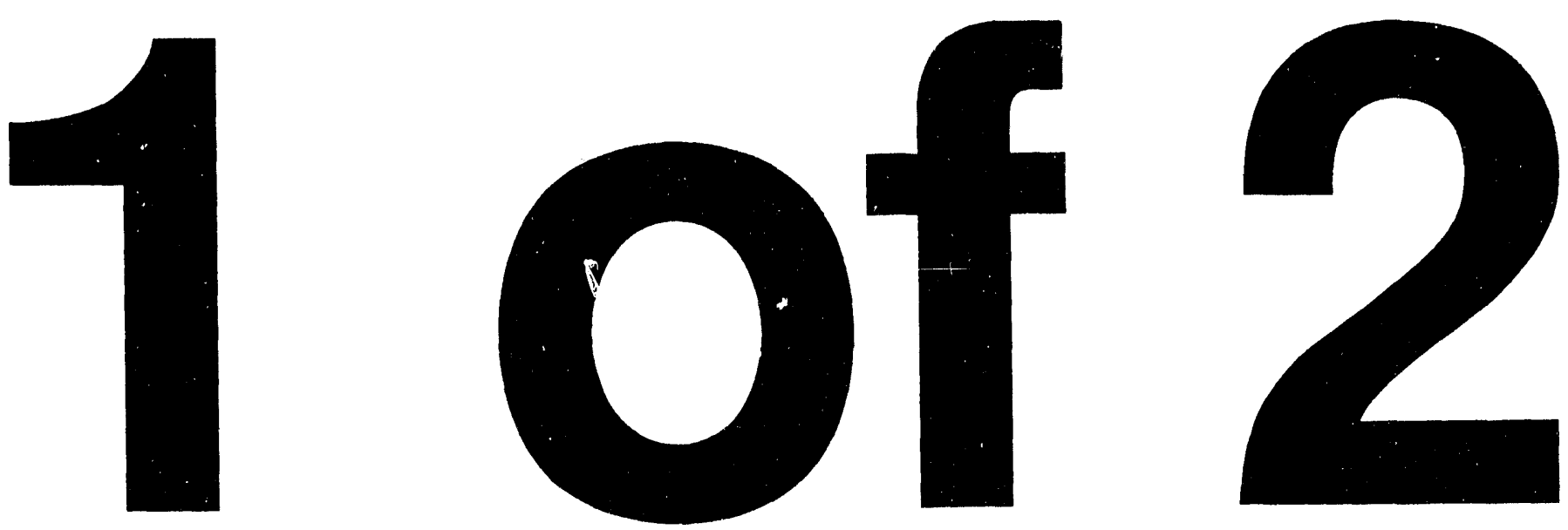


\title{
Electric Power Annual 1992
}

\author{
January 1994
}

\section{Energy Information Administration}

Office of Coal, Nuclear, Electric and Alternate Fuels

U.S. Department of Energy

Washington, DC 20585

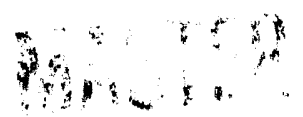




\section{Contacts}

Questions regarding the contents of this report may be directed to:

Energy Information Administration

Survey Management Division, EI-52

U.S. Department of Energy

1000) Independence Avenue, S.W.

Washington, D.C. 20585

Questions of a general nature should be directed to:

Howard Walton (202/254-55(0))

Director, Survey Management Division;

Neal Moerschel (202/254-5640)

Chief, Electric Data Systems Branch;

Fred Mayes (202/254-5300)

Chief, Renewable and Financial Data

Systems and Outreach Branch

Contributions to this report were provided by the following employees of the Survey Management Division:

Publication Coordination: Sandra R. Smith

The U.S. Eleuric Power Industry at a Glance:

John Makens; Melvin Johnson

Generating Capability at U.S. Electric Utilities:

Karen MCDaniel

Elecric Utility Net Gencration:

Melvin Johnson; Deborah Bolden
U.S. Electric Utility Fossil-Fuel Statistics:

Kenneth McClevey; Melvin Johnson;

Deborah Bolden

U.S. Electric Utility Retail Sales and Revenue:

Linda Bromley;

Stephen Calopedis

U.S. Electric Utility Financial Statistics:

Roger Sacquety

U.S. Electric Utility Environmental Statistics:

John G. Colligan; Elsie Bess

U.S. Electric Power Transactions:

John Makens

U.S. Nonutility Power Producers:

John G. Colligan; Betly Williams

U.S. Electric Utility Demand-Side Management:

Linda Bromley

Major Disturbances and Unusual Occurrences in U.S. Electric Power Systems:

Dehorah Bolden

Technical Notes: Knaub, J.R., Coordinator 


\section{Preface}

The Electric Power Annual presents a summary of electric utility statistics at national, regional and State levels. The objective of the publication is to provide industry decisionmakers, government policymakers, analysts and the general public with historical data that may be used in understanding U.S. electricity markets.

\section{Background}

The Electric Power Annual is prepared by the Survey Management Division; Office of Coal, Nuclear, Electric and Alternate Fuels; Energy Information Administration (EIA); U.S. Department of Energy. "The U.S. Electric Power Industry at a Glance" section presents a profile of the electric power industry ownership and performance, and a review of key statistics for the year. Subsequent sections present data on generating capability, including proposed capability additions; net generation; fossil-fuel statistics; retail sales; revenue; financial statistics; environmental statistics; electric power transactions; demand-side management; and nonutility power producers. In addition, the appendices provide supplemental data on major disturbances and unusual occurrences in U.S. electricity power systems. Each section contains related text and tables and refers the reader to the appropriate publication that contains more detailed data on the subject matter. Monetary values in this publication are expressed in nominal terms.

\section{Target Audience}

In the private sector, the majority of users are research. ers and analysts and ultimately the policymaking and decisionmaking members of electric utility companies. Financial and investment institutions, economic development organizations interested in new power plant construction, special interest groups, lobbyists, electric power associations, and the news media will find data in the Electric Power Annual useful.

In the public sector, users include analysts, researchers, statisticians, and other professionals engaged in regulatory, policy, and program areas for Federal, State, and local governments. The Congress and other legislative bodies may aiso be interested in general trends related to electricity at State and national levels. Much of the data in this report can be used in analytic studies to evaluate new legislation. Public service commissions and other special government groups share an interest in State-level statistics. These groups can also compare the statistics for their States with those of other jurisdictions.

\section{Coverage of Sources}

Data published in the Electric Power Annual are compiled from two statistical forms filed monthly and seven forms filed annually by electric utilities, and one form filed annually by nonutility power producers. These forms are described in detail in Appendix C, "Technical Notes,"

These firms are: the Form EIA-759, "Monthly Power Plant Report"; the Federal Energy Regulatory Commission (FERC) Form 423, "Monthly Report of Cost and Quality of Fuels for Flectric Plants": the Form EIA-861, "Annual Electric Utility Report"; the Form EIA-860, "Annual Electric Generator Report"; the FERC Form 1. "Annual Report of Major Electric Utilities, Licensees and Others"; the Form EIA-412, "Annual Report of Public Electric Utilities"; the Form EIA-767. "Steam-Electric Plant Operation and Design Report": the Form ElA-867. "Annual Nonutility Power Producer Report": the Department of Energy, Emergency Planning and Operations Form OE-411, "Coordinated Bulk Power Supply Program"; and the Department of Energy, Office of Fossil Energy. Fuels Programs, Form FE-781R, "Annual Report of International Electric Export/Impori Data." In addition. the Electric Power Annual includes data collected on the Form OE-417R. "Electric Power Sysiem Emergency Report." A brief description of each of these forms follows

The Form EIA-759 is used to collect monthly data on net generation: consumption of coal, petroleum, and gas; and end-of-the-month stocks of coal and petroleum for each plant by prime mover. Data are collected from all electric utilities that operate power plants (except those having plants solely on standby). approximately 750 of the 3,250 electric utilities in the United States.

The FERC Form 423 is a restricted census used to collect monthly data on steam-electric and combinedcycle power plants with a total generator nameplate capacity of 50 ) or more megawatts (approximately 230 electric utilities). Data collected on the FERC Form 
423 include information on fossil fuels regarding quantity, quality, delivered cost, origin, fuel type, supplier, and type of contraci under which the fuels are purchased.

The Form EIA-861 is a census of electric utilities in the United States, its territories, and Puerto Rico. The data from the Form EIA.861 contained in this publication are for the United States only. The survey is used to collect annual information on the production, sales, revenue from sales, trade of electricity, and demandside management activities from approximately 3,250 electric utilities.

The Form EIA-860 is used to collect data annually from all electric utilities in the United States that operate power plants or plan to operate a power plant within 10 years of the reporting year. The survey is used to collect data on power plant site information, generator specifications including maximum generator nameplate capacity, net summer and winter capability, heat rate, in service date, status, prime movers, energy sources, and the ownership of generators. Information on electric generators is reported by approximately 900 electric utilities.

The FERC Form 1 is an annual restricted-universe census of the major investor-owned electric utilities in the United States having, in each of the last 3 consecutive years, sales or transmission service that exceeds one of the following: (1) 1 million megawathours of total sales, (2) 100 megawathours of sales for resale, (3) 500 megawatthours of power exchanges delivered, or (4) 500 megawat thours of wheeling for others (deliveries plus losses). Financial statistics including income; taxes; depreciation and amortization; electric operating revenue; electric maintenance expenses; year-end balance sheets; and, general corporate information are reported by approximately 180 major investor-owned electric utilities.

The Form EIA-412 is a restricted-universe census used annually to collect accounting, financial, and operating data from major publicly owned electric utiities in the United States. Publicly owned electric utilities engaged in the generation, transmission, or distribution of electricity that had 120,000 megawatthours of sales to ultimate consumers and/or 120,000) megawatthours of sales for resale for the 2 previous years as reported on the Form ElA-861, "Annual Electric Utility Report," must submit the Form EIA-412. These criteria result in approximately 450 submissions from publicly owned electric utilities.

The Form EIA-767 is a restricted-universe census of power plants with an organic- or nuclear-fueled steamelectric existing or planned nameplate capacity of 10 or more megawatts. The form is used to collect data annually on plant operation and equipment design (including boiler, generator, cooling system, flue gas desulfurization units, flue gas particulate collectors, and stack data). Information regarding approximately 900 power plants on this survey is provided by 312 electric utilities.

The Form EIA-867 is a restricted-universe census used to coilect annual data from all existing and planned nonutility power producers in the United States. In 1992, the reporting threshold of the Form ElA-867 was lowered to include all facilities with a combined nameplate capacity of 1 or more megawatts. Previously data were collected every 3 years from facilities with a nameplate capacity between 1 and 5 megawatts. For the purpose of this data collection, a nonutility power producer is an enterprise that has electric generating capacity and is not an electric utility. They include qualifying cogenerators, qualifying small power producers, and other nonutility generators (including independent power producers) without a designated franchised service area. The form is used to collect data on the installed capacity, energy consumption, generation, and electric energy sales to electric utilities from approximately 2,000 facilities.

The Form OE-411 is an annual report supplied to the Department of Energy by the 10 North American Electric Reliability Councils (NERC). These reports have been compiled from data furnished by the mem. ber electric utilities. The form is used to collect information on electric utility 10 -year plans and peakload information at the NERC region level. The responsibility for collecting these data has been delegated to the Office of Emergency Planning and Operations within the Department of Energy.

The Form OE-417R is used to collect information on major electric utility system emergencies, including the type of emergency, the utility and area affected, the date and time of the event, a description of the event, and expected time of restoration of service. The responsibility for collecting these data has been delegated to the Office of Emergency Planning and Operations within the Department of Energy.

The Form FE-781R is used to collect monthly data annually from holders of Export Authorizations and Presidential Permits (subject to the authority of Part 11. Federal Power Act) engaged in the export of electric energy across the international borders of the United States with Canada and Mexico. The information coliected on the form includes the volume of energy received by and/or delivered to holders of Export Authorizations and Presidential Permits, and the costs and revenue associated with these transactions. The responsibility for collecting these data has been delegated to the Office of Fossil Energy Fuels Programs, within the Department of Energy. 


\section{Contents}

The U.S. Electric Power Industry at a Glance $\ldots \ldots \ldots \ldots \ldots \ldots$ Industry Profile

A Review of 1992

Generating Capability at U.S. Electric Utilities . . . . . . . . . . . . . . . . . . . . . . .

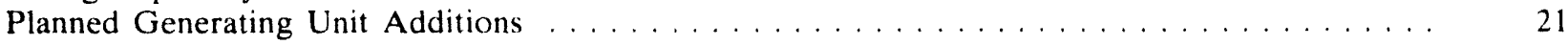

Net Generation from U.S. Electric Utilities . . . . . . . . . . . . . . . . . . . . .

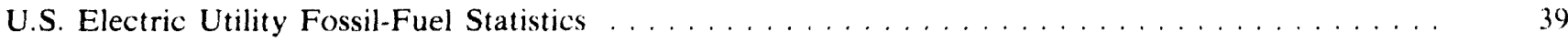

U.S. Electric Utility Retail Sales and Revenue . . . . . . . . . . . . . . . . . . . . . . 49

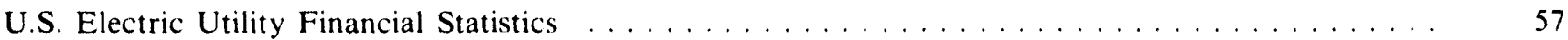

U.S. Electric Utility Environmental Statistics . . . . . . . . . . . . . . . . . . . . . 69

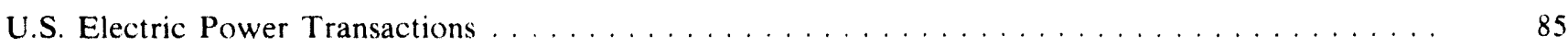

U.S. Electric Utility Demand-Side Management . . . . . . . . . . . . . . . . . . . . . . . . 101

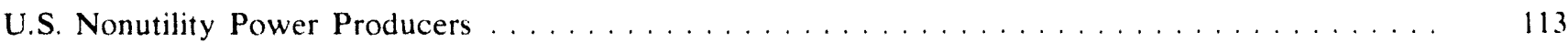

Appendices

A. Major Disturbances and Unusual Occurrences in U.S. Electric Power Systems . . . . . . . 131

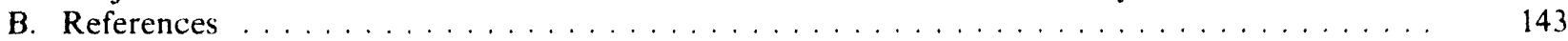

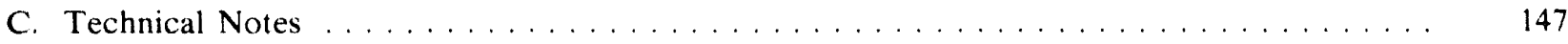

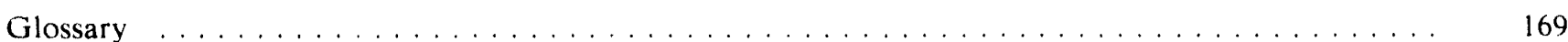




\section{Tables}

1. Electric Power Industry Summary Statistics for the United States, 1992 and $1991 \ldots 16$

2. Generating Capability at U.S. Electric Utilities by Prime Mover and Primary Fnergy

3. Summary of Capability Additions, Retirements, and Total Operable Capability at U.S. Electric Utilities by Energy Source, End of Year, $1992 \ldots \ldots \ldots \ldots \ldots \ldots$

4. Planned Capahility Additions at U.S. Flectric Utilities by Energy Source, 1993 Through

5. Generating Capability at Electric Utilities by Census $D$ vision and State, End of Year, 1992 and 1991

6. Coal-Fired, Nuclear, Hydroelectric, and Other Generating Capability at Electric Utilities by

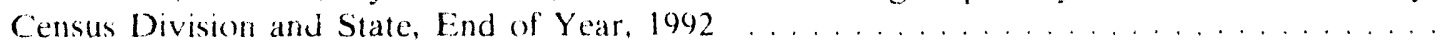

7. Petroleum-, Gas-, and Dual-Fired Steam Generating Capability at Electric Utilities by

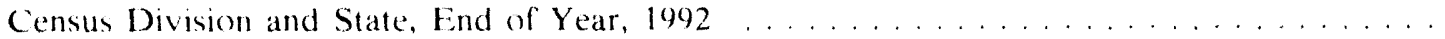

8. Petroleum-, Gas-, and Dual-Fired Gas Turbine/Internal Combustion Generating Capability at Electric: Utilities hy Census Division and State, End of Year. 1992 . . . . . . . . . . .

9. Planned Capability Additions at Electric Utilities by Energy Source, North American Electric Reliability Council Region, and Hawaii, 1993 Through $2002 \ldots \ldots$. . . . . . . . .

10. Planned Capability Additions at Electric Utilities by Energy Source, Census Division, and

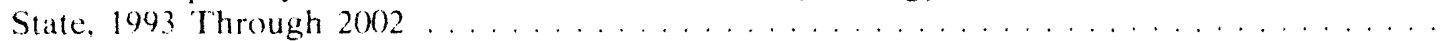

11. Net Generation from U.S. Electric Utilities hy Energy Source, 1988 Through $1992 \ldots \ldots$

12. Net Generation from Electric Utilities by Selected Prime Mover, Census Division. and State, 1992 and 1991

13. Net Generation from Electric Utilities by Energy Source, Census Division, and State, 1992 and 1991

14. Petroleum-Fired Net Generation from Electric Utilities by Selected Prime Mover, Census

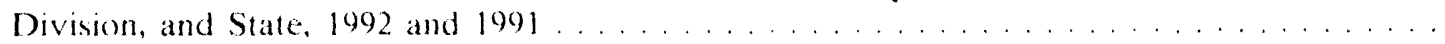

15. Gas-Fired Net Generation from Electric Utilities by Selected Prime Mover, Census

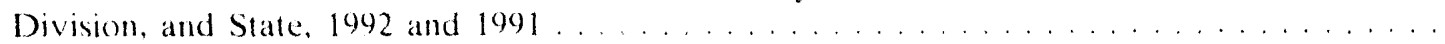

16. Consumption of Fossil Fuels and Year-End Stocks of Coal and Petroleum at U.S. Electric

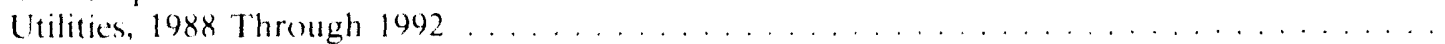

17. Receipts and Average Delivered Cost of Fossil Fuels at U.S. Electric Utilities, 1988

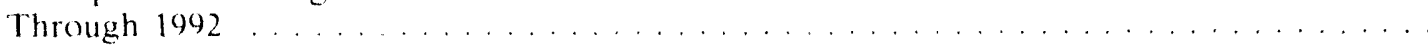

18. Consumption of Fossil Fuels at Electric Utilities by Census Division and State, 1992 and

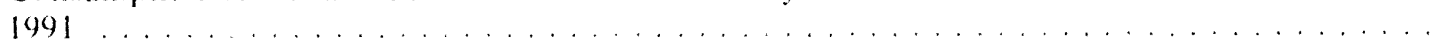

19. Petroleum Consumption at Electric Utilities by Selected Prime Mover. Census Division, and

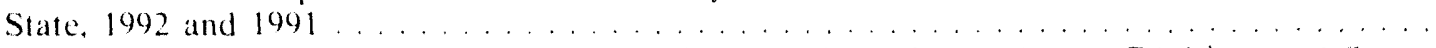

20. Cras Consumption at Electric Ltilities by Selected Prime Mover. Census Division, and State. 1992 and 1991

21. Coal and Petroleum Stocks at Electric Utilities hy Census Division and State, as of

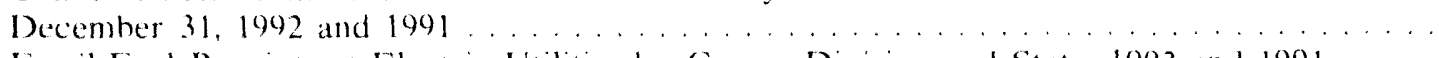

22. Fossil-Fuel Receipts at Electric Utilities by Census Division and State, 1992 and $1991 \ldots .$.

23. Average Delivered Cost of Fossil-Fuel Receipts at Electric Utilities by Census Division and

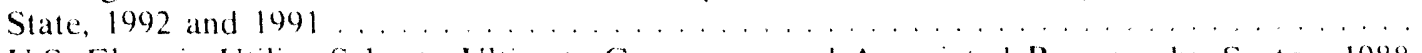

24. U.S. Flectric Utility Sales to Ultimate Consumers and Associated Revenue by Sector, 1988 Through 1992

25. Average Revenue per Kilowatthour for U.S. Electric Utilities by Sector, 1988 Through

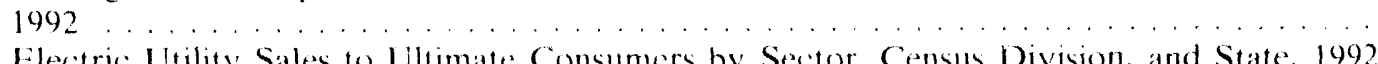

26. Electric Utility Sales to Llltimate Consumers by Sector, Census Division, and State, 1992

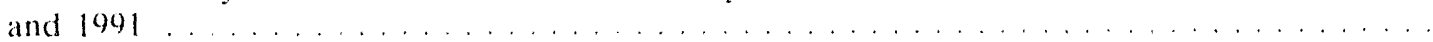

27. Number of Ultimate Consumers Served by Electric Utilities by Sector, Census Division, and State, 1992 and $199 !$

28. Revenue from Electric Utility Sales to Ultimate Consumers by Sector, Census Division, and State, 1992 and 1991

29. Average Revenue per Kilowathour for Electric Utilities by Sector, Census Division, and State, j992 and 1991

30. Composite Statement of Income for Major U.S. Investor-Owned Electric Utilities. 1988 Through 1992

Page 
31. Composite Balance Sheet for Major U.S. Investor-Owned Electric Utilities, 1988 Through 1992

32. Composite Financial Indicators for Major U.S. Investor-Owned Electric Utilities, 1988

Through 1992

33. Revenue and Expense Statistics for Major U.S. Investor-Owned Electric Utilities, 1988

Through 1992

34. Revenue and Expense Percentages for Major U.S. Investor-Owned Electric Utilities, 1988

Through 1992

35. Average Operating Expenses for Major U.S. Investor-Owned Electric Utilities, 1988

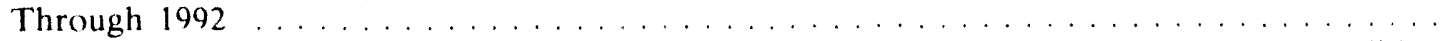

36. Composite Statement of Income for Major U.S. Publicly Owned Generator Electric Utilities, 1989 Through 1992

37. Composite Balance Sheet for Major U.S. Publicly Owned Generator Electric Utilities, 1989

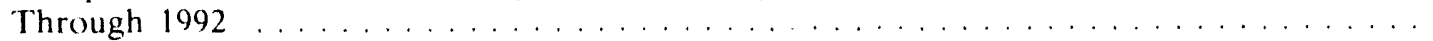

38. Composite Financial Indicators for Major U.S. Publicly Owned Generator Electric Utilities, 1989 Through 1992

39. Revenue and Expense Statistics for Major U.S. Publicly Owned Generator Electric Utilities, 1989 Through 1992

40. Composite Statement of Income for Major U.S. Publicly Owned Nongenerator Electric

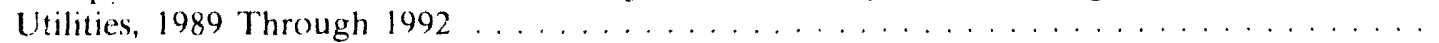

41. Composite Balance Sheet for Major U.S. Publicly Owned Nongenerator Electric Utilities, 1989 Through 1992

42. Composite Financial Indicators for Major U.S. Publicly Owned Nongenerator Electric

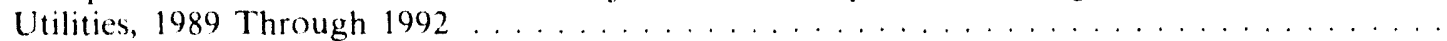

43. Revenue and Expense Statistics for Major U.S. Publicly Owned Nongenerator Electric

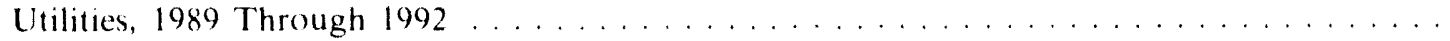

44. Estimated Emissions from Fossil-Fueled Steam-Electric Generating Units at U.S. Electric Utilities, 1988 Through 1992

45. Number and Capacity of Fossil-Fueled Steam-Electric Generators for U.S. Electric: Utility Plants with Environmental Equipment, 1988 Through $1992 \ldots \ldots \ldots \ldots$

46. Estimated Emissions from Fossil-Fueled Steam-Electric Genera:ing Units at Electric Utilities by Census Division, and State, 1992 and $1991 \ldots \ldots \ldots \ldots \ldots$

47. Estimated Emissions from Fossil-Fueled Steam-Electric Generating Units at Electric Utilities

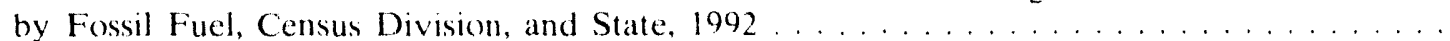

48. Number and Capacity of Coal-Fired Steam-Electric Generators for Electric Utility Plants with Environmental Equipment by Census Division and State, $1992 \ldots \ldots \ldots$

49. Number and Capacity of Petroleum-and Gas-Fired Steam-Electric Generators for Electric Utility Plants with Environmental Equipment by Census Division and State, $1992 \ldots . .$.

50. Average Quality of Fossil Fuels Burned at Electric Utilities by Census Division and State, 1992 and 1991

51. Average Flue Gas Desulfurization Costs at Electric Utilities by Census Division and State, 1988 Through 1992

52. Flue Gas Desulfurization (FGD) Capacity in Operation at U.S. Electric Utility Plants as of December 1992

53. Sources and Disposition of Electricity in the United States, 1988 Through $1992 \ldots \ldots$

54. Net Generation from Electric Utilities by North American Electric Reliability Council Region and Hawaii, 1988 Through $1992 \ldots \ldots \ldots \ldots \ldots \ldots$

55. Flectric Utility Sales to Ultimate Consumers by Sector, North American Electric Reliability

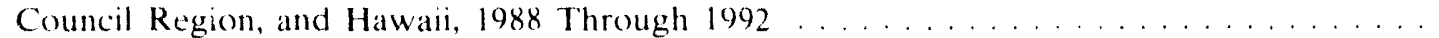

56. Generating Capability at Electric Utilities by North American Electric Reliability Council Region and Hawaii, as of December 1988 Through $1992 \ldots \ldots \ldots \ldots \ldots$

57. Noncoincidental Peak I oad at Electric Utilities by North American Electric Reliability Council Region and Hawaii, 1988 Through $1992 \ldots \ldots \ldots \ldots \ldots \ldots \ldots \ldots$

58. Electric Utility Receipts by North American Electric Reliability Council Region and

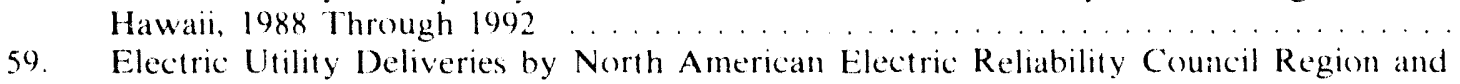

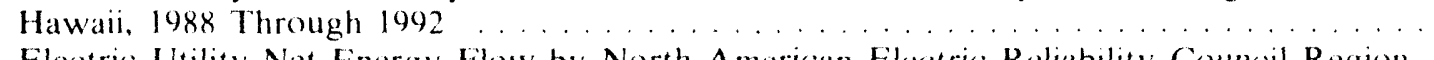

60. Electric Utility Net Energy Flow by North American Electric Reliahility Council Region and Hawaii, 1988 Through 1992

61. Electric Utility Purchases of Nonutility Generated Electricity by North American Electric Reliability Council Region and Hawaii, 1988 Through $1992 \ldots \ldots \ldots \ldots \ldots \ldots$

62. Net Imports at Electric Utilities by North American Electric Reliability Council Region and Hawaii, 1988 Through 1992 
63. Imports to Electric Utilities by North American Electric Reliability Council Region and

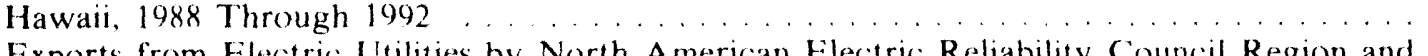

64. Exports from Electric Utilities by North American Electric Reliability Council Region and

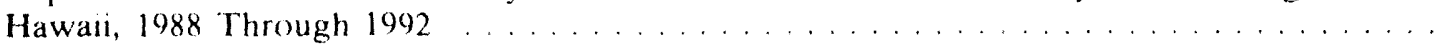

65. Annual Demand-Side Management Peakload Reductions, Energy Savings, and Cost at U.S. Electric Utilities, 1989 Through 1992

66. Annual Actual Reductions in Peak Load at Electric Utilities by Demand-Side Management Program, North American Electric Reliability Council Region, and Hawaii, 1990 Through 1992

Annual and Incremental Effects at Electric Utilities by Demand-Side Management Program,

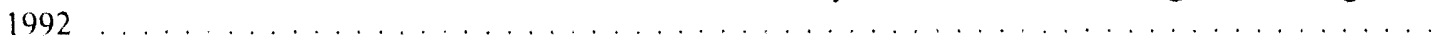

68. Annual and Incremental Effects at Electric Utilities by Sector, $1992 \ldots \ldots \ldots \ldots$

69. Annual Potential Peakload Reduction at Electric Utilities by Direct Load Control, Interruptible íoad, North American Electric Reliability Council Region, and Hawaii, Se-

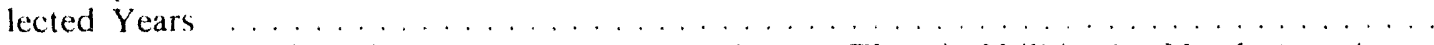

70. Annual Demand-Side Management Energy Savings at Electric Utilities by North American Electric Reliability Council Region and Hawaii, Selected Years . . . . . . . . . . . . . . . .

71. Demand-Side Management Utility Cost at Electric Utilities by North American Electric Reliability Council Region and Hawaii, Selected Years . . . . . . . . . . . . . . .

72. Direct and Indirect Utility Cost at Electric Utilities by Demand-Side Management Program,

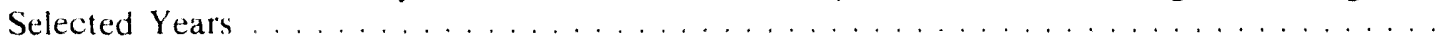

73. Number of Electric Utilities Having Different Energy Efficiency End Uses and Program Types by Sector $1992 \ldots \ldots \ldots \ldots \ldots \ldots \ldots \ldots \ldots$

74. Summary Statistics for U.S. Nonutility Power Producers, 1989 Through $1992 \ldots \ldots$

75. Installed Capacity at Nonutility Generating Facilities by Fossil Fuels, Renewable Energy Sources, and Census Division, 1989 Through $1992 \ldots \ldots \ldots \ldots \ldots \ldots$

76. Installed Capacity at Nonutility Generating Facilities by Energy Source and Census Divi-

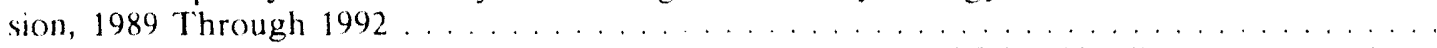

77. Installed Capacity at Nonutility Generating Facilities by Qualifying Facility Status and Census Division, 1989 Through 1992

78. Instalied Capacity at Nonutility Generating Facilities by Major Industry Group and Census

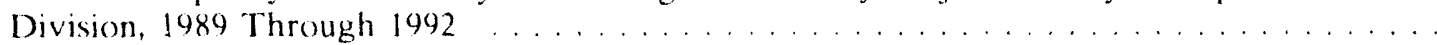

79. Gross Generation for Nonutility Power Producers by Energy Source and Census Division,

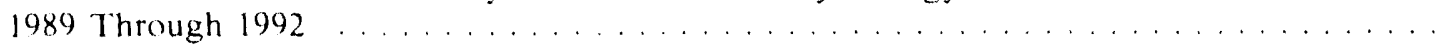

80. Gross Generation at Nonutility Generating Facilities by Qualifying Facility Status and Cen-

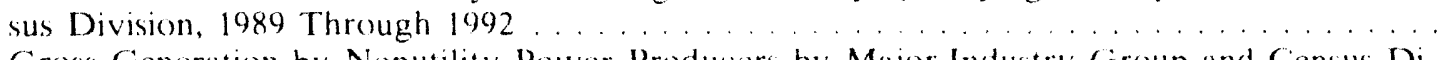

81. Gross Generation by Nonutility Power Producers by Major Industry Group and Census Di-

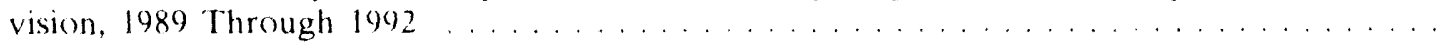

82. Nonutility Electricity Supply and Disposition for Facilities by Census Division and State, 1992

83. Estimated Emissions from Nonutility Power Producers Facilities by Census Division, 1989

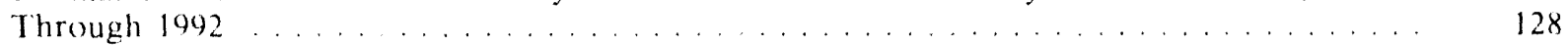

A 1. Major Disturbances and Unusual Occurrences in U.S. Electric Power Systems, $1992 \ldots 132$

C1. Sulfur Dioxide, Nitrogen Oxide, and Carbon Dioxide Emission Factors . . . . . . . . . 164

C2. Carbon Dioxide Emission Factors For Coal by Rank and State of Origin . . . . . . . . 160

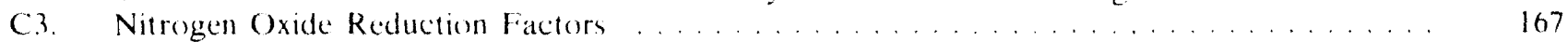

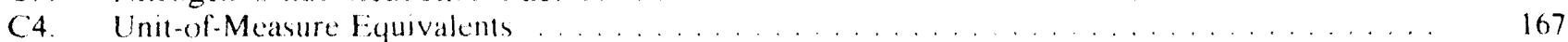




\section{Illustrations}

Page

1. Generating Capability at U.S. Electric Utilities by Class of Ownership, $1992 \ldots \ldots . . . .$.

2. U.S. Electric Utility Net Generation by Class of Ownership, $1992 \ldots \ldots \ldots \ldots$

3. U.S. Electric Utility Sales to Ultimate Consumers by Class of Ownership, 1992 . . . . . . .

4. Number of U.S. Electric Utilities by Class of Ownership, $1992 \ldots \ldots \ldots$

5. Number of Ultimate Consumers Served by U.S. Electric Utilities by Class of Ownership,

6. Revenue from U.S. Electric Utility Sales to Ultimate Consumers by Class of Ownership,

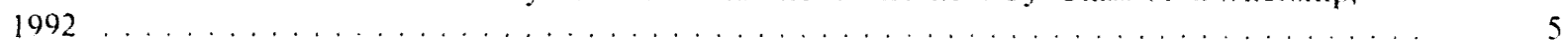

7. U.S. Electric Utility Sales for Resale by Class of Ownership, $1992 \ldots \ldots \ldots$

8. Revenue from U.S. Electric Utility Sales for Resale by Class of Ownership, $1992 \ldots \ldots$

9. U.S. Electric Utility Sales to Ultimate Consumers by Sector, $1992 \ldots \ldots \ldots 12$

10. U.S. Electric Utility Average Revenue per Kilowathour by Sector, $1992 \ldots \ldots \ldots$

11. U.S. Electric Utility Net Generation by Energy Source, $1992 \ldots \ldots \ldots$

12. Monthly U.S. Electric Utility Net Generation, 1992 and $1991 \ldots \ldots$

13. Generating Capability at U.S. Electric Utilities by Energy Source, $1992 \ldots \ldots \ldots$

14. Installed Capacity at U.S. Nonutility Generating Facilities by Type of Facility, 1992 . . . .

15. Planned Capacity Additions for U.S. Nonutility Generating Facilities by Energy Source, as

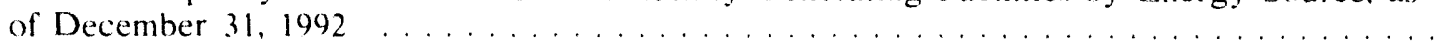

16. Allocation of the Revenue Dollar from Electric Operations for Major U.S. Investor-Owned

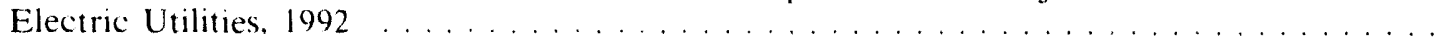

17. Electric Operating Expenses for Major U.S. Investor-Owned Electric Utilities, 1992 ....

18. Average Operating Expenses of Fossil-Fueled and Nuclear Steam-Electric Plants for Major U.S. Investor-Owned Electric Utilities, 1992

19. North American Electric Reliability Council Regions for the Contiguous United States and Alaska. 


\section{The U.S. Electric Power Industry at a Glance}

The first section of this chapter provides a graphically illustrated profile of the electric power industry in the United States. The second section summarizes pertinent statistics on various aspects of the U.S. electric power industry for the year.

\section{Industry Profile}

The U S. electric power industry is a combination of traditional and nontraditional electricity-producing companies. For the purpose of this report, the traditional electric utility industry is comprised of investorowned, publicly owned, Federal, and cooperative electric utilities. The Public Utilities Regulatory Policies Act (PURPA) of 1978 and the continued deregulation of the industry have lead to the emergence of nontraditional electricity producing companies or nonutility power producers. ${ }^{1}$

Investor-Owned Electric Utilities. Investor-owned electric utilities currently account for more than 75 percent of all U.S. electric utility generating c'apability, generation, sales, and revenue. Like all private businesses, the fundamental objective of an investor-owned utility is to produce a return for investors. The investorowned electric utility either distributes its profits to stockholders as dividends or reinvests these profits. It is granted a service monopoly in certain geographic areas and is obliged to serve all consumers. As franchised monopolies, these electric utilities are regulated and required to charge reasonable prices, to charge comparable prices to similar classifications of consumers, and to give consumers access to services under similar conditions. Most investor-owned electric utilities are operating companies that provide basic services for the generation, transmission, and distribution of electricity. The majority of investor-owned electric utilities perform all three functions. Investor-owned electric utilities operate in all States except Nebraska.
The electric utilities in Nebraska consist primarily of municipal systems and public power districts.

Publicly Owned Electric Utilities. Publicly owned electric utilities in the United States are nonprofit local government agencies established to serve their communities and nearby consumers at cost, returning excess funds to the consumer in the form of community contributions, economic and efficient facilities, and lower rates. Publicly owned electric utilities (which number approximately 2,000$)$ include municipals, public power districts, State authorities, irrigation districts, and other State organizations. Most municipal electric utilities simply distribute power, although some larger ones produce and transmit electricity as well. They obtain their financing from municipal treasuries and from revenue bonds secured by proceeds from the sale of electricity. Public power districts and projects are concentrated in Nebraska, Washington, Oregon, Arizona, and California. Voters in a public power district elect commissioners or directors to govern the district, independent of any municipal government. State authorities, like the Power Authority of the State of New York or the South Carolina Public Service Authority, are agencies of their respective State governments. Irrigation districts may have still other forms of organization. In the Salt River Project Agricultural Improvement and Power District in Arizona, for example, votes for the Board of Directors are apportioned according to the size of landholdings.

U.S. Federal Electric Utilities. Power produced by U.S. Federal electric utilities is not generated for profit. As required by law, preference in purchasing the electricity produced is given to publicly owned and cooperative electric utilities and to other nonprofit entities. The Federal Government is primarily a producer and wholesaler of electricity. These wholesale producers include the U.S. Army Corps of Engineers, the U.S. Bureau of Indian Affairs, the U.S. Bureau of Reclamation, the International Water and Boundary $\mathrm{Com}$ mission, and the U.S. Department of Energy. Electric-

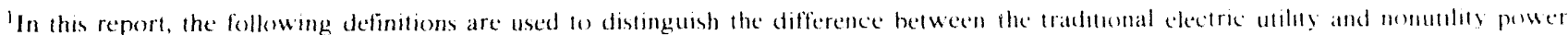
producer: An electric utility is any person, corporation, municupality. State political subdivision or ageney, irrigation project. lederal puwer administration, or other legal entity that is primarily engaged in the retail or wholesale sale, exchange. and/or transmisston of electric energy A legal entity selling electric energy produced at a yualifying facility (QF) under the Public Utility Regulatory Policoes ACl (PLRPA) M not an electric utility, but is a nonutility power producer. A nonutility power producer is any person. corporation. municipality. State pellitial subdivision or agency. Federal agency, or other legal entity that either: (1) produces electric energy at a gualifying facilty ((2) under the Public Utility Regulatory Policies Act (PURPA), or (2) produces electric energy but is primatrily engaged in business actistices other than the sale of electric energy, such as agriculture, minng, manufacturing, transportation, or education
} 
ity generated by these wholesale producers is marketed by Federal power marketing administrations: Bonneville, Southeastern, Southwestern, and Western Area. The power marketing administrations of the $U$. S. Department of Energy operate in all States except those in the Northeast, upper Midwest, and Hawail. In addition to the four major power marketing administrations, the Alaska Power Administration operates and distributes power from its own projects. The Tennessee Valley Authority is the largest Federal power producer and it markets electricity in both the wholesale and retail markets.

Cooperative Electric Utilities. Cooperative electric utilities in the United States are owned by their members and are established to provide electricity to those members. The Rural Electrification Administration, U.S. Department of Agriculture, was established under the Rural Electrification Act of 1936 with the purpose of extending electric service to small rural communities (usually under 1,500 customers) and farms where it was more expensive to provide service. They are incorporated under State law and are usually directed by an elected board of directors, which in turn selects a manager. Qualifying through the Rural Electrification Administration, the National Rural Utilities Cooperative Finance Corporation, the Federal Financing Bank, and the Bank for Cooperatives are the most important sources of debt financing for cooperatives. There are approximately 950 cooperative electric utilities in the United States, currently doing business in 47 States. Cooperative electric utilities do not operate in Connecticut, Hawaii, Rhode Island, or in the District of Columbia.

\section{U.S. Nonutility Power Producers}

U.S. nonutility power producers are comprised of cogenerators and small power producers, which qualify under PURPA (these facilities are generally referred to as qualifying facilities (QF's)), and other nonutility generators (including independent power producers) without a designated franchise service area. QF's receive certain benefits under PURPA. See the chapter on "Nonutility Power Producers" for a description of these benefits. Cogenerators are generating facilities that produce electricity and another form of useful thermal energy (such as heat or steam) for industrial, commercial, heating, or cooling purposes. To receive status as a QF under PURPA, the facility must produce electric energy and another form of useful thermal energy through the sequential use of energy, and meet certain ownership, operating, and efficiency criteria established by the Federal Energy Regulatory Commission (FERC). The FERC is responsible for the implementation of PURPA. Under PURPA, a small power producer generates electricity using biomass (waste), renewable resources (water, wind, and solar), or geothermal energy as a primary energy source. Fossil fuels can be used, but renewable resources must provide at least 75 percent of the total energy input.

Independent power producers (IPP) in the United States are wholesale electricity producers, other than $Q F^{\prime}$ 's under PURPA, that are unaffiliated with franchised utilities in the area in which the IPP's are selling power and that lack significant marketing power. Unlike traditional electric utilities, IPP's do not possess transmission facilities and do not sell power in any retail service territory where they have a franchise. An IPP is an entity that is not a QF.

A new class of IPP's--exempt wholesale generators (EWGs)--was established by the Energy Policy Act of 1992. This Act modified the Public Utility Holding Company Act (PUHCA) to create this new class of IPP's by exempting them from the corporate and geographic restrictions that PUHCA imposes. Public utility holding companies are allowed to own interests in IPP facilities and can form corporate subsidiaries to develop and operate independent power projects anywhere in the world. ${ }^{2}$

\section{Presentation of Data}

The following graphic presentation (Figures 1 through 8 ) on the U.S. electric utility industry by class of ownership includes: generating capability; net generation and sales of electricity; the number of utilities, generators, and ultimate consumers; and the revenue from the sale of electricity. These data are collected and compiled from various sources as indicated in the Preface. Data on generating capability and net generation of electricity are presented for all electric utilities that produce power in the United States; data on electricity sales and revenue include all electric utilities that have retail sales in the United States. 
Figure 1. Generating Capability at U.S. Electric Utilities by Class of Ownership, 1992

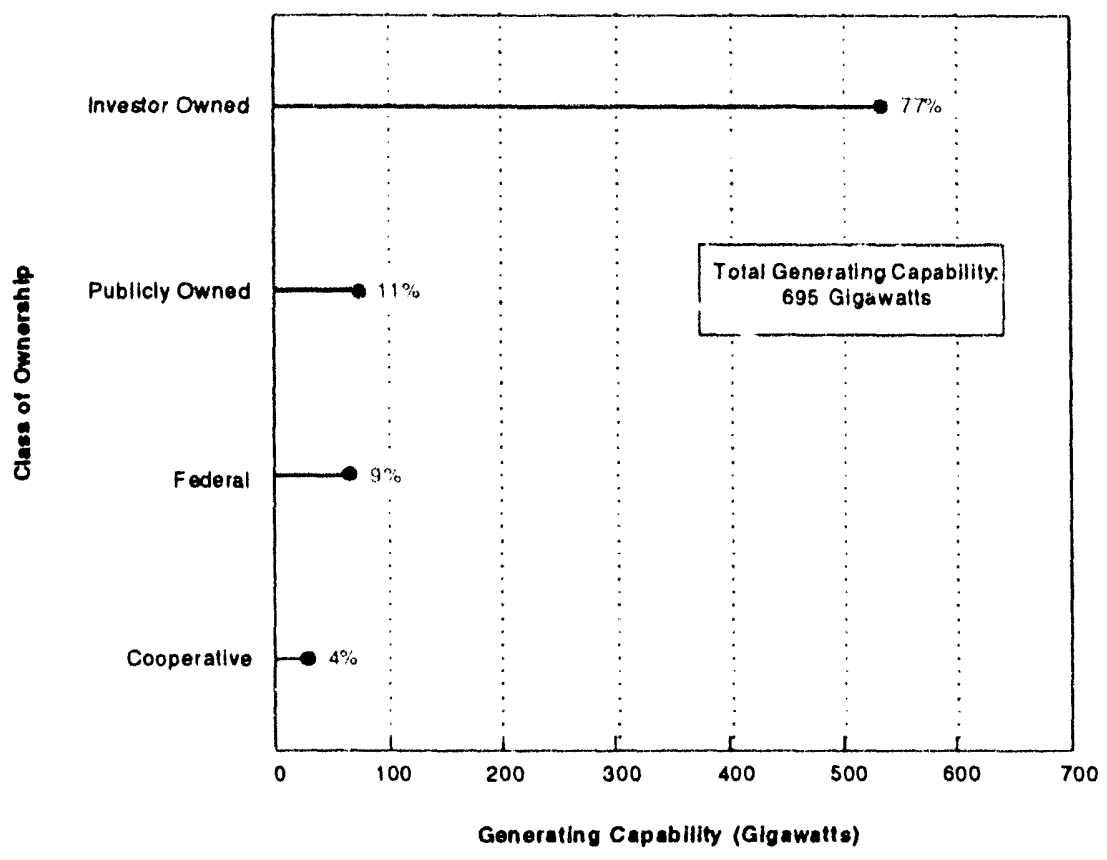

Notes: -Generating capability is net summer capability. Data are final - Totals may not equal sum of components because of iridependent rounding.

Sources: Energy Information Administration, •Capability: Form ElA-860, "Annual Electric Generator Report." •Ownership: Form ElA-861, "Annual Electric Utility Report."

Figure 2. U.S. Electric Utility Net Generation by Class of Ownership, 1992

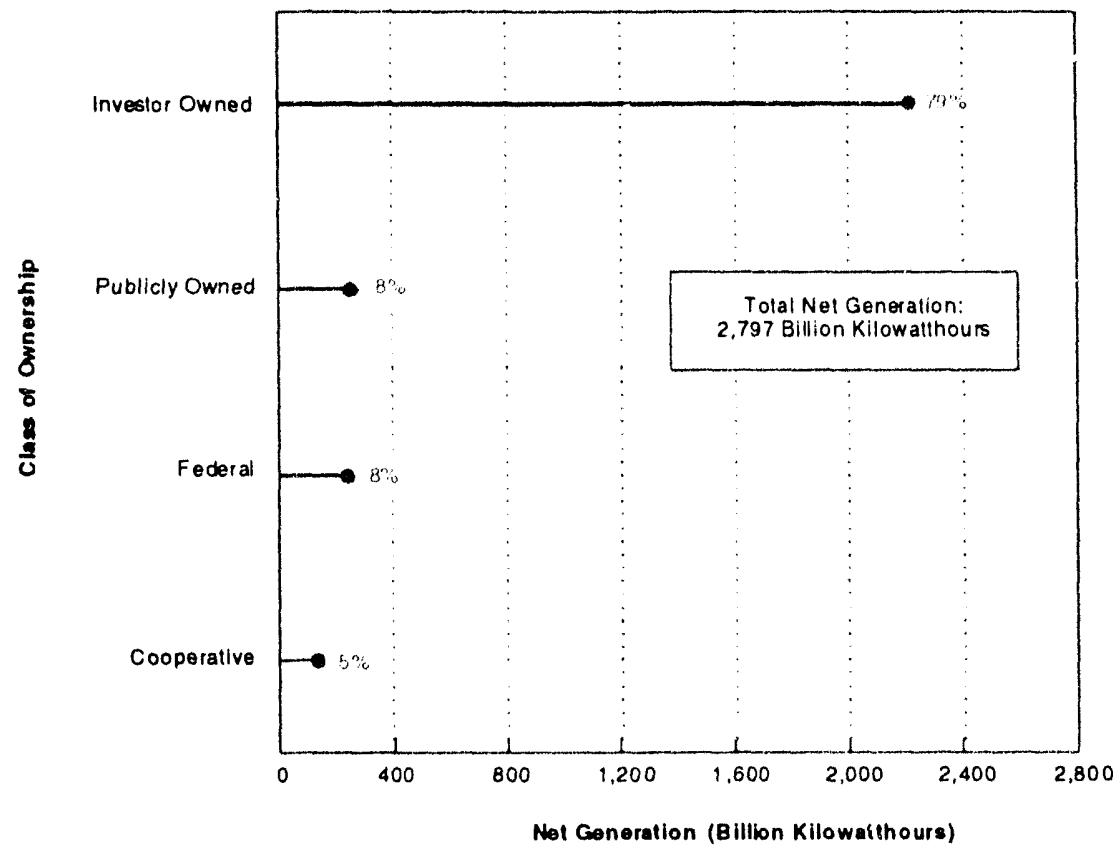

Notes: -Data are final. - Totals may not equal sum of components because of independent rounding.

Source: Energy Information Administration, •Generation: Form EIA-759, "Monthly Power Plant Report." Ownership: Form ElA. 861, "Annual Electric Utility Report." 
Figure 3. U.S. Electric Utility Sales to Ultimate Consumers by Class of Ownership, 1992

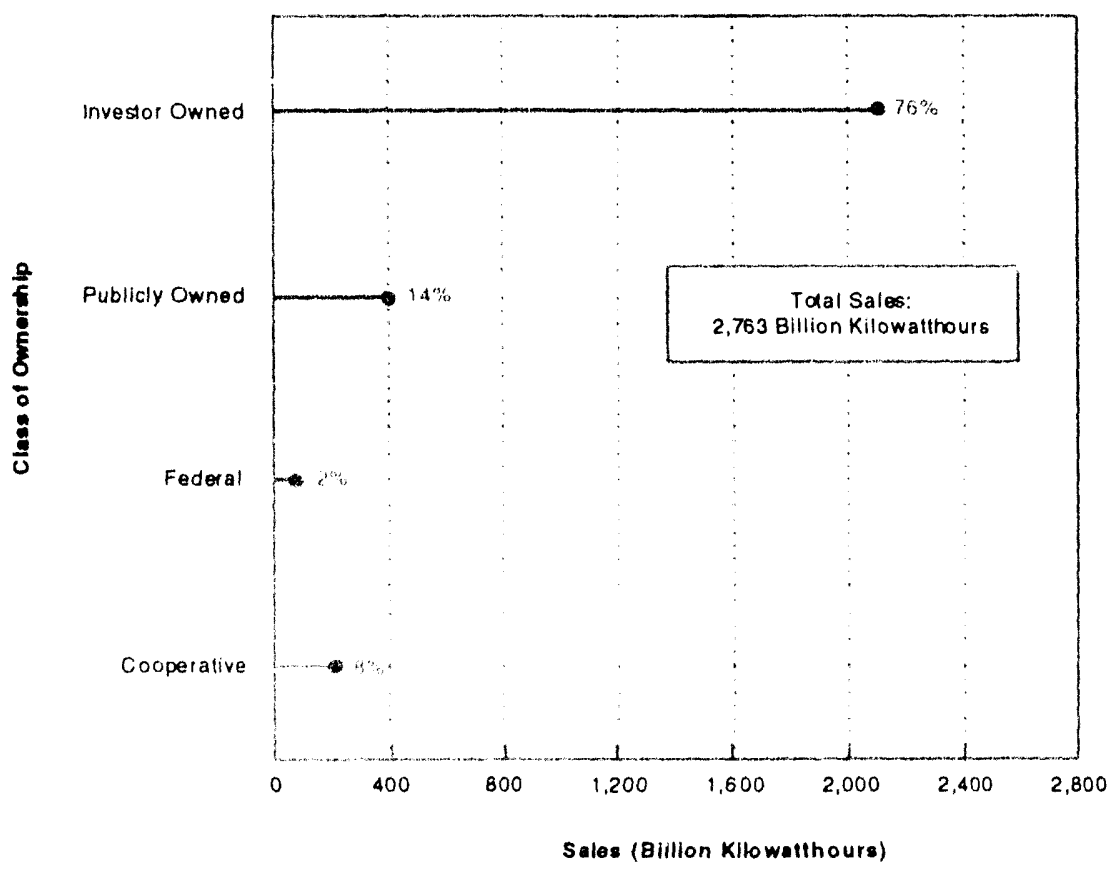

Notes: -Data are preliminary. - Totals may not equal sum of components because of independent rounding. Sources: Energy Information Administration, Form ElA-861, "Annual Electric Utility Report."

Figure 4. Number of U.S. Electric Utilities by Class of Ownership, 1992

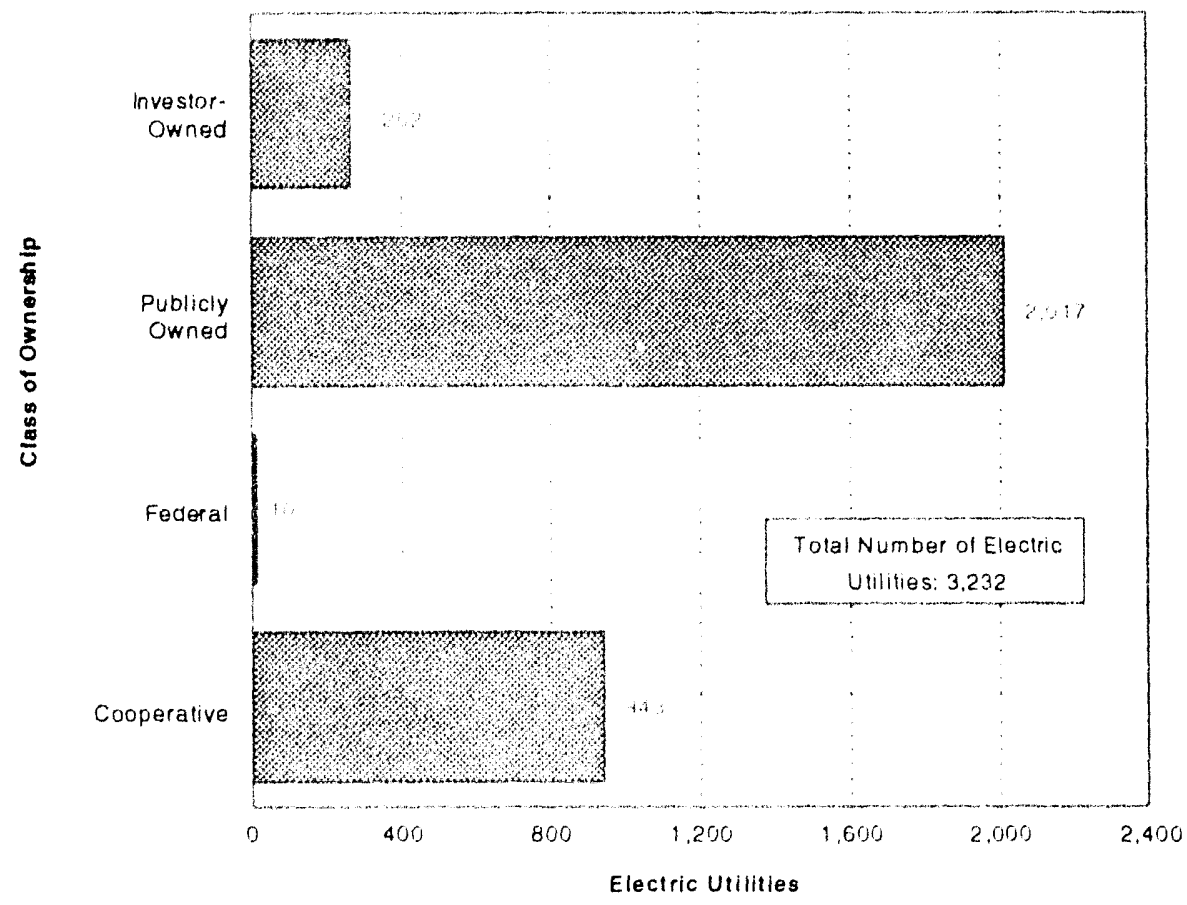

Notes: -Data are preliminary.

Source: Energy Information Administration, Form E|A-861, "Annual Electric Utility Report." 
Figure 5. Number of Ultimate Consumers Served by U.S. Electric Utilities by Class of Ownership, 1992

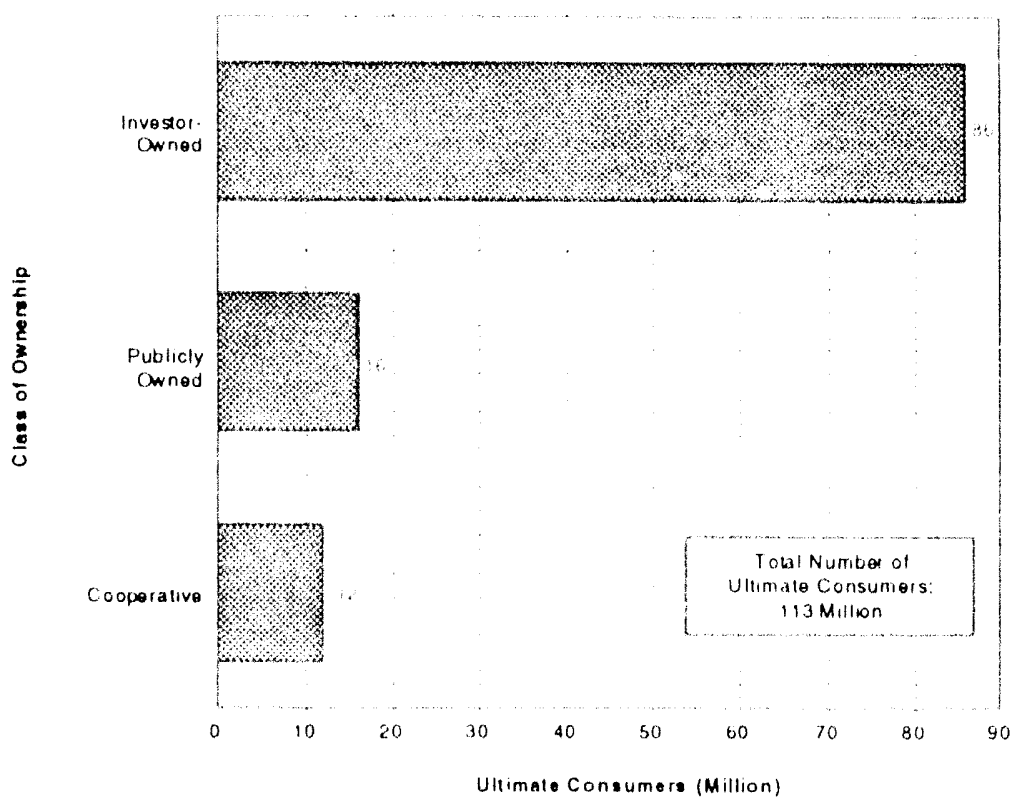

Notes: -Data are preliminary. - The number of ultimate consumers served by Federal electric utilities is less than 1 million. $\cdot$ The number of ultimate consumers is an average of the number of consumers at the close of each month. $\cdot$ Totals may not equal sum of components because of independent rounding.

Source: Energy Information Administration, Form ElA-861. "Annual Electric Utility Report."

Figure 6. Revenue from U.S. Electric Utility Sales to Ultimate Consumers by Class of Ownership, 1992

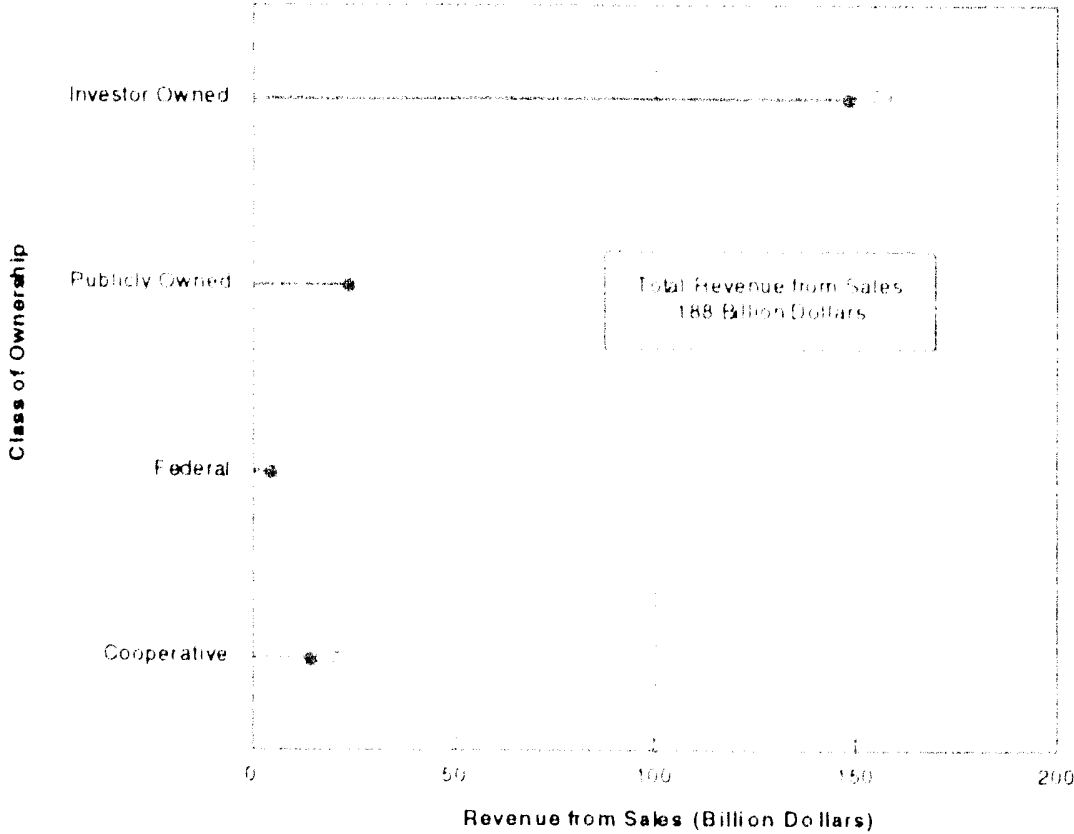

Notes: -Data are preliminary. - Totals may not equal sum of components because of independent rounding.

Source: Energy Information Administration, Form ElA-861. "Annual Electric Utility Report." 
Figure 7. U.S. Electric Utility Sales for Resale by Class of Ownership, 1992

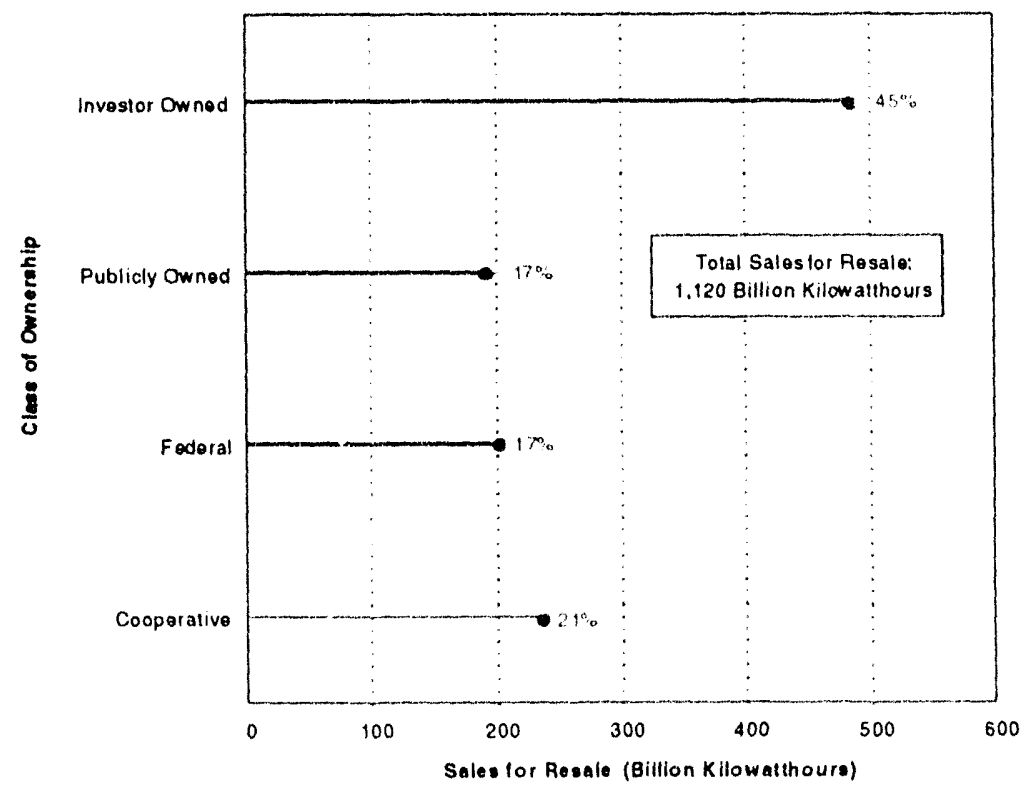

Notes: -Data are preliminary. - Totals may not equal sum of components because of independent rounding. Source: Energy Information Administration. Form EIA-861, "Annual Electric Utility Report."

Figure 8. Revenue from U.S. Electric Utility Sales for Resale by Class of Ownership, 1992

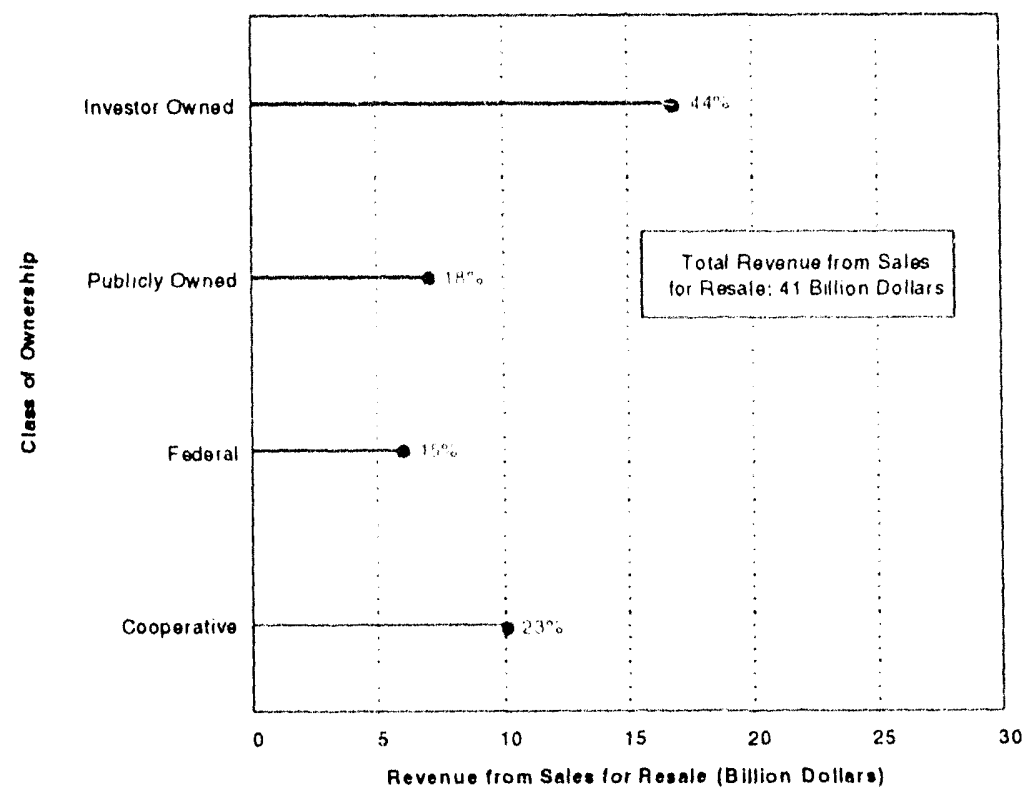

Notes: -Data are preliminary. - Totals may not equal sum of components because of independent rounding. Source: Energy Information Administration, Form EIA-861, "Annual Electric Utility Report." 


\section{A Review of 1992}

This section includes a graphic presentation as a supplement to the text. Various statistics related to the U.S. electric power industry by sector, energy source, or facility type are provided in Figures 9 through 15 following the text.

\section{Renewable Energy Resources}

Section 171 of Public Law 102-486, the Energy Policy Act of 1992, requires the Administrator of the Energy Information Administration to annually collect and publish the results of a survey of electricity production from domestic renewable energy resources. This requirement includes reporting data on electricity production in kilowatthours, total installed capacity, and measures of production efficiency such as capacity factor that distinguish the results between various renewable energy resources. The information described in this section on "Renew ble Energy Resources" and in Table 1, "Electric Power Industry Summary Statistics in the United States, 1992 and 1991," represents the information required by Section 171 of the Act More disaggregated information may be found in other tables in this publication.

In 1992, generation from renewable energy sources accounted for about 11 percent $(329,230$ million kilowatthours) of the electric power industry's production of electricity (Table 1). ${ }^{4}$ Conventional hydroelectric generation accounts for the greatest share $(96$ percent) of the electric utilities' generation from renewable sources. Generation from biomass accounts for the greatest share $(71$ percent) of nonutility generation from renewable sources.

Electric Utilities. Exclusive of conventional hydroelectric power, generation from renewable sources accounted for 0.4 percent of total electric utility generation in 1992. Electric utilities generated 8,104 million kilowathours from geothermal steam; 2,093 million kilowatthours from biomass; and 3 million kilowatthours from photovoltaic. The capacity factors for electric utility geothermal and biomass plants were
53 percent and 51 percent, respectively, in 1992." Photovoltaic plants had a capacity factor of about 12 percent. The efficiency ${ }^{\dagger}$ for biomass plants averaged 26 percent, or about 13,000 Btu per kilowatthour. ' In contrast, the efficiency of fossil-fueled electric utility boilers is approximately 33 percent.

Exclusive of hydroelectric capability, the net summer capability at electicic utility plants that used renewables as primary energy sources totaled 2,207 megawatts, as of year-end 1992. This represents 0.3 percent of total electric utility generating capacity. In contrast, nonutility capacity that used renewable energy sources was 13,249 megawatts (excluding conventional hydroelectric plants) or 23 percent of total nonutility generating capacity.

Nonutility. Nonutility generation from renewable sources accounted for 25 percent of total nonutility generation. ${ }^{8}$ In 1992, nonutilities generated 53,607 million kilowathours from biomass; 9,446 million kilowatthours from water (conventional hydroelectric); 8,578 million kilowatthours from geothermal steam; 2,916 million kilowathours from wind; 743 million kilowat thours from solar thermal plants and 4 million kilowatthours from photovoltaic plants. The capacity factor for geothermal plants averaged 78 percent in 1992; 62 percent for biomass plants; 40 percent for conventional hydroelectric plants; 23 percent for solar thermal plants; 18 percent for wind-powered plants; and 7 percent for photovoltaic plants. The average efficiency of all biomass plants operated by nonutilities was approximately 11 percent or 30,000 Btu per kilowatthour. Some nonutility biomass plants produce steam for industrial processes in addition to generating electricity. The calculated efficiency for these plants is misleadingly low because only electric output is used in the computation. The overall efficiency of cogenerator plants is generally good but difficult to calculate because the proportion of industrial steam to electricity varies greatly. For biomass plants that produce only electricity, average efficiency is about 17 percent or $20,000 \mathrm{Btu}$ per kilowatthour.

The total installed capacity of nonutility power producers' plants that used renewable sources was 15,933 megawatts (including 2,684 megawatts of conventional hydroelectric capacity) as of year-end 1992 .

\footnotetext{
${ }^{3}$ Renewahle energy sources include hydroelectric (conventional), geothermal, biomass (wood, wood waste, peat, wood liquors, railroad lies, pitch, wood sludge, municipal solid waste, agricultural waste, straw, tires, landfill gases, fish oils, and other waste), wind, solar thermal, and photovoltaic.

${ }^{4}$ All electric utilities net generation and gross generation of nomutility power producers with an installed capacity of 1 or more megawatts. The ratio of the electrical energy produced by a generating unit for the period of tome considered to the electrical energy that could have been produced at continuous full-power operation during the same period.

SThe capacity factor is the ratio of the average load on the plant(s) for a considered period of time to the aggregate capacity of the plant(s).

${ }^{6}$ Efficiency is calculated using the rato, if energy consumed to energy produced. Information to calculate efficiency is only available for combustible fuels

${ }^{7}$ Plants that consumed 50 or more percent biomass fuels based on Btu input.

${ }^{x}$ Nonutility power producers with an installed electric generating capacity of 1 or more megawatts.
} 


\section{U.S. Electric Utility Statistics}

Sales. U.S. sales of electricity to ultimate consumers in 1992 reached 2,763 billion kilowatthours. nearly unchanged from 1991 sales of 2,762 billion kilowatthours (Table 1). Sales of electricity were higher than in 1991 in the industrial sector by 3 percent. Sales were less in other end-use sectors--residential by 2 percent, commercial and other sales by 1 percent. Average revenue per kilowathour of electricity sold to ultimate consumers in 1992 was 6.8 cents, an increase of 0.1 cents from the 1991 level.

Generation. In 1992, total U.S. generation by electric utilities (2,797 billion kilowatlhours) was I percent lower than in 1991. This was the first time in 10 years that a decline from the previous year for net generation levels was reported. Nonetheless, generation of electricity from nuclear power achieved a record level of 619 billion kilow atthours, an increase of 1 percent from 1991. A slight'y improved capacity factor of $70.9 \mathrm{per}$ cent, con pared with 70.2 percent in 1991 , contributed to this growth in nuclear-powered generation."

The sharpest decline (20) percent) in generation in 1992 accured for petroleum-fired units. During the year. petroleum-fired plants generated 89 hillion kilowatthours, 23 hillion kilowatthours below the amount reported during 1991. The second largest decline in generation (13 percent) was reported for hy. droclectric plants. Hydroclectric generation fell to the second lowest level in 10 years. Drought conditions over the past several years, primarily in the Pacific Northwest and in California, comtributed to this de cline.

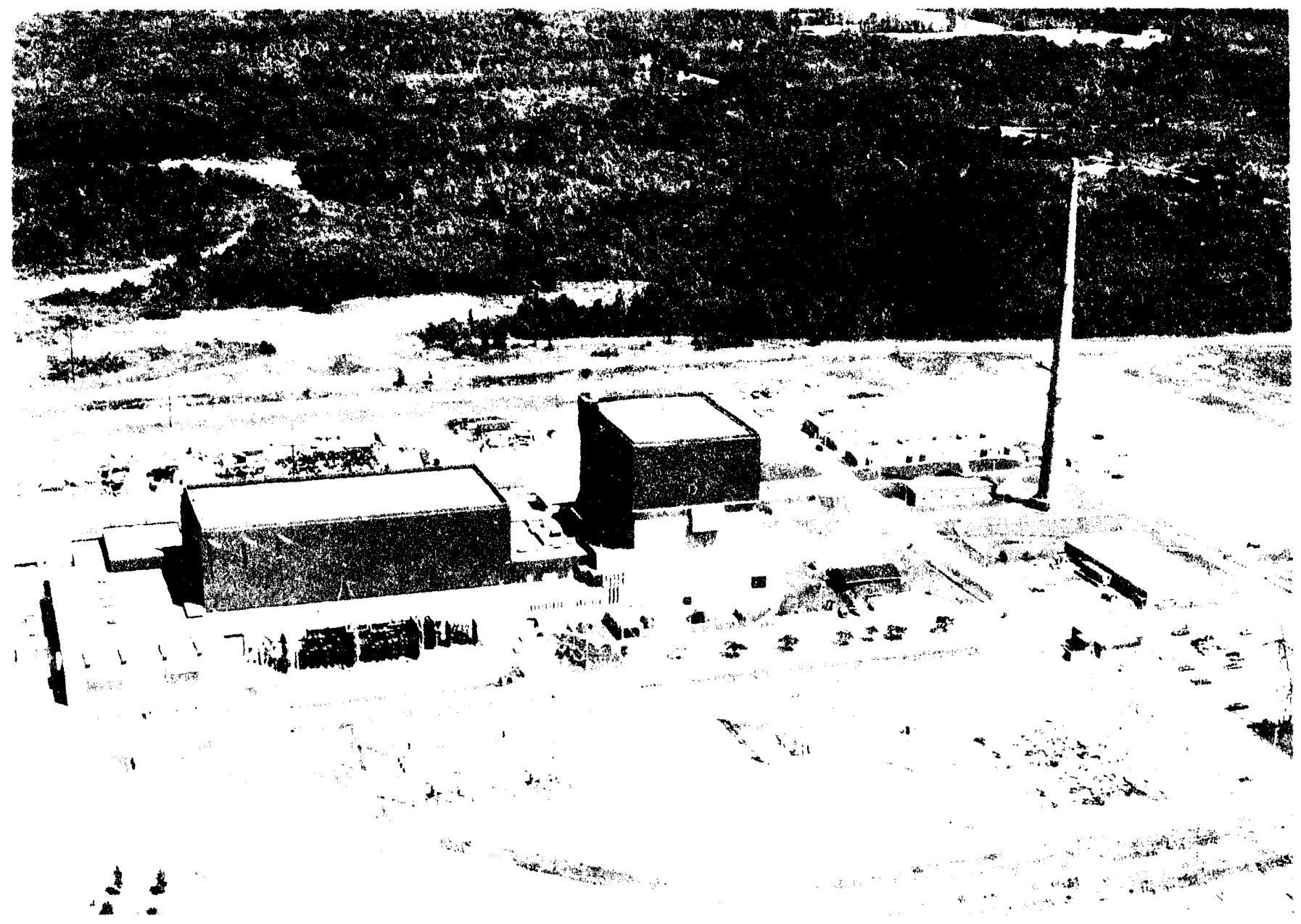

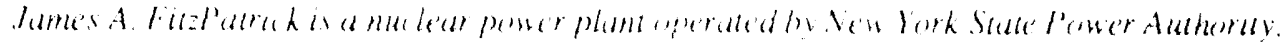


The reduction in 1492 electric utility net generation from the 1991 level represents the first national drop since 1982. "However, electricity sales did not decline in 1992 from 1991 sales as was the case in 1982. The level of electric utility generation in 1992 was substi. tated by monutility power production and demand-side management initatives

Fossil-Fuel Receipts and costs. A number of factors appear to have had a motable effect on the volume of receipts and the cost of fossil fuch delivered to elecetric: utilities during 1992. Varbations in anmual weather conditions had substantial effects on electroc utility fued purchases. In 1992, a drought in the western Unted States, Hurricane Andrew in the South, and mild winfer and summer temperatures throughout much of the Nation played a major role in determining elecerte utility fuel requirements for 1992

The average cost of all fossil fuels delivered to clectre utilities" in 1992 was $\$ 1.59$ per million Btu, the howest average annual ens since 1978. " Fuel oil was the mom expensive at $\$ 2.55$ per million Btu; natural gas was seeond at $\$ 2.33$ per millom Btu: and coal wat the leatst expensive at $\$ 1.4$ per million But The average eose of eoal decreased 80.04 per million 310 in 1992: fuel ofl was unchanged: and natural gas increased 80.18 per million Ban. However, since coal accomented for 82 per. cent of the total Btu comtent of fossil fuels detereded (1) clectric uthlities in 1992. Hhe overall average cost

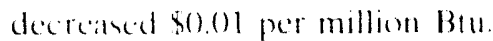

- Coal. Abundant supplies of colal, which were available or electric utilities in 1992, contributed to depressed eoal prices the aterage delinered

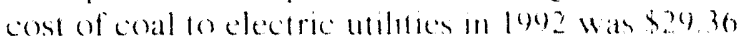
per short on. This was a 2 -pereent alcerease from the $\$ 30.02$ per short ton reported in legl and the lowest aterage cost of conal delicered lo clectere

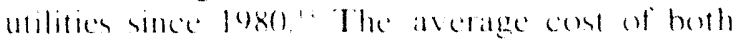
contract and spot-market conal delivered to ches. tric utilites decreased in 1902. The average cost of contrace coal decreased by $\$ 0.60$ per shem lon to $\$ 29.84$ per short tom. The average cost of spet market coal dropped 80 . 38 pere short ton to a level af $\$ 26.64$ per short tom. This is the lowest aterage amnual cost for coal purchased in the spent-market and delivered to electro molities smee 1977.4 As has been the case since 1985 . the average delivered cost of enal purchased under contract wan higher than that for coal purchased in the spentmathel (\$29.89 versus $\$ 26.64$ per shorr fons). This indicates an excess supply of coal and an expectation of a continued decline in the eost of coal Auting at dectins in the average cost of eod is the lave that electric utalities follow strategies that will reduce their fuel costs. With spot market costs $\$ 3.25$ per shont ton less, on atverage, than the average cost of contract coal, clectric utilities will often minimize their contract receipts and opt for spot market purchases. Some electric utilities have found 11 ecommicat to pay a fee to "buy out" oldet contracts and increase purchases under newer, less-expensive contracts. Also, the cost of coal under some contrats is adjusted annually aceording tochanges an conal-related indices, while some contracts are periodically upen for renegothation. Since the overall cost of eoal has been decreasing for the past several years, remegotiation of eomtraces of index-related adjustments usually result in a reduction in the cost of coal. In addition, several electric utilities have heen able to reduce the cost of transporting the coal to the plath enther hy renegotiation of contracts or by increasme competition among the carriers

In the western linted States a continume drought reduced hydrockectric generation. An increase in coal fired gencratom in the region appears to have made up for the shortfall. This was most signifi. cant in comlohuming 10 an annual increase in coal receipts of o mollion short toms 10776 million short toms

- Petroleum. The petroléum marker was relatively stable during 1992. No affer-effects of the Persan Ciulf complict of 1 't are readily apparent in the data suhmiled for clectric utility fuel purchases during 1902. The average cost of pelockem prod.

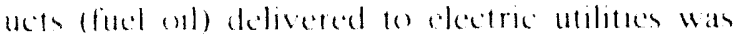
$\$ 16.15$ per harrel $1 \$ 2.55$ per million B101. an in-

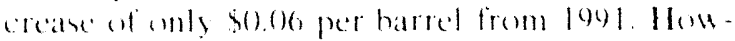

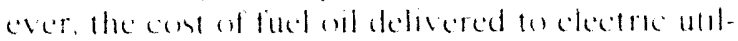
stee did mereare rather shatply mel-sear, in tan dem whlh the cost of natural gas Recepts of fied al al clectre: unlition tolated $14+4$ million tarrels. a decrease 1120 mollow batrek from ley the

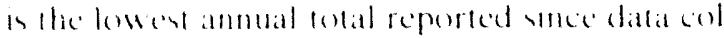

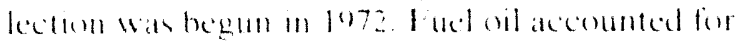

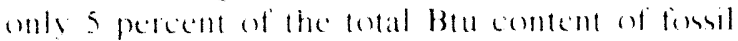

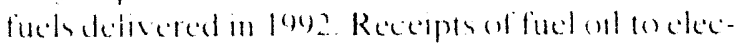
trie molites peated at 6.36 million barrek in 1977. and have sime decreared to a pount that only at feu clectre milities, located promarily in Florida, New York. and Massathusetls, are heavily dependeme on the fued for electre gencratam

- Gas. The natural gas markets appeared lobe some. "lat less stable than the petroleum mathels dar-

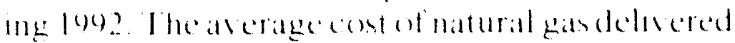

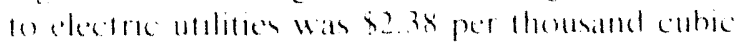

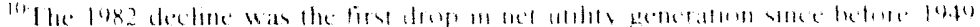

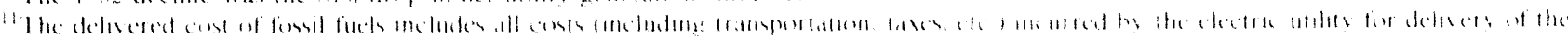
fitce to the platut

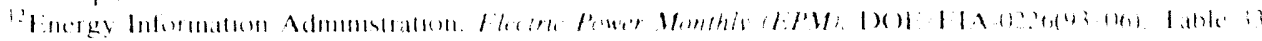

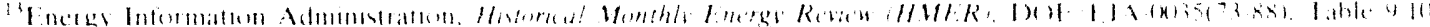

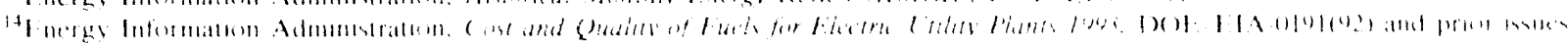


feet $(\$ 2.33$ per million Btu), an incre se of 8 percent from 1991. The lowest average monthly cost of natural gas delivered to electric utilities was $\$ 2.01$ per thousand cubic feet (Mcf) reported in March. However, by Octoher the average cost of natural gas had increased to $\$ 3.05$ per Mcf." Several factors have been noted as contributing to this price increase including "shut-in" wells (wells where production has been stopped) due lo low prices, Organization of Petroleum Exporting Countries (OPEC'S) reduction in production of heavier crudes, which compete with natural gas, and Hurricane Andrew, which "blew away" an estimated 5 percent of the gas-producing wells in the Gulf of Mexico. ${ }^{16}$

Receipts of natural gas at electric utilities totaled 2,638 billion cubic feet ( $B C f$ ), nearly unchanged from the 2,631 Bci reported in 1991. Monthly receipts of natural gas peaked in July at 316 Bef as electric utilities increased purchases of natural gas under interruptible contracts. Receipts were low. est in January and February, 160) Bce each."

Capability. At the end of 1992 , electric utility generating capability in the United States totaled 695.059 megawatts. This capability inciuded 3.341 megawatts of newly added capability. The newly added capability in 1992 was 8 percent less than the newly added capability in 1991. " Cass-fired capability accounted for 5.3 percent of the capability that entered service in 1992 Hydroelectric capability additions represented ti percent: coal-fired capability additions accounted for 15 percent; and petroleum-fired capability additoms represented 14 percent. No new nuclear units started operation in 1992.

U.S. electric utilities, at the end of 1992 , included 27,898 megawalls of gas-fired capahility additions in their 10-year plans." of this 27,898 megawatls of planned gas-fired capability addtions, 2,185 megawalts is combined-cycle steam capability using waste heat produced from gas-fired gas lurbines. Gas-fired capability additions during the next 10 years will be primarily in simple-cycle gas turbines and gas turbines operating as combined-eycle units. (jas lurbines have relatively short construction times, and can be brought on line quickly, at a relatively low cose. These planned gas-fired units are expected to serve the peak and intermediate kads of electric utilities.

Emissions. In 1992, emissions from electric utilities' fossilfueled steam plants used for the generation of electricity in the finited states were estimated to be: sulfur dioxide $\left.(\mathrm{SO})_{2}\right), 15$ million tons; nitrogen oxides $\left(\mathrm{NO} \mathrm{O}_{x}\right), 8$ million tons; and carbon dioxide, $\left(\mathrm{CO}_{2}\right)$, 1,859 million toms."

Financial Status. In 1992, electric utility op. 'sating revenues ( $\$ 169.5$ billion) for major U.S. investorowned electric utilities were up a modest 1.6 percent: however, net income ( $\$ 18.4$ billion) showed a gain of 8.5 percent from 1991. Operating income decreased $\$ 0.3$ billion due to increases in other operating and maintenance expenses, depreciation, and taxes other than income laxes. This decrease in operating income, howeve., was offet by a decline in fuel expenses and income taxes. Flectric operating expense's (\$139.0 billion) increased by 2.3 percent

Other inconte and expenses, as well extraordinary items after taxes, were affected negatively due to after tax write offs and regulat., ry rate decisions directly related to the treatment of nuclear plants. Earnings available to common stock increased by $\$ 1.3$ billion or 8.9 per. cent. Dividends paid to owners of common stock declined 1091.1 pereent in 1992, compared with 96.2 percemt in 1991, hased on dividends declared during the vear. Earnings available per average common share were $\$ 2.61$, reversing the 1991 decline of $\$ .13$ to $\$ 2.53$.

In 1492, investment in the major U.S. investor-owned segment of the industry increased by $\$ 18.8$ billion. ( )f that increase, net utility plant accounted for $\$ 10.1$ hillion. Construction wo,k in progress (CW Wl') was $\$ 20.6$ billion, an increase of 14.2 percent. This reversed the downward trend that resulted from a number of remaining nuclear plants being completed and, therefore. reclassified from ('Wh' inte plant in service. The fotal asset furmover ratio (operating revenues divided by total assets) remained steady at 0.37

Total capilalization of $\$ 356.0$ billon increased by 2.1 pereent from ly91. The ration of long-term debt to total capitalization stood at 48.9 , essentially unchanged from the previous year.

In 1902. clectric utility uperating revente $1 \$ 21.7$ hillion) for the major publicly owned generator electric utilities grew by 2.9 percent. Generator electric utility operating expenses increased by 1.8 percent, resulting in an increase in net income ( $\$ 1.0$ billion) of 28.0 percent. Total assets for gencerator clectric utilities increased 3.8 percent to $\$ 106.9$ billion. For the major publicly ouned nomgenerator clectric utilitices, clectro utility operating revenue $(\$ 7.2$ hillion) grew by 1.8 pereent. Nongenerator electric utility operating expenses decreased less than $\$ 1$ billion to end the year at $\$ 6.8$

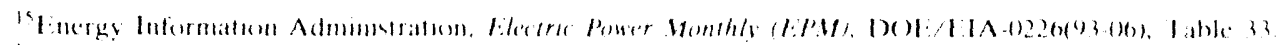

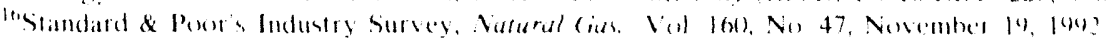

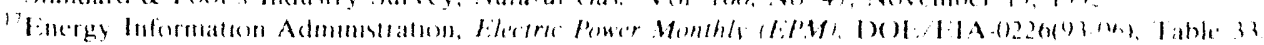

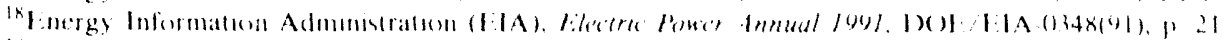

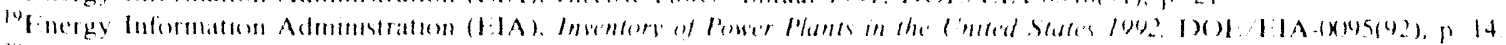

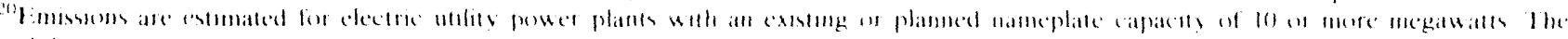

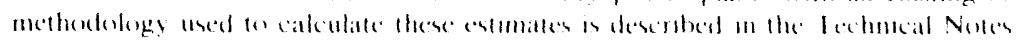


billion. Net income for nongenerators was $\$ 0.3$ billion, up 34.5 percent. Total assets for nongenerator clectric utilities increased by 4.3 percent (1) end the year at $\$ 9.4$ billion.

Demand-Side Management. In 1902, energy savings and peakload reductions resulting from demand-side management programs were reported by 905 electric utilities. Of these, $5(14$ were classified as large utilities. an increase of 41 utilities over 1991.21 These large utilities estimated that they achicved reductions in their annual peak loads of 17,657 megawalts in 1992. compared to 16.7 .39 megawatts in 1991. In 1992, their potential, contractually available peakload reduction was 25,005 megawats. Energy efficiency probrams accounted for 45 percent of actual peakload reduction in 1992. Direct load control and interruptible load programs accounted for 42 percent of actual peakload reductions and 89 percent of potential peakload reductions. Energy savings increased from 23.343 million kilowatthours in 1991 10 31.767 million kilowatthours in 1992. Eighty percent of energy savings resulted from energy efficiency programs. Total utility cost increased 28 percent from 1.7 hillion dollars to 2.2 billion dollars::

large atilities in the Southeastern and Western United States agaton led all DSM program activities by a wide margin. Among the North American Ficetric Relahility Council (NERC) reguons, the Southwestern Electric Reliability council (SE:RC) and the Western Systems Coordinating Council (WSC C) accounted for 56 percent of total actual peakload reductoms and 67 per. cent of total energy savings. St:RC "s large amount of energy savings was due to the inclusion of Tennessese Valley Authority. whose large encrgy efficiency program accounted for 24 percent of the regunds enerey savmgs, and has the largest amoumt of total actual peakload reductoms due to Carolma Power and I ight. which consider cogencration a part of their DSM pro. gram. The WSCC and Northeast Power Cordonalling Council (NPCC) accounted for 50 percent of total I)SM expenditures.

The residental sector aceounded for 41 pereent of energy savmgs, and 43 pereent of actual peakload reduce. tions. The industral secent accounted for the largest pereent of the polential peakloal reductioms (5) pere cent). (of the $9(05$ electric utilites with os M programs. 412 reported energy effictelley programs in the rest. dential sector. 268 in the commercial sector, and 189 in the industrial sectine (Table 73).

In 199?, energy savings are expected to increase 28 percent over 1992 levels 1040.816 million kilowatthours, potential peakload reductions are projected to increase nearly 10 percent 1027,478 megawatts, and total utility cost is projected to increase 25 percent 102.8 billion dollars. Between 1993 and 1997. DSM savings and cost are expected to continue to grow linergy savings are projected to increase at an annual rate of 16 percent to $72,78.3$ million kilowathours, potential peakload reductoms are expected 10 increase at an anmual rate of 5 percent to 33,344 megawalts and utility costs are projected to inerease 163.8 billon dollats in 1997

\section{U.S. Nonutility Power Producer Statistics}

Generation. In 1992, 1.5. momutility power producers with facilitics having an installed capacity of 1 or more megawatts (previously the cutoff was 5 or more megawatls) generated 290 billon kilowathours of electricily. Receipte from clectric utilities and nonutilities totaled 8.3 hillion kilowatthours. Nonutility power prodecere delivered 175 billion kilowatthours or approxmately 60 percent of theor gross generation and used $2(14$ billon kilowatthours at these facilities for operating power plants and for industral processing. The highess kevel of nomutiliey production of electricity accurred II Califormat and Texas, with 59 and 52 hillion kilowatthours, respectively. For Califorma (comparing facelitice of 5 or more megawatts), this was a 9 -percent increase aver 1091.

(irose gencration for nomutility power producers (with an installed capally of 5 or more megawalls) in 1992 was 17 percent higher than a year carler slightly more than half of the generation by nonutility power producers was gastired, whth generatom from wored and wable accounting for 18 percent of the total. (of the lotal momulatity generation, 241 billion kllowatthours were from qualifying facilities, four limes the quantity from nonqualifying facolities. Isee the Chapter on "Nomuthlity Pener Producers" for a definitom of the se ficilites). The largest shate of gross generation was produced by fitcilities in the $W$ est south (entral (emsus Dovisom, followed by the Pasilic

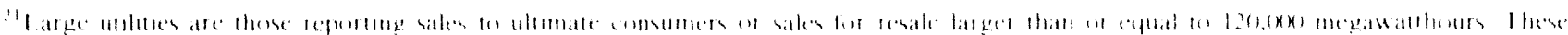

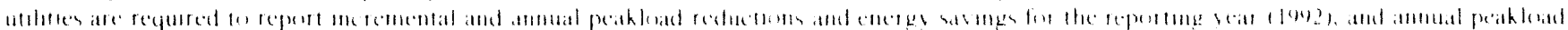

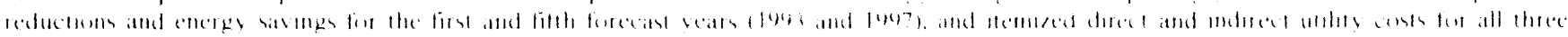

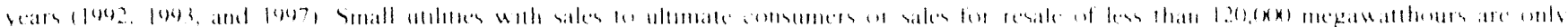

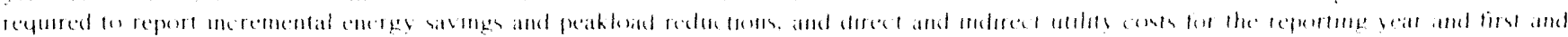
lifth fintecast reats

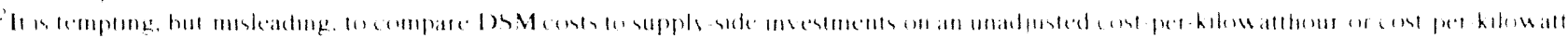

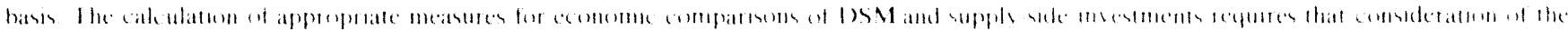

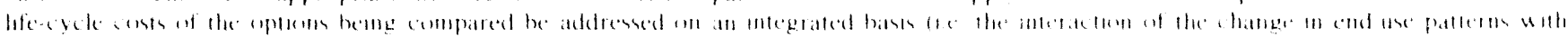

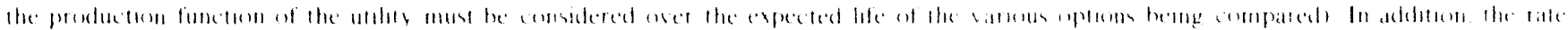

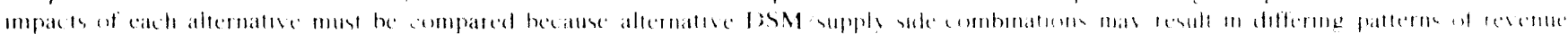

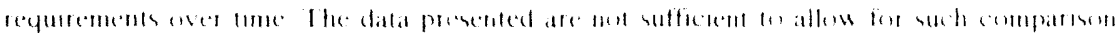


Census Diviston. The manufacturing sector deminates electricity generatom and is concentrated in the West South Central and Sorth Allantic Cemsm Divisums where there is a large petential for cogeneration an the refiming and paper and pulp industries, respectively

Capacity. The total installed capacity of moncultity power producers with an imstalled capacity of 1 or more megawatls in the Unted Stales was $56, \times 14$ megawatts at the end of log2. The installed capacity for facelites of 5 or more megawats increased by 15 percent from 1001 . Nomulility capactly for farcilles of : megawall and less than 5 megawalts was 1.651 mega-

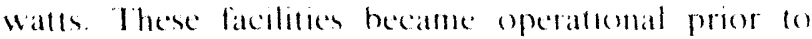
1992, hut due to the volatility of the inclustry and lack of standardied naming comentioms, they were not identified proor to 1892 Nomuldity capacoly in 1992 was equis aleme to 8 pereent of the traditomal U. S elece tric utility installed capatony

Natural gas was the fued most used by nomutilities of allenergy senurees. gas aceounfed for the latgest amount (21,542 megawates) of monuthly capacity. The West

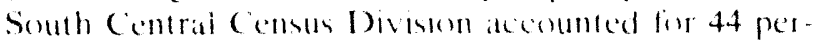
cent of that gastired caparety. The recond largest share of monotiley capacily was provided by petro. leum, followed by word and waske. The bagest wolume of petroleum capacity (2.07) megawalls) was localled in the Middle Allathle Cemus Division. (ogenteration accoume for 73 percent of montutile capacily $162 \mathrm{per}$. cont qualifying facility capacity and 11 percent nomqualifying facility capacily). Small power producers and independent porter producers accoum for 15 and 12 percent, renpectively of monutility capactey

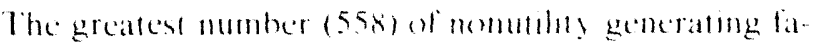

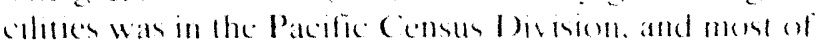
the capacty (12.848 megawatls) Wath alde in the Pacifie

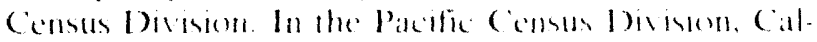
forma deminated became the State acturely promoted

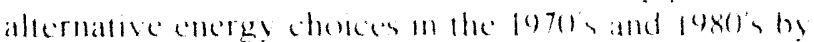

provideng incentives to montraditomal electricity producers. Many of these incentives have since expired or have been rescinded, but lhey served to assist in the development of nommility generation. In the West south Contral Comses Dovison, Texas dominated mamly hecause of the large potental for cogeneration in the petroleum refining industry, where thermal and electric bate requirements are collocated

Nomutilities gencrally install generator facilities with manmal regulatory requirements which result in consterably less lead time fe finance and build as compared to electrite utility lacilates As a result, momutilities gencrally plan for 3 years whle clectre utilities requarements make a lo-year period more appropriate Capacily additions planned through 1905 by U.S nomumilites lotal 17.686 megawatts, compared with 15.198 megawatts (gentrator nameplate capacity) planned for the same periond by U.S. electric utilities. However, electric holities have planned 52,774 mega walts (generator nameplate capacity) in capacity addilions for the lo-year period, 1993-200)2. Of the nomuthly planned capacily, 60) pereent is petroleum and/or Eas-fired. Coal-fired capacely represents approsumately 21 pereent of the ofal planned monutility addilioms

Fmissions. Air emmstome from monutility facilities of I megawatl or more were 1,210 thousand toms of $S()_{2}$. 1,259 thousand tons of $N()_{2}$, and $549,8.32$ thousand toms of $\mathrm{CO})_{2}$. Vor tacilutes of 5 or more megawalts. estimated S( ) emissiom were 1.201 thousand short lons, an 8-percent increase from log). The estimates of 1992 emissioms in the linged States for $\mathrm{NO})_{1}$ and $\mathrm{CO}_{2}$ were 1.234 thensand short fom and 540.189 thousand short toms.

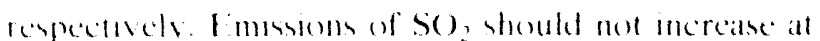
the same ralle is $N()_{\text {, and }}(0)$ ? emossions, because

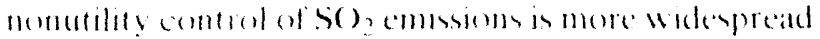

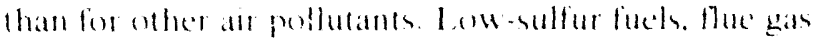
desulfurization, and mustied bed combustan are the

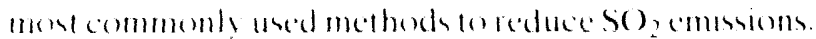

\section{Figure 9. U.S. Electric Utility Sales to Ultimate Consumers by Sector, 1992}

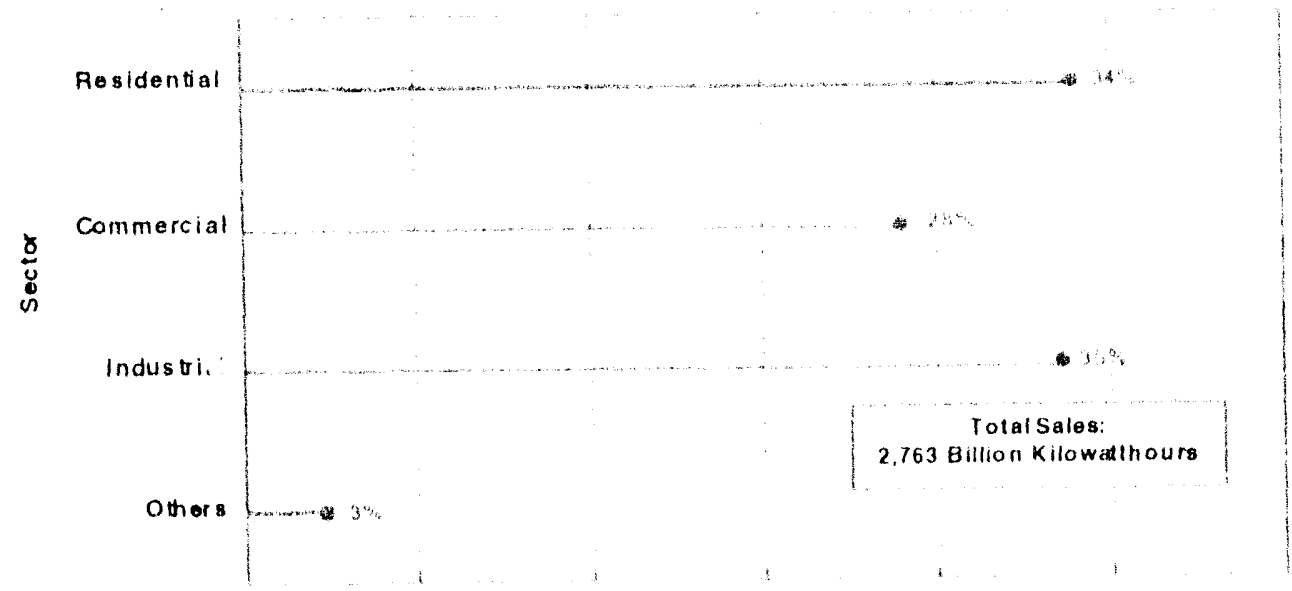

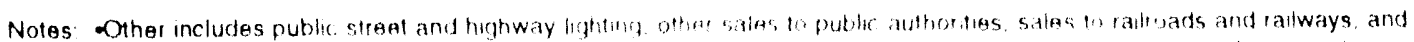

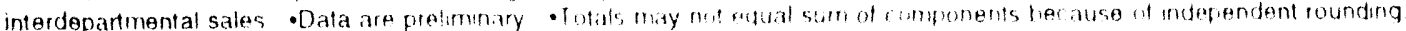

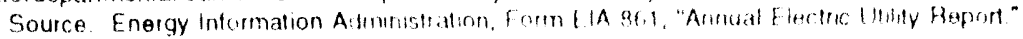

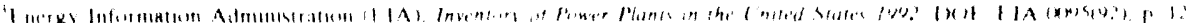


Figure 10. U.S. Electric Utility Average Revenue per Kilowatthour by Sector, 1992

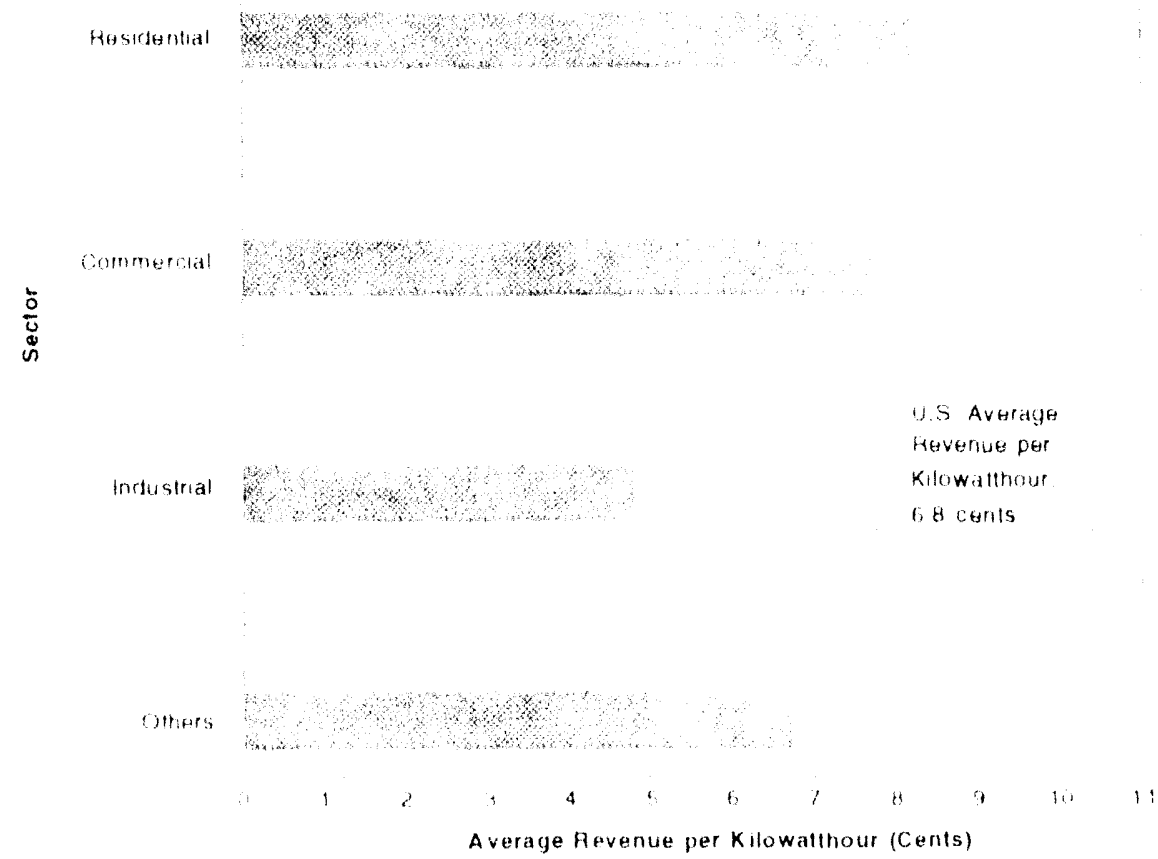

Notes: Other includes sales to public street and highway lighting. other sales to public authorties. sales to railroads and railways. and interdepartmental sales. - Data ate preliminary

Source: Energy Information Adruinstration. Forn EIA 861. "Annual Electric Utilty Report."

Figure 11. U.S. Electric Utility Net Gerieration by Energy Source, 1992

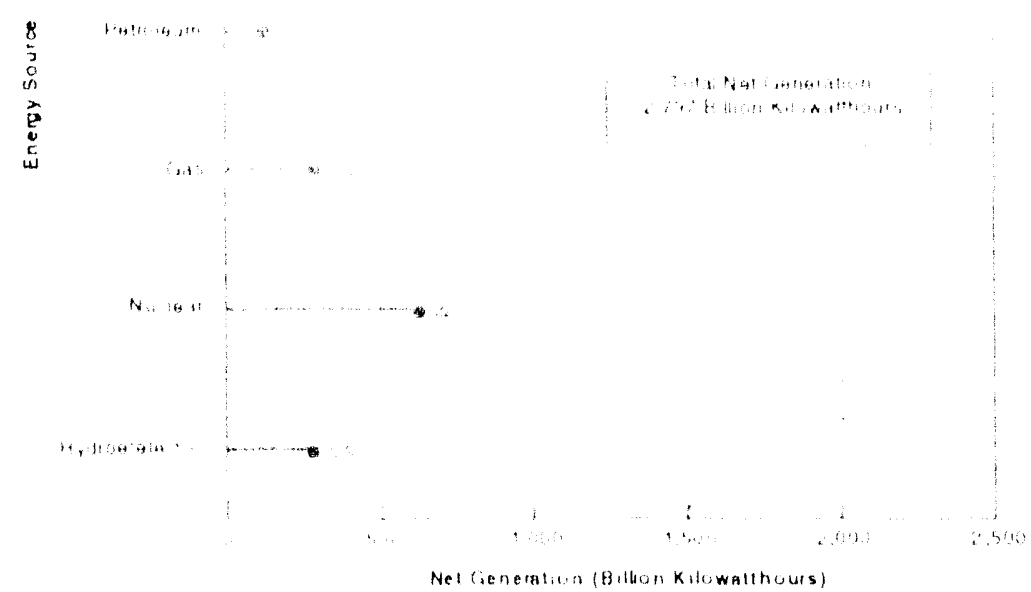

Notes: The total net generation value includes 10 billon kilowithw. from other energy sources (including geothermal, biomass, wind, and photovoltaic), which represents less than 1 percen of total generation. Hydroelectric includes both conventional and pumped storage net generation. - Data are frral. Totals may not equal sum of components because of independent rounding. 
Figure 12. Monthly U.S. Electric Utility Net Generation, 1992 and 1991

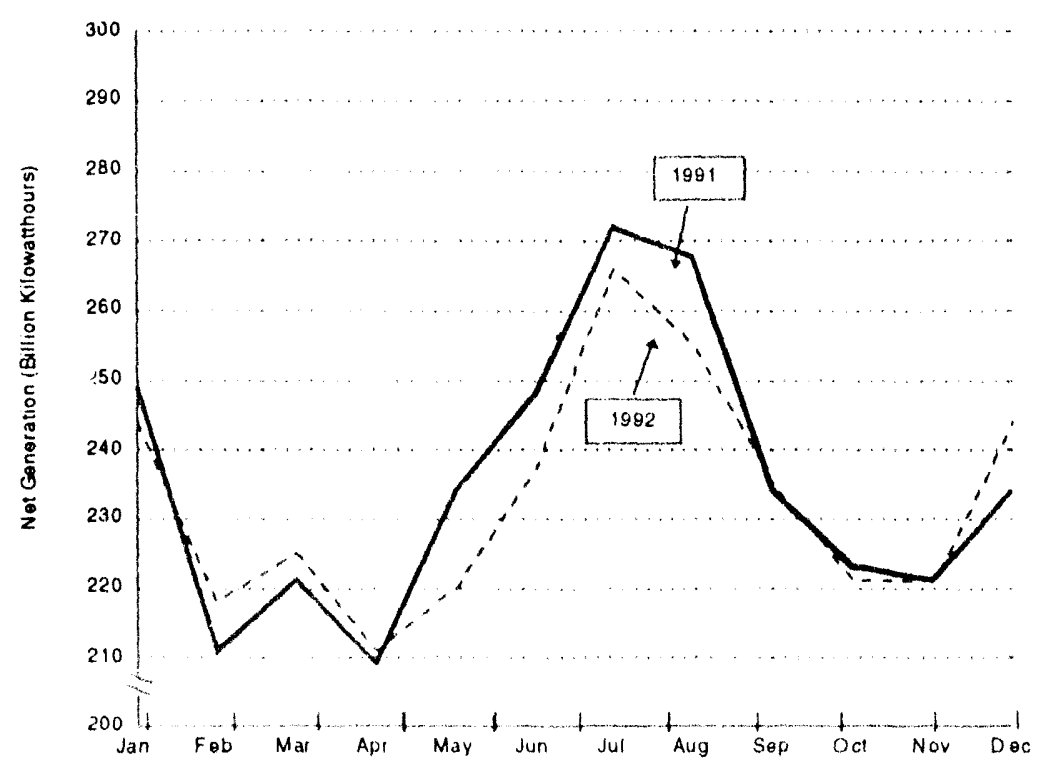

Note: $\cdot$ Data are final.

Source: Energy Information Administration, Form EIA.759, "Monthly Power Plant Report."

Figure 13. Generating Capability at U.S. Electric Utilities by Energy Source, 1992

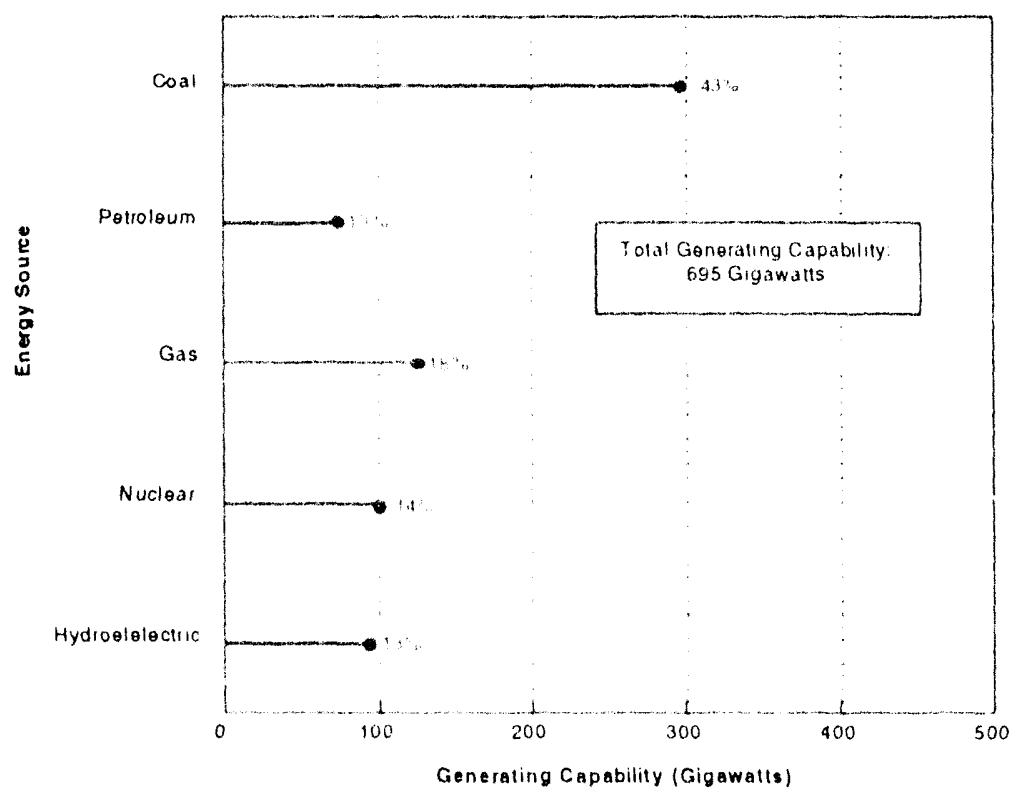

Notes: -The total generating capability value includes 2 gigawatts of other generating capability (geothermal, biomass, photovoltaic, and wind), which represents less than 1 percent of total generating capability. •Data are final. - Totals may not equal sum of components because of independent rounding.

Source: Energy Information Administration, Form ElA-860, "Annual Electric Generator Report." 
Figure 14. Installed Capacity at U.S. Nonutility Generating Facilities by Type of Facility, 1992

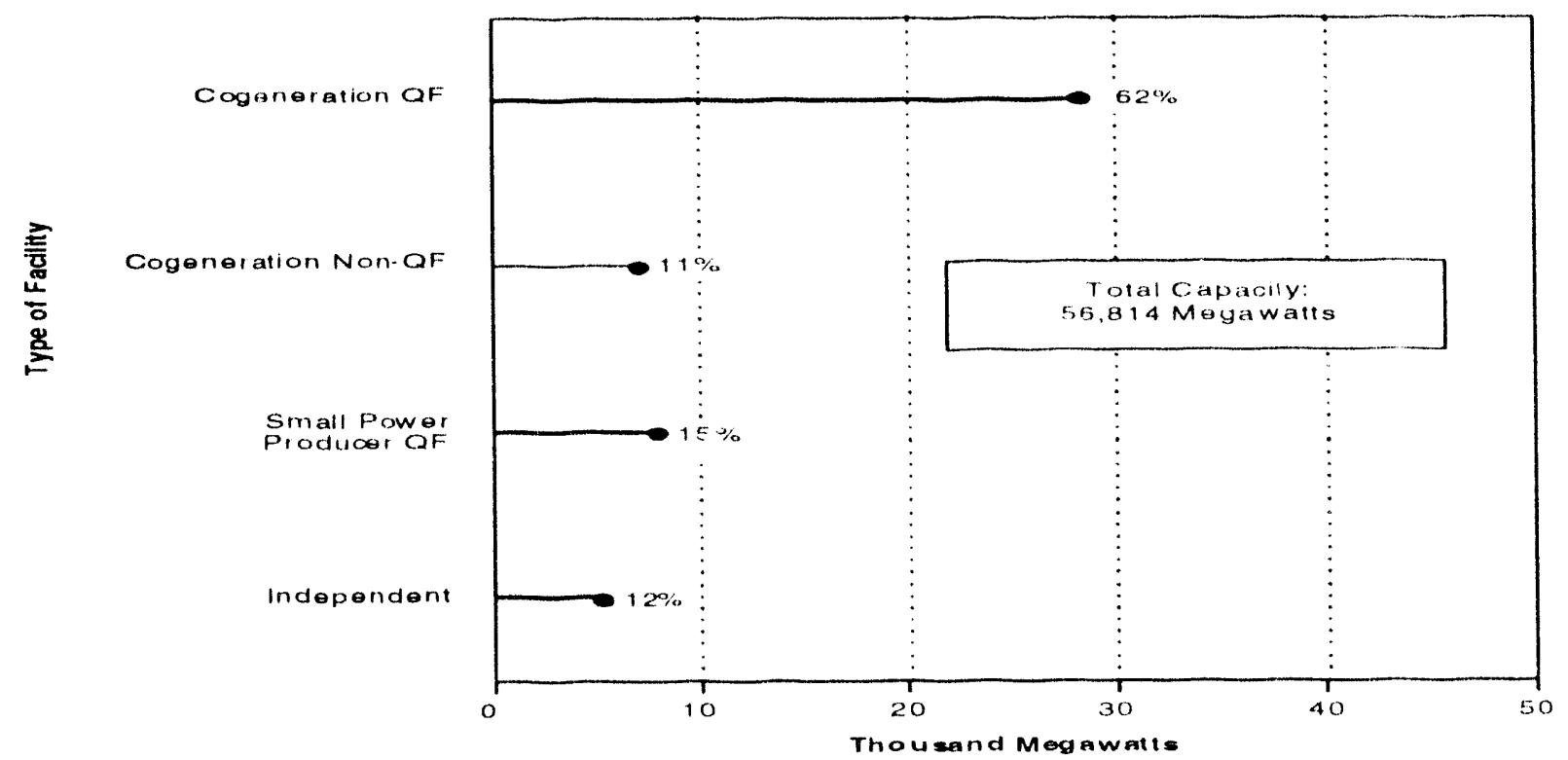

Notes: -Data are preliminary. - Totals may not equal sum of components because of independent rounding. $\bullet Q F=Q$ Qualifying Facility.

Source: Energy Information Administration, Form ElA-867, "Annual Nonutility Power Producer Report".

Figure 15. Planned Capacity Additions for U.S. Nonutility Generating Facilities by Energy Source, as of December 31, 1992

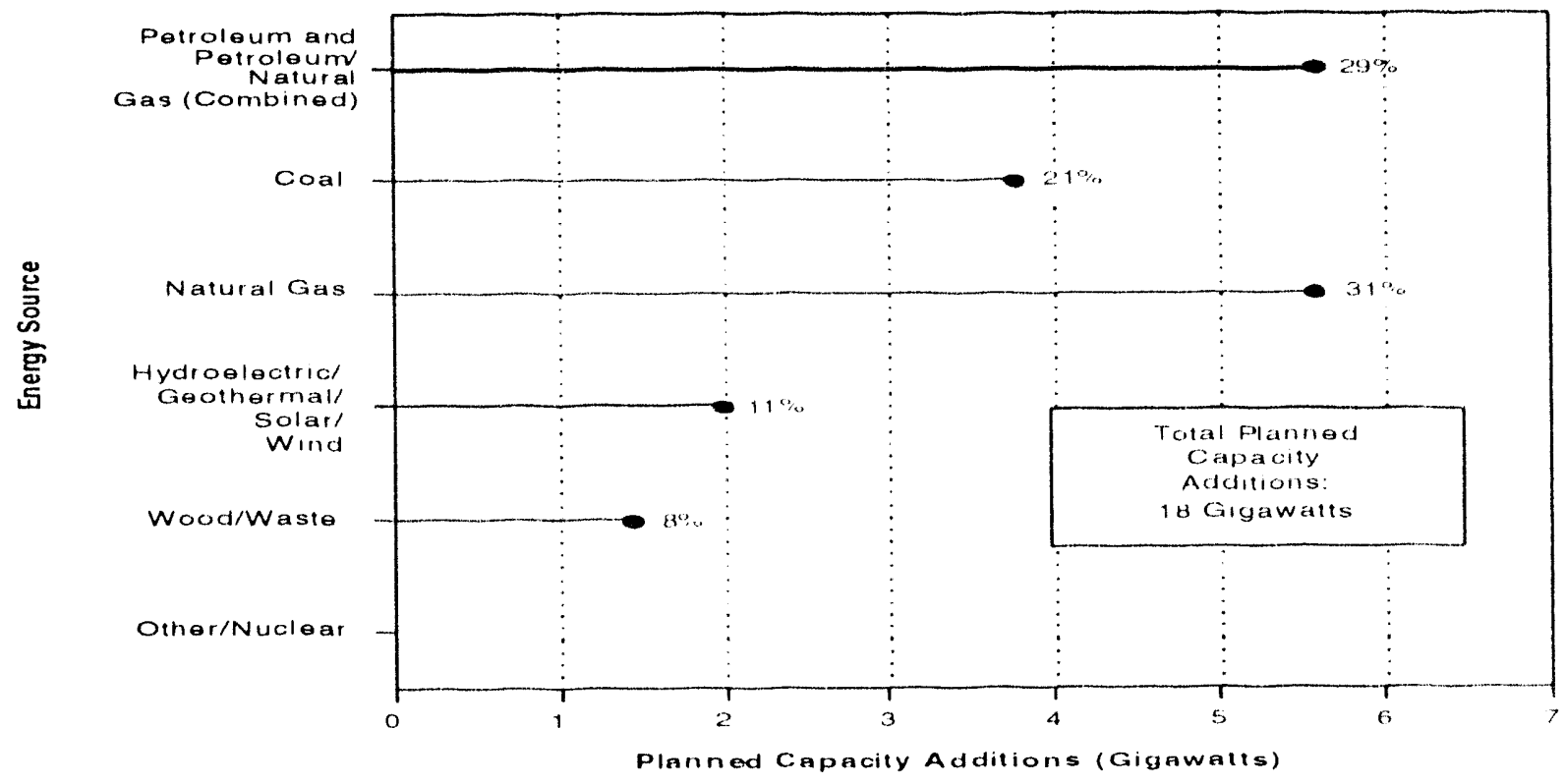

Notes: - Totals may not equal sum of components because of independent rounding. • Other includes hydrogen, sulfur, batteries, chemicals, and spent sulfite liguor. Data for planned capacity additions represent all planned generating facilities that meet one or more of three criteria presented in the "Nonutility Power Producers" chapter. -Data are preliminary.

Source: Energy Information Administration, Form EIA-867, "Annual Nonutility Power Producer Report". 
Table 1. Electric Power Industry Summary Statistics for the United States, 1992 and 1991

\begin{tabular}{|c|c|c|c|}
\hline Item & 1992 & 1991 & Percent Change \\
\hline \multicolumn{4}{|l|}{ Electric Utilities } \\
\hline Generating Capabillty (megawatts) & 695,059 & 693.016 & 03 \\
\hline Coal & 300.547 & 299.611 & 3 \\
\hline$\ldots \ldots \ldots \ldots$ & 71.852 & 72.878 & .14 \\
\hline$\ldots$ & 128.092 & 126,837 & 10 \\
\hline 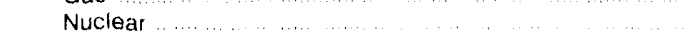 & 98.985 & 99,589 & .6 \\
\hline \multicolumn{4}{|l|}{ Renewable } \\
\hline Hydroelectric (conventıonal) & 74.345 & 73.617 & 10 \\
\hline Geothermal & 1.739 & 1,563 & 113 \\
\hline Biomass ${ }^{2}$ & 464 & 464 & 0 \\
\hline$\ldots \ldots+\ldots$ & $\cdot$ & 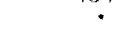 & 0 \\
\hline Solat Thermal & 0 & 0 & 0 \\
\hline Photovoltaic $\ldots \ldots \ldots \ldots$ & 3 & 3 & 0 \\
\hline Hydroelectric Pumped Storage & 19,030 & 18.414 & 3.3 \\
\hline Net Generation (million kilowatthours) & 2.797 .219 & $2.825,023$ & $\begin{array}{r}1.0 \\
-10\end{array}$ \\
\hline Coal & $1,575,895$ & $1,551,167$ & 16 \\
\hline$\ldots \ldots \ldots \ldots \ldots \ldots \ldots \ldots \ldots \ldots \ldots \ldots$ & 88.916 & 111.463 & -20.2 \\
\hline 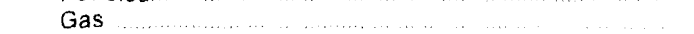 & 263.872 & 264.172 & -1 \\
\hline (n) & 618,776 & 612,565 & 10 \\
\hline \multicolumn{4}{|l|}{ Renewable } \\
\hline 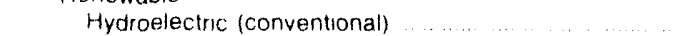 & 243,736 & 280.061 & -130 \\
\hline Geothermal & 8,104 & 8.087 & 2 \\
\hline Biomass ${ }^{2}$ & 2,093 & 2.046 & 23 \\
\hline Wind & 0 & 0 & 0 \\
\hline Solar Therrnal & 0 & 0 & 0 \\
\hline Photovoltaic $\ldots . . . . . . .$. & 3 & 3 & 0 \\
\hline Hyc oelectric Pumped Slorage“ & -4.177 & -4.541 & -80 \\
\hline \multicolumn{4}{|l|}{ Consumption } \\
\hline Coal (miltion short tons) & 80 & 772 & 10 \\
\hline Petroleum (million barrels) ${ }^{5}$ & 147 & 185 & -205 \\
\hline Gas (billion cubic feet) & 2.766 & 2.789 & $\begin{array}{r}-20.5 \\
-8\end{array}$ \\
\hline \multicolumn{4}{|l|}{ Stocks (Year End) } \\
\hline Coal (milion short tons) & 154 & 158 & -25 \\
\hline Petroleum (million barreis) ${ }^{6}$ & 72 & 75 & -40 \\
\hline \multicolumn{4}{|l|}{ Receipts } \\
\hline Coal (million short tons) & 776 & 770 & 8 \\
\hline Petroleum (million barrels)? & 144 & 170 & -153 \\
\hline Gas (billion cubic teet) & 2.638 & 2,631 & 3 \\
\hline \multicolumn{4}{|l|}{ Cost (cents per million Btu) } \\
\hline Coal ...................... & 1412 & 144.7 & .24 \\
\hline Petroleum ${ }^{\text {to }}$ & 2551 & 2548 & 1 \\
\hline Gas $\ldots$ & 2328 & 2153 & 81 \\
\hline \multicolumn{4}{|l|}{ Sales To Uitimate Consumers } \\
\hline (million kilowatthours) & $2,763,343$ & 2.162 .003 & 0 \\
\hline Residential & 935,940 & 955.417 & .20 \\
\hline 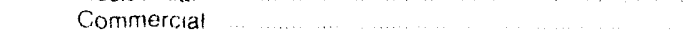 & 761.269 & 765.664 & 6 \\
\hline industrial & 972.691 & 946.583 & 2.8 \\
\hline Other ${ }^{11}$ & 93.443 & 94.339 & .9 \\
\hline \multicolumn{4}{|l|}{ Revenue From Sales to Ultimate Consumers } \\
\hline (billion dollars) & 188 & 186 & 1.1 \\
\hline 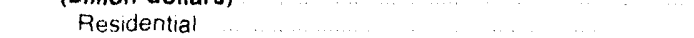 & 77 & 77 & 0 \\
\hline Commercial & 58 & 58 & 0 \\
\hline Industrial & 47 & 46 & 22 \\
\hline Oner" & 6 & 6 & 0 \\
\hline Average Revenue per Kilowatthour (cents) & 6.8 & 67 & 15 \\
\hline Residential .............. & 82 & 8.0 & 25 \\
\hline Commercial & 77 & 7.5 & 2.7 \\
\hline Industrial & 48 & 48 & 0 \\
\hline Other" & 6.7 & 65 & 31 \\
\hline \multicolumn{4}{|l|}{ Emissions (thousand short tons) ${ }^{12}$} \\
\hline Sulfur Dioxide (SO2) & 14,981 & 15.336 & 23 \\
\hline Nitrogen Oxides (NOX) & 7.889 & 7.892 & 0 \\
\hline Carbon Dioxide $(\mathrm{CO} 2)$ & 1.858 .772 & 1.871 .561 & -7 \\
\hline Noncoincidental Summer Peak Load (megawatts) & 549,211 & 551.106 & -3 \\
\hline DSM Actual Peak Load Reductions (megawatts) & 17.657 & 16.739 & 5.5 \\
\hline DSM Energy Savings (million kilowatthours) & 31,767 & 23.343 & 361 \\
\hline DSM Cost (million dollars) & 2,243 & $\begin{array}{r}23.342 \\
1.748\end{array}$ & 28.3 \\
\hline
\end{tabular}


Table 1. Electric Power Industry Summary Statistics for the United States, 1992 and 1991 (Continued)

\begin{tabular}{|c|c|c|c|c|}
\hline Item & $19921 \mathrm{MW}$ or $>$ & $19925 \mathrm{MW}$ or & $19915 \mathrm{MW}$ or & Percent Change \\
\hline \multicolumn{5}{|l|}{ Nonutility Power Producers } \\
\hline Installed Capacity (megawatts) & 56.814 & 55,163 & 48,171 & 14.5 \\
\hline Coal' ${ }^{13}$ & 8,503 & 8,443 & 7,291 & 15.8 \\
\hline Petroleum Only" & 1,730 & 1,579 & 1,207 & 30.8 \\
\hline Gas Only's & 21,542 & 21,104 & 20,259 & 4.2 \\
\hline 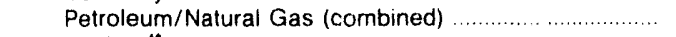 & 8,478 & 8,354 & 5,049 & 65.5 \\
\hline Nuclear'te & 20 & 20 & 20 & 0 \\
\hline \multicolumn{5}{|l|}{ Renewable } \\
\hline 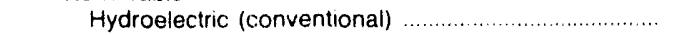 & 2,684 & 2.133 & 1,587 & 34.4 \\
\hline 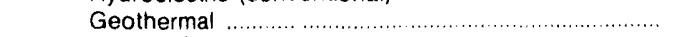 & 1.254 & 1,243 & 1,048 & 18.6 \\
\hline 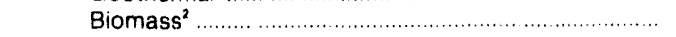 & 9,812 & 9.540 & 9,207 & 3.6 \\
\hline 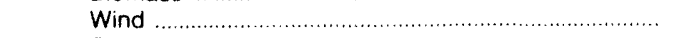 & 1,822 & 1,786 & 1.652 & 8.1 \\
\hline 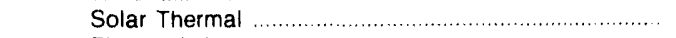 & 354 & 354 & 354 & 0 \\
\hline 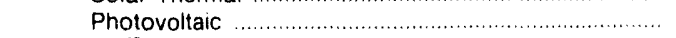 & 7 & 7 & 7 & 0 \\
\hline Other" & 611 & 602 & 491 & 22.5 \\
\hline Gross Generation (miltion kllowatthours) ....................... & 296,001 & $289,85 €$ & 248,448 & 16.7 \\
\hline $\mathrm{Coal}^{13}$ & 47,363 & 47,160 & 40,587 & 162 \\
\hline Petroleum ' $\ldots$ & 10.963 & 10,692 & $7,8: 4$ & 368 \\
\hline Gas $^{15}$ & 158,798 & 156,317 & 131,340 & 190 \\
\hline Nuclear's & 67 & 67 & 80 & -163 \\
\hline \multicolumn{5}{|l|}{ Renewable } \\
\hline Hydroelectric (conventional) & 9,446 & 7,611 & 6,243 & 219 \\
\hline 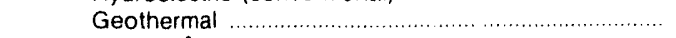 & 8,578 & 8,533 & 7.651 & 11.5 \\
\hline Biomass $^{2}$ & 53,607 & 52,354 & 47,741 & 9.7 \\
\hline Wind & 2,916 & 2,872 & 2,606 & 10.2 \\
\hline 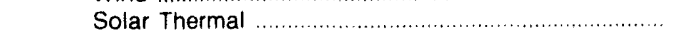 & 743 & 743 & 774 & -40 \\
\hline 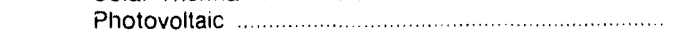 & 4 & 4 & 5 & -200 \\
\hline Other ${ }^{7}$ & 3,516 & 3.504 & 3,609 & -2.3 \\
\hline \multicolumn{5}{|l|}{ Supply and Disposition (million kllowatthours) } \\
\hline Gross Generation & 296,001 & 289,856 & 248,448 & 16.7 \\
\hline Receipts's & 83,421 & 76,198 & 68,264 & 11.6 \\
\hline 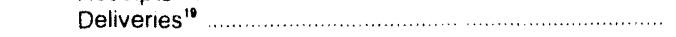 & 175,160 & 171,836 & 140,537 & 22.3 \\
\hline 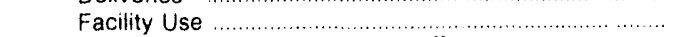 & 204,261 & 194,218 & 176,175 & 102 \\
\hline \multicolumn{5}{|l|}{ Emissions (thousand short tons) ${ }^{20}$} \\
\hline Sulfur Dioxide (SO2) & 1,219 & 1,201 & 1,112 & 8.0 \\
\hline Nitrogen Oxides (NOX) & 1.259 & 1,234 & 1.101 & 12.1 \\
\hline 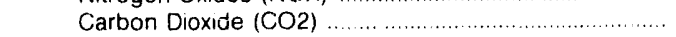 & 549,832 & 540.189 & 487,963 & 10.7 \\
\hline
\end{tabular}

1 Net summer capability based on primary energy source; waste heat, waste gases, and waste steam are included in the original primary energy source (i.e., coal, petroleum, or gas)--historical data have been revised to reflect this change.

2 Includes wood, wood waste, peat, wood liquors, railroad ties, pitch, wood sludge, municipal solid waste, agricultural waste, straw, tires, landfill gases, fish oils, and/or other waste.

3 includes petroleum coke

4 Represents total pumped storage facility p.oduction minus energy used for pumping

5 Does not include petroleum coke consumption of 780 thousand short tons in 1992 and 722 thousand short tons in 1991

- Does not include petroleum coke stocks of 65 thousand short tons at year end 1992 and 70 thousand shorts tons at year end 1991

- Does not include petroleum coke receipts of 687 thousand short tons in 1992 and 485 thousand short tons in 1991

- Includes small amounts of coke-oven, refinery, and blast furnance gas.

- Average cost of fuel delivered to electric generating plants with a total steam-electric nameplate capacity of 50 or more megawatts: average cost val ues are wiighted by BTU.

1n Does not include petroleum coke cost of 75.0 cents per million Btu in 1992 and 81.0 cents per million Btu in 1991

"Includes public street and highway lighting, other sales to public authorities, sales to railroads and railways, and interdepartmental saies

12 Incliydes only those power plants with a fossil-fueled steam-electric nameplate capacity (existing or planned) of 10 or more megawatts. As of 1992. emission factors for the calculation of carbon dioxide emissions and reductions from nitrogen oxide control technologies have been changed--historical data were revised to reflect that change--see the Technical Notes for more information

13 includes coal, anthracite culm and coal waste.

14 Includes petroleum coke, diesel, kerosene, and petroleum sludge and tar

15 Includes natural gas, butane, ethane, propane, waste heat and waste gases

it Nuclear reacto, and generator at Argonne National Laboratory used primarily for research and development in testing reactor fuels as well as for training. The generation from the unit is usec for internal consumption.

17 Includes hydrogen, sulfur, batteries, chemicals, and spent sulfite liquor

is Includes purchases, interchanges, and exchanges of electric energy with utilities and other nonutilities.

10 Inciudes sales, interchanges, and exchanges of electrir. energy with utilities and other nonutilities. The disparity in these data and data reported on other EIA surveys occurs dL'? to differences in the respondent universe. The Form ElA-867 is filed by nonutiities reporting the energy delivered. while other data sources are filed ty electric utilities reporting energy received. Differences in termınology and accounting procedures attribute to the disparity In addition, since the frame for the Form EIA-867 is derived from utility surveys, the Form EIA-867 universe lags 1 year

${ }_{20}$ As of 1992, emission factors for the calculation of carbon dioxide emissions and reductions from nitrogen oxide control technologies have been changed--historical duia were revised to reflect that change--see Technical notes for more information

21 DSivi ... Demand-Side Management.

Notes: -Data for nonutility power producers, demand-side management, ernissions, sales to ultimate consumers, revenue from sales, and average revenue per kilowatthour are preliminary for 1992; other data in thıs table are final. - Totals may not equal sum of components because of independen rounding. Percent change is calculated hetore rounding. - less than 0.5 megawatts

Sources: -Energy Information Administration, Form ElA.759 "Monthly Power Plant Report"; Form ElA-860, "Annual Electric Generator Report": Form E!A-861, "Annual Electric Utility Report"; Form ElA-767, "Steam-Electric Plant Operation and Design Report": Form ElA-867, "Annual Nonutility Power Producer Report." -Federal Energy Regulatory Commission (FERC) Form 423, "Monthly Peport of Cost and Quality of Fuels ior Electric Plants. " - Otfice of the Assistant Secretary for Emergency Planning and Operations, Form OE-411, "Coordinated Bulk Power Supply Program" 


\section{Generating Capability at U.S. Electric Utilities}

More than one-third of the primary energy in the $\mathrm{Na}$ tion is used to generate electricity. ${ }^{24}$ Consumers expect electricity to be instantly available, that is, at the flick of a switch. In fact, electricity is so important to the functioning of our society that its unavailability is newsworthy. The U.S. electric power industry is organized to ensure that an adequate supply of electricity is available to meet all demand requirements at any given instant, both now and in the future. This chapter provides an inventory of the capability of various methods for converting energy into electricity, as well as, providing information regarding the plans the industry has for building additional capability.

\section{Background}

The generating units operated by an electric utility vary by intended usage, that is, by the type of load requirements the utility must meet. The load requirements placed on an electric utility are generally categorized as base load, intermediate load, and peak load. A baseload generating unit is normally used to satisfy all or part of the minimum load of the system and, as a consequence, produces electricity at an essentially constant rate and runs continuously. These units are generally the newest, largest, and most efficient of the three types. (The operating efficiency of a generating unit is a function of the amount of net heat that it can extract from the energy source for use in the production of electricity.) A peakload generating unit, which is normally the least efficient of the three types of units, is used to meet requirements during the periods of greatest load on the system. Intermediate-load generating units meet system requirements that are greater than base load but less than peak load. These units are used during the transition between baseload and peakload requirements. Utilities also have reserve or standby generating units, which are available to the system in the event of an unexpected increase in load or an unexpected outage within the system. Consequently, an inventory of net capability must account for reserve or standby capability, as well as generating units that are not available to the system for various reasons (such as routine maintenance).

Net capability in this report, unless otherwise stated, refers to that which is operable and includes both active and inactive capability. Once a new generator has been declared available to generate power to the electrical grid, it is considered a part of the operable capability of the utility until it is retired from service. Generating units that are used for standby service, generators that are placed in cold reserve or cold standby, and generators that are out of service for an extended period (exceeding 1 year) comprise the inactive operable capability. ${ }^{25}$ Active operable capability includes generators that are generating or available to generate; this includes generators that may be down for scheduled maintenance, refueling, or forced outages.

An electric utility plant (station) contains generating units and auxiliary equipment that are used to convert various types of energy into electric energy. A fossilfueled generating unit may be designed to use (burn) one or more fossil fuels to produce electricity. A generating unit capable of burning more than one fossil fuel is referred $t o$ as a dual-fired unit. Some dual-fired units can only burn one fuel at a time (that is, the fuels are fired sequentially), while others can burn more than one fuel simultaneously (concurrent firing of different fuels). A sequentially fired unit generally uses one fossil fuel as its primary energy source but can switch to a second fossil fuel as an alternate energy source. Unless stated otherwise, information regarding generating capability in this report is based on the primary energy source.

\footnotetext{
${ }^{24}$ Energy Information Administration, Monthly Enargy Review, DO)E/EIA-(X)35(93/10), pp. 11 and 35 .

${ }^{25}$ As of the year-end 1992, about 3 percent of the operable capability was inactive. Energy Information Administration. Inventory of Power, Plants in the United States 1992. DOE/EIA-(0)95(92), p. 31
} 


\section{Prime Movers}

Electric utilities use a variety of prime movers based on the loads, availability of fuels, and energy requirements of the utility. The most common prime movers are the steam turbine, internal-combustion engine, gas combustion turbine, water turbine, and wind turbine. ${ }^{2 t}$ Most prime movers used to produce electricity today are turbines. The energy sources most often used with prime movers are the fossil fuels -- coal, petroleum. and natural gas.

Steam-Turbine Generating Units. Most of the electricity in the United States is produced in steam turbines. In a fossil-fueled steam turbine, the fuel is burned in a boiler to produce steam. The resulting steam then turns the turbine blades that turn the shaft of the generator to produce electricity. In a nuclear-powered steam turbine, the boiler is replaced by a reactor containing a core of nuclear fuel (primarily enriched uranium). Heat produced in the reactor by fission of the uranium is used to make steam. The steam is then passed through the turbine generator to produce electricity, as in the fossil-fueled steam turbine. Steam-turbine generating units are used primarily to serve the base load of electric utilities. Fossil-fueled steam-turbine generating units range in size (nameplate capacity) from 1 megawatt to over 1,000 megawatts. Nuclear-powered steamturbine generating units in operation today range in size from 75 megawatts to over 1,400 megawatts.

Gas Turbine Generating Units. In a gas turbine (combustion-turhine) unit, hot gase's produced from the combustion of natural gas and distillate oil in a high-pressure combustion chamber are passed directly through the turbine. which spins the generator to produce electricity. Gas turbines are commonly used to serve the peak loads of the electric utility. Gas-turbine units can be installed at a variety of site locations, because their size is generally less than 100 megawatts. Gas-turbine units also have a quick startup time, compared with steam-turbine units. As a result, gas-furbine units are suitable for peaking, emergency, and reservepower requirements.

The gas turhine, as is typical with peaking units, has a lower efficiency than the steam lurbine used for baseload power. The efficiency of the gas turbine is increased when coupled with a steam turbine in a combined-rycle operation. In this operation, hot gases (which have already been used to spin one turbine generator) are moved to a waste-heat recovery steam boiler where the water is heated to produce steam that, in turn, produces electricity by running a second steamturbine generator. In this way, two generators produce electricity from one initial fuel input. All or part of the heat required to produce steam may come from the exhaust of the gas turbine. Thus, the steam-turbine generator may be supplementarily fired in addition to the waste heat. Combined-cycle generating units generally serve inc mediate loads.

Internal-Combustion Engines. These prime movers have one or more cylinders in which the combustion of fuel takes place. The engine, which is connected to the shaft of the generator, provides the mechanical energy to drive the generator 10 produce electricity. Internal-combustion (or diesel) generators can be easily transported, can be installed upon short notice, and can begin producing electricity nearly at the moment they start. Thus, like gas turbines they are usually operated during periods of high demand for electricity. They are generally about 5 megawatts in size.

Hydroelectric Generating Units. Hydroelectric power is the result of a process in which flowing water is used 10) spin a turbine connected to a generator. The two hasic types of hydroclectric systems are those based on falling water and those based on natural river current. In the first system, water accumulates in reservoirs created by the use of dams. This water then falls through conduits (penstocks) and applies pressure against the turbine blades to drive the generator to produce electricity. In the second system, called a runof-the-river system, the force of the river current (rather than falling water) applies pressure to the turbine blades to produce electricity. Since run-of-the-river systems do not usually have reservoirs and cannot store substantial quantities of water, power production from this type of system depends on seasonal changes and stream flow. These conventional hydroelectric generating units range in size from less than 1 megawatt to 700 megawatts. Because of their ability to start quickly and make rapid changes in power output, hydroelectric generating units are suitable for serving peak loads and providing spinning reserve power, as well as serving baseload requirements.

Another kind of hydroelectric power generation is the pumped storage hydroelectric system. Pumped storage hydroelectric plants use the same principle for generation of power as the conventional hydroelectric operations based on falling water and river current. However, in a pumped storage operation, low-cost off-peak energy is used to pump water to an upper reservoit where it is stored as potential energy. The water is then released to now back down through the turbine generator to produce electricity during periods of high demand for electricity.

Other Generating Units. Other methods of electric power generation, which presently contribute only small amounts to total power production, have potential for expansion. These include geothermul, solar.

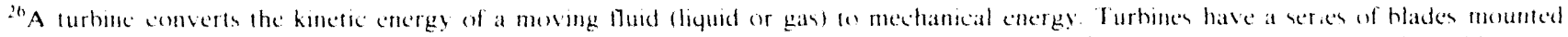

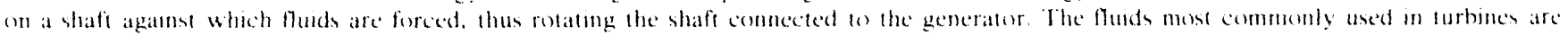
seatm, bon air. or combustom profucts, and water
} 
wind, and biomass (wood, municipal solid waste, agricultural waste, etc.). Geothermal power comes from heat energy buried beneath the surface of the earth. Although most of this heat is at depths beyond current drilling inethods, in some areas of the country, magma" nows close enough to the surface of the earth to produce steam. That steam can then he harnessed for use in conventional steam-turbine plants. Solar power is derived from the energy (both light and heat) of the sun. Photovoltaic conversion generates electric power directly from the light of the sun; whereas, solarthermal electric generators use the heat from the sun to produce steam to drive turbines. Wind power is derived from the conversion of the energy contained in wind into electricity. A wind turbine is similar to a typical wind mill. However, because of the intermitlent nature of sunlight and wind, high capacity utilization factors cannot be acheved for these plants. Several electric utilities have incorporated wood and weste (for example, municipal waste, corn cobs, and (ats) as en ergy sources for producing electricity at their power plants. These sources replace fossil fuels in the boiler. The combustion of wood and waste creates steam that is typically used in conventional steam-celectric plants.

\section{Generator Rating}

The rating of a generator is a measute of its ability to produce electricity. Generaters ate rated by nameplate capacity The nameplate capacity is the full-hate con tinuous rating of the gencrater under specified conditioms, as designated by the manufacturer, and is usually indicated on a metal plate attathed phisteally to the generator . Vit copublity is the steady hourly output that the generating unt is expected o supply to the system load, as demomstrated hy lest procedures. The capatility of the gencrating unit in the summer is gen crally less than in the winter dac to high ambermt-all and cooling-water comperatures, wheh catuse generating units to be less efficient. The measure used in this publication for clectric utilities is net summer capabil. ity. The nameplate capacity of a generator is generally greater than its net capabilit?

\section{Planned Generating Unit Additions}

Electric unilities must provide a comtmunus and dependable supply of electricits to their comsumers. They must mantain a balance hetween supply and demand and, at the same time, mantatin an atequate reserve margm forensure system reliahility. To accomplish this, electric utilities comtimually assess their need for new gencrating capabilaty
The most important factor in determining the need for new clectric generating capability is growth in the demand for electricity. Growth in demand is influenced primarily by ecomomic forces for example, the Grose National Product) and the cost of fuels and electricity. Electric utilities constantly monitor their peak demands and energy requirements and ustally update their forecasts of these anmually. Flectric utilities use various methodologies to forecast anmual peak demand and energy requirements, from which they determine the amount of capthility that is needed to meet expected demand. Two additional faters that contribute to the need for new gencrating capability are the retirements of older generators and the decreasing efficiency of aging generatung units.

Before deceding to add new capability electric utilities consider of hee optioms that may he more cost-effective in mecting foulure demand. Also, they may chosese to combine the additum of new capability with other opteoms that enclude repowering and/or life extemsion of their exesting capability, load-management programs and or purchases of power from nomutilities.

L lectrte utilitice are considering repowering as a costclfectse means of theeting future entergy requirements. Several repowering lechnologies have been developed. Repowering generally consists of modifying old coallired clectrec generating units by replacing the boiles with a new combustion technology which results in betler performance and an increase in capacity. Several repowering techomolongles were reported as part of the lo-gear comstruction platus of thilitics. In some cases. an exasting steam-clectice plant is reconfigured at at combined-ence plame by adding a gas lurbine. Several ekecter utilities have al ready completed this kind of reperwering and mote repowering is included in thes

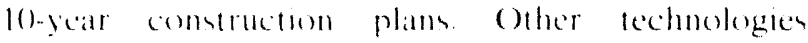
repower whllekan-colalechnology Repowernge with

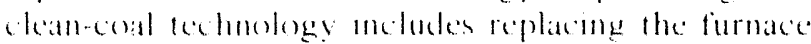
and boileg in an old plant with mew, deanere-burning.

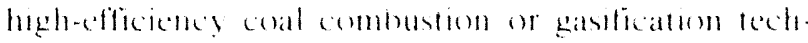
mology Although utilutes are comsidering their re perled plane for implementing these techmologies as "demomstration" profecels. lest programs hate shown that these fechometeges do hate dependability for forture use by electroc utilities in the lented states

Althemgh life extemsom (plant refirbishment) adeds litlle, if any. new capability some militice hate chesen

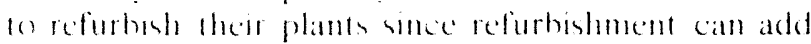
about 20 seare of life to aged plants mearing retirement and is less expensive than repowering.

W'ith soncerms aheut future demand, in particular, fu. lare peat demands. utilities are studying and implementing wats a concourage customers to reduce or shift loak These techniques include allowing coustom.

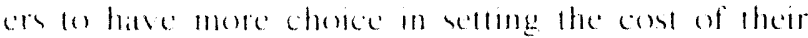


energy, controlling their energy use and at the same time reducing overall demand. Reducing demand delays the need for new capability.

One the decision has been made to add capability. either by bulding new power plants or adding new generating units at existing power plants, the lype of capability to be added is determined by matching the loal to be served with the appropriate lype of generating unit. If the needs of a utility ate limited to capability required to meet peak kemand, then gas furbine, internal-combustion, or pumped-storage hydrocketric gencrating units are likely to be the chone for new additions. To meed other energy requirements (intermediate and base load). the optioms avalable to the utility include the additson of steam-electric. combinedcyele or comentomal-hydroclectric geterating units.

\section{Data Sources}

The following tables contain a summary of the number of electric generators and the amount of electric gencrating capability in the United States at mational, regional, and state level for the period 1988 through 1992. as well an capability additums planned hy electric utilutes for 1993 through $20(12$.

During the past year, several updates were made for these data. These changes include the installation of new generators the retirement of existing generators: the use of a promary energy source for dual-fired units different from that which has been reported in the past: and the modification of generators, such as the rewinding of stators or the retrofitting of associated generator equipment. Data previously reported in error were corrected Respondents that did not meet the reporting requirements of Form FIA-860) were deleted. The capacity of generators sold 10 nomutilities was also deleted. The inclusion of new respondents also resulted in data changes

Estimates of net summer capability and net winter capability are made for uperable nonnuclear electric generating units with no reported capability. Additionally. estimales are made for all electric gencrating units that are not nuclear or coal-fired and ate under const ruction or in the planning stage. These estimates are calculated using a statistical relationship that exists between the capahility (summer and winter) and installed generator nameplate capacity for units that were in commercial operation as of the end of 1984. For a description of the estimation formula, see Technical Notes. Appendix C.

Data in the lables were obtained from the form FilA-860, "Annual Electric Cienerator Report," Data are reported annually on the Form EIA-860) by approximately 870 electric utilities in the United States that operate power plants or plan 10 operate power plants within lo years of the reporting year. These 10 -year platm include generating unsts that are under construction or in various stages of planning at the time data are submitted. Moredetailed statistics on operable capacily and planned capability additions are published in the Inventory of Power Plants in the L'nited States: :

\section{Table 2. Generating Sapability at U.S. Electric Utilities by Prime Mover and Primary Energy Source, End of Year, 1988 Through 1992 (Megawatts)}

\begin{tabular}{|c|c|c|c|c|c|}
\hline Prime Mover/Primary Energy Source & 1992 & 1991 & 1990 & 1989 & 1988 \\
\hline Fossil Steami & 446,201 & ${ }^{*} 446,575$ & 446,985 & 443,866 & 441,947 \\
\hline Coalfired & 500.547 & 299611 & 299.876 & 296.614 & 294.685 \\
\hline Petroleum. Futed & 44.472 & 45,711 & 49789 & 51,340 & 51.137 \\
\hline Gas Fired & 101,182 & 101253 & 97.320 & 95.912 & 96.124 \\
\hline Gas Turbine/Internal Combustion & 54,291 & 52,790 & 50,861 & 50,022 & 48,604 \\
\hline Petroleum Fired & 27.381 & 27.235 & 37.275 & 27.018 & 26,352 \\
\hline Gias Fired & 26,910 & 25.555 & 23.516 & 23.004 & 22,252 \\
\hline Hydroelectric & 93,375 & 92,031 & 90,885 & 90,467 & 90,284 \\
\hline Nuclear & 98,985 & 99.589 & 99,624 & 98,161 & 94,695 \\
\hline Other & 2,207 & 2,031 & 2,111 & 2,103 & 2,124 \\
\hline U.S. Total & 695,059 & 693,016 & 690,465 & 684,619 & 677,654 \\
\hline
\end{tabular}

- Reters to benewables (excluding hydroelectros including tuomass, reothermal wind and photovoltaic

A Revised to correct lotal value:

Notes. Waste heal. waste gases and waste steam are included in the ongual primary energy source category (ite coal, petroleum or gas) - Data are final - Tolals may not equal sum of components hec ause of indeperident rounding - Generating capabity is net summer capability

Soures Enetgy information Acmonstration Form ElA \&60, Annual Electric Generator Report 
Table 3. Summary of Capability Additions, Retirements, and Total Operable Capability at U.S. Electric Utilitios by Energy Source, End of Year, 1992

\begin{tabular}{|c|c|c|c|c|c|c|}
\hline \multirow{2}{*}{$\begin{array}{c}\text { Primary Enorgy } \\
\text { Source }\end{array}$} & \multicolumn{2}{|c|}{ Added } & \multicolumn{2}{|c|}{ Retired } & \multicolumn{2}{|c|}{ Operable } \\
\hline & $\begin{array}{l}\text { Number of } \\
\text { Ceneratore }\end{array}$ & $\begin{array}{l}\text { Capability' } \\
\text { (megawatte) }\end{array}$ & $\begin{array}{l}\text { Number of } \\
\text { Generators }\end{array}$ & $\begin{array}{l}\text { Capabllity' } \\
\text { (megawatts) }\end{array}$ & $\begin{array}{l}\text { Number of } \\
\text { Generators }\end{array}$ & $\begin{array}{l}\text { Capability' } \\
\text { (megawatts) }\end{array}$ \\
\hline $\begin{array}{l}\text { Coal } \\
\text { Petroleum } \\
\text { Gas } \\
\text { Hydroelectric } \\
\text { Nuclear } \\
\text { Other } \\
\text { U.S. Total }\end{array}$ & $\begin{array}{r}1 \\
40 \\
17 \\
23 \\
0 \\
0 \\
81\end{array}$ & $\begin{array}{r}498 \\
460 \\
1,758 \\
624 \\
0 \\
0 \\
3,341\end{array}$ & $\begin{array}{r}5 \\
42 \\
16 \\
0 \\
2 \\
3 \\
68\end{array}$ & $\begin{array}{r}254 \\
529 \\
1,061 \\
0 \\
603 \\
67 \\
2,514\end{array}$ & $\begin{array}{r}1,238 \\
3,239 \\
2,115 \\
3,497 \\
109 \\
70 \\
10,268\end{array}$ & $\begin{array}{r}300,547 \\
71,852 \\
128,092 \\
93,375 \\
98,985 \\
2,207 \\
695,059\end{array}$ \\
\hline
\end{tabular}

Net summer capability.

- Refers to renewables (excluding hydroelectric) including biomass, geothermal, wind, and photovoltaic.

Notes: - Data are final. - Totals may not equal sum of components because of independent rounding. - Total capability cannot be calculated from the prior year's capability by adjusting for retirements and newly added capability because capability ratings for independent generators change each year and generators are purchased from or sold to nonutilities. Waste heat, waste gases, and waste steam are included in the original primary energy source category (i.e., coal, petroleum, or gas).

Source: Energy Information Administration, Form EIA-860, "Annual Electric Generator Report."

Table 4. Planned Capability Additions at U.S. Electric Utilities by Energy Source, 1993 Through 2002

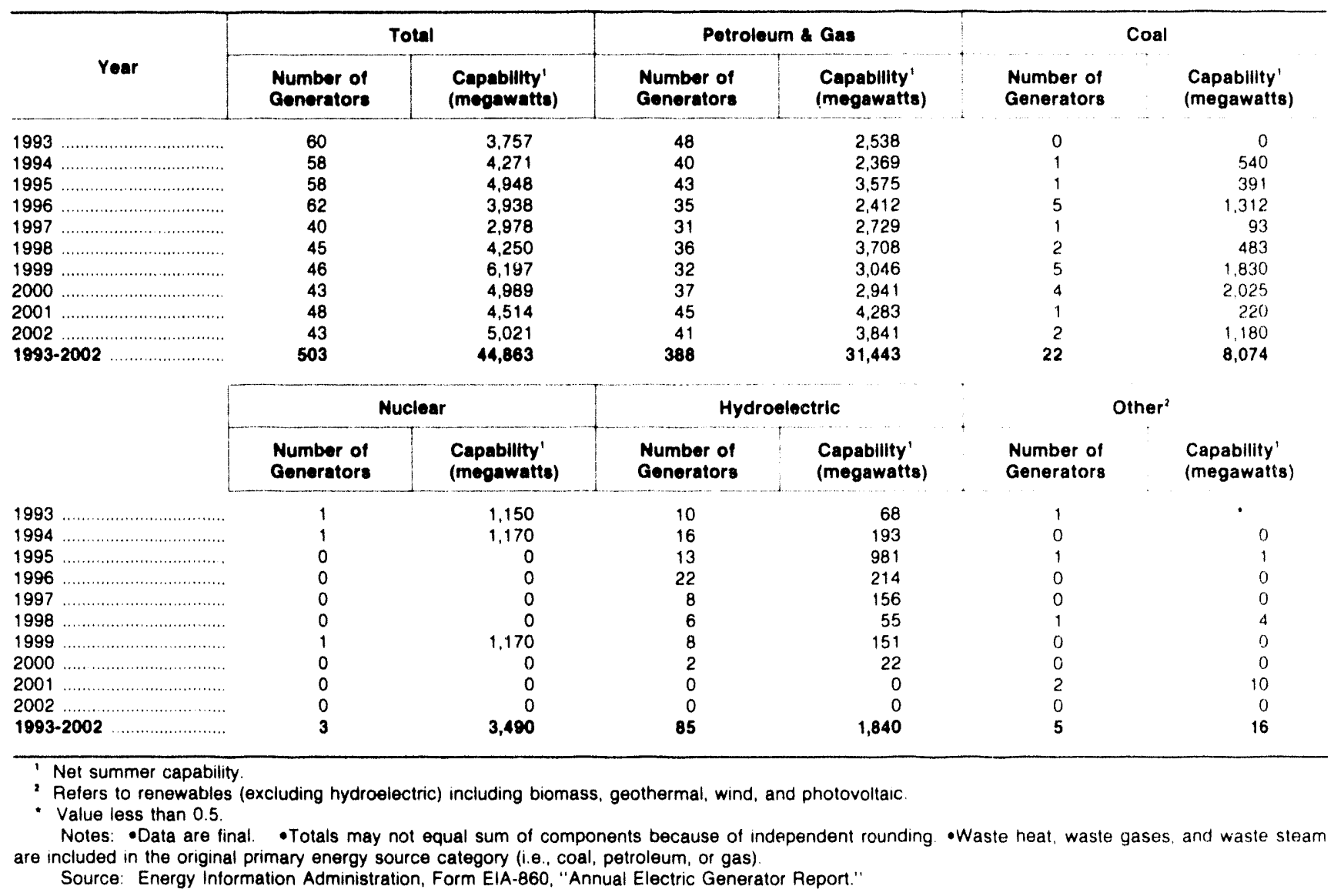


Table 5. Generating Capability at Electric Utilities by Census Division and State, End of Year, 1992 and 1991

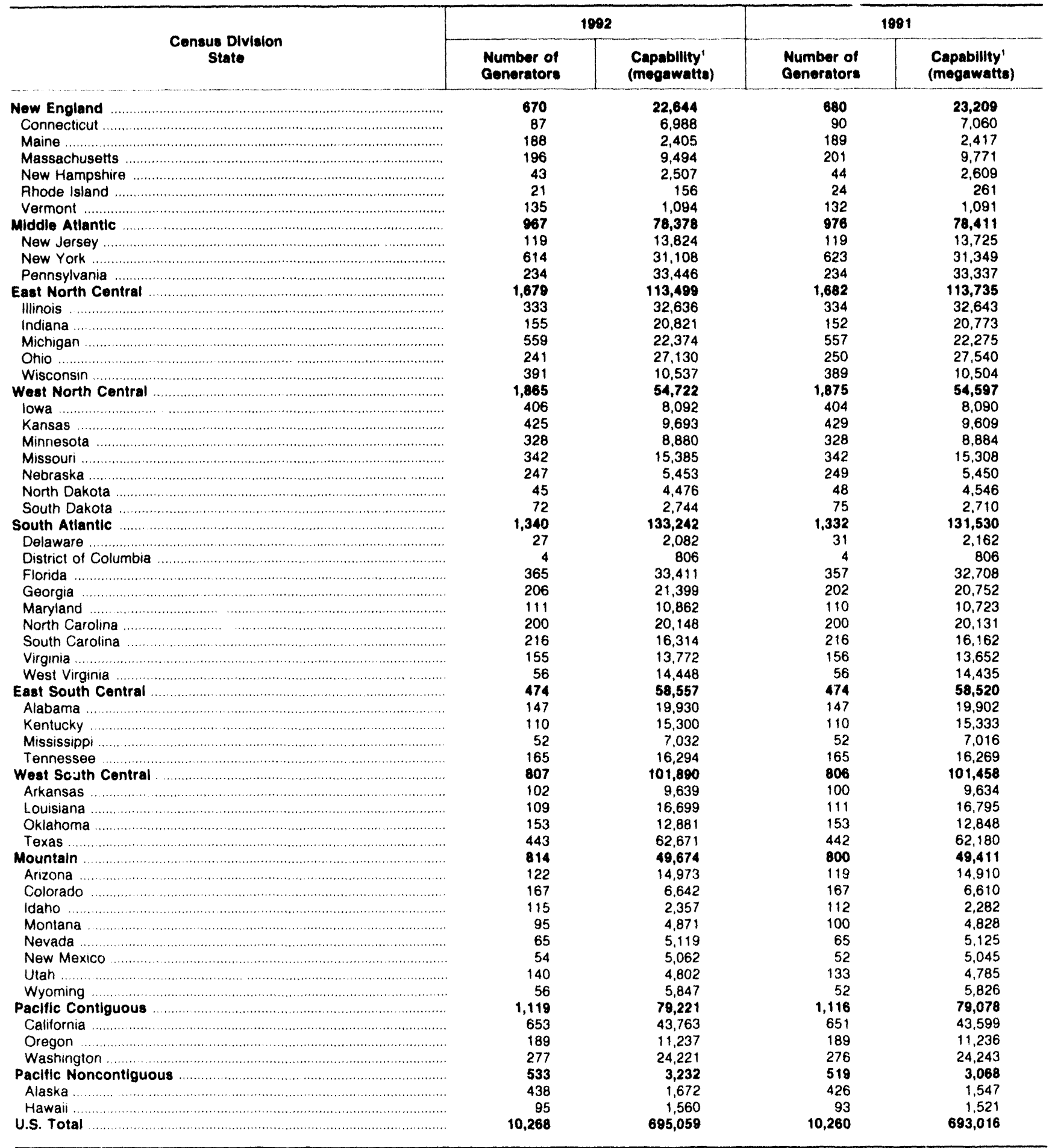

- Net summer capability.

Notes: -Data are final. -Totals may not equal sum of components because of independent rounding

Source: Energy Information Administration, Form ElA-860, "Annual Electric Generator Report." 
Table 6. Coal-Fired, Nuclear, Hydroelectric, and Other Generating Capability at Electric Utilities by Census Division and State, End of Year, 1992

\begin{tabular}{|c|c|c|c|c|c|c|c|c|}
\hline \multirow[b]{2}{*}{$\begin{array}{c}\text { Census Division } \\
\text { State }\end{array}$} & \multicolumn{2}{|c|}{ Coal } & \multicolumn{2}{|c|}{ Nuclear } & \multicolumn{2}{|c|}{ Hydroelectric } & \multicolumn{2}{|c|}{ Other' } \\
\hline & $\begin{array}{l}\text { Number of } \\
\text { Generators }\end{array}$ & $\begin{array}{l}\text { Capabillty" } \\
\text { (megawatts) }\end{array}$ & $\begin{array}{l}\text { Number of } \\
\text { Generatore }\end{array}$ & $\begin{array}{c}\text { Capability } \\
\text { (megawatts) }\end{array}$ & $\begin{array}{l}\text { Number of } \\
\text { Generators }\end{array}$ & $\begin{array}{l}\text { Capabillity } \\
\text { (megawatts) }\end{array}$ & $\begin{array}{l}\text { Number of } \\
\text { Generators }\end{array}$ & $\begin{array}{l}\text { Capabillty" } \\
\text { (megawatts) }\end{array}$ \\
\hline New England & 15 & 2,646 & 8 & 6,393 & 369 & 3,132 & 5 & 111 \\
\hline Connecticut & 1 & 385 & 4 & 3,212 & 35 & 135 & 2 & 64 \\
\hline Maine & 0 & 0 & 1 & 870 & 133 & 420 & 0 & 0 \\
\hline Massachusetts & 9 & 1,684 & 1 & 665 & 64 & 1,855 & 0 & 0 \\
\hline 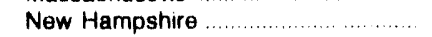 & 5 & 578 & 1 & 1.150 & 31 & 290 & 0 & 0 \\
\hline Rhode Island & 0 & 0 & 0 & 0 & 1 & 1 & 0 & 0 \\
\hline 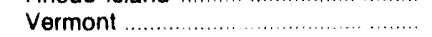 & 0 & 0 & 1 & 496 & 105 & 430 & 3 & 47 \\
\hline Middle AtIantic & 99 & 23,041 & 19 & 17,415 & 379 & 7,357 & 0 & 0 \\
\hline New Jersey .... & 8 & 1,629 & 4 & 3,853 & 3 & 360 & 0 & 0 \\
\hline New York ......... & 32 & 3,897 & 6 & 4,831 & 331 & 5,085 & 0 & 0 \\
\hline Pennsylvania & 59 & 17.515 & 9 & 8,731 & 45 & 1,912 & 0 & 0 \\
\hline East North Central & 391 & 76,763 & 23 & 20,103 & 482 & 2,844 & 10 & 196 \\
\hline Illinois & 58 & 14,947 & 13 & 12,609 & 14 & 10 & 0 & 0 \\
\hline Indiana & 80 & 19,562 & 0 & 0 & 21 & 69 & 0 & 0 \\
\hline 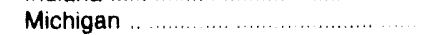 & 80 & 11.976 & 5 & 3,942 & 232 & 2,198 & 0 & 0 \\
\hline Ohio & 120 & 23,164 & 2 & 2,046 & 9 & 125 & 3 & 90 \\
\hline Wisconsin & 53 & 7.114 & 3 & 1.506 & 206 & 443 & 7 & 106 \\
\hline Weat North Central & 204 & 35,032 & 8 & 5,600 & 161 & 3,913 & 12 & 88 \\
\hline lowa & 50 & 5.909 & 1 & 515 & 25 & 125 & 0 & 0 \\
\hline Kansas & 20 & 5.149 & 1 & 1,159 & 0 & 0 & 2 & $\cdot$ \\
\hline 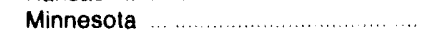 & 53 & 5,771 & 3 & 1,547 & 54 & 143 & 10 & 88 \\
\hline Missouri & 48 & 10,782 & 1 & 1,125 & 29 & 1.112 & 0 & 0 \\
\hline Nebraska & 15 & 3,066 & 2 & 1.254 & 20 & 168 & 0 & 0 \\
\hline 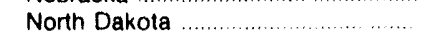 & 12 & 3,856 & 0 & 0 & 5 & 545 & 0 & 0 \\
\hline South Dakota & 6 & 499 & 0 & 0 & 28 & 1,821 & 0 & 0 \\
\hline South Atlantic & 216 & 64,541 & 27 & 23,543 & 457 & 11,952 & 3 & $\cdot$ \\
\hline Delaware & 5 & 931 & 0 & 0 & 0 & 0 & 0 & 0 \\
\hline District of Columbia & 0 & 0 & 0 & 0 & 0 & 0 & 0 & 0 \\
\hline Florida $\ldots \ldots$ & 29 & 10,034 & 5 & 3,830 & 7 & 47 & 0 & 0 \\
\hline 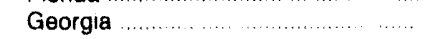 & 39 & 13,104 & 4 & 3,741 & 118 & 2.815 & 0 & 0 \\
\hline Maryland & 15 & 4,617 & 2 & 1,650 & 13 & 428 & 0 & 0 \\
\hline North Carolina & 47 & 12,500 & 5 & 4,639 & 104 & 1.962 & 0 & 0 \\
\hline 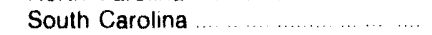 & 24 & 4,812 & 7 & 6,364 & 125 & 3,485 & 0 & 0 \\
\hline Virginia & 24 & 4,215 & 4 & 3,319 & 68 & 3,108 & 3 & $\cdot$ \\
\hline West Virginia & 33 & 14,328 & 0 & 0 & 22 & 108 & 0 & 0 \\
\hline East South Central & 143 & 36,605 & 8 & 8,275 & 205 & 7,477 & 0 & 0 \\
\hline Alabama & 42 & 11,599 & 5 & 4,836 & 89 & 2.934 & 0 & 0 \\
\hline Kentucky & 58 & 14,096 & 0 & 0 & 30 & 795 & 0 & 0 \\
\hline Mississippi & 6 & 2,227 & 1 & 1,143 & 0 & 0 & 0 & 0 \\
\hline Tennessee $\ldots \ldots \ldots \ldots$ & 37 & 8,683 & 2 & 2,296 & 86 & 3.747 & 0 & 0 \\
\hline West South Central & 57 & 31,305 & 7 & 7,332 & 124 & 2,946 & 1 & * \\
\hline Arkansas & 5 & 3.817 & 2 & 1,694 & 40 & 1,293 & 0 & 0 \\
\hline Louisiana & 6 & 3,343 & 2 & 2.006 & 0 & 0 & 0 & 0 \\
\hline Oklahoma & 10 & 4.874 & 0 & 0 & 37 & 1,009 & 0 & 0 \\
\hline Texas $\ldots$ & 36 & 19,271 & 3 & 3,632 & 47 & 644 & 1 & $*$ \\
\hline Mountain & 103 & 28,693 & 3 & 3,810 & 418 & 10,266 & 9 & 39 \\
\hline Arizona & 14 & 5,070 & 3 & 3,810 & 41 & 2,779 & 0 & 0 \\
\hline Colorado & 31 & 4,954 & 0 & 0 & 47 & 1,078 & 0 & 0 \\
\hline Idaho & 0 & 0 & 0 & 0 & 112 & 2,302 & 0 & 0 \\
\hline Montana & 6 & 2,260 & 0 & 0 & 84 & 2,478 & 2 & 13 \\
\hline Nevada $\ldots \ldots \ldots \ldots$ & 8 & 2,692 & 0 & 0 & 17 & 1.031 & 0 & 0 \\
\hline New Mexico & 13 & 3,901 & 0 & 0 & 6 & 59 & 0 & 0 \\
\hline 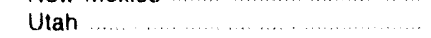 & 12 & 4,271 & 0 & 0 & 82 & 251 & 7 & 27 \\
\hline Wyomıng & 19 & 5,545 & 0 & 0 & 29 & 287 & 0 & 0 \\
\hline Pacific Contiguous & 5 & 1,868 & 6 & 6,514 & 846 & 43,132 & 27 & 1,772 \\
\hline California & 0 & 0 & 4 & 4,310 & 417 & 13,169 & 25 & 1.715 \\
\hline Oregon & 1 & 508 & 1 & 1,104 & 175 & 9.011 & 1 & 11 \\
\hline Washington & 4 & 1,360 & 1 & 1,100 & 254 & 20,952 & $i$ & 46 \\
\hline Pacific Noncontiguous & 5 & 54 & 0 & 0 & 56 & 356 & 3 & $*$ \\
\hline Alaska & 5 & 54 & 0 & 0 & 52 & 352 & 3 & • \\
\hline 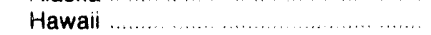 & 0 & 0 & 0 & 0 & 4 & 3 & 0 & 0 \\
\hline U.S. Total & 1,238 & 300,547 & 109 & 98,985 & 3,497 & 93,375 & 70 & 2,207 \\
\hline
\end{tabular}

1 Refers to renewables (excluding hydroelectric) including biomass, geothermal, wind, and photovoltaic

- Net summer capability.

- Value less than 0.5

Notes: -Data are final. -Totals may not equal sum of components because of independent rounding. •Waste heat, waste gases, and waste steam are included in the original primary energy source category (i.e., coal, petroleum, or gas)

Source: Energy Information Administration, Form ElA-860, "Annual Electric Generator Report." 
Table 7. Petroleum-, Gas-, and Dual-Fired Steam Generating Capability at Electric Utilitles by Census Division and State, End of Year, 1992

\begin{tabular}{|c|c|c|c|c|c|c|c|c|}
\hline \multirow{2}{*}{$\begin{array}{c}\text { Census Division } \\
\text { State }\end{array}$} & \multicolumn{2}{|c|}{ Petroloum } & \multicolumn{2}{|c|}{ Gas } & \multicolumn{2}{|c|}{$\begin{array}{c}\text { Dual-Fired } \\
\text { Petroloum/Gas }\end{array}$} & \multicolumn{2}{|c|}{$\begin{array}{l}\text { Total } \\
\text { Petroleum and Gas }\end{array}$} \\
\hline & $\begin{array}{l}\text { Number of } \\
\text { Conerators }\end{array}$ & $\begin{array}{c}\text { Capablilty' } \\
\text { (megawatte) }\end{array}$ & $\begin{array}{l}\text { Number of } \\
\text { Generators }\end{array}$ & $\begin{array}{c}\text { Capablilty' } \\
\text { (mogawatts) }\end{array}$ & $\begin{array}{l}\text { Number of } \\
\text { Cenerators }\end{array}$ & $\begin{array}{l}\text { Capability' } \\
\text { (megawatta) }\end{array}$ & $\begin{array}{l}\text { Number of } \\
\text { Ganerators }\end{array}$ & $\begin{array}{l}\text { Capabllity' } \\
\text { (megawatts) }\end{array}$ \\
\hline 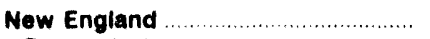 & 44 & $\mathbf{5 , 5 3 3}$ & 2 & 105 & 22 & 3,088 & 68 & 8,726 \\
\hline 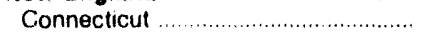 & 19 & 2,288 & 0 & 0 & 2 & 528 & 21 & 2,816 \\
\hline Maine & 13 & 1,042 & 0 & 0 & 0 & 0 & 13 & 1,042 \\
\hline Massachusetts & 12 & 2,203 & 2 & 105 & 16 & 2,026 & 30 & 4,334 \\
\hline 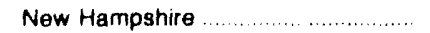 & 0 & 0 & 0 & 0 & 1 & 406 & 1 & 406 \\
\hline Rhode island & 0 & 0 & 0 & 0 & 3 & 128 & 3 & 128 \\
\hline Vermont & 0 & 0 & 0 & 0 & 0 & 0 & 0 & 0 \\
\hline Middle Atlantic & 46 & 9,238 & 43 & 8,627 & 11 & 2,303 & 100 & 20,168 \\
\hline New Jersey & 15 & 1,286 & 14 & 1,916 & 3 & 117 & 32 & 3.319 \\
\hline (. & 18 & 4,692 & 28 & 6,510 & 8 & 2,186 & 54 & 13,388 \\
\hline Pennsylvania & 13 & 3,260 & 1 & 201 & 0 & 0 & 14 & 3,461 \\
\hline Eaet North Central & 24 & 5,071 & 20 & 702 & 9 & 1,069 & 53 & 6,842 \\
\hline 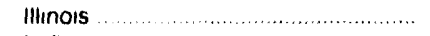 & 13 & 3,116 & 8 & 180 & 6 & 166 & 27 & 3,461 \\
\hline 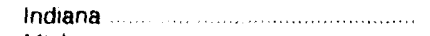 & 5 & 193 & 2 & 120 & 0 & 0 & 7 & 313 \\
\hline Ohio $\ldots \ldots \ldots \ldots$ & 1 & 64 & 1 & 17 & 0 & 0 & 2 & 81 \\
\hline Wisconsin $\ldots \ldots \ldots$ & 0 & 0 & 6 & 92 & 0 & 0 & 6 & 92 \\
\hline West North Central & 5 & 72 & 77 & 2,509 & 5 & 58 & 87 & 2,639 \\
\hline lowa $\ldots \ldots \ldots$ & 3 & 22 & 6 & 121 & 0 & 0 & 9 & 142 \\
\hline$\ldots \ldots \ldots \ldots \ldots$ & 0 & 0 & 45 & 1,890 & 3 & 22 & 48 & 1,912 \\
\hline 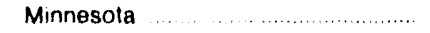 & 2 & 50 & 9 & 86 & 0 & 0 & 11 & 136 \\
\hline Missourı $\ldots \ldots \ldots \ldots \ldots \ldots \ldots$ & 0 & 0 & 5 & 90 & 2 & 36 & 7 & 126 \\
\hline 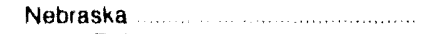 & 0 & 0 & 11 & 259 & 0 & 0 & 11 & 259 \\
\hline North Dakota $\ldots . . . . . \ldots \ldots \ldots \ldots \ldots \ldots \ldots \ldots \ldots$ & 0 & 0 & 0 & 0 & 0 & 0 & 0 & 0 \\
\hline South Dakota $\ldots . . . . . . . . . . . . . . . . . .$. & 0 & 0 & 1 & 64 & 0 & 0 & 1 & 64 \\
\hline South Atlantic $\ldots \ldots \ldots \ldots \ldots \ldots$ & 50 & 6,643 & 63 & 5,809 & 40 & 8,248 & 153 & 20,700 \\
\hline Delaware & 1 & 84 & 0 & 0 & 4 & 576 & 5 & 660 \\
\hline District of Columbia & 2 & 550 & 0 & 0 & 0 & 0 & 2 & 550 \\
\hline Flonida & 26 & 3,833 & 51 & 5.314 & 24 & 5,109 & 101 & 14,257 \\
\hline Georgia & 2 & 115 & 5 & 98 & 5 & 352 & 12 & 565 \\
\hline 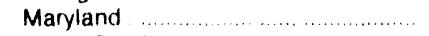 & 12 & 1,012 & 1 & 137 & 3 & 1,302 & 16 & 2.451 \\
\hline North Carolina $\ldots \ldots \ldots \ldots \ldots \ldots \ldots$ & 2 & 28 & 1 & 68 & 0 & 0 & 3 & 96 \\
\hline South Carolına & 2 & 92 & 3 & 69 & 3 & 91 & 8 & 252 \\
\hline Virgınıa $\ldots \ldots \ldots \ldots \ldots \ldots \ldots$ & 3 & 929 & 2 & 122 & 1 & 818 & 6 & 1,869 \\
\hline Kentucky $\ldots \ldots \ldots \ldots$ & 2 & 58 & i & 115 & 0 & 0 & 3 & 173 \\
\hline 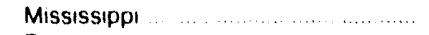 & 0 & 0 & 29 & 2,562 & 3 & 863 & 32 & 3,426 \\
\hline Tennessee & 0 & 0 & 0 & 0 & 0 & 0 & 0 & 0 \\
\hline West South Central $\ldots \ldots \ldots \ldots$ & 3 & 298 & 321 & 55,643 & 0 & 0 & 324 & 55,941 \\
\hline 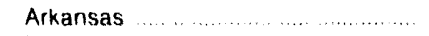 & 0 & 0 & 16 & 2,515 & 0 & 0 & 16 & 2.515 \\
\hline Loulsiana $\ldots \ldots \ldots \ldots$ & 2 & 212 & 74 & 10,948 & 0 & 0 & 76 & 11,160 \\
\hline Oklahoma & 0 & 0 & 33 & 6.127 & 0 & 0 & 33 & 6,127 \\
\hline Texas $\ldots \ldots \ldots$ & 1 & 86 & 198 & 36,054 & 0 & 0 & 199 & 36,140 \\
\hline Mountain $\ldots \ldots \ldots \ldots \ldots \ldots \ldots \ldots$ & 0 & 0 & 72 & 3,698 & 0 & 0 & 72 & 3,698 \\
\hline Arizona & 0 & 0 & 21 & 1,509 & 0 & 0 & 21 & 1,509 \\
\hline Colorado & 0 & 0 & 15 & 26.3 & 0 & 0 & 15 & 263 \\
\hline Idaho $\ldots \ldots \ldots \ldots$ & 0 & 0 & 0 & 0 & 0 & 0 & 0 & 0 \\
\hline Montana $\ldots \ldots \ldots \ldots$ & 0 & 0 & 1 & 70 & 0 & 0 & 1 & 70 \\
\hline 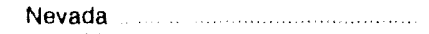 & 0 & 0 & 9 & 725 & 0 & 0 & 9 & 725 \\
\hline 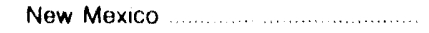 & 0 & 0 & 24 & 966 & 0 & 0 & 24 & 966 \\
\hline Utah $\ldots \ldots$ & 0 & 0 & 2 & 166 & 0 & 0 & 2 & 166 \\
\hline Wyomıng $\ldots \ldots \ldots \ldots$ & 0 & 0 & 0 & 0 & 0 & 0 & 0 & 0 \\
\hline Pacific Contiguous $\ldots \ldots \ldots \ldots$ & 2 & 86 & 111 & 20,712 & 13 & 1,256 & 126 & 22,053 \\
\hline California & 0 & 0 & 110 & 20,563 & 13 & 1,256 & 123 & 21,819 \\
\hline Oregon & 0 & 0 & 1 & 148 & 0 & 0 & 1 & 148 \\
\hline 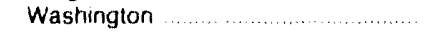 & 2 & 86 & 0 & 0 & 0 & 0 & 2 & 86 \\
\hline Pacific Noncontiguous $\ldots . . . . . . . . . . .$. & 25 & 1,152 & 2 & 85 & 0 & 0 & 27 & 1,237 \\
\hline Alaska $\ldots \ldots$ & 0 & 0 & 2 & 85 & 0 & 0 & 2 & 85 \\
\hline 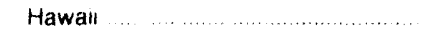 & 25 & 1,152 & 0 & 0 & 0 & 0 & 25 & 1,152 \\
\hline U.S. Total & 201 & 28,151 & 742 & 100,618 & 103 & 16,885 & 1,046 & 145,654 \\
\hline
\end{tabular}

1 Nel summer capability.

Notes: Data are final. - Totals may not equal sum of components because of independent rounding •Waste heat, waste gases, and waste steam are included in the original primary energy source category (i.e., coal, petroleum, or gas)

Source: Energy information Administration, Form ElA-860, "Annual Electric Generator Report." 
Table 8. Petroleum-, Gas-, and Dual-Fired Gas Turbine/Internal Combustion Generating Capability at Electric Utilities by Census Division and State, End of Year, 1992

\begin{tabular}{|c|c|c|c|c|c|c|c|c|}
\hline \multirow{2}{*}{$\begin{array}{c}\text { Census Divielon } \\
\text { state }\end{array}$} & \multicolumn{2}{|c|}{ Potroloum } & \multicolumn{2}{|c|}{ Oas } & \multicolumn{2}{|c|}{$\begin{array}{c}\text { Dustfired } \\
\text { Potrobum/Case }\end{array}$} & \multicolumn{2}{|c|}{$\begin{array}{c}\text { Total } \\
\text { Potroleum and Gas }\end{array}$} \\
\hline & $\begin{array}{l}\text { Number of } \\
\text { Coneratore }\end{array}$ & $\begin{array}{l}\text { Capablilty' } \\
\text { (megawatts) }\end{array}$ & $\begin{array}{l}\text { Number of } \\
\text { Conerators }\end{array}$ & $\begin{array}{l}\text { Capabillty' } \\
\text { (meanwatte) }\end{array}$ & $\begin{array}{l}\text { Number of } \\
\text { Ceneretore }\end{array}$ & $\begin{array}{l}\text { Capabillity' } \\
\text { (megawatts) }\end{array}$ & $\begin{array}{l}\text { Number of } \\
\text { Cenerators }\end{array}$ & $\begin{array}{l}\text { Capablilty' } \\
\text { (mogawatts) }\end{array}$ \\
\hline 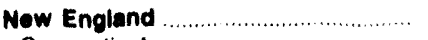 & 182 & 1,127 & 9 & 114 & 14 & 395 & 205 & 1,636 \\
\hline 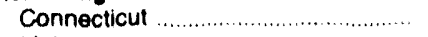 & 24 & 375 & 0 & 0 & 0 & 0 & 24 & 375 \\
\hline Maine & 41 & 73 & 0 & 0 & 0 & 0 & 41 & 73 \\
\hline 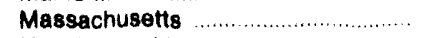 & 70 & 465 & 9 & 114 & 13 & 378 & 92 & 957 \\
\hline 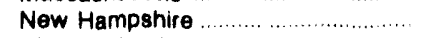 & 4 & 66 & 0 & 0 & 1 & 17 & 5 & 83 \\
\hline 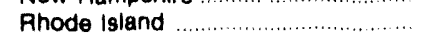 & 17 & 27 & 0 & 0 & 0 & 0 & 17 & 27 \\
\hline 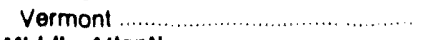 & 26 & 120 & 0 & 0 & 0 & 0 & 26 & 120 \\
\hline 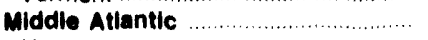 & 236 & 5,672 & 124 & 4,674 & 10 & 52 & 370 & 10,397 \\
\hline 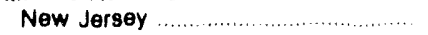 & 28 & 2,002 & 43 & 2,638 & 1 & 23 & 72 & 4,663 \\
\hline . & 112 & 2,085 & 70 & 1,794 & 9 & 28 & 191 & 3,908 \\
\hline Pennsylvania ........... & 96 & 1,585 & 11 & 242 & 0 & 0 & 107 & 1.827 \\
\hline East North Central & 393 & 3,003 & 248 & 3,026 & 79 & 722 & 720 & 6,751 \\
\hline Illinois & 78 & 591 & 115 & 964 & 28 & 56 & 221 & 1,610 \\
\hline 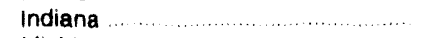 & 26 & 287 & 16 & 580 & 5 & 11 & 47 & 878 \\
\hline Michigan $\ldots \ldots \ldots \ldots$ & 143 & 530 & 70 & 780 & 18 & 53 & 231 & 1,362 \\
\hline Ohio $\ldots \ldots \ldots \ldots$ & 62 & 809 & 30 & 396 & 13 & 419 & 105 & 1,625 \\
\hline Wisconsin & 84 & 787 & 17 & 307 & 15 & 183 & 116 & 1,277 \\
\hline West North Central & 600 & 3,682 & 409 & 2,966 & 384 & 802 & 1,393 & 7,450 \\
\hline lowa & 161 & 479 & 53 & 686 & 107 & 235 & 321 & 1,400 \\
\hline 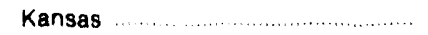 & 58 & 317 & 133 & 882 & 163 & 275 & 354 & 1,473 \\
\hline Minnesota $\ldots \ldots \ldots \ldots$ & 112 & 839 & 46 & 219 & 39 & 136 & 197 & 1.195 \\
\hline 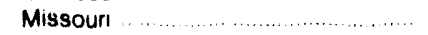 & 137 & 1,390 & 69 & 730 & 51 & 120 & 257 & 2,240 \\
\hline Nebraska & 81 & 300 & 98 & 372 & 20 & 34 & 199 & 706 \\
\hline (2., & 26 & 65 & 2 & 10 & 0 & 0 & 28 & 75 \\
\hline South Dakota. & 25 & 291 & 8 & 68 & 4 & 2 & 37 & 361 \\
\hline South Atiantic. & 249 & 5,783 & 148 & 4,475 & 87 & 2,247 & 484 & 12,505 \\
\hline Delaware & 13 & 122 & 3 & 336 & 1 & 33 & 17 & 491 \\
\hline 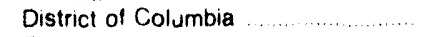 & 2 & 256 & 0 & 0 & 0 & 0 & 2 & 256 \\
\hline 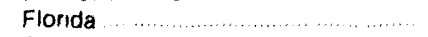 & 117 & 3,033 & 97 & 2,020 & 9 & 190 & 223 & 5,242 \\
\hline Georgia $\ldots \ldots \ldots \ldots$ & 22 & 942 & 1 & 5 & 10 & 227 & 33 & 1.174 \\
\hline 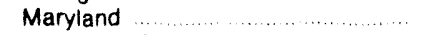 & 43 & 719 & 20 & 990 & 2 & 7 & 65 & 1,716 \\
\hline North Carolına & 16 & 273 & 8 & 178 & 17 & 500 & 41 & 951 \\
\hline South Carolina & 8 & 182 & 14 & 692 & 30 & 529 & 52 & 1,402 \\
\hline Virginia .............. & 27 & 245 & 5 & 255 & 18 & 761 & 50 & 1,261 \\
\hline West Virginia & 1 & 12 & 0 & 0 & 0 & 0 & 1 & 12 \\
\hline East South Central & 31 & 1,205 & 48 & 1,298 & 3 & 50 & 82 & 2,552 \\
\hline Alabama $\ldots \ldots \ldots \ldots$ & 1 & 18 & 9 & 494 & 0 & 0 & 10 & 512 \\
\hline Kentucky & 8 & 76 & 8 & 110 & 3 & 50 & 19 & 236 \\
\hline 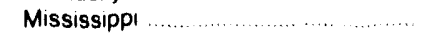 & 2 & 31 & 11 & 206 & 0 & 0 & 13 & 237 \\
\hline 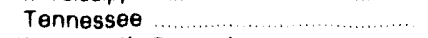 & 20 & 1.080 & 20 & 488 & 0 & 0 & 40 & 1.568 \\
\hline West South Central. & 60 & 293 & 201 & 4,021 & 33 & 51 & 294 & 4,365 \\
\hline Arkansas & 19 & 204 & 9 & 105 & 11 & 11 & 39 & 320 \\
\hline Louisiana & 1 & 16 & 24 & 174 & 0 & 0 & 25 & 190 \\
\hline Oklahoma & 11 & 30 & 46 & 814 & 16 & 28 & 73 & 871 \\
\hline Texas & 29 & 42 & 122 & 2,929 & 6 & 12 & 157 & 2,983 \\
\hline Mountain & 98 & 384 & 93 & 2,488 & 20 & 295 & 209 & 3,167 \\
\hline Arizona $\ldots \ldots \ldots$ & 2 & 75 & 37 & 1,727 & 4 & 3 & 43 & 1,805 \\
\hline 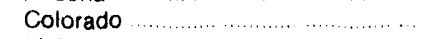 & 42 & 141 & 20 & 125 & 12 & 80 & 74 & 346 \\
\hline Idaho & 3 & 56 & 0 & 0 & 0 & 0 & 3 & 56 \\
\hline Montana . . . . & 0 & 0 & 2 & 50 & 0 & 0 & 2 & 50 \\
\hline Nevada & 20 & 48 & 7 & 411 & 4 & 212 & 31 & 671 \\
\hline 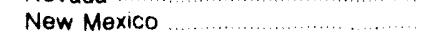 & 6 & 24 & 5 & 113 & 0 & 0 & 11 & 137 \\
\hline Utah & 15 & 26 & 22 & 62 & 0 & 0 & 37 & 88 \\
\hline Wyoming & 8 & 15 & 0 & C & 0 & 0 & 8 & 15 \\
\hline Pacific Contiguous & 42 & 636 & 59 & 2,781 & 8 & 465 & 109 & 3,881 \\
\hline Californa & 32 & 542 & 46 & 1,846 & 6 & 362 & 84 & 2,750 \\
\hline 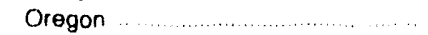 & 2 & 6 & 6 & 345 & 2 & 103 & 10 & 454 \\
\hline Washington & 8 & 88 & 7 & 590 & 0 & 0 & 15 & 678 \\
\hline Pacific Noncontiguous & 415 & 886 & 26 & 681 & 1 & 38 & 442 & 1,585 \\
\hline Alaska & 349 & 462 & 26 & 681 & 1 & 38 & 376 & 1,181 \\
\hline Hawall ... & 66 & 404 & 0 & 0 & 0 & 0 & 66 & 404 \\
\hline U.S. Total & 2,304 & 22,649 & 1,365 & 26,525 & 639 & 5,116 & 4,308 & 54,291 \\
\hline
\end{tabular}

' Net summer capability.

Notes -Data are final. - Totals may not equal sum of components because of independent rounding. -Waste heat, waste gases, and waste steam are included in the original primary energy source category (i.e., Coal, petroleum, or gas).

Source Energy information Administration, Form EIA-860, "Annual Electric Generator Report." 
Table 9. Planned Capablity Additions at Electric Utilities by Energy Source, North American Electric Rellability Councll Region, and Hawall, 1993 Through 2002

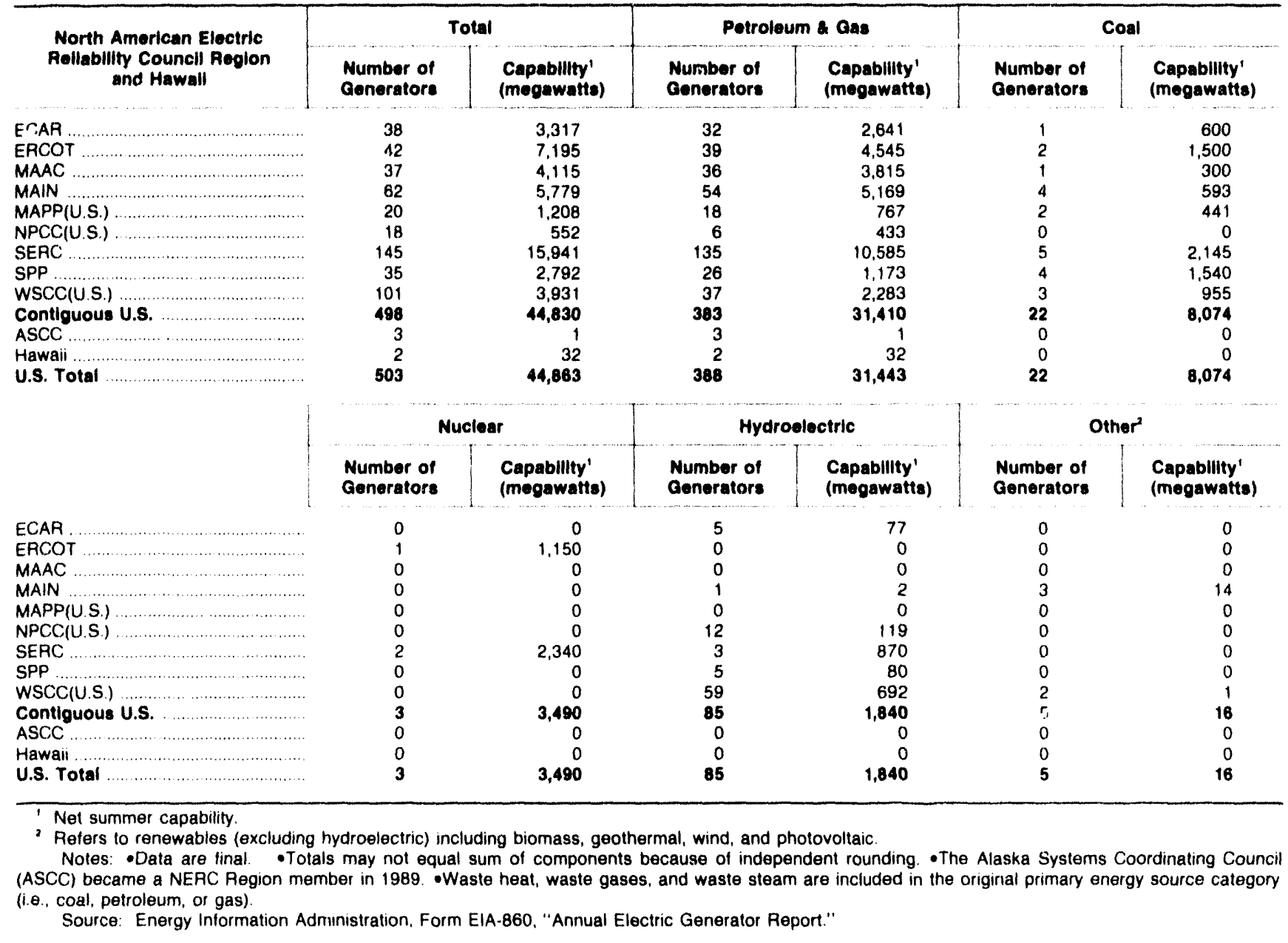


Table 10. Planned Capability Additions at Electric Utilities by Energy Source, Census Division, and State, 1993 Through 2002

\begin{tabular}{|c|c|c|c|c|c|c|}
\hline \multirow{2}{*}{$\begin{array}{l}\text { Census Divialon } \\
\text { and State }\end{array}$} & \multicolumn{2}{|c|}{ Total } & \multicolumn{2}{|c|}{ Potroleum Cas } & \multicolumn{2}{|c|}{ Coal } \\
\hline & $\begin{array}{l}\text { Number of } \\
\text { Cenerators }\end{array}$ & $\begin{array}{l}\text { Capability' } \\
\text { (mogawatts) }\end{array}$ & $\begin{array}{l}\text { Number of } \\
\text { Cenerators }\end{array}$ & $\begin{array}{l}\text { Capablilty' } \\
\text { (mogawatts) }\end{array}$ & $\begin{array}{l}\text { Number of } \\
\text { Generators }\end{array}$ & $\begin{array}{l}\text { Capablilty' } \\
\text { (megawatts) }\end{array}$ \\
\hline 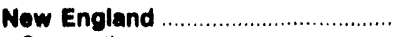 & 10 & 340 & 3 & 291 & 0 & $\mathbf{0}$ \\
\hline 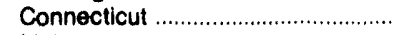 & 0 & 0 & 0 & 0 & 0 & 0 \\
\hline 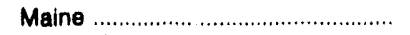 & 5 & 47 & 0 & 0 & 0 & 0 \\
\hline 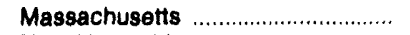 & 0 & 0 & 0 & 0 & 0 & 0 \\
\hline New Hampshire .................................. & 0 & 0 & 0 & 0 & 0 & 0 \\
\hline 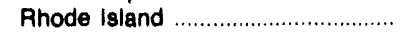 & 3 & 291 & 3 & 291 & 0 & 0 \\
\hline 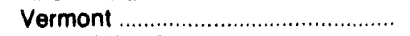 & 2 & 2 & 0 & 0 & 0 & 0 \\
\hline 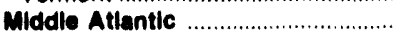 & 22 & 2,276 & 17 & 2,206 & 0 & 0 \\
\hline New Jersey ........................................ & 14 & 2,064 & 14 & 2,064 & 0 & 0 \\
\hline 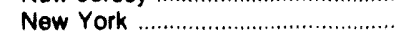 & 8 & 212 & 3 & 142 & 0 & 0 \\
\hline 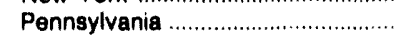 & 0 & 0 & 0 & 0 & 0 & 0 \\
\hline 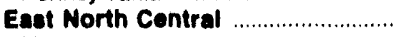 & 81 & 7,199 & 71 & 6,588 & 4 & 593 \\
\hline 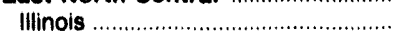 & 26 & 3,239 & 26 & 3,239 & 0 & 0 \\
\hline Indiana & 12 & 961 & 12 & 961 & 0 & 0 \\
\hline 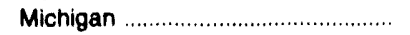 & 1 & 1 & 1 & 1 & 0 & 0 \\
\hline Ohio & 12 & 647 & 10 & 645 & 0 & 0 \\
\hline 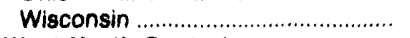 & 30 & 2,351 & 22 & 1.742 & 4 & 593 \\
\hline 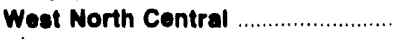 & 52 & 3,734 & 46 & 1,753 & 6 & 1,981 \\
\hline 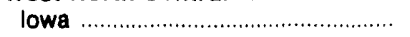 & 10 & 326 & 9 & 308 & 1 & 18 \\
\hline 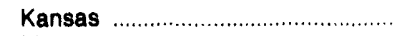 & 13 & 712 & 12 & 32 & 1 & 680 \\
\hline Minnesota & 4 & 174 & 4 & 174 & 0 & 0 \\
\hline 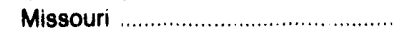 & 19 & 1,814 & 16 & 954 & 3 & 860 \\
\hline 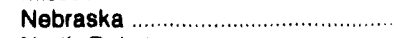 & 5 & 285 & 5 & 285 & 0 & 0 \\
\hline 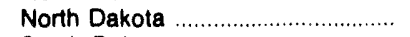 & 1 & 423 & 0 & 0 & 1 & 423 \\
\hline South Dakota & 0 & 0 & 0 & 0 & 0 & 0 \\
\hline 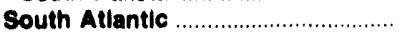 & 138 & 13,686 & 129 & 10,371 & 6 & 2,445 \\
\hline 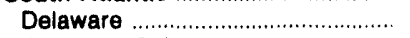 & 3 & 131 & 3 & 131 & 0 & 0 \\
\hline District of Columbia ............................. & 0 & 0 & 0 & 0 & 0 & 0 \\
\hline Florida & 38 & 3,914 & 37 & 3,476 & 1 & 438 \\
\hline 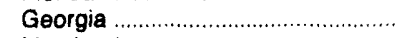 & 42 & 3,718 & 39 & 2,848 & 0 & 0 \\
\hline 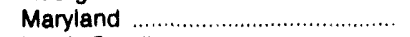 & 20 & 1,919 & 19 & 1,619 & 1 & 300 \\
\hline North Carolina & 16 & 1,266 & 16 & 1,266 & 0 & 0 \\
\hline 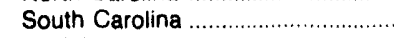 & 11 & 1,723 & 9 & 798 & 2 & 925 \\
\hline Virginia & 8 & 1,013 & 6 & 231 & 2 & 782 \\
\hline West Virginia & 0 & 0 & 0 & 0 & 0 & 0 \\
\hline 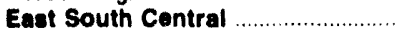 & 43 & 6,014 & 37 & 2,999 & 1 & 600 \\
\hline Alabama & 23 & 1,638 & 23 & 1,638 & 0 & 0 \\
\hline 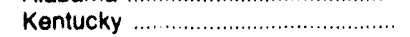 & 13 & 1,709 & 9 & 1,034 & 1 & 600 \\
\hline 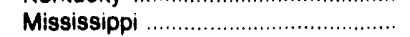 & 5 & 328 & 5 & 328 & 0 & 0 \\
\hline 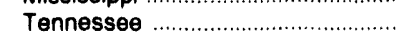 & 2 & 2,340 & 0 & 0 & 0 & 0 \\
\hline 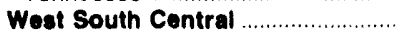 & 53 & 7,764 & 45 & 5,035 & 2 & 1,500 \\
\hline Arkansas & 4 & 115 & 1 & 82 & 0 & 0 \\
\hline 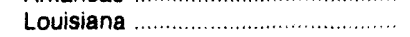 & 0 & 0 & 0 & 0 & 0 & 0 \\
\hline Oklahoma & 3 & 220 & 1 & 174 & 0 & 0 \\
\hline Texas & 46 & 7.429 & 43 & 4,779 & 2 & 1.500 \\
\hline 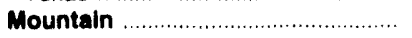 & 55 & 2,621 & 21 & 1,292 & 3 & 955 \\
\hline Arizona & 8 & 538 & 2 & 131 & $i$ & 360 \\
\hline Colorado & 4 & 609 & 1 & 66 & 1 & 515 \\
\hline 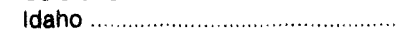 & 6 & 99 & 0 & 0 & 0 & 0 \\
\hline 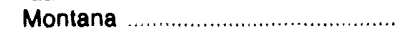 & 8 & 191 & 0 & 0 & 0 & 0 \\
\hline Nevada & 14 & 1,064 & 14 & 1,064 & 0 & 0 \\
\hline 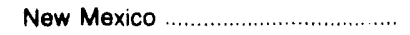 & 2 & 28 & 2 & 28 & 0 & 0 \\
\hline Utah & 12 & 10 & 2 & 2 & 0 & 0 \\
\hline 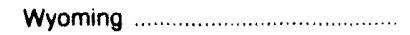 & 1 & 80 & 0 & 0 & 1 & 80 \\
\hline Pacific Contiguous ............................. & 44 & 1,195 & 14 & 876 & 0 & 0 \\
\hline California & 28 & 624 & 10 & 400 & 0 & 0 \\
\hline 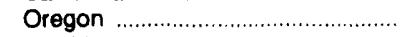 & 3 & 408 & 3 & 408 & 0 & 0 \\
\hline Washington & 13 & 163 & 1 & 67 & 0 & 0 \\
\hline Pacific Noncontiguous ................... & 5 & 33 & 5 & 33 & 0 & 0 \\
\hline Alaska & 3 & 1 & 3 & 1 & 0 & 0 \\
\hline 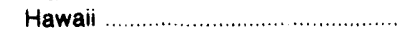 & 2 & 32 & 2 & 32 & 0 & 0 \\
\hline U.S. Total & 503 & 44,863 & 388 & 31,443 & 22 & 8,074 \\
\hline
\end{tabular}

' Net summer capability.

Notes: -Data are final. - Totals may not equal sum of components because of independent rounding. •Waste heat, waste gases, and waste steam are included in the original primary energy source category (i.e., coal, petroleum, or gas).

Source: Energy Information Administration, Form EIA-860, "Annual Electric Generator Report." 
Table 10. Planned Capability Additions at Electric Utilities by Energy Source, Census Division, and State, 1993 Through 2002 (Continued)

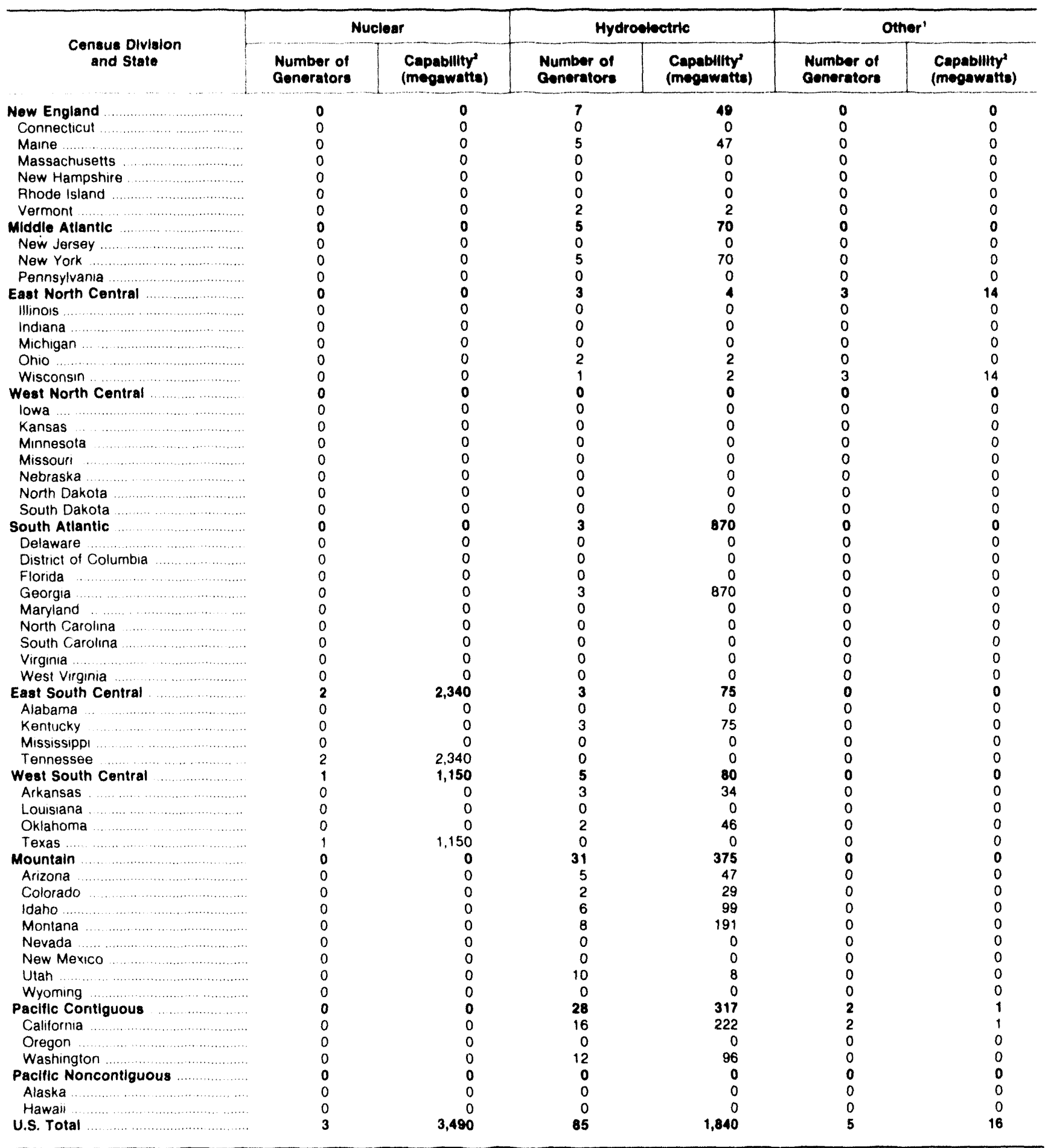

- Relers to renewables (excluding hydroelectric) including biomass, geothermal, wind, and photovoltaic.

Net summer capability.

Notes: -Data are final. -Totals may not equal sum of components because of independent rounding. - Waste heat, waste gases, and waste steam are included in the original primary energy source category (i.e., coal, petroleum, or gas).

Source: Energy information Administration, Form ElA.860. "Annual Electric Generator Report." 


\section{Net Generation from U.S. Electric Utilities}

This chapter provides summary statistics on the amount of electricity produced by electric utilities in the United States. The different energy sources used by electric utilities to produce electric power are also discussed in this chapter.

\section{Background}

The production of electricity is generally referred to as generation, and is measured in kilowatthours. Gross generation is the amount of power produced by an electric power plant (station), measured at the terminals of the plant (that is, prior to the point at which the power leaves the station and is available to the system). Some of the electric power generated at a power plant is used to operate equipment at the plant. Power used at the plant generally ranges between 1 percent (for hydroelectric units) and 7 percent (for steam-electric units). Net generation is the power available to the system (gross generation less use at the plant); however, it is greater than that available to consumers due to losses during transmission and distribution (approximately 8 to 9 percent). Net generation is the measure used for electric power production by electric utilities in this report.

\section{Generation from Fossil Fuels}

Coal. Historically, most generation of electricity in the United States has been from coal. After the Arab oil embargo of 1973, concerns over the availability of petroleum imports, increasing petroleum costs, and curtailments of natural gas made coal-fired generation even more important. In 1978, the passage of the Powerplant and Industrial Fuel Use and the Natural Gas Policy Acts encouraged further use of coal by electric utilities. Although both Federal and State environmental laws and regulations existed during the 1970 's, renewed interest in environmental issues raised concerns about electric power plant emissions, particularly from those burning coal. The Clean Air Act Amendments of 1990 established a goal of a 10-millionton reduction in sulfur dioxide emissions and a 2-million-ton reduction in nitrogen oxide emissions by 2000 from 1980 levels (see the chapter on Environmental Statistics). Coal-fired generation continues to provide more than one-half the total net generation of electricity by electric utilities in the Nation. Most of the electricity production from coal by electric utilities occurs in the East North Central and South Atlantic Census Divisions where substantial amounts of coal are mined.

Petroleum. During the early 1970 's, electric utilities used petroleum extensively to generate electricity. However, after the 1973 embargo by the Organization of Petroleum Exporting Countries (OPEC) on petroleum exports to the United States, petroleum prices rose sharply. Further price increases occurred in 1979 and 1980 following the Iranian revolution and subsequent reductions in Iranian petroleum exports. Consequently during the past decade, utilities have not built large, petroleum-fired steam units. In addition, many utilities have either converted steam units to coal or switched fuels where dual-fired capability exists. Most of the utilities that still rely heavily on petroleum to generate electricity are located along the eastern seaboard and in California.

Gas. The demand for gas (primarily natural gas) to heat homes and serve business and industry has historically taken priority over demand from electric utilities under both Federal and State regulations. In the 1970's, many utilities were on occasion denied gas when available pipelines reached capacity in serving heating demand during the months from November to March (the peak heating season). By the middle 1970's, curtailments to electric utilities also occasionally occurred during the nonheating season as producers conserved supply in preparation for heating season demand. In the face of an attractive interstate price structure but deprived of supplies during many months of the year, utilities in the 1970's used relatively less-expensive gas when it was available, then switched to other more expensive fuels when gas supplies were curtailed. Gas became more available to utilities with the passage of the Natural Gas Policy Act of 1978 and more frequent exemptions from the gas-use restrictions of the Powerplant and Industrial Fuel Use Act (Fuel Use Act) of 1978. Amendments to the Fuel Use Act in 1987 created potential for additional use of gas. These amendments eased restrictions on the use of gas by removing a legal requirement to obtain an exemption for the construction of new gas-fired generating capability. The West South Central Census Division, where most of the gas production in the Nation occurs, supplies more than half of the gas-fired generation in the country. 


\section{Nuclear-Powered Generation}

Generation from nuclear power has generally increased since the 1950's, and this trend continues. Since 1984, nuclear plants have provided the second largest share of total U.S. generation of electricity, after coalfired plants. Although no new nuclear units have been ordered since 1978 and units ordered after 1974 were not built, many units that were under construction have either been completed and entered service or will enter service in the near future. Licensing delays, questions about radioactive waste disposal, and concern about nuclear plant safety have slowed these units from entering service and are still major obstacles to additional growth in the use of this energy source for generating electricity. Most of the nuclear-powered generation comes from the Middle Atlantic, East North Central, and South Atlantic Census Divisions (where over 60 percent of the nuclear units in the country are located.)

\section{Generation from Renewable Fuels}

Hydroelectric. Water is currently the leading renewable energy source used by electric utilities to generate electric power. Hydroelectric plants operate where suitable waterways are available; many of the best of these sites have already been developed. Generating electricity using water has several advantages. The major advantage is that water, a renewable resource, is a source of cheap power. In addition, because there is no fuel combustion, there is little air pollution in comparison with fossil-fuel plants and limited thermal pollution compared with nuclear plants. Like other energy sources, the use of water for generation has limirations, including environmental impacts caused by damming rivers and streams, which affects the habitats of the local plant, fish, and animal life. Over 60 percent of the hydroelectric power in the United States is generated in the Pacific and Rocky Mountain States.

Other Sources. Other renewable resources -geothermal (heat energy beneath the surface of the earth), wood, waste, wind, and the sun (solar) .. are energy sources that are constantly replenished. These energy sources have received increased attention in recent years, but a limited number of such generating facilities are in use today. Currently, renewable resources (other than water) supply less than 1 percent of the electricity generated by electric utilities. Most of the electricity produced from this category is from geothermal power. Electric utilities currently operate geothermal plants in two States (California and Utah). The Geysers, operated by the Pacific Gas and Electric Company, is the largest geothermal plant in the Nation. Only a few utilities operate units that produce electricity from wind and solar energy. The largest share of the electricity from these energy sources is produced from facilities in California. Wood and waste resources can be used to replace fossil fuels in utility boilers. To date, just a few electric generating units have been built that use wood or waste products as a primary fuel.

\section{Data Sources}

The data in the following tables are aggregated at national, regional, and State levels for the period 1988 through 1992. Data in the tables were obtained from the Form EIA-759, "Monthly Power Plant Report," which is used to collect monthly data from all operators of electric utilities (approximately 750) in the United States. More detailed statistics from the Form EIA-759 are published in the Electric Power Monthly. ${ }^{24}$

Table 11. Net Generation from U.S. Electric Utilities by Energy Source, 1988 Through 1992 (Million Kilowatthours)

\begin{tabular}{|c|c|c|c|c|c|}
\hline Energy Source & 1992 & 1991 & 1990 & 1989 & 1988 \\
\hline Coal ........... & $1,575,895$ & $1,55 t, 167$ & $1,559,606$ & $1,553,661$ & $1,540,653$ \\
\hline Petroleum' & 88,916 & 111,463 & 117,017 & 158,318 & 148,900 \\
\hline 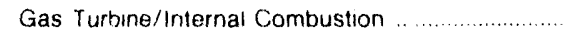 & 2,871 & 3,287 & 3,615 & 7.207 & 5,099 \\
\hline Gas $\ldots \ldots$ & 263,872 & 264,172 & 264,089 & 266,598 & 252,801 \\
\hline 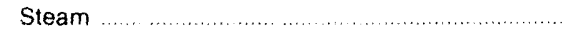 & 245,612 & 245,880 & 245,901 & 245,057 & 236,280 \\
\hline Gas Turbine/Internal Combustion & 18,260 & 18,291 & 18,189 & 21.542 & 16,521 \\
\hline Nuclear & 618,776 & 612,565 & 576,862 & 529,355 & 526,973 \\
\hline Other $^{2} \ldots \ldots \ldots \ldots \ldots$ & 10,200 & 10,137 & 10,651 & 11,309 & 11,984 \\
\hline U.S. Total ................. & $2,797,219$ & $2,825,023$ & $2,808,151$ & $2,784,304$ & $2,704,250$ \\
\hline
\end{tabular}

Includes petroleum coke

- Reters to renewables (excluding hydroelectric) including biomass, geothermal, wind, and photovoltaic Notes: - Oata are final. - Totals may not equal sum of components because of independent rounding. Source: Energy Information Administration, Form EIA.759, "Monthily Power Plant Report." 
Table 12. Net Generation from Electric Utilities by Selected Prime Mover, Census Division, and State, 1992 and 1991

(Million Kilowatthours)

\begin{tabular}{|c|c|c|c|c|c|c|}
\hline \multirow{2}{*}{$\begin{array}{c}\text { Consus Division } \\
\text { State }\end{array}$} & \multicolumn{2}{|c|}{ Total } & \multicolumn{2}{|c|}{ Fossll Steam } & \multicolumn{2}{|c|}{ Gas Turbine/Internal Combustion } \\
\hline & 1992 & 1991 & 1992 & 1991 & 1992 & 1991 \\
\hline New England .................... & 84,585 & 87,008 & 41,111 & 46,912 & 575 & 988 \\
\hline 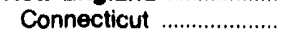 & 25,154 & 23,552 & 7,638 & 10,452 & 11 & 24 \\
\hline 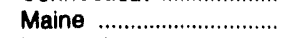 & 8,335 & 9,519 & 1,261 & 1,267 & $\cdot$ & 2 \\
\hline Massachusetts ............... & 32,838 & 35,802 & 27,429 & 30,207 & 553 & 946 \\
\hline New Hampshire .............. & 13,451 & 12,705 & 4,618 & 4,728 & 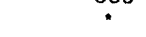 & 1 \\
\hline Rhode Island ..................... & 109 & 171 & 101 & 162 & 8 & 10 \\
\hline Vermont & 4,698 & 5,259 & 64 & 96 & 2 & 4 \\
\hline Middle Atlantic ............... & 309,430 & 325,473 & 175,750 & 187,169 & 1,126 & 2,167 \\
\hline 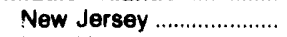 & 31,167 & 37,029 & 8,961 & 11,004 & 749 & 1,373 \\
\hline 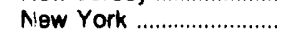 & 112,229 & 126,077 & 62,172 & 72,080 & 309 & 643 \\
\hline Pennsylvania ..................... & 166,034 & 162,367 & 104,617 & 104,085 & 68 & 150 \\
\hline East North Central ......... & 487,563 & 500,461 & 364,313 & 371,104 & 321 & 469 \\
\hline 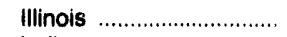 & 124,824 & 127,851 & 50,998 & 55,879 & 24 & 54 \\
\hline 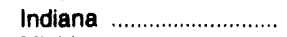 & 97,300 & 98,200 & 96,716 & 97,731 & 21 & 70 \\
\hline 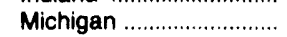 & 82,679 & 94,567 & 62,726 & 66,444 & 228 & 247 \\
\hline Ohio & 136,297 & 132,694 & 120,907 & 117,390 & 30 & $2 B$ \\
\hline Wisconsin & 46,464 & 47.149 & 32,967 & 33,660 & 17 & 71 \\
\hline West North Central ........ & 212,828 & 221,171 & 162,584 & 170,532 & 345 & 754 \\
\hline lowa & 29,427 & 31,228 & 24,994 & 26,049 & 32 & 130 \\
\hline 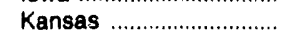 & 31,764 & 32,315 & 23,076 & 26,056 & 197 & 391 \\
\hline Minnesota & 37.784 & 40,428 & 25,420 & 27,139 & 32 & 50 \\
\hline 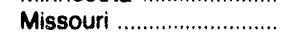 & 56,627 & 60,121 & 47,043 & 48,931 & 51 & 139 \\
\hline Nebraska ........................... & 22,387 & 22,972 & 12,527 & 13,842 & 30 & 38 \\
\hline North Dakota & 28,592 & 27,535 & 26,893 & 25,778 & ${ }^{30}$ & $*$ \\
\hline South Dakota .................... & 6,246 & 6,573 & 2,631 & 2,738 & 3 & 6 \\
\hline 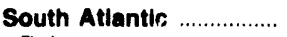 & 547,468 & 541,105 & 371,854 & 369,455 & 3,489 & 3,622 \\
\hline 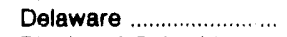 & 6,267 & 7,604 & 5,999 & 7,125 & 269 & 479 \\
\hline District of Columbia ....... & 74 & 180 & 61 & 171 & 13 & 9 \\
\hline 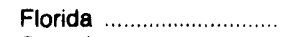 & 133,977 & 130,744 & 107,129 & 108,495 & 1,497 & 1.478 \\
\hline 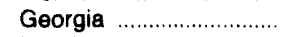 & 91.779 & 90,809 & 58,401 & 60,123 & 40 & 31 \\
\hline Maryland ........................... & 39,587 & 38,215 & 26,825 & 27,481 & 273 & 291 \\
\hline 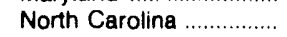 & 83,007 & 83.520 & 54,204 & 46,993 & 214 & 191 \\
\hline South Carolina ................ & 71,479 & 69,838 & 23,180 & 24,199 & 52 & 34 \\
\hline 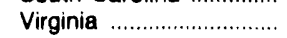 & 48,964 & 48,941 & 24,144 & 23,969 & 1,132 & 1,111 \\
\hline West Virginia .................... & 72,334 & 71,254 & 71,911 & 70,898 & 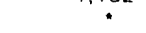 & $*$ \\
\hline East South Central .......... & 264,028 & 257,793 & 196,417 & 190,558 & 769 & 729 \\
\hline Alabama & 90,792 & 85,051 & 61,074 & 58,386 & 61 & 33 \\
\hline 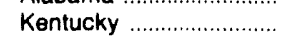 & 77,351 & 75,505 & 73,582 & 71,845 & 2 & 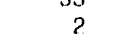 \\
\hline 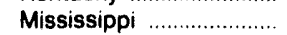 & 20,488 & 23,305 & 11,676 & 13,532 & 638 & 640 \\
\hline 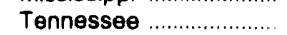 & 75,396 & 73,932 & 50,085 & 46,794 & 68 & 54 \\
\hline Weat South Central ...... & 378,465 & 378,717 & 316,574 & 318,229 & 6,204 & 6,151 \\
\hline Arkansas & 37,370 & 38,365 & 22,664 & 22,139 & 0 & 3 \\
\hline 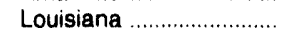 & 55,188 & 57,158 & 44,237 & 42,567 & 595 & 634 \\
\hline Oklahoma & 45,943 & 44,850 & 39,981 & 39,981 & 2,752 & 3,013 \\
\hline 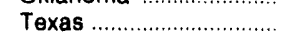 & 239,964 & 238,343 & 209,692 & 213,541 & 2,857 & 2,501 \\
\hline 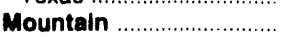 & 257,180 & 249,057 & 203,779 & 189,910 & 1,175 & 900 \\
\hline Arizona & 70,109 & 66,767 & 36,721 & 33,966 & 868 & 608 \\
\hline Colorado & 31.899 & 31,038 & 30,343 & 29,364 & 52 & 12 \\
\hline Idaho & 6,260 & 8,282 & 00 & $20,00$. & $*$ & $*$ \\
\hline Montana & 25,468 & 28,157 & 17,157 & 16,159 & 8 & 15 \\
\hline Nevada .............................. & 20,963 & 20,922 & 18,887 & 18,444 & 94 & 117 \\
\hline New Mexico ....................... & 27,708 & 25,065 & 27,428 & 24,765 & 25 & 62 \\
\hline 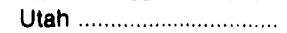 & 32,921 & 30,158 & 32,027 & 29,277 & 128 & 91 \\
\hline 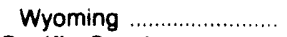 & 41,852 & 38,667 & 41,217 & 37,936 & 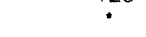 & -4 \\
\hline Pacific Contiguous ........ & 244,645 & 252,619 & 68,647 & 54,146 & 3,549 & 2,305 \\
\hline California ............................. & 119,310 & 104,968 & 55,324 & 43,414 & 1,611 & 1,124 \\
\hline 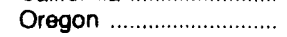 & 41,220 & 46,298 & 3,688 & 2,820 & 1.478 & 1,169 \\
\hline Washington & 84,115 & 101,353 & 9,635 & 7,911 & 460 & 12 \\
\hline Pacific Noncontiguous & 11,028 & 11,620 & 6,523 & 7,209 & 3,578 & 3,494 \\
\hline Alaska & 4,167 & 4,286 & 722 & 791 & 2,527 & 2,600 \\
\hline 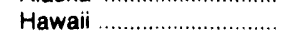 & 6,861 & 7,333 & 5,801 & 6.419 & 1,051 & 894 \\
\hline U.S. Total & $2,797,219$ & $2,825,023$ & $1,907,553$ & $1,905,223$ & 21,131 & 21,579 \\
\hline
\end{tabular}

- Value less than 0.5 million kilowatthours.

Notes: -Data are final. - Negative generation denotes that electric power consumed for plant use exceeds gross generation. • Totals may not equal sum of components because of independent rounding.

Source: Energy Information Administration, Form ElA-759, "Monthly Power Plant Report." 
Table 13. Net Generation from Electric Utilities by Energy Source, Census Division, and State, 1992 and 1991

(Million Kilowatthours)

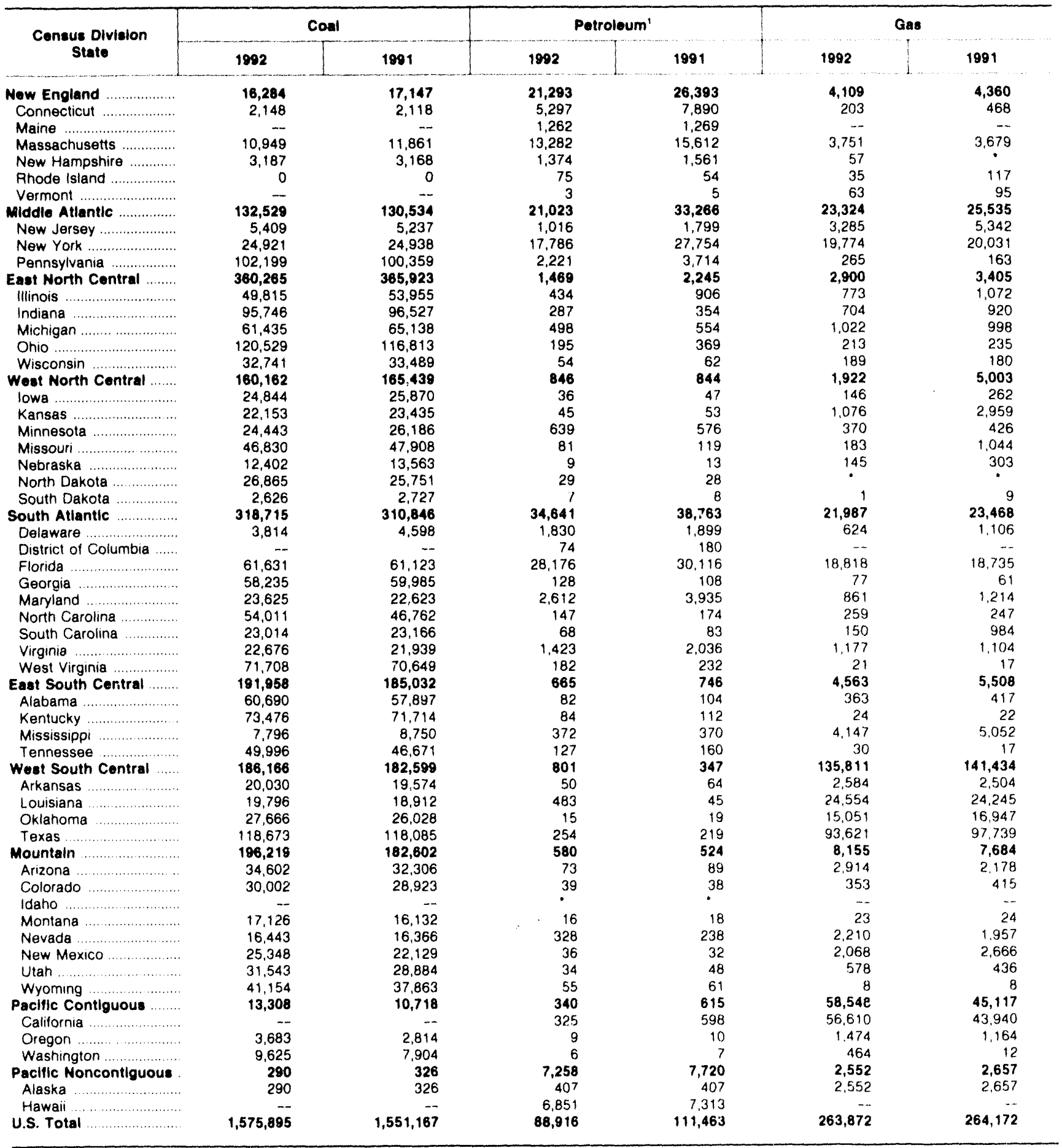

1 Includes petroleum coke

* Value less than 0.5 million kilowatthours

Notes - Data are final. Negative generation denotes that electric power consumed for plant use exceeds gross generation. $\cdot$ Totals may not equal sum of components because of independent rounding.

Source: Energy Information Administration. Form ElA.759, "Monthly Power Plant Report." 
Table 13. Net Generation from Electric Utilities by Energy Source, Census Division, and State, 1992 and 1991 (Continued)

(Million Kilowatthours)

\begin{tabular}{|c|c|c|c|c|c|c|}
\hline \multirow{2}{*}{$\begin{array}{c}\text { Census Division } \\
\text { State }\end{array}$} & \multicolumn{2}{|c|}{ Nuclear } & \multicolumn{2}{|c|}{ Hydroelectric' } & \multicolumn{2}{|c|}{ Other $^{2}$} \\
\hline & 1892 & 1991 & 1992 & 1991 & 1992 & 1991 \\
\hline Now England ................... & 38,474 & 33,820 & 3,959 & 4,740 & 466 & 549 \\
\hline Connecticut ........................ & 16,771 & 12,243 & 360 & 394 & 374 & 439 \\
\hline Maine …….................... & 5,358 & 6,264 & 1,715 & 1,985 & -- & -- \\
\hline Massachusetts ….............. & 4,742 & 4.417 & 114 & 233 & - & -- \\
\hline New Hampshire ............. & 7,869 & 6,788 & 964 & 1,188 & -- & -- \\
\hline Rhode Island ..................... & - & -- & 0 & 0 & - & -- \\
\hline Vermont .............................. & 3,735 & 4,108 & 806 & 941 & 92 & 109 \\
\hline Middie Atlantic .............. & 105,883 & 110,731 & 26,671 & 25,406 & 0 & - \\
\hline New Jersey ....................... & 21,595 & 24,807 & -138 & -155 & - & -- \\
\hline New York ........................ & 24,155 & 28,448 & 25,593 & 24,906 & 0 & -- \\
\hline Pennsylvania ..................... & 60,133 & 57,476 & 1,217 & 656 & -- & -- \\
\hline East North Central ......... & 118,604 & 124,712 & 3,858 & 3,723 & 468 & 455 \\
\hline Illinois & 73,742 & 71,866 & 52 & 53 & 8 & -- \\
\hline Indiana ............................... & -- & -- & 562 & 399 & - & -- \\
\hline Michigan ........................... & 18,849 & 27,021 & 876 & 856 & - & -- \\
\hline Ohio & 14,805 & 14,833 & 244 & 145 & 310 & 298 \\
\hline Wisconsin ............................ & 11,207 & 10,991 & 2,123 & 2,270 & 150 & 157 \\
\hline West North Central ....... & 39,895 & 40,092 & $\mathbf{9 , 5 7 5}$ & 9,370 & 428 & 422 \\
\hline lowa & 3,405 & 4,147 & 981 & 883 & 14 & 20 \\
\hline 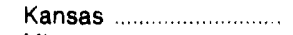 & 8,491 & 5,859 & -- & $\theta$ & • & • \\
\hline Minnesota & 11,166 & 12,059 & 758 & 778 & 407 & 403 \\
\hline 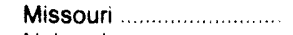 & 8,084 & 9,979 & 1,450 & 1,072 & -- & -- \\
\hline 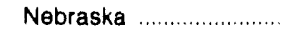 & 8,748 & 8,048 & 1,075 & 1,045 & 6 & -- \\
\hline North Dakota .................... & -- & -- & 1,699 & 1,757 & -- & -- \\
\hline South Dakota & - & -- & 3,612 & 3,828 & -- & -- \\
\hline South Atlantic .................. & 155,401 & 152,866 & 16,724 & 15,161 & • & • \\
\hline Delaware & -- & -- & -- & -- & -- & -- \\
\hline District of Columbia ...... & -. & - & -- & -- & -- & -- \\
\hline Florida & 25,116 & 20,508 & 236 & 263 & - & -- \\
\hline Georgia & 27,996 & 26,016 & 5,342 & 4,639 & -. & -- \\
\hline Maryland ............................ & 10,664 & 9,036 & 1,825 & 1.407 & 0 & 0 \\
\hline North Carolina & 22,754 & 30,312 & 5,835 & 6,024 & -. & - \\
\hline South Carolina & 45,537 & 43,108 & 2,710 & 2,497 & -- & -- \\
\hline 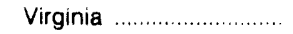 & 23,334 & 23,886 & 353 & -26 & - & • \\
\hline West Virginia & -- & -- & 423 & 356 & -- & -- \\
\hline East South Central ....... & 43,225 & 41,594 & 23,617 & 24,812 & - & - \\
\hline Alabama & 19,397 & 15,875 & 10,260 & 10,758 & - & -- \\
\hline Kentucky ...................... & -- & -- & 3,767 & 3,658 & -- & -- \\
\hline Mississippi …….............. & 8,174 & 9,133 & -- & -- & -- & - \\
\hline Tennessee & 15,654 & 16,587 & 9,590 & 10,497 & -- & - \\
\hline West South Central ...... & 46,178 & 46,418 & $\mathbf{9 , 2 2 8}$ & 7,642 & 281 & 276 \\
\hline Arkansas & 11,326 & 12,662 & 3,380 & 3,561 & - & -- \\
\hline Louisiana ............................. & 10,356 & 13,956 & -- & -- & -- & -- \\
\hline Oklahoma & -- & - & 3,210 & 1,857 & -- & -- \\
\hline Toxas & 24,496 & 19,800 & 2,638 & 2,225 & 281 & 276 \\
\hline Mountain & 25,609 & 25,096 & 26,352 & 32,903 & 265 & 249 \\
\hline Arizona & 25,609 & 25,096 & 6,911 & 7,098 & -- & -- \\
\hline Colorado & - & - & 1.505 & 1,663 & 0 & • \\
\hline Idaho & -- & -- & 6,260 & 8,281 & -- & -- \\
\hline Montana & -- & -- & 8,223 & 11,921 & 79 & 62 \\
\hline Nevada & -- & -- & 1,982 & 2,362 & -- & -. \\
\hline New Mexico ........................ & -- & -.. & 255 & 237 & -- & -- \\
\hline Utah & -- & -- & 580 & 604 & 186 & 186 \\
\hline Wyoming & -- & -- & 636 & 736 & -- & -. \\
\hline Pacific Contiguous ......... & 45,509 & 37,237 & 118,648 & 150,745 & 8,292 & 8,186 \\
\hline California & 35,244 & 31,542 & 19,205 & 20,975 & 7,925 & 7,912 \\
\hline Oregon & 4.573 & 1,465 & 31,476 & 40,844 & 6 & $\bullet$ \\
\hline Washington & 5,692 & 4,230 & 67,967 & 88,926 & 361 & 274 \\
\hline Pacific Noncontiguous. & - & - & 928 & 817 & 0 & 0 \\
\hline Alaska & -- & -- & 918 & 896 & 0 & 0 \\
\hline 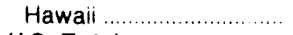 & -- & $\ldots$ & 10 & 20 & 0 & 0 \\
\hline U.S. Total & 618,776 & 612,565 & 239,559 & 275,518 & 10,200 & 10,137 \\
\hline
\end{tabular}

Station losses include energy used for pumped storage. Energy used in 1992 for pumping was 23,249 million kilowatthours and in 1991 was 24,394 million kilowatthours.

2 Refers to renewables (excluding hydroelectric) including biomass, geothermal, wind, and photovoltaic

- Value less than 0.5 million kilowatthours.

Notes: -Data are final. - Negative generation denotes that electric power consumed for plant use exceeds gross generation. • Totals may not equal sum of components because of independent rounding.

Source: Energy Information Administration, Form ElA-759, "Monthly Power Plant Report." 
Table 14. Petroleum-Fired Net Generation from Electric Utillties by Selected Prime Mover, Census Division, and State, 1992 and 1991

(Million Kilowatthours)

\begin{tabular}{|c|c|c|c|c|c|c|}
\hline \multirow{2}{*}{$\begin{array}{c}\text { Census Division } \\
\text { State }\end{array}$} & \multicolumn{2}{|c|}{ Total' } & \multicolumn{2}{|c|}{ Steam } & \multicolumn{2}{|c|}{ Gas Turbine/Internal Combustion } \\
\hline & 1992 & 1991 & 1992 & 1891 & 1892 & 1991 \\
\hline Now England .................... & 21,293 & 26,393 & 21,081 & 28,124 & 212 & 268 \\
\hline $\begin{array}{l}\text { Connecticut } \\
\text { Maine }\end{array}$ & 5,297 & 7,890 & 5,287 & 7,866 & 11 & 24 \\
\hline 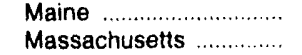 & 1,262 & 1,269 & 1,261 & 1,267 & $*$ & 2 \\
\hline 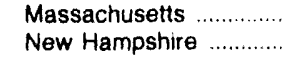 & 13.282 & 15,612 & 13,091 & 15,386 & 191 & 226 \\
\hline $\begin{array}{l}\text { New Hampshire } \\
\text { Rhode island }\end{array}$ & 1.374 & 1,561 & 1,374 & 1,560 & $\bullet$ & 1 \\
\hline $\begin{array}{l}\text { Rhode island } \\
\text { Vermont }\end{array}$ & 75 & 54 & 67 & 45 & 8 & 10 \\
\hline 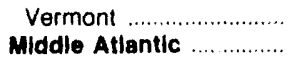 & 3 & 5 & 1 & 1 & 2 & 4 \\
\hline 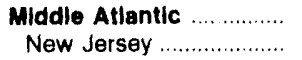 & 21,023 & 33,266 & 20,766 & 32,689 & 257 & 577 \\
\hline 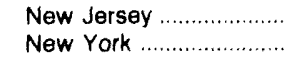 & 1,016 & 1,799 & 913 & 1,619 & 103 & 179 \\
\hline New York ......................... & 17,786 & 27,754 & 17,678 & 27,462 & 108 & 292 \\
\hline Pennsylvania ........................ & 2,221 & 3,714 & 2,175 & 3,608 & 46 & 105 \\
\hline East North Central ........ & 1,469 & 2,245 & 1,447 & 2,176 & 23 & 69 \\
\hline 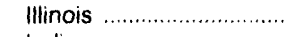 & 434 & 906 & 428 & 885 & 6 & 21 \\
\hline Indiana ............................. & 287 & 354 & 286 & 347 & 1 & 7 \\
\hline Michigan ........................ & 498 & 554 & 492 & 545 & 6 & 9 \\
\hline Ohio & 195 & 369 & 188 & 360 & 7 & 9 \\
\hline 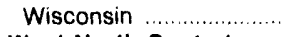 & 54 & 62 & 53 & 39 & 2 & 23 \\
\hline West North Central ....... & 846 & 844 & 809 & 762 & 38 & 82 \\
\hline 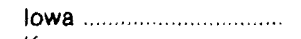 & 36 & 47 & 30 & 33 & 6 & 14 \\
\hline 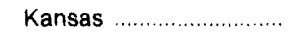 & 45 & 53 & 27 & 30 & 17 & 23 \\
\hline Minnesota ......................... & 639 & 576 & 636 & 566 & 3 & 10 \\
\hline Missouri ............................ & 81 & 119 & 76 & 96 & 4 & 22 \\
\hline Nebraska .......................... & 9 & 13 & 6 & 7 & 3 & 6 \\
\hline North Dakota .................. & 29 & 28 & 29 & 28 & 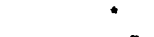 & 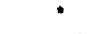 \\
\hline South Dakota ................. & 7 & 8 & 4 & 2 & 3 & 6 \\
\hline South Atlantic .................. & 34,641 & 38,763 & 33,896 & 37,914 & 745 & 850 \\
\hline 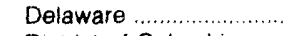 & 1,830 & 1,899 & 1,821 & 1,879 & 8 & 20 \\
\hline District of Columbia ...... & 74 & 180 & 61 & 171 & 13 & 9 \\
\hline Florida $\ldots \ldots \ldots \ldots \ldots \ldots \ldots \ldots$ & 28,176 & 30,116 & 27,630 & 29,487 & 546 & 629 \\
\hline Georgia $\ldots \ldots \ldots \ldots \ldots \ldots$ & 128 & 108 & 94 & 88 & 34 & 20 \\
\hline Maryland ....................... & 2,612 & 3,935 & 2,570 & 3,848 & 42 & 87 \\
\hline North Carolina ................ & 147 & 174 & 124 & 161 & 23 & 13 \\
\hline South Carolina ............... & 68 & 83 & 58 & 78 & 10 & 5 \\
\hline 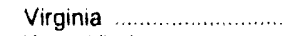 & 1,423 & 2,036 & 1,355 & 1,970 & 68 & 66 \\
\hline West Virginla & 182 & 232 & 182 & 232 & 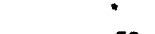 & 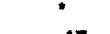 \\
\hline East South Central ........ & 665 & 746 & 615 & 699 & 50 & 47 \\
\hline Alabama & 82 & 104 & 71 & 96 & 12 & B \\
\hline 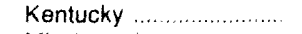 & 84 & 112 & 84 & 111 & $\cdot$ & 1 \\
\hline Mississippi ..................... & 372 & 370 & 371 & 370 & 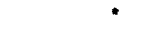 & • \\
\hline Tennessee ...................... & 127 & 160 & 89 & 123 & 38 & 37 \\
\hline West South Central ...... & 801 & 347 & 787 & 324 & 14 & 23 \\
\hline Arkansas ........................... & 50 & 64 & 49 & 61 & $\cdot$ & 3 \\
\hline Louisiana ........................ & 483 & 45 & 486 & 45 & -3 & $*$ \\
\hline Oklahoma ........................ & 15 & 19 & 14 & 16 & 1 & 3 \\
\hline 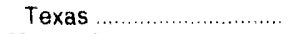 & 254 & 219 & 237 & 201 & 16 & 18 \\
\hline Mountain & 580 & 524 & 559 & 502 & 21 & 21 \\
\hline 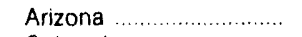 & 73 & 89 & 67 & 87 & 5 & 2 \\
\hline Colorado ......................... & 39 & 38 & 35 & 35 & 4 & 3 \\
\hline 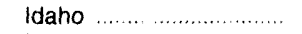 & $\cdot$ & $\cdot$ & - & -- & $\dot{.}$ & $\cdot$ \\
\hline Montana ...................... & 16 & 18 & 15 & 17 & $\cdot$ & 1 \\
\hline Nevada .......................... & 328 & 238 & 321 & 221 & 6 & 17 \\
\hline New Mexico ................... & 36 & 32 & 35 & 32 & $\cdot$ & • \\
\hline 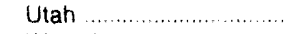 & 34 & 48 & 30 & 45 & 4 & 2 \\
\hline Wyoming & 55 & 61 & 55 & 65 & $\bullet$ & -4 \\
\hline Pacific Contiguous & 340 & 615 & 285 & 566 & 55 & 49 \\
\hline California & 325 & 598 & 275 & 555 & 50 & 43 \\
\hline Oregon ....................... & 9 & 10 & 6 & 6 & 4 & 4 \\
\hline Washington $\ldots \ldots \ldots \ldots \ldots$ & 6 & 7 & 5 & 6 & 1 & 1 \\
\hline Pacific Noncontiguous & 7,258 & 7,720 & 5,802 & 6,419 & 1,456 & 1,301 \\
\hline Alaska ........................... & 407 & 407 & 1 & $\bullet$ & 406 & 407 \\
\hline 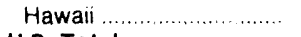 & 6,851 & 7,313 & 5,801 & 6,419 & 1,051 & 894 \\
\hline U.S. Total & 88,916 & 111,463 & 86,046 & 108,176 & 2,871 & 3,287 \\
\hline
\end{tabular}

Includes petroleum coke

- Value less than 0.5 million kilowatthours.

Notes: - Data are final. - Negative generation denotes that electric power consumed for plant use exceeds gross generation. $\bullet$ Totals may not equal sum of components because of independent rounding

Source: Energy Inforrnation Administration, Form ElA-759, "Monthly Power Plant Report." 
Table 15. Gas-Fired Net Generation from Electric Utilities by Selected Prime Mover, Census Division, and State, 1992 and 1991

(Million Kilowatthours)

\begin{tabular}{|c|c|c|c|c|c|c|}
\hline \multirow{2}{*}{$\begin{array}{c}\text { Census Division } \\
\text { State }\end{array}$} & \multicolumn{2}{|c|}{ Total } & \multicolumn{2}{|c|}{ Steam } & \multicolumn{2}{|c|}{ Gas Turbine/Internal Combustion } \\
\hline & 1992 & 1991 & 1992 & 1991 & 1992 & 1991 \\
\hline Now England ...................... & 4,109 & 4,360 & 3,746 & 3,640 & 363 & 720 \\
\hline Connecticut ........................ & 203 & 468 & 203 & 468 & $\ldots$ & -.. \\
\hline Maine …....................... & -- & -- & - & -- & -- & -- \\
\hline Massachusetts …….......... & 3,751 & 3,679 & 3,388 & 2,960 & 363 & 720 \\
\hline New Hampshire .............. & 57 & 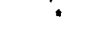 & 57 & - & 0 & $\cdot$ \\
\hline Rhode Island .................... & 35 & 117 & 35 & 117 & -- & ... \\
\hline Vermont ............................ & 63 & 95 & 63 & 95 & -- & -- \\
\hline Middle Atlantic .............. & 23,324 & 25,535 & 22,455 & 23,945 & 869 & 1,590 \\
\hline New Jersey ....................... & 3,285 & 5,342 & 2,639 & 4,148 & 646 & 1,194 \\
\hline New York ......................... & 19,774 & 20,031 & 19,573 & 19,680 & 201 & 351 \\
\hline Pennsylvania ...................... & 265 & 163 & 243 & 118 & 22 & 45 \\
\hline East North Contral ........ & 2,900 & 3,405 & 2,602 & 3,005 & 298 & 400 \\
\hline Illinois ................................ & 773 & 1,072 & 755 & 1,039 & 18 & 33 \\
\hline Indiana ............................ & 704 & 920 & 684 & 857 & 20 & 62 \\
\hline Michigan ............................ & 1,022 & 998 & 800 & 760 & 222 & 238 \\
\hline 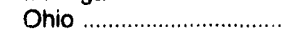 & 213 & 235 & 189 & 217 & 23 & 18 \\
\hline Wisconsin & 189 & 180 & 173 & 131 & 15 & 48 \\
\hline West North Central ....... & 1,922 & 5,003 & 1,614 & 4,331 & 308 & 672 \\
\hline lowa & 146 & 262 & 120 & 146 & 26 & 116 \\
\hline 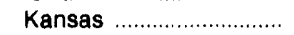 & 1.076 & 2.959 & 896 & 2,591 & 180 & 368 \\
\hline Minnesota $\ldots . . . \ldots \ldots \ldots \ldots . . . . . . . . .$. & 370 & 426 & 341 & 386 & 30 & 40 \\
\hline 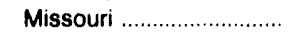 & 183 & 1,044 & 137 & 927 & 47 & 117 \\
\hline Nebraska .......................... & 145 & 303 & $\$ 19$ & 272 & 26 & 32 \\
\hline North Dakota ...................... & $\cdot$ & 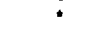 & $*$ & 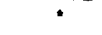 & . & $\cdot$ \\
\hline South Dakota & 1 & 9 & 1 & 9 & • & • \\
\hline South Atlantic .................. & 21,987 & 23,468 & 19,243 & 20,696 & 2,744 & 2,773 \\
\hline Delaware ........................ & 624 & 1,106 & 364 & 648 & 260 & 458 \\
\hline District of Columbia ...... & -- & -. & - & -. & -- & -- \\
\hline Florida & 18,818 & 18,735 & 17,867 & 17,885 & 951 & 850 \\
\hline Georgia ........................... & 77 & 61 & 71 & 49 & 6 & 12 \\
\hline Maryland ........................... & 861 & 1,214 & 630 & 1,010 & 230 & 203 \\
\hline North Carolina ................ & 259 & 247 & 69 & 70 & 191 & 178 \\
\hline South Carolina .................... & 150 & 984 & 108 & 956 & 42 & 28 \\
\hline Virginia ……........................ & 1,177 & 1,104 & 113 & 60 & 1,064 & 1,044 \\
\hline West Virginia & 21 & 17 & 21 & 17 & - & -. \\
\hline East South Central & 4,563 & 5,508 & 3,844 & 4,826 & 719 & 682 \\
\hline Alabama & 363 & 417 & 313 & 393 & 49 & 24 \\
\hline Kentucky ............................ & 24 & 22 & 22 & 21 & 1 & 1 \\
\hline Mississippi ......................... & 4,147 & 5,052 & 3,508 & 4,412 & 638 & 640 \\
\hline Tennessee ....................... & 30 & 17 & 0 & 0 & 30 & 17 \\
\hline West South Central ....... & 135,811 & 141,434 & 129,622 & 135,306 & 6,190 & 6,128 \\
\hline Arkansas & 2,584 & 2,504 & 2,584 & 2,504 & 0 & 0 \\
\hline Louisiana .......................... & 24,554 & 24,245 & 23,956 & 23,610 & 599 & 635 \\
\hline Oklahoma & 15,051 & 16,947 & 12,301 & 13,937 & 2,751 & 3,010 \\
\hline Texas ............................... & 93,621 & 97,739 & 90.781 & 95,255 & 2,840 & 2,483 \\
\hline Mountain & 8,155 & 7,684 & 7,001 & 6,805 & 1,154 & 879 \\
\hline Arizona & 2.914 & 2,178 & 2,052 & 1.573 & 862 & 605 \\
\hline Colorado & 353 & 415 & 306 & 406 & 48 & 9 \\
\hline Idaho & -- & -- & -- & -- & -- & -- \\
\hline Montana & 23 & 24 & 15 & 10 & 8 & 14 \\
\hline 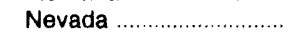 & 2,210 & 1,957 & 2,122 & 1,856 & 88 & 100 \\
\hline New Mexico ...................... & 2,068 & 2,666 & 2,044 & 2,604 & 25 & 62 \\
\hline Utah & 578 & 436 & 454 & 348 & 124 & 88 \\
\hline Wyoming .......................... & 8 & 8 & 8 & 8 & - & -. \\
\hline Pacific Contiguous ........ & 58,548 & 45,117 & 55,054 & 42,861 & 3,494 & 2,256 \\
\hline California & 56,610 & 43,940 & 55,049 & 42,859 & 561 & 1,081 \\
\hline Oregon & 1,474 & 1,164 & 0 & - & 1,474 & 1.164 \\
\hline Washington ....................... & 464 & 12 & 5 & 2 & 459 & 10 \\
\hline Pacific Noncontiguous. & 2,552 & 2,657 & 431 & 464 & 2,121 & 2,193 \\
\hline Alaska & 2,552 & 2,657 & 431 & 464 & 2,121 & 2,193 \\
\hline Hawaii ............................... & -- & - & -- & - & - & -- \\
\hline U.S. Total & 263,872 & 264,172 & 245,612 & 245,880 & 18,260 & 18,291 \\
\hline
\end{tabular}

- Value less than 0.5 million kilowatthours

Notes: - Data are final. - Negative generation denotes that electric power consumed for plant use exceeds gross generation. - Totals may not equal sum of components because of independent rounding.

Source: Energy Information Administration, Form EIA-759, "Monthly Power Plant Report." 


\section{U.S. Electric Utility Fossil-Fuel Statistics}

This chapter contains statistics on consumption of fossil fuels by U.S. electric utilities to generate electricity, and end-of-year fossil-fuel stocks for all U.S. electric utility plants. Statistics are also included for receipts and costs of fossil fuels at power plants with a steamelectric and combined-cycle nameplate capacity of 50, or more megawatts, approximately 86 percent of the total capability at U.S. electric utilities. These data are aggregated to national, Census division, and State levels.

\section{Background}

Various sources of energy are used by electric utilities to produce electricity; however, fossil fuels supply about 70 percent of the energy sources for the generation requirements of the Nation. Coal, petroleum, and gas are currently the dominant fossil fuels used by the industry." Statistics on consumption, purchases (receipts), and stocks of fossil fuels at electric utilities are interdependent. That is, the stocks on site at the utility at the end of the current year result from the stocks that were available at the end of the prior year, the amount of fuel purchased during the current year, and the amount of fuel consumed during the year.

\section{Fossil-Fuel Consumption and Stocks}

Coal, the energy source used by electric utilitien to gencrate more than one-half of the electricity needed in the Nation, is consumed extensively throughout the United States (particularly in the East North Central, West North Central, West South Central, and the South Atlantic Census Divisions). The use of petroleum for generation is not as common on a national level as during the early 1970's; however, some areas of the country (such as in the New England, Middle Atlantic, and South Atlantic Census Divisions) continue to use it extensively. Consumption of gas occurs mostly in areas of the country where it is readily accessible, particularly in the West South Central Census Division, and in dual-fired generator units, which use gas and petroleum as substitute fuels.

The purposes of on-site storage are to provide an uninterrupted supply, to allow bulk shipments, and to take advantage of favorable market conditions. Electric utilities maintain stockpiles of coal and pitroleum to minimize the effect of an interruption or curtailment in fuel availability (for example, railroad strikes, coal. mine strikes, or oil embargoes). Since gas is generally not stored, there are no stocks of gas.

\section{Fossil-Fuel Receipts and Costs}

Statistics on electric utility receipts provide information regarding the delivery of fossil fuels to steamelectric plants. The costs include all costs incurred by an electric utility in the purchase and delivery of fuel to the plant. The type of contract under which a fuel is purchased has a significant effect on the cost of the fuel delivered and can be used as a good indicator of market conditions. Transactions where petroleum and coal are obtained by the utility under purchase orders or contracts with a duration of 1 year or more are referred to as contract purchases. Shipments of petroleum and coal under purchase orders or contracts of less than 1-year duration are considered spot purchases. Transactions to secure gas that are conducted under a contract with uninterrupted delivery are identified as firm purchases. Interruptible purchases are those in which the gas is received under a contract that permits curtailment of service under certain circumstances. For example, under both Federal and State regulations, requirements for gas to heat homes and serve industry have priority over requirements of the electric power industry. Consequently, a contract under which gas is purchased is most generally one that allows for an interruption in its accessibility.

Coal. Coal is ohtaned from three major coalproducing areas in the United States. Appaluchian coal is mined in both surface and underground mines located in Pennsylvania, Maryland. Virginia, West Virginia, eastern Kentucky, Tennessee. Alabama, and Ohio. This coal is bituminous in rank and of low-to-medium sulfur content. Its heat content in British Thermal Units (Btu) averages over $12,(0(x)$ Btu per pound. The coal is transported primarily by train, barge, and truck to electric utility plants throughout the eastern United States. Interior coal is mined in both surface and underground mines located primarily in Illinois, Indiana, western Kentucky, and Missouri. It is bituminous coal

"onhed fossil fuels molude petroleum eoke, refinery gas, coke oven gas, hlast furnace gas, and liquified petroleum gas 
with a high percentage of sulfur and contains approximately 11,000 Btu per pound. Most of this coal is delivered to plants in the central and Southeastern United States. Western coal is mined in Montana, Wyoming, Colorado, Utah, North Dakota, Arizona, and New Mexico. It is delivered to plants throughout the western and central United States. Over one-half of the coal in this region is subbituminous coal that is low in sulfur content (less than 0.5 percent) and contains approximately 9,000 Btu per pound. Most of this coal originates in the Powder River basin of northeast Wyoming and southeast Montana. Coal from this region is delivered by unit train to plants as far east as Indiana and Georgia.

The cost of coal delivered to electric utilities can vary significantly from State to State. Coal delivered to the New England Census Division from the Appalachian coal fields may cost as much as $\$ 60$ per short ton due to transportation costs and the higher cost of producing eastern coal (generally in underground mines). Environmental restrictions within a State may require electric utilities to burn only the more expensive, low-sulfur coal resulting in a higher delivered cost. In the West, especially in the Mountain Census Division, coalburning plants are often built close to the mine thus reducing transportation costs. In addition, the cost of mining coal from large surface mines located in the western United States is significantly less than that of underground eastern mines, resulting in a delivered cost of under $\$ 15$ per short ton for States such as Montana and Wyoming. In States such as North Dakota, South Dakota, and Texas, the cost of coal delivered to electric utilities is well below the national average because of the lower cost of low-grade lignite.

Petroleum. Although nationwide receipts at electric utilities are less than one-half the volume of the 1970's, several electric utilities in the New England area, and in New York, Florida, and Hawaii still depend on petroleum for a significant portion of their fossil-fuel requirements. Receipts can vary widely from year to year at electric utilities due to changes in the cost of petroleum. Fuel oil numbers 4,5 , and 6 (heavy oil) constitute the majority of all petroleum receipts at electric utilities. Smaller amounts of fuel oil number 2 (light oil) are also used by electric utilities primarily for startup and flame stabilization of the boilers.

The cost of petroleum delivered to electric utilities varies considerably from State to State. The most important factor in determining cost is the type of fuel oil that is being delivered. States receiving only low. grade heavy oil will show a delivered cost much lower than a State receiving only light oil. Most of the petroleum delivered to the New England, Middle Atlantic, and South Atlantic Census Divisions, California, and Hawaii for use by electric utilities is the number 6 fuel oil. The cost of fuel oil can also vary cuause of its sulfur content. Electric utilities that are required to meet stringent environmental standards must purchase low-sulfur fuel oil at premium prices.

Gas. Gas is used extensively as a primary fuel throughout areas of the country where it is readily accessible (for example, the West South Central Census Division and in California). Large volumes of gas are also transported by pipeline to the Middle Atlantic, and South Atlantic Census Divisions. Gas receipts in these Census divisions and in California can vary considerably from year to year because some electric utilities switch between use of petroleum and gas in dual-fired generating units. The highest volume of gas receipts at electric utilities occurs during the summer months when demand for electricity peaks and when there is a greater amount available to electric utilities because of lower demands from residential and commercial consumers. In some northern parts of the United States, receipts of gas at electric utilities are limited during the winter months due to the priority for residential heating and industry needs. Many electric utilities have the capability of burning either petroleum or gas. The cost of the fuel is usually the determining factor. One major advantage of gas over all other fossil fuels is that it is a clean burning fuel. Therefore, some electric utilities use gas in order to comply with ellvironmental regulations.

Petroleum Coke. Petroleum coke is the final product or residue produced from the process of breaking down complex petroleurin hydrocarbons into lighter petroleum products, such as gasoline. This process is known as cracking

\section{Data Sources}

Data in the following tables were obtained from two sources. The first is the Form ElA.759, "Monthly Power Plant Report," which is used to collect monthly data from all operators of power plants (approximately 750 ) in the United States. More detailed statistics on stocks and consumption are published in the Electric Power Monthly. "The second source is the Federal Energy Regulatory Commission (FERC) Form 423, "Monthly Report of Cost and Quality of Fuels for Electric Plants," which is a restricted census used to collect data from approximately 230 electric utilities. More detailed statistics on receipts and costs of fossil fuels are published in the Cost and Quality of Fuels for Electric Utility Plants.?

\footnotetext{
${ }^{31}$ Energy Information Administration, Electric Power Monthly, DOE/EIA -0226(93/1-12)(Washington, D() 19931.

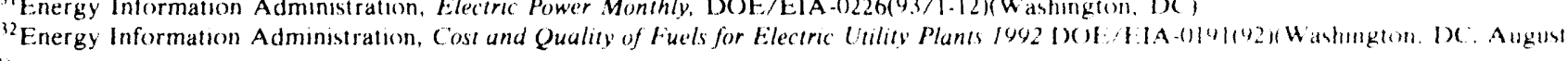


Caution should be used in comparing stocks, receipts, and consumption data since all operators of power plants are surveyed by the Form EIA-759, while the
FERC Form 423 is limited to operators of power plants with a fossil-fueled steam-electric and combined-cycle nameplate capacity of 50 or more megawatts.

Table 16. Consumption of Fossil Fuels and Year-End Stocks of Coal and Petroleum at U.S. Electric Utilities, 1988 Through 1992

\begin{tabular}{|c|c|c|c|c|c|}
\hline Item & 1992 & 1991 & 1990 & 1989 & 1988 \\
\hline \multicolumn{6}{|l|}{ Consumption } \\
\hline Coal (thousand short tons) & 779,860 & 772,268 & 773,549 & 766,888 & 758,372 \\
\hline Petroleum (thousand barrels)' $\ldots \ldots \ldots \ldots . . . . . . .$. & 147,335 & 184,886 & 196,054 & 267.451 & 248,096 \\
\hline \multirow[t]{2}{*}{ Gas (million cubic teot) } & $2,765,608$ & $2,789,014$ & $2,787,332$ & 2.787 .012 & $2,635,613$ \\
\hline & & & & & $\cdot$ \\
\hline \multicolumn{6}{|l|}{ Stock8 } \\
\hline Coal (thousand short tons) & 154,130 & 157.876 & 156,166 & 135,860 & 146.507 \\
\hline Petroleum (thousand barreis)' & 71,849 & 74,993 & 83,501 & 61,270 & 69,285 \\
\hline
\end{tabular}

- Does not include petroleum coke

Notes. Data are final. Totals may not equal sum of components because of independent rounding

Source Energy Information Administration, Form EIA-759, "Monthly Power Plant Report."

Table 17. Receipts and Average Delivered Cost of Fossil Fuels at U.S. Electric Utilities, 1988 Through 1992

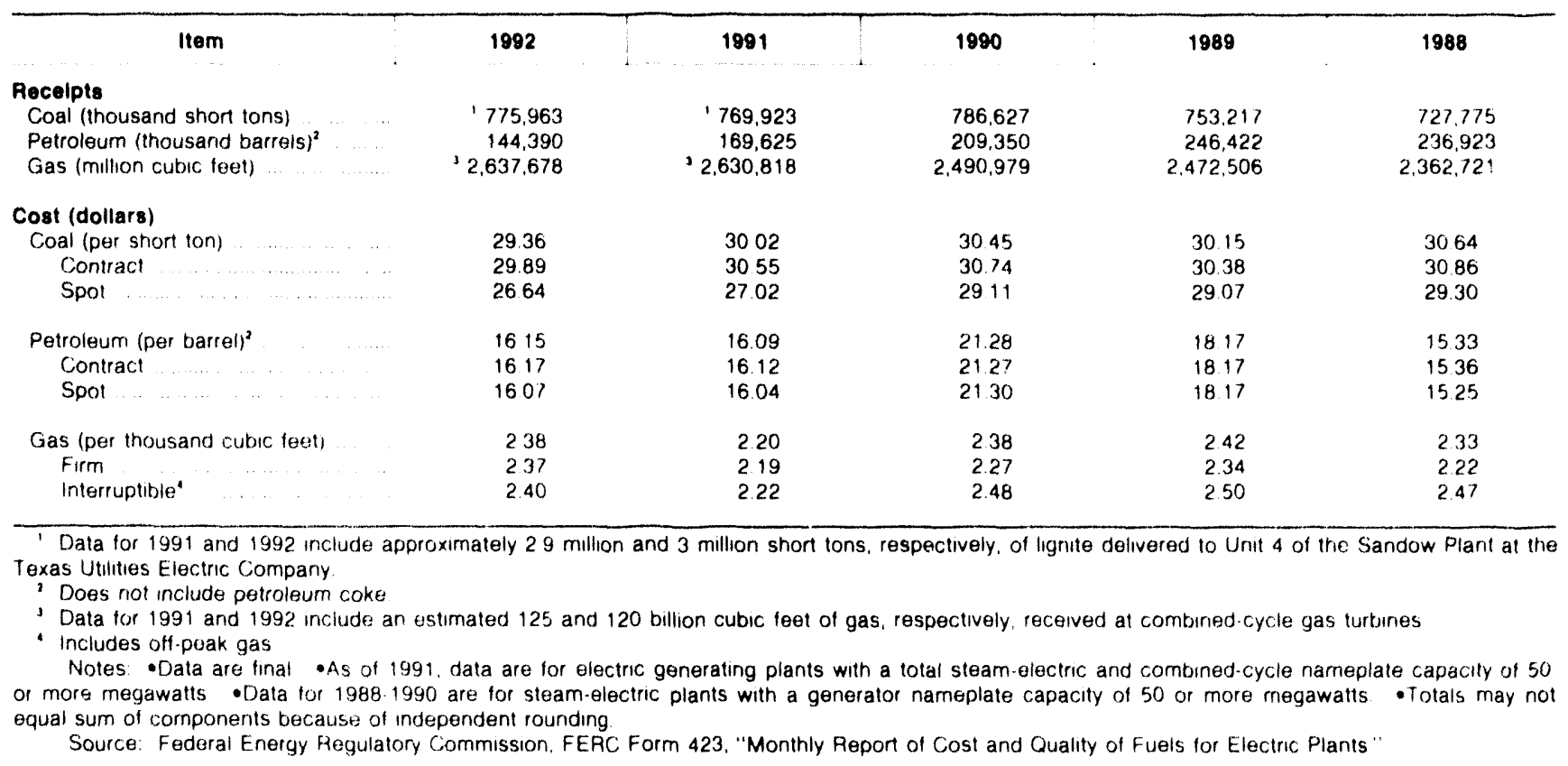


Table 18. Consumption of Fossil Fuels at Electric Utilities by Census Division and State, 1992 and 1991

\begin{tabular}{|c|c|c|c|c|c|c|}
\hline \multirow{2}{*}{$\begin{array}{l}\text { Census Division } \\
\text { State }\end{array}$} & \multicolumn{2}{|c|}{$\begin{array}{c}\text { Coal } \\
\text { (thoueand short tons) }\end{array}$} & \multicolumn{2}{|c|}{$\begin{array}{c}\text { Petroleum' } \\
\text { (thousand barrels) }\end{array}$} & \multicolumn{2}{|c|}{ (million cubic teet) } \\
\hline & 1992 & 1991 & 1992 & 1991 & 1992 & 1991 \\
\hline Now England $\ldots \ldots \ldots \ldots \ldots$ & 6,112 & 6,421 & 34,982 & 42,791 & 42,343 & 46,564 \\
\hline Connecticut ..................... & 817 & 840 & 8.788 & 13,029 & 2,100 & 4,702 \\
\hline Maine & - & $-\ldots$ & 2,237 & 2,307 & - & .. \\
\hline Massachusetts ............... & 4,044 & 4,339 & 21,455 & 24,594 & 38,341 & 39,133 \\
\hline New Hampshire ............ & 1,251 & 1,242 & 2,315 & 2.704 & 633 & 0 \\
\hline Rhodo Island ................ & 0 & 0 & 178 & 142 & 469 & 1,638 \\
\hline Vermont & $\ldots$ & -. & 8 & 15 & 801 & 1.091 \\
\hline Middle Atlantic .............. & 52,488 & 52,617 & 34,832 & 54,668 & 250,602 & 275,551 \\
\hline New Jersey ...................... & 2,118 & 2,081 & 2,092 & 3,293 & 38.772 & 61,874 \\
\hline 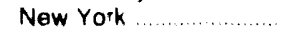 & 9,963 & 9,874 & 29.201 & 45.315 & 208.731 & 211,640 \\
\hline Pennsylvania $\ldots \ldots \ldots \ldots . . . . .$. & 40,407 & 40,662 & 3,538 & 6.060 & 3,100 & 2,037 \\
\hline East North Central & 169,029 & 173,718 & 4,231 & 5,525 & 47.513 & 52,588 \\
\hline lllinois $\ldots \ldots \ldots \ldots$ & 25,264 & 27.754 & 2,271 & 3,044 & 9,293 & 12.865 \\
\hline Indiana $\ldots . . . . . . . . . . . . .$. & 46,937 & 47,720 & 264 & 351 & 7.771 & 10.043 \\
\hline Michigan . & 28,238 & 29,896 & 1,125 & 1,230 & 24,908 & 23,736 \\
\hline Ohio ......... & 50,358 & 49,577 & 489 & 753 & 2.956 & 3.237 \\
\hline Wisconsin & 18,231 & 18,771 & 82 & 147 & 2,584 & 2.708 \\
\hline Weat North Central ...... & 102,557 & 104,246 & 568 & 778 & 25,456 & 62,239 \\
\hline lowa & 15,357 & 15,846 & 90 & 109 & 2,265 & 3.671 \\
\hline Kansas $\ldots \ldots$ & 14,068 & 14732 & 104 & 156 & 13.981 & 36,122 \\
\hline Minnesota & 15,841 & 16,114 & 63 & 92 & 4,906 & 5,870 \\
\hline 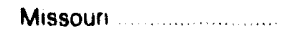 & 23,815 & 24,286 & 209 & 287 & 2,351 & 12,709 \\
\hline Nebraska & 7.881 & 8.524 & 25 & 30 & 1.903 & 3,689 \\
\hline North Dakote & 23,192 & 22,174 & 58 & 69 & 1 & 1 \\
\hline South Dakota & 2.402 & 2,570 & 19 & 35 & 48 & 177 \\
\hline South Attantic & 126,093 & 123,729 & 56,369 & 63,529 & 239,787 & 255,024 \\
\hline Delaware & 1,628 & 1.958 & 2,708 & 2,808 & 8.384 & 14.354 \\
\hline District of Columbia & $\ldots$ & -- & 250 & 497 & $\ldots$ & $\ldots$ \\
\hline Florida & 25,016 & 24,870 & 44,940 & 48,430 & 202.576 & 201.319 \\
\hline Georgia & 23,656 & 24,848 & 268 & 213 & 1.162 & 838 \\
\hline Maryland & 8,993 & 8,632 & 5,111 & 7.637 & 11.575 & 16,059 \\
\hline North Carolina & 21,011 & 18,078 & 314 & 349 & 3,159 & 3,020 \\
\hline South Carolina ............... & 9,078 & 9,218 & 159 & 144 & 1.795 & 9.823 \\
\hline Virginia & 8,661 & 8,568 & 2.310 & 3,112 & 10,936 & 9.471 \\
\hline West Virginia & 28,050 & 27,557 & 307 & 340 & 201 & 140 \\
\hline East South Central ........ & 80,203 & 77,917 & 1,212 & 1,344 & 58,109 & 66,928 \\
\hline Alabama & 24,988 & 23,700 & 141 & 163 & 3,368 & 4,081 \\
\hline Kentucky & 31,715 & 31,432 & 195 & 228 & 269 & 227 \\
\hline Mississippi $\ldots \ldots \ldots \ldots$ & 3,237 & 3,570 & 651 & 681 & 54,180 & 62.409 \\
\hline Tonnessee & 20,263 & 19,216 & 225 & 272 & 291 & 211 \\
\hline West South Central & 129,351 & 127,908 & 689 & 707 & $1,399,083$ & $1,454,413$ \\
\hline Arkansas & 12,241 & 11.978 & 95 & 129 & 27,015 & 27.903 \\
\hline Louisiana & 13,077 & 12,406 & 93 & 89 & 254,922 & 254.245 \\
\hline Oklahoma & 16,699 & 15,668 & 28 & 38 & 148,980 & 167.214 \\
\hline Texas & 87,333 & 87,856 & 473 & 452 & 968,165 & $1,005,051$ \\
\hline Mountain & 105,609 & 98,400 & 1,073 & 1,001 & 89,679 & 84,369 \\
\hline Arizona & 17,280 & 16,116 & 135 & 159 & 30,939 & 23,282 \\
\hline 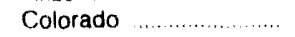 & 15.902 & 15,416 & 84 & 82 & 5.019 & 5.715 \\
\hline Idaho & $\ldots$ & + & 1 & 1 & $\ldots$ & $\ldots$ \\
\hline 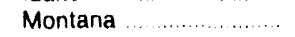 & 10,768 & 10,223 & 35 & 41 & 220 & 268 \\
\hline 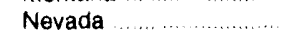 & 7.914 & 7,892 & 584 & 447 & 24,355 & 21.738 \\
\hline New Mexico .................... & 14,775 & 12,809 & 73 & 67 & 22.486 & 28,100 \\
\hline 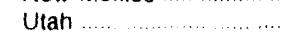 & 13,857 & 12,829 & 62 & 82 & 6,576 & 5,190 \\
\hline Wyoming & 25,114 & 23,115 & 100 & 122 & 83 & 76 \\
\hline Pacific Contiguous .......... & 8,142 & 7,015 & 637 & 1,076 & 584,082 & 460,009 \\
\hline Californa & - & -. & 605 & 1,037 & 564,432 & 449,014 \\
\hline Oregon & 1,994 & 1.831 & 19 & 23 & 14,264 & 10.856 \\
\hline Washington & 6,148 & 5.184 & 13 & 16 & 5,385 & 139 \\
\hline Pacific Noncontiguous. & 277 & 298 & 12,743 & 13,465 & 28,953 & 31,330 \\
\hline Alaska & 277 & 298 & 755 & 769 & 28,953 & 31,330 \\
\hline 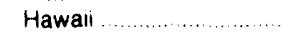 & -- & - & 11,989 & 12,696 & $\ldots$ & $\ldots$ \\
\hline U.S. Total & 779,660 & 772,268 & 147,335 & 184,886 & $2,765,608$ & $2,789,014$ \\
\hline
\end{tabular}

1 Does not include petroleum coke. Petroleum coke consumption in 1992 was 999 thousand short tons and in 1991 was 722 thousand short tons. Notes: Data are final. Totals may not equal sum of components because of independent rounding.

Source: Energy Information Administration, Form ElA.759, "Monthly Power Plant Report" 
Table 19. Petroleum Consumption at Electric Utilities by Selected Prime Mover, Census Division, and State, 1992 and 1991

(Thousand Barrels)

\begin{tabular}{|c|c|c|c|c|c|c|}
\hline \multirow{2}{*}{$\begin{array}{c}\text { Cenaus Division } \\
\text { State }\end{array}$} & \multicolumn{2}{|c|}{ Total } & \multicolumn{2}{|c|}{ Stoam } & \multicolumn{2}{|c|}{ Cas Turbine/Internal Combustion } \\
\hline & 1992 & 1991 & 1992 & 1991 & 1992 & 1991 \\
\hline New England & 34,982 & 42,791 & 34,550 & 42,239 & 432 & 552 \\
\hline Connecticut & 8,788 & 13,029 & 8.758 & 12,960 & 31 & 69 \\
\hline 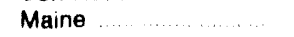 & 2,237 & 2,307 & 2,233 & 2,299 & 4 & 8 \\
\hline Massachusetts & 21,455 & 24,594 & 21,083 & 24,156 & 372 & 439 \\
\hline New Hampshire ......... & 2,315 & 2,704 & 2,314 & 2,700 & 2 & 5 \\
\hline Rhode Island & 178 & 142 & 162 & 123 & 17 & 19 \\
\hline Vermont & 8 & 15 & 2 & 2 & 7 & 13 \\
\hline Middle Atlantic & 34,832 & 54,668 & 34,116 & 53,115 & 716 & 1,553 \\
\hline New Jersey & 2,092 & 3,293 & 1,827 & 2,794 & 266 & 499 \\
\hline New York .... & 29.201 & 45,315 & 28,908 & 44,557 & 293 & 759 \\
\hline Pennsylvania $\ldots . . .$. & 3,538 & 6,060 & 3,381 & 5,765 & 157 & 295 \\
\hline East North Central & 4,231 & 5,525 & 4,105 & 5,259 & 126 & 267 \\
\hline Illinois & 2.271 & 3,044 & 2,249 & 2,975 & 22 & 70 \\
\hline Indiana $\ldots \ldots \ldots$ & 264 & 351 & 255 & 327 & 8 & 24 \\
\hline 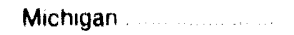 & 1,125 & 1,230 & 1,087 & 1,184 & 38 & 46 \\
\hline Onio $\ldots \ldots \ldots$ & 489 & 753 & 451 & 698 & 38 & 55 \\
\hline Wisconsin & 82 & 147 & 63 & 74 & 19 & 72 \\
\hline West North Central ..... & 568 & 778 & 408 & 496 & 160 & 282 \\
\hline lowa & 90 & 109 & 61 & 64 & 29 & 45 \\
\hline Kansas & 104 & 156 & 64 & 93 & 41 & 63 \\
\hline Minnesota & 63 & 92 & 39 & 51 & 24 & 41 \\
\hline 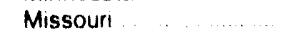 & 209 & 287 & 167 & 202 & 41 & 85 \\
\hline Nebraska & 25 & 30 & 13 & 13 & 12 & 18 \\
\hline North Dakola & 58 & 69 & 56 & 67 & 1 & 2 \\
\hline South Dakota & 19 & 35 & 8 & 6 & 12 & 28 \\
\hline South Atiantlc & 56,369 & 63,529 & 54,653 & 61,408 & 1,716 & 2,121 \\
\hline Delaware & 2.708 & 2,808 & 2,684 & 2.760 & 24 & 48 \\
\hline District of Columbia & 250 & 497 & 204 & 464 & 46 & 33 \\
\hline Florida & 44,940 & 48,430 & 43,769 & 46.921 & 1,172 & 1.509 \\
\hline Georgia & 268 & 213 & 182 & 150 & 86 & 64 \\
\hline Maryland & 5.111 & 7.637 & 5,008 & 7,440 & 103 & 197 \\
\hline North Carolına & 314 & 349 & 214 & 264 & 101 & 86 \\
\hline South Carolina & 159 & 144 & 103 & 116 & 56 & 28 \\
\hline Virginia & 2.310 & 3,112 & 2,182 & 2.756 & 128 & 157 \\
\hline West Virginia & 307 & 340 & 307 & 339 & $\cdot$ & 1 \\
\hline East South Central & 1,212 & 1,344 & 1,121 & 1,226 & 91 & 117 \\
\hline Alabama & 141 & 163 & 124 & 145 & 17 & 17 \\
\hline Kentucky & 195 & 228 & 193 & 224 & 2 & 4 \\
\hline Mississippi & 651 & 681 & 650 & 673 & $\cdot$ & 8 \\
\hline Tennessee & 225 & 272 & 153 & 184 & 71 & 88 \\
\hline West South Central & 689 & 707 & 648 & 651 & 41 & 56 \\
\hline Arkansas & 95 & 129 & 94 & 120 & 1 & 9 \\
\hline Louisiana ......... & 93 & 89 & 92 & a7 & 1 & 1 \\
\hline Oklahoma & 28 & 38 & 25 & 34 & 2 & 4 \\
\hline Texas & 473 & 452 & 437 & 410 & 36 & 42 \\
\hline Mountain & 1,073 & 1,001 & 1,018 & 940 & 55 & 61 \\
\hline Arizona & 135 & 159 & 121 & 153 & 14 & 5 \\
\hline Colorado & 84 & 82 & 72 & 72 & 12 & 10 \\
\hline Idaho & 1 & 1 & $\ldots$ & $\ldots$ & 1 & 1 \\
\hline Montana & 35 & 41 & 34 & 39 & 1 & 1 \\
\hline Nevada & 584 & 447 & 565 & 409 & 19 & 38 \\
\hline New Mexico & 73 & 67 & 72 & 67 & 1 & 1 \\
\hline Utah & 62 & 82 & 54 & 77 & 8 & 5 \\
\hline Wyoming & 100 & 122 & 100 & 122 & 0 & 0 \\
\hline Pacific Contiguous & 637 & 1,076 & 501 & 963 & 136 & 112 \\
\hline Califorma & 605 & 1.037 & 482 & 933 & 124 & 104 \\
\hline Oregon & 19 & 23 & 9 & 18 & 9 & 5 \\
\hline Washington $\ldots . . . . .$. & 13 & 16 & 10 & 12 & 3 & 4 \\
\hline Pacific Noncontiguous & 12,743 & 13,465 & 10,043 & $10,98 \overline{8}$ & 2,701 & 2,478 \\
\hline Alaska & 755 & 769 & 4 & 1 & 751 & 768 \\
\hline Hawail & 11,989 & 12,696 & 10,039 & 10,986 & 1,950 & 1.710 \\
\hline U.S. Total. & 147,335 & 184,886 & 141,163 & 177,286 & 6,172 & 7,600 \\
\hline
\end{tabular}

- Value less than 0.5

Notes: Data are final - Totals may not equal sum of components because of independent rounding. •Does not include petroleum coke. Petroleum coke consumption in 1992 was 999 thousand short tons and in 1991 was 722 thousand short tons.

Source Energy Information Administration, Form ElA-759, "Monthly Power Plant Repont." 
Table 20. Gas Consumption at Electric Utilitles by Selected Prime Mover, Census Division, and State, 1992 and 1991

(Million Cubic Feet)

\begin{tabular}{|c|c|c|c|c|c|c|}
\hline \multirow{2}{*}{$\begin{array}{c}\text { Consus Division } \\
\text { state }\end{array}$} & \multicolumn{2}{|c|}{ Total } & \multicolumn{2}{|c|}{ steam } & \multicolumn{2}{|c|}{ Gas Turbine/Internal Combustion } \\
\hline & 1992 & 1991 & 1992 & 1991 & 1992 & 1991 \\
\hline $\begin{array}{l}\text { New England } \\
\text { Connecticut }\end{array}$ & $\begin{array}{r}42,343 \\
2,100\end{array}$ & $\begin{array}{r}46,564 \\
4,702\end{array}$ & $\begin{array}{r}38,657 \\
2,100\end{array}$ & $\begin{array}{r}37,703 \\
4,702\end{array}$ & $\begin{array}{r}3,686 \\
\cdots\end{array}$ & 8,861 \\
\hline Maine & -- & - & -- & 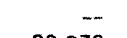 & $\cdots$ & $\cdots$ \\
\hline $\begin{array}{l}\text { Massachusetts } \\
\text { New Hampshire ................... }\end{array}$ & 38,341 & 39,133 & 34,655 & 30,273 & 3,686 & 8,861 \\
\hline $\begin{array}{l}\text { New Hampshire } \\
\text { Rhode Island }\end{array}$ & 633 & 0 & 633 & - & 0 & 0 \\
\hline $\begin{array}{l}\text { Rhode Island } \\
\text { Vermont }\end{array}$ & 469 & 1,638 & 469 & 1,638 & $\cdots$ & $\cdots$ \\
\hline $\begin{array}{l}\text { Vermont } \\
\text { Middle Allantic... }\end{array}$ & 801 & 1,091 & 801 & 1,091 & .. & ..- \\
\hline $\begin{array}{l}\text { Middle Allantic } \\
\text { Now Jersey ...... }\end{array}$ & 250,602 & 275,551 & 238,639 & 253,424 & 11,963 & 22,126 \\
\hline $\begin{array}{l}\text { Now Jersey ..... } \\
\text { Now York ....... }\end{array}$ & 38,772 & 61,874 & 30,221 & 46,027 & 8.551 & 1,846 \\
\hline New York ....... & 208.731 & 211,640 & 205,618 & 206,077 & 3,113 & 5,564 \\
\hline Pennsylvania ......... & 3.100 & 2,037 & 2,801 & 1,320 & 299 & 717 \\
\hline East North Contral & 47,513 & 52,588 & 43,700 & 47,121 & 3,813 & 5,467 \\
\hline Illinois .................. & 9,293 & 12,865 & 9,002 & 12,407 & 291 & 458 \\
\hline Indiana $\ldots \ldots . . . .$. & 7,771 & 10,043 & 7,470 & 9,069 & 302 & 974 \\
\hline Michigan & 24.908 & 23,736 & 22,470 & 20,964 & 2.438 & 2.772 \\
\hline Ohio $\ldots . . .$. & 2.956 & 3,237 & 2,450 & 2,787 & 506 & 450 \\
\hline Wisconsin $\ldots \ldots$ & 2,584 & 2,706 & 2,308 & 1,894 & 276 & 813 \\
\hline West North Central & 25,456 & 62,239 & 21,160 & 52,685 & 4,296 & 9,553 \\
\hline lowa $\ldots \ldots$ & 2,265 & 3,671 & 1,735 & 2,003 & 531 & 1.668 \\
\hline Kansas ..... & 13,981 & 36.122 & 11,692 & 31,005 & 2,289 & 5,117 \\
\hline Minnesota & 4,906 & 5,870 & 4,557 & 5,339 & 349 & 532 \\
\hline Missouri & 2,351 & 12,709 & 1,602 & 10,902 & 750 & 1.807 \\
\hline Nebraska & 1,903 & 3,689 & 1,530 & 3,278 & 372 & 411 \\
\hline North Dakota & 1 & 1 & 1 & $\cdot$ & & - \\
\hline South Dakota & 48 & 177 & 43 & 158 & 5 & 19 \\
\hline South Allantlc & 239,787 & 255,024 & 206,641 & 221,583 & 33,146 & 33,441 \\
\hline Delaware & 8,384 & 14,354 & 5,818 & 8,784 & 2,566 & 5,570 \\
\hline District of Columbia & $\cdots$ & -- & - & - & $\ldots$ & $\cdots$ \\
\hline Florida & 202,576 & 201.319 & 188,669 & 188,847 & 13,907 & 12,473 \\
\hline Georgia & 1.162 & 838 & 1,065 & 676 & 97 & 162 \\
\hline Maryland & 11,575 & 16.059 & 8,725 & 13,290 & 2,850 & 2.770 \\
\hline North Carolina & 3,159 & 3,020 & 0 & 0 & 3,159 & 3,020 \\
\hline South Carolina & 1.795 & 9,823 & 1.065 & 9,297 & 730 & 526 \\
\hline Virginia $\ldots \ldots$ & 10,936 & 9.471 & 1,098 & 549 & 9,838 & 8.922 \\
\hline West Virginia ...... & 201 & 140 & 201 & 140 & $\ldots$ & -- \\
\hline East South Central & 58,109 & 66,928 & 42,485 & 51,483 & 15,623 & 15,445 \\
\hline Alabama $\ldots .$. & 3,368 & 4,081 & 3,030 & 3,843 & 338 & 238 \\
\hline Kentucky & 269 & 227 & 240 & 205 & 29 & 22 \\
\hline Mississippi & 54,180 & 62,409 & 39.215 & 47,436 & 14,965 & 14.973 \\
\hline Tennessee & 291 & 211 & 0 & 0 & 291 & 211 \\
\hline West South Central & $1,399,083$ & $1,454,413$ & $1,328,391$ & $1,383,729$ & 70,692 & 70,685 \\
\hline Arkansas & 27,015 & 27,903 & 27.015 & 27,903 & 0 & 0 \\
\hline Louisiana & 254,922 & 254,245 & 247,797 & 245,926 & 7.125 & 8,319 \\
\hline Oklahoma & 148,980 & 167.214 & 119,089 & 135,876 & 29.892 & 31,338 \\
\hline Texas & 968,165 & $1.005,051$ & 934,490 & 974,024 & 33,675 & 31.028 \\
\hline Mountain & 89,679 & 84,369 & 75,941 & 73,773 & 13,738 & 10,596 \\
\hline Arizona & 30,939 & 23,282 & 21,545 & 16,761 & 9,394 & 6.521 \\
\hline Colorado & 5.019 & 5,715 & 4,318 & 5,571 & 701 & 144 \\
\hline Idaho ..... & -- & $\cdots$ & -- & -- & $\cdots$ & -.. \\
\hline Montana & 220 & 268 & 116 & 80 & 104 & 188 \\
\hline Nevada & 24,355 & 21,738 & 22,822 & 20,158 & 1.534 & 1,580 \\
\hline New Mexico & 22,486 & 28,100 & 22,172 & 27,279 & 315 & 821 \\
\hline 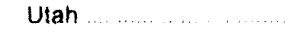 & 6.576 & 5,190 & 4,886 & 3,848 & 1.690 & 1,343 \\
\hline Wyoming & 83 & 76 & 83 & 76 & $\cdots$ & $\cdots$ \\
\hline Pacific Contiguous & 584,082 & 460,009 & 547,658 & 436,416 & 36,424 & 23,593 \\
\hline California $\ldots \ldots$ & 564.432 & 449,014 & 547,614 & 436,395 & 16,819 & 12,619 \\
\hline Oregon $\ldots \ldots \ldots$ & 14,264 & 10.856 & 0 & $\ldots$ & 14,264 & 10,856 \\
\hline 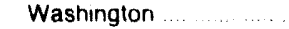 & 5.385 & 139 & 44 & 20 & 5,340 & 119 \\
\hline Pacific Noncontlguous & 28,953 & 31,330 & 0 & 0 & 28,953 & 31,330 \\
\hline Alaska & 28,953 & 31,330 & 0 & 0 & 28.95 .1 & 31.330 \\
\hline Hawail ..... & $-\cdot$ & $-\cdot$ & -. & $\ldots$ & $\cdots$ & $\cdots$ \\
\hline U.S. Total & $2,765,608$ & $2,789,014$ & $2,543,273$ & $2,557,917$ & 222,335 & 231,097 \\
\hline
\end{tabular}

- Value less than 05

Notes. Data are final - Totals may not equal sum of components because of independent rounding

Source Energy Information Administration, Form ElA.759, "Monthly Power Plant Report." 
Table 21. Coal and Petroleum Stocks at Electric Utilitles by Census Division and State, as of December 31, 1992 and 1991

\begin{tabular}{|c|c|c|c|c|}
\hline \multirow{2}{*}{$\begin{array}{c}\text { Census Division } \\
\text { state }\end{array}$} & \multicolumn{2}{|c|}{$\begin{array}{l}\text { Coal } \\
\text { (thousand short tons) }\end{array}$} & \multicolumn{2}{|c|}{$\begin{array}{c}\text { Potroleum' } \\
\text { (thousand barrele) }\end{array}$} \\
\hline & 1992 & 1991 & 1992 & 1991 \\
\hline Now England & 1,237 & 1,128 & 6,073 & 5,289 \\
\hline Connecticut & 150 & 173 & 2.162 & 1,775 \\
\hline Maine & -- & -- & 681 & 784 \\
\hline 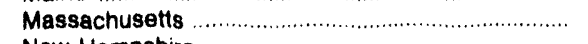 & 727 & 583 & 2,563 & 2,411 \\
\hline 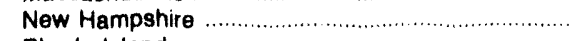 & 361 & 373 & 528 & 178 \\
\hline Rhode Island & 0 & 0 & 104 & 111 \\
\hline Vermont & - & -- & 36 & 30 \\
\hline 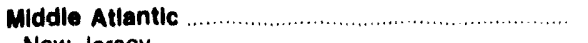 & 17,743 & 16,638 & 15,536 & 15,628 \\
\hline New Jersey & 771 & 681 & 1,822 & 2,190 \\
\hline New York & 2,106 & 1,546 & 11,855 & 11,666 \\
\hline 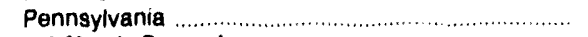 & 14,866 & 14,412 & 1,859 & 1,772 \\
\hline East North Contral & 40,250 & 39,394 & 2,798 & 2,757 \\
\hline 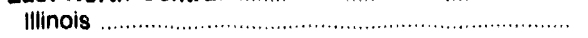 & 7,399 & 6,977 & 1,226 & 1,092 \\
\hline Indiana & 11,294 & 9,953 & 180 & 183 \\
\hline 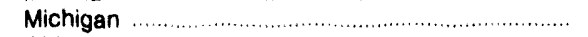 & 7.402 & 8,099 & 727 & 826 \\
\hline Ohio & 10,395 & 10,213 & 467 & 462 \\
\hline Wisconsin & 3,760 & 4,151 & 197 & 194 \\
\hline 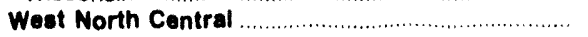 & 19,712 & 20,169 & 1,694 & 1,782 \\
\hline lowa & 4,301 & 4,499 & 187 & 196 \\
\hline 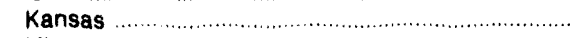 & 2.747 & 3,310 & 655 & 688 \\
\hline Minnesota & 2,175 & 2,616 & 167 & 159 \\
\hline 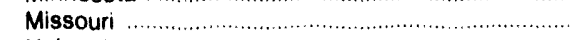 & 6,211 & 5,458 & 374 & 412 \\
\hline 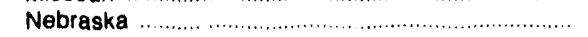 & 1,798 & 1,976 & 205 & 213 \\
\hline North Dakota & 2,194 & 1,999 & 46 & 49 \\
\hline South Dakota & 285 & 312 & 60 & 66 \\
\hline South Atlantic & 27,977 & 28,746 & 14,357 & 15,039 \\
\hline 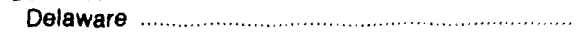 & 361 & 458 & 302 & 605 \\
\hline District of Columbia & -- & -- & 118 & 119 \\
\hline Florida & 4,021 & 4,781 & 8,221 & 8,689 \\
\hline Georgia & 4.692 & 5,251 & 523 & 555 \\
\hline Maryland & 2,400 & 2,220 & 1,610 & 1,879 \\
\hline North Carolina & 4.512 & 4,657 & 231 & 257 \\
\hline South Carolina & 2,206 & 1,988 & 343 & 378 \\
\hline Virginia & 1,922 & 1,685 & 2,833 & 2,398 \\
\hline West Virginia & 7,863 & 7,707 & 175 & 158 \\
\hline East South Central & 13,401 & 14,210 & 1,651 & 1,622 \\
\hline Alabama & 4,071 & 4,247 & 168 & 139 \\
\hline Kentucky & 5,415 & 5,881 & 119 & 102 \\
\hline 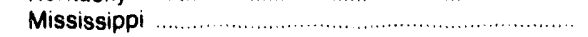 & 899 & 933 & 904 & 968 \\
\hline 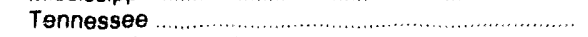 & 3,016 & 3,148 & 461 & 413 \\
\hline West South Central & 16,483 & 17,694 & 8,297 & 7,943 \\
\hline Arkansas . & 1,572 & 2.150 & 269 & 259 \\
\hline Louisiana & 1,701 & 2,235 & 1,743 & 1,295 \\
\hline Oklahoma & 3,066 & 2,835 & 617 & 521 \\
\hline Texas & 10,143 & 10.474 & 5,668 & 5,868 \\
\hline 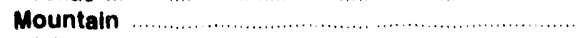 & 16,009 & 18,086 & 1,383 & 1,892 \\
\hline Arizona & 3.543 & 4,177 & 745 & 767 \\
\hline Colorado & 3,410 & 3,466 & 185 & 221 \\
\hline Idaho & -- & -- & 14 & 15 \\
\hline Montana & 735 & 741 & 14 & 18 \\
\hline Nevada & 1.447 & 1,412 & 253 & 689 \\
\hline New Mexico & 1.570 & 1,399 & 103 & 120 \\
\hline Utah & 3,153 & 4.123 & 28 & 30 \\
\hline 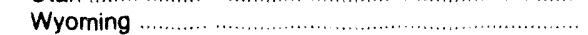 & 2,153 & 2,767 & 42 & 32 \\
\hline Pacific Contiguous & 1,312 & 1,804 & 18,841 & 21,672 \\
\hline California & - & -. & 18,211 & 21,022 \\
\hline 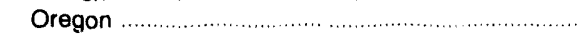 & 615 & 660 & 269 & 286 \\
\hline 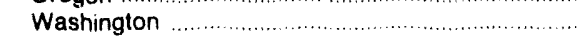 & 697 & 1,45 & 360 & 363 \\
\hline Pacific Noncontiguous & 6 & 8 & 1,219 & 1,369 \\
\hline Alaska & 6 & 8 & 306 & 241 \\
\hline Hawaii & .- & -. & 914 & 1,128 \\
\hline U.S. Total . . . & 154,130 & 157,876 & 71,849 & 74,993 \\
\hline
\end{tabular}

1 Does not include petroleum coke. Petroleum coke stocks at the end of 1992 were 67 thousand short tons and in 1991 were 70 thousand short tons. Notes: Data are final. - Totals may not equal sum of components because of independent rounding.

Source: Energy Information Administration, Form ElA-759, "Monthly Power Plant Report." 
Table 22. Fossil-Fuel Recelpts at Electric Utilities by Census Division and State, 1992 and 1991

\begin{tabular}{|c|c|c|c|c|c|c|}
\hline \multirow{2}{*}{$\begin{array}{c}\text { Census Division } \\
\text { State }\end{array}$} & \multicolumn{2}{|c|}{$\begin{array}{c}\text { Coal } \\
\text { (thousand short tons) }\end{array}$} & \multicolumn{2}{|c|}{$\begin{array}{c}\text { Petroleum' } \\
\text { (thousand barrels) }\end{array}$} & \multicolumn{2}{|c|}{$\frac{\text { Gas }}{\text { (mililon cubic feet) }}$} \\
\hline & 1992 & 1991 & 1992 & 1991 & 1992 & 1991 \\
\hline New England & 6,213 & 6,433 & 35,861 & 39,568 & 42,087 & 45,852 \\
\hline Connecticut .. & 793 & 871 & 9,108 & 11,724 & 2,000 & 4,690 \\
\hline Maine ................ & $-\cdots$ & -. & 2,198 & 2.235 & $-\cdots$ & $\ldots$ \\
\hline Massachusetts ... & 4,194 & 4,278 & 21,871 & 23,310 & 37,913 & 38,248 \\
\hline New Hampshire ............................ & 1,226 & 1,284 & 2,605 & 2,132 & 916 & 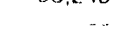 \\
\hline Rhode Island & $\ldots$ & .. & 80 & 167 & 458 & 1,821 \\
\hline 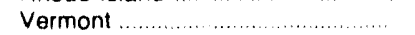 & -. & $\ldots$ & $\ldots$ & $\ldots$ & 800 & 1,093 \\
\hline Middle Atlantic & 53,680 & 52,066 & 38,740 & 53,535 & 229,709 & 246,863 \\
\hline New Jersey & 2,205 & 2,027 & 2,438 & 2,907 & 32,305 & 51,744 \\
\hline (.......................... & 10,393 & 9,235 & 32,680 & 45.887 & 195,476 & 194,870 \\
\hline Pennsylvania .......... & 41,082 & 40,804 & 3,622 & 4,741 & 1,929 & 249 \\
\hline East North Central & 169,346 & 170,575 & 3,920 & 4,432 & 43,401 & 45,531 \\
\hline 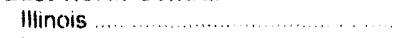 & 25,449 & 26,813 & 2,299 & 2.341 & 8.952 & 11.126 \\
\hline Indiana & 47,838 & 46,292 & 270 & 360 & 7,467 & 9,026 \\
\hline 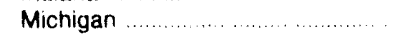 & 27,875 & 28,866 & 929 & 1.024 & 22,222 & 20.720 \\
\hline 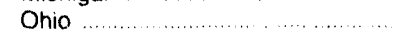 & 50,596 & 49,517 & 369 & 624 & 2,458 & 2,966 \\
\hline Wisconsin $\ldots \ldots \ldots \ldots$ & 17,589 & 19,087 & 54 & 83 & 2,70 & 1.693 \\
\hline West North Central & 101,643 & 105,054 & 496 & 585 & 18,23 & 48,575 \\
\hline 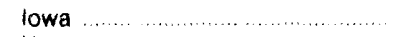 & 15,037 & 16,344 & 60 & 70 & 1,816 & 2,083 \\
\hline 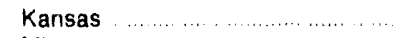 & 13,634 & 14,401 & 51 & 90 & 10,437 & 28,979 \\
\hline 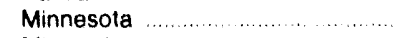 & 15,154 & 16.187 & 36 & 37 & 3,008 & 3,354 \\
\hline Missouri & 24.502 & 25,204 & 288 & 314 & 1.592 & 10,820 \\
\hline Nebraska & 7,759 & 8,908 & 8 & 8 & $1,3+0$ & 3,166 \\
\hline 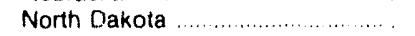 & 23,427 & 21,683 & 53 & 62 & - & \\
\hline 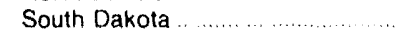 & 2,130 & 2,326 & $\ldots$ & 4 & 39 & 172 \\
\hline South Atlantlc & 125,181 & 124,355 & 54,488 & 57,679 & 217,976 & 231,677 \\
\hline Delaware & 1,532 & 2,002 & 2,214 & 2,448 & 2,188 & 5,087 \\
\hline District of Columbia & $\ldots$ & -- & 231 & 454 & -- & $\cdots$ \\
\hline Florida & 24,377 & 24.461 & 43,311 & 44,855 & 191,121 & 191,825 \\
\hline Georgia & 22,851 & 24,694 & 217 & 217 & 1.199 & 790 \\
\hline 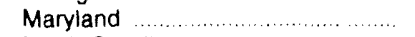 & 9,284 & 8,668 & 5.076 & 6,875 & 8,584 & 13,234 \\
\hline North Carolina & 20,660 & 18,167 & 193 & 226 & 2.917 & 2,932 \\
\hline 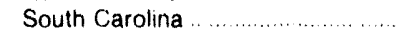 & 9.255 & 9,215 & 84 & 114 & 1,315 & 9,518 \\
\hline Virginia & 8,915 & 8,599 & 2,801 & 2,158 & 10.433 & 8,096 \\
\hline West Virginia & 28,307 & 28,549 & $3 \mathrm{C} 1$ & 333 & 219 & 196 \\
\hline East South Central & 80,758 & 77,397 & 1,108 & 1,241 & 41,671 & $51,81 y$ \\
\hline Alabama & 24,886 & 24,350 & 131 & 153 & 2,923 & 3,434 \\
\hline 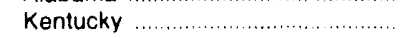 & 32,292 & 30,591 & 221 & 248 & 240 & 205 \\
\hline Mississippi & 3,208 & 3,727 & 607 & 657 & 38,508 & 48,180 \\
\hline Tennessee & 20,372 & 18,730 & 149 & 183 & -. & $\ldots$ \\
\hline West South Central & 128,757 & 127,713 & 627 & 617 & $1,365,720$ & $1,404,965$ \\
\hline Arkansas & 11,630 & 12,443 & 97 & 118 & 27,137 & 27,672 \\
\hline 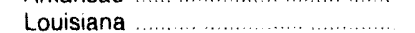 & 12,675 & 12,212 & 93 & 89 & 237,653 & 223.528 \\
\hline Oklahoma & 16,840 & 15,868 & 115 & 21 & 145,415 & 163.914 \\
\hline Texas & 87,613 & 87.189 & 324 & 389 & 955,515 & 989,850 \\
\hline Mountain & 102,617 & 99,693 & 790 & 825 & 80,491 & 76,185 \\
\hline Arizona & 16,315 & 17,020 & 140 & 133 & 29,420 & 22,575 \\
\hline Colorado & 15,597 & 15,500 & 27 & 17 & 1,521 & 2,680 \\
\hline Idaho & -.- & 10. & - & - & 1, - & 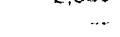 \\
\hline 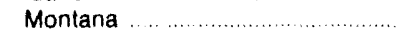 & 10,860 & 10,398 & 16 & 22 & 118 & 83 \\
\hline 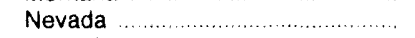 & 7.894 & 8,084 & 390 & 417 & 22,804 & 19,916 \\
\hline New Mexico & 14,929 & 12.888 & 74 & 78 & 21,661 & 26,895 \\
\hline Utah & 12,840 & 13,254 & 29 & 46 & 4,884 & 3,960 \\
\hline Wyoming & 24,181 & 22,549 & 114 & 110 & 83 & 76 \\
\hline Pacific Contiguous & 7,768 & 6,636 & 35 & 2,145 & 580,334 & 460,628 \\
\hline California & $\ldots$ & - & 1 & 2,045 & 565,619 & 449,661 \\
\hline 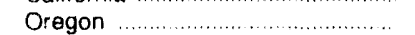 & 1,932 & 1,719 & 19 & 84 & 14,684 & 10,940 \\
\hline Washington & 5,836 & 4.917 & 15 & 15 & 30 & 27 \\
\hline Pacific Noncontiguous & - & - & 8,324 & 8,998 & 18,086 & 18,722 \\
\hline Alaska & - & $\sim \sim$ & - & $\ldots$ & 18,086 & 18.722 \\
\hline Hawaii & - & $\ldots$ & 8.324 & 8,998 & $\ldots$ & $\ldots$ \\
\hline U. S. Total & 775,963 & 769,923 & 144,390 & 169,625 & $2,637,678$ & $2,630,818$ \\
\hline
\end{tabular}

1 Does not include petroleum coke. Petroleum inka receipts in 1992 were 687 thousand short tons and in 1991 were 485 thousand short tons

- Value less than 0.5 .

Notes: Data are final. Data are for electric gerierating plants with a total steam-electric and combined-cycle nameplate capacity of 54 or more megawatts. - Totals may not equal sum of components because of independent rounding.

Source: Federal Energy Regulatory Commis:sion, FERC Form 423, "Monthly Report of Cost and Quality of Fuels for Electric Plants." 
Table 23. Average Delivered Cost of Fossil-Fuel Receipts at Electric Utilities by Census Division and State, 1992 and 1991

\begin{tabular}{|c|c|c|c|c|c|c|c|c|c|}
\hline \multirow{3}{*}{$\begin{array}{c}\text { Census Division } \\
\text { State }\end{array}$} & \multicolumn{3}{|c|}{ Coal } & \multicolumn{3}{|c|}{ Petroleum' } & \multicolumn{3}{|c|}{ Gas } \\
\hline & \multicolumn{2}{|c|}{1992} & \multirow{2}{*}{$\begin{array}{c}1991 \\
\text { (cents } \\
\text { per } \\
10^{6} \text { Btu) }\end{array}$} & \multicolumn{2}{|c|}{1992} & \multirow{2}{*}{$\begin{array}{c}1991 \\
\text { (cents } \\
\text { per } \\
10^{\circ} \text { Btu) }\end{array}$} & \multicolumn{2}{|c|}{1992} & \multirow{2}{*}{$\begin{array}{c}1991 \\
\text { (cents } \\
\text { per } \\
10^{8} \text { Btu) }\end{array}$} \\
\hline & $\begin{array}{c}\text { (\$ per } \\
\text { short } \\
\text { ton) }\end{array}$ & $\begin{array}{c}\text { (cents } \\
\text { per } \\
10^{\circ} \text { Btu) }\end{array}$ & & $\begin{array}{l}\text { (\$ per } \\
\text { barrel) }\end{array}$ & $\begin{array}{c}\text { (cents } \\
\text { per } \\
10^{6} \text { Btu) }\end{array}$ & & $\begin{array}{l}\text { (S per } \\
\text { Mct) }\end{array}$ & $\begin{array}{c}\text { (cents } \\
\text { per } \\
10^{6} \text { Btu) }\end{array}$ & \\
\hline 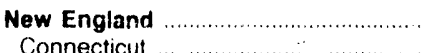 & 45.14 & 172.0 & 178.9 & 14.85 & 233.2 & 225.9 & 2.65 & 256.9 & 215.6 \\
\hline 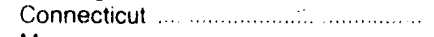 & 51.30 & 194.8 & 216.6 & 15.27 & 241.0 & 247.4 & 2.74 & 265.9 & 209.0 \\
\hline 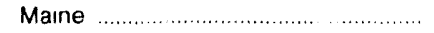 & -- & -. & -- & 14.48 & 228.8 & 208.5 & -- & -.. & -.. \\
\hline 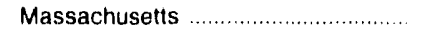 & 44.11 & 168.7 & 172.5 & 15.03 & 236.3 & 221.0 & 2.68 & 259.3 & 218.4 \\
\hline 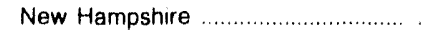 & 44.69 & 168.5 & 174.4 & 12.23 & 185.8 & 179.6 & 2.10 & 205.9 & - \\
\hline 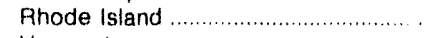 & $-\cdots$ & -- & -- & 12.50 & 195.0 & 241.1 & 2.20 & 213.4 & 198.0 \\
\hline 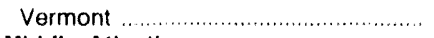 & - & -- & - & - & - & -.. & 2.00 & 202.4 & 174.0 \\
\hline Middle Atlantlc & 37.56 & 149.6 & 156.5 & 16.92 & 267.3 & 273.6 & 2.45 & 237.4 & 217.2 \\
\hline New Jersey & 46.62 & 173.1 & 178.2 & 18.96 & 303.3 & 302.1 & 2.18 & 210.9 & 195.7 \\
\hline New York ...... & 38.62 & 148.8 & 159.4 & 16.72 & 263.8 & 271.9 & 2.48 & 241.2 & 2.22 .8 \\
\hline Pennsylvania ............. & 36.81 & 148.4 & 154.7 & 17.34 & 275.2 & 272.8 & 3.06 & 297.2 & 295.3 \\
\hline East North Central .......... & 32.05 & 145.6 & 148.7 & 20.23 & 326.9 & 336.3 & 1.56 & 221.2 & 218.1 \\
\hline Illinois ....................... & 37.06 & 173.7 & 171.4 & 19.27 & 305.1 & 308.8 & 2.24 & 220.1 & 210.4 \\
\hline Indiana & 27.89 & 131.2 & 134.4 & 25.57 & 443.3 & 493.9 & 2.48 & 247.7 & 237.7 \\
\hline 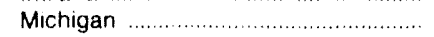 & 34.23 & 155.6 & 159.2 & 18.34 & 296.8 & 285.5 & .81 & 195.4 & 195.9 \\
\hline Ohio & 34.40 & 143.5 & 147.9 & 26.09 & 451.4 & 428.7 & 2.31 & 223.8 & 217.9 \\
\hline 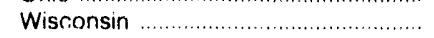 & 25.92 & 133.3 & 135.8 & 27.19 & 463.7 & 445.8 & 2.42 & 240.0 & 270.3 \\
\hline 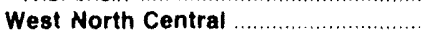 & 18.92 & 110.0 & 112.2 & 19.32 & 318.5 & 335.8 & 2.06 & 209.8 & 171.7 \\
\hline lowa $\ldots \ldots \ldots \ldots \ldots \ldots$ & 19.58 & 110.4 & 110.4 & 24.57 & 424.0 & 437.7 & 3.08 & 306.8 & 268.5 \\
\hline 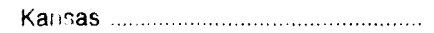 & 20.99 & 117.9 & 122.6 & 25.58 & 437.8 & 431.6 & 1.94 & 199.9 & 170.7 \\
\hline Minnesota & 20.96 & 118.6 & 126.0 & 26.24 & 450.9 & 382.9 & 1.85 & 183.7 & 170.2 \\
\hline 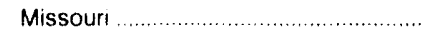 & 27.57 & 1336 & 134.2 & 14.67 & 234.9 & 261.9 & 1.89 & 187.2 & 149.1 \\
\hline Nebraska & 12.77 & 74.6 & 74.5 & 26.87 & 464.9 & 457.3 & 2.28 & 238.2 & 196.8 \\
\hline 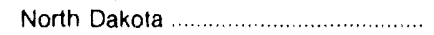 & 9.45 & 72.1 & 70.9 & 26.72 . & 457.7 & 426.1 & 4.18 & 403.3 & 433.9 \\
\hline South Dakota & 13.68 & 113.3 & 113.3 & $\ldots$ & $\ldots$ & 487.9 & 2.88 & 282.7 & 175.8 \\
\hline South Atlantic & 41.28 & 165.6 & 169.7 & 15.51 & 244.5 & 230.0 & 2.34 & 230.5 & 212.0 \\
\hline Delaware & 45.31 & 173.4 & 178.2 & 15.31 & 241.8 & 237.9 & 2.70 & 260.0 & 236.9 \\
\hline District of Columbia & $\ldots$ & - & -- & 21.03 & 350.4 & 318.6 & $\ldots$ & $\ldots$ & - \\
\hline Florida & 45.03 & 182.0 & 185.7 & 15.38 & 241.7 & 224.8 & 2.30 & 227.7 & 213.5 \\
\hline Georgia & 43.36 & 180.1 & 179.9 & 25.64 & 434.4 & 473.8 & 2.89 & 282.2 & 276.3 \\
\hline 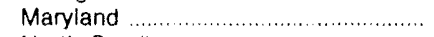 & 40.68 & 159.5 & 163.4 & 14.56 & 230.3 & 226.1 & 2.66 & 255.0 & 225.8 \\
\hline 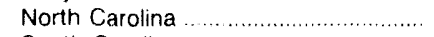 & 43.00 & 172.6 & 177.9 & 25.65 & 441.1 & 473.5 & 2.96 & 286.0 & 267.5 \\
\hline South Carolina & 39.13 & 152.7 & 162.6 & 26.79 & 461.7 & 475.1 & 1.73 & 169.0 & 148.9 \\
\hline 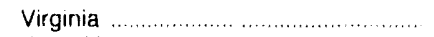 & 37.81 & 147.3 & 152.2 & 15.45 & 247.1 & 222.7 & 2.48 & 2372 & 182.2 \\
\hline West Virginia & 36.88 & 147.2 & 151.7 & 28.35 & 483.8 & 537.4 & 3.53 & 352.5 & 363.3 \\
\hline 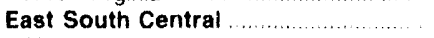 & 33.05 & 138.5 & 142.3 & 19.49 & 317.5 & 345.4 & 1.88 & 183.2 & 159.6 \\
\hline Alabama & 41.67 & 172.7 & 181.0 & 26.49 & 459.8 & 5118 & 2.28 & 222.9 & 187.1 \\
\hline 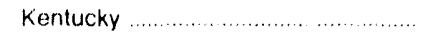 & 27.01 & 116.2 & 1177 & 27.99 & 479.4 & 505.1 & 2.77 & 271.5 & 259.7 \\
\hline 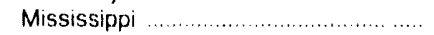 & 39.94 & 159.7 & 166.9 & 12.82 & 200.0 & 215.7 & 1.85 & 179.7 & 157.3 \\
\hline Tennessee & 31.01 & 127.3 & 125.2 & 27.93 & 480.2 & 498.3 & -. & - & $-\cdots$ \\
\hline West South Central & 22.55 & 147.4 & 149.9 & 24.42 & 416.4 & 477.3 & 2.28 & 221.3 & 199.7 \\
\hline 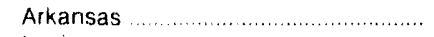 & 28.84 & 165.3 & 159.7 & 27.71 & 480.8 & 560.7 & 1.57 & 153.2 & 140.9 \\
\hline 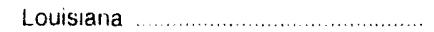 & 24.93 & 153.5 & 164.7 & 23.12 & 387.9 & 413.4 & 1.91 & 182.8 & 153.1 \\
\hline Oklahoma & 21.47 & 123.4 & 131.8 & 25.33 & 435.6 & 408.7 & 3.20 & 308.2 & 286.5 \\
\hline Texas & 21.58 & 149.1 & 149.9 & 23.49 & 399.0 & 471.0 & 2.25 & 219.5 & 197.4 \\
\hline 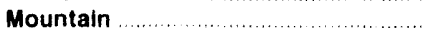 & 21.64 & 111.3 & 113.6 & 24.41 & 405.7 & 445.6 & 2.07 & 201.8 & 181.5 \\
\hline Arizona & 2831 & 137.4 & 140.8 & 2751 & 466.5 & 499.0 & 2.28 & 221.3 & 200.5 \\
\hline 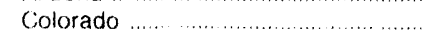 & 21.67 & 109.2 & 108.7 & 27.25 & 479.3 & 512.6 & 2.14 & 214.0 & 2149 \\
\hline Idaho & -. & -- & $\ldots$ & -- & -.. & $-\ldots$ & -- & $-\cdots$ & $\ldots$ \\
\hline 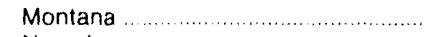 & 12.14 & 70.8 & 67.1 & 30.15 & 509.1 & 471.7 & 4.12 & 341.9 & 393.5 \\
\hline 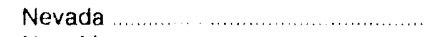 & 32.32 & 146.2 & 140.6 & 20.56 & 331.3 & 393.3 & 1.91 & 186.7 & 173.4 \\
\hline 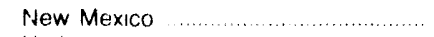 & 23.83 & 132.2 & 137.6 & 29.38 & 515.5 & 535.3 & 1.99 & 195.4 & 170.1 \\
\hline 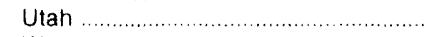 & 27.54 & 120.9 & 119.4 & 28.47 & 484.1 & 490.3 & 1.87 & 174.5 & 161.5 \\
\hline 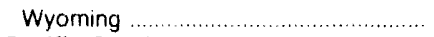 & 13.42 & 75.9 & 83.1 & 28.01 & 479.3 & 494.3 & 3.33 & 320.1 & 333.6 \\
\hline Pacific Contiguous & 22.17 & 129.6 & 142.6 & 26.42 & 448.7 & 314.4 & 2.79 & 269.9 & 283.9 \\
\hline 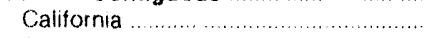 & - & - & - & 13.26 & 217.9 & 306.2 & 2.81 & 271.8 & 286.9 \\
\hline 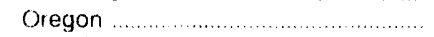 & 21.23 & 110.1 & 108.4 & 26.44 & 449.2 & 475.3 & 1.96 & 193.7 & 1570 \\
\hline Washington & 22.48 & 137.3 & 1551 & 27.39 & 466.0 & 572.9 & 3.31 & 315.5 & 383.0 \\
\hline Pacific Noncontiguous & - & - & - & 18.32 & 292.1 & 330.6 & 1.18 & 117.6 & 115.6 \\
\hline Alaska & -. & -- & -- & -- & -- & - & 1.18 & 117.6 & 115.6 \\
\hline Hawaii .... & -. & - & - & 18.32 & 292.1 & 330.6 & ... & $\ldots$ & ... \\
\hline U. S. Total & 29.36 & 141.2 & 144.7 & 16.15 & 255.1 & 254.8 & 2.38 & 232.8 & 215.3 \\
\hline
\end{tabular}

' Does not include petroleum coke. Petroleum coke cost in 1992 was 75.0 cents per million Btu and in 1991 was 81.0 cents per million Btu. Mct thousand cubic feet.

Notes - Data are final. Data are for electric generating plants with a total steam-electric and combined-cycle narneplate capacity of 50 or more megawatts. -Totais may not equal sum of components because of independent rounding.

Source: Federal Energy Regulatory Commission, FERC Form 423, "Monthly Report of Cost and Quality of Fuels for Electric Plants." 


\section{U.S. Electric Utility Retail Sales and Revenue}

This chapter provides summary statistics on the sale of electricity to ultimate consumers by U.S. electric utilities, its associated revenue, and the average revenue per kilowatthour sold at the national, Census, and State levels.

\section{Background}

Because electricity itself cannot be stored, it must be generated, transmitted to the consumer, and consumed instantaneously. Electric utility companies were formed to provide these services. An electric system consists of energy conversion plants (stations) that convert different forms of energy to electric power; transformers to raise the voltage in order to reduce losses in transmitting the power; transmission lines to transmit the power to the general vicinity of consumption; transformers to lower the voltage; and distribution lines to distribute the power to the ultimate consumers. The entire system of generating stations, transformers, transmission lines, distribution lines, etc., is a power system. Power companies plan, design, build, and operate this power system. Some companies may only operate part of a power system. For example, many small power companies only distribute power to ultimate consumers, buying their power from other companies that generate power. Power systems are interconnected for mutual operating and economic advantages.

U.S. electric utilities are high-investment businesses and historically have been treated as monopolies because duplicate facilities, particularly transmission and distribution lines, would be inefficient. Thus, franchises are granted to electric utilities for given geographical areas by regulatory officials. To obtain a franchise, electric utilities must provide service to all consumers in their territories at a reasonable cost.

The service territory of an electric utility is usually composed of many different combinations of consumers. Electric utilities classify their consumers by different factors such as demand, rate schedule, Standard Industrial Classification (SIC) code, distribution voltage, accounting methods, end-use applications, and other social and economic characteristics. Electric utilities use consumer classifications for planning purposes (load growth, peak demands) and for deriving their rate schedules, often with the approval of a government regulatory agency.

\section{End-Use Sectors}

Consumers within the service territory of an electric utility are generally grouped into end-use sectors -residential, commercial, and industrial. The categorization of consumer is determined by the electric utility based on its service territory, size, location, ownership, and regulatory structure.

The residential sector includes private households and apartment buildings, where energy is consumed primarily for space heating, water heating, air conditioning, lighting, refrigeration, cooking, and ciothes drying.

The commercial sector includes nonmanufacturing business establishments, including hotels, motels, restaurants, wholesale businesses, and retail stores; and, health, social, and educational institutions. However, electric utilities may classify commercial service as that to all consumers, including light manufacturers, whose demand or annual usage fall within a specified range. The range may be set by the electric utility based on its rate schedule.

The industrial sector includes manufacturing, construction, mining, agriculture, fishing, and forestry establishments -- Standard Industrial Classification (SIC) codes 1-39. However, electric utilities may classify industrial service based on demand or annual usage exceeding a specified range. As in the commercial sector, the range may be set by the electric utility based on its rate schedule.

Other sales include public street and highway lighting, railroads and railways, municipalities, divisions or agencies of State and Federal governments under special contracts or agreements, and other utility departments as defined by the pertinent regulatory agency and/or electric utility. 


\section{Revenue Requirements}

The revenue requirements of an electric utility are set to reimburse the utility for providing electric service. The revenue requirement is the anticipated cost of providing services for some period of time in the future, usually a year. Revenue requirements are based on operating expenses, depreciation expense, taxes, and return on the ratebase (profit of the electric utility). The process of determining electricity prices generally follows three stages (1) identification of revenue requirements, (2) allocation of the requirements for different classes of service (sectors), and (3) establishment of rate schedules for each sector.

The rate schedules developed to generate revenue requirements for electric utilities are unique to each utility. The authority for the approval of these rates is based on the ownership class applicable to the utility. For example, investor-owned electric utilities are regulated by State public service commissions and the Federal Energy Regulatory Commission. Public electric utilities, in most States, are controlled through locally elected or appointed officials. A more detailed discussion on utility classes of ownership is contained in the "Industry Profile" section in the first chapter of this publication.

A rate schedule is a statement that the utility will provide service to a particular class of consumer at a certain price. Prices between sectors vary based on various objectives of the utility. These objectives include the need to allocate the various costs incurred in providing service, to maintain the existing consumer base of the utility, and to promote new business.

\section{Average Revenue per Kilowatthour}

The average revenue per kilowatthour of electricity sold by electric utilities is calculated by dividing total annual revenue by total annual retail sales for each sector and State. The resulting measurement is the cost (per kilowatthour of electricity sold) for providing service to a sector, given the rate schedule of the electric utility for that particular sector. Average revenue per kilowatthour from residential consumers is generally higher than for any other sector. This is due, in part, to the higher costs associated with serving many consumers who use relatively small amounts of electricity. These costs include direct-load costs (such as those for distribution lines, transformers, and meters) in addition to consumer or administrative costs. The industrial sector, which generally covers consumers with the highest use of electricity, has the lowest average revenue per kilowatthour. This is because of the economies of serving a few consumers who use relatively large amounts of electricity.

Federal electric utilities generally have the lowest average revenue per kilowathour for the ownership classes because they have access to relatively low-cost financing and mostly utilize less expensive hydroelectric facilities. Because publicly owned electric utilities also have access to relatively low-cost financing and are nonprofit entities, they have lower average revenue per kilowatthour than investor-owned electric utilities. Although cooperative electric utilities have economic advantages similar to those of the publicly owned electric utilities, they generally serve sparsely populated areas. As a consequence, conperative electric utilities generally have higher average revenue per kilowatthour than do investor-owned utilities.

Because of the type and availability of capacity and the cost of fuel, the average revenue per kilowatthour differs across U.S. Census divisions. The New England and Middle Atlantic Census Divisions tend to have an average revenue per kilowathour that is higher than average because of their reliance on petroleum; whereas, the East and West South Central Census Divisions rely on gas-fired generation and the East North Central and South Atlantic Census Divisions rely on coal-fired generation. Petroleum is generally a more expensive energy source than coal and natural gas. Because the Mountain Census Division relies on less expensive hydroelectric generation, the average revenue per kilowatthour in this region is usually below the national average for all classes of consumers. The Census divisions where Federal hydroelectric facilities provide significant amounts of electricity, such as the East South Central Census Division, also have lower than average revenue per kilowatthour.

\section{Data Sources}

Summary statistics on retail sales of electricity by electric utilities and average revenue are provided in the following tables. These data were obtained from the Form EIA-861, "Annual Electric Utility Report." The form is used to collect annual data from all electric utilities (approximately 3,250), that own and/or operate facilities within the United States, its territories, and Puerto Rico, for the generation, transmission, distribution, or sale of electric energy primarily for use by the public. More detailed statistics on sales, average revenue, and average revenue per kilowatthour are published in the Electric Sales and Revenue."

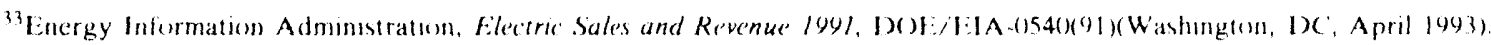


Table 24. U.S. Electric Utility Sales to Ultimate Consumers and Associated Revenue by Sector, 1988 Through 1992

\begin{tabular}{|c|c|c|c|c|c|}
\hline Item & 1992 & 1991 & 1990 & 1989 & 1988 \\
\hline \multicolumn{6}{|l|}{ Sales (million kllowatthours) } \\
\hline Residential ................................ & 935,940 & 955,417 & 924,019 & 905,525 & 892,866 \\
\hline Commercial & 761,269 & 765,664 & 751,027 & 725,861 & 699,100 \\
\hline Industrial & 972,691 & 946,583 & 945,522 & 925,659 & 896,498 \\
\hline Other' & 93,443 & 94,339 & 91,988 & 89,765 & 89,598 \\
\hline 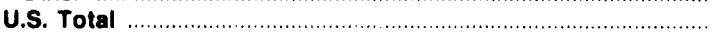 & $2,763,343$ & $2,762,003$ & $2,712,555$ & $2,646,809$ & $2,578,062$ \\
\hline \multicolumn{6}{|l|}{ Revenue (million dollars) } \\
\hline 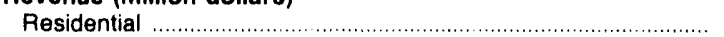 & 76,848 & 76,828 & 72,378 & 69,240 & 66,790 \\
\hline Commercial & 58,342 & 57,655 & 55,117 & 52,228 & 49,224 \\
\hline Industrial . . & 46,992 & 45,737 & 44,857 & 43,719 & 42,145 \\
\hline Other' ${ }^{\prime}$ & $\begin{array}{r}40,502 \\
6,296\end{array}$ & 6,138 & $\begin{array}{r}4,037 \\
5,891\end{array}$ & 5,609 & $\begin{array}{r}4<, 140 \\
5,551\end{array}$ \\
\hline U.S. Total & 188,480 & 186,359 & 178,243 & 170,797 & 163,710 \\
\hline
\end{tabular}

1 Includes public street and highway lighting, other sales to public authorities, sales to railroads and railways, and interdepartmental sales.

Notes: - Data for 1992 are preliminary; data for prior years are final. - Totals may not equal sum of components because of independent rounding. Source: Energy Information Administration, Form ElA-861, "Annual Electric Utility Report."

Table 25. Average Revenue per Kilowatthour for U.S. Electric Utilities by Sector, 1988 Through 1992 (Cents)

\begin{tabular}{|c|c|c|c|c|c|}
\hline Sector & 1992 & 1991 & 1990 & 1989 & 1988 \\
\hline Residential & 8.2 & 8.0 & 7.8 & 7.6 & 7.5 \\
\hline 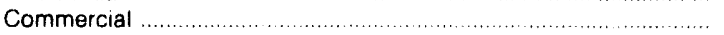 & 7.7 & 7.5 & 7.3 & 7.2 & 7.0 \\
\hline Industrial & 4.8 & 4.8 & 4.7 & 4.7 & 4.7 \\
\hline Other ${ }^{1}$ & 6.7 & 6.5 & 6.4 & 6.2 & 6.2 \\
\hline All Sector8 & 6.8 & 6.7 & 6.6 & 6.5 & 6.4 \\
\hline
\end{tabular}

1 Includes public street and highway lighting, other sales to public authorities, sales to railroads and railways, and interdepartmental sales.

Notes: - Data for 1992 are preliminary; data for prior years are final. - The average revenue per kilowatthour of electricity sold is calculated by dividing revenue by sales. Totals may not equal sum of components because of independent rounding

Source. Energy Information Administration, Form ElA-861, "Annual Electric Utility Report." 
Table 26. Electric Utility Sales to Ultimate Consumers by Sector, Census Division, and State, 1992 and 1991

(Million Kilowatthours)

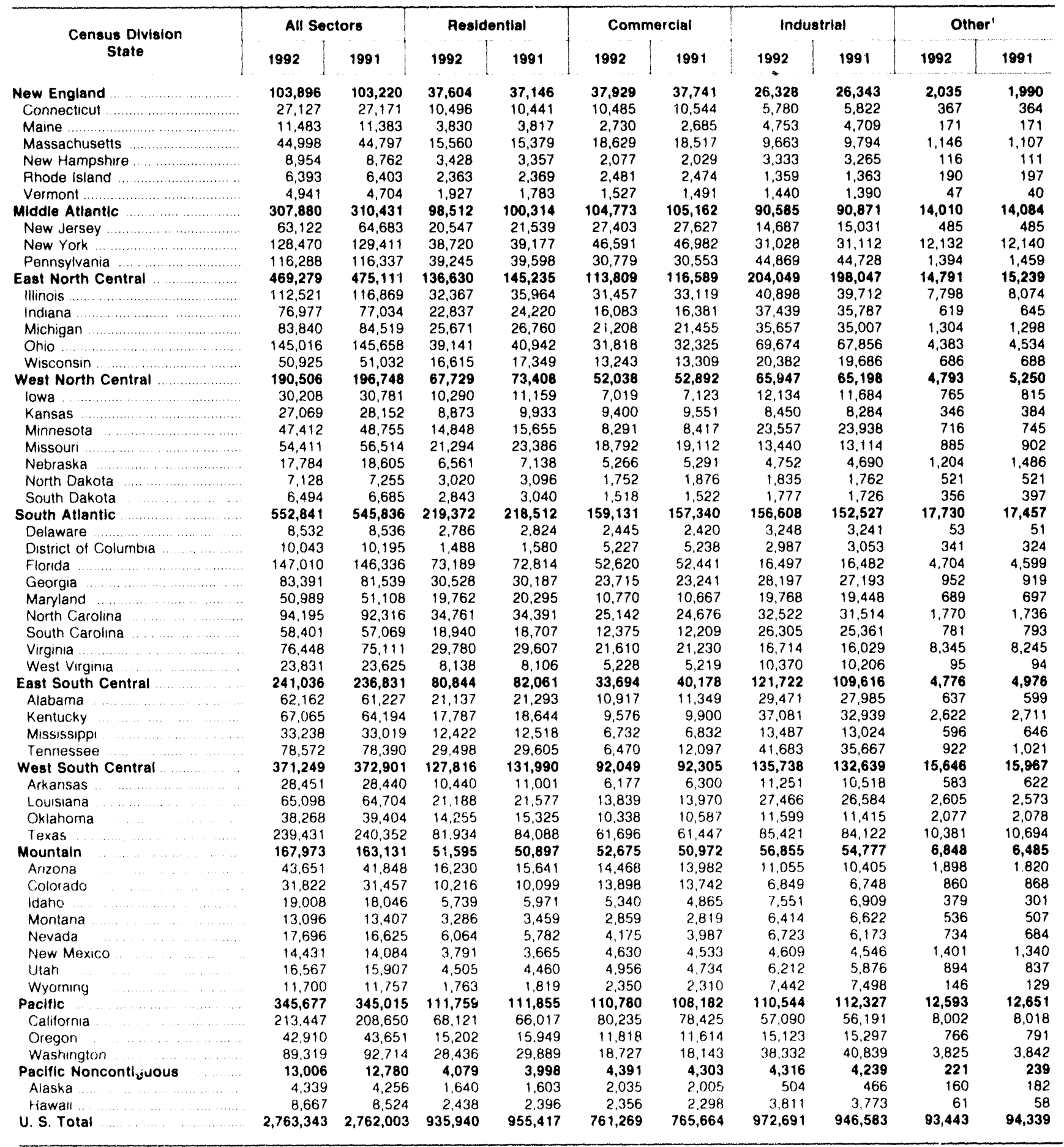

- Includes public street and highway lighting. other sales to public authorities, sales to railroads and railways, and interdepartmental sales.

Notes: Data for 1992 are preliminary, data for prior years are firial. - Totals may not equal sum of components because of independent rounding Source Energy Iniormation Administration, Form EIA.861. "Annual Electric Utility Report." 
Table 27. Number of Ultimate Consumers Served by Electric Utilities by Sector, Census Division, and State, 1992 and 1991 (Thousands)

\begin{tabular}{|c|c|c|c|c|c|c|c|c|c|c|}
\hline \multirow{2}{*}{$\begin{array}{c}\text { Census Divialon } \\
\text { State }\end{array}$} & \multicolumn{2}{|c|}{ All Sectors } & \multicolumn{2}{|c|}{ Residential } & \multicolumn{2}{|c|}{ Commercial } & \multicolumn{2}{|c|}{ Industrial } & \multicolumn{2}{|c|}{ Other' } \\
\hline & 1992 & 1991 & 1992 & 1991 & 1992 & 1991 & 1992 & 1991 & 1992 & 1991 \\
\hline New Englend. & 6,108 & 6,058 & 5,397 & 5,354 & 637 & 631 & 26 & 25 & 49 & 48 \\
\hline 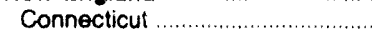 & 1,446 & 1,441 & 1,311 & 1,306 & 125 & 125 & 5 & 5 & 5 & 5 \\
\hline 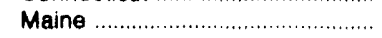 & 675 & 667 & 585 & 577 & 70 & 70 & 1 & 1 & 19 & 19 \\
\hline 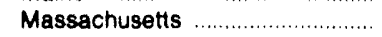 & 2,665 & 2,648 & 2,350 & 2,337 & 285 & 282 & 14 & 14 & 16 & 15 \\
\hline 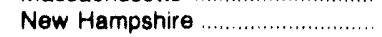 & 579 & 569 & 496 & 488 & 75 & 73 & 2 & 2 & 6 & 6 \\
\hline Rhode Island & 440 & 437 & 391 & 389 & 45 & 45 & 3 & 3 & 1 & 1 \\
\hline 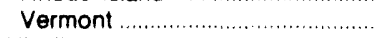 & 304 & 297 & 263 & 258 & 36 & 36 & 1 & 1 & 3 & 3 \\
\hline 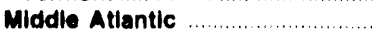 & 15,833 & 15,741 & 13,998 & 13,895 & 1,732 & 1,744 & 55 & 53 & 49 & 48 \\
\hline New Jersey & 3,327 & 3,323 & 2,931 & 2,914 & 372 & 389 & 14 & 13 & 10 & 10 \\
\hline Now York ....... & 7,216 & 7,171 & 6,355 & 6,309 & 818 & 820 & 12 & 12 & 31 & 30 \\
\hline Pennsylvania .......... & 5,290 & 5,247 & 4,711 & 4,674 & 542 & 536 & 29 & 29 & 8 & 8 \\
\hline East North Central & 18,727 & 18,562 & 16,773 & 16,630 & 1,796 & 1,782 & 76 & 72 & 83 & 79 \\
\hline Illinois & 4,910 & 4,878 & 4,434 & 4,405 & 448 & 449 & 3 & 5 & 21 & 20 \\
\hline Indiana & 2,524 & 2,492 & 2,247 & 2,218 & 248 & 246 & 16 & 16 & 12 & 13 \\
\hline Michigan & 4.175 & 4,140 & 3,745 & 3,716 & 397 & 392 & 15 & 14 & 18 & 18 \\
\hline Ohio & 4,810 & 4,761 & 4,294 & 4,252 & 465 & 460 & 32 & 31 & 19 & 18 \\
\hline 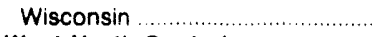 & 2,307 & 2,292 & 2,053 & 2,040 & 237 & 235 & 5 & 6 & 12 & 10 \\
\hline West North Central ....................... & 8,556 & 8,515 & 7,408 & 7,367 & 983 & 979 & 48 & 47 & 117 & 121 \\
\hline lowa $\ldots \ldots \ldots \ldots$ & 1,327 & 1.318 & 1,152 & 1,145 & 160 & 158 & 4 & 4 & 11 & 12 \\
\hline Kansas & 1,224 & 1,267 & 1,038 & 1,069 & 161 & 172 & 13 & 13 & 11 & 12 \\
\hline 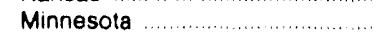 & 2.050 & 2,016 & 1,812 & 1,781 & 203 & 199 & 11 & 10 & 24 & 26 \\
\hline 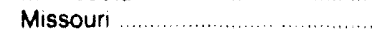 & 2,474 & 2,449 & 2,184 & 2.164 & 264 & 259 & 11 & 11 & 15 & 15 \\
\hline 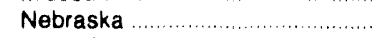 & 819 & 808 & 666 & 656 & 108 & 106 & 5 & 5 & 39 & 40 \\
\hline 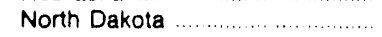 & 318 & 317 & 266 & 265 & 44 & 44 & 3 & 3 & 5 & 5 \\
\hline South Dakota & 345 & 340 & 289 & 286 & 42 & 42 & 2 & 2 & 11 & 11 \\
\hline South Atlantic & 21,216 & 20,817 & 18,663 & 18,318 & 2,264 & 2,217 & 80 & 81 & 208 & 201 \\
\hline Delaware & 327 & 321 & 293 & 288 & 33 & 31 & 1 & 1 & 1 & 1 \\
\hline District of Columbia & 220 & 220 & 193 & 193 & 27 & 27 & $\cdot$ & $\cdot$ & $\cdot$ & - 1 \\
\hline Florıda & 6,930 & 6,803 & 6.082 & 5,975 & 733 & 717 & 21 & 22 & 94 & 89 \\
\hline 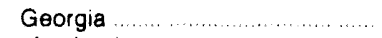 & 3,095 & 3.026 & 2,750 & 2,691 & 306 & 299 & 14 & 14 & 25 & 22 \\
\hline 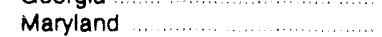 & 1,988 & 1.957 & 1,787 & 1,759 & 190 & 186 & 11 & 11 & 1 & 1 \\
\hline North Carolina & 3,363 & 3.302 & 2.917 & 2,860 & 402 & 396 & 14 & 15 & 30 & 31 \\
\hline 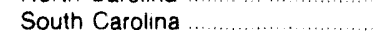 & 1,712 & 1,680 & 1.476 & 1,449 & 213 & 210 & 4 & 4 & 19 & 17 \\
\hline Virginia & 2,702 & 2,640 & 2,401 & 2,346 & 261 & 254 & 5 & 4 & 36 & 36 \\
\hline West Virginia & 877 & 868 & 764 & 757 & 99 & 97 & 11 & 11 & 3 & 4 \\
\hline East South Central. & 7,247 & 7,186 & 6,288 & 6,205 & 858 & 861 & 58 & 40 & 42 & 81 \\
\hline Alabama $\ldots \ldots \ldots$ & 1,952 & 1.918 & 1,693 & 1,666 & 240 & 235 & 12 & 9 & 7 & 8 \\
\hline 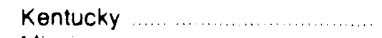 & 1,748 & 1.745 & 1,528 & 1,525 & 192 & 192 & 10 & 9 & 18 & 18 \\
\hline Mississippi $\ldots \ldots \ldots \ldots \ldots \ldots \ldots$ & 1,186 & 1,183 & 1.021 & 1,006 & 149 & 147 & 7 & 6 & 9 & 24 \\
\hline 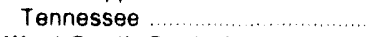 & 2,360 & 2,340 & 2,046 & 2,007 & 277 & 286 & 29 & 16 & 8 & 30 \\
\hline West South Central & 12,386 & 12,194 & 10,757 & 10,586 & 1,368 & 1,345 & 113 & 113 & 148 & 150 \\
\hline Arkansas & 1,174 & 1,158 & 1,021 & 1,004 & 115 & 114 & 23 & 22 & 15 & 17 \\
\hline Louisiana & 1,881 & 1.864 & 1,656 & 1,642 & 191 & 189 & 15 & 14 & 20 & 19 \\
\hline Oklahoma & 1,592 & 1.574 & 1,374 & 1,359 & 188 & 187 & 17 & 16 & 14 & 13 \\
\hline 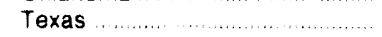 & 7,739 & 7.598 & 6,706 & 6,582 & 874 & 855 & 59 & 61 & 100 & 101 \\
\hline 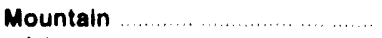 & 6,494 & 6,422 & 5,621 & 5,558 & 766 & 760 & 35 & 34 & 72 & 70 \\
\hline Arizona & 1,687 & 1,646 & 1.496 & 1,457 & 164 & 161 & 5 & 5 & 22 & 22 \\
\hline Colorado & 1,658 & 1,700 & 1,438 & 1,475 & 203 & 209 & 2 & 2 & 15 & 13 \\
\hline Idaho & 502 & 489 & 420 & 409 & 74 & 72 & 4 & 4 & 4 & 3 \\
\hline Montana & 425 & 420 & 349 & 346 & 59 & 57 & 4 & 5 & 13 & 12 \\
\hline 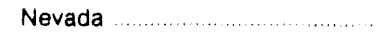 & 616 & 594 & 536 & 515 & 78 & 76 & $i$ & 1 & 2 & 2 \\
\hline New Mexico & 698 & 687 & 597 & 588 & 86 & 85 & 5 & 5 & 9 & 9 \\
\hline Utah & 664 & 645 & 588 & 572 & 62 & 60 & 10 & 9 & 4 & 4 \\
\hline Wyoming & 245 & 242 & 199 & 196 & 39 & 39 & 3 & 3 & 4 & 4 \\
\hline Pacific Contiguous & 16,094 & 15,906 & 14,075 & 13,975 & 1,881 & 1,800 & 55 & 52 & 83 & 79 \\
\hline Calitornia & 12,316 & 12,205 & 10,761 & 10,728 & 1,469 & 1.398 & 38 & 34 & 48 & 46 \\
\hline Oregon & 1,415 & 1,388 & 1.224 & 1,201 & 173 & 169 & 7 & 7 & 12 & 11 \\
\hline Washington & 2,363 & 2,313 & 2,090 & 2.047 & 239 & 233 & 11 & 10 & 23 & 23 \\
\hline Paciflc Noncontiguous & 620 & 615 & 531 & 521 & 83 & 82 & 1 & 1 & 6 & 11 \\
\hline Alaska & 237 & 237 & 199 & 196 & 33 & 32 & $\cdot$ & $\cdot$ & 4 & 9 \\
\hline Hawail ............ & 384 & 378 & 331 & 326 & 50 & 50 & 1 & 1 & 2 & 2 \\
\hline U. S. Average & 113,282 & 112,016 & 99,510 & 98,409 & 12,367 & 12,201 & 548 & 518 & 858 & 888 \\
\hline
\end{tabular}

' Includes public street and highway lighting, other sales to public authorities, sales to railroads and railways, and interdepartmental sales - Value less than 0.5 thousand

Notes: -Data for 1992 are preliminary; data for prior years are final. Totals may not equal sum of components because of independent rounding - The number of ultimate consumers is an average of the number of consumers at the close of each month

Source: Energy information Administration. Form ElA.861. "Annual Electric Utility Repont." 
Table 28. Revenue from Electric Utility Sales to Ultimate Consumers by Sector, Census Division, and State, 1992 and 1991

(Million Dollars)

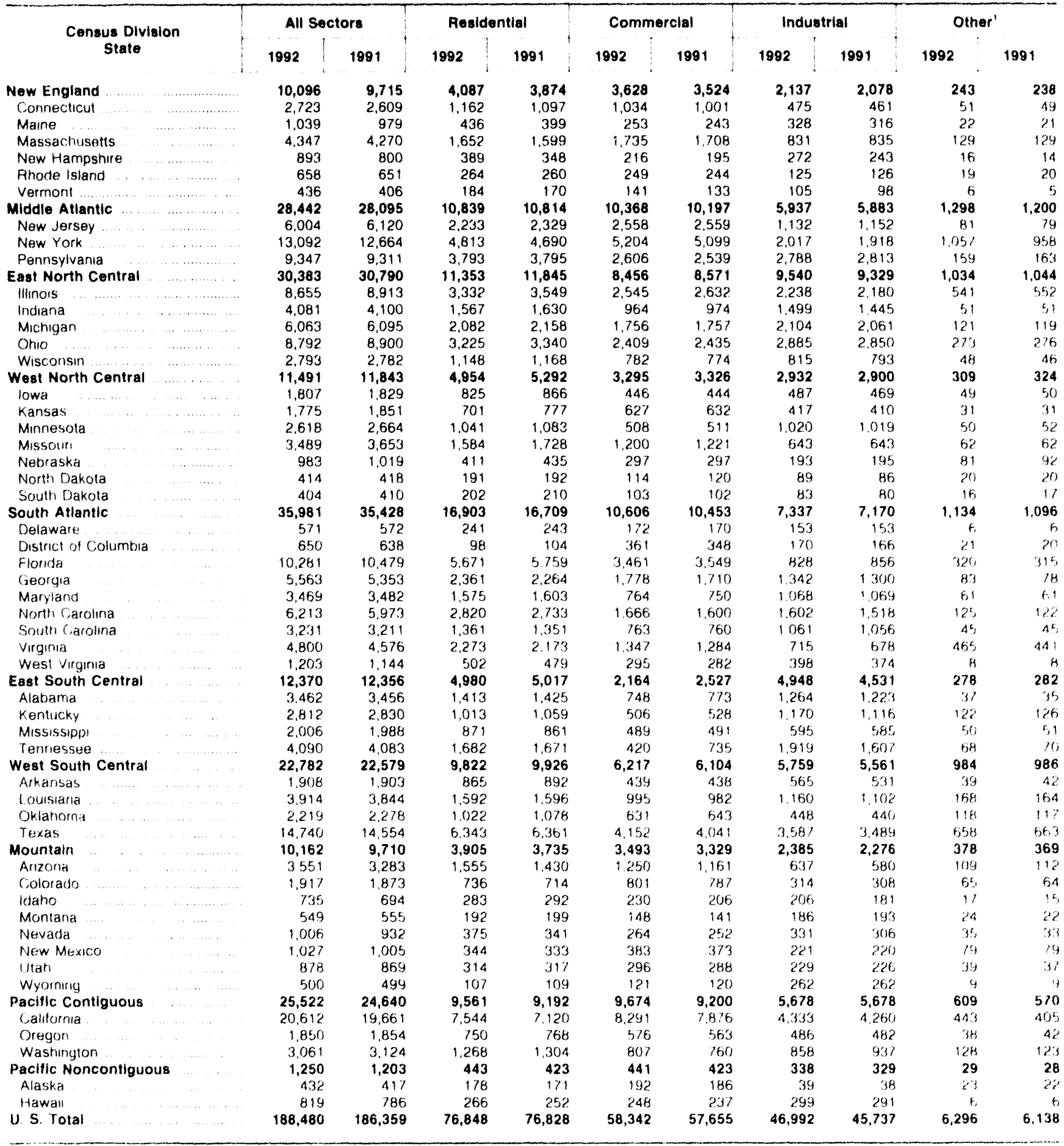

Inciudes public streel and highway lighting, other sales to public authorities, sales to raitroads and railways, and interdepartmental sales

Notes - Data for 1992 are preliminary, data for prior years are final. Totals may not equal sum of components because of independent rounding Source Energy Information Administration, Form ElA.861. "Annual Electric Utility Report" 
Table 29. Average Revenue per Kilowatthour for Electric Utilities by Sector, Census Division, and State, 1992 and 1991 (Cents)

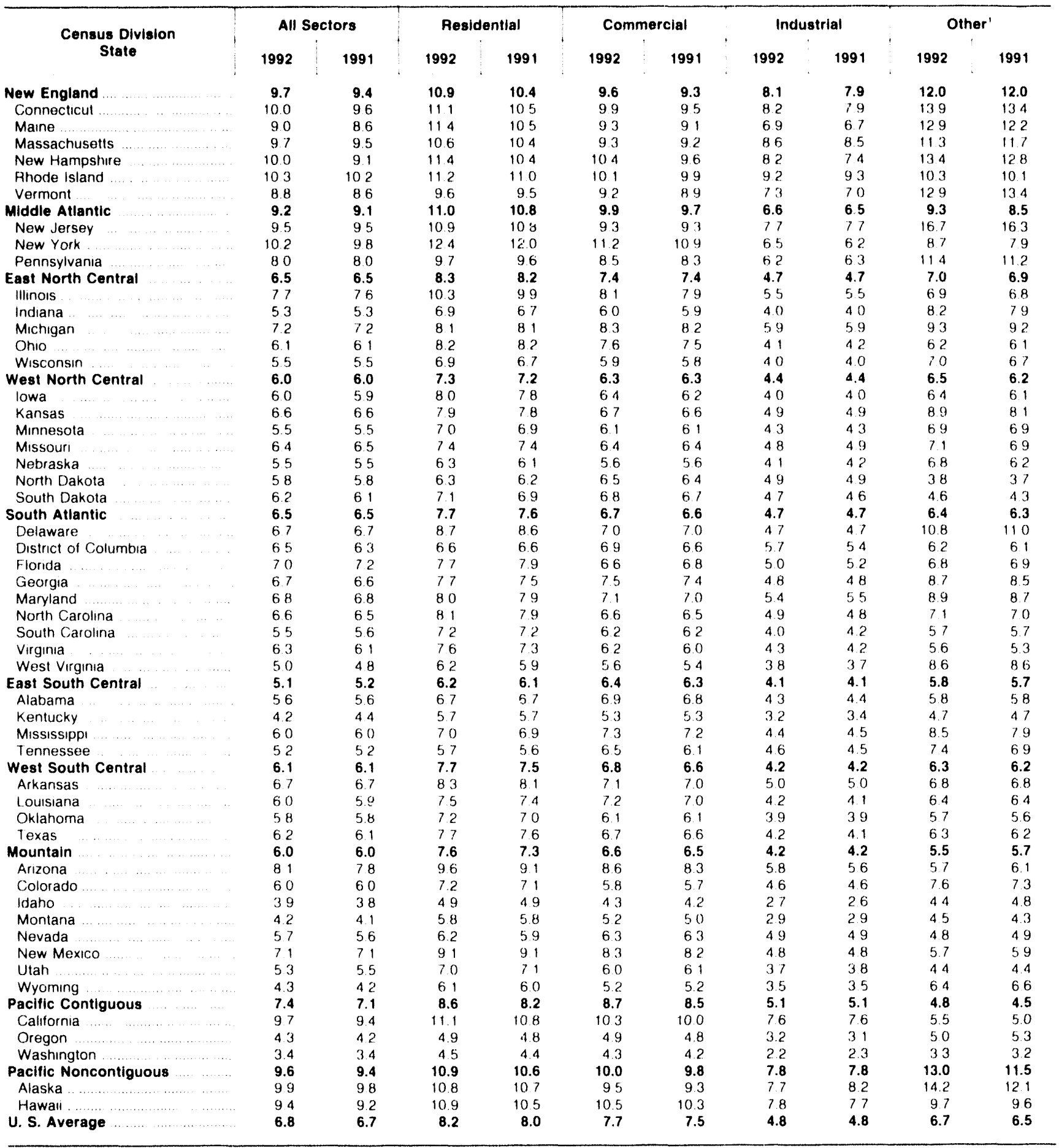

- Includes public street and highway lightıng. other sales to public authorities, sales to rallioads and railways, and interdepartmental sales. The average revenue for other sales may include ownership, operation, maintenance, and rental fees lor equipment and/or demand and service charges

Notes: Data for 1992 are prelımınary; data for prior years are final. The average revenue per kilowatthour of eleciricity sold is calculated by dividing revenue by sales. Totals may not equal sum of components because of independent rounding

Source Energy Information Administration, Form ElA-861, "Annual Electric Utility Report." 


\section{U.S. Electric Utility Financial Statistics}

This chapter presents data on the financial results of operations for major U.S. investor-owned and publicly owned electric utilities. Composite financial data on other segments of the U.S. electric utility industry, for example, Federal electric utilities and rural electric cooperatives, are not included. The data exhibited consist of the Composite Statement of Income, the Composite Balance Sheet, Financial Indicators, and Revenue and Expense Statistics. Historical data are provided for a 5-year period on major U.S. investor-owned electric utilities and for a 4-year period on major U.S. publicly owned electric utilities. Statistics on the average operating expenses for all plants owned by major U.S. investor-owned electric utilities are also provided.

\section{Background}

Today, virtually all investor-owned electric utilities are subject to State and Federal regulatory jurisdiction. State commissions have the authority to regulate electric rates of utilities engaged in providing service 10 ultimate consumers (retail sales) and to oversee the issuance of mortgage bonds, debentures, notes, preferred stock, and common stock. The Federal Energy Regulatory Commission (FERC) regulates, among other things, electric rates for interstate wholesale transactions. The ratemaking process sets rates at levels that cover all operating expenses and taxes with a remaining balance that will enable a utility to pay a fair return on funds invested by the stockholders.

A component of any economic regulatory activity is the determination of financing and accounting rules. As a consequence of regulatory jurisdiction, regulations for financing and accounting are more critical to the electric power industry than to most other nonregulated industries. Both FERC and State commissions normally use quasi-judicial proceedings for financial and accounting regulation.

Many of the publicly owned electric utilities are selfregulated (for example, the City of Dover, Delaware). while some fall under the jurisdiction of the public utility cornmission within the State(s) where they provide electricity to ultimate consumers a in the State of Ohio). Because of the absence of any requirement for reporting to a specific regulatory body, the accounting practices and policies of publicly owned electric utilities vary greatly. Many publicly owned electric utilities use the FERC Uniform System of Accounts or variations of this (and other) accounting systems As a result, the composite statistics provided must be viewed with an appropriate degree of caution.

Electric utilities must submit data for a 12 -month period (does not necessarily end on December 31) and show consistency in their methods and reporting dates. Because of the respondent burden in preparing this information, publicly owned electric utilities are permitted to use the year-end period on which their fiscal practices are based. Data are provided for the major publicly owned electric utilities by generator and nongenerators. The prior publications provided a subset of the major publicly owned electric utilities with fiscal years ending June 30 and Decenber 31 .

\section{Composite Statement of Income}

This statement provides a summary of the revenue collected from consumers in return for services rendered within the reporting period; reflects the costs incurred by the electric utility in the production and delivery of electricity: and reports the net income or profit that remains for the owners of the business. Because of the unique nature of regulated electric utilities, the income statement that is standard to other nonregulated industries has been recast to reflect the reporting conventions in the electric power industry For example, accounting for capital used in construction requires additional reporting on the income statement because of the perpetual nature of construction work in progress. Also, on occasion, electric utilities are required to defer the recovery of certain costs and earnings from consumers until a future period. This introduces additional accounting requirements, which must be reflected on all financial statements.

\section{Composite Balance Sheet}

The balance sheet represents an accounting at a particular time. For this section, the composite balance sheets are presented for major investor-owned electric utilities at the end of a calendar year and for major publicly owned electric utilities for the 12-month fiscal year ending in 1992. A summary of plant, property, and cash held by the electric utilities, as well as the receivables of the electric utilities, are represented as assets on the composite balance sheet. Future funds obligated by the electric utilities to acquire assets are 
shown as liabilities and any increased investment by stockholders is shown as capital on the balance sheet The standard balance sheet used in the electric power industry emphasizes capital intensily while the halance sheet used by nonregulated industries emphasizes li. quidity.

\section{Composite Financial Indicators}

The financial statement accounts presented in this chap. ter represent compled statistices resulting from the ate. tivity of the selected electric utilities. The measurement of how well the electric uthlity industry performs in different areas can be approximated by comparme some of the asset and income accounts foufter relevant accounts. Sing the financial statement information, some hasic indicators that can be used to analye or assess the financial condition of the industry are provided. The method used on derive these selected financial indicators is ratio analysis

Activity ratios of the investor-owned electric utilities evaluate how assets are managed. The eleceric utility industry is one of the most captal intemsive mdustres in the Cnited States and actwity ration are paramoum indicators of the magnitude of this capital infensits. These ratoos demometrate the financoal relatomship. which exask between the assels and revenue, sales. and income that these fixed and total ansets gemerate. The ratios on eleterlefixed-asiet inet plant idrnower and tolat-asset turnover assess the efficent we of assets in the generation of income

Leverage ratios of the investor-ouned electric utilities summarize the werall deht burden and deht structure. In addotom, these ratlom indicale the financial ahllity on meet debt service requirements and how well manage. ment uses leverage to morease the alue of the msentment of the stockholders The financial mundenes of an industry is directly related to the ahility of the industry to rase capital and to be able 10 provide a rea. somable return on the capial invested In order for meat sure the ability of do thes, a number of vodicators are uned. (urrent asse'ts be current liabilate's is a measure of liquidity. For example. do the investor-sinned electric uthlities have sufficient cash and (nther assets (current). which can be quickly comverted to cash fo cover maturing obligations (current liabilities)" long-term debt to capitalization, preferred sock to capitalizationt. and common-stock equity to capitalizatom portray the hinancial structure and highlight the extent we which debt and other fixed obligations are used to finance upera. tions. Total debt to total assets shows the amoun if debt that has been incurred in relationship to the antal assets possessed. As the value of thes ratio increases, the financial risks also hecome greater and more apparent. Common-stock equity tri total assets evaluales financial strength. As net worth increases in relation. ship to total assets, the debt portion is decreased and financial risks are lowered. Interest coverage before eaxes without dfler (Allowance for Funds losed
During (constructiont), a noncasti source of incemes is an indicator of the athlity of the investor-owned electric utility to ensure ite payment of annual interest costs and maintain tes credil ratings

Profitability ratios of the investor-owned electric utili. ties indicate operating effectiveness and are used of further evaluate the management of income, The profit margin is equal to net meome divided by revenue. This ratuo is used extensively and represents the overall measure of income performance Return on averagecommon-stock equaty measures the rate of return on eyuity capital invested Since one of the matn objectives of management in to earn the highest return permissible, the ratio is the best single measure of the effectiveness of management from the perspective of the stockhold. ers Return on investment measures the serall ralle of return that has heen earned on assets. This ratlo, de. termuned by dividing tolal assets into net income, pro. vides an indicator of eserall financial performance

Ratios on the publicly owned electric utilities are proided fo assist in understanding the financial perfor. mance of the publicly ouned segment of the molustry Six ratios are calculated from the statement of income and five ration are calculated from the balance sheet. Electric utility plame per dollar of reventse highlights the captal intensty of the utility. Current assets a) current liabilities provides a measure of the ease by which the uthlity can meet is current obligatoms. Filectre utility

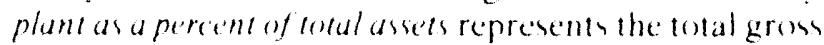
investment in elecerre plant divided by the lotal assets. A sigmeficant vartatum in this rates should signal a rel. aldely fumblamental change in the activities of the clece. the uthlity Vit relecte utility plant as a pereent of tolal assels represents the remanmeng bosk latue and a segmeficant vartaten should segnal a chatnge for the clectric utilay. Debe as a pereent of lotal liabilite's represemes the amount of deht cempared to total liablities and other credits. facumulated prowsion for depreciation as a perent of total alectric plant meatures the cost of re. conery of the use of the absete seer a persed of time for an electre utellty: an increase indicates that plant

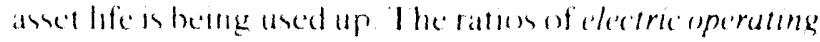
and mantenance expense's. electris depresiatom and ame ortizatien. taxes and lax c'quidulents, and interest on longterm debt we dectre operating revenue are indicators ef bese resources were used to produce income. Vel income per doflar of reventer provides the amount of the revenue dollar that cexeeds expenses and deductions.

\section{Revenue and Expense Statistics}

These summary statistice are basic in any analyse of the operatme soundness of an electre mility. In order 10 conduct the analysis, it is necessary lo separate the electric utility revenuc and expense information from other utility revenue and expense data. Emphass is placed on folat electric operating expenses. Data are presented so that operating cosis are separate from maintenance deprectationt. and laxes. For comparative 


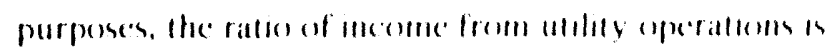
alsoincluded

\section{Electric Operating Expenses}

In order to provide the comsumed with electrictly, II

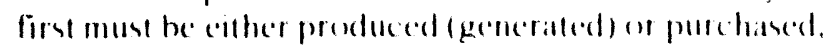
then transported fo the general area where it will be

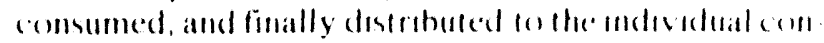

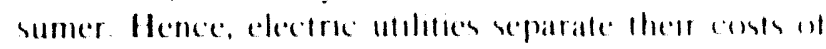

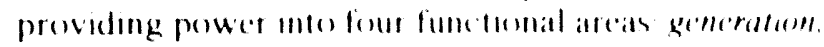

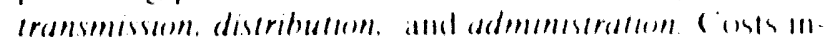

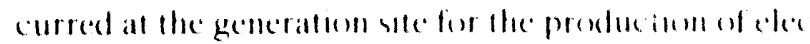
ercelly are generally referred to als operallong expenses

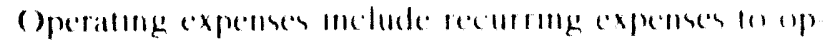

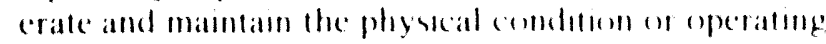
efficency of the plant These expenses melude Wages and henclies of the operators plant mannlenamee seces

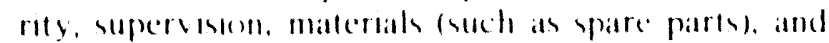
supplies fexcept fieel comsumed durmg plant operallom and mantenance) The fuel experteses include the costh

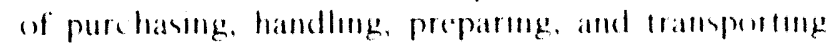

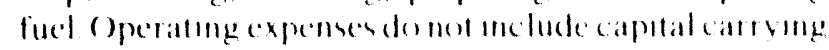
conts, such as interest on debl, return an equaty depte chatlon, amorteatlon expenses, and assoctated laxes Capreal carrymg costs most be added to the operatmg

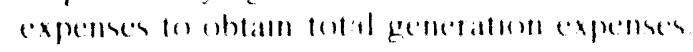

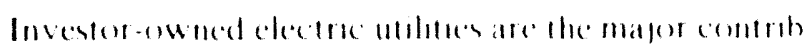

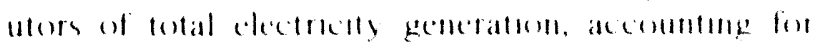

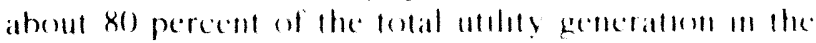

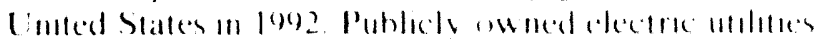

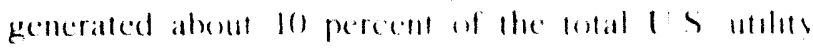
Eencratlon, while the remander was ancented for hy

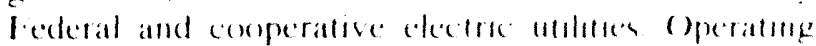

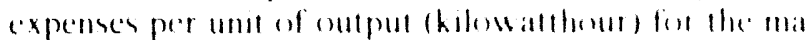

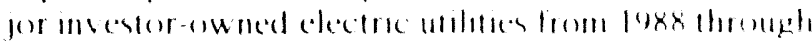

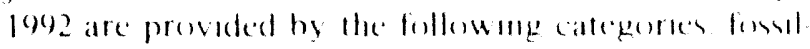

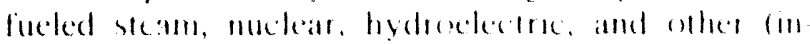
cludes gas lurbme: and small seale elentre plants

\section{Data Sources}

Financial Statistics. The limancial blatshes repolled

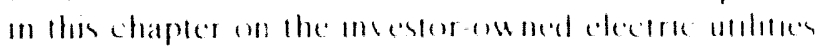
are compled form datat extracted fom the I I Re

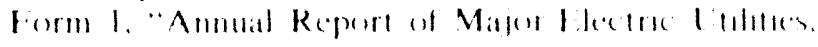

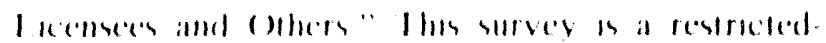

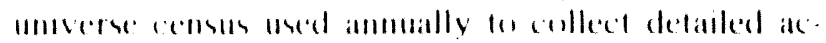

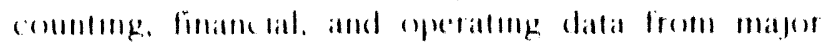

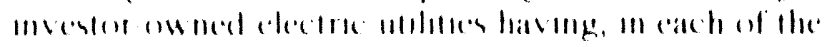

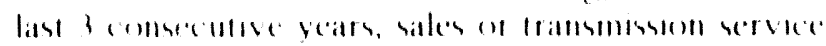
that excereds ane af the following

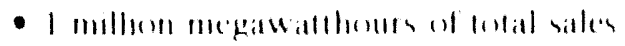

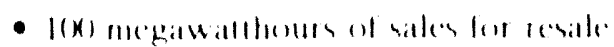

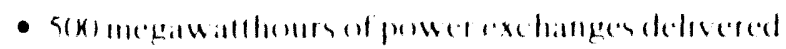

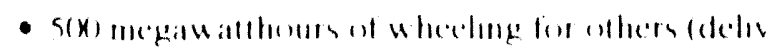
crives plus loseses)

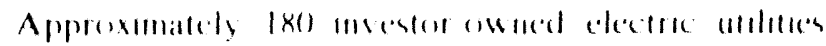

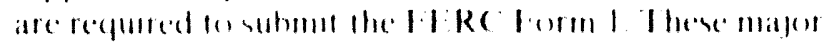

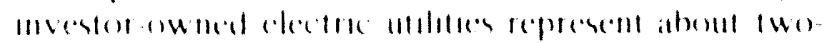

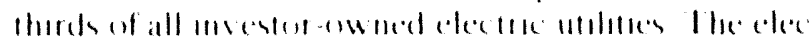

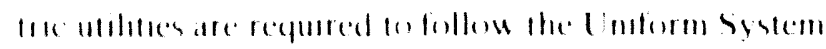

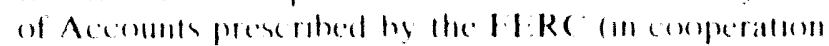

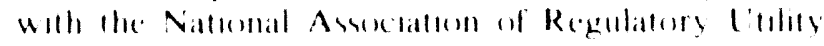

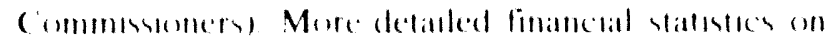

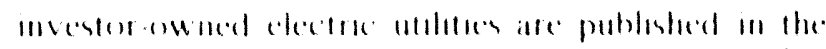

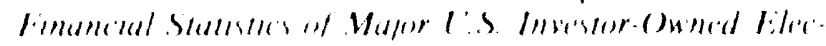
irle l'mlitle's

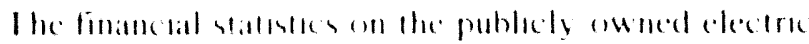
utrlenes are comprited from data extracted from the

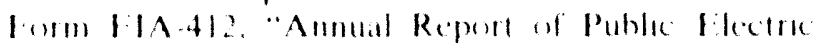

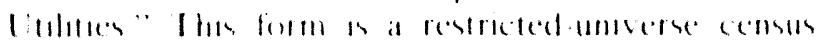

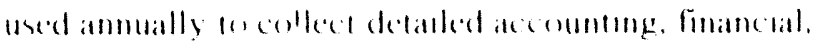
and operatme data from mafor publicly awned electre

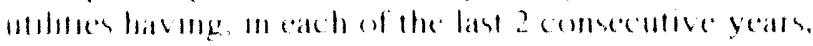
sitles that asceed ant alle of the following

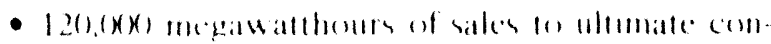
sumers

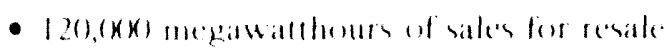

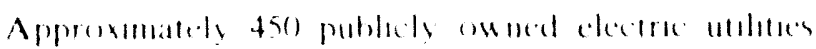

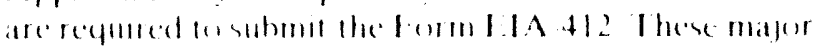

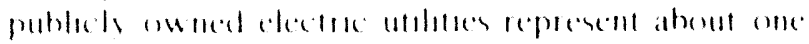

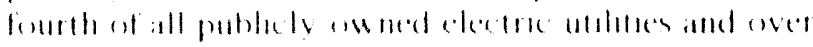

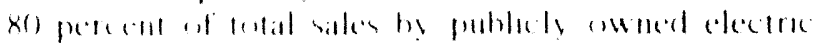

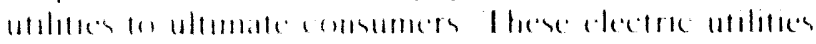

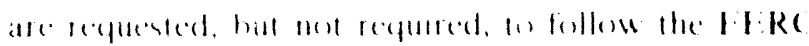

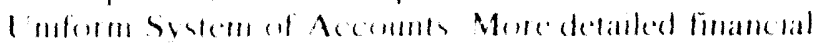

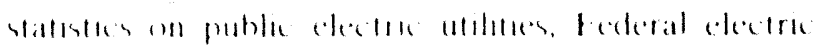

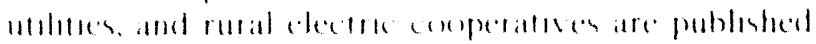

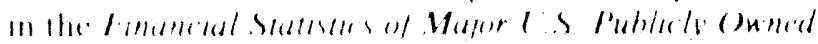

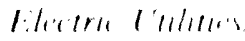

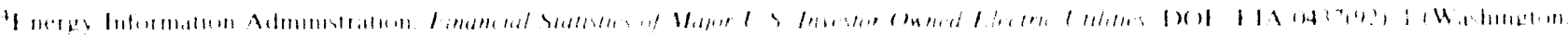

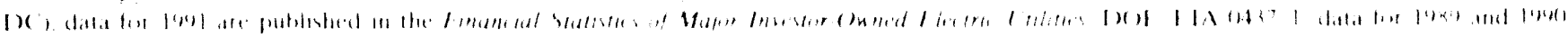

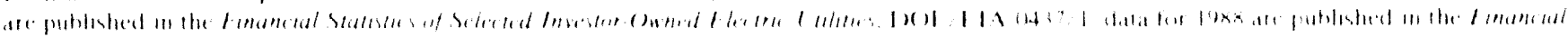

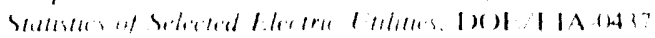

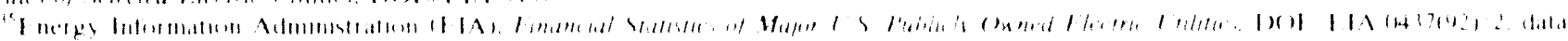

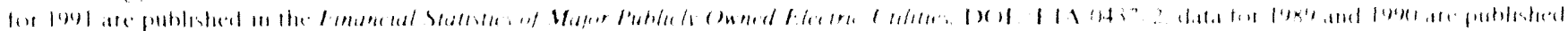

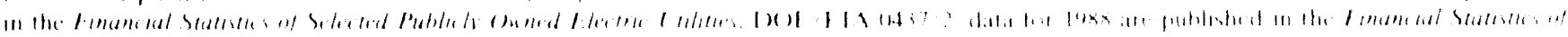

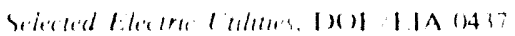


Table 30. Composite Statement of Income for Major U.S. Investor-Owned Electric Utilities, 1988 Through 1992

(Thousand Dollars)

\begin{tabular}{|c|c|c|c|c|c|}
\hline Description & $1992^{\prime}$ & $1991^{\prime}$ & 1990 & 1989 & 1988 \\
\hline Operating Aevenue & $185,493,45 \forall$ & $182,450,728$ & $172,999,954$ & $167,067,596$ & $159,488,265$ \\
\hline Elecinic & $169,488,035$ & $166.803,843$ & 157.278 .537 & $150,903,317$ & $143,930,420$ \\
\hline Gas $\ldots$ & $14.937,370$ & 14.560 .221 & $14.611,056$ & $15,119,408$ & $14.580,945$ \\
\hline Other Utillity & $1,068,053$ & 1.086 .663 & 1.110 .362 & $1,044.871$ & 976,899 \\
\hline Operating Expenses: & $153,682,429$ & $150,361,969$ & $142,471,369$ & $136,500,226$ & $129,730,357$ \\
\hline Electric & $139,009,093$ & $135,947,991$ & $127,900,634$ & $121,552,060$ & $115,347,626$ \\
\hline Fuel & $30,254,398$ & 31.312 .220 & $32,634,846$ & $32,937,516$ & $31.903,430$ \\
\hline Other Operating and Maintenance & $69,212,541$ & $66,645,950$ & $60,231.131$ & $54,785.240$ & $51,752,113$ \\
\hline Depreciation' & $17,091,753$ & 16.127 .176 & $14,888.584$ & 15.032 .961 & $13,469,355$ \\
\hline Taxes Other Than Income raxes & $12.760,152$ & $12,270,379$ & $11,433,264$ & 10.796 .423 & $10,319,912$ \\
\hline Income Taxes & $7.197,682$ & $7,690.521$ & 7.146 .859 & 6.848 .369 & $6.080,204$ \\
\hline Deterred Income Tax & $3,017,335$ & $2.294,676$ & $1,855,377$ & $1,479,626$ & $2,078,160$ \\
\hline Investment Tax Credil (Net) & -524.768 & $-392,931$ & $-289,428$ & $-328,075$ & $-255,548$ \\
\hline Gas $\ldots$ & $13,691,253$ & $13,406,370$ & 13.523 .155 & $13,972.207$ & $13,473,072$ \\
\hline income Taxes & 279,618 & 308,656 & 428.107 & 336.660 & 330.991 \\
\hline Other & $13.411,635$ & 13097,714 & $13,095,048$ & $13,635.547$ & $13,142,081$ \\
\hline Other Uility & 982.083 & 1.007 .609 & 1.047 .580 & 975.958 & 909,659 \\
\hline Income Taxes & 26,956 & 3,530 & 7,805 & 16,480 & 15,921 \\
\hline Other & 955.127 & $1.004,079$ & $1,039.775$ & 959,478 & 893.738 \\
\hline Operating income & $31,811,029$ & $32,088,758$ & $30,528,585$ & $30,567,370$ & $29,757,908$ \\
\hline Electric & 30.478 .942 & $30.855,852$ & $29,377,903$ & $29,351,256$ & $28,582,794$ \\
\hline Gas & $1,246,117$ & $1.153,852$ & 1.087 .901 & 1.147 .200 & $1.107,873$ \\
\hline Other & 85.970 & 79,055 & 62.782 & 68,913 & 67.240 \\
\hline $\begin{array}{l}\text { Other Income and Deductions } \\
\text { Allowance for Other Funds Used Durng }\end{array}$ & $1,689,045$ & 523,325 & $1,830,496$ & $2,560,660$ & $2,039,670$ \\
\hline Construction & 611.514 & 706.102 & $1,080,217$ & $1,202,004$ & $1,615,721$ \\
\hline Less Taxes & 379,461 & 852.579 & 389,448 & 943.175 & $1,070,681$ \\
\hline Delerred Earnings (Misc) (accl 421$)$ & 1.341 .354 & 1.271 .525 & $1,477,520$ & 1.073 .178 & $1,898.737$ \\
\hline Less Other Income and Expenses & -115.638 & 601,723 & 337,793 & $1.228,653$ & 404.107 \\
\hline Total income Before Interest Charges & $33,500,074$ & $32,612,083$ & $32,359,081$ & $33,128,030$ & $31,797,578$ \\
\hline Net interest Charges & $15,223,174$ & $15,736,248$ & $\mathbf{1 5 , 7 3 5 , 6 3 0}$ & $14,852,295$ & $14,388,924$ \\
\hline $\begin{array}{l}\text { Interest Expense } \\
\text { LESS Aliowance for Borrowed Funds Used During }\end{array}$ & $15,307,441$ & $16.010,348$ & 16.186 .426 & $15,648,011$ & $15,333,123$ \\
\hline $\begin{array}{l}\text { Less Aliowance for Borrowed Funds Used During } \\
\text { Construction }\end{array}$ & 558,348 & 635.525 & 814.229 & $1,142,007$ & 1.261 .283 \\
\hline Other Charges - Net & 474,080 & 361.424 & 363.433 & 346.291 & 315,084 \\
\hline Net Income Betore Extraordinary Charges & $18,276,900$ & $16,875,836$ & $16,623,451$ & $18,275,735$ & $17,410,653$ \\
\hline LeSs Extraordinary Items After Taxes" & $-107,544$ & $-73,829$ & $-273,715$ & 962,974 & $1,368,946$ \\
\hline Net Income & $18,384,444$ & $16,949,664$ & $16,897,166$ & $17,312,761$ & $16,041,707$ \\
\hline Prelorred Stock Dividend Requirements & $2,039,449$ & $1,945,213$ & $2,025,157$ & $2,417,239$ & $2,264,454$ \\
\hline Earnings Avallable for Common Stocks & $16,344,995$ & $15,004,451$ & $14,872,009$ & $14,895,522$ & $13,777,253$ \\
\hline Common Stocks Dividends & $14,897,608$ & $14,427,570$ & $14,189,677$ & $14,030,562$ & $13,517,681$ \\
\hline Additions to Retained Earnings & $2,184,266$ & 254,189 & 424,940 & 705,327 & $-13,385$ \\
\hline Average Shares of Common Stock Outstanding & $6,261,284$ & $5,932,492$ & $5,596,535$ & $5,824,221$ & $5,400,881$ \\
\hline Farnings Avallable Per Average Common Share (Dollars) & 2.61 & 2.53 & 2.66 & 2.56 & 2.55 \\
\hline
\end{tabular}

\footnotetext{
Excluded are the independent power producers jurisdictional to the Federal Energy Regulatory Commission

- Due to its emergence from bankruptcy, the 1991 financial statements for the Public Servce Company of New Hampshire are from May 16 through December 31 Excluded are the indopendent power producers jurisdictional to the Federal Energy Regulatory Commission

3 Includes amortization and depletion

- Other Income and Expenses and Extraordinary Items After Taxes were alfected negatively by afterlax write offs. accounting adjustments. and regulatory rate decisions The majority of the charges were directly related to the the treatment of nuclear plants Notes: Data are final - Totals may not equal sum of components because of independent rounding

Source Federal Energy Regulatory Commission. FEFC Form 1. "Annual Report of Major Electric Utilities, Licensees and Others" See Appendix C for a detalled description of this restricted-universe census
} 
Table 31. Composite Balance Sheet for Major U.S. Investor-Owned Electric Utilities, 1988 Through 1992

(Thousand Dollars)

\begin{tabular}{|c|c|c|c|c|c|}
\hline Description & $1992^{\prime}$ & $1991^{2}$ & 1890 & 1989 & 1988 \\
\hline \multicolumn{6}{|l|}{ Aesets } \\
\hline Utillty Plant - Net $\ldots \ldots \ldots \ldots$ & $386,864,738$ & $376,771,703$ & $371,310,063$ & $363,223,395$ & $361,638,256$ \\
\hline Electric Utility Plant - Net .... & $358,300,259$ & $349,611,025$ & $344,912,770$ & $337,460,182$ & $335,866,884$ \\
\hline Electric Utility Plant ...................... & $498,118,599$ & $479,822,229$ & $458,081,342$ & $428,700,561$ & $409,092,233$ \\
\hline Construction Work in Progress ... & $20,648,234$ & $18,077,211$ & $22,558,726$ & $33,714,555$ & $40,298,296$ \\
\hline Less Accumulated Depreciation ............... & $160,466,573$ & $148,288,414$ & $135,727,298$ & $124,954,934$ & $113,523,644$ \\
\hline 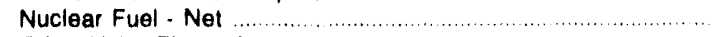 & $6,836,719$ & $6,911,645$ & $7,812,038$ & $8,700,644$ & $9,642,680$ \\
\hline Other Utility Plant - Net & $21,727,760$ & $20,249,033$ & $18,585,255$ & $17,062,569$ & $16,128,692$ \\
\hline $\begin{array}{l}\text { Other Property and Investments } \\
\text { Current and Accrued Assets } \\
\text { Deferred Deblts }\end{array}$ & $\begin{array}{l}18,045,977 \\
43,447,871 \\
57,993,875\end{array}$ & $\begin{array}{l}17,385,415 \\
43,357,785 \\
50,024,920\end{array}$ & $\begin{array}{l}17,703,929 \\
41,534,662 \\
47,322,374\end{array}$ & $\begin{array}{l}16,136,757 \\
41,516,163 \\
44,846,622\end{array}$ & $\begin{array}{l}15,200,683 \\
39,122,286 \\
38,335,664\end{array}$ \\
\hline Total Assets. & $506,352,461$ & $487,539,823$ & $477,871,029$ & $465,722,937$ & $454,296,889$ \\
\hline \multicolumn{6}{|l|}{ Capitalization and Llabillties } \\
\hline Capitalization & $356,026,762$ & $348,828,405$ & $340,983,205$ & $334,068,968$ & $329,813,736$ \\
\hline Common Stock Equity (End of Year) & $156,346,650$ & $151,671,304$ & $147,424,082$ & $145,175,878$ & $142,715,825$ \\
\hline Common Stock & $103,963,697$ & $99,723,170$ & $96,502,507$ & $94,602,732$ & $93,158,701$ \\
\hline Retained Earnings (Adjusted) ......... & $52,382,953$ & $51,948,134$ & $50,921,575$ & $50,573,146$ & $49,557,124$ \\
\hline Preferred Stock & $25,539,216$ & $25,262,285$ & $25,621,039$ & $25,944,650$ & $26,371,225$ \\
\hline Long-term Debt & $174,140,896$ & $171,894,816$ & $167,938,084$ & $162,948,440$ & $160,726,686$ \\
\hline Current and Other Llabllities & $150,325,698$ & $138,711,418$ & $136,887,824$ & $131,653,970$ & $124,483,152$ \\
\hline Other Noncurrent Liabilities ....... & $8,627,882$ & $6,931,193$ & $7,224,872$ & $7,803,119$ & $7,711,888$ \\
\hline Current and Accrued Liabilities & $45,557,601$ & $43,357,436$ & 44.283 .442 & $42,023,659$ & $38,412,073$ \\
\hline 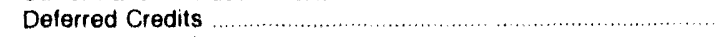 & $96,140,215$ & $88,422,789$ & $85,379,510$ & $81,827,192$ & $78,359,191$ \\
\hline Accumulated Deferred Income Taxes & $65,020,984$ & $59,188,298$ & $56,529,757$ & $53,328,188$ & $50,247,264$ \\
\hline Accumulated Deferred Investment Tax Credit ......................... & $14,046,840$ & $14,689,786$ & $15,290,316$ & $15,886,418$ & $16,792,695$ \\
\hline Other Deferred Credits (Adjusted) & $17,072,392$ & $14,544,705$ & $13,559,436$ & $12,612,586$ & $11,319,232$ \\
\hline Total Capltalization and Liabilities & $506,352,461$ & $487,539,823$ & $477,871,029$ & $465,722,937$ & $454,296,889$ \\
\hline
\end{tabular}

- Excluded are the independent power producers jurisdictional to the Federal Energy Regulatory Commission.

2 Due to its emergence trom bankruptcy, the 1991 financial statements for the Public Service Company of New Hampshire are from May 16 through December 31. Excluded are the independent power producers jurisdictional to the Federal Energy Regulatory Commission.

Notes: Data are final. Totals may not equal sum of components because of independent rounding.

Source: Federal Energy Regulatory Commission, FERC Form 1. "Annual Report of Major Electric Utilities, Licensees and Others." See Appendix C for a detaled description of this restricted-universe census.

Figure 16. Allocation of the Revenue Dollar from Electric Operations for Major U.S. Investor-Owned Electric Utilities, 1992

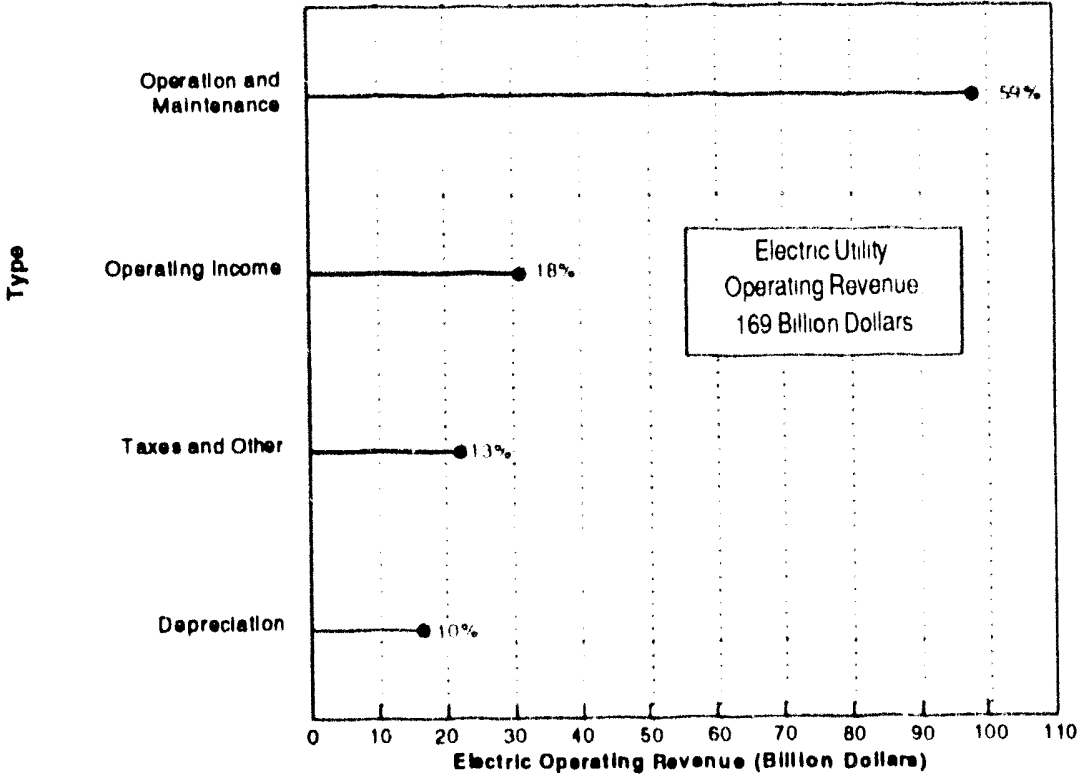

Notes: -Depreciation includes amortization and depletion. - Totals may not equal sum of components because of independent rounding. -Data are final.

Source: Federal Energy Regulatory Commission, FERC Form 1, "Annual Report of Major Electric Utilities, Licensees and Others." See Appendix $C$ for a detailed description of this restricted-universe census. 
Table 32. Composite Financial Indicators for Major U.S. Investor-Owned Electric Utilities, 1988 Through 1992

\begin{tabular}{|c|c|c|c|c|c|c|}
\hline & Description' & $1992^{\prime}$ & $1991^{3}$ & 1990 & 1989 & 1988 \\
\hline \multicolumn{7}{|c|}{ Activity } \\
\hline 1 & Electric Fixed Assel (Net Plant) Turnover & 047 & () 48 & 046 & 0.45 & 043 \\
\hline 2 & Total Asset Turnover $\ldots \ldots$ & 37 & 37 & 36 & 36 & 35 \\
\hline \multicolumn{7}{|c|}{ Loverage } \\
\hline 3 & Current Assets to Current L.abilities & .95 & 1.00 & 94 & .99 & 102 \\
\hline 4. & Longterm Debt to Capitalization & 48.91 & 49.28 & 49.25 & 4878 & 4873 \\
\hline 5 & Preferred Stock to Capitalization. & 717 & 724 & 7.51 & 777 & 800 \\
\hline 6 & Common Stock Equity to Capitalization & 4391 & 4348 & 4324 & 43.46 & 1327 \\
\hline 7 & Total Debt to Total Assets & 36.13 & 36.69 & 3679 & .3626 & 3667 \\
\hline 8 & Common Stock Equity to Total Assets & 3088 & 31.11 & 3085 & 3117 & 3142 \\
\hline 9 & Interest Coverage Betore Taxes without AFUDC & 2.62 & 249 & 2.38 & 2.46 & 235 \\
\hline \multicolumn{7}{|c|}{ Profltabillty } \\
\hline 10 & Profit Margin & 991 & c 29 & 977 & 1036 & 1006 \\
\hline 11 & Return on Average Common Stock Equily ${ }^{5}$ & 11.94 & 1133 & 1155 & 12.03 & 1123 \\
\hline 12 & Return on investment & 3.63 & 348 & 354 & 3.72 & 353 \\
\hline
\end{tabular}

1 Indicators $1,2,3$, and 9 are ratios. Indicators 4 through 8 and 10 through 12 are percentages

- Excluded are the independent power producers jurisdictional to the Federal Energy Regulatory Commission.

Due to its emergence trom bankruptcy, the 1991 inancial statements for the Public Service Company of New Hampshire are trom May 16 through December 31 Excluded are the independent power producers jurisdictional to the Federal Energy Regulatory Commission

- Total debt is the sum of Lung-term Debt and Short-term Debt The values for Short-term Debt included in Current and Accrued Liabilties (Notes Payable) were $\$ 8.791,477$ for $1992, \$ 6,986,960$ for $1991, \$ 7,874,293$ for $1990, \$ 5,928,421$ for 1989 , and $\$ 5,843,202$ for 1988

She Average Common Stock Equity is the average of the beginning and ending year balances. The values for the beginning of each yeat were $\$ 156,346,650$ for 1992. \$151.671.304 for 1991: \$147,424,082 for 1990; \$145.175,878 for 1989, and \$142,715,825 for 1988

AFUDC Allowance for Funds Used During Construction.

Notes. Data are final. Formulas for computing the financial indicators are in Appendix C. • indicators 4.5, and 5 may not sum to 100 percent because of independent rounding

Source: Federal Energy Regulatory Commission. FERC Form 1. "Annual Report of Major Electric Utilities, Licensees and Others." See Appendix

$\mathrm{C}$ for a detailed description of this restricted-universe census.

Figure 17. Electric Operating Expenses for Major U.S. Investor-Owned Electric Utilities, 1992

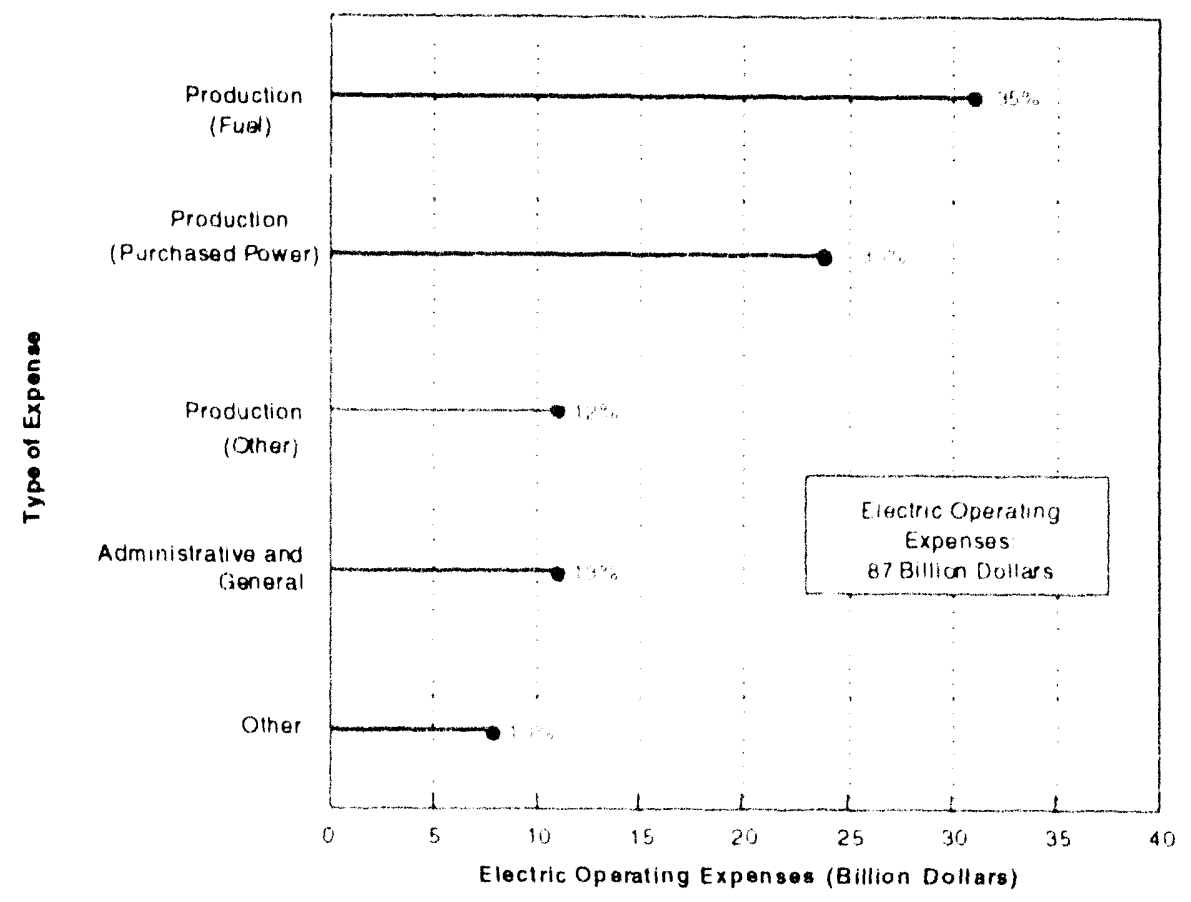

Notes: Other includes transmission, distribution, customer account, customer service, and sales. - Totals may not equal sum of components because of independent rounding. -Data are final. Percents in the figure are percentage of utility operating expenses.

Source: Federal Energy Regulatory Commission, FERC Form 1, "Annual Report of Major Eiectric Utilities, Licensees and Others." See Appendix $C$ for a detailed description of this restricted-universe census. 
Table 33. Revenue and Expense Statistics for Major U.S. Investor-Owned Electric Utilities, 1988 Through 1992

(Thousand Dollars)

\begin{tabular}{|c|c|c|c|c|c|}
\hline Description & $1992^{\prime}$ & $1991^{2}$ & 1990 & 1989 & 1988 \\
\hline Utility Operating Revenue. & $185,493,456$ & $182,450,728$ & $172,999,954$ & $167,067,596$ & $159,488,265$ \\
\hline Electric Utility .......................... & $169,488,035$ & $166,803,843$ & $157,278,537$ & $150,903,317$ & $143,930,420$ \\
\hline Other Utility & $16,005,423$ & $15,646,884$ & $15,721,418$ & $16,164,279$ & $15,557,844$ \\
\hline Utility Operating Expenses & $153,682,429$ & $150,361,969$ & $142,471,369$ & $136,500,226$ & $129,730,357$ \\
\hline Electric Utility & $139,009,093$ & $135,947,991$ & $127,900,634$ & $121,552,060$ & $115,347,626$ \\
\hline Operation & $87,272,134$ & $85,933,743$ & $81,086,488$ & $76,451,124$ & $72,742,004$ \\
\hline Production ...................... & $66,979,805$ & $66,101,528$ & $62,501,048$ & $59,235,893$ & $56,186,332$ \\
\hline 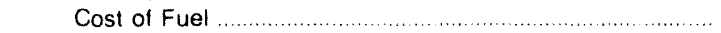 & $30,254,398$ & $31,312,220$ & $32,634,846$ & $32,937,516$ & $31,903,430$ \\
\hline 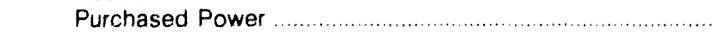 & $26,212,238$ & $24,169,252$ & $20,340,504$ & $17,959,051$ & $16,061,339$ \\
\hline Other & $10,513,169$ & $10,620,056$ & $9,525,698$ & $8,339,326$ & $8,221,563$ \\
\hline 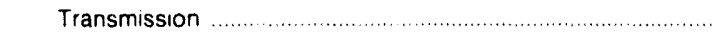 & $1,308,101$ & $1,247,286$ & $1,130,272$ & $1,113,547$ & $1,026,861$ \\
\hline Distribution & $2,498,514$ & $2,530,490$ & $2,443,859$ & $2,393,944$ & $2,331,160$ \\
\hline Customer Accounts & $3,347,124$ & $3,203,212$ & $3,247,245$ & $2,992,829$ & $2,894,179$ \\
\hline Customer Service & $1,531,369$ & $1,451,507$ & $1,180,636$ & 959,473 & 887.963 \\
\hline Sales & 198,647 & 203,230 & 212,233 & 208,655 & 177,006 \\
\hline Administrative and General & $11,408,575$ & $11,196,490$ & $10,371,195$ & $9,546,783$ & $9,238,502$ \\
\hline 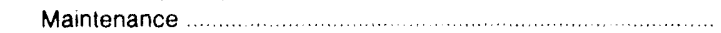 & $12,194,805$ & $12,024,427$ & $11,779,489$ & $11,271,632$ & $10,913,539$ \\
\hline Depreciation & 17.091 .753 & $16,127,176$ & $14,888,584$ & $15,032,961$ & $13,469,355$ \\
\hline Taxes and Other & $22,450,401$ & $21,862,645$ & $20,146,073$ & $18,796,343$ & $18,222,728$ \\
\hline Other Utility & $14,673,336$ & $14,413,979$ & $14,570,735$ & $14,948,165$ & $14,382,731$ \\
\hline Income From Utility Operations. & $31,811,029$ & $32,088,758$ & $30,528,585$ & $30,567,370$ & $29,757,908$ \\
\hline
\end{tabular}

- Excluded are the independent power producers jurisdictional to the Federal Energy Regulatory Commission

2 Due to its emergence from bankruptcy, the 1991 financial statements for the Public Service Company of New Hampshire are from May 16 through December 31 . Excluded are the independent power producers jurisdictional to the Federal Energy Regulatory Commission

Notes: - Data are final. - Totals may not equal sum of components because of independent rounding.

Source: Federal Energy Regulatory Commission, FERC rorm 1, "Annual Report of Major Electric Utilities, Licensees and Others." See Appendix C for a detailed description of this restricted-universe census.

Table 34. Revenue and Expense Percentages for Major U.S. Investor-Owned Electric Utilities, 1988 Through 1992

\begin{tabular}{|c|c|c|c|c|c|}
\hline Description & $1992^{\prime}$ & $1991^{2}$ & 1990 & 1989 & 1988 \\
\hline Utijity Operating Revenue & 100.0 & 100.0 & 100.0 & 100.0 & 100.0 \\
\hline Electric Utility $\ldots \ldots \ldots \ldots$ & 914 & 914 & 909 & 903 & $90.6^{2}$ \\
\hline 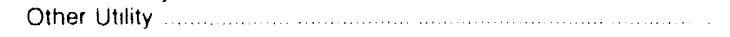 & 86 & 86 & 9.1 & 97 & 9.8 \\
\hline Utility Operating Expenses $\ldots \ldots \ldots \ldots$ & 82.9 & 82.4 & 82.4 & 81.7 & 81.3 \\
\hline Electric Utility & 74.9 & 74.5 & 73.9 & 72.8 & 723 \\
\hline Operation $\ldots$ & 47.0 & 47.1 & 46.9 & 458 & 45.6 \\
\hline … & 36.1 & $36 \%$ & 36.1 & 35.5 & 35.2 \\
\hline Cost of Fuel & 16.3 & 17.2 & 189 & 19.7 & 20.0 \\
\hline Purchased Power & 14.1 & 13.2 & 11.8 & 107 & 10.1 \\
\hline 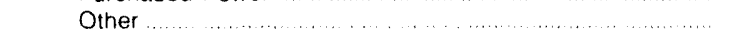 & 5.7 & 58 & 55 & 5.0 & 5.2 \\
\hline Transmission & .7 & 7 & 7 & $?$ & 6 \\
\hline (n) & 1.3 & 14 & 14 & 1.4 & 1.5 \\
\hline 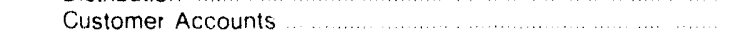 & 18 & 18 & 19 & 18 & 1.8 \\
\hline Customer Service & 8 & 8 & 7 & 6 & $\varepsilon$ \\
\hline Sales & 1 & 1 & 1 & .1 & 1 \\
\hline Administrative and General $\ldots \ldots \ldots$ & 6.2 & 61 & 6.0 & 5.7 & 58 \\
\hline Maintenance & 66 & 6.6 & 6.8 & 6.7 & 6.8 \\
\hline Depreciation & 9.2 & 88 & 86 & 9.0 & 8.4 \\
\hline Taxes and Other & 12.1 & 12.0 & 11.6 & 11.3 & 114 \\
\hline 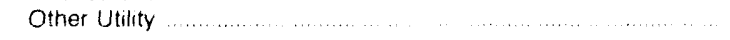 & 7.9 & 79 & 8.4 & 8.9 & 90 \\
\hline Income From Utility Operations & 17.1 & 17.6 & 17.6 & 18.3 & 18.7 \\
\hline
\end{tabular}

- Excluded are the independent power producers jurisdictional to the Federal Energy Regulatory Commission.

2 Due to its emergence from bankruptcy, the 1991 financial statements for the Public Service Company of New Hampshire are from May 16 through December 31. Excluded are the independent power producers jurisdictional to the Federal Energy Regulatory Commission.

Notes: -Data are final. Percents in this table are percentage of utility operating revenues. - Totals may not equal surn of components because of independent rounding

Source: Federal Energy Regulatory Commission, FERC Form 1. "Annual Report of Major Electric Utilites, Licensees and Others." See Appendix C for a detailed description of this restricte.' 'Jniverse census. 
Table 35. Average Operating Expenses for Major U.S. Investor-Owned Electric Utilities, 1988 Through 1992

(Mills per Kilowatthour)

\begin{tabular}{|c|c|c|c|c|c|}
\hline Plant Type & $1992^{\prime}$ & $1991^{2}$ & 1990 & 1989 & 1988 \\
\hline & \multicolumn{5}{|c|}{ Operation } \\
\hline $\begin{array}{l}\text { Nuclear } \\
\text { Fossil Steam } \\
\text { Hydroelectric } \\
\text { Gas Turbine and Small Scale }\end{array}$ & $\begin{array}{r}10.43 \\
2.38 \\
4.33 \\
10.18\end{array}$ & $\begin{array}{r}10.49 \\
2.29 \\
3.88 \\
9.61\end{array}$ & $\begin{array}{r}10.04 \\
2.21 \\
3.35 \\
8.76\end{array}$ & $\begin{array}{r}10.29 \\
1.99 \\
3.27 \\
5.66\end{array}$ & $\begin{array}{l}9.50 \\
\$ .98 \\
4.45 \\
6.61\end{array}$ \\
\hline Gas Turbine and Small Scale & \multicolumn{5}{|c|}{ Maintenance } \\
\hline $\begin{array}{l}\text { Nuclear } \\
\text { Fossil Steam } \\
\text { Hydroelectric } \\
\text { Gas Turbine and Small Scale }\end{array}$ & $\begin{array}{r}5.93 \\
2.95 \\
3.30 \\
12.15\end{array}$ & $\begin{array}{r}5.50 \\
2.98 \\
2.89 \\
12.93\end{array}$ & $\begin{array}{r}5.68 \\
2.97 \\
2.58 \\
12.23\end{array}$ & $\begin{array}{l}5.87 \\
2.78 \\
2.39 \\
8.60\end{array}$ & $\begin{array}{r}5.17 \\
2.87 \\
3.05 \\
10.11\end{array}$ \\
\hline Gas Turbine and Small Scale" & \multicolumn{5}{|c|}{ Fuel } \\
\hline $\begin{array}{l}\text { Nuclear } \\
\text { Fossil Steam } \\
\text { Hydroelectric } \\
\text { Gas Turbine and Small Scaled }\end{array}$ & $\begin{array}{r}6.12 \\
17.49 \\
28.59\end{array}$ & $\begin{array}{r}6.71 \\
17.91 \\
30.96\end{array}$ & $\begin{array}{r}7.18 \\
18.55 \\
32.57\end{array}$ & $\begin{array}{r}7.45 \\
18.28 \\
-\overline{34.77}\end{array}$ & $\begin{array}{r}7.88 \\
17.98 \\
32.06\end{array}$ \\
\hline Gas Turbine and Small Scale‘ & \multicolumn{5}{|c|}{ Total $^{5}$} \\
\hline $\begin{array}{l}\text { Nuclear } \\
\text { Fossil Steam } \\
\text { Hydroelectric } \\
\text { Gas Turbine and Small Scale }\end{array}$ & $\begin{array}{r}22.48 \\
22.83 \\
7.63 \\
50.92\end{array}$ & $\begin{array}{r}22.70 \\
23.17 \\
6.76 \\
53.51\end{array}$ & $\begin{array}{r}22.91 \\
23.72 \\
5.33 \\
53.56\end{array}$ & $\begin{array}{r}23.61 \\
23.05 \\
5.66 \\
49.03\end{array}$ & $\begin{array}{r}22.50 \\
22.70 \\
7.50 \\
48.78\end{array}$ \\
\hline
\end{tabular}

1 Excluded are the independent power producers jurisdictional to the Federal Energy Regulatory Commission.

2 Due to its emergence from bankruptcy, the 1991 financial statements for the Public Service Company of New Hampshire are from May 16 through December 31. Excluded are the independent power producers jurisdictional to the Federal Energy Regulatory Commission

3 Includes Pumped Storage.

- Includes gas turbine, internal combustion, photovoltaic, and wind plants

3 Totals may not equal sum of components because of independent rounding.

Notes: - Data are final. Expenses are average expenses weighted by net generation. $\bullet A$ mill is a monetary cost and billing unit equal to $1 / 1000$ of the U.S. dollar (equivalent to $1 / 10$ of 1 cent)

Source: Federal Energy Regulatory Commission, FERC Form 1, "Annual Report of Major Electric Utilities, Licensees and Others."

Figure 18. Average Operating Expenses of Fossil-Fueled and Nuclear Steam-Electric Plants for Major U.S. Investor-Owned Electric Utilities, 1992

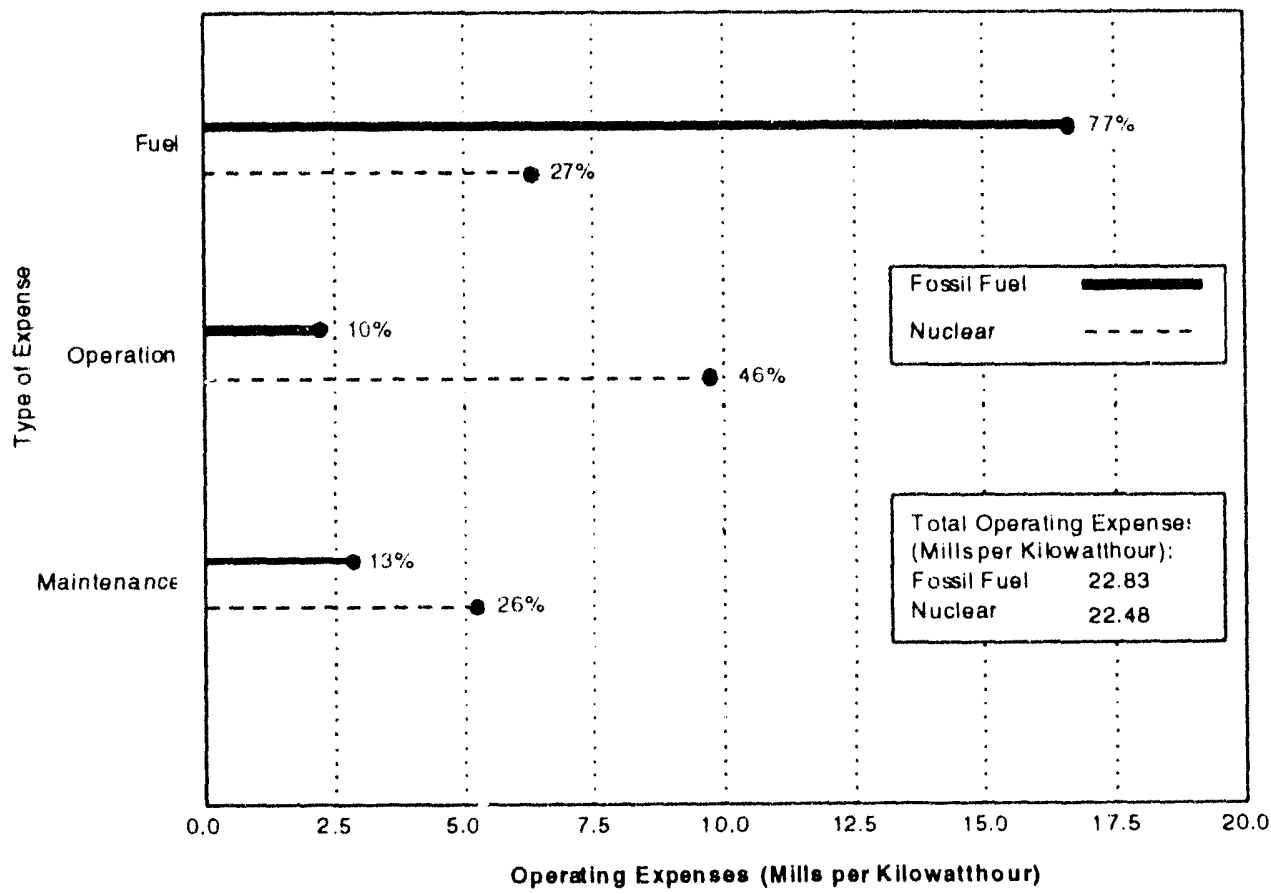

Notes: - Totals may not equal sum of components because of independent rounding. - Data are final. Percents in the figure are percentage of utility operating expenses.

Source: Federal Energy Regulatory Commission, FERC Form1, "Annual Report of Major Electric Utilities, Licensees and Others." See Appendix $C$ for a detailed description of this restricted-universe census. 
Table 36. Composite Statement of Income for Major U.S. Publicly Owned Generator Electric Utilities, 1989 Through 1992

(Thousand Dollars)

\begin{tabular}{|c|c|c|c|c|}
\hline Description & 1992 & 1991 & 1990 & 1989 \\
\hline 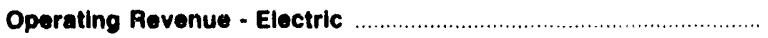 & $21,686,349$ & $21,082,870$ & $20,470,371$ & $19,261,832$ \\
\hline 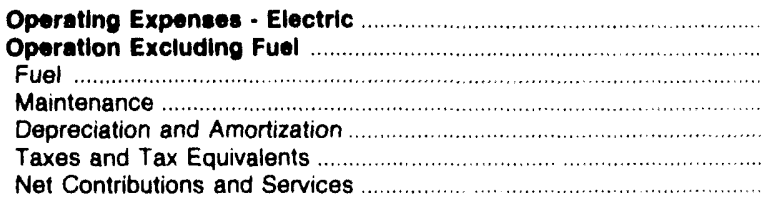 & $\begin{array}{r}17,190,647 \\
9,591,495 \\
2,935,940 \\
1,564,792 \\
2,417,279 \\
681,140 \\
-\ldots\end{array}$ & $\begin{array}{r}16,886,921 \\
9,082,917 \\
3,072,158 \\
1,446,295 \\
2,300,532 \\
595,719 \\
389,300\end{array}$ & $\begin{array}{r}16,460,700 \\
9,198,194 \\
2,749,890 \\
1,455,786 \\
2,075,595 \\
550,042 \\
431,193\end{array}$ & $\begin{array}{r}15,721,118 \\
8,723,046 \\
2,587,003 \\
1,486,423 \\
2,051,058 \\
500,424 \\
373,165\end{array}$ \\
\hline 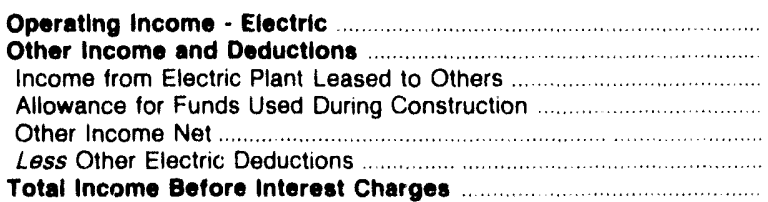 & $\begin{array}{r}4,495,703 \\
1,628,944 \\
15,129 \\
24,183 \\
1,839,484 \\
249,852 \\
6,124,646\end{array}$ & $\begin{array}{r}4,195,949 \\
1,843,761 \\
5,942 \\
71,025 \\
1,890,138 \\
123,345 \\
6,039,710\end{array}$ & $\begin{array}{r}4,009,671 \\
1,869,720 \\
11,330 \\
123,282 \\
1,735,107 \\
-- \\
5,879,390\end{array}$ & $\begin{array}{r}3,540,714 \\
1,977,538 \\
5,325 \\
231,996 \\
1,740,217 \\
5,518,252\end{array}$ \\
\hline $\begin{array}{l}\text { Net Interest Charges } \\
\text { Interest Expenses } \\
\text { Other Income Deductions }\end{array}$ & $\begin{array}{r}5,025,758 \\
4,757,583 \\
268,175\end{array}$ & $\begin{array}{r}5,205,799 \\
4,775,003 \\
430,796\end{array}$ & $\begin{array}{r}5,064,936 \\
4,663,114 \\
401,822\end{array}$ & $\begin{array}{r}4,740,190 \\
4,337,962 \\
402,229\end{array}$ \\
\hline $\begin{array}{l}\text { Net Income Before Extraordinary Charges } \\
\text { Less Extraordinary Items }\end{array}$ & $\begin{array}{r}1,098,889 \\
115,275 \\
983,613\end{array}$ & $\begin{array}{r}833,911 \\
65,544 \\
768,367\end{array}$ & $\begin{array}{l}814,455 \\
108,958 \\
705,497\end{array}$ & $\begin{array}{r}778,062 \\
653,861 \\
124,201\end{array}$ \\
\hline
\end{tabular}

Net income reflects $\$ 584$ million of extraordinary deduction associated with the abandonment of the Rancho Seco Nuclear Plant reported by the Sacramento Municipal Utility District.

Notes: -Data are final. - Totals may not equal sum of components because of independent rounding. $\bullet$ The number of publicly owned generating electric utilities that reported were 225 for 1992,218 for 1991,216 for 1990, and 214 for 1989

Source: Energy Information Administration. Form EIA-412. "Annual Report of Public Electric Utithties."

Table 37. Composite Balance Sheet for Major U.S. Publicly Owned Generator Electric Utilities, 1989 Through 1992

(Thousand Dollars)

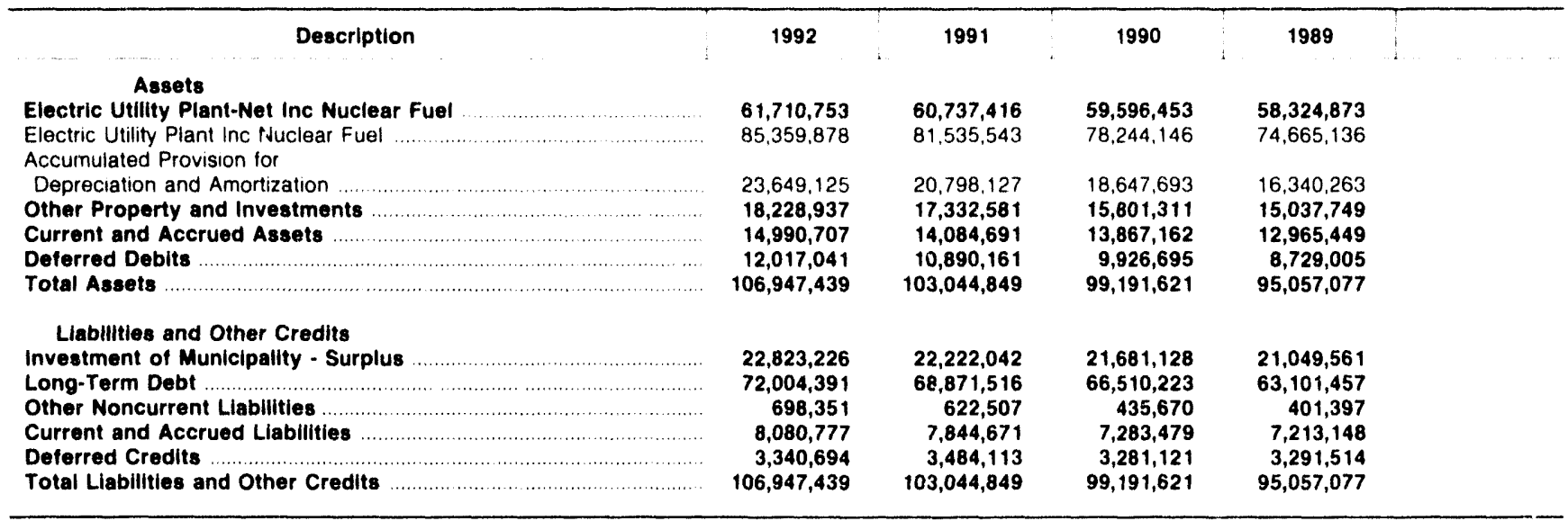

Notes: - Data are final. - Totals may not equal sum of components because of independent rounding. - The number of publicly owned generating electric utilities that reported were 225 for 1992, 218 for 1991, 216 for 1990, and 214 for 1989

Source: Energy Information Administration, Form EIA-412, "Annual Report of Public Electric Utilities." 
Table 38. Composite Financial Indicators for Major U.S. Publicly Owned Generator Electric Utilities, 1989 Through 1992

\begin{tabular}{|c|c|c|c|c|}
\hline Description & 1992 & 1991 & 1990 & 1989 \\
\hline Electric Utility Plant per Dollar of Revenue & 3.9 & 3.9 & 3.8 & 3.9 \\
\hline Current Assets to Current Liabilities & 1.9 & 1.8 & 1.9 & 1.8 \\
\hline Electric Utility Plant as a Percent of Total Assets. & 79.8 & 79.1 & 78.9 & 78.5 \\
\hline Net Electric Utility Plant as a Percent of Total Assets & 57.7 & 58.9 & 60.1 & 614 \\
\hline Debt as a Percent of Total Liabilities & 74.9 & 74.4 & 74.4 & 74.0 \\
\hline $\begin{array}{l}\text { Accumulated Provision for Depreciation as a Percent of Electric } \\
\text { Utility Plant }\end{array}$ & 27.7 & 25.5 & 23.8 & 21.9 \\
\hline $\begin{array}{l}\text { Electric Operation and Maintenance Expenses as a Percent of } \\
\text { Electric Operating Revenues }\end{array}$ & 65.0 & 64.5 & 65.5 & 66.4 \\
\hline $\begin{array}{l}\text { Electric Depreciation and Amoritization as a Percent of Electric } \\
\text { Operating Revenues }\end{array}$ & 10.5 & 10.9 & 10.1 & 10.6 \\
\hline $\begin{array}{l}\text { Taxes and Tax Equivalents as a Percent of Electric Operating } \\
\text { Revenues }\end{array}$ & 3.1 & 2.8 & 2.7 & 26 \\
\hline Interest Expenses as a Percent of Electric Operating Revenues ......... & 21.9 & 226 & 228 & 22.5 \\
\hline Net Income as a Percent of Electric Operating Revenues.. & 4.5 & 3.6 & 3.4 & 6 \\
\hline
\end{tabular}

Notes: Data are final. - Totals may not equal sum of components because of independent rounding. - The number of publicly owned generating electric utilities that reported were 225 for 1992, 218 for 1991,216 for 1990, and 214 for 1989.

Source: Energy Information Administration, Form ElA.412, "Annual Report of Public Electric Utilities"

Table 39. Revenue and Expense Statistics for Major U.S. Publicly Owned Generator Electric Utilities, 1989 Through 1992 (Thousand Dollars)

\begin{tabular}{|c|c|c|c|c|}
\hline Description & 1992 & 1991 & 1990 & 1989 \\
\hline Operating Revenue - Electric & $21,686,349$ & $21,082,870$ & $20,470,371$ & $19,261,832$ \\
\hline Operating Expenses - Electric & $17,190,647$ & $16,886,921$ & $16,460,700$ & $15,721,118$ \\
\hline Operation including Fuel & $12,527,435$ & $12,155,075$ & $11,948,084$ & $11,310,048$ \\
\hline Production & $9,712,324$ & $9,465,070$ & $9.525,315$ & 8976,237 \\
\hline Transmission & 534,512 & 508.711 & 471,887 & 440,256 \\
\hline Distribution $\ldots$ & 388,703 & 362,654 & 328,897 & 314,678 \\
\hline an. & 299,209 & 289.398 & 272,849 & 248.501 \\
\hline Customer Service & 82,731 & 73,901 & 60.411 & 62.431 \\
\hline Sales $\ldots$ & 17,545 & 18.077 & 18.043 & 11,927 \\
\hline Administrative and General & $1,492,411$ & $1,437,265$ & 1.270 .683 & $1,256,018$ \\
\hline Maintenance & $1,564,792$ & $1,446,295$ & 1.455 .786 & $1.486,423$ \\
\hline Depreciation and Amortization. & $2,285,807$ & $2,300.532$ & 2.075 .595 & 2.051 .058 \\
\hline 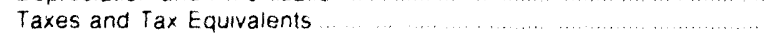 & 681.140 & 595.719 & 550,042 & 500.424 \\
\hline Net Contributions and Services. & - & 389.300 & 431.193 & 373.165 \\
\hline Income from Electric Utility Operations & $4,495,703$ & $4,195,949$ & $4,009,671$ & $3,540,714$ \\
\hline
\end{tabular}

Notes: - Data are final - Totals may not equal sum of components because of independent rounding. The number of publicly owned generating electric utilities that reported were 225 for 1992, 218 for 1991,216 for 1990, and 214 for 1989

Source Energy Information Administration. Form ElA.412, "Annual Report of Public Electric Utilties" 
Table 40. Composite Statement of Income for Major U.S. Publicly Owned Nongenerator Electric Utilities, 1989 Through 1992

(Thousand Dollars)

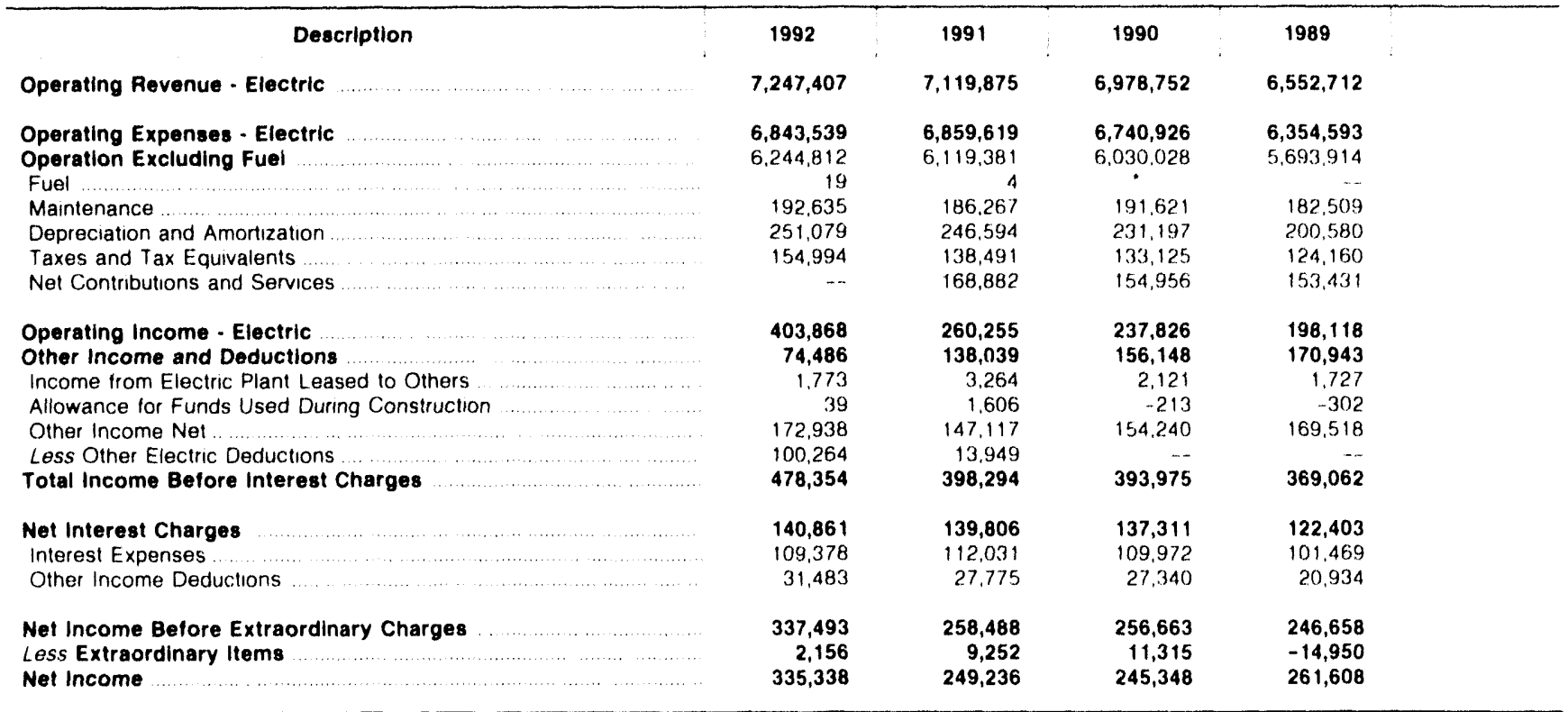

- Value less than 0.5

Notes. Data are final. Totals may not equal sum of components because of independent rounding - The number of publicly owned nongenerating electric utilities that reported were 258 for 1992,252 for 1991,251 for 1990 , and 240 for 1989

Source. Energy Information Administration. Form EIA-412, "Annual Report of Public Electric Utilities"

Table 41. Composite Balance Sheet for Major U.S. Publicly Owned Nongenerator Electric Utilities, 1989 Through 1992 (Thousand Dollars)

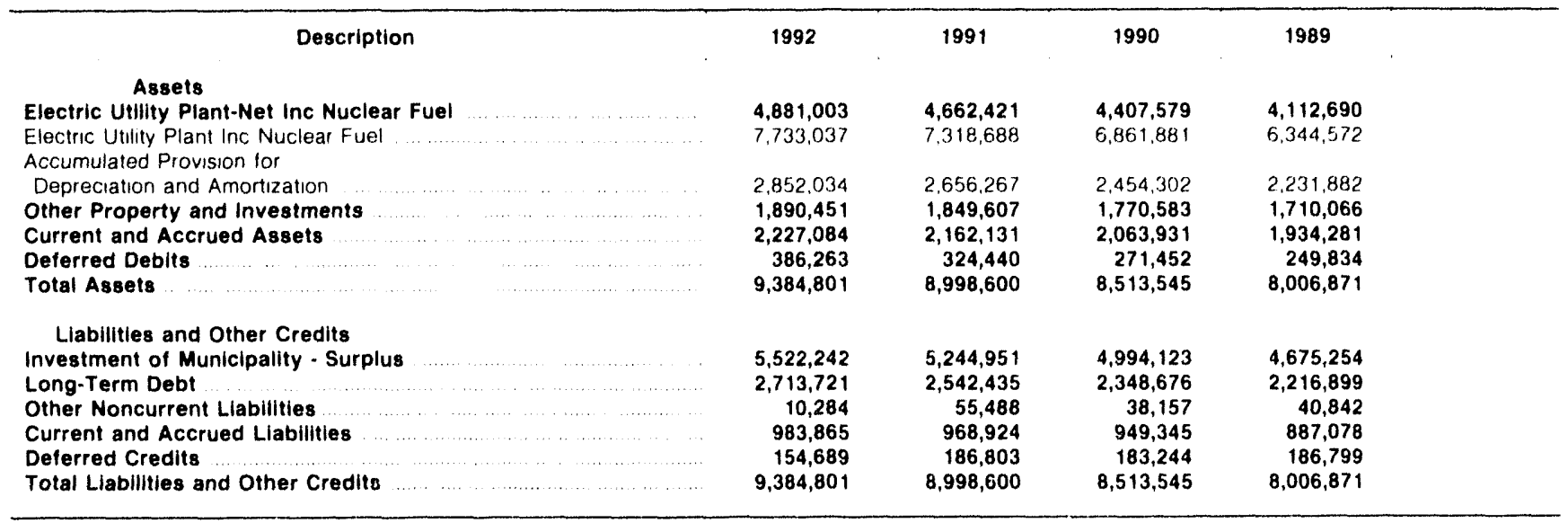

Notes: Data are final. Totals may not equal sum if components because of independent rounding - The number of pubicly owned nongenerating electric utilities that reported were 258 for 1992, 252 for 1991.251 for 1990, and 240 for 1989

Source: Energy Intormation Administration. Form E.A.412. "Annual Report of Public Electric Utilities." 
Table 42. Composite Financial Indicators for Major U.S. Publicly Owned Nongenerator Electric Utilities, 1989 Through 1992

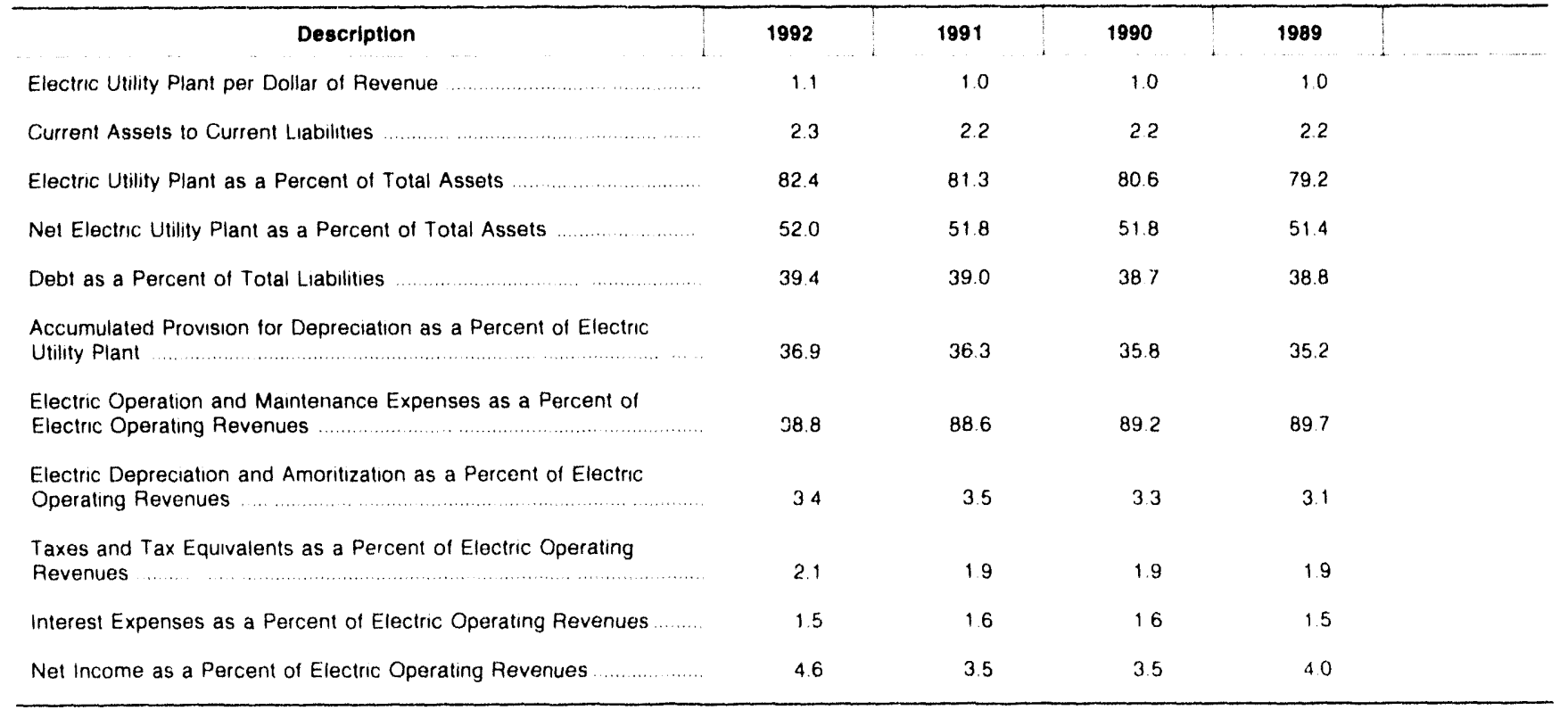

Notes: Data are final. Totals may not equal sum of components because of independent rounding. $\bullet$ The number of publicly owned nongenerating electric utilities that reported were 258 for 1992. 252 for 1991,251 for 1990 , and 240 for 1989

Source Energy Information Administration, Form ElA-412, "Annual Report of Public Electric Utilities."

Table 43. Revenue and Expense Statistics for Major U.S. Publicly Owned Nongenerator Electric Utilities, 1989 Through 1992

(Thousand Dollars)

\begin{tabular}{|c|c|c|c|c|}
\hline Description & 1992 & 1991 & 1990 & 1989 \\
\hline Operating Revenue - Electric & $7,247,407$ & $7,119,875$ & $6,978,752$ & $6,552,712$ \\
\hline Operating Expenses - Electric & $6,843,539$ & $6,859,619$ & $6,740,926$ & $6,354,593$ \\
\hline Operation Including Fuel & $6,244.831$ & 6.119 .385 & $6,030,028$ & $5,693,914$ \\
\hline Production & $5.617,261$ & $5.523,601$ & $5.478,840$ & $5,052,577$ \\
\hline Transmission & 32,956 & 32,264 & 30,119 & 26,459 \\
\hline 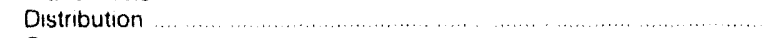 & 176.188 & 164,147 & 144,962 & 233,363 \\
\hline Customer Accounts & 109.196 & 102,488 & 99,305 & 93,509 \\
\hline Customer Service & 15,629 & 15,536 & 13,967 & 13.583 \\
\hline 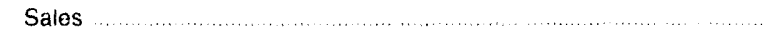 & 11,646 & 11.587 & 11,222 & 5,065 \\
\hline Administrative and General & 281,954 & 269,762 & $25 !, 614$ & 269,357 \\
\hline Maintenance ........................... & 192,635 & 186,267 & 191,621 & 182,509 \\
\hline Depreciation and Amortization & 248,040 & 246,594 & 231,197 & 200,580 \\
\hline Taxes and Tax Equivalents & 154,994 & 138.491 & 133,125 & 124,160 \\
\hline 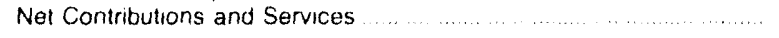 & $\ldots$ & 168.882 & 154,956 & 153.431 \\
\hline Income from Electric Utility Operations & 403,868 & 260,255 & 237,826 & 198,118 \\
\hline
\end{tabular}

Notes: Data are final - Totals may not equal sum of components because of independent rounding - The number of publicly owned nongenerating electric utilities that reported were 258 for 1992,252 for $, 891,251$ for 1990 , and 240 for 1989.

Source: Energy Information Administration. Form \& 4.412. "Annual Report of Public Electric Utilities" 


\section{U.S. Electric Utility Environmental Statistics}

When fossil fuels are burned in the production of electricity, a variety of gases and particulates are formed. If these gases and particulates are not captured by some pollution control equipment, they are released into the atmosphere. This chapter provides a brief summary of the gaseous emissions from U.S. electric utilities and the methods employed to reduce or eliminate their release into the atmosphere.

\section{Background}

Among the gases emitted during the burning of fossil fuels are sulfur dioxide $\left(\mathrm{SO}_{2}\right)$, nitrogen oxides $\left(\mathrm{NO}_{x}\right)$, and carbon dioxide $\left(\mathrm{CO}_{2}\right)$. Coal-fired generating units produce more $\mathrm{SO}_{2}$ and $\mathrm{NO}_{x}$ than other fossil-fuel units for two reasons. First, because coal generally contains more sulfur than other fossil fuels. it creates more $\mathrm{SO}_{2}$ when burned. Second, there are more NO $)_{x}$ emissions from coal-fired plants because more coal-fired capacity than other fossil-fueled capacity is in use.

Sulfur is an element that is present in almost all coal, although some kinds of coal contain more sulfur than others depending on the geographic location of the coal mine and the type of coal being mined. Western coal has less sulfur than eastern coral. Over one-half of the coal mined in the West is subbituminous coal that is low in sulfur content (about 0.5 percent) and contains approximately $9,(00)$ Btu per pound. Bituminous eastern coal can exceed both a 5 -percent sulfur content and a heat content of $12,0(0)$ Btu per pound. The average percent of sulfur contained in coal ranges from 0.3 percent in the West to approximately 2.5 percent in the East. During combustion, the sulfur combines with the oxygen in the air to form $\mathrm{SO}_{2}$. As the $\mathrm{SO}_{2}$ mixes further with oxygen and trace substances in the air, a variety of sulfate compounds emerges. How these transformations take place, and in what proportions, is a subject of vigorous research. The behavior of $\mathrm{SO}_{2}$ emissions depends partly on the type of coal used and how it is burned. In addition, the presence of light. moisture. and other pollutants in the atmosphere may also be important in triggering the complex changes that $\mathrm{SO}_{2}$ emissions undergo. To a lesser degree, sulfur is also contained in petroleum and varies according 10 the type of petroleum (for example, light oil. heavy oil, etc.). Petroleum burned at utility power plants can range from almost no sulfur to about 3.5 percent sulfur. The weighted average percent of sulfur contained in petroleum consumed by utility plants ranges from about .5 percent in western plants to about 1.4 percent for plants in New England. The amount of sulfur contained in natural gas is insignificant.

Nitrogen is a colorless, odorless gas that makes up about 78 percent of the atmosphere. Nitrogen in the atmosphere during the combustion process (burning of fuels at the plant) combines with oxygen and water to form several NO. Also, a small amount of nitrogen in the coal is converted to $\mathrm{NO}_{x}$. The most important is nitrogen dioxide, one of the compounds that gives photochemical smog its characteristic yellowishbrown color. Only about 10 percent of the nitrogen compounds in the air are the result of human activity. The rest are formed by natural processes, such as the decay of organic matter. However, since the humanmade 10 percent is emitted mostly in industrial urban areas, concentration there can become high enough to cause concern.

$\mathrm{SO}_{2}$ and $\left.\mathrm{NO}\right)_{x}$ are referred to as precursors to acid deposition, because, under the right set of conditions, they react with other chemicals in the atmosphere to form sulfuric acid and nitric acid, respectively. These two acids do not accumulate in the atmosphere, but are absorbed by rain droplets, thus cleansing the atmosphere and discharging acid onto the earth in the form of "acid rain." In addition, sulfuric acid may form microscopic droplets that can be deposited directly onto the ground. This form of deposition, as well as the direct capture of $\mathrm{SO}_{2}$ by vegetation, is referred to as dry deposition

$\mathrm{CO}_{2}$ is a colorless, odorless, nontoxic gas formed by the combustion of carbon and carbon compounds found in coal. petroleum, and gas. Currently, the only way to limit the emission of $\mathrm{CO}_{2}$ when burning fossil fuels is extremely expensive. $\mathrm{CO}_{2}$ is normally removed from the atmosphere by green plants and abourbed by the ocean. The increased use of fosssl fuels in recent years, as well an extensive deforestation, has calused a buildup of $\mathrm{CO}_{2}$ in the atmosphere. This increase of $\mathrm{CO}_{2}$ causes the atmosphere to absorb infrared radiation reflected from the earth that would otherwise have been dissipated into space. This phenomenon could increase temperature and is called the "greenhouse" effeet because it is similar to the trapping of the energy of the sun in a greenhouse. These potential increases in lemperatures are of concern because they could cause dramatic climatic changes, shifts in agricultural zones, and partial melting of the polar ice caps resultung 
in floodeng of coastal areas. Houcver, sigmlicant uncertantices exist regarding global warming, and noconclusions can be drawn regarding future warming hased on pase comperature records.

Efforts are underway en determine what methods can be employed of reduce or eliminate the release of $\mathrm{CO}_{2}$ from power plants. Tail gats cleamup ( $\left(C_{2}\right.$ scrubbing)

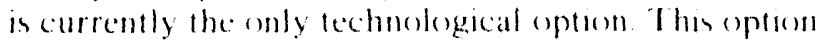
would require the adaptatem by the clectrice utitity in. dusery of acid gas removal fechmolegges used by the petroleum and petrochemical industres Because of the polential expense involved and the uncertanty contcerning the impacts of emossions from the gas, 10 e emission standards of required reductums exist

Addotomally. the Department of Energy is developing clean coal technologies (such as pressuried muidized. bed combustion) for new plants and repowering applications. Dute to the increased conversion effickences

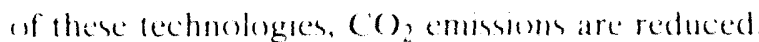

\section{Emission Standards}

To respond en concerms about emissoms of $\left.S_{0}\right)_{2}$ and NO, as well as several other air pollutants. Congress passed the (lean Air Act (CAA) in 196.3 It was not until 1970, however, that the Envirommental Protection Agency was compowered lo set enforceable and quality standards. In 1971. This Agency establishod New Source Performance Slandards (NSPS) that required coalfired utiluy boilers buill after August 17. 1971 . 10 emet no more than 1.2 perunds of $S()$, pes mol. lion $B t 11$ of heat input. Reyutrements for vio, were more complex, whth allowable limuts rangmg from (1).2

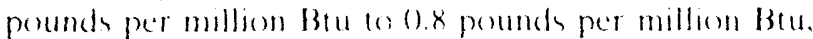
depending on the type of fuel burmed and the combustion device used

In 1977. Comgress amended the (A A le requare States

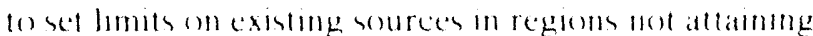
geals establisted in the Act. In 1979, the Environmental Protection Agency entablished the Rerred New Source Performance Standarde (RNSPS). The new standards retain the 1971 NSPS of 1.2 pounde of 50 ? per millom Btu of heat input, but require $S()_{2}$ emmssoms from all new or modified (post 1978) boilers to he re duced by at least ge perecent unlese 9(1)percent removal reduces emossions to less than () to pounds per million Btu. If emosions fall below that level. reductions between 70 and 90 percent ate permitted, depending on the sulfur content of the coal. KNSPS for No, are complex and, as whth NSPS, set limits varying from (1.2 (1) 0.8 pound per million Btu, depending on the type of fuel hurned and combustion device used. RNSPS for N(), differ from NSPS in the number of calcegries of combustom inter which they are divided.

The prinary goak of the Clean Aor ACt Amendments (CAAA) of 190) that impact gencrators of clectricity are a 10-million-lon reduction in SO) emissoms and a 2-million-ton reduction in $\mathrm{NO})_{x}$ emissions from 1980) levels. The reduction in $\mathrm{SO}_{2}$ is 10 occur in $\mathrm{two}$ phases that hegin in 1995 and $2(k)$, respectively. The CAAA established an innovative marketable emission allowance program. The CAAA contains a list of the allowances to be issued in Phase 1 and the Environmental Protection Agency published a preliminary list of Phase 2 allowances in Junt 1992.

\section{Emission Reductions}

Sulfur Dioxide. (One method available lo reduce the so) comitted when burning coal, is to switch to a coal that has a louer sulfur content. Emissions of sulfur disexide may also be reduced by using less-polluting fuels, particularly gats. Another approach is 10 install equipment designed (o) remove $\mathrm{SO})_{2}$ from the gas (thue gas) released through the flues of the plant. Additional methods for reducing emissions of $\mathrm{SO} \mathrm{O}_{2}$, which include converting boilem on the lluidized-bed combustion process and employing the technolongy of integrated. gasificaton combined cycle, are currently under study and not in extensive use

Vitrogen Oxides. Formation of $\mathrm{NO}$, is less dependent on the type of fuel burned than on how the fuel is burned. Apart from the nitrogen content of the fuel. the extent of nitric-oxide formation depends primarily (II) the combustion temperature. No, emissions can be reduced by low excess-air firing: low-combustion temperatures; use of low-mirngen fuels (such as nalural gas and light distillate sil); staged combustion in which lecalued fiel-rech conditums are crealed where both thermal and fued $\mathrm{NO}$, are minimied, and use of kow. No, hurners and huidized-hed combustion

\section{Environmental Equipment}

Whale not the only kind of environmental equipment imstalled at power plants, flue gas desulfurization units, particulate collectors and conling towers are the most signilicant. In a flue gas desulfurizatum unit (scrubber), the gases resullong from combustom are passed through tank comtaning a materal that captures and neutralmes the S(3) Particulate matter is most frequently removed from the combustion gases by either filtering (a series of tiller bages that trap the ash and dust much like a bouschold vacuum cieancer) in a baghouse or with an electrostatic precipitater In the latter, the parliculates are given an electric charge and collected. Particulate collection is mainly centered on coal com. bustion because of the large percentage of ash that coal contams. Petroleum thas very lithle ash and natural gits hats practically nome

For a fossil-fucled steam-electric generatung unit, ahout worthirds of the heal produced by burning the fuel is released to the environment, and only about once-third is used lo produce electricity. Most waste heat (comtaned in the cooling water is dissipated intes at body 
of water, such as a river, lake, or bay. Cooling towers are installed where there is insufficient cooling water and where the waste heat discharged into the cooling water affects plants or marine life. A cooling tower is a structure for transferring heat in the water to the atmosphere. The most common type of cooling tower is the wet tower, also called the evaporative tower. In a wet tower, cooling is caused mainly by evaporation of the water and partly by direct-heat transfer.

Environmental equipment can be a significant part of the cost of a power plant. This additional cost includes the initial capital cost of installation and the recurring operation and maintenance $(O \& M)$ costs. Capital costs are given as a cost per kilowatt of installed nameplate capacity.

\section{Data Sources}

Estimates are provided in the following tables on $\mathrm{SO}_{2}$, $\mathrm{NO}_{x}$, and $\mathrm{CO}_{2}$ emissions from fossil-fueled steamelectric generating units. The methodology for computing emission estimates is described in Appendix $C$. Additional detailed information on emissions from electric utilities can be obtained in Chapter 6 of the Annual Energy Outlook. ${ }^{36}$ Also presented in the following tables are the number and capacity of fossil-fueled steam- sectric generators with environmental equipment (scrubbers, particulate collectors, and cooling towers). Because power plants can have more than one type of environmental equipment, the generators at these plants can be included in more than one category. Also, not all utility plants have environmental equip. ment. Data regarding the quality of fossil fuels used to produce electricity by electric utilities, including heat, sulfur, and ash content, are also provided in the following tables. Iastly, average flue gas desulfurization costs (that is, operation and maintenance costs per kilowatthour of generation and installation costs per kilowatt of nameplate capacity) are presented.

These estimates were either derived or obtained directly from the Form ElA-767, "Steam-Electric Plant Operation and Design Report." This form is a restricted-universe census used to collect boilerspecific data from almost 900 U.S. electric utility power plants with organic- or nuclear-fueled steam-electric nameplate capacity of 10 or more megawatts operated by over 300 electric utilities. The entire form, including data on environmental equipment, is filed by about 700 power plants with a nameplate capacity of 100 or more megawatts. Information on power plants with a nameplate capacity between 10 and 100 megawatts is submitted only for fuel consumption and flue gas desulfurization equipment. There are 71 nuclear power plants in the Form EIA-767 respondent universe. 
Table 44. Estimated Emissions from Fossil-Fueled Steam-Electric Generating Units at U.S. Electric Utilities, 1988 Through 1992

(Thousand Short Tons)

\begin{tabular}{|c|c|c|c|c|c|}
\hline Emission & 1992 & 1991 & 1990 & 1989 & 1988 \\
\hline Sulfur Dioxide (SO2) & 14.981 & 15.336 & 15666 & 16060 & 15.923 \\
\hline Nitrogen Oxides (NOX)' & 7.889 & 7.892 & 7,893 & 7.944 & 7.822 \\
\hline Carbon Dioxide $(\mathrm{CO} 2)^{\prime}$ & 1.858 .772 & $1,871,561$ & $1,866,408$ & $1,906,568$ & $1,891,049$ \\
\hline
\end{tabular}

- As of 1992 data, reductions from Nox control technologies have been changed-histoncal data were revised to reflect that change--see the Technical Notes for more information

- As of 1992 data emission factors for the calculation of $\mathrm{CO} 2$ have been changed.-histoncal data were invised to reflect that change--see the Technical Notes for more information SO2. NOx and $\mathrm{CO} 2$ einissions are oniy for steain-electric plants 10 megawatts and larger based on fuel consumption data reported on Form EIA.767 Total emissions of $\mathrm{CO} 2$ using Form ElA.759 fuel consumption data are pubilshed in Emissions of Greenhouse Gases in the United States 1985.1990 (DOE/E.AA-0573)

Notes Estumates for 1992 are preliminary, estimates for prior years are final DEstimates are derived from the Form ElA-76?. "Steam-Electric Plant Operation and Design Report " (See Technical Notes for methodology)

Source Energy Information Adminstration. Form EIA.767, "Steam-Electnc Plant Operation and Design Report"

Table 45. Number and Capacity of Fossil-Fueled Steam-Electric Generators for U.S. Electric Utility Plants with Environmental Equipment, 1988 Through 1992

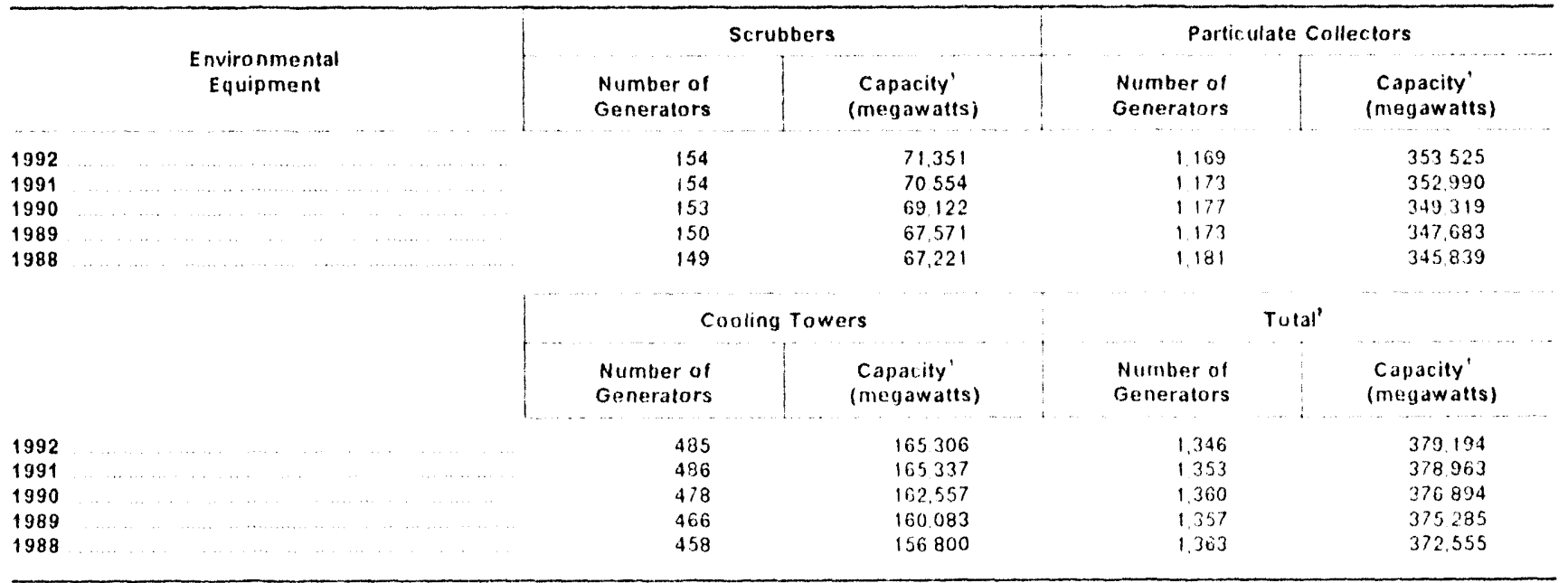

Nameplate capacity

- Components are not additive since some generators are included in more than one category and not all unts have environmental equipment Notes Data for 1992 are preliminary data for pnor years are final - These data are only for plants with a fossilfueled steam-electric capacity of 100 or more megavatts. eftistoncal data have been revised to reflect audtional data reported by respondents

Source Energy Information Admustration. Form EIA.767. "Steam-Electric Plant Operation and Design Report" 
Table 46. Estimated Emissions from Fossll-Fueled Steam-Electric Generating Units at Electric Utilitles by Census Division and State, 1992 and 1991

(Thousand Short Tons)

\begin{tabular}{|c|c|c|c|c|c|c|}
\hline \multirow{2}{*}{$\begin{array}{c}\text { Coneus Divislon } \\
\text { state }\end{array}$} & \multicolumn{3}{|c|}{1992} & \multicolumn{3}{|c|}{1991} \\
\hline & $\begin{array}{l}\text { Sulfur } \\
\text { Dioxide }\end{array}$ & $\begin{array}{l}\text { Nitrogen } \\
\text { Oxidese }\end{array}$ & $\begin{array}{c}\text { Carbon } \\
\text { Dloxide' }\end{array}$ & $\begin{array}{c}\text { Sulfur } \\
\text { Dioxide }\end{array}$ & $\begin{array}{l}\text { Nitrogen } \\
\text { Oxides }\end{array}$ & $\begin{array}{c}\text { Carbon } \\
\text { Dloxide' }\end{array}$ \\
\hline Now England & 302 & 117 & 35,950 & 338 & 127 & 40,548 \\
\hline 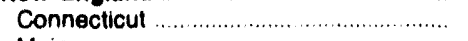 & 34 & 16 & 6,582 & 44 & 20 & 8,864 \\
\hline Maine & 7 & 3 & 1,047 & 11 & 3 & 1,071 \\
\hline Massachusetts & 203 & 75 & 23,343 & 235 & 79 & 25,395 \\
\hline 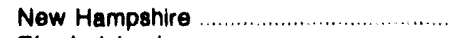 & 57 & 23 & 4,570 & 48 & 24 & 4,706 \\
\hline Rhode Island & - & • & 100 & • & 1 & 155 \\
\hline Vermont & - & - & 308 & - & 1 & 357 \\
\hline 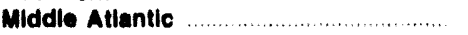 & 1,599 & 558 & 168,851 & 1,671 & 585 & 179,062 \\
\hline - & 61 & 45 & 9.427 & 64 & 51 & 11,060 \\
\hline 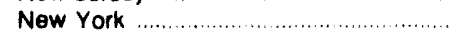 & 342 & 154 & 55,302 & 388 & 174 & 62,715 \\
\hline Pennsylvania & 1.197 & 358 & 104,122 & 1,218 & 361 & 105,287 \\
\hline East North Central & 4,869 & 1,868 & 379,060 & 5,175 & 1,813 & 387,092 \\
\hline Illinois & 842 & 306 & 53,965 & 853 & 340 & 59,307 \\
\hline 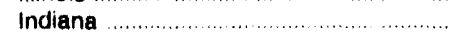 & 1.182 & 539 & 105,641 & 1,403 & 546 & 107,096 \\
\hline Michigan & 353 & 313 & 65,462 & 386 & 327 & 68,362 \\
\hline 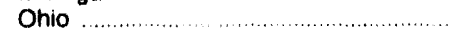 & 2,228 & 552 & 123,125 & 2,242 & 536 & 120,939 \\
\hline Wisconsin & 264 & 158 & 30,867 & 292 & 164 & 31,388 \\
\hline West North Central & 1,215 & 913 & 183,106 & 1,317 & 953 & 189,156 \\
\hline lowa & 175 & 155 & 24.785 & 184 & 158 & 25,789 \\
\hline Kansas & 67 & 129 & 27,053 & 77 & 144 & 29,753 \\
\hline 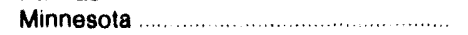 & 78 & 151 & 30,595 & 80 & 160 & 31.070 \\
\hline 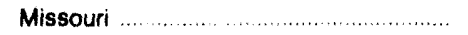 & 681 & 284 & 50,477 & 745 & 289 & 52,035 \\
\hline Nebraska $\ldots \ldots \ldots \ldots$ & 52 & 82 & 14,417 & 53 & 89 & 15.685 \\
\hline 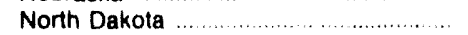 & 130 & 94 & 32,930 & 145 & 93 & 31,769 \\
\hline South Dakota & 32 & 18 & 2,848 & 33 & 20 & 3,056 \\
\hline 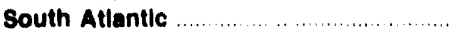 & 3,456 & 1,345 & 347,799 & 3,435 & 1,329 & 356,300 \\
\hline Delaware & 40 & 19 & 5,845 & 51 & 28 & 8.750 \\
\hline District of Columbia & 1 & - & 98 & 1 & - & 222 \\
\hline Florida & 745 & 394 & 84,806 & 724 & 392 & 96,273 \\
\hline Georgia $\ldots \ldots \ldots \ldots \ldots \ldots$ & 787 & 194 & 55,886 & 795 & 201 & 56,817 \\
\hline Maryland & 259 & 96 & 26,713 & 263 & 92 & 27,143 \\
\hline North Carolina & 378 & 195 & 53,972 & 331 & 170 & 46,854 \\
\hline South Carolina & 154 & 80 & 23,752 & 163 & 35 & 24,603 \\
\hline Virginia & 177 & 72 & 23,908 & 177 & 71 & 23,951 \\
\hline West Virginia & 916 & 295 & 72,819 & 930 & 291 & 71,687 \\
\hline East South Contral $\ldots \ldots \ldots \ldots \ldots \ldots \ldots$ & 2,210 & 820 & 197,904 & 2,135 & 806 & 193,451 \\
\hline Alabama & 537 & 229 & 62,044 & 533 & 223 & 59,589 \\
\hline Kentucky & 767 & 358 & 74,661 & 741 & 356 & 73,535 \\
\hline Mississippi $\ldots \ldots \ldots \ldots$ & 102 & 42 & 10,920 & 105 & 47 & 12,498 \\
\hline Tennessee & 803 & 192 & 50,279 & 755 & 180 & 47,828 \\
\hline West South Central & 756 & 1,264 & 292,103 & 732 & 1,248 & 293,635 \\
\hline Arkansas & 66 & 102 & 23,995 & 66 & 101 & 23,795 \\
\hline Louisiana & 110 & 189 & 38,364 & 103 & 178 & 36,468 \\
\hline 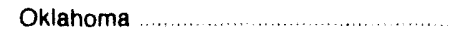 & 108 & 168 & 38,300 & 103 & 165 & 37,696 \\
\hline … & 473 & 804 & 191.444 & 459 & 804 & 195,677 \\
\hline Mountain & 464 & 786 & 199,360 & 436 & 746 & 186,604 \\
\hline Arizona & 128 & 144 & 27,942 & 122 & 134 & 24,809 \\
\hline Colorado & 87 & 136 & 32,372 & 84 & 139 & 32,012 \\
\hline Idaho $\ldots \ldots \ldots$ & -- & -- & -- & $\cdots$ & $\cdots$ & -- \\
\hline Montana & 22 & 80 & 19.708 & 20 & 77 & 18,755 \\
\hline Nevada & 59 & 71 & 21,184 & 56 & 70 & 20,957 \\
\hline New Mexico $\ldots \ldots \ldots \ldots$ & 59 & 152 & 19,469 & 51 & 135 & 17,485 \\
\hline Utah ............ & 31 & 77 & 32,773 & 29 & 74 & 30,559 \\
\hline Wyoming .................. & 78 & 126 & 45,911 & 75 & 118 & 42,029 \\
\hline Pacific Contiguous & 85 & 205 & 49,838 & 72 & 171 & 40,456 \\
\hline California & 1 & 137 & 34,204 & 1 & 113 & 27.639 \\
\hline Oregon & 14 & 21 & 4,014 & 11 & 19 & 3,257 \\
\hline Washington & 70 & 47 & 11,620 & 59 & 39 & 9,560 \\
\hline Pacific Noncontiguous & 23 & 12 & 4,802 & 25 & 14 & 5,257 \\
\hline Alaska & 1 & - & 2 & 1 & - & 1 \\
\hline 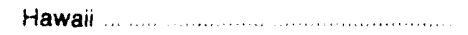 & 23 & 12 & 4,800 & 24 & 14 & 5,256 \\
\hline (2) & 14,981 & 7,889 & $1,858,772$ & 15,336 & 7,892 & $1,871,561$ \\
\hline
\end{tabular}

- As of 1992 data, emission factors for the calculation of carbon dioxide emissions and reductions from nitrogen oxide control technologies have been changed-historical data were revised to reflect that change..-see the Technical Notes for more information

- Value less than 0.5 .

Notes: Estimates for 1992 are preliminary; estimates for prior years are final. -Totals may not equal sum of components because of independent rounding. •Estimates are derived from the Form ElA-767, "Steam-Electric Plant Operation and Design Report." (See Technical Notes for methodology)

Source: Energy Information Administration. Form ElA-767, "Steam-Electric Plant Operation and Design Report." 
Table 47. Estimated Emisslons from Fossll-Fueled Steam-Electric Generating Units at Electric Utillities by Fossil Fuel, Census Division, and State, 1992 (Thousand Short Tons)

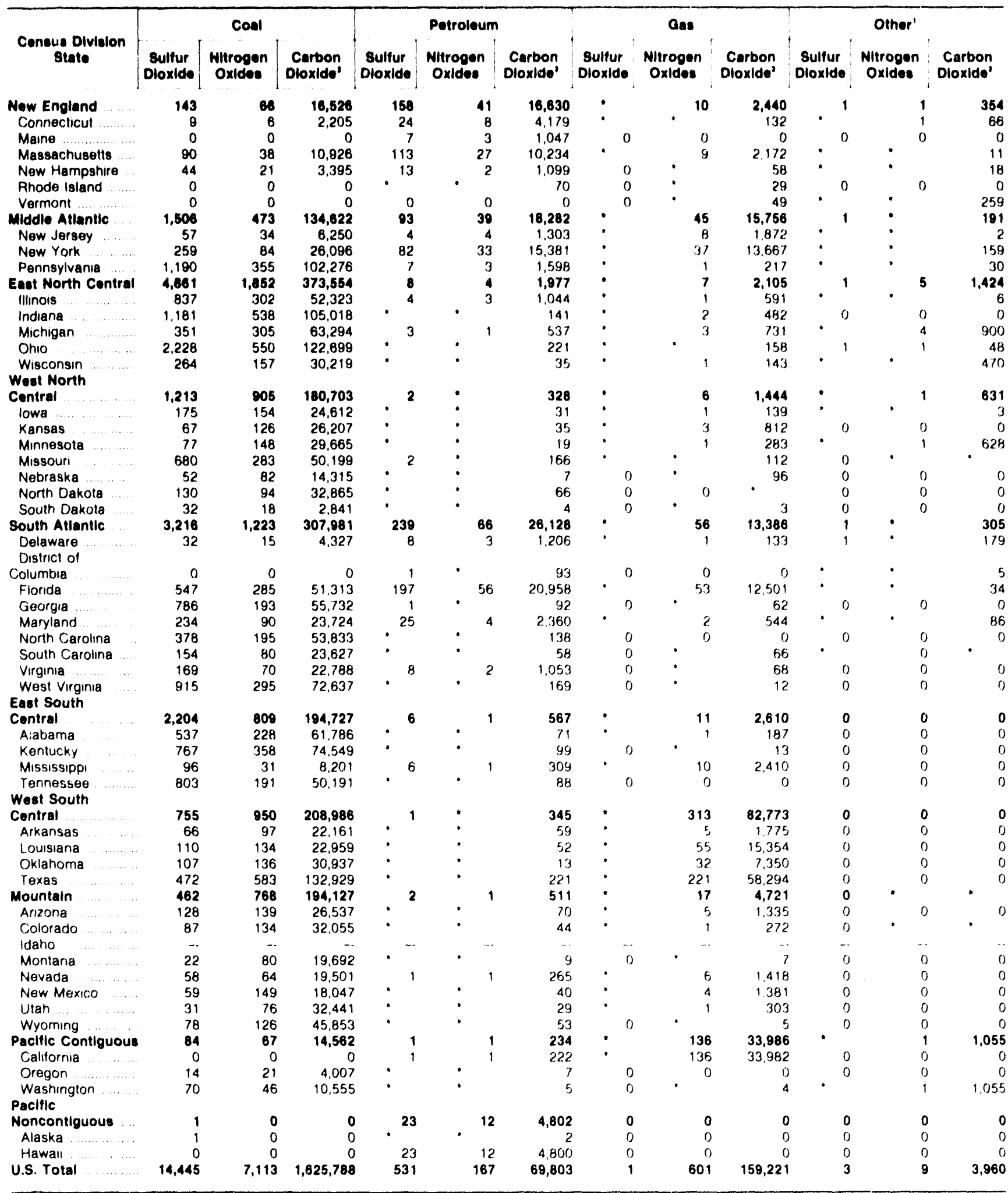

' Includes light oil, methane, coal/oil mixture, propane gas, blast furnace gas, wood, and refuse.

- As of 1992 data, emission lactors for the calculation of carbon dioxide emissions and reductions trom nitrogen oxide control technologies have been changed-historical data were revised to reflect that change.-see the Technical Notes for more information

Notes. Totals may not equal sum of components because of independent rounding - Estumates are preliminary $\bullet$ Estimates are derived trom the Form ElA.767. "Steam-Electric Plant Operation and Design Report." (See Technical Notes for methodology). "Value less than 0.5.

Source: Energy Intormation Administration, Form ElA.767, "Steam.Electric Plant Operatiori and Design Repon" 
Table 48. Number and Capacity of Coal-Fired Steam-Electric Generators for Electric Utility Plants with Environmental Equipment by Census Division and State, 1992

\begin{tabular}{|c|c|c|c|c|c|c|c|c|}
\hline \multirow{2}{*}{$\begin{array}{c}\text { Census Division } \\
\text { state }\end{array}$} & \multicolumn{2}{|c|}{$\begin{array}{l}\text { Cenerating } \\
\text { Units' }\end{array}$} & \multicolumn{2}{|c|}{ Scrubbera } & \multicolumn{2}{|c|}{$\begin{array}{l}\text { Particulate } \\
\text { Collectors }\end{array}$} & \multicolumn{2}{|c|}{ Cooling Towers } \\
\hline & $\begin{array}{l}\text { Number of } \\
\text { Ceneratore }\end{array}$ & $\begin{array}{l}\text { Capacity } \\
\text { (megawatts) }\end{array}$ & $\begin{array}{l}\text { Number of } \\
\text { Cenerators }\end{array}$ & $\begin{array}{c}\text { Capacity' } \\
\text { (mogawatto) }\end{array}$ & $\begin{array}{l}\text { Number of } \\
\text { Ceneratore }\end{array}$ & $\begin{array}{c}\text { Capacity" } \\
\text { (megawatts) }\end{array}$ & $\begin{array}{l}\text { Number of } \\
\text { Cenerators }\end{array}$ & $\begin{array}{c}\text { Capacity² } \\
\text { (megawatts) }\end{array}$ \\
\hline New England & 15 & 2,773 & 0 & 0 & 15 & 2,773 & 0 & 0 \\
\hline Connecticut & 1 & 400 & 0 & 0 & 1 & 400 & 0 & 0 \\
\hline Maine ................ & 0 & 0 & 0 & 0 & 0 & 0 & 0 & 0 \\
\hline Massachusetts & 9 & 1,764 & 0 & 0 & 9 & 1,764 & 0 & 0 \\
\hline New Hampshire. & 5 & 609 & 0 & 0 & 5 & 609 & 0 & 0 \\
\hline Fhode Island $\ldots \ldots \ldots \ldots \ldots \ldots$ & 0 & 0 & 0 & 0 & 0 & 0 & 0 & 0 \\
\hline Vermont & 0 & 0 & 0 & 0 & 0 & 0 & 0 & 0 \\
\hline Middle Atlantic & 85 & 24,153 & 9 & 4,727 & 85 & 24,153 & 17 & 11,931 \\
\hline New Jersey & 8 & 1.732 & 0 & 0 & 8 & 1,732 & 0 & 0 \\
\hline Now York ..... & 25 & 3,758 & 1 & 691 & 25 & 3,758 & 0 & 0 \\
\hline Pennsylvania ........ & 52 & 18,664 & 8 & 4,035 & 52 & 18,664 & 17 & 11,931 \\
\hline East North Central & 303 & 82,381 & 17 & 8,220 & 303 & 82,381 & 41 & 20,485 \\
\hline Iliınois & 55 & 17,123 & 4 & 1,439 & 55 & 17,123 & 2 & 562 \\
\hline 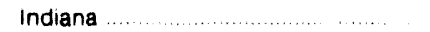 & 68 & 21,565 & 10 & 4,468 & 68 & 21,565 & 23 & 9,395 \\
\hline Michigan & 49 & 12,116 & 0 & 0 & 49 & 12,116 & 2 & 195 \\
\hline Onio $\ldots \ldots \ldots$ & 93 & 24.544 & 3 & 2,314 & 93 & 24,544 & 11 & 8,854 \\
\hline Wisconsin & 38 & 7,033 & 0 & 0 & 38 & 7,033 & 3 & 1,479 \\
\hline West North Central & 136 & 35,675 & 26 & 11,372 & 136 & 35,675 & 36 & 11,345 \\
\hline lowa & 27 & 5,645 & 1 & 176 & 27 & 5.645 & 6 & 1,681 \\
\hline Kansas & 20 & 5,644 & 8 & 3,930 & 20 & 5,644 & 7 & 2.854 \\
\hline Minnesota & 25 & 5,417 & 8 & 3.333 & 25 & 5,417 & 9 & 3,787 \\
\hline Missouri ... & 37 & 11,426 & 3 & 1,125 & 37 & 11,426 & 6 & 767 \\
\hline Nebraska & 14 & 3,092 & 0 & 0 & 14 & 3,092 & 4 & 430 \\
\hline 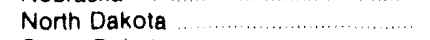 & 12 & 3,994 & 6 & 2.809 & 12 & 3,994 & 4 & 1,826 \\
\hline$\ldots \ldots \ldots \ldots \ldots \ldots \ldots \ldots \ldots$ & 1 & 456 & 0 & 0 & 1 & 456 & 0 & 0 \\
\hline South Atiantic & 214 & 68,654 & 14 & 6,968 & 212 & 68,591 & 64 & 35,400 \\
\hline Delaware & 6 & 1,034 & 0 & 0 & 6 & 1,034 & 1 & 442 \\
\hline 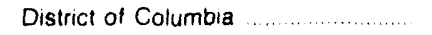 & 0 & 0 & 0 & 0 & 0 & 0 & 0 & 0 \\
\hline Florida $\ldots \ldots \ldots$ & 27 & 10,752 & 7 & 3,976 & 27 & 10,752 & 11 & 6,167 \\
\hline Georgia & 38 & 14.537 & 1 & 123 & 38 & 14,537 & 12 & 9,774 \\
\hline Maryland & 15 & 4,943 & 0 & 0 & 15 & 4,943 & 2 & 1,370 \\
\hline 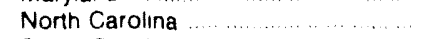 & 47 & 12,556 & 0 & 0 & 45 & 12,494 & 8 & 3,188 \\
\hline 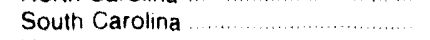 & 24 & 5,324 & 4 & 1,501 & 24 & 5,324 & 14 & 3,923 \\
\hline 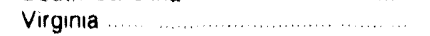 & 24 & 4.549 & 0 & 0 & 24 & 4.549 & 3 & 713 \\
\hline 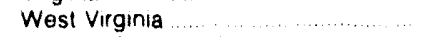 & 33 & 14,958 & 2 & 1,368 & 33 & 14,958 & 13 & 9,822 \\
\hline East South Central & 132 & 40,471 & 23 & 8,622 & 132 & 40,471 & 28 & 12,893 \\
\hline Alabama & 39 & 12,586 & 4 & 1,597 & 39 & 12.586 & 4 & 2,599 \\
\hline 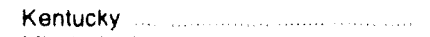 & 54 & 15,956 & 17 & 6.625 & 54 & 15,956 & 21 & 9,394 \\
\hline 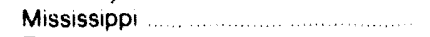 & 6 & 2,150 & 2 & 400 & 6 & 2.150 & 3 & 900 \\
\hline Tennessee & 33 & 9,780 & 0 & 0 & 33 & 9,780 & 0 & 0 \\
\hline 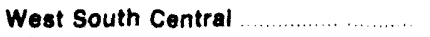 & 57 & 33,463 & 16 & 10,547 & 57 & 33,463 & 30 & 17,035 \\
\hline Arkansas & 5 & 3,958 & 0 & 0 & 5 & 3,958 & 4 & 3,400 \\
\hline Louisiana & 6 & 3,572 & 1 & 721 & 6 & 3,572 & 4 & 2,454 \\
\hline 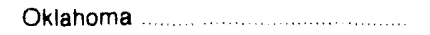 & 10 & 5,210 & 1 & 520 & 10 & 5,210 & 8 & 4,072 \\
\hline 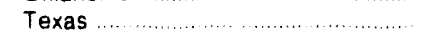 & 36 & 20,724 & 14 & 9,306 & 36 & 20,724 & 14 & 7,109 \\
\hline 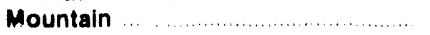 & 87 & 30,488 & 48 & 20,701 & 87 & 30,488 & 75 & 25,993 \\
\hline Arizona & 13 & 5,554 & 8 & 2,683 & 13 & 5,554 & 11 & 5,152 \\
\hline Colorado & 26 & 4,976 & 5 & 1,974 & 26 & 4,976 & 24 & 4,524 \\
\hline Idaho & - & -. & - & - & - & - & - & - \\
\hline 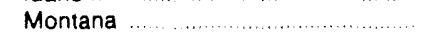 & 5 & 2,464 & 4 & 2,273 & 5 & 2,464 & 4 & 2,273 \\
\hline Nevada & 8 & 2.769 & 5 & 879 & 8 & 2,769 & 7 & 1,951 \\
\hline (n) & 10 & 4,282 & 10 & 4.282 & 10 & 4,282 & 5 & 2,012 \\
\hline (n. & 10 & 4,604 & 7 & 3,969 & 10 & 4,604 & 10 & 4,604 \\
\hline (n) & 15 & 5,838 & 9 & 4,641 & 15 & 5,838 & 14 & 5,476 \\
\hline Pacific Contiguous & 3 & 2,020 & 0 & 0 & 3 & 2,020 & 2 & 1,460 \\
\hline 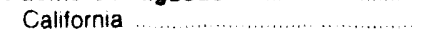 & 0 & 0 & 0 & 0 & 0 & 0 & 0 & 0 \\
\hline Oregon & 1 & 561 & 0 & 0 & 1 & 561 & 0 & 0 \\
\hline Washington & 2 & 1,460 & 0 & 0 & 2 & 1,460 & 2 & 1,460 \\
\hline Pacific Noncontiguous $\ldots \ldots \ldots$ & 0 & 0 & 0 & 0 & 0 & 0 & 0 & 0 \\
\hline Alaska & 0 & 0 & 0 & 0 & 0 & 0 & 0 & 0 \\
\hline 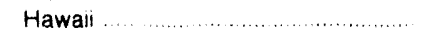 & 0 & 0 & 0 & 0 & 0 & 0 & 0 & 0 \\
\hline U.S. Total & 1,032 & 320,078 & 153 & 71,157 & 1,030 & 320,016 & 293 & 136,542 \\
\hline
\end{tabular}

- Components are not additive since some generators are included in more than one category and not all units have environmental equipment.

Nameplate capacity

Notes - Totals may not equal sum of components because of independent rounding. -These data are only for plants with a fossil-fueled stearnelectric capacity of 100 or more megawatts. Data are pruliminary.

Source: Energy Information Administration, Form EIA-767. "Steam.Electric Plant Operation and Design Report." 
Table 49. Number and Capacity of Petroleum- and Gas-Fired Steam-Electric Generators for Electric Utility Plants with Environmental Equipment by Census Division and State, 1992

\begin{tabular}{|c|c|c|c|c|c|c|c|c|}
\hline \multirow{2}{*}{$\begin{array}{c}\text { Census Division } \\
\text { State }\end{array}$} & \multicolumn{2}{|c|}{$\begin{array}{l}\text { Generating } \\
\text { Units }^{\prime}\end{array}$} & \multicolumn{2}{|c|}{ Scrubbers } & \multicolumn{2}{|c|}{$\begin{array}{l}\text { Particulate } \\
\text { Collectors }\end{array}$} & \multicolumn{2}{|c|}{ Coollng Towers } \\
\hline & $\begin{array}{l}\text { Number of } \\
\text { Canerators }\end{array}$ & $\begin{array}{c}\text { Capacity } \\
\text { (megawatts) }\end{array}$ & $\begin{array}{l}\text { Number of } \\
\text { Generators }\end{array}$ & $\begin{array}{c}\text { Capacity } \\
\text { (megawatts) }\end{array}$ & $\begin{array}{l}\text { Number of } \\
\text { Generators }\end{array}$ & $\begin{array}{c}\text { Capacity } \\
\text { (megawatts) }\end{array}$ & $\begin{array}{l}\text { Number of } \\
\text { Generators }\end{array}$ & $\begin{array}{l}\text { Capacity } \\
\text { (megawatts) }\end{array}$ \\
\hline Now England. & 25 & 6,244 & 0 & 0 & 24 & 5,829 & 1 & 415 \\
\hline Connecticut .. & 11 & 2.098 & 0 & 0 & 10 & 1,683 & 1 & 415 \\
\hline Maine ............... & 4 & 846 & 0 & 0 & 4 & 846 & 0 & 0 \\
\hline New Hampshire. & 1 & 414 & 0 & 0 & 1 & 414 & 0 & 0 \\
\hline Ahode Island & 3 & 132 & 0 & 0 & 3 & 132 & 0 & 0 \\
\hline 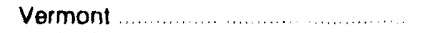 & 0 & 0 & 0 & 0 & 0 & 0 & 0 & 0 \\
\hline Middle Atlantic & 48 & 12,829 & 0 & 0 & 45 & 10,993 & 4 & 2,012 \\
\hline 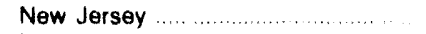 & 10 & 1.737 & 0 & 0 & 9 & 1.602 & 2 & 311 \\
\hline 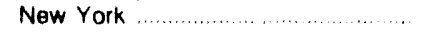 & 28 & 7,726 & 0 & 0 & 28 & 7,726 & 0 & 0 \\
\hline Pennsylvania $\ldots \ldots \ldots \ldots \ldots \ldots \ldots \ldots$ & 10 & 3,365 & 0 & 0 & 8 & 1.664 & 2 & 1,701 \\
\hline East North Central & 15 & 2,461 & 0 & 0 & 10 & 928 & 5 & 1,533 \\
\hline 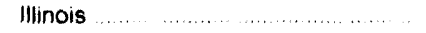 & 1 & 210 & 0 & 0 & 0 & 0 & 1 & 210 \\
\hline Ohio $\ldots \ldots \ldots \ldots$ & 1 & 51 & 0 & 0 & 1 & 51 & 0 & 0 \\
\hline Wisconsin $\ldots \ldots \ldots \ldots$ & 2 & 88 & 0 & 0 & 2 & 88 & 0 & 0 \\
\hline West North Central. & 18 & 1,484 & 0 & $\mathbf{0}$ & 5 & 168 & 14 & 1,337 \\
\hline 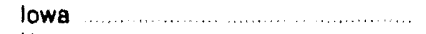 & 3 & 65 & 0 & 0 & 3 & 65 & 0 & 0 \\
\hline 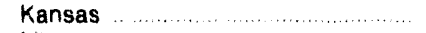 & 10 & 1,255 & 0 & 0 & 0 & 0 & 10 & 1.255 \\
\hline 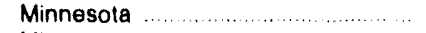 & 1 & 82 & 0 & 0 & 1 & 32 & 0 & 0 \\
\hline 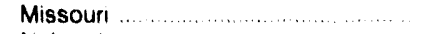 & 4 & 83 & 0 & 0 & 1 & 22 & 4 & 83 \\
\hline Nebraska $\ldots \ldots \ldots \ldots \ldots$ & 0 & 0 & 0 & 0 & 0 & 0 & 0 & 0 \\
\hline North Dakota ............................... & 0 & 0 & 0 & 0 & 0 & 0 & 0 & 0 \\
\hline South Dakota $\ldots \ldots \ldots \ldots \ldots$ & 0 & 0 & 0 & 0 & 0 & 0 & 0 & 0 \\
\hline South Atlantic $\ldots \ldots \ldots \ldots \ldots \ldots \ldots$ & 53 & 15,588 & 0 & 0 & 40 & 12,339 & 17 & 4,425 \\
\hline 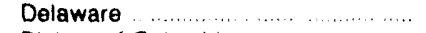 & 4 & 597 & 0 & 0 & 4 & 597 & 2 & 132 \\
\hline District of Columbia $\ldots \ldots \ldots \ldots \ldots \ldots \ldots$ & 2 & 580 & 0 & 0 & 0 & 0 & 2 & 580 \\
\hline 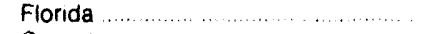 & 31 & 9,975 & 0 & 0 & 22 & 8,625 & 9 & 1,351 \\
\hline Georgia $\ldots \ldots \ldots \ldots$ & 0 & 0 & 0 & 0 & 0 & 0 & 0 & 0 \\
\hline 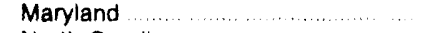 & 12 & 2,534 & 0 & 0 & 10 & $1,2 \uparrow 6$ & 3 & 1.480 \\
\hline 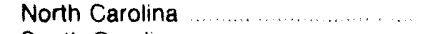 & 0 & 0 & 0 & 0 & 0 & 0 & 0 & 0 \\
\hline South Carolina $\ldots . . . \ldots \ldots \ldots \ldots \ldots \ldots$ & 0 & 0 & 0 & 0 & 0 & 0 & 0 & 0 \\
\hline 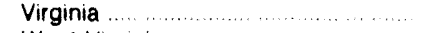 & 4 & 1.902 & 0 & 0 & 4 & 1,902 & 1 & 882 \\
\hline Alabama $\ldots \ldots \ldots \ldots$ & 0 & 0 & 0 & 0 & 0 & 0 & 0 & 0 \\
\hline 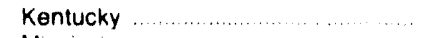 & 1 & 147 & 0 & 0 & 1 & 147 & 0 & 0 \\
\hline 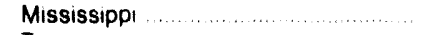 & 4 & 281 & 0 & 0 & 0 & 0 & 4 & 281 \\
\hline Tennessee $\ldots \ldots \ldots \ldots \ldots$ & 0 & 0 & 0 & 0 & 0 & 0 & 0 & 0 \\
\hline 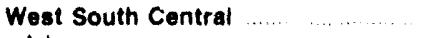 & 87 & 13,721 & 0 & 0 & 4 & 2,258 & 85 & 12,562 \\
\hline Arkansas & 2 & 183 & 0 & 0 & 0 & 0 & 2 & 183 \\
\hline 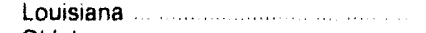 & 14 & 2.535 & 0 & 0 & 2 & 1,184 & 13 & 1,943 \\
\hline Oklahoma & 16 & 3,915 & 0 & 0 & 1 & 567 & 15 & 3,348 \\
\hline 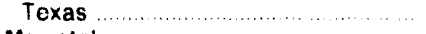 & 55 & 7,088 & 0 & 0 & 1 & 507 & 55 & 7,088 \\
\hline Mountain & 33 & 2,982 & 1 & 195 & 5 & 478 & 33 & 2,982 \\
\hline Arizona & 14 & 1,577 & 1 & 195 & 1 & 195 & 14 & 1,577 \\
\hline 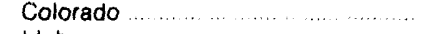 & 3 & 111 & 0 & 0 & 2 & 101 & 3 & 111 \\
\hline Idaho & -- & $\cdots$ & - & -- & -- & -- & -- & $-\cdots$ \\
\hline Montana $\ldots \ldots \ldots \ldots \ldots \ldots$ & 0 & 0 & 0 & 0 & 0 & 0 & 0 & 0 \\
\hline Nevada & 4 & 243 & 0 & 0 & 0 & 0 & 4 & 243 \\
\hline 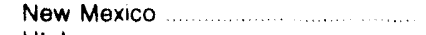 & 9 & 800 & 0 & 0 & 0 & 0 & 9 & 800 \\
\hline 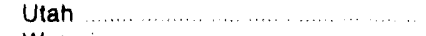 & 3 & 252 & 0 & 0 & 2 & 153 & 3 & 252 \\
\hline Wyoming & 0 & 0 & 0 & 0 & 0 & 0 & 0 & 0 \\
\hline Pacific Contiguous & 30 & 3,379 & 0 & 0 & 5 & 368 & 29 & 3,216 \\
\hline Californıa & 30 & 3.379 & 0 & 0 & 5 & 368 & 29 & 3,216 \\
\hline Oregon $\ldots \ldots \ldots \ldots \ldots \ldots$ & 0 & 0 & 0 & 0 & 0 & 0 & 0 & 0 \\
\hline 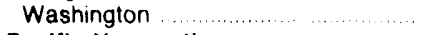 & 0 & 0 & 0 & 0 & 0 & 0 & 0 & 0 \\
\hline Pacific Noncontiguous ................. & 0 & 0 & 0 & 0 & 0 & 0 & 0 & 0 \\
\hline Alaska & 0 & 0 & 0 & 0 & 0 & 0 & 0 & 0 \\
\hline 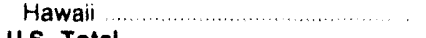 & 0 & 0 & 0 & 0 & 0 & 0 & 0 & 0 \\
\hline … & 314 & 59,116 & 1 & 195 & 139 & 33,509 & 192 & 28,764 \\
\hline
\end{tabular}

- Components are not additive since scme generators are included in more than one category and not all units have environmentat equipment

Nameplate capacity.

Notes: -Totals may not equal sum of components because of independent rounding. - These data are only for plants with a fossil-fueled stearn electric capacity of 100 or more megawatts - Data are preliminary

Source. Energy Intormation Administration, Form EIA-767, "Steam.Electric Plant Operation and Design Report" 
Table 50. Average Quality of Fossil Fuels Burned at Electric Utilities by Census Division and State, 1992 and 1991

\begin{tabular}{|c|c|c|c|c|c|c|c|c|c|c|c|c|}
\hline \multirow{3}{*}{$\begin{array}{c}\text { Census Divialon } \\
\text { State }\end{array}$} & \multicolumn{6}{|c|}{ Coal } & \multicolumn{4}{|c|}{ Petroleum } & \multicolumn{2}{|c|}{ Gas } \\
\hline & \multicolumn{3}{|c|}{1992} & \multicolumn{3}{|c|}{1991} & \multicolumn{2}{|c|}{1992} & \multicolumn{2}{|c|}{1991} & \multirow{2}{*}{$\begin{array}{c}1992 \\
\begin{array}{c}\text { Average } \\
\text { Btu per } \\
\text { Cublc }\end{array}\end{array}$} & \multirow{2}{*}{ 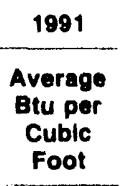 } \\
\hline & $\begin{array}{l}\text { Average } \\
\text { Btu } \\
\text { per } \\
\text { Pound }\end{array}$ & $\begin{array}{c}\text { Sulfur } \\
\text { Percent } \\
\text { by } \\
\text { Welght }\end{array}$ & $\begin{array}{c}\text { Ash } \\
\text { Percent } \\
\text { by } \\
\text { Welght }\end{array}$ & $\begin{array}{c}\text { Average } \\
\text { Btu } \\
\text { per } \\
\text { Pound }\end{array}$ & $\begin{array}{c}\text { Sulfur } \\
\text { Percent } \\
\text { by } \\
\text { Wolght }\end{array}$ & $\begin{array}{c}\text { Ash } \\
\text { Percent } \\
\text { by } \\
\text { Welght }\end{array}$ & $\begin{array}{c}\text { Average } \\
\text { Btu } \\
\text { per } \\
\text { Gallon }\end{array}$ & $\begin{array}{c}\text { Sulfur } \\
\text { Percent } \\
\text { by } \\
\text { Weight }\end{array}$ & $\begin{array}{c}\text { Average } \\
\text { Btu } \\
\text { per } \\
\text { Gallon }\end{array}$ & $\begin{array}{c}\text { Sulfur } \\
\text { Percent } \\
\text { by }\end{array}$ & & \\
\hline New England ...................... & 13,109 & 1.24 & 7.5 & 13,128 & 1.18 & 7.1 & 151,320 & 1.40 & 151,003 & & & 1,041 \\
\hline 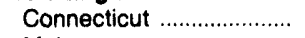 & 13,212 & .57 & 6.3 & 13,217 & .57 & 6.1 & 151,145 & .91 & 151 & : & & 1,033 \\
\hline Maine …............................. & - & -- & - & - & - & - & 150,768 & 1.03 & 150, & & & - \\
\hline Massachusetts ................ & 13,071 & 1.20 & 8.2 & 13,078 & 1.25 & 7.5 & 150,994 & 1.61 & 150,58 & &, 031 & 1,044 \\
\hline New Hampshire ............... & 13,159 & 1.80 & 6.4 & 13,237 & 1.40 & 6.3 & 155,755 & 1.74 & $155,47 !$ & 1.36 & 1,019 & - \\
\hline 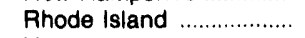 & $\ldots$ & - & - & - & - & -- & 148,327 & 1.00 & 146,666 & 1.00 & 1,031 & 1,032 \\
\hline 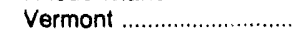 & -- & -- & -- & - & -- & -- & -- & - & 140,000 & .30 & 1,000 & 1,000 \\
\hline Middle Atlantic ................. & 12,549 & 1.93 & 11.2 & 12,506 & 1.99 & 11.7 & 150,246 & .74 & 150,163 & .80 & 1,031 & 1,031 \\
\hline 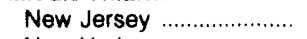 & 13.105 & 1.26 & 8.2 & 13,087 & 1.32 & 8.2 & 149,048 & .42 & 148,626 & .40 & 1,034 & 1,032 \\
\hline New York ........................... & 12,880 & 1.63 & 8.3 & 12,847 & 1.75 & 9.0 & 150,435 & .78 & 150,289 & .84 & 1,031 & 1,031 \\
\hline Pennsylvania ....................... & 12,436 & 2.05 & 12.1 & 12,391 & 2.38 & 12.5 & 149,388 & .62 & 150,247 & .72 & 1,031 & 1,030 \\
\hline 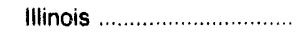 & 10,601 & 2.02 & 8.5 & 10,560 & 1.87 & 8.5 & 149,623 & .62 & 149,806 & .62 & 1,016 & 1,020 \\
\hline 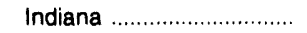 & 10,497 & 1.87 & 8.5 & 10,512 & 2.03 & 8.6 & 137,137 & .35 & 137,378 & .30 & 1,020 & 1,024 \\
\hline 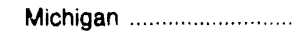 & 10,792 & .67 & 6.8 & 10,846 & .70 & 6.7 & 145,058 & .73 & 146,186 & .72 & 1,016 & 986 \\
\hline Ohio & 11,937 & 2.60 & 11.4 & 11,914 & 2.60 & 11.6 & 137,711 & .36 & 140,406 & .57 & 1,034 & 1,026 \\
\hline 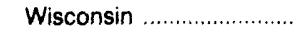 & 9,589 & .77 & 42 & 9,583 & .82 & 6.3 & 139,188 & .30 & 138,779 & .39 & 982 & 1,007 \\
\hline Weat North Central ........ & 8,523 & .88 &. .2 & 8,591 & .93 & 7.2 & 143,439 & 1.06 & 143,123 & .97 & 989 & 985 \\
\hline lowa & 8,797 & .69 & 5.8 & 8,838 & .68 & 6.0 & 138,026 & .45 & 138,029 & .38 & 1,003 & 1,006 \\
\hline 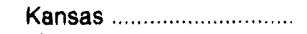 & 8,827 & .48 & 5.7 & 8,943 & .57 & 5.7 & 140,329 & .50 & 138,968 & .47 & 982 & 974 \\
\hline 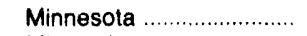 & 8,774 & .52 & 6.6 & 8,751 & .53 & 7.1 & 139,070 & .42 & 138,715 & .42 & 1,006 & 1,006 \\
\hline 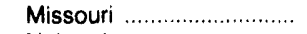 & 10,197 & 1.77 & 7.6 & 10,233 & 1.88 & 7.8 & 147,201 & 1.60 & 146,894 & 1.43 & 1,002 & 1,013 \\
\hline Nebraska ............................ & 8,524 & .38 & 5.1 & 8,518 & .36 & 5.0 & 139,080 & .22 & 142,312 & .51 & 956 & 944 \\
\hline North Dakota ...................... & 6,489 & .75 & 9.6 & 6,560 & .82 & 9.2 & 139,463 & .50 & 138,632 & .46 & 1,022 & 998 \\
\hline 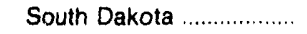 & 6,245 & .88 & 9.0 & 6,238 & .84 & 8.8 & 138,041 & .36 & 137,542 & .35 & 1,011 & 1,007 \\
\hline 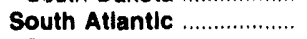 & 12,379 & 1.52 & 10.0 & 12,366 & 1.52 & 9.9 & 151,074 & 1.36 & 150,867 & 1.25 & 1,012 & 1,020 \\
\hline 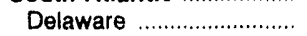 & 12,953 & 1.01 & 8.9 & 13,183 & 1.00 & 8.8 & 150,159 & 1.07 & 150,759 & 1.19 & 1,037 & 1,140 \\
\hline District of Columbia ........ & $\rightarrow$ & - & - & - & - & - & 143,643 & .92 & 143,214 & .93 & - & - \\
\hline Florida & 12,203 & 1.73 & 8.4 & 12,215 & 1.72 & 8.4 & 151,548 & 1.38 & 151,416 & 1.26 & 1,010 & 1,012 \\
\hline 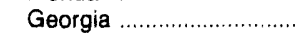 & 11,937 & 1.67 & 10.3 & 11,816 & 19 & 10.0 & 142,504 & 1.13 & 140,030 & .73 & 1,024 & 1,024 \\
\hline 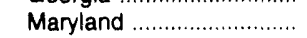 & 12,745 & 1.34 & 10.6 & 12,788 & & 10.7 & 150,042 & 1.56 & 149,927 & 1.36 & 1,045 & 1,046 \\
\hline West Virginia ...................... & 12,447 & 2.01 & 11.4 & 12,465 & & 11.3 & 139,824 & .33 & 139,213 & .36 & 1,000 & 1,000 \\
\hline East South Central ......... & 11,971 & 1.90 & 10.1 & 11,985 & 1.91 & 10.2 & 146,572 & 1.71 & 145,458 & 1.55 & 1,028 & 1,025 \\
\hline Alabama & 12,046 & 1.43 & 11.8 & 12,103 & 1.39 & 11.7 & 137,086 & .33 & 137,254 & .31 & 1,022 & 1,024 \\
\hline 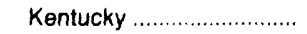 & 11.776 & 2.21 & 10.1 & 11,717 & 2.27 & 10.3 & 138,933 & .30 & 138,829 & .27 & 1,022 & 1,020 \\
\hline Mississippi ......................... & 12,349 & 1.70 & 8.2 & 12,564 & 1.58 & 8.3 & 152,579 & 2.73 & 151,798 & 2.69 & 1,029 & 1,025 \\
\hline Tennessee & 12,126 & 2.03 & 8.4 & 12,168 & 2.02 & 8.6 & 138,688 & .31 & 138,880 & .28 & -- & - \\
\hline West South Central ........ & 7,576 & .65 & 10.3 & 7,599 & .65 & 10.5 & 138,550 & .44 & 140,750 & .49 & 1,028 & 1,031 \\
\hline 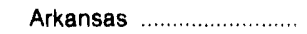 & 8,526 & .31 & 5.0 & 8,615 & .31 & 5.0 & 139,050 & .62 & 140,082 & .43 & 1,024 & 1,028 \\
\hline 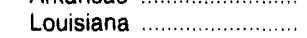 & 7,960 & .50 & 7.1 & 7,954 & .51 & 7.3 & 142,976 & 49 & 140,888 & .44 & 1,037 & 1,035 \\
\hline 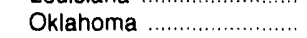 & 8,710 & .41 & 5.2 & 8,741 & .43 & 5.3 & 140,615 & .62 & 140.711 & 62 & $1.03 i$ & 1,041 \\
\hline 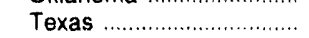 & 7,169 & .77 & 12.5 & 7,206 & .75 & 12.6 & 137,290 & .38 & 140,985 & .51 & 1,025 & 1,029 \\
\hline 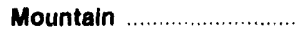 & 9,805 & .54 & 11.0 & 9,843 & .54 & 10.8 & 145,386 & .59 & 142,750 & .48 & 1,026 & 1,021 \\
\hline 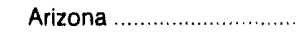 & 10,322 & .51 & 12.4 & 10,382 & .53 & 12.5 & 140,141 & .35 & 139,571 & .24 & 1,032 & 1,027 \\
\hline 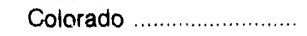 & 9,916 & .38 & 7.0 & 9,906 & .37 & 6.8 & 146,780 & .63 & 143,234 & .53 & 962 & 970 \\
\hline 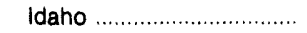 & - & -- & -- & -- & -- & -- & -- & - & $\sim$ & -- & -- & -- \\
\hline 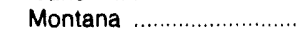 & 8,577 & .66 & 8.9 & 8,524 & .65 & 8.8 & 136,865 & .50 & 136,865 & .50 & 1,206 & 1,194 \\
\hline 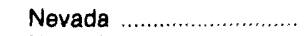 & 11,861 & .48 & 9.7 & 11,955 & .49 & 9.6 & 147,734 & .73 & 146,673 & 69 & 1,025 & 1,024 \\
\hline New Mexico ................... & 9,150 & .80 & 21.5 & 9,230 & .78 & 21.2 & 134,864 & .11 & 135,193 & .14 & 1,021 & 1,019 \\
\hline 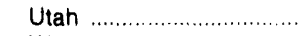 & 11,470 & 47 & 11.4 & 11,552 & .46 & 10.9 & 139,175 & .33 & 139,585 & .29 & 1.074 & 1.067 \\
\hline 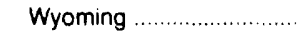 & 8,725 & .53 & 7.5 & 8,689 & .52 & 7.7 & 140,502 & .34 & 140,599 & .35 & 1,039 & 1,051 \\
\hline Pacific Contiguous ......... & 8,476 & .59 & 11.1 & 8,115 & .57 & 11.9 & 147,407 & .50 & 146,484 & .42 & 1,032 & 1,027 \\
\hline California & -- & -- & - & - & -- & -- & 147.759 & .50 & 146.705 & 42 & 1,032 & 1.027 \\
\hline Oregon & 9,416 & .40 & 4.3 & 8,349 & .34 & 4.8 & 138,800 & .50 & 138,800 & .50 & - & - \\
\hline 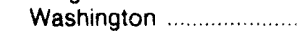 & 8,172 & .65 & 13.3 & 8,033 & .65 & 14.4 & 140,903 & .31 & 140,897 & 31 & 1,027 & 1,037 \\
\hline Paciflc Noncontiguous & 7,906 & .16 & 8.4 & 7,864 & .19 & 8.7 & $149,5 \div 1$ & .68 & 149,083 & .67 & -- & - \\
\hline Alaska & 7,906 & .16 & 8.4 & 7,864 & 19 & 8.7 & 134,360 & .39 & 134,360 & .29 & -- & - \\
\hline 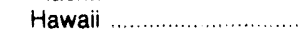 & -. & $-\ldots$ & - & - & - & $\therefore$ & 149,527 & 68 & 149,084 & .67 & - & - \\
\hline U.S. Average & 10,338 & 1.27 & 9.6 & 10,347 & 1.30 & 9.7 & 150,473 & 1.12 & 150,289 & 1.07 & 1,027 & 1,028 \\
\hline
\end{tabular}

Notes: -Data for 1992 are preliminary; data for prior years are final - Totals may not equal sum of components because of independent rounding. Source: Energy Information Administration, Form EIA-767, "Steam-Electric Plant Operation and Design Report." 
Table 51. Average Flue Gas Desulfurization Costs at Electric Utilities by Census Division and State, 1988 Through 1992

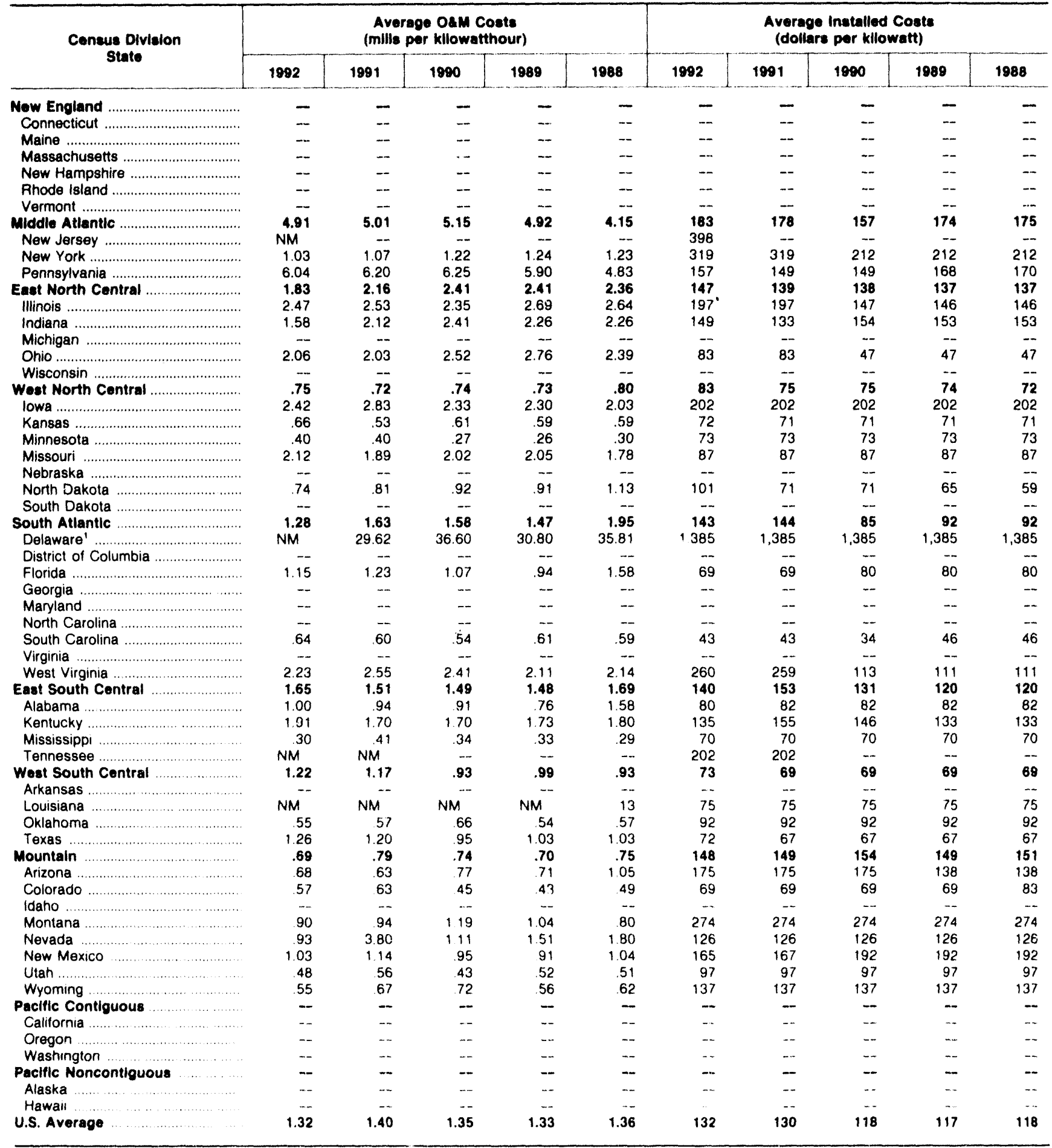

1 The high cost shown for Delaware is attributable to the flue gas desulfurization (FGD) units belonging to a plant that provides steam for sale and steam used to produce electricity. The FGD costs include the costs incurred in the production of steam for sale. In 1992 the plant was sold to a nonutility power producer.

O\&M = Operation and Maintenance

NM = Not meaningful because these plants did not generate during the year

Notes: - Data for 1992 are preliminary; data for prior years are final - Totals may not equal sum oi components because of independent rounding •A mill is a monetary cost and billing unit equal to $1 / 1000$ of the U.S. dollar (equivalent to $1 / 10$ of 1 cent)

Source Energy Information Administration. Form ElA.767. "Steam-Electric Plant Operation and Design Report" 
Table 52. Flue Gas Desulfurization (FGD) Capacity in Operation at U.S. Electric Utility Plants as of December 1992

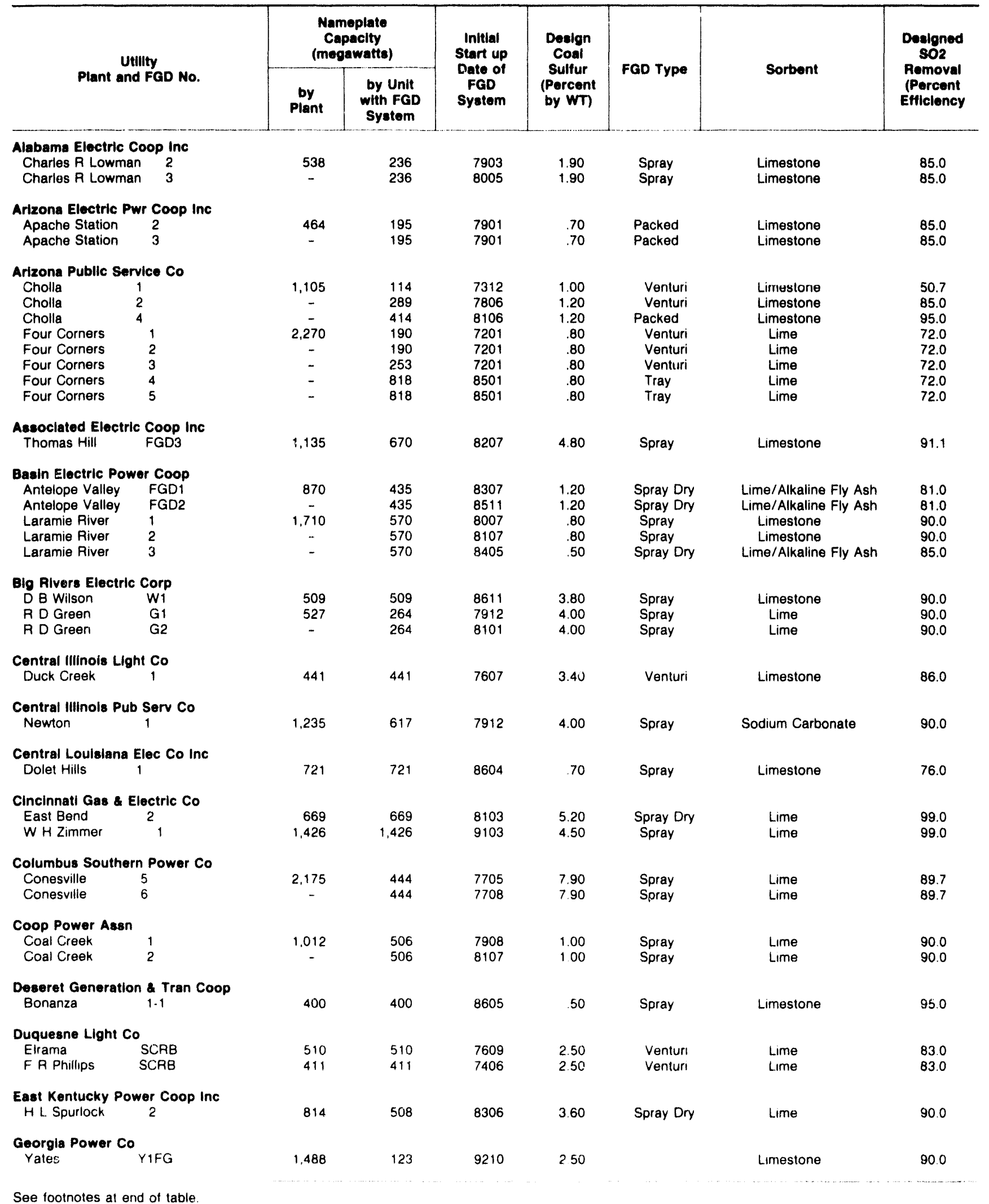


Table 52. Flue Gas Desulfurization (FGD) Capacity in Operation at U.S. Electric Utility Plants as of December 1992-Continued

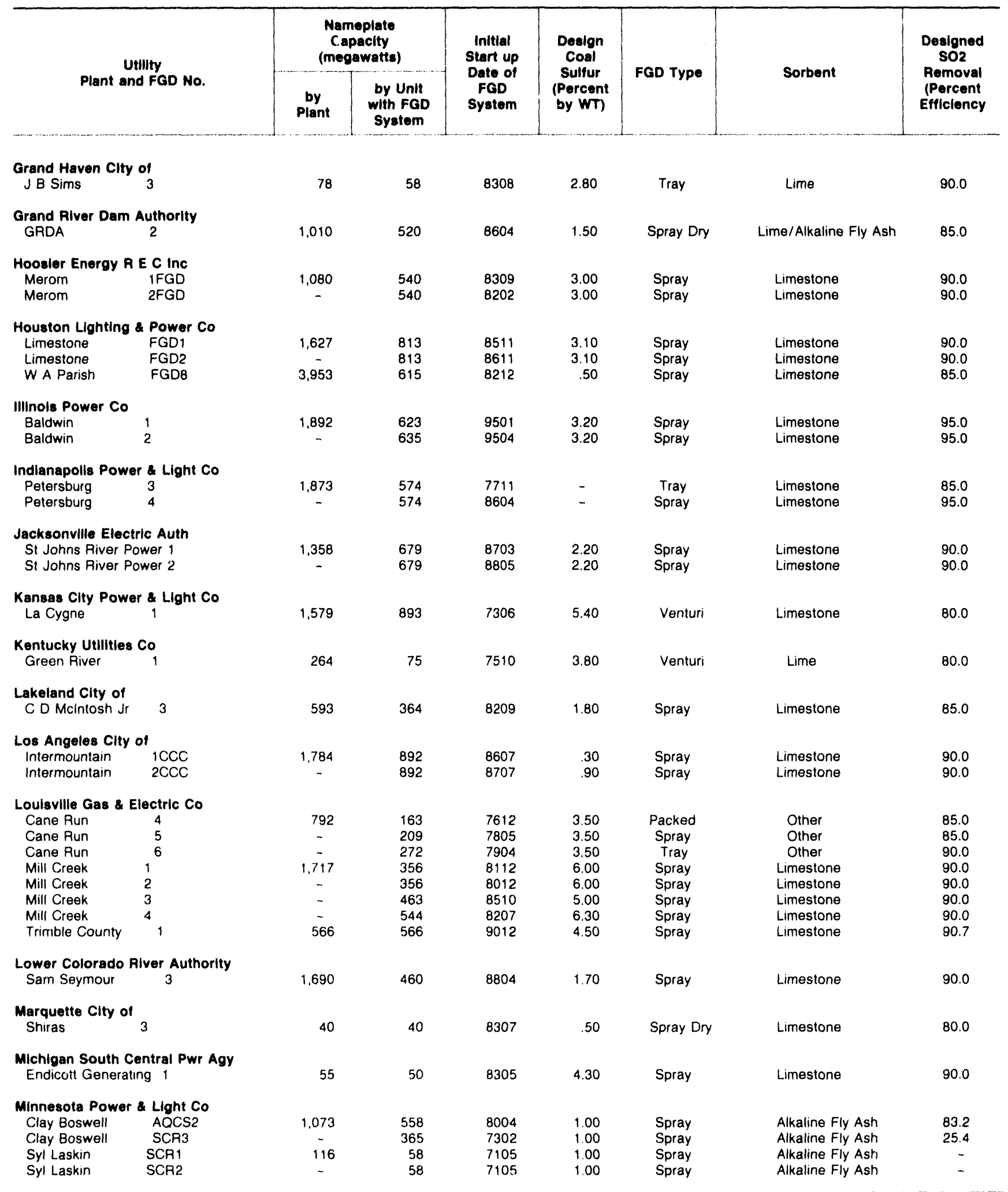

See footnotes at end of table. 
Table 52. Flue Gas Desulfurization (FGD) Capacity in Operation at U.S. Electric Utility Plants as of December 1992-Continued

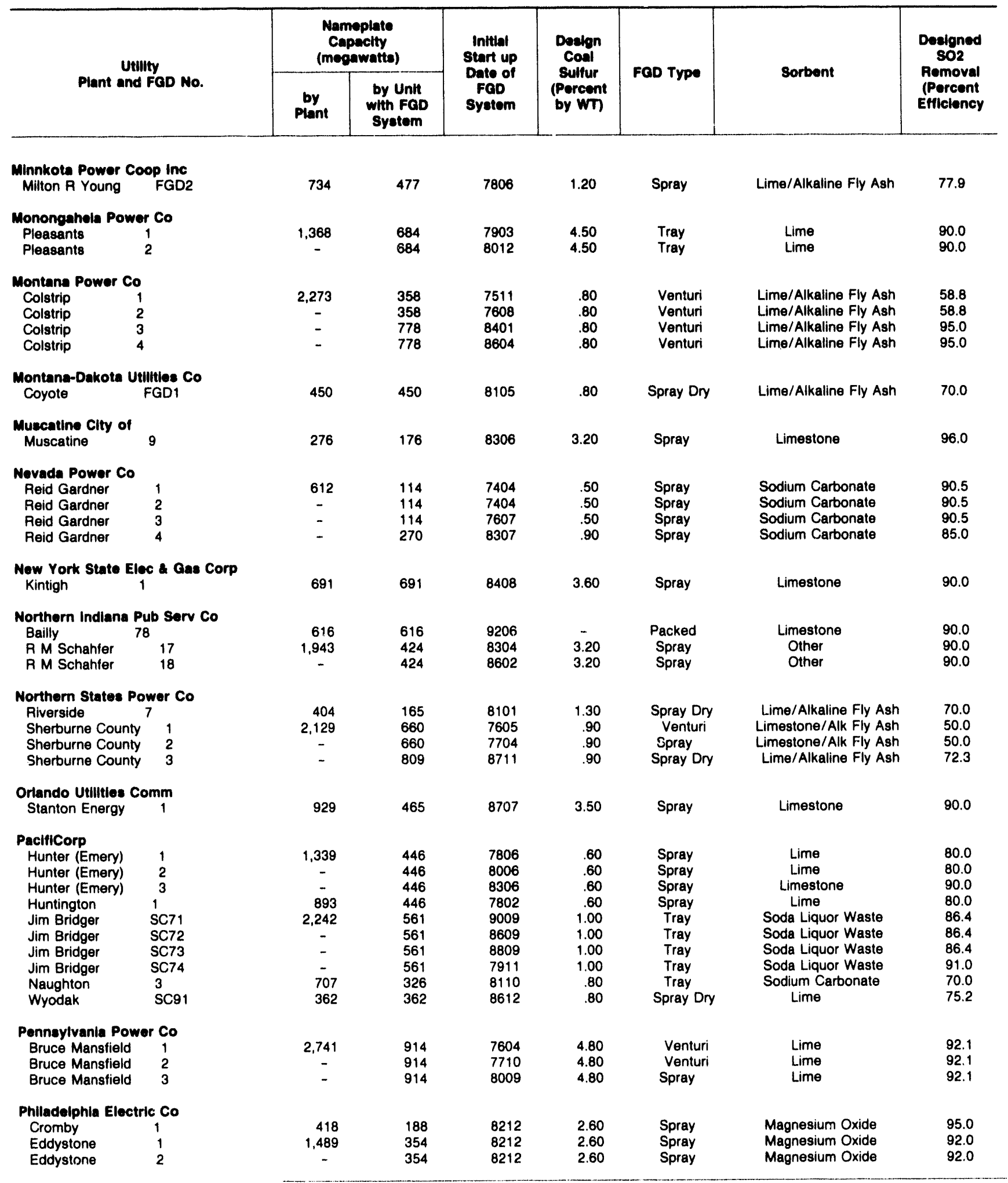

See footnotes at end of table. 
Table 52. Flue Gas Desulfurization (FGD) Capacity in Operation at U.S. Electric Utility Plants as of December 1992-Continued

\begin{tabular}{|c|c|c|c|c|c|c|c|}
\hline \multirow{2}{*}{$\begin{array}{c}\text { Utility } \\
\text { Plant and FCD No. }\end{array}$} & \multicolumn{2}{|c|}{$\begin{array}{c}\text { Namoplate } \\
\text { Capacity } \\
\text { (mogawatts) }\end{array}$} & \multirow{2}{*}{$\begin{array}{c}\text { Initial } \\
\text { Start up } \\
\text { Date of } \\
\text { FGD } \\
\text { System }\end{array}$} & \multirow{2}{*}{$\begin{array}{l}\text { Dealgn } \\
\text { Coal } \\
\text { Sulfur } \\
\text { (Porcent } \\
\text { by WT) }\end{array}$} & \multirow{2}{*}{ FGD Type } & \multirow{2}{*}{ Sorbent } & \multirow{2}{*}{$\begin{array}{c}\text { Designed } \\
\text { SO2 } \\
\text { Removal } \\
\text { (Percent } \\
\text { Efficiency }\end{array}$} \\
\hline & $\begin{array}{l}\text { by } \\
\text { Plant }\end{array}$ & $\begin{array}{l}\text { by Unit } \\
\text { with FGD } \\
\text { Syatem }\end{array}$ & & & & & \\
\hline \multicolumn{8}{|l|}{ Plains Elec GeneTrans Coop Inc } \\
\hline $\begin{array}{ll}\text { Escalante } & 1\end{array}$ & 233 & 233 & 8412 & 0.80 & Spray & Limestone & 95.0 \\
\hline \multicolumn{8}{|l|}{ Platte River Power Authority } \\
\hline Rawhide $\quad 101$ & 285 & 285 & 8404 & .30 & Spray Dry & Lime/Alkaline Fly Ash & 80.0 \\
\hline \multicolumn{8}{|l|}{ Public Service Co of Colorado } \\
\hline Cherokee 4 & 710 & 350 & 8905 & .40 & Spray Dry & Other & 26.0 \\
\hline \multicolumn{8}{|l|}{ Public Service Co of NM } \\
\hline San Juan 1 & 1,779 & 361 & 7804 & 1.30 & Tray & Other & 90.0 \\
\hline San Juan & - & 350 & 7808 & 1.30 & Tray & Other & 90.0 \\
\hline San Juan & - & 534 & 8203 & 1.30 & Tray & Other & 90.0 \\
\hline San Juan & - & 534 & 8204 & 1.30 & Tray & Other & 90.0 \\
\hline \multicolumn{8}{|l|}{ PSI Energy Inc } \\
\hline Gibson & 3,340 & 668 & 8210 & 4.40 & Spray & Limestone & 86.0 \\
\hline \multicolumn{8}{|l|}{ Plchmond Clty of } \\
\hline Whitewater Valley & - & - & 9410 & 2.30 & Spray Dry & Limestone & 75.0 \\
\hline \multicolumn{8}{|l|}{ Salt River Proj $A g \mid \&$ Diat } \\
\hline Coronado FGD1 & 822 & 411 & 7912 & 1.00 & Spray & Limestone & 82.5 \\
\hline Coronado $\quad F G D 2$ & - & 411 & 8011 & 1.00 & Spray & Limestone & 82.5 \\
\hline \multicolumn{8}{|l|}{ San Antonio City of } \\
\hline J K Spruce FGD1 & 546 & 546 & 9212 & .60 & Spray & Limestone & 70.0 \\
\hline \multicolumn{8}{|l|}{ San Miguel Electric Coop Inc } \\
\hline San Miguel $\quad$ SM-1 & 410 & 410 & 8201 & 2.00 & Spray & Limestone & 86.0 \\
\hline \multicolumn{8}{|l|}{ Seminole Electric Coop Inc } \\
\hline Seminole $\quad 1$ & 1,304 & 652 & 8402 & 3.00 & Spray & Limestone & 86.0 \\
\hline Seminole & $\sim$ & 652 & 8412 & 3.00 & Spray & Limestone & 86.0 \\
\hline \multicolumn{8}{|l|}{ Slerra Pacific Power Co } \\
\hline North Valmy 2 & 521 & 267 & 8507 & .50 & Spray Dry & Lime & 70.0 \\
\hline \multicolumn{8}{|l|}{ SIkeston Clty of } \\
\hline Sikeston & 261 & 261 & 8111 & 2.80 & Venturi & Limestone & 75.5 \\
\hline \multicolumn{8}{|l|}{ South Carolina Pub Serv Auth } \\
\hline $\begin{array}{ll}\text { Cross } & 2\end{array}$ & 1,147 & 556 & 8312 & 1.60 & Spray & Limestone & 81.4 \\
\hline Winyah & 1,260 & 315 & 7707 & 1.10 & Venturi & Limestone & 45.0 \\
\hline Winyah & - & 315 & 8006 & 2.30 & Spray & Limestone & 90.0 \\
\hline Winyah & - & 315 & 8111 & 1.70 & Spray & Limestone & 90.4 \\
\hline \multicolumn{8}{|l|}{ South Mississippl El Pwr Assn } \\
\hline R D Morrow $\quad 1$ & 400 & 200 & 7809 & 1.50 & Spray & Limestone & 85.0 \\
\hline R D Morrow & - & 200 & 7906 & 1.50 & Spray & Limestone & 85.0 \\
\hline Southern IIIInols Power Coop & & & & & & & \\
\hline Marion 4 & 272 & 173 & 7904 & 4.40 & Venturi & Limestone & 89.4 \\
\hline Southern Indlana Gas \& Elec & & & & & & & \\
\hline A B Brown 1 & 530 & 265 & 7904 & 4.50 & Spray & & 85.0 \\
\hline A B Brown & - & 265 & 8602 & 4.50 & Spray & & 900 \\
\hline Southwestern Electric Power & & & & & & & \\
\hline Pirkey $\quad 1$ & 721 & 721 & 8501 & 1.50 & Spray & Limestone & 85.0 \\
\hline Soyland Power Coop Inc & & & & & & & \\
\hline Pearl Station IA & 22 & 22 & 7611 & 3.40 & Venturı & Other & 11.8 \\
\hline
\end{tabular}


Table 52. Flue Gas Desulfurization (FGD) Capacity in Operation at U.S. Electric Utility Plants as of December 1992-Continued

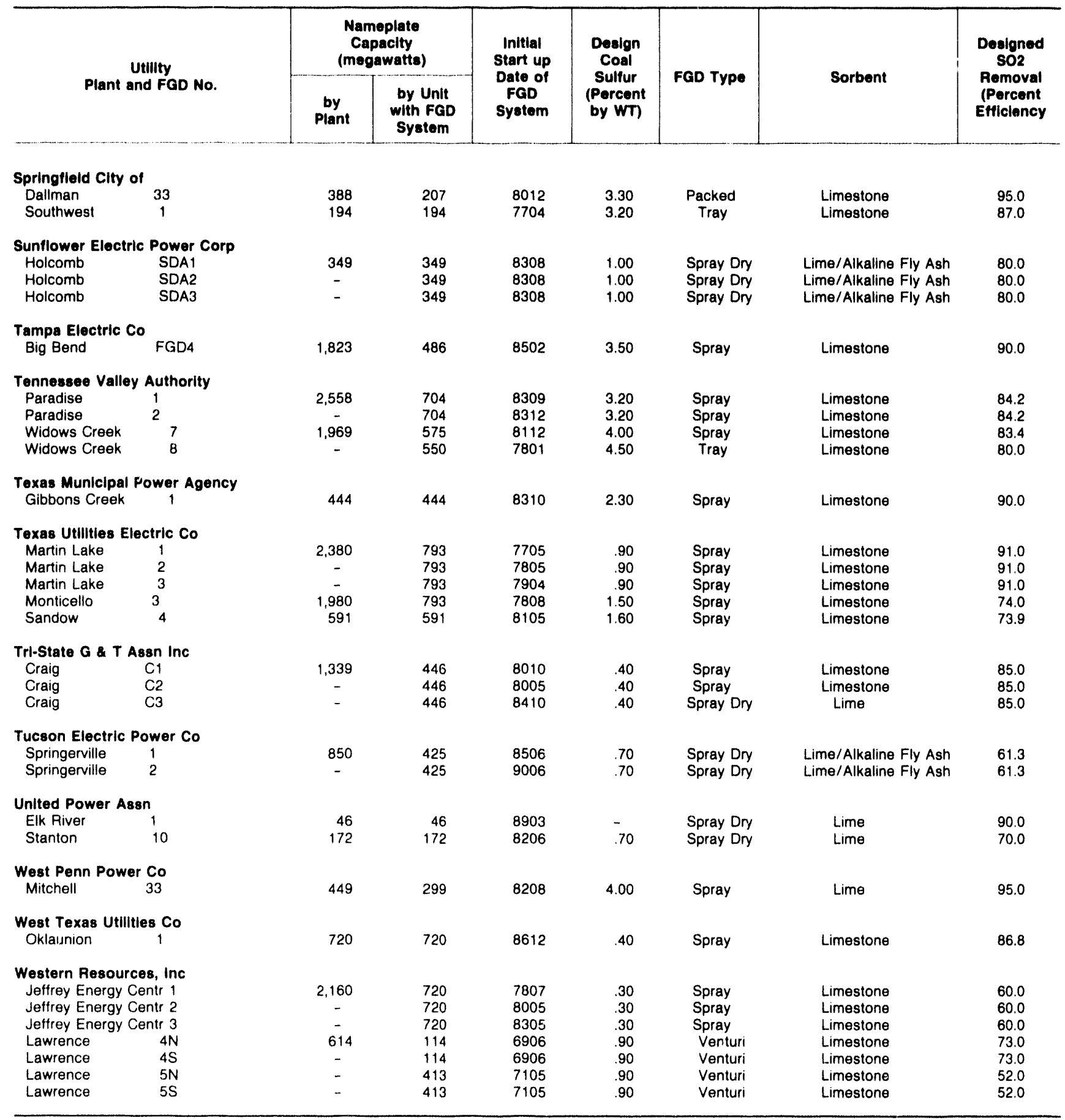

Notes: $\bullet$ Data are preliminary. $\bullet$ SO2 $=$ Sulfur Dioxide; $W T=$ weight; $F G D=$ Flue Gas Desulfurization.

Source: Energy Information Administration, Form EIA-767, "Steam-Electric Plant Operation and Design Report." 


\section{U.S. Electric Power Transactions}

This chapter provides summary information for the U.S. electric utility industry on its operations and wholesale electricity trade at the international (Canada and Mexico), national, and North American Electric Reliability Council (NERC) region levels. The NERC is an organization established by the electric utility industry for maintaining, coordinating, and promoting reliability among the interconnected systems of North America.

\section{Background}

An electric power system is a group of generation, transmission, distribution, communication, and other facilities that are physically connected and operated as a single unit under one control. Transmission and distribution lines and associated facilities are used to transmit electricity from its point of origin (the generator) to the ultimate consumer. Although, due to its physical characteristics, electricity flows along all available paths, it follows the path of least resistance. The flow of electricity must be closely monitored to ensure that sufficient generating capacity is available and on-call to satisfy all demand (load) for electricity placed on the power system. In addition, for system standardization and reliability purposes, the flow is maintained at a frequency of 60 cycles per second.

The flow of electricity within the system is maintained and monitored by dispatch centers. The dispatch center must inventory and prioritize all generating capacity available to it, track transactions involving the buying or selling of either electric power or capacity, monitor current load, and anticipate future load on the system. It is the responsibility of the dispatch center to match the supply of electricity with its demand. The demand for electricity is not constant in nature. That is, load requirements fluctuate continuously, based on such factors as time of day, season of the year, and the characteristics of territory served by the system. Nonetheless, the dispatch center must be ready to meet the highest level of load placed on the system. The dispatch center must accommodate the loss of generating facilities (both when planned and when unexpected). In addition, the center must monitor transmission lines to determine whether the flow of electricity is approaching the carrying limits of the lines. In order to carry out its responsibilities in a timely fashion, the dispatch center is authorized to buy and sell electricity based on system requirements.
Authority for these transactions has been preapproved under interconnection agreements (contracts) that have been signed by all the electric utilities that are physically interconnected and/or have coordination agreements with other utilities not physically interconnected. (All these agreements are subject to regulatory approval.) Within these agreements, there are transaction categories that include purchases, sales for resale exchanges, and wheeling of energy.

Purchase transactions involve buying power among electric utilities and nonutility producers of electricity. Sales for resale transactions refer to power sold by one electric utility to other utilities for distribution. Some transactions involving the trade of electric energy are based on the availability of excess generating capacity or the diversity in load requirements. For example, if one electric utility has its lowest load during the winter season, it may arrange to offer its available excess generating capacity in exchange for excess generating capacity available at a facility with low summer load. This type of arrangement is an exchange transaction. However, the repayment or replacement of exchange energy may extend over several years. Wheeling transactions are the movement of electricity from one utility io another utility over the transmission facilities of the intervening utilities.

\section{Electric Utility Transactions}

Electric utility transactions (wholesale electricity trade) allow electric utilities to share resources and to provide mutual assistance in time of potential and actual need. They allow the utility systems to provide lower cost service to their consumers by taking advantage of the load diversity of each utility. These transactions also allow each utility to conserve its own resources, to share the benefits of reduced operating costs with its consumers, to receive emergency energy support from other utilities, and to reduce the cost of its own requirements for operating reserve. However, due to the complexity of electric power transactions involving the specifics of contracts, simultaneous energy transactions, the unintended receipt and delivery of energy (inadvertent flow), and losses, the reporting of both the classification and quantity of each transaction among utilities may not be consistent.

Electric utilities originally became interested in energy transactions because of the savings gained from re- 
duced or avoided production costs. They avoided building expensive additional capacity by obtaining it from other sources. Purchasing power from other uti]ities helped utilities meet peakload without using expensive oil- or gas-fired turbines. Similarly, utilities benefitted from being able to delay or stagger construction of additional baseload plants. Electric utilities have also delayed or replaced new plant construction by purchasing electricity from nonutility generators under long-term contracts.

\section{Power Pool Transactions}

In addition to dealing in one-time purchase and sale transactions, many electric utilities have joined together and formed power pools to achieve better operating efficiencies and to gain additional support for maintaining a functional electrical system. Thus, they share the benefits achieved by joint planning, coordinated use of generating and transmission facilities, and/ or coverage of facility outages. This coordination also provides the opportunity to manage short-term saving, much of it coming from varying fuel prices and the costs associated with different mixes of capacity.

Power pools can be made up of two electric utilities, like the Michigan Electric Coordinated System (Detroit Edison Company and Consumer Power Company), include all the major investor-owned utilities within a State (the New York Power Pool), or cross State lines (the PJM Power Pool includes parts or all of Pennsylvania, New Jersey, Maryland, and Delaware).

Power pools may run under a single-system dispatch to meet combined-load requirements and maintenance programs, or just share the benefits of planned or hourly wholesale sales of power and energy among the member utilities. Power pools may have responsibility for coordinating flow within the geographic area of the interconnected systems. In any case, they are bound by the operating standards established by the electric power industry. These standards require the coordination and maintenance of system stability and reliable service on a regional basis.

\section{NERC Profile}

The North American Electric Reliability Council (NERC) consists of 10 regional reliability councils whose memberships comprise essentially all of the electric utility systems in the contiguous United States, Canada, and Baja California Norte, Mexico. The regional councils are responsible for maintaining and setting standards on the reliability and stability requirements for the electricity flowing within the three power grids (the Eastern Power Grid, the Western Power Grid, and the Electric Reliability Council of Texas Power Grid) present in the contiguous United States.
The data for NERC regions in this publication are based upon the assignment of all electric utilities to an individual region and are for the U.S. portion of the regions only (Figure 19).

\section{Regulation of U.S. Electric Utility Transactions}

The Federal Energy Regulatory Commission (FERC) is responsible for regulating interstate wholesale transactions. U.S. electric utilities file with the FERC for approval of proposed rate schedules for transmission services and charges, and for wholesale transactions. Transmission filings cover the allocation of electric power flows on the transmission line systems. Other categories described in the filings usually cover the responsibilities of the utilities to one another during normal and emergency conditions, operating-reserves support, diversity exchanges, and unscheduled or inadvertent-energy flows. Recently, new authority was granted the FERC by the Energy Policy Act of 1992 to ensure that any wholesale generator--electric utility or nonutility--can access the transmission grid to reach their markets. After application, the FERC can order electric utilities to provide transmission (wheeling) services, provided that the proposed transaction is in the public interest and meets key criteria related to pricing, reliability, and self-dealing.

Wholesale transactions include capacity sales, energy sales, and energy exchanges. Wholesale transactions are further divided by duration of the sale and the type of capacity and energy sold. The length of the sale can be for an hour, a day, a week, a month (or several months), a season, several years, or some combination of these time periods.

Capacity sales are usually considered firm sales (that is, associated energy may be taken, or the capacity must be paid for if the energy is not taken; and the delivery is scheduled during normal system operating conditions). This capacity may be made available from the entire system or from an identified generating unit. The capacity offered in these transactions may be available only during a set period of seasonal diversity, an off-peak time of the day, or from a generator, which is currently not fully utilized, that is fired by a particular fuel. The energy associated with this capacity sale, if required, has a separate cost schedule from the capacity charge attached to each kilowatt of power.

Nonfirm sales, sometimes called energy, economy, or interruptible sales, do not have a demand ar capacity charge included in the price of the trans ction. These transactions are subject to curtailmen: or cessation of delivery by the supplier in accordan, with prior agreements or under specified conditions. The sales are often based on splitting the benefits gained by the parties involved. They are used to gain operational savings, such as avoiding the use of more expensive fuels, and 
Figure 19. North American Electric Reliability Council Regions for the Contiguous United States and Alaska

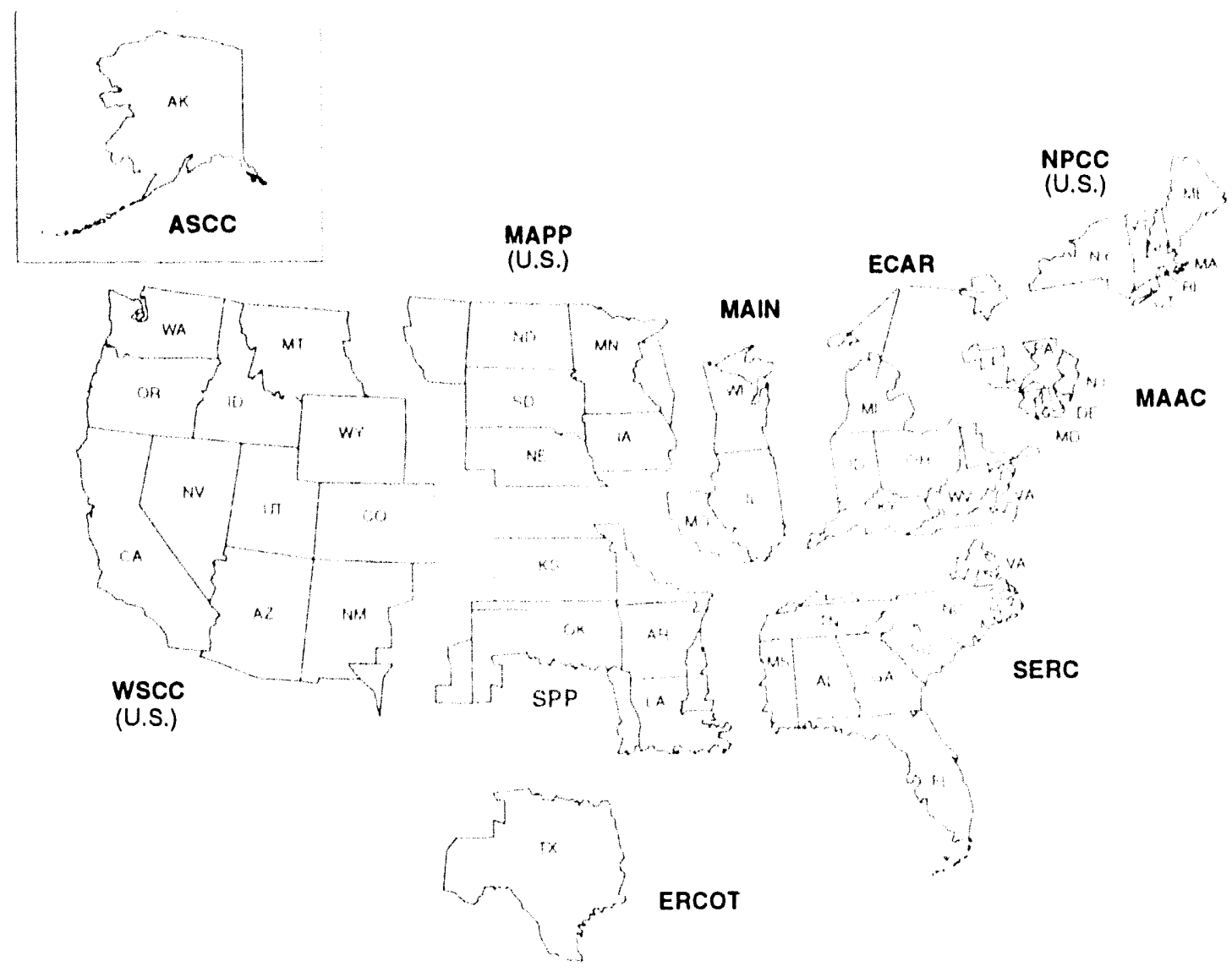

Regional Electric Area Council Areas:

ECAR- East Central Area Reliability Coordination Agreement

MAIN- Mid-American Interpool Network

MAAC- Mid-Atlantic Area Council MAPP (U.S.)- Mid-Continent Area Power Pool

NPCC (U.S.). Northeast Power Coordinating Council
SERC- Southeastern Electric Reliability Council

SPP. Southwest Power Pool

ERCOT- Electric Reliability Council of Texas

WSCC (U.S.)- Western Systems Coordinating Council

ASCC- Alaska Systems Coordinating Council Council

Source: North American Electric Reliability Council. 
selling electricity generated by the spillage of excess reservoir water.

Energy exchanges involve transfers of energy to other systems at no monetary charge. The energy must be returned in kind at a later date agreed upon by both parties. Otherwise, the receiving party pays for the energy received. The incidental miscellaneous transfer of energy and inadvertent flow are also handled in the same manner. In total, these wholesale transactions have become very important tools used by the U.S. electric utility industry to reduce costs and avoid expensive new capacity.

\section{Other Wholesale Electricity Tradt Concerns}

Environmental issues associated with air, solid-waste disposal, water quality, and aquatic habitat have received more attention from utility and power plant operators. Plant operating restrictions caused by air and water emissions have altered or restricted the dispatching of some facilities and in certain cases, plant cooling water sources have been contaminated or shut down due to aquatic organisms. Transmission line right-ofways and projected line construction are also being affected because of concerns linked to generated electromagnetic forces surrounding the transmission lines.

Legislative and regulatory initiatives have been implemented to address emissions at power plants. For example, the Clean Air Act Amendments of 1991 estab. lished emission allowances for Nitrogen Oxides, Sulfur Dioxides, and Carbon Dioxides for power plants based on historical levels. (The implementation will be on a two-tiered time horizon, 1995 for an identified set of utility plants and 2000 for all others.) The cost of compliance is expected to increase the cost of the output of some existing plants, alter construction approaches to new facilities, and change the fuel use of other power plants. The impact of the changes will affect the availability of future power from power plants emitting high levels and increase the attractiveness of acquiring power from other facilities and electrical systems emitting low levels. In addition, traditional wholesale trade pattcrns may be altered through changing costs and availability of electrical energy.

\section{International Transactions}

U.S. electric utilities have also taken advantage of being able to enter into international trade agreements to acquire energy from Canada and Mexico. These trade agreements between utilities cover a variety of transaction options. These options include purchasing nonfirm energy from relatively inexpensive renewable resources (hydroelectric from Canada and geothermal from Mexico); acquiring additional generating capability to support the requirements for supply at U.S. electric utilities; the holding of purchased electricity (as reservoir water) to be reacquired when needed by U.S. electric utilities; and sharing the benefits of coordinated operations planning for the systems. In some instances, consumers can be served more efficiently if they are connected to foreign transmission lines, because they are geographically closer to those lines.

\section{Data Sources}

Statistics on electricity transactions among U.S. electric utilities and on international electricity trade (including the United States, Canada, and Mexico) are presented in the following tables. These data were oblained from the Form EIA-861, "The Annual Electric Utility Report": the Form ElA-860. "Annual Electric Generator Report": the Department of Energy. Office of the Assistant Secretary for Emergency Planning and Operations, Form OE-411, "Coordinated Bulk Power Supply Program"; and the Department of Energy. Office of the Assistant Secretary for Fossil Energy, Form FE-781R. "Annual Report of International Electric Export/Import Data." Moredetailed information on U.S. electric power transactions is published in the Electric Trade in the United States." 
Table 53. Sources and Disposition of Electricity in the United States, 1988 Through 1992 (Million Kilowatthours)

\begin{tabular}{|c|c|c|c|c|c|}
\hline Item & 1992 & 1991 & 1990 & 1989 & 1988 \\
\hline \multicolumn{6}{|l|}{ Source } \\
\hline Net Generation ................. & $2,805,092$ & $2,835,377$ & $2,821,493$ & $2,811,398$ & $2,730,774$ \\
\hline 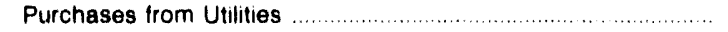 & $1,146,323$ & $1,127,669$ & 998,525 & 959,375 & 922,038 \\
\hline 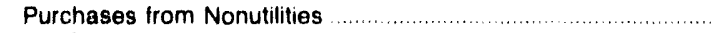 & 166,283 & 139,436 & 116,065 & 89.813 & 68,030 \\
\hline 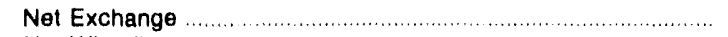 & $-3,504$ & 1,172 & -1.130 & 2,369 & 32,955 \\
\hline 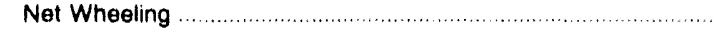 & 5,756 & 4,963 & 6,077 & 3,525 & 2.262 \\
\hline \multicolumn{6}{|l|}{ Disposition } \\
\hline Sales to Ultimate Consumers & $2,763,343$ & $2,762,003$ & $2,712,555$ & $2,646,809$ & $2,578,062$ \\
\hline Requirements and Nonrequirements Sales for Resale .................. & $1,119,948$ & $1,116,655$ & 999,268 & 975,676 & 945,993 \\
\hline 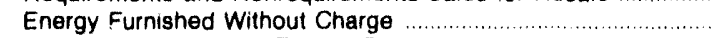 & 4.409 & 4.210 & 5,896 & 5,647 & 5,525 \\
\hline Energy Used by Utility Electric Department ............................. & 15,651 & 15.154 & 18,974 & 19,501 & 16,362 \\
\hline Energy Losses ${ }^{2}$ & 216,599 & 210,596 & 204,339 & 218,846 & 209,516 \\
\hline
\end{tabular}

' The shift in magnitude for net exchange reflects a change in accounting procedures by electric utilities because of reclassification of various transactions for bulk trade. In addition, the Tennessee Valley Authority reduced their net exchanges by 15 billion kilowatthours from 1988 .

2 These values are not measured; however, they represent losses and unaccounted for energy. These values are calculated in order that source and disposition of energy are equivalent.

Notes: -Data for 1992 are preliminary; data for prior years are final. • Annual net generation data shown here should only be used in comparison with other Form ElA-861 data. Differences in this net generation data and net generation reported on the Form ElA-759, "Monthly Power Plant Report," (Table

1) occur due to the tıme frame in reporting. Since the components of net generation are provided monthly by the Form ElA-759 by prime mover and energy source, the Form ElA-759 is used as the official Energy Information Administration source for net generation. •Totals may not equal sum of components because of independent rounding. - The source and disposition of electricity represent the total volume of energy transactions between utilities. These data should not be summed as they are the aggregation of data reported for each utility and could be double counted due to the nature and types of electricity trade. - Due to the complexity of electric power transactions that involve specifics of contracts, simultaneous energy transactions. the unintended receipt and delivery of energy (inadvertent flow), and losses, uniformity in reporting the classification and quantity of each transaction among utilities may not exist Source: Energy Information Administration, Form ElA-861. "Annual Electric Utility Report."

Table 54. Net Generation from Electric Utilities by North American Electric Reliability Council Region and Hawaii, 1988 Through 1992 (Million Kilowatthours)

\begin{tabular}{|c|c|c|c|c|c|}
\hline $\begin{array}{c}\text { North American Electric } \\
\text { Rellablity Council Region } \\
\text { and Hawail }\end{array}$ & 1992 & 1991 & 1990 & 1989 & 1988 \\
\hline ECAR . & 483,530 & 488,102 & 485,128 & 487,659 & 487.040 \\
\hline ERCOT & 190,442 & 192,000 & 188,586 & 185,011 & 179,442 \\
\hline MAAC & 193,330 & 197.235 & 193,393 & 193,889 & 191,874 \\
\hline MAIN & 200,288 & 206,906 & 201,653 & 200,660 & 198,666 \\
\hline MAPP(U.S.) & 120,053 & 122,991 & 120,750 & 116,410 & 118,238 \\
\hline 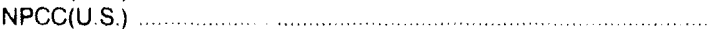 & 202,978 & 218.053 & 227,866 & 233,624 & 223,996 \\
\hline 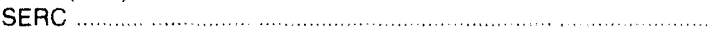 & 637,803 & 630,562 & 611,708 & 612,643 & 571,541 \\
\hline SPP ................ & 242,514 & 244,415 & 244,762 & 239,032 & 233.396 \\
\hline WSCC(U.S.) ........... & 522.863 & 523,468 & 535.242 & 530,205 & 514,622 \\
\hline (1) & $2,793,802$ & $2,823,732$ & $2,809,087$ & $2,799,130$ & $2,718,815$ \\
\hline ASCC & 4.735 & 4,654 & 4.660 & 4,575 & 4,460 \\
\hline Hawaii & 6,555 & 6.991 & 7,746 & 7.692 & 7,499 \\
\hline U.S. Total & $2,805,092$ & $2,835,377$ & $2,821,493$ & $2,811,398$ & $2,730,774$ \\
\hline
\end{tabular}

Notes: - Data for 1992 are preliminary; data for prior years are final. Annual net generation data shown here should only be used in comparison with other Form ElA-861 data. Differences in this net generation data and net generation reported on the Form ElA.759, "Monthly Power Plant Report." (Table 1) occur due to the time frame in reporting. Since the components of net generation are provided monthly by the Form ElA.759 by prime mover and energy source, the Form ElA.759 is used as the official Energy Information Administration source for net generation - Totals may not equal sum of components because of independent rounding. -The Alaska Systems Coordinating Council (ASCC) became a NERC Region member in 1989.

Source: Energy Information Administration, Form ElA-861. "Annual Electric Utility Report" 
Table 55. Electric Utility Sales to Ultimate Consumers by Sector, North American Electric Reliability Council Region, and Hawall, 1988 Through 1992

(Million Kilowatthours)

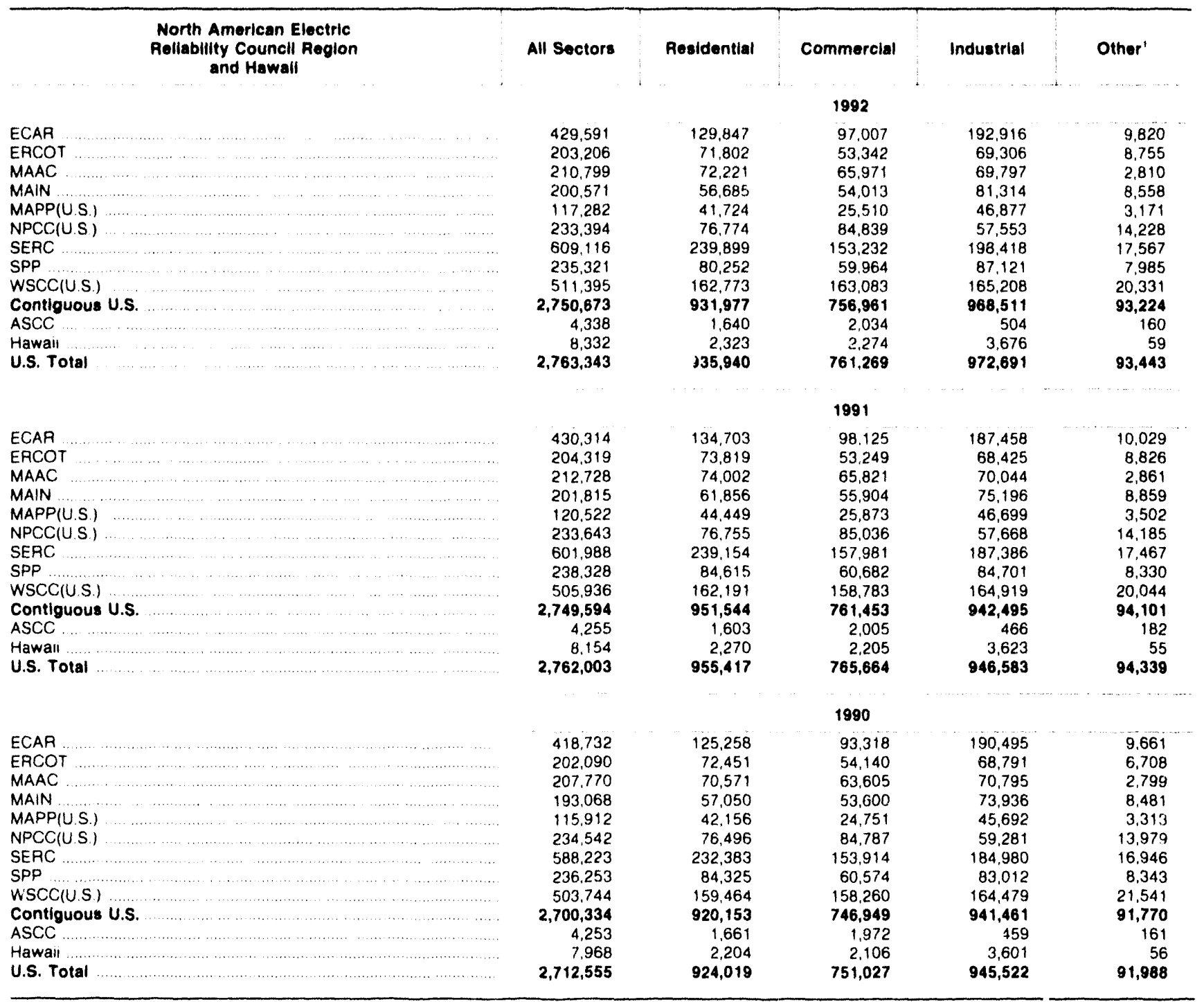

1 Includes public street and highway lighting, other sales to public authorities, sales to railoads and railways, and interdepartmental sales. Notes: -Data for 1992 are preliminary; data for prior years are final. Totals may not equal sum of components because of independent rounding - The Alaska Systems Coordinating Council (ASCC) became a NERC Region member in 1989.

Source: Energy Information Administration. Form E|A-861, "Annual Electric Utility Report." 
Table 55. Electric Utility Sales to Uitimate Consumers by Sector, North American Electric Rellability Council Region, and Hawall, 1988 Through 1992 (Continued) (Million Kilowatthours)

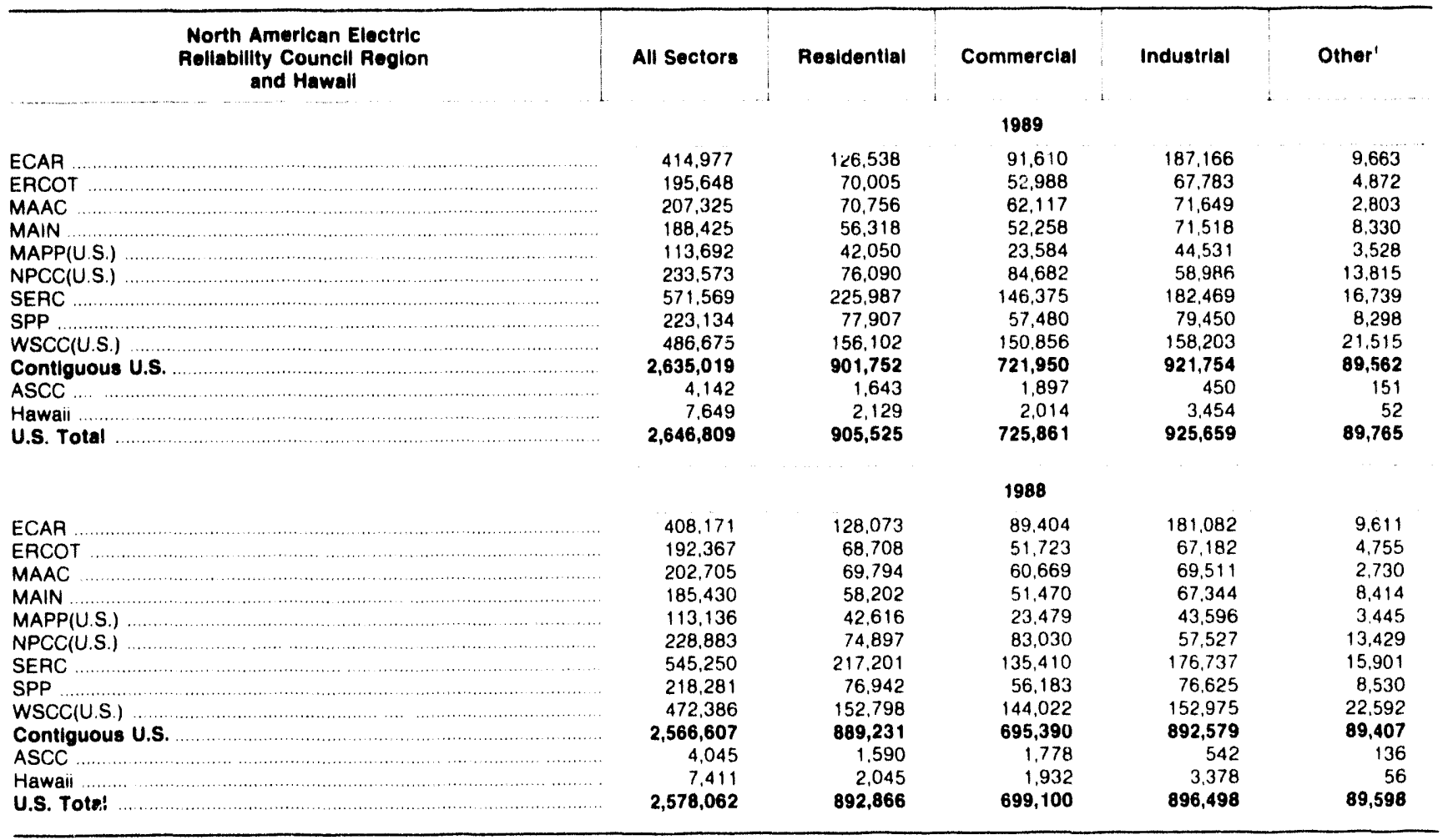

- Includes public street and highway lighting, other sales to public authorities. sales to railroads and railways, and interdepartmental sales

Notes: Data for 1992 are preliminary; data for prior years are firal. Totals may not equal sum of components because of independent rounding -The Alaska Systems Coordinating Council (ASCC) became a NERC Region member in 1989.

Source: Energy Information Administration, Form ElA-861, "Annual Electric Utility Report."

Table 56. Generating Capability at Electric Utilities by North American Electric Reliability Council Region and Hawail, as of December 1988 Through 1992 (Megawatts)

\begin{tabular}{|c|c|c|c|c|c|}
\hline $\begin{array}{l}\text { North American Electric } \\
\text { Reliability Councll Region } \\
\text { and Hawall }\end{array}$ & 1992 & 1991 & 1990 & 1989 & 1988 \\
\hline 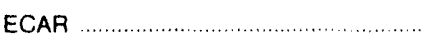 & 104,661 & 104.925 & 102,379 & 102.545 & 101,257 \\
\hline ERCOT & 51,688 & 51.213 & 51,016 & 49.733 & 48,928 \\
\hline MAAC & 51,553 & 51,331 & 50,323 & 50,071 & 48,766 \\
\hline MAIN & 49,730 & 49,544 & 49,475 & 49,511 & 49,631 \\
\hline 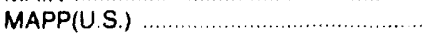 & 30,968 & 31,057 & 30,772 & $3 c .376$ & 30.348 \\
\hline NPCC(U.S.) & 54,637 & 55,443 & 55,587 & 54.460 & 54,067 \\
\hline 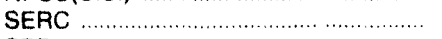 & 148,127 & 146,447 & 146,286 & 145,129 & 142,404 \\
\hline SPP & 70,771 & 70,642 & 70,519 & 70.468 & 70.311 \\
\hline WSCC(U.S.) & 129,694 & 129.346 & 129.280 & 129,296 & 128,986 \\
\hline Contiguous U.S. & 691,828 & 689,948 & 685,637 & 681,58 & 674,697 \\
\hline ASCC & 1,672 & 1.547 & 1,542 & $1.54 t$ & 1,504 \\
\hline 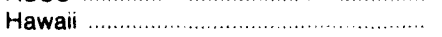 & 1.560 & 1,521 & 1,487 & 1.483 & 1.453 \\
\hline U.S. Total & 695,059 & 693,016 & 690,465 & 684,619 & 677,654 \\
\hline
\end{tabular}

Notes: -Data are final. -Totals may not equal sum of components because of independent rounding. • The Alaska Systems Coordinatir.y Council (ASCC) hecame a NERC Region member in 1989.

Source: Energy Information Administration. Form EIA-860, "Annual Electric Generator Report." 


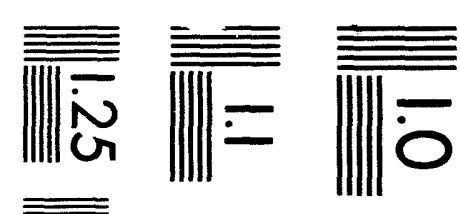

$$
\begin{aligned}
& \underline{\|\| \bar{A}}
\end{aligned}
$$

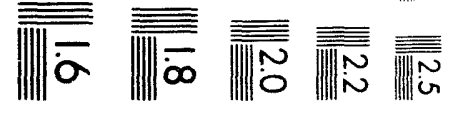



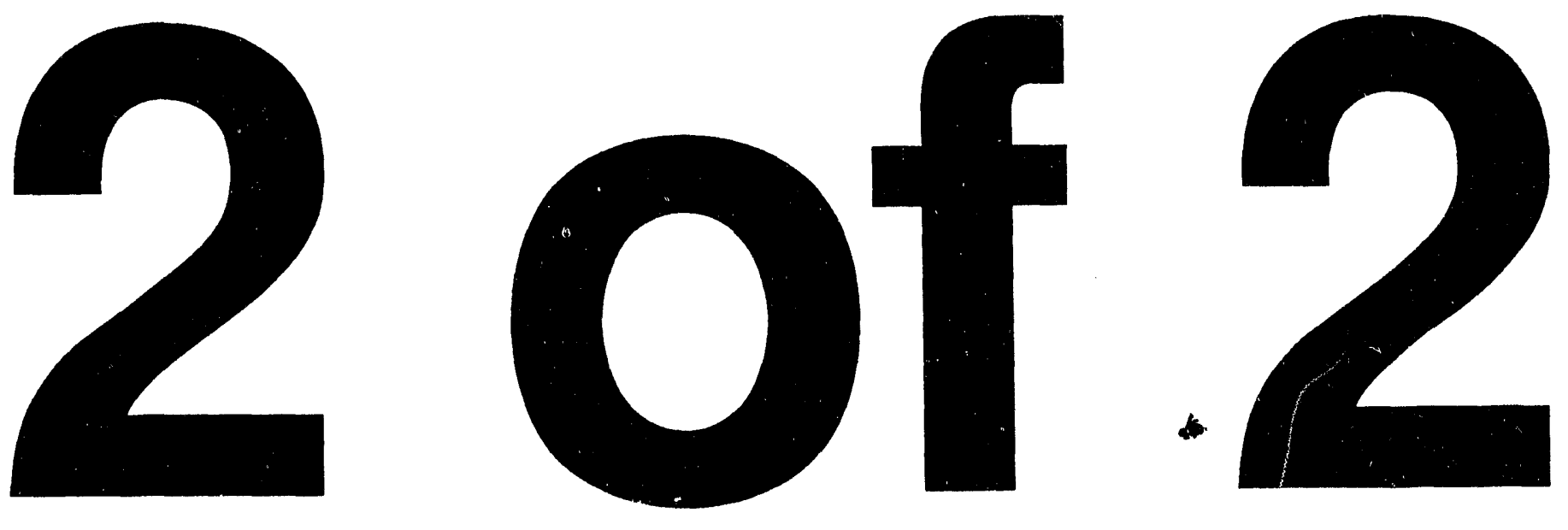
Table 57. Noncoincidental Peak Load at Electric Utilities by North American Electric Reliability Council Region and Hawaii, 1988 Through 1992 (Megawatts)

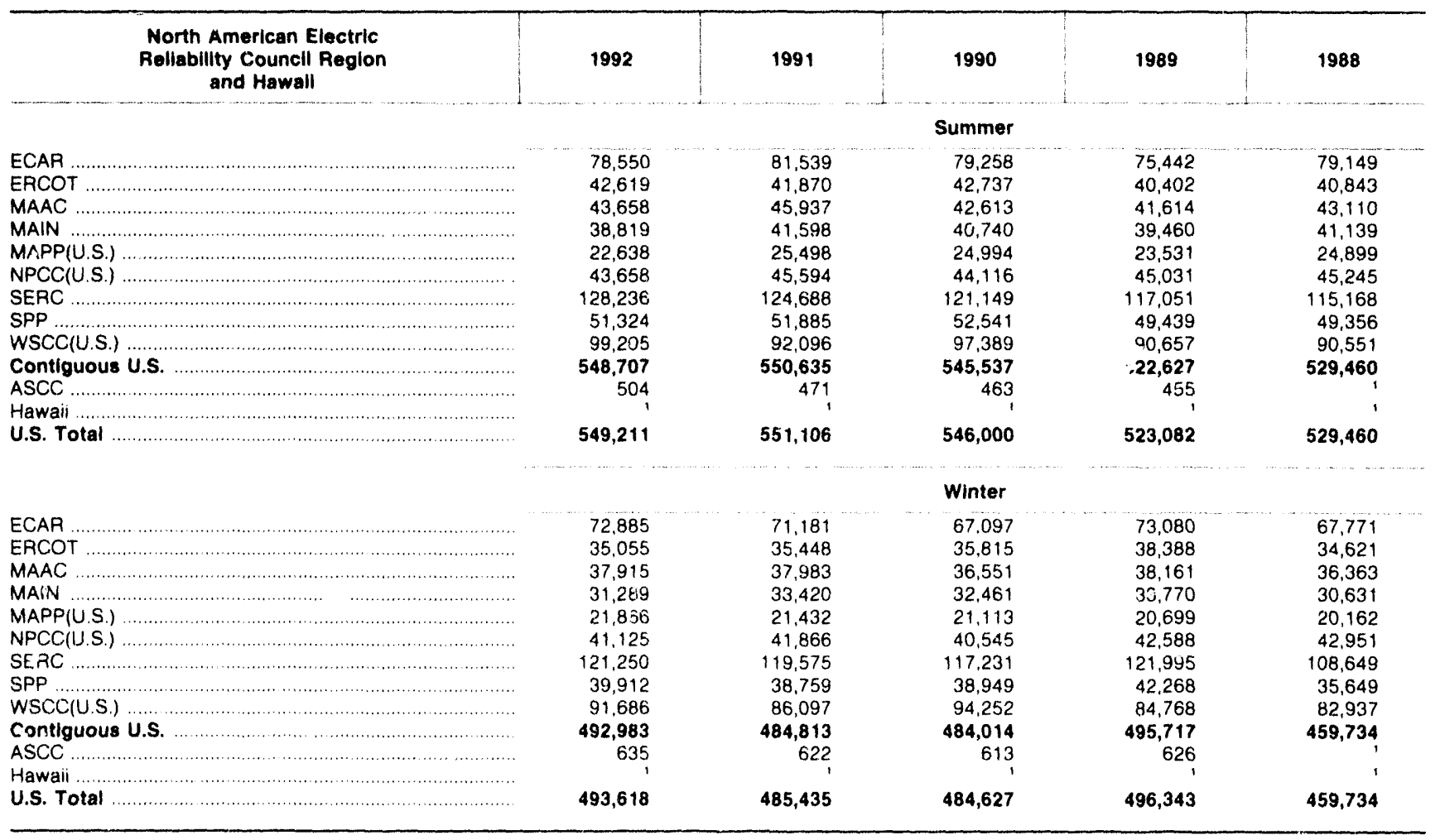

1 Data for Alaska were first submitted in 1989; data for Hawaii are not submitted for this form.

Notes: Data are final. - Totals may not equal sum of components because of independent rounding. - The Alaska Systems Coordinating Councit (ASCC) became a NERC Region member in 1989

Source: Department of Energy, Office of the Assistant Secretary for Emergency Planning and Operations, Form OE-411, "Coordinated Bulk Power Supply Program." 
Table 58. Electric Utility Receipts by North American Electric Reliability Council Region and Hawaii, 1988 Through 1992

(Million Kilowatthours)

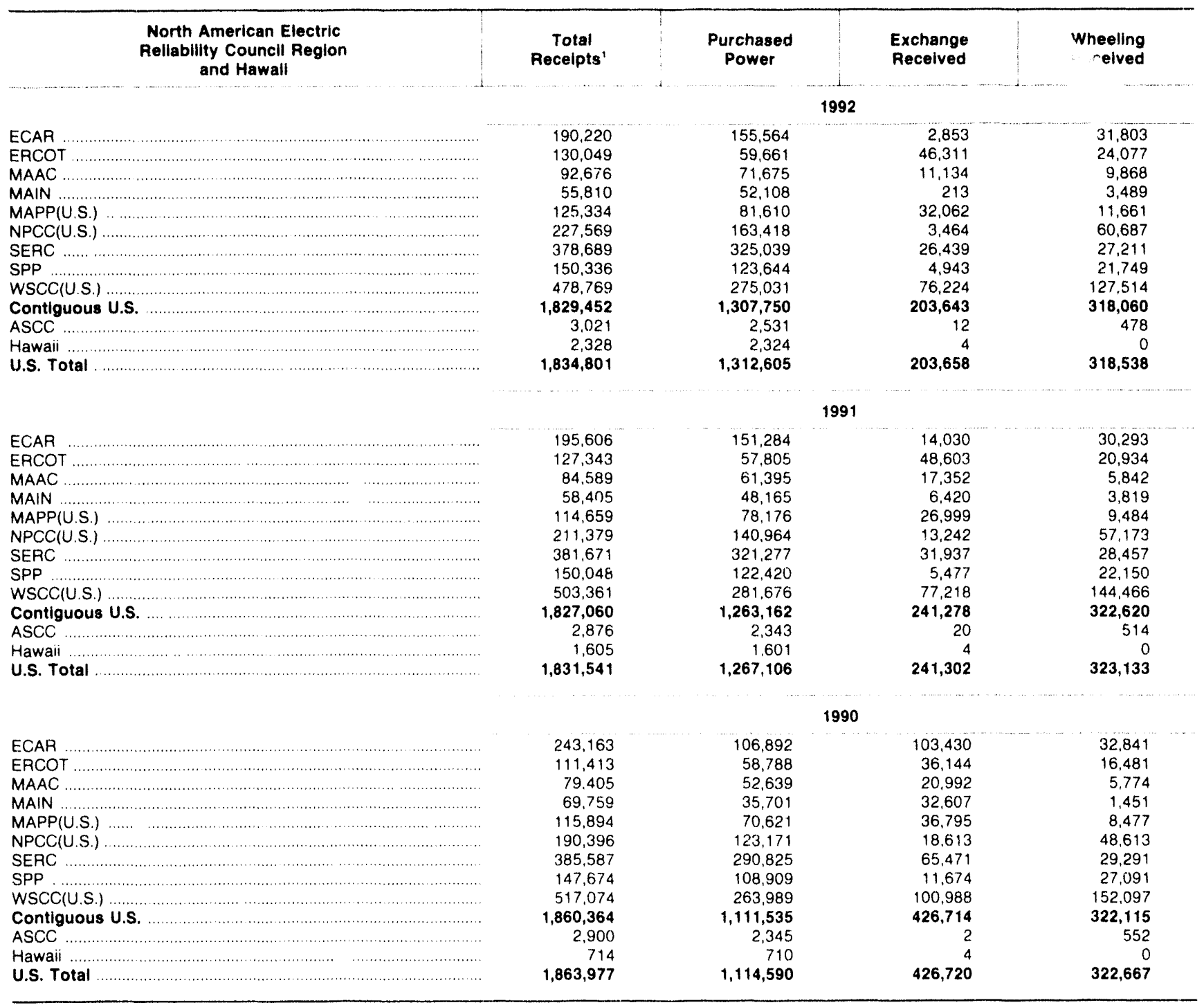

- Equals purchased power plus excharige received plus wheeling received.

Notes: -Data for 1992 are preliminary; data for prior years are final. - Totals may not equal sum of components because of independent rournding. - The Alaska Systems Coordinating Council (ASCC) became a NERC Region member in 1989. This is a summation of utility trade for utilities that operate within the NERC Region. Due to the complexity of electric power transactions that involve specifics of contracts, simultaneous eriergy transactions, the unintended receipt and delivery of energy (inadvertent flow), and losses, uniformity in reporting the classification and quantity of each transaction among utilities may not exist. Includes utility, import, export, and nonutility transactions.

Source: Energy Information Administration, Form EIA-861, "Annual Electric Utillty Report." 
Table 58. Electric Utility Receipts by North American Electric Reliability Council Region and Hawaii, 1988 Through 1992 (Continued)

(Million Kilowatthours)

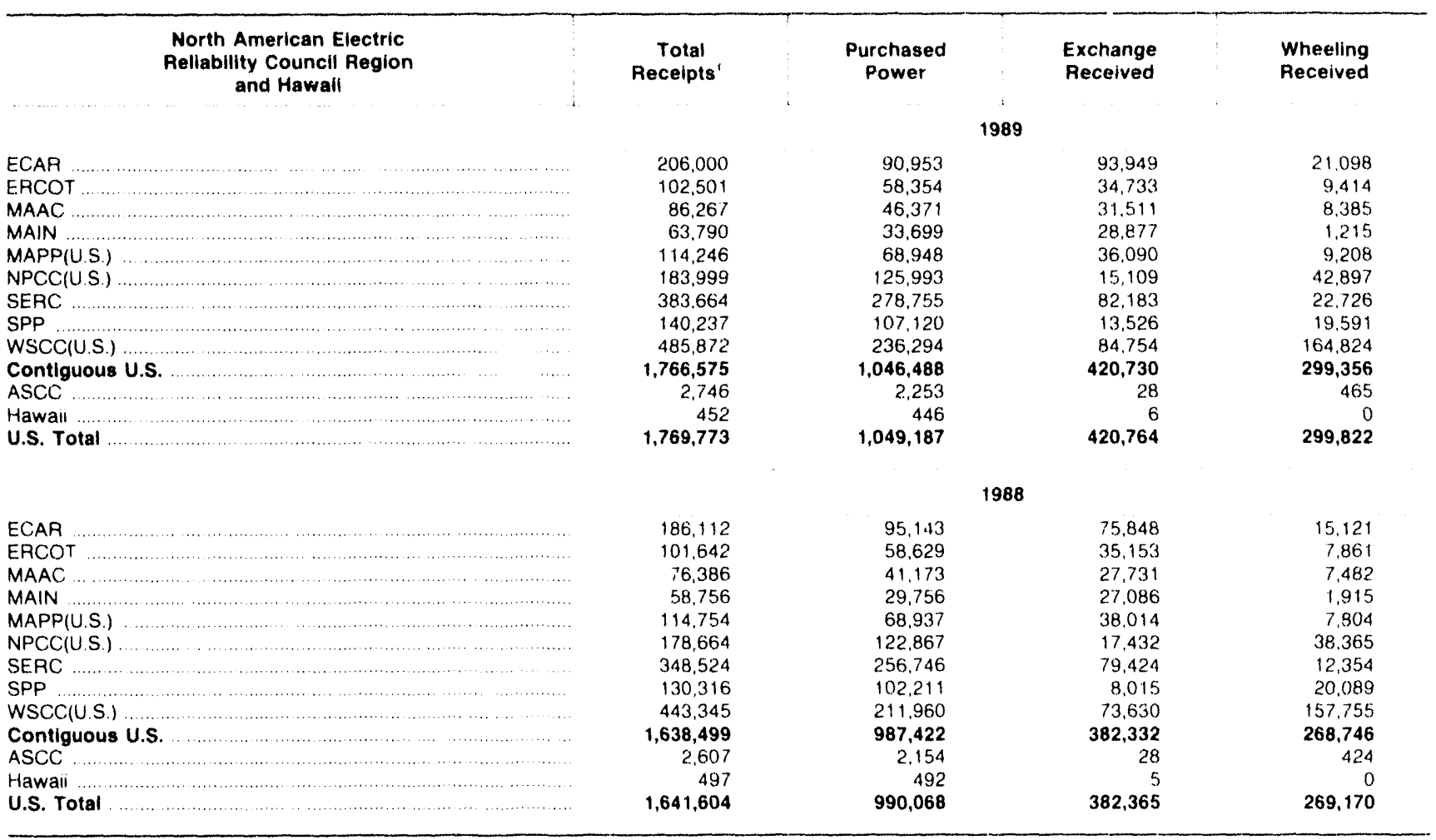

1 Equals purchased power plus exchange recelved pius wheeling received.

Notes: - Data for 1992 are preliminary, data for prior years are tinal. - Totals may not equal sum of components because of independent rounding. - The Alaska Systems Coordinating Council (ASCC) became a NERC Region member in 1989 - This is a summation of utility trade for uttlities that operate within the NERC Region. - Due to the complexity of electric power transactions that involve specifics of contracts, simultaneous energy transactions, the unintended receipt and delivery of energy (inadvertent flow), and losses, uniformity in reporting the classification and quantity of each transaction among utilities may not exist. - Includes utility. import, export, and nonutility transactions.

Source: Energy Information Administration. Form EIA-361. "Annual Electric Utility Report." 
Table 59. Electric Utility Deliveries by North American Electric Reliability Council Region and Hawaii, 1988 Through 1992

(Million Kilowatthours)

North American Electric
Reliability Council Region
and Hawali

ECAR
ERCOI
MAAC
MAIN
MAPP(U S.)
NPCC(IS.)
SERC
SPP
WSCC(U S)
Contiguous U.S.
ASCC
Hawai
US. That

U.S. Total

ECAA

ERCOT

MAAC

MAIN

MAPP(US.)

NPCC(U.S.)

SEAC

SPP

WSCC(US)

Contiguous U.S.

ASCO

Hawan

U.S. Total

\begin{tabular}{c|c} 
Total \\
Deliveries
\end{tabular}

Requirements and
Nonrequirements

Sales for Resale

Exchange
Delivered

$$
\begin{array}{r}
212.729 \\
102.966 \\
59.416 \\
40.706 \\
116.200 \\
178.603 \\
357.147 \\
137.540 \\
431.5639 \\
1,636,870 \\
3,020 \\
3
\end{array}
$$

$1,639,893$

221,435
101,790
51,289
48,267
106,020
177,038
364,167
$1,36,561$
465,536
$1,672,100$
2,849
5

$1,674,954$

278,650
85,076
49,621
63,588
109,484
166,593
367,232
136,099
484,419
$1,7 \mathbf{4 0 , 8 2 2}$
2,883
5
$1,7 \mathbf{4 3}, 709$
178,224

32,294

$48.36 \mathrm{in}$

37.240

71.447

71.447
116.451

300,686

109.595

223,114

$1,117,421$

$?, 5245$

$1,119,948$

182.081

$31,38: 3$

31,670

$38.1: 36$

ti8.849

112.418

$306, i 18$

107.884

235,142

$1,114,341$

2). 314

$1.116,655$

153,2827

32.153

20), $68: 3$

24.191

64005

$98,97 ?$

279.122

95.289

228.643
9

996,941

2.327

999,268
1992

2.887
46.517
1.27
62
33.406
1.657
31.053
6.306
83.426
207,145
1.4
3

31,618

24.090

9.179

3.40 .1

\begin{tabular}{|c|c|}
\hline 9.1933 & 30.161 \\
\hline $49,4 / 0$ & 20,937 \\
\hline $13.7 / 6$ & $6.84 \%$ \\
\hline $6.39 ?$ & 3,739 \\
\hline 29.235 & 7.935 \\
\hline 7.635 & $5,6,926$ \\
\hline 30.001 & $2 i, 447$ \\
\hline 6,600 & $2201 \mathrm{H}$ \\
\hline 83.801 & $142,59 ?$ \\
\hline 240,103 & 317656 \\
\hline 21 & iis \\
\hline t, & 0 \\
\hline 240,130 & 318,17 \\
\hline
\end{tabular}

10.847

60.49 .

2.) 408

2. 1639

$1.35,023$

312,304

$4 \mathrm{iH}$

312,782

1991

1990

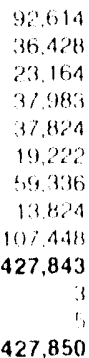

36.753

16,496

5, $7, A$

1,414

$\therefore$ bito

as 399

28.1 in

26.:385,

148.388

316,038

t, 6

316,591

U.S. Total

- Equals sales for resale plus exchange: defiverod plus wheoling delivered

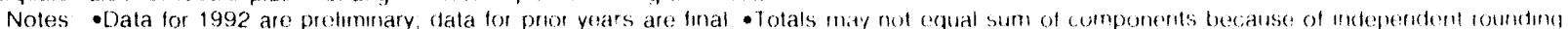

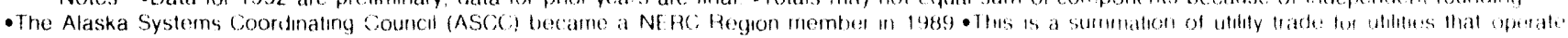

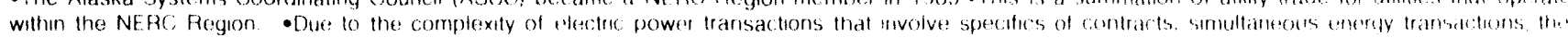

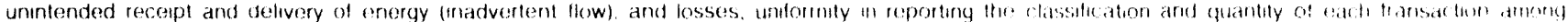

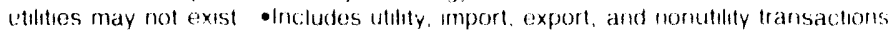

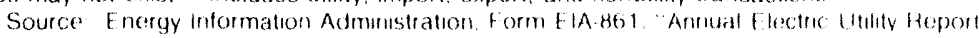


Table 59. Electric Utility Deliveries by North American Electric Reliability Council Region and Hawail, 1988 Through 1992 (Continued)

(Million Kilowatthours)

\begin{tabular}{|c|c|c|c|c|}
\hline $\begin{array}{c}\text { North American Electric } \\
\text { Rellability Council Reglon } \\
\text { and Hawall }\end{array}$ & $\begin{array}{c}\text { Total } \\
\text { Dellverles' }\end{array}$ & $\begin{array}{l}\text { Requirements and } \\
\text { Nonrequirements } \\
\text { Sales for Resale }\end{array}$ & $\begin{array}{l}\text { Exchange } \\
\text { Delivered }\end{array}$ & $\begin{array}{l}\text { Wheeling } \\
\text { Dellvered }\end{array}$ \\
\hline & \multicolumn{4}{|c|}{1989} \\
\hline ECAR ... & 245,874 & 152.703 & 72,177 & 20,994 \\
\hline (1) & 76,668 & 32.355 & 35,017 & 9,297 \\
\hline MAAC & 55,290 & 17,940 & 28,990 & 8,360 \\
\hline MAIN & 60,612 & 23,746 & 35,661 & 1,205 \\
\hline (1) & 164,638 & 99,653 & 22,634 & 42,351 \\
\hline SEAC & 375,248 & 277.693 & 75,670 & 21,885 \\
\hline SPP & 134,684 & 96,202 & 18,558 & 19,924 \\
\hline WSCC(U.S.) & 469,146 & 213,689 & 91,833 & 163,623 \\
\hline Contiguous U.S. & $1,687,660$ & 973,432 & 418,392 & 295,836 \\
\hline ASCC & 2,705 & 2,244 & $\cdot$ & 461 \\
\hline Hawaii & 3 & 0 & 3 & 0 \\
\hline 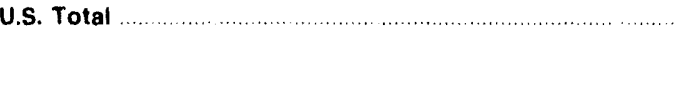 & $1,690,368$ & 975,676 & 418,395 & 296,297 \\
\hline … & 232,759 & 159,063 & 58,661 & 15,036 \\
\hline ERCOT & 75,182 & 31,905 & 35,364 & 7,913 \\
\hline MAAC & 47,606 & 16,628 & 23,513 & 7,465 \\
\hline MAIN & 56,863 & 21.291 & 33,666 & 1,906 \\
\hline MAPP(U.S.) & 108,391 & 62,928 & 38,757 & 6,705 \\
\hline NPCC(U.S.) & 154,736 & 97.267 & 19,380 & 38,089 \\
\hline SERC & 330,155 & 261,562 & 56,850 & 11,743 \\
\hline SPP & 125,734 & 94,034 & $+1,743$ & 19,956 \\
\hline WSCC(U.S.) & 428,207 & 199,053 & 71,472 & 157,682 \\
\hline Contiguous U.S. & $1,559,633$ & 943,731 & 349,406 & 266,496 \\
\hline ASCC & 2,590 & 2,177 & 0 & 413 \\
\hline Hawaii & 89 & 85 & 4 & 0 \\
\hline U.S. Total & $1,562,312$ & 945,993 & 349,410 & 266,909 \\
\hline
\end{tabular}

- Equals sales for resale plus exchange delivered plus wheeling delivered

* Value less than 0.5.

Notes: - Data for 1992 are preliminary; data for prior years are final. - Totals may not equal sum of components because of independent rounding - The Alaska Systems Coordinating Council (ASCC) became a NERC Region member in 1989. This is a sumimation of utility trade for utilities that operate within the NERC Region. Due to the complexity of electric power transactions that involve specifics of contracts, simultaneous energy transactions, the unintended receipt and delivery of energy (inadvertent flow). and losses, uniformity in reporting the classification and quantity of each transaction among utilities may not exist - Includes utility, import, export, and nonutility transactions

Source Energy Information Administration, Form EIA.861. "Annual Electric Utility Report." 
Table 60. Electric Utility Net Energy Flow by North American Electric Reliability Council Region and Hawaii, 1988 Through 1992

(Millicin Kilowatthours)

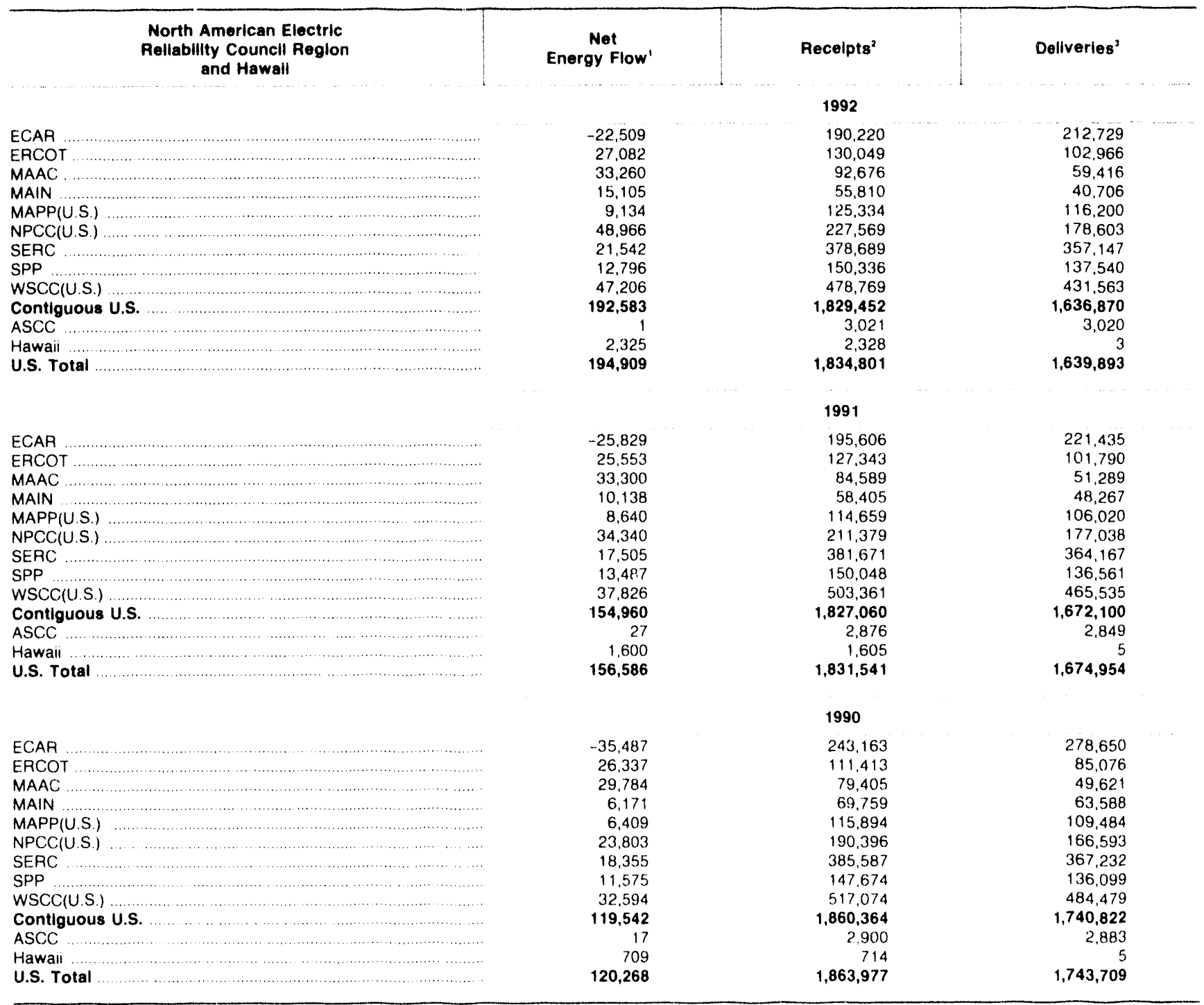

Equals receipts minus deliveries.

Equals purchased power plus ex:change received plus wheeling received

3 Equals sales for resale plus exchange delivered plus wheeling delivered

Notes: - Data for 1992 are preliminary; data for prior years are final. Totals may not equal sum of components because of independent rounding

- The Aiaska Systems Coordinating Council (ASCC) became a NERC Region member in 1989. This is a summation of utility trade for utilities that operate within the NERC Region. Due to the complexity of electric power transactions that involve specifics of contracts, simultaneous energy transactions, the unintended receipt and delivery of energy (inadvertent flow), and losses, uniformity in reporting the classification and quantity of each transaction among utilities may not exist. Includes utility, import, export, and nonutility transactions

Source Energy Information Administration. Form ElA-861. "Annual Electric Utility Report." 
Table 60. Electric Utility Net Energy Flow by North American Electric Reliability Council Region and Hawaii, 1988 Through 1992 (Continued) (Million Kilowatthours)

\begin{tabular}{|c|c|c|c|}
\hline $\begin{array}{c}\text { North American Electric } \\
\text { Reliability Council Region } \\
\text { and Hawail }\end{array}$ & $\begin{array}{c}\text { Net } \\
\text { Energy Flow' }\end{array}$ & Receipts ${ }^{2}$ & Deliverles $^{3}$ \\
\hline & \multicolumn{3}{|c|}{1989} \\
\hline $\begin{array}{l}\text { ECAR } \\
\text { ERCOT } \\
\text { MAAC } \\
\text { MAIN } \\
\text { MAPP(U.S.) } \\
\text { NPCC(US.) } \\
\text { SERC } \\
\text { SPP } \\
\text { WSCC(U.S.) } \\
\text { COntIguous U.S. } \\
\text { ASCC } \\
\text { Hawaii . } \\
\text { U.S. Total }\end{array}$ & $\begin{array}{r}-39,874 \\
25,833 \\
30,977 \\
3,178 \\
8,746 \\
19,361 \\
8,416 \\
5,552 \\
16,726 \\
78,915 \\
41 \\
449 \\
79,405\end{array}$ & $\begin{array}{r}206,000 \\
102,501 \\
86,267 \\
63,790 \\
114,246 \\
183,999 \\
393,664 \\
140,237 \\
485,872 \\
1,766,575 \\
2,746 \\
452 \\
1,769,773\end{array}$ & $\begin{array}{r}245,874 \\
76,668 \\
55,290 \\
60,612 \\
105,500 \\
164,638 \\
375,248 \\
134,684 \\
469,146 \\
1,687,660 \\
2,705 \\
3 \\
1,690,368\end{array}$ \\
\hline $\begin{array}{l}\text { ECAP } \\
\text { EACOT } \\
\text { MAAC } \\
\text { MAIN (UA.S.) } \\
\text { NPCC(U.S.) } \\
\text { SERC } \\
\text { SPP } \\
\text { WSCC(U.S.) } \\
\text { Contiguous U.S. } \\
\text { ASCC } \\
\text { Hawaii Total } \\
\text { U.S. Total }\end{array}$ & $\begin{array}{r}-46,647 \\
26,460 \\
28,780 \\
1,894 \\
6,363 \\
23,927 \\
18,369 \\
4,582 \\
15,138 \\
78,866 \\
17 \\
408 \\
79,292\end{array}$ & $\begin{array}{r}186,112 \\
101,642 \\
76,386 \\
58,756 \\
114,754 \\
178,664 \\
348,524 \\
130,316 \\
443,345 \\
1,638,499 \\
2,607 \\
497 \\
1,641,604\end{array}$ & $\begin{array}{r}232,759 \\
75,182 \\
47,606 \\
56,863 \\
108,391 \\
154,736 \\
330,155 \\
125,734 \\
428,207 \\
1,559,633 \\
2,590 \\
89 \\
1,562,312\end{array}$ \\
\hline
\end{tabular}

- Equals receipts minus deliveries

2 Equals purchased power plus exchange received plus wheeling received

3 Equals sales for resale plus exchange delivered plus wheeling delivered.

Notes: Data for 1992 are preliminary; data for prior years are final. - Totals may not equal sum of components because of independent rounding. - The Alaska Systems Coordinating Council (ASCC) became a NERC Region member in 1989. This is a summation of utility trade for utilities that operate within the NERC Region. Due to the complexity of electric power transactions that involve specifics of contracts, simultaneous energy transactions, the unintended receipt and delivery of energy (inadvertent flow), and losses, uniformity in reporting the classification and quantity of each transaction among utilities may not exist. Includes utility, import, export, and nonutility transactions.

Source: Energy information Administration, Form EIA-861. "Annual Electric Utility Report."

Table 61. Electric Utility Purchases of Nonutility Generated Electricity by North American Electric Reliability Council Region and Hawaii, 1988 Through 1992

(Million Kilowatthours)

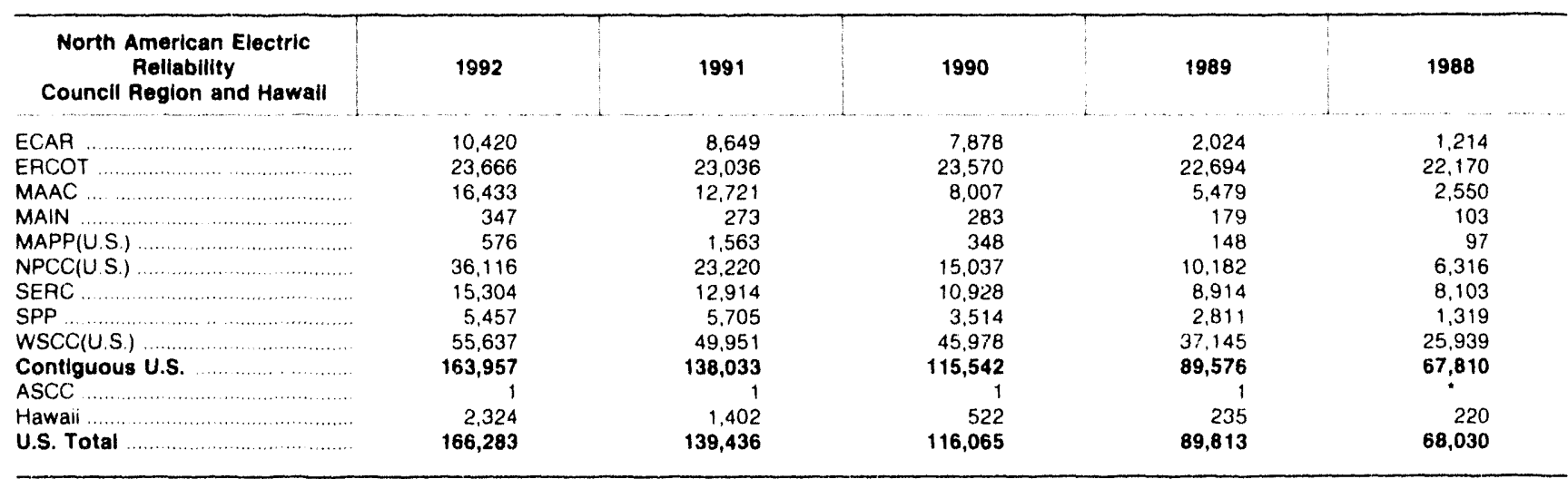

- Value less than 0.5 thousand

Notes: -Data for 1992 are preliminary; data for prior years are final. - Totals may not equal sum of components because of independent rounding -The Alaska Systems Coordinating Council (ASCC) became a NERC Region member in 1989

Source: Energy information Administration, Form ElA-861. "Annual Electric Utility Report." 
Table 62. Net Imports at Electric Utilities by North American Electric Reliability Council Region and Hawaii, 1988 Through 1992

(Thousand Kilowatthours)

\begin{tabular}{|c|c|c|c|c|c|}
\hline $\begin{array}{c}\text { North American Electric } \\
\text { Reliability Councll Region } \\
\text { and Hawall }\end{array}$ & 1992 & 1991 & 1990 & 1989 & 1988 \\
\hline ECAR ... & $-231,967$ & $-446,412$ & $-10,918,913$ & $-5,426,212$ & A 164,437 \\
\hline 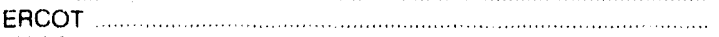 & $-169,142$ & $-195,548$ & $-8,744$ & $-10,315$ & $-11,762$ \\
\hline 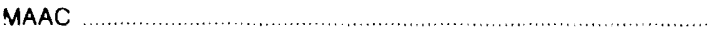 & - & - & - & - & -. \\
\hline MAIN & -. & -. & $\rightarrow$ & - & - \\
\hline MAPP(US.) & $6.921,800$ & $3,307.714$ & 742.954 & -373.343 & $-1,279,546$ \\
\hline NPCC(U.S.) & $12,053,907$ & $10,989,137$ & $6,562,311$ & $11,147,862$ & $23,349,907$ \\
\hline SERC & - & 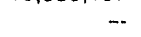 & - & 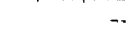 & -.. \\
\hline 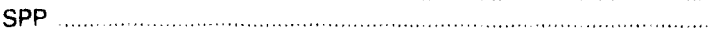 & -. & -. & -. & -. & -. \\
\hline (n) & $9,773,701$ & $8,617,259$ & $5,602,571$ & $5,637,853$ & $9,546,828$ \\
\hline (1) & $28,348,299$ & $22,272,150$ & $1,980,179$ & $10,975,843$ & $31,769,864$ \\
\hline ASCC & $*$ & 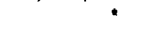 & 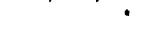 & $*$ & 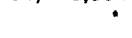 \\
\hline 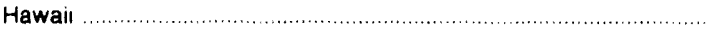 & - & -- & -- & -. & -. \\
\hline U.S. Totat & $28,348,299$ & $22,272,150$ & $1,980,179$ & $10,975,843$ & $31,769,864$ \\
\hline
\end{tabular}

- Value less than 0.5

$\mathrm{A}=$ Revised data.

Notes: - Data are final. - Totals may not equal sum of components because of independent rounding. $\bullet$ Values identify point of entry or exit, but do not necessarily identify point of consumption. - These data reflect electricity imported from Canada and Mexico. -Net imports data represent gross imports minus gross exports. - The Alaska Systems Coordinating Council (ASCC) became a NERC Region member in 1989.

Source: Otfice ol Fueis Programs, Fossil Energy, Form FE-781R, "Annual Report of International Electric Export/Import Data."

Table 63. Imports to Electric Utilities by North American Electric Reliability Council Region and Hawaii, 1988 Through 1992

(Thousand Kilowatthours)

\begin{tabular}{|c|c|c|c|c|c|}
\hline $\begin{array}{l}\text { North American Electric } \\
\text { Rellabllity Council Region } \\
\text { and Hawail }\end{array}$ & 1992 & 1991 & 1990 & 1989 & 1988 \\
\hline ECAR & 82,151 & 106,606 & 38,234 & 13,451 & 381,621 \\
\hline 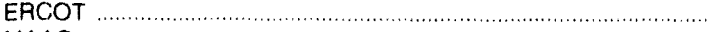 & - & 14 & 1,121 & 1,333 & - \\
\hline MAAC & - & -. & -. & - & .. \\
\hline MAIN & -. & -. & -. & -. & - \\
\hline MAPP(U.S.) & $8.573,652$ & $4,708,775$ & $3,072,170$ & $2,260,790$ & $2.361,083$ \\
\hline NPCC(U.S.) & $14,699,638$ & $13,051,823$ & $9,272,554$ & $13,707,688$ & $24,319,405$ \\
\hline SERC & - & - & $-\cdots$ & 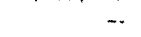 & - \\
\hline (1) & - & - & - & $-\cdots$ & -- \\
\hline WSCC(U.S.) & $13,848,735$ & $12,945,048$ & $10,122,141$ & $10,127,191$ & $11,774,401$ \\
\hline Contiguous U.S. & $37,204,176$ & $30,812,266$ & $22,506,220$ & $26,110,432$ & $38,836,510$ \\
\hline ASCC & 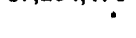 & 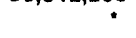 & 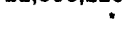 & 0 & 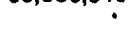 \\
\hline 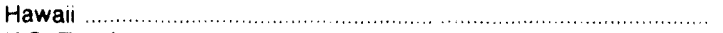 & - & 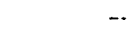 & -.. & $\ldots$ & .. \\
\hline U.S. Total & $37,204,176$ & $30,812,266$ & $22,506,220$ & $26,110,432$ & $38,836,510$ \\
\hline
\end{tabular}

- Value less than 0.5

Notes: - Data are final. - Totals may not equal sum of components because of independent rounding. $\bullet$ alues identify point of entry or exit, but do not necessarily identify point of consumption. - These data reflect electricity imported from Canada and Mexico. •The Alaska Systems Coordinating Council (ASCC) became a NERC Region member in 1989.

Source: Office of Fuels Frograms, Fossil Energy, Form FE-781R, "Annual Report of International Electric Export/Import Data." 
Table 64. Exports from Electric Utilities by North American Electric Reliability Council Region and Hawail, 1988 Through 1992

(Thousand Kilowatthours)

\begin{tabular}{|c|c|c|c|c|c|}
\hline $\begin{array}{c}\text { North American Electric } \\
\text { Rellability Council Region } \\
\text { and Hawall }\end{array}$ & 1992 & 1991 & 1990 & 1989 & 1988 \\
\hline ECAR ... & 314,118 & 553,018 & $10,957,147$ & $5,439,663$ & A 217,184 \\
\hline ERCOT & 169,142 & 195,562 & 9,865 & 1,648 & 11,762 \\
\hline MAAC &.- & $\rightarrow$ & -- & $\cdots$ & $-\cdot$ \\
\hline MAIN & -. & -. & -.. & $\cdots$ & -. \\
\hline MAPP(U.S.) & $1,651,852$ & $1.401,061$ & $2,329,216$ & $2,634,133$ & $3,640,629$ \\
\hline NPCC(US.) & $2,645,731$ & $2,062,686$ & $2.710,243$ & $2,559,806$ & 969,498 \\
\hline SERC & - & $\ldots$ & $\ldots$ & $\ldots$ & $\cdots$ \\
\hline SPP & - & 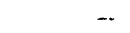 & -- & -. & -.. \\
\hline WSCC(U.S.) & $4,075,034$ & $4,327,789$ & $4,519,570$ & $4,489,338$ & $2,227.573$ \\
\hline 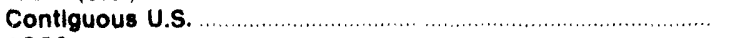 & $8,855,877$ & $8,540,116$ & $20,526,041$ & $15,134,589$ & $7,066,646$ \\
\hline ASCC & $\cdot$ & $\cdot$ & + & $\bullet$ & $\cdot$ \\
\hline Hawaii & -. & $\ldots$ & - & - & - \\
\hline U.S. Total & $8,855,877$ & $8,540,116$ & $20,526,041$ & $15,134,589$ & $7,066,646$ \\
\hline
\end{tabular}

- Value less than 0.5

$R=$ Revised data

Notes: - Data are final. - Totals may not equal sum of components because of independent rounding $\bullet$ Values identify point of entry or exit, but do not necessarily identify point of consumption. These data reflect electricity imported trom Canada and Mexico. -The Alaska Systems Coordinating Council (ASCC) became a NERC Region member in 1989 .

Source: Otfice of Fuels Programs, Fossil Energy, Form FE-781R, "Annual Report of International Electric Export/Import Data." 


\section{U.S. Electric Utility Demand-Side Management}

In recent years, U.S. electric utilities have come to realize that a flexible and diverse management strategy provides the greatest opportunity for success in the competitive and uncertain environment in which they operate. An important component of this strategy has been the increasing reliance on demand-side management (DSM) programs to modify the growth in demand and energy use, cost-effectively meet customer energy service requirements, selectively expand customer services, and improve the use of generating resources. This chapter provides a brief description of the key elements of electric utility DSM program development in the United States.

\section{Background}

DSM consists of the planning, implementing, and monitoring of utility activities that are designed to encourage consumers to modify their pattern of electricity usage, including the timing and level of electricity demand. The primary objective of most DSM programs is to provide cost-effective energy and capacity resources to help defer the need for new sources of power supply, including generating facilities, power purchases, and transmission and distribution capacity additions. Identifying the right mix of DSM options can be mutually beneficial to the utility, the consumer, and society. The utility can benefit from lowered cost of service, improved operating efficiency, reduced capital requirements, and enhanced consumer service. Consumers can benefit from reduced costs and improved value of service. Society can benefit from reduced emissions and the conservation of energy resources.

DSM programs have become a key component of the integrated resource plans (IRPs) of a growing number of electric utilities. The IRP process differs from traditional utility planning practices primarily in its increased attention to DSM programs and its integration of supply and demand-side resources into a flexible resource portfolio. Utilities and State regulatory commissions are using the IRP process to assess a variety of resource options that cost-effectively meet consumer energy-service requirements, while being responsive to external changes such as economic conditions, energy prices, new technologies and changes in regula- tory and tax policy. Regulatory review of utility resource planning along with requirements that utilities follow an IRP process evolved from the forecasting and siting reviews that were begun by many States in the 1970 's. The evolution to periodic advance review of utility resource planning was, in part, a response by regulators to the completion of controversial capacity additions over which there had been limited or no advance regulatory oversight. By 1992, 41 States had begun implementing integrated resource planning. ${ }^{3 k}$ In addition to balanced consideration of supply and demand-side options, the IR P process includes consideration of risk and diversity of supply, maintaining system reliability, and in some instances the application of specific values to reflect environmental and other impacts.

\section{Identify Program Alternatives}

The types of DSM programs that utilities select to alter the timing and level of demand for electricity will vary significantly depending on their overall organizational and market environment, strategic objectives, and system operating characteristics. DSM programs generally promote one of four basic objectives that riffer in their intended effects on electricity use (measured in kilowatthours) and demand (measured in kilowatts). First, energy efficiency, or conservation, programs are aimed at reducing the energy used by specific end-use devices and systems through the promotion of highefficiency equipment and building design, typically reducing energy consumption throughout many hours of the year. Such high-efficiency measures generally use less electricity 10 provide consumers an equivalent or greater level of electric energy services (light, heat, cooling, or drive power). This category covers the great majority of DSM programs across all consumer classes. Second, load management programs are aimed at reducing or shifting demand at certain critical times (such as summer or winter peak), and are focused on changing the timing of electricity demand. These program types usually have only a minor affect on the amount of annual tectricity consumption. For example, residential and commercial air conditioners or water heaters may be allowed to operate unimpeded during off-hour peak demand hours, but are cycled on and off by direct control of the utility during a few peak.

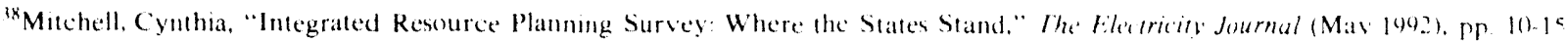


demand hours. Third. flexihle load hape programs provideconsumers a prese sgual or incentive to modify theer consumption in response to changes in the utility's cost of providing power. Real time pricing is an example of this type of program. Fourth, etralegic load growth or electrification programs are designed to increase dectricily consumptom typeally by building usage during valleys of how comsumption or introducing new. efficient dectrolechnologes. Such proguams may facilitate the efficient operation of haseload generating units, reduce rales, and help cussomers need environmental requirements, enhance product quality, or lower costs by replacing less efficient energy sources.

The energy savings and peak load reductions reported by electric utilities to ElA fall into one of six LSSM program typen."

Energy Efficiency - Energy efficiency programs vary by season and lime-of-day and are aimed at reducing. the energy used by specific end-use devices and systems, typically without reducing the level of energy services provided. These programs reduce oserall elecetricity comsumption over many hours during the year. although the largest impacts of cost-effective programs often coincide with periods of peak usage. Such savings are gen rally achieved hy substituting technically more advanced cquipment to produce the same level of enduse services (e.g. lighting, heating, motor drive) with les electricity. Examples include high-efficiency apphances, efficient lighting. high-efficiency heating, ventilating and ait conditioning (HVAC) yystems or control modilications, efficient building design, advanced electro motom and drive systems. and heat recovery systems Energy effickency programs fre. guently incomporate rebates, finathemg of other finan. cial meconteses for participation, rather than relying primarily on alesmative rate struetures as do some other program callegories.

Direct Load Control . This category represents the consumer load that can be interrupted during the periods of peak foad by direct control of the utility system operater. This lype of comerol usually movlves residential comsumers.

Interruptible load. Thu category accoumts for the comsumer load that in acerdance with centractual arrangements, can be interrupted during periods of peak load wither by the direce comerol of the utility system operator or by the action of the comsumer at the direct request of the system operator. It usually affects large-volunic commercial and industral consumers.
Other Load Management - This callegury refers to pro. grams other than Direet I a ad Combol and Interruptible load that lomit peakloads, or shift peak load from on-peak tooff-peak lime periods, or encourage customers 10 respond to changes in the utility's cost of pro. viding power. It includes technologies that primarily shift all or part of a load from one time-of-day to another and secondarily may have an impace on energy comsumption. Examples include space heating and water heating storage systems, cool storage systems, and load limiting devices in energy management systems This category also includes programs that aggressively promote time-of-use (rol) rates and other innovative rates such as real time pricing. These rates are intended (1) reduce consumer bills and shift hours of ciperation of equipment from on-peak to off-peak or high-cost to low-cost periods through the appication of timedifferentiated rates

Other Demand-Side Management Program - This residual category captures the effects of DSM programs that cannot be meaningfully included in any of the other program categories. The energy effects attributable to this category represent the net effects of all the residual programs. Programs that promote consumer's substitution of other energy types for efectricity and self-generation of electricity for consumes own use are included."

Load Building - This category represents programs that are atmed at increasing the usage of existing electric equipment or the addition of electric equipment. Examples include industrial technologies such as induction heating and melting, direct arc furnaces and infra. red drying; cooking for commercial establishments; and heat pumps for residences. Load Building includes programs that promote the substitution of electricity for other fuek

\section{Planning and Selection of Programs}

The key elements of the DSM program planning and selection process are 10 identify and evaluate key consumer characteristics that influence acceptance and response to DSM programs and utility considerations affecting resource requirements and the cost of alternalive resource options. Among the comsumer characteristles that influence a program's success are demographics, income, knowledge and awareness, attitude and motivation, discount rate, and price experience. External influences such as economic conditions, en. ergy prices, technologies, regulation, and tax credits also influence consumer's decisions regarding fuel and appliance chosces, appliance and equipment efficiency, and appliance use. The utility's considerations are usu-

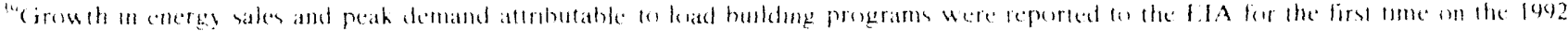

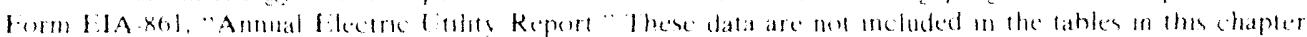

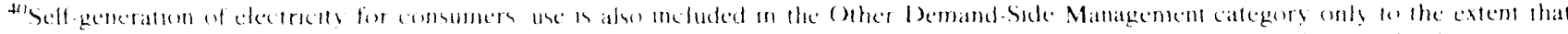

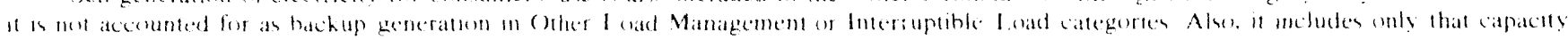

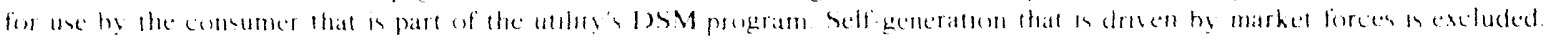


ally focused on the interaction of load shape changes and supply-side resources options, transmission and distribution effects, and regulatory compliance.

To compare DSM programs to other demand- and supply side resources, regulators have developed standardized benefit/cost tests. There are four benefit/cost tests that are widely used in planning to identify cost effective DSM programs. ${ }^{41}$ For each test, the net present value and benefit/cost ratio can be determined. The present value equals total benefits of the program less total costs; the benefit cost ratio is the ratio of total benefits to total costs. Based on these values, the utility can prioritize DSM programs to determine which, if any, might be implemented.

The Utility rost Test measures the net benefits or costs of programs ased on costs incurred by and the revenue requirements of the utility (i.e., it excludes participant costs). It determines if the utility's cost for DSM programs is less than the avoided supply cost.

The Participant Test measures the quantifiable benefits and costs to consumers who participate in the DSM program. It attempts to answer whether or not the participant is better off with the DSM technology and likely to participate in programs.

The Rate Impact Measure Test captures the present value impact on all consumers' average rates due to the DSM program. It evaluates whether average rates for consumers (including nonparticipants) will go up, down, or remain unaffected.

The Total Resource Cost Test shows the net benefits or costs of a DSM program as a resource option based on the total costs of the program, including both participants and utility cost (the Societal Cost Test is a variant of this test which incorporates externalities and excludes tax credits). It determines if the total cost of DSM to participants and non-participants is less than the supply cost for an equivalent amount of capacity and energy.

The Societal Test considers the broadest point of view, including the total resource cost and external costs and benefits, such as environmental impacts. It determines if the total cost of the DSM program is less than the alternative supply cost (including environmental costs).

The inclusion of environmental externalities in planning generally affects DSM options favorably. For example, if only traditional costs are considered in the planning process, a supply-side option might appear more attractive than a particular energy efficiency program.

However, traditional costs seldom reflect the ful' cost to society of utility activities that adversely affe: the environment. In assessing supply and demand-side options for planning purposes, regulators have been moving to consider broad impacts of utility resource acquisition on society, including environmental and other externalities. Environmental externalities are real impacts on the production or utility functions of others, including impacts on health and property values, which are not reflected in the prices of gonds and services. ${ }^{42}$ Under traditional command-and-control air quality regulation, the additional emissions associated with operating a polluting facility for more hours do not increase the production costs of the source. Thus, many residual air emissions are classified as externalities. Externalities also may include national security costs associated with reliance on foreign oil or transition costs associated with local economic dislocations. Environmental externalities have become a part of the criteria for comparison and selection of utility resource options in 26 states and the District of Columbia. ${ }^{43}$

\section{Implement Programs}

Another component of DSM program development is the marketing plan to implement a package of cost-effective programs through customer education, direct contact, trade ally cooperation (for example, building contractors and appliance dealers), advertising/ promotion, alternative pricing, incentives, financing, and direct installation. The programs differ in the types of services offered to consumers. For example, general information programs attempt to inform consumers about DSM options through such mechanisms as brochures, bill stuffers, television and radio advertisements, and woikshops. Direct installation programs involve installation of energy efficiency measures in the facilities of participating consumers by the utility, or its contractors. These programs generally cover low-cost measures, such as water-heater wraps and compact fluorescent lamps. Energy audits provide information on the physical and operating characteristics of a building and its energy uses and processes. Audit services vary from simple walk-throughs to building management training programs and site-specific process and efficiency evaluations. Incentive programs offer cash or noncash awards to manufacturers of energy efficient electric equipment, deliverers of energy products or service such as appliance and equipment dealers, building contractors, and architectural and engineering firms, or directly 10 consumers, that encourage con-

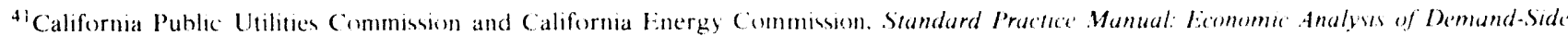
Management Programs. (Sacramento, California. December 1987).

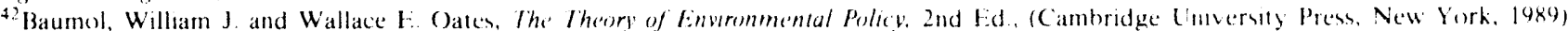
r. 17

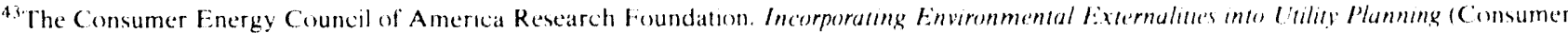
Entergy Council of American Research Foundation, Washington. D). $\therefore$ 1993)
} 
sumer participation in a DSM program and adoption of recommended measures. Appliance rebates and zero- or low-interest loans are common examples of incentive programs. Lastly, utilities offer alternativerate programs, such as discounts or refunds on monthly electric bills, in return for consumer participation in programs designed to reduce peak demand or to modify the load shape

Most DSM programs are aimed at specific subsets of the utility population, typically by consumer classes and market segments. For example, the residential sector is often subdivided hy housing type (for example. single-unit, multi-unit, mobile home). Residential sector programs typically consider the relative similarity of end uses and consumption patterns to identify loadshape modification opportunities with relatively predictable outcomes. Because per-unit electricity consumption in the residential sector is less than that of ihe commercial and industrial sectors, residential DSM programs are usually designed to achieve highparticipation rates in order to alter the load curve of the utility system significantly.

Most commercial electricity consumption is for lighting, air conditioning, and space heating. However, the relative importance of the different end uses varies significantly across consumer types. Office buildings, retail establishments, schools, supermarkets, and restaurants exhibit distinctly different patterns of electricity consumption. Recently, utility-sponsored efforts to develop DSM potential in the commercial sector have increased significantly, with program activities focusing on energy-management assistance, cool storage. lighting, heat pump, and water heating improvements.

DSM program development in the industral sector hats been slow compared with its developnent in the residential and commercial sectors. The wide variety of industrial process uses initially hindered the design of DSM programs tailored to the industrial sector. Utilities traditionally relied on alternative rate-design approaches, such as interruptible service and time-of-use rates to achieve DSM objectives in the industrial sector. Utilities first began to broaden their DSM approach to include incentive and financing programs for industrial lighting, thermal storage, electrotechnology, and advanced motors and drive systems, which have the potentral to meet energy-efficiency and load-management objectives. Recently, a number of utifities have devel. oped flexible custom measure programs which allow industrial energy users and utilities to work together to identify cost-effective measures.

\section{Monitor and Evaluate Programs}

Electric utilities must rely on systematic measurement, statistical analysis, and engineering expertise to evaluate the operation and performance of DSM programs to verify DSM results, to assess the effectiveness of the program, and to provide feedback on the results that are essential for future decisions about DSM programs. Utilities report DSM-program results in a number of ways, depending largely on the load modification objectives of their programs. For example, utilities interested in peak clipping typically measure program success in terms of total peakload reduction or its reduction per consumer. Utilities interested in reducing overall energy consumption measure both peak reduction and total energy savings. When evaluating program success, utilities typically determine the level of purchased-power reductions, load and energy reductions, program costs per unit of energy and/or demand savings, and program participation rates.

While the consumption of electricity can be measured in a variety of ways, such as monthly electric bills. special shortterm metering, whole-building loadresearch data, or end-use load monitoring, the saving of electricity-the difference between actual consumption and what would have occurred in the absence of a DSM program--can only be eslimated based on engineering data or statistical analysis

The andytical procedures applied to estimate electricIty and load changes involve a variety of techniques. These techniques include using engineering estimates (1) derive the energy-saving effect per installation of an energy-fficient device, monitoring electricity use for selected consumers before and after participation in a DSM activity, and contrasting the aggregated effects of DSM program participants and nomparticipants.

Fialuation and verification lodetermine whether DSM programs achice their stated ohjectives are essential because (1) utilities are scheduled fo mvest billioms of dollars i., DSM programs. (2) utilities are counting on the saved electricity as one source of supply to meet expected increases in future electricity demand, (3) state regulators are increasingly allowing utilities to collect financial incentives and recover cont revenues based on the results of IOSM programs, (4) the results of conservation programs may he recognesed for purposes of envirommental compliance, and (5) utilities and regulators reed to know what mix of DSM technologies and techniques yields the most cost-effective energy savings th

As utility DSM hudgets have grown, exceeding $\$ 2.2$ billion in 1992, it has become increasingly important loknow what DSM programs have aceomplished. This

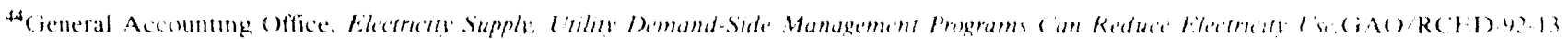

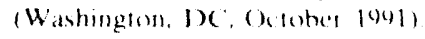


has led to more sophisticated efforts to measure and evaluate a greater number of programs. Nevertheless, detailed impact and process evaluations have been completed on only a small fraction of all DSM programs. These evaluations may vary with respect to the methodologies employed, the issues and types of programs studied, and the purposes for which evaluations were conducted. Because practices may vary substantially from one utility to the next, it is difficult to generalize regarding the quality of the data supporting the estimates of energy savings and peak reductions reported to EIA or the extent to which such estimates have been subject to after-the-fact verification. In 1994. EIA intends to examine DSM data quality and verification practices. The study will summarize the stateof-the-art with respect to DSM program evaluation. describe the relationship between evaluation and verification, introduce typical evaluation and verification methodologies, and discuss the factors which influence the extent 10 which it is reasonable to reach broad conclusions about the quality of savings estimates. The results of the study will be presented in a feature article of EIA's Electric Power Monthly.

\section{Data Sources}

The data in the following tables were collected on the revised Schedule $V$ of the 1992 Form EIA-861. "Annual Electric (Itility Report. "In 1991, the rapud growth in DSM, the widening range of activities, and the increasing demand for more detailed program performance and cost data led the EIA to conclude that its 3-year ISSM data collection form needed revision. The current Schedule $V$ includes reporting of actual and potential peakload reductions and energy savings for six program calegories (Energy Efficiency. Direct Load Control, Interruptible l, oad. Other Load Management, Other DSM Programs, and Load Building) by four major consumer sectors (residential, commetcial, industrial, and other). The prior hedule collected actual and potential peakload reductions for Direct Load Control, Interruptible load, and Fnergy Ifficiency combined with all other DSM programs. En- ergy savings were reported for all program categories combined. Data were not reported by consumer sector. The years $t o$ be reported have also been changed. On the current schedule, utilities provide information for the reporting year (1992) and the first-and fifth-forecast years (1993 and 1997). The prior version of the schedule collected data for the reporting year and each of the following 10 years.

Other additions to the current schedule include the collection of incremental and annual peakload reduc. tions and energy savings for the reporting year. Annual effects are the total effects in energy use and peak load caused $h$ all new and prior year participants in the DSM programs that are in place during a given year. It includes all participants in existing and in new programs (those implemented daring the given year). Incremental effects are the annual effects in energy use and peak load caused by new participants in DSM programs during a given year. Incremental effects are annualized to indicate the program effects that would have occurred had these participants been in the program on January 1 of the given year.

On the current whedule, costs are reported in one of three calegories. If the cost can be tracked to a specific program caregory. it is reported as a direct utility cost under that program category. If the cost cannot he tracked to a program calegory, 11 is reported as an indirect utility cost under the approprate ascountung category fadministrative. marketing. momotoring and (valuation, or other). Total momutility eost is also re ported In prior years, cost was reported as an aggregate figure for all DSM programs for the reporting year and each of the 10 forecast years

A final addition to the revised xhedule is a checkbox fo identify specitic encrgy efficiency end uses (heating and cooling systems, water heating, lightung, new constructum, efce) and program types (rebates, audits. hams) by eomsumer sector that the utility promoles. The checkbox provides program-specific information (in the end uses and program lypes tised hy utilities IO) increase energy efficiency 
Table 65. Annual Demand-Side Management Peakload Reductions, Energy Savings, and Cost at U.S. Electric Utilities, 1989 Through 1992

\begin{tabular}{|c|c|c|c|c|}
\hline Item & 1992 & 1991 & 1990 & 1989 \\
\hline $\begin{array}{l}\text { Actual Peakload Reductions (megawatts) } \\
\text { Energy Savings (million kilowatthours) } \\
\text { Cost (thousand dollars) }\end{array}$ & $\begin{array}{r}17,657 \\
31,767 \\
2,243,270\end{array}$ & $\begin{array}{r}16,739 \\
23,343 \\
1,747,933\end{array}$ & $\begin{array}{r}14,772 \\
18,671 \\
1,177,457\end{array}$ & $\begin{array}{r}12,463 \\
16,268 \\
872,935\end{array}$ \\
\hline
\end{tabular}

Represents the total effects caused by all participants in ciemand side management programs in effect durnng a given year Included are new and existing participants in existing programs (those implemented in prior years that are in place during the reporting year) and all participanis in new programs (those implemented during the ieporting year)

2 Represents the actual reduction in annual peak load achieved by consumers in the following demand side management program categories: energy efficiency. direct load control, interruptible load. other load management, other demand-side management; reflects real changes in the demand for electricity at the time of annual peak load, as opposed to the installed peakload reduction capability (i e. Potential Peak Reduction).

3 Referred to in the Electric Power Annual, 1991 as "Expenditures," these data represent the sum of the direct and indirect utility costs for the year and reflect the total cash expenditures incurred for the year, reported in nominal dollars, that flowed out to support demand-side management programs.

Notes: - Data for 1992 are preliminary; data for prior years are final. Data are provided for electric utilities with sales to ultimate consumers or sales for resale greater than or equal to 120,000 megawatthours. Data for 1992 for peakload growth $(386,729$ megawatts), energy sales (1,738,450

megawatthours), and cost (\$24.585 (thousands)) attributable to Load Building programs are excluded.

Source: Energy Information Administration, Form ElA-861. "Annual Electric Utility Report." 
Table 66. Annual Actual Reductions in Peak Load at Electric Utilities by Demand-Side Management Program, North American Electric Reliability Council Region, and Hawaii, 1990 Through 1992

(Megawatts)

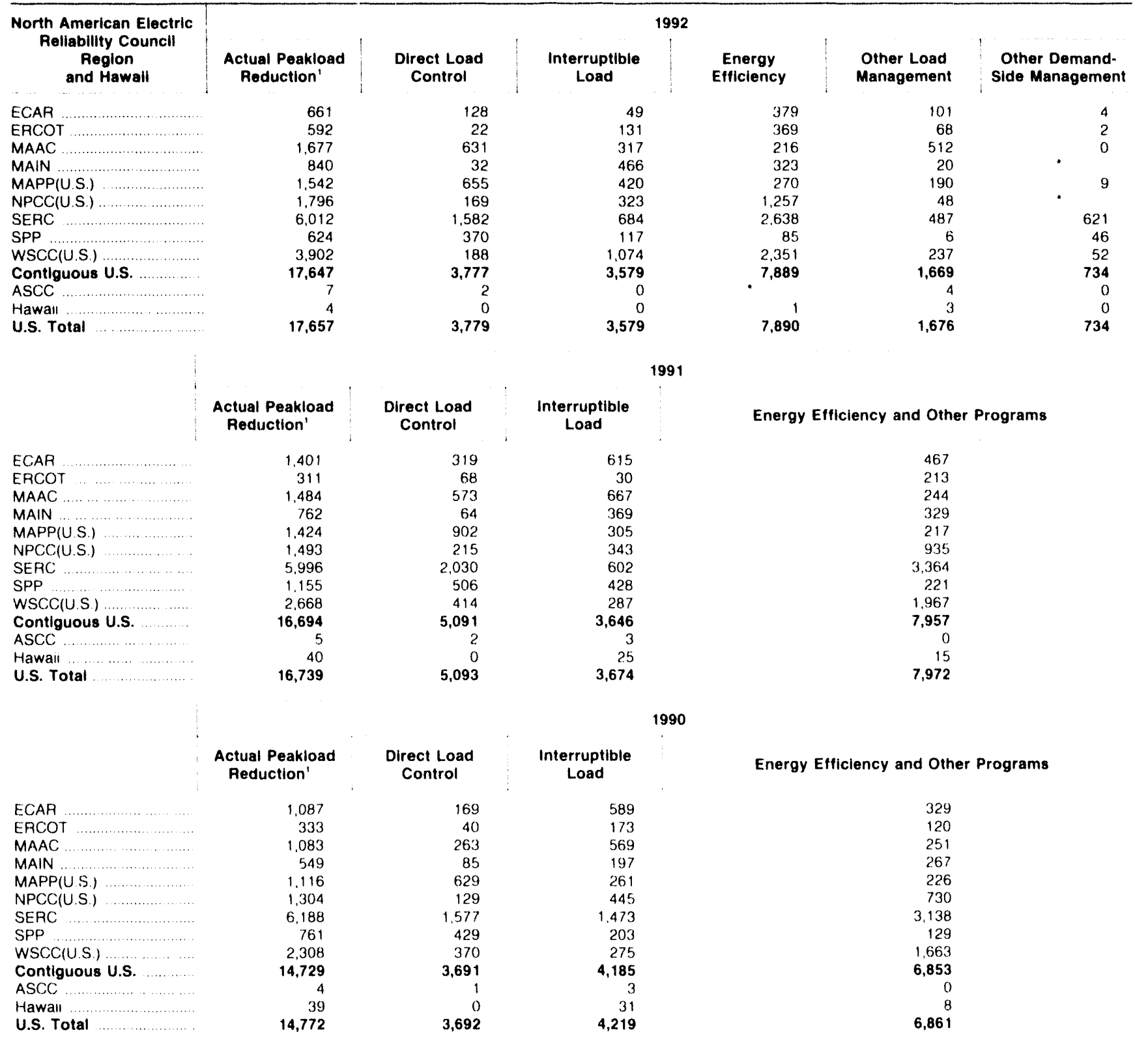

Represents the sum of the achieved reductions in the annual peak load attributable to direct load control, interruptible load, energy efficiency, other load management, and other demand-side management; whereas, in the Electric Power Annual, 1991, 1991 and 1990 peakload reductions attributable to energy efficiency, other load management, and other demand-side management were reported together under conservation and other programs

- Value less than 0.5

Notes: Data for 1992 are preliminary; data for prior years are final. - Data are provided for electric utilities with sales to ultimate consumers or sales for resale greater than or equal to 120,000 megawatthours. These data reflect actual real changes in the demand for electricity at the time of annual peak load. as opposed to the installed peakload reduction capabitty (i.e. Potential Peak Feduction), achieved by all program participants during the reporting year Program participants included new and existıng participants in existing programs (those implemented in prior years that are in place during the reporting year) and all participants in new programs (those implemented during the reporting year). The Alaska Systems Coordinatıng Council (ASCC) becarne a NERC Region member in 1989

Source: Energy Information Administration, Form EIA-861, "Annual Electric Utility Report" 
Table 67. Annual and Incremental Effects at Electric Utilites by Demand-Side Management Program, 1992

\begin{tabular}{|c|c|c|c|}
\hline Program & $\begin{array}{c}\text { Potential Peakload Reduction' } \\
\text { (megawatts) }\end{array}$ & $\begin{array}{l}\text { Actual Peakload Reduction } \\
\text { (megawatts) }\end{array}$ & $\begin{array}{l}\text { Energy Savings } \\
\text { (milliun kllowatthours) }\end{array}$ \\
\hline & \multicolumn{3}{|c|}{ Annual Effects ${ }^{3}$} \\
\hline Large Electric Utillities" & & & \\
\hline Energy Efticiencys & -. & 7,890 & 25,565 \\
\hline Direct Load Control & 7,626 & 3.779 & 289 \\
\hline Interruptibie Load ................ & 14,566 & $3,5 / 9$ & 1,994 \\
\hline Other Load Management $t^{b}$ & 1,899 & 1,676 & 419 \\
\hline Other Demand-Side Managernent ${ }^{7}$ & 914 & 734 & 3,500 \\
\hline Total Electric Utilities & 25,005 & 17,657 & 31,767 \\
\hline
\end{tabular}

Incremental Effects

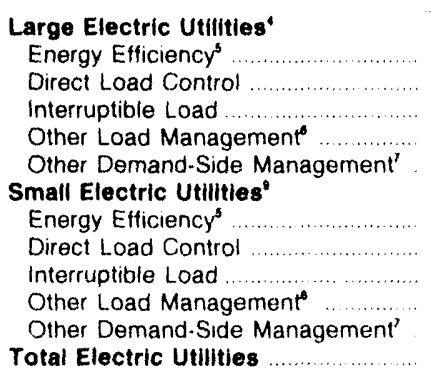

...

'Reflects the installed, contractually available, peakload reduction by program category, excluding energy efficiency, during the electric utility's annual system peak load. Energy Efficiency includes programs aimed at reducing energy consumption over many hours during the year. These programs reduce load and if they coincide with periods of peak usage they are included in the actual peakload reduction. However, these programs cannot be implemented specifically at the time of peak usage and are therefore not included in the potential peakload reduction.

2 Reflects real changes in peak load by program categories, including energy efficiency. during the electric utilitys annual system peak load.

${ }^{3}$ Represents the total effects caused by all participants in demand-side management programs in effect during a given year. Included are new and existing participants in existing programs (those implemented in prior years that are in place during the reporting year) and all participants in new programs (those implemented during the reporting yoar)

- Refers to electric utilities with sales to ultimate consumers or sales for resale greater than or equal to 120,000 megawatts

- Includes programs armed at reducing energy consumption over many hours during the year. These programs reduce load and if they coincide with periods of peak usage they are included in the actual peakload reduction. However, these programs cannot be implemented specifically at the time of peak usage and are therefore not included in the potential peakload reduction.

- Reters to programs other than direct load control and interruptible load that limit or shift load from on-peak to off-peak time periods, including technologies that primarily shitt all or part of a load from one time-ot-day to another and secondarily may have an impact on energy consumption. Examples include space heating and water heating storage systems, cool storage syslems, load limiting devices in energy management systerns, and programs that aggressively promote time-of-use rates and other innovative rates such as real time pricing.

7 Includes programs that promote consumer's substitution of electricity by other energy types and self-generation of electricity for consumer use. Selfgeneration is included only to the extent that it is not accounted for as backup generation in other load management or interruptible load categories, used by the consumer, and initiated by the electric utility (i.e., not a consumer response driven by market torces).

- Represents the total effects caused by new participants in existing demand-side management programs and all participants in new demand-side management programs during the year. Incremental effects are annualized to indicate the program effects that would have occurred had participants been initiated into the program on January 1 of the reporting year.

- Fefers to electric utilities with sales to ultımate consumers and sales for resale less than 120,000 megawatts.

Note: Data are preliminary:

Source: Energy Intormation Administration, Form EIA-861, "Annual Electric Utility Report." 
Table 68. Annual and Incremental Effects at Electric Utilites by Sector, 1992

\begin{tabular}{|c|c|c|c|}
\hline Sector & $\begin{array}{l}\text { Potential Peakload Reduction' } \\
\text { (megawatts) }\end{array}$ & $\begin{array}{c}\text { Actual Peakload Reduction } \\
\text { (megawatts) }\end{array}$ & $\begin{array}{l}\text { Energy Savings } \\
\text { (million kllowatthours) }\end{array}$ \\
\hline & \multicolumn{3}{|c|}{ Annual Effects ${ }^{3}$} \\
\hline \multicolumn{4}{|l|}{ Large Electric Utilities` } \\
\hline Residential .................. & 7.027 & 7,606 & 13,107 \\
\hline Commercial & 4,235 & 4.598 & 9,617 \\
\hline 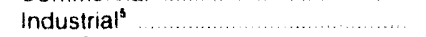 & 12.858 & 4,920 & 8.417 \\
\hline Other ${ }^{8}$ & 885 & 532 & 626 \\
\hline Total Electric Utilities & 25,005 & 17.657 & 31,767 \\
\hline & \multicolumn{3}{|c|}{ Incremental Effects' } \\
\hline \multicolumn{4}{|l|}{ Large Electric Utilities" } \\
\hline Residential .................. & 1,229 & 1.112 & 1,818 \\
\hline (2) & 793 & 1,251 & 2,953 \\
\hline Industrial ${ }^{3}$ & 3,826 & 1,468 & 882 \\
\hline Other ${ }^{\circ}$ & 229 & 108 & 132 \\
\hline \multicolumn{4}{|l|}{ Small Electric Utillties" } \\
\hline Residential. & 330 & 139 & 14 \\
\hline Commercial ............... & 54 & 32 & 5 \\
\hline Industrial $\left.\right|^{3}$ & 133 & 113 & 26 \\
\hline Other ${ }^{s}$ & 140 & 48 & 3 \\
\hline Total Electric Utilities & 4,734 & 4.271 & 5.833 \\
\hline
\end{tabular}

- Reflects the installed, contractually available, peakioad reduction by program category, excluding energy efficiency, during the electric utility 's annua system peak load. Energy Efficiency includes programs aimed al reducing energy consumption over many hours during the year. These programs reduce load and if they coincide with periods of peak usage they are included in the actual peakload reduction However, these programs cannol be implemented specifically at the time of peak usage and are therefore not included in the potential peakload reduction

- Reflects real changes in peak load by program categories, including energy efficiency, during the electric utilitys annual system peak ioad

3 Represents the total effects caused by all participants in demand-side management programs in effect during 1992 . Included are new and existing participants in existing programs (those implemented in prior years that were in place during 1992) and all participants in new programs (those implemented during 1992)

- Refers to electric utilities with sales to ultimate consumers or sales for resale greater than or equal to 120.000 megawatis

sepresents manufacturing. construction, mining, agriculture, fishırig. and forestry establishments

- Includes public street and highway lighting, other sales to public authorities, sales to railroads and railways, and interdepartmental sales.

- Reflects the total effects caused by new participants in existing demand-side management programs and all participants in new programs during 1992

The effects are annualized to indicate program effects that would have resulted had participants been initiated into the prograin on January 1 . 1992

- Refers to electric utilities with sales to ultimate consumers and sales for resale less than 120.000 megawatts

Note: Data are preliminary:

Source Energy Information Administration, Form ElA-861, "Annual Eiectric Utility Report" 
Table 69. Annual Potential Peakload Reduction at Electric Utilities by Direct Load Control, Interruptible Load, North American Electric Keliability Council Region, and Hawaii, Selected Years

(Megawatts)

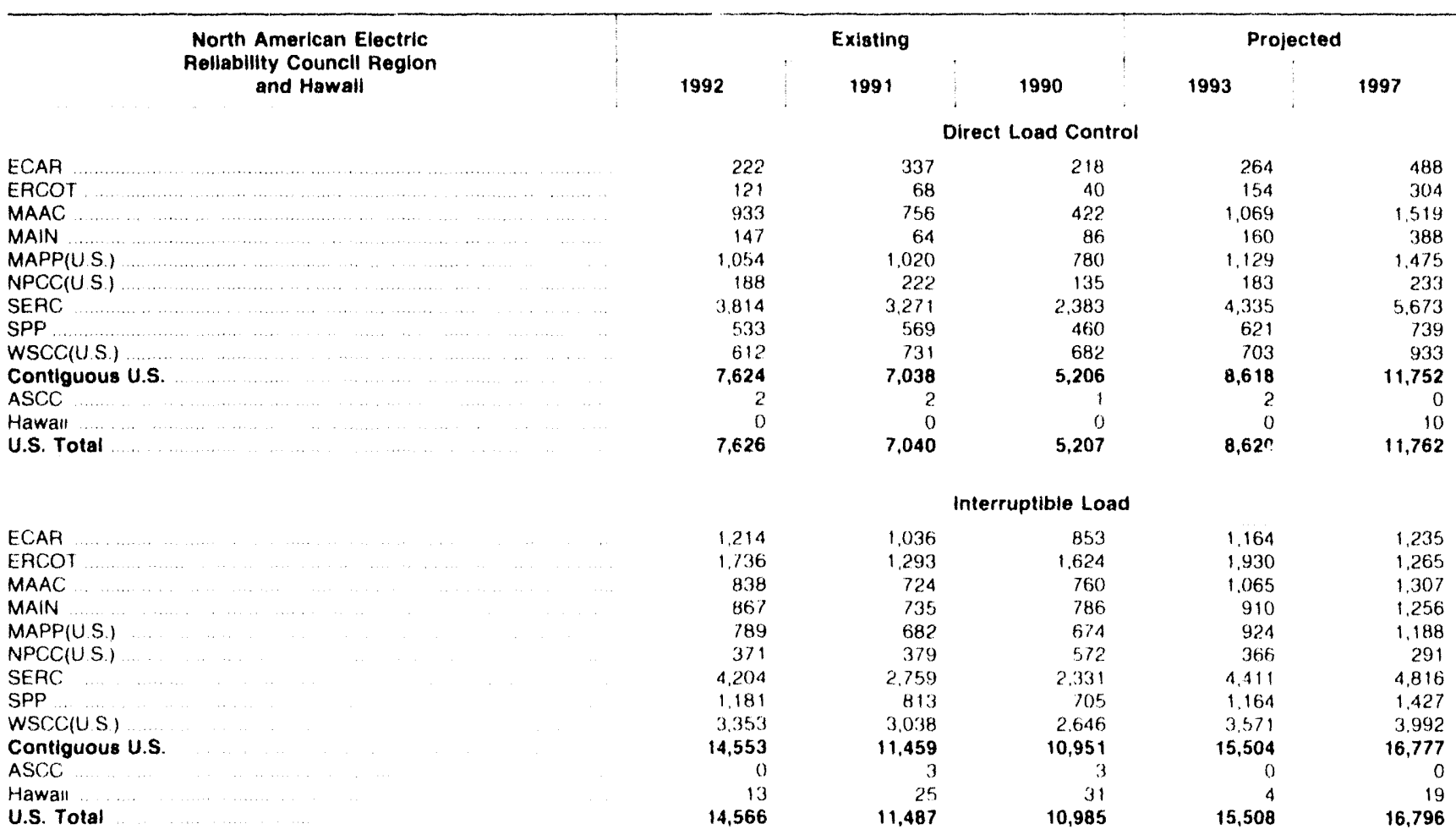

Notes: Data for 1992, 1993, and 1997 are prelimnary, data for prior years are final - Totals may not equal sum of compunents because of independent rounding - Data are provided for electrit; utities with sales 10 ultimate consurners or sales for resale greater than or equal to 120.000 megawatthours. These data reflect total installed, contractually avaltable, peaktoad reduction by participants in all program categories (except energy efficiency) during the electric utility's arinual system peak load Program participants include new and existing participants in existing programs (those implemented in pror years that are in place during the reported year) and all participants in new programis (those implemented during the reported year).

Source: Energy Information Adminıstration, Form E.A.861. "Annual Electric Uility Repor!

Table 70. Annual Demand-Side Management Energy Savings at Electric Utilities by North American Electric Reliability Council Region and Hawaii, Selected Years (Million Kilowatthours)

\begin{tabular}{|c|c|c|c|c|c|c|}
\hline \multirow{2}{*}{$\begin{array}{c}\text { North American Electric } \\
\text { Reliability Council Region } \\
\text { and Hawail }\end{array}$} & \multicolumn{4}{|c|}{ Existing } & \multicolumn{2}{|c|}{ Projected } \\
\hline & 1992 & 1991 & 1990 & 1989 & 1993 & 1997 \\
\hline ECAR & 1.129 & 1,072 & 636 & 5,7 & 1663 & 4,652 \\
\hline$\ldots \ldots+1, \ldots$ & 1,013 & 393 & 227 & 191 & 1,158 & 1.473 \\
\hline 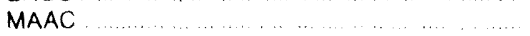 & 954 & 549 & 450 & 139 & 1,621 & 5.756 \\
\hline MAIN & 1.212 & 1.081 & 721 & 409 & 1,627 & 2,997 \\
\hline MAPP(US.) & 940 & 494 & 465 & 326 & 1,254 & 3,306 \\
\hline NPCC(US) & 5.049 & 3.657 & 2.065 & 1.373 & 6,687 & 14,116 \\
\hline SERC $\ldots \ldots$ & $1.3,302$ & 11,900 & 10.812 & 10.153 & $1,3,888$ & 17.770 \\
\hline$\ldots$ & 273 & 156 & 146 & 105 & 207 & 408 \\
\hline WSCC(US) ................... & 7.885 & 3,877 & 2.993 & 2.569 & 12,590 & 22.119 \\
\hline Contiguous U.S. & 31.758 & 23,179 & 18,515 & 16,122 & 40,795 & 72,596 \\
\hline ASCC $\quad \ldots \ldots \ldots \ldots$ & $\cdot$ & 0 & 0 & 4 & 7 & 22 \\
\hline Hawart $\quad \ldots \ldots \ldots \ldots \ldots \ldots$ & 9 & 164 & 156 & 142 & 14 & 165 \\
\hline 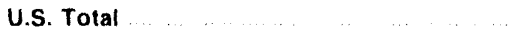 & 31,767 & 23,343 & 18,671 & 16.268 & 40,816 & 72,783 \\
\hline
\end{tabular}

- Value less than 0.5

Notes -Data for 1992, 1993, and 1997 are preliminary, data for pror years zre final - rotals may not equal sum of components because of independent rounding. Data are provided for electric utlities with saies to ultumate consumers or sales for resale greater than or equal to 120,000 megawatthours. These data reflect the savings in aggregate electricity for consumers that participate in one or more demand side management programs They represent changes at the consumer meter and include those aclivities implernented by third parties under contrac. in the electric utility Data represent the energy savings of new and existing participants in existing programs (those implemented in prior years that are in place during the reporting year) and all participants in new programs (those implemented during the ieporting vear). The Alaska Systems Coordinating Council (ASCC) became a NERC Region member in 1989.

Source Energy Information Administration, Form EIA-B61. "Annual Electric Utility Report" 
Tabie 71. Demand-Side Management Utility Cost at Electric Utilities by North American Electric Reliability Council Region and Hawaii, Selected Years (Thousand Dollars)

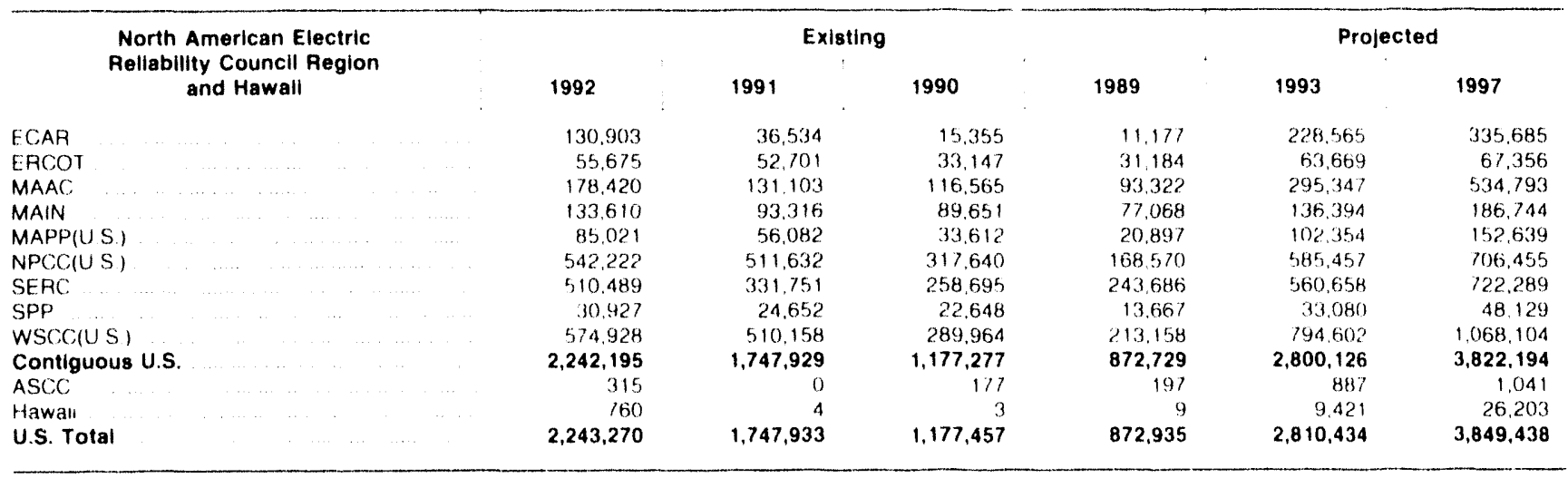

Notes - Data for 1992, 1993, and 1997 are prelimnary, data for prior years are tinal - Totals may not equal sum of components because of independent rounding. Data are provided for electric utihties with sales 10 ultimate consumers or sates for resale greater inan or equal to 120,000 megawatthours. These data reter to electric utility costs and represent the total cash expenditures incurred during the year, in nominat dollars, that flows out to support demand-side management programs Electric utility load building cost (\$20,398 (thousands) in 1992) is excluded. - The Alaska Systems Coordinating Council (ASCC) became a NERC, Region member in 1989

Source Energy Information Administration, Form EIA 861, "Annual Flectric Utilify Report"

Table 72. Direct and Indirect Utility Cost at Electric Utilities by Demand-Side Management Program, Selected Years

(Thousand Dollars)

\begin{tabular}{|c|c|c|c|}
\hline \multirow[b]{2}{*}{ Program } & \multicolumn{2}{|l|}{ Existing } & Projected \\
\hline & 1992 & 1993 & 1997 \\
\hline Total Direct Cost' & $1,847,182$ & $2,404,720$ & $3,399,457$ \\
\hline Energy Efficiency & 1.204 .661 & $1.644,994$ & 2.438649 \\
\hline Direct load Control & 322.127 & 376.193 & 476,514 \\
\hline Interruphible load & 178.031 & 216.400 & 252619 \\
\hline Other Load Management & 78,676 & $42 / 21$ & 137708 \\
\hline Other Demand Side Manayement & 63.687 & $n .411$ & 93927 \\
\hline Total Indirect Cost $t^{2}$ & 396,088 & 405,714 & 449,981 \\
\hline Administrative & 154.494 & $1 / 0.409$ & $192>0$ \\
\hline Marketing & 56.225 & 740 & $4,6,6: 1$ \\
\hline Montoring and $t$ valuation & 71.610 & 104085 & 110179 \\
\hline Other' & 109.759 & $\sin 28$ & 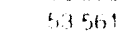 \\
\hline Total Utility Cost" & $2,243,270$ & 2.810 .434 & $3,849,438$ \\
\hline
\end{tabular}

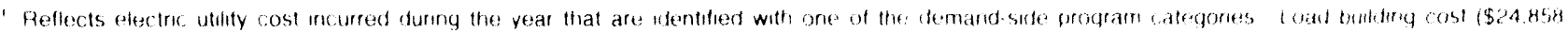
(thousands) for $1992 \$ 31.207$ (thousands) for 1993 , and $\$ 34960$ (thousards) for 1997 ) aft ardurted

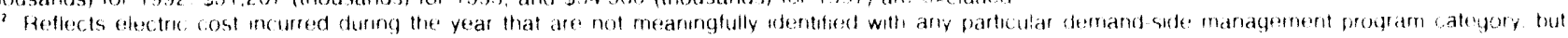
can be attributatble to one of several accounting cost categores

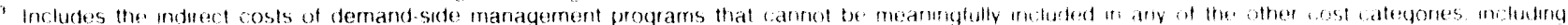
costs incurred in the research and development of demand side management teromotimgles,

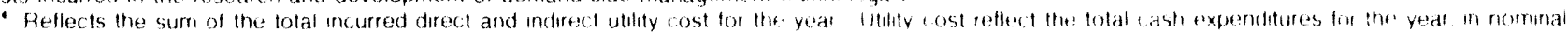
dollats, that flows out to suoport ifemand side management programs

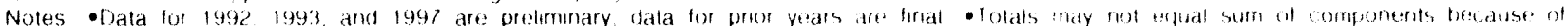

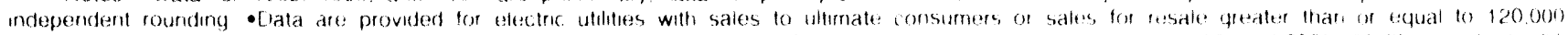

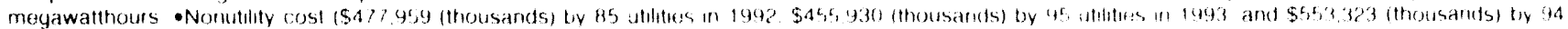
utilites in 199i) are excluded

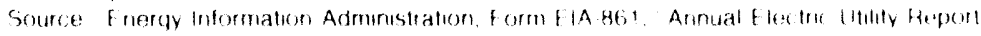


Table 73. Number of Electric Utilities Having Different Energy End Uses and Program Types by Sector, 1992

\begin{tabular}{|c|c|c|c|}
\hline Item & Residential & Commercial & Industrial \\
\hline \multicolumn{4}{|l|}{ End Uses } \\
\hline Heating System & 359 & 224 & 130 \\
\hline (n) & 360 & 264 & 162 \\
\hline Water Heating & 412 & 215 & 129 \\
\hline Lighting & 229 & 268 & 190 \\
\hline Building Shell & 210 & 136 & 97 \\
\hline (2) & 238 & 148 & 100 \\
\hline Appliances ............. & 168 & 80 & 46 \\
\hline 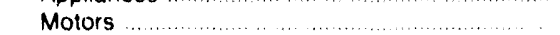 & -. & 150 & 159 \\
\hline 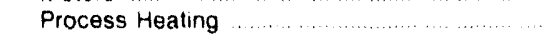 & .. & 47 & 87 \\
\hline Electrolytics ....... & -. & 5 & 26 \\
\hline (n) & 44 & 52 & 36 \\
\hline \multicolumn{4}{|l|}{ Program Types } \\
\hline Energy Audits & 383 & 298 & 205 \\
\hline Rebates & 347 & 234 & 155 \\
\hline Loaning ................... & 189 & 91 & 58 \\
\hline 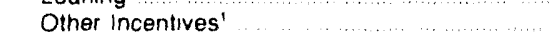 & 145 & 102 & 82 \\
\hline Other & 143 & 102 & 82 \\
\hline
\end{tabular}

'This category reflects programs that offer cash or noncash awards 10 electric energy efficiency deliverers, such as appliance and equipment dealers, buildirig contractors, and architectural and engineering firms, that encourage consumer participation in a demand-side management program and adoption of recommended measures.

Notes: Data are preliminary. Data represent the total number of electric utilities that focus energy efficiency activities on specific end uses and program types

Source Energy Information Administration, Form EIA-861. "Annual Electric Utility Report." 


\section{U.S. Nonutility Power Producers}

For over a decade, electric power produced by nonutility power producers re-emerged as an increasing part of U.S. electricity generation. While more than 50 percent of the electricity in the United States was produced by the industrial sector at the turn of the century, by 1950 it had decreased to 15 percent. This decrease was due to the steady growth of the traditional electric utility industry during the first half of the century. Traditional utilities include investorowned, publicly owned, Federal, and cooperative electric utilities. In the 1970's, inflation, the energy crises, environmental concerns, and the rising costs of nuclear power ratsed electricity rates and reduced investment in new capacity. These factors led to a re-examination of alternatives such as nonutility electric power, which led to the passage of the Public Utility Regulatory Policies ACl (PURPA) of 1978

In 1989, the Einergy Information Administration (EIA) began collecting nonutility electricity generation data on the Form EIA-867, "Annual Nonutility Power Pro. ducer Report." This enabled the EIA to supplement its data on electric utility production and 10 fill the information gap on this growing source of electric power. The initial survey was developed to include capacity, fuel consumption, generation, and deliveries of electricity to traditional utilities. Due to the sensitivity of data on costs and reliability expressed by rep. resentatives of the nonutility power producers, these data were excluded from the survey. See "Form EIA-867" in Appendix C.

This chapter provides an overview of U.S. nomutility power producers, their genterating technologics, and statistical data on capacity, generation, sales, and emissions for 1989 through 1992. These data are aggregated at the U.S. and Census division levels. Since nonutility data are confidential, the EIA implemented information disclosure rules. See "Nondisclosure of Data" in Appendix $C$

\section{Background}

During the early part of the 20th century, the development of large central-station power plants, economies of scale, decreased rates, and greatly improved reliability made electricity inexpensive and demand soared. Most industrial plants shifted away from generating their oun power and opted to purchase electricity from their local utilities. By 1950, the electric utility industry was serving virtually all clectricily demand, except for a few industries that generated small amounts for their own use. Electrictly was inexpensive, capacity growth appeared to be limitless, and elecaric utilities were strictly regulated to protect the consum. ers. During the 1970's, however, the electric utility industry changed from one characterted by decreasing marginal costs lo one of increasing costs Inflation, the energy crises, environmental concerns, and the rising costs of nuclear power led to in reased electricity rates and reduced growth in capacity

A monutility power producing facility seckmg to es tablish an interconnected operatom with an electric utility faced three major obstacles. First, utilities were seldom willing enther 10 purchase the electric power output of nomutility producers or pay a fan rate for that output second, some utilities charged high rates for backup serveces to momutility power producers Third, facilites that provided electricity or a dolloty connected to the grid risked being comstered a puble utility and subger we extensive state and Federal reg ulation

In the late lo70's, Congress acted to relieve a llateon wide energy cross by enatumg the National Encrgy Act of 1978, which encomprased PlRPA and four other laws. the National Fnergy (omservation Policy Act, the Powerplant and Indusirial fuel L Se Act, the Natural cas Polley Act, and the Lnergy lax Acl PURPA proveded for increased comservation of energy and increased effieseney in the use of facilities and re. sources by electrie molites. Il called for state regula fory authorities to encourage conservattom and uthlity efficiency and to provide for equatable rates Some if the provisions of PURPA were designed lo encourage the development of cogencration and small pouer production by loosening the economere regulatory, and instifutional batrers that discouraged cogenterattom and the use of renewatle energy resturces.

PURPA makes a dinonction betureen facihties that qualify for benefits, referred 10 ats qualilyme facilitie

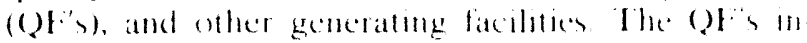

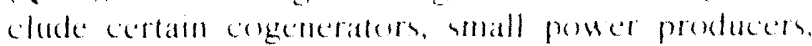

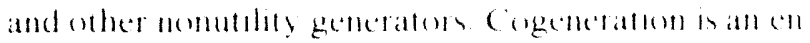

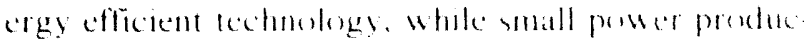

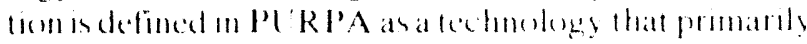

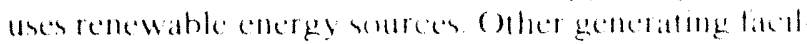
illes include indestrat and onmmendal genematrem and

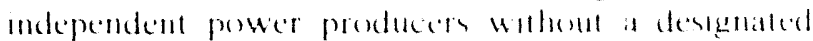


franchised service area. The Federal Energy Regulatory Commission (FFRC) is responsible for the implementation of PURPA and has established rules fo encourage the development of cogenerators and small power production facilities. In addition, each State regulatory authority is required to implement such rules for each electric: utility under its rate-making authority. The rules for the FERC program that define $Q F$ 's are published in the Code of Federal Regulations. Title 18. Part 292

Inder FERC rules, cogeneration and small power production facilities may be designated as QF's based on meeting specific: ownershipts, operating, and efficiency criteria. A facility may file an information report. known as a "self qualifying notice," with the FERC if it meets the requrements of FERC published rules, or it may apply to the FERC for certification as a $Q F$ under PURPA QF's are guaranteed that electric utiltties will purchase their output at the utility's avoided cost, which is the meremental cost that an electric util ity would incur we produce or purchase an amount of power equivalent to that purchased from QF's. Additionally, QP's are guaran eed that electric utilitices will prowide hack-up serice at prevaling (nomdiscrmmatoryl rates

\section{Recent I egislative and Regulatory Activities}

Recently the U.S Congress passed the Energy Policy Act of 1992 amending the Public Utility Holding Company Act (PUHCA). PLHCA was designed todiscourage holding companes from structuring their operatoons in ways that would prevent effective State regulation. The following are provistoms of the Act. potentally impactung the monutility industry

- The creation of exempt wholesale generators (EW (is), corporate entities who are engaged exclusively in the husiness of wholesale celectric gencration and who ale excmpt from corporate organtational restrictiom under PUHCA. Entitics Who are curnently subject o PUHCA registered holding compantes and exempt utility holding compances and entities who are not currently subfeet of PLHCA (nomutilities and non-holding company utilities) are permilled to own EWG's withou limitation. For registered holding compances approval from the Securities Fxchange Commission is requered for financing of EW and service sales and construction contracts in-

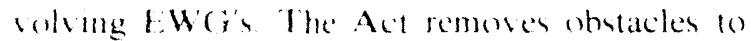
wholesale power competition in the PLHCA by allow mg both utilities and nomutilities fo form exempl wholesale genterators without triggering the restrictoms of the 1935 人it

- The Act allowe FFRC to order upon application wholesale, but mot retall, transmission aceess on a case-by-case basis and transmission service by utilities, subject to certain protection.

- The establishment of a program for providing Federal support on a competitive basis for renewable energy technologies. Also expands program to nromote the export of these renewable energy technologies to emerging markets in developing countries.

\section{Nonutility Classifications}

Cogeneration. The major technology used in nonutility generation is known as cogeneration. Cogeneration is the combined production of electric power and another form of useful energy (such as heat or steam) through the use of one energy source. The process can begin cither with heat or steam production or with electricity generation. where the unused energy from the first process can be used as input to the second process. The primary energy source is generally a fossil fuel (coal, petroleum, or natural gas), although renewables are also used. particularly wood and waste. To receive ( $F$ status under PURPA from FERC, a cogenerating facility must meet the operating criteria to produce electric energy and "another form of useful thermal energy through the sequential use of energy." In addition, depending on the technology of the cogeneration facility, it must meet specific efficiency criteria.

Cogeneration use's a number of technologies to produce both electric power and another form of useful energy. The technology selected depends on the requirement for processed steam. Cogenerating technologies are classified as "topping-cycle" and "bottoming-cycle" systems, depending on whether electrical or thermal energy is produced first. In a ypical topping-cycle system (Figure 20), the energy input to the system is first transformed into electricity hy using high-temperature. high-pressure steam from a boiler to drive a turbine to generate electricity. The waste heat, or the lower pressure steam exhausting from the turbine, is used as at source of processed heat. Topping-cycle systems are the most common and are used in commercial, rural, and industrial applications. The wo configurations in Figure 20 represent most topping-cycle facilities

In a bottoming-cycle system (Figure 21), hightemperature thermal energy is produced first for applications such as reheat furnaces, glass kilus, or aluminum metal furnaces. Heat is extracted from the hot exhaust stream and transferred (through one or more mediums) (o drive a turbine. Bottoming-eycle systems are generally used by industrial processes that require very high-temperature heat, thus, making it economical b recover the waste heal.

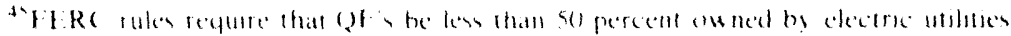


Fossil-fueled steam turbine systems are used in most industrial cogenerating processes, while gas-lurbine systems are used in most other processes. (Bas-turbine systems use combustion gases 10 drive a lurbine 10 produce electricity and recover heat from the exhaust gases for waste-heat hoilers. Compared with gas turbine systems, diesel engine systems are limited in application since they provide less uscable processed heat per unit of electric power output. In a diesel system. the engine is cooled with water. The healed water is then used for processed steam, heat, or hot water applications. Exhaust gases can be used in a similar manner. Diesel systems are attractive to small cogenerating applicatons that need an instantancous supply of elec. tricity where the electric power requirement is gener. ally greater than the heal requirement. With diesel systems, boiler warmup lime is not necessary as requered by some technologices.

Small Power Production. To be designated as a small power producer under the 1978 PURPA regulations a facility was limited to a capacity no greater than 80 megawatts and had to generate electricity using rencw. able energy as a primary source. In 1900) for specific energy sources (biomass (waste), solar, geothermal, and wind) the size restriction lo qualify as a small power producer was removed. Fossil fuels can be used, but 75 percent or more of total energy comsumpton must be derived from renewable resources and the atggregate of fossil fuel usage canturef exeeed 25 percent of total energy input during any calendar year. Reliance an these technologies can reduce the need for consume fossil fuch to gencrate clectric power

Renewable energy includes solas, wind, biomass. geothermal. and water (hydratule). Solar themal technology converts solar energy through high concentrafion and heat absorption me electricity or process ent ergy and is mamly used in the Pacific Comtguous ( entsus Division. Wind generators produce a mechanical energy directly through shaft power. Windmills rotatting parallel of perpendicular to the ground are the most common harnesses used in wind technology and are manly concentrated in the Pacific (ontiguens and West South (entral (ensus Divisions. Biomass energy is derived from a variely of resources The biomass resource base potentially includes hundreds of plant species, vartous agricultural and indust rial residues and processing wastes, municipal solid waste and sewage, and anmal wastes. Industrial wood and wored waste is the most prevalent form of homass energy used by nonutilities. The industries that produce paper. woud. and agricultural products ate increasing their use of biomass 10 improve efliciency of their operations and to contribute to their on-site emergy requirements These industries are indigenous to the South Atlantu and Pacific Comtiguous (ensus Divisions. (ieothermal technologies convert heal naturally present in the earth into heat energy and clectricity by tapping into highand low-temperature flude and by extracting steam Hydropower is deried by comverting the pollential energy of water 10 clectrical energy using a hydratulic turbine connected to a generator. Hydropower and geothermal technologies are mainly concentrated in the Pacific Contiguous (ensus Division

Other Nonutility Cienerators. In addition of facilities that are classificed as qualifying eogenerators and umall power producers, other monumbly companies produce clectric power for these own use and fore sate to clectrio utilities. They include independent pewer producers (IPP's), nonqualifying eogenerators, and other commercial and industral establishments These nomutility companie" are huile mannly lo supply and sell power to eleciric utilites. They do not qualify under PURPA

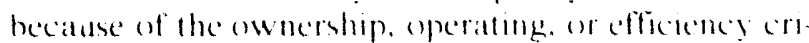

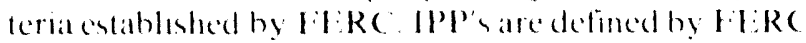
as producers of electre power other than (2) that

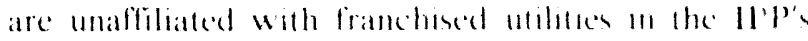
market area and that for ofler reasoms latek signiticant market power. IPl's may lack marked power doe to site or access fo transmissionte.

\section{Nonutility Operations}

Business Classification. The nomutility pomer producing industry operates in various sectors of the l.s. economy and is classified aceordeng to the Standerd

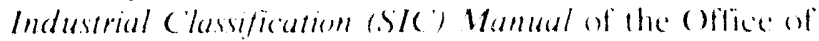
Management and Budget. The matn classfications ate

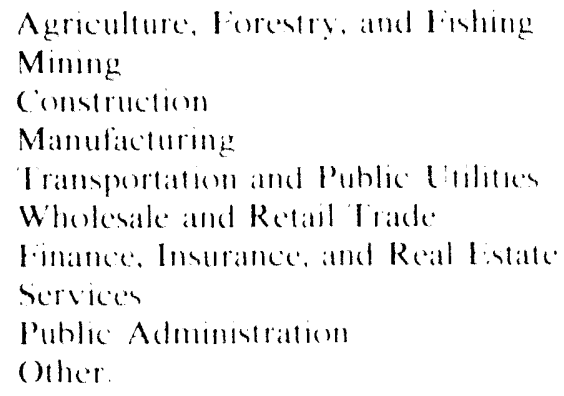

A list of the categorien of primatry husmess andwits within each classitication is contanned in Appendix ("

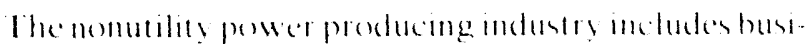

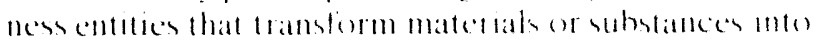
new products using mechameal ar ihemeal prosesses.

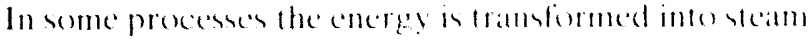
for gencrating both electresty and andether useful ther mal output. This themal antput can be ased direcelly in a matmutaturing process steh as paper productoon and inderectly for heatmg huildmgs on by ather end users. In the agricultural and manufiaturmg sectors. the usefut thermal energy is promarily for procese steam, while in the finametal sector the decful thermal encrgy is primarily for spate heatmes.

Energy Sources. Mose momutility pemer produceres use

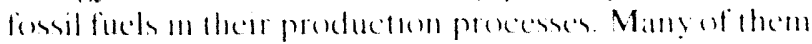

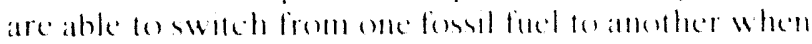
fuel supply is inferrupled of when there is a price ad

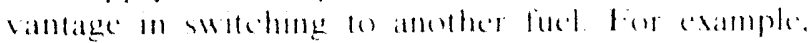


they may switch from gas 10 oil in winter when their gas supplies are diverted to residential use, or from on to coal when onl prices rise. Other nomutility power producers use vartous renewable energy sources Increasingly, many firms are also able 10 switch from fussil fuels te renewable fuch Many monutility power producers use combustors that are abte to burn two or more differeal fuels simultaneously, in varying rombinations. to generate the desired heal output. Other momutility power producers can omly hum one fuel at a time, but their combustors can he converted to burn different fuels. Finally, many producers have multiple combustors that use different fuels to supply heat or power. Thus, the adaptabslity of nonutility power pro. ducers to use multiple fuel soureses depends primarily (m) the type of erencrating equipmem at atable and on economic conditions a nonutility power producer

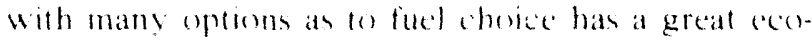
momice ad antage over a producer who is tied to onls ane fuel serurete.

\section{Data Sources}

Summary tatktice on momuthity capacily, generation. sales, and emtsutom in the l'nited States are prowided in the following tables. Data fer lege are preliminary: data for 1984 through 1991 are find " There data were chtamed from the Form FIA 867 . "Annual Nomutilits Power Producer Report" The form HalA-867 is a mandaterv survey of all existme and planmed momutility

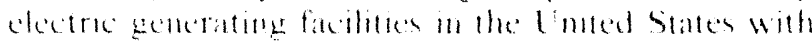
a tolal gencrator natmeplate capacity of l or more mega watte. In 1992. the reporting threshold of the form flA.867 was lowered he include all fatcilites with it combuned nameplate capaleits of 1 on more megawall

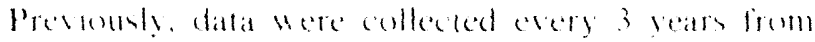

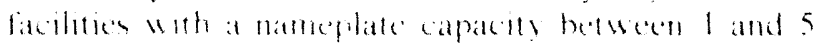
megawalls Plammed generaturs are defoned at a pro.

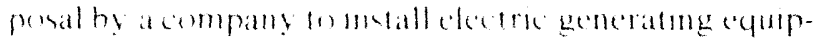

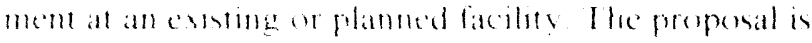

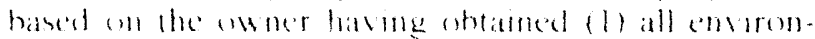
mental and regulatory apporsak. (2) a semed contrat

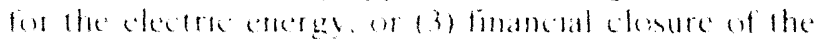

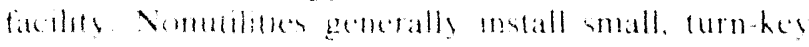
packaged genceramg latellates with mommal regulatory requiremente wheh result in completably less lead

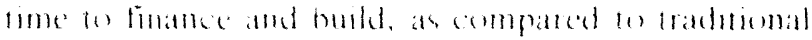

electric utility facilitues. Data on planned nonutility capacity additions as of December 31, 1992, are presented by energy source in Figure 15. These data represent all nomutility planned generating facilities that meet one or more of the criteria defuned earlier.

Some nonutility power producers of 1 or more megawatts use only fossil fuels: some use only renewable encrgy; and some use a combination of both fossil fuels and renewable energy sources. Although the majority of nonutility power producers generate electric: power using fossil energy, those using renewable energy represent a large portion of capacity. Because of the consumption of multiple energy sources by some generating units, capacily and generation were allocated by encrgy source. The algorithms used to allocate installed capacity and generation by entergy source are discussed in the Technical Notes (Appendix (c).

The onter energy sources in Tables 74, 76, and 79 include hydrogen, sulfur, batteries, chemicals, fish oil and soent sulfite liquor. Data previously published for other energy sources in 1989 and 1990 have been reclassified and are included in the category that best reflects its characteristics

The change in data prevously published in 1989 and 1990) for major industry groups in Tables 78 and 81 was duc to a clarification of a monutility facility's "pri. mary" businces acturity.

The change between the number of facilities previously publushed as qualifying and mon-qualsfyng in rables 77 and 80 in 1989 and 1990 , is dece to changes in facility status. The number of facilities shown for toge meludes operational facilitios in 1991 and new facilities or planned facelitics that became operational during that yeatis

The ental rapacity for 1989 through 1902 (Table 74) moluder all operable generatung umts including units mot normally used but on standhy with little or 100 exereration, and units ont of exvice for the entire reporting yeat that are expereded ob beturned to servecte in the fulure I nits on stanthy and out of service represented s percent of the total momutility generating capacity 111 199?

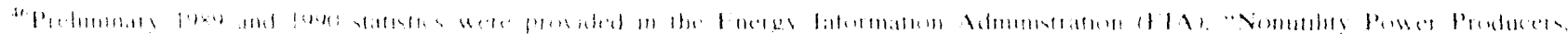

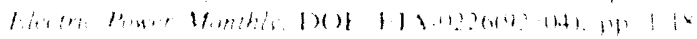


Figure 20. Topping-Cycle Plant Configuration

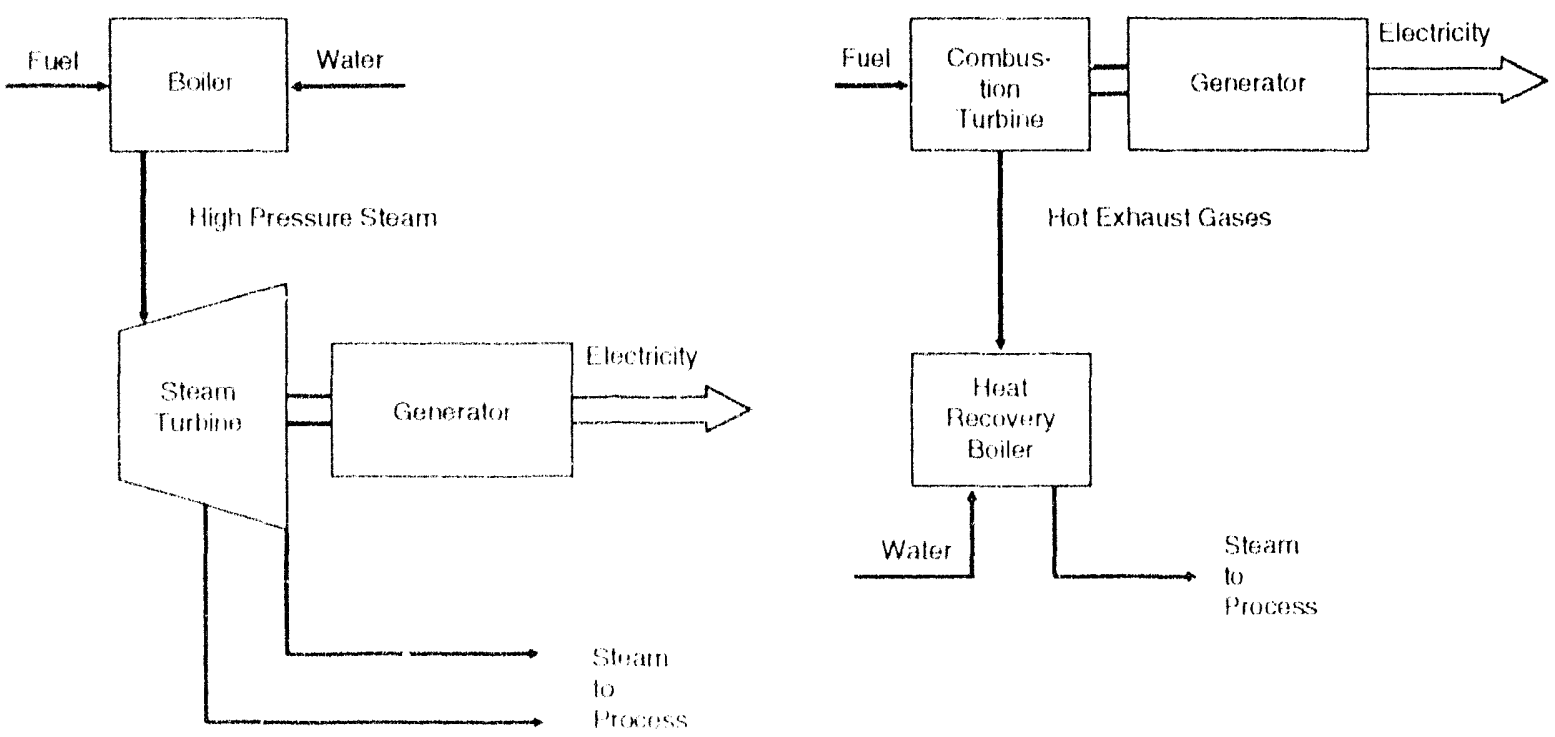

1. A boiler produces steam to power a turbinegenerator to produce electricity. The turbine steam leaving the turbine is used in thermal applications such as space heating or food preparation.

2. A combustion turbine or diesel engine bums fuel to spin a shaft connected to a generator to produce electricity. Waste heat from the buming fuel is recaptured in a waste-heat recovery boiler and is used for direct heating or is used to produce steam for thermal applications.

Source: Federal Energy Regulatory Commission, Cogeneration, 1985. 
Figure 21. Bottoming-Cycle Plant Configuration

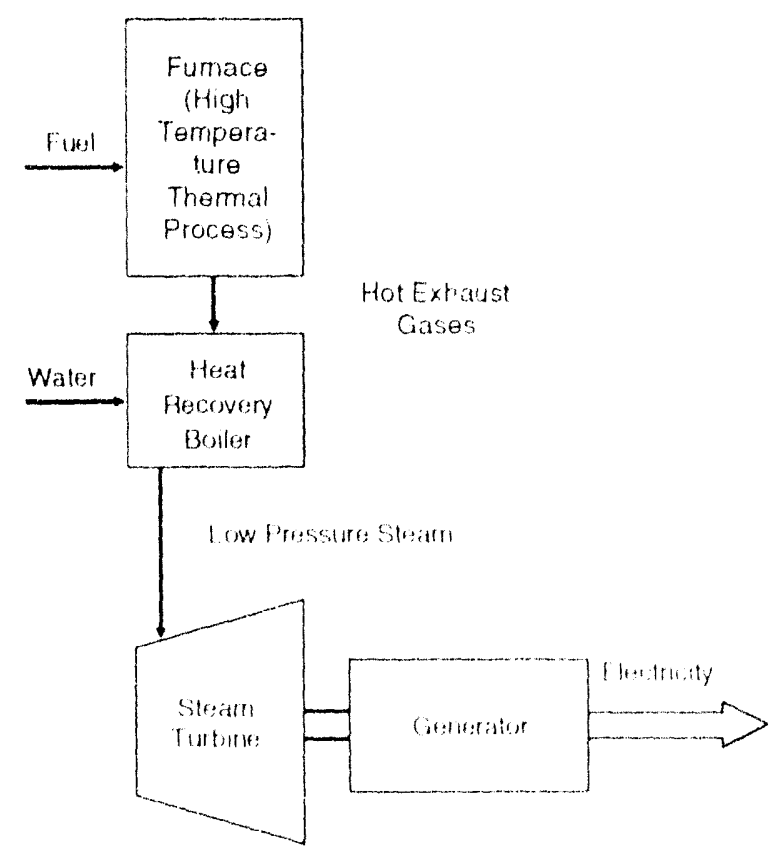

A fumace is used in a smelting or forming process. A waste-heat recovery boiler recaptures the unused energy and uses it to produce steam to drive a steam turbine generator to produce electricity.

Source: Federal Energy Regulatory Commission, Cogeneration, 1985. 
Table 74. Summary Statistics for U.S. Nonutility Power Producers, 1989 Through 1992

\begin{tabular}{|c|c|c|c|c|c|}
\hline \multirow{2}{*}{ Item } & \multirow{2}{*}{$\begin{array}{c}1 \text { Megawatt or } \\
\text { More } \\
1992\end{array}$} & \multicolumn{4}{|c|}{5 Megawatts or More } \\
\hline & & 1992 & 1991 & 1990 & 1989 \\
\hline Installed Capacity (megawatts) ............................ & 56,814 & 55,163 & 48,171 & 42,869 & 36,645 \\
\hline Coal' & 8,503 & 8,443 & 7,291 & 6,712 & 6,229 \\
\hline (.). & 1,730 & 1,579 & 1,207 & 811 & 917 \\
\hline Natural Gas' & 21,542 & 21,104 & 20,259 & 16,682 & 13,999 \\
\hline Petroleum/Natural Gas (Combined) ..................... & 8,478 & 8,354 & 5,049 & 6,167 & 4,439 \\
\hline 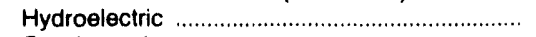 & 2.684 & 2,133 & 1,587 & 1,477 & 1,386 \\
\hline 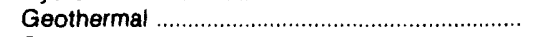 & 1,254 & 1,243 & 1,048 & 1,031 & 944 \\
\hline 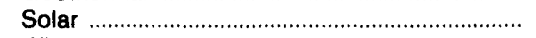 & 360 & 360 & 360 & 360 & 200 \\
\hline Wind & 1,822 & 1,786 & 1,652 & 1,405 & 1,339 \\
\hline Wood & 6,805 & 6.735 & 6,580 & 5.786 & 5,254 \\
\hline Waste ${ }^{6}$ & 3,006 & 2,805 & 2,627 & 2,230 & 1,742 \\
\hline 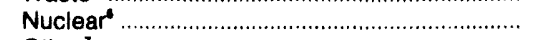 & 20 & 20 & 20 & 20 & 20 \\
\hline Other' & 611 & 602 & 491 & 187 & 176 \\
\hline Gross Generation (million kllowatthours) ..... & 296,001 & 289,856 & 248,448 & 217,241 & 187,356 \\
\hline Coal' & 47,363 & 47,160 & 40,587 & 32,131 & 31,511 \\
\hline Petroleum ${ }^{2}$ & 10,963 & 10,692 & 7.814 & 7,330 & 5,742 \\
\hline Natural Gas' & 158,798 & 156,317 & 131,340 & 116.706 & 98,875 \\
\hline 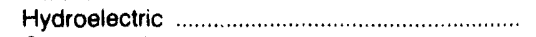 & 9,446 & 7,611 & 6,243 & 6,235 & 5,931 \\
\hline Geothermal & 8,578 & 8,533 & 7,651 & 6,872 & 5,046 \\
\hline 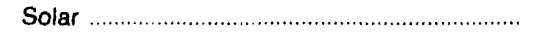 & 746 & 746 & 779 & 663 & 489 \\
\hline Wind & 2,916 & 2,872 & 2,606 & 2,251 & 1,833 \\
\hline Wood & 36,255 & 36.024 & 33.785 & 30,812 & 27,835 \\
\hline Waste ${ }^{8}$ & 17,352 & 16,330 & 13,956 & 11,415 & 8,296 \\
\hline 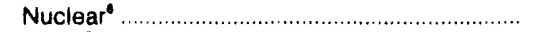 & 67 & 67 & 80 & 116 & 49 \\
\hline 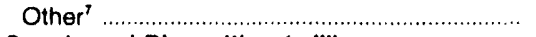 & 3,516 & 3,504 & 3,609 & 2,710 & 1,750 \\
\hline \multicolumn{6}{|l|}{$\begin{array}{l}\text { Supply and Disposition (million } \\
\text { kllowatthours) }\end{array}$} \\
\hline Gross Generation & 296,001 & 289,856 & 248,448 & 217,241 & 187,356 \\
\hline Receipts ${ }^{\bullet}$ & 83,421 & 76,198 & 68,264 & 63,743 & 61,479 \\
\hline Deliveries' & 175,160 & 171,836 & 140,537 & ค 126,048 & 98,916 \\
\hline Facility Use & 204,261 & 194,218 & A 176,175 & ' 154,936 & R 149,918 \\
\hline
\end{tabular}

- Includes coal, anthracite culm and coal waste.

? Includes petroleum, petroleum coke, diesel, kerosene, and petroleum sludge and tar.

3 Includes natural gas, butane, ethane, propane, waste heat and waste gases.

4 Includes wood, wood waste, peat, wood liquors, railroad ties, pitch and wood sludge

- Includes municipal solid waste, agricultural waste, straw, tires, landfill gases and other waste.

- Nuclear reactor and generator at Argonne National Laboratory used primarily for research and development in testing reactor fuels as well as for train-

ing. The generation from the unit is used for internal consumption.

Inciudes hydrogen, sulfur, batteries, chemicals, and spent sulfite liquor. Data previously published for other energy sources in 1989 and 1990 have been reclassified and are included in the category that best reflects its characteristics

- Includes purchases, interchanges, and exchanges of electric energy with utilities and other nonutilities

- Includes sales, interchanges, and exchanges of electric energy with utilities and other nonutilities. The disparity in this data and data reported on other EIA surveys occurs due to differences in the respondent universe. The Form EIA-867 is filed by nonutilities reporting the energy delivered, while other data sources are filed by electric utilities reporting energy received. Differences in terminology and accounting procedures attribute to the disparity. In addition, since the trame for the Form ElA.867 is derived from utility surveys the Form EIA.867 universe lags 1 year.

$\mathrm{R}=$ Revised data.

Notes: Data for 1992 are preliminary; data for prior years are final. •Totals may not equal sum of components because of independent rounding.

- Percent change is calculated before rounding. - See the Technical Notes for the methodology for allocating capacity and generation by energy sources, respectively.

Source: Energy Information Administration, (EIA) Form ElA-867, "Annual Nonutility Power Producer Report." 
Table 75. Installed Capacity at Nonutility Generating Facilities by Fossil Fuels, Renewable Energy Sources, and Census Division, 1989 Through 1992 (Megawatts)

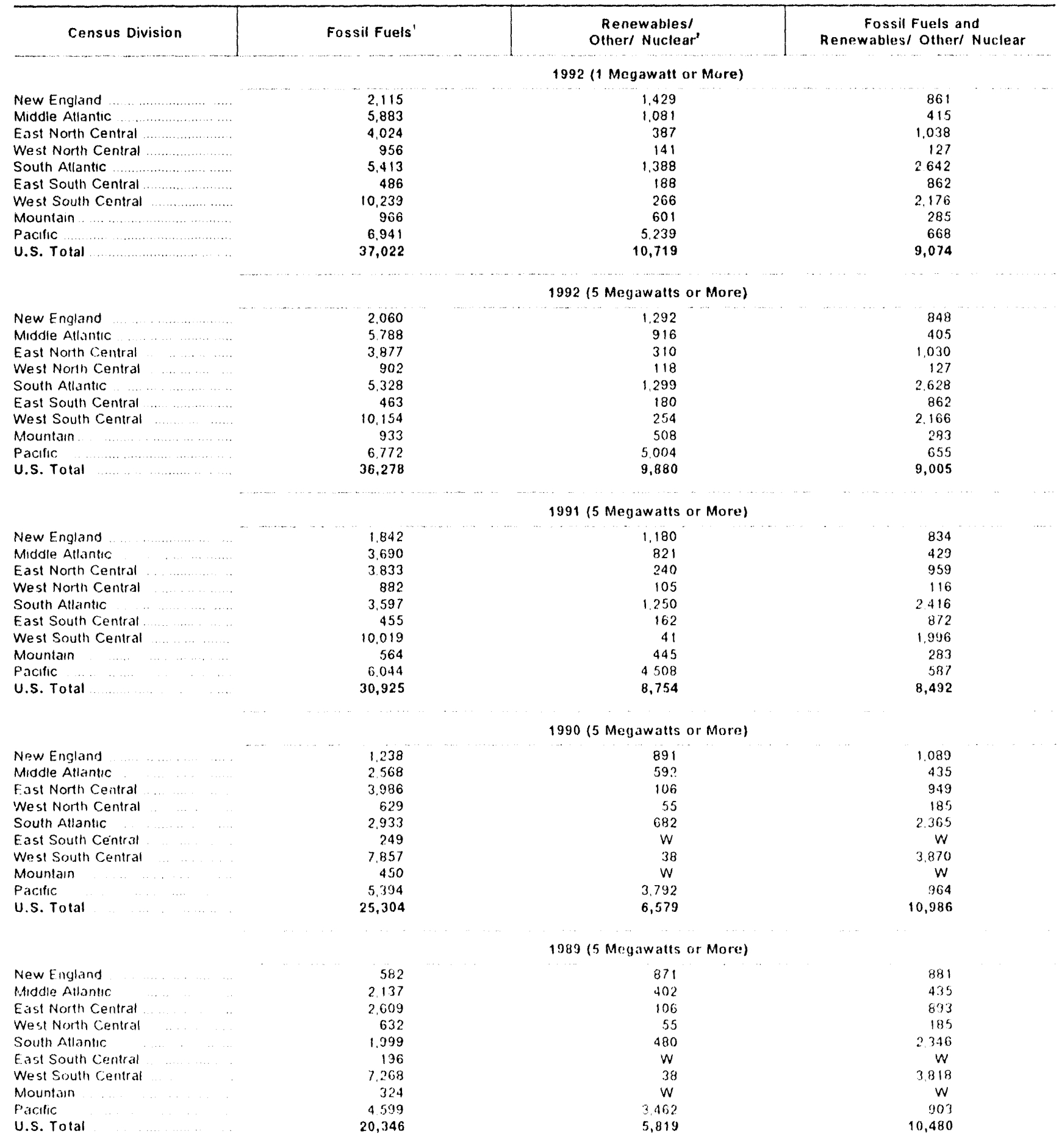

includes petroleum natural gas and coat as a single energy source

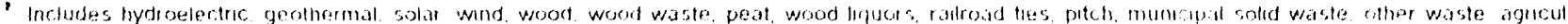

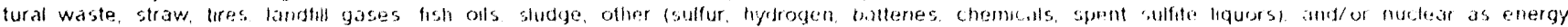
sources

$W=$ Witheld to avoid disclosure of indusdual company data

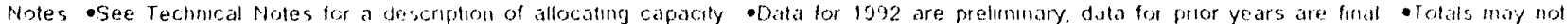
equal sum of components because of independent rounding.

Source Energy Information Administration. Form E1A 967. "Annual Nonutility Prower Producer Repert" 
Table 76. Installed Capacity at Nonutility Generating Facilities by Energy Source and Census Division, 1989 Through 1992 (Megawatts)

\begin{tabular}{|c|c|c|c|c|c|c|c|}
\hline Census Division & Coal' & $\begin{array}{c}\text { Natural } \\
\text { Gas' }^{\prime}\end{array}$ & $\begin{array}{l}\text { Petroleum and } \\
\text { Petroleum/ } \\
\text { Natural Gas } \\
\text { (Combined) }\end{array}$ & $\begin{array}{l}\text { Hydroelectric/ } \\
\text { Geothermall } \\
\text { Solarl } \\
\text { Wind }\end{array}$ & $\begin{array}{l}\text { Wood"' } \\
\text { Waste" }\end{array}$ & $\begin{array}{l}\text { Other' } 1 \\
\text { Nuclear }\end{array}$ & Total \\
\hline & \multicolumn{7}{|c|}{1992 (1 Megawatt or More) } \\
\hline New England & 261 & 413 & 1,702 & 579 & 1,448 & $\cdots$ & 4,404 \\
\hline 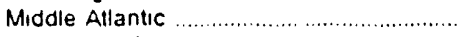 & 1,582 & 1.570 & 2.971 & W & 787 & W & 7,379 \\
\hline East North Central. & 1.240 & 2,845 & 619 & $w$ & 626 & w & 5,449 \\
\hline 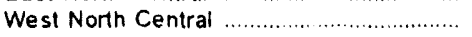 & 737 & 146 & 146 & 73 & 122 & $\cdots$ & 1,224 \\
\hline South Allantic & 2.649 & 825 & 2.474 & 205 & 2,870 & 420 & 9,443 \\
\hline 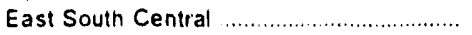 & 288 & 255 & $W$ & -- & 889 & $W$ & 1,535 \\
\hline 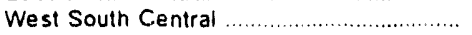 & 828 & 9.521 & 1,020 & W & 1,095 & $w$ & 12,680 \\
\hline Mountain & 175 & 790 & $W$ & 514 & 166 & W & 1,852 \\
\hline 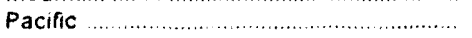 & 743 & 5,176 & W & 4,037 & 1.808 & $w$ & 12,848 \\
\hline \multirow[t]{2}{*}{ U.S. Total. } & 8,503 & 21,542 & 10,207 & 6,120 & 9,812 & 630 & 56,814 \\
\hline & \multicolumn{7}{|c|}{1992 (5 Megawatts or More) } \\
\hline (2) & $W$ & $w$ & 1,660 & 463 & 1,418 & -- & 4,200 \\
\hline 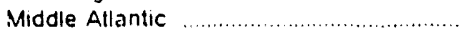 & 1.572 & 1.541 & 2,906 & $W$ & 735 & W & 7,108 \\
\hline 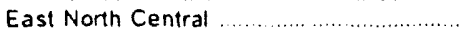 & 1,221 & 2,751 & 577 & $w$ & 591 & W & 5,217 \\
\hline West North Central & 733 & W & 111 & $W$ & 116 & - & 1,147 \\
\hline South Atlantic & 2.632 & 797 & 2.433 & 155 & 2.822 & 415 & 9,255 \\
\hline 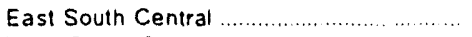 & 285 & 239 & $w$ & -- & 880 & W & 1,505 \\
\hline 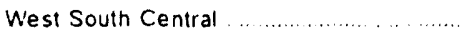 & $w$ & 9.453 & 996 & W & 1.084 & W & 12.574 \\
\hline 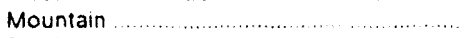 & 175 & 764 & $w$ & 426 & 159 & $w$ & 1,724 \\
\hline 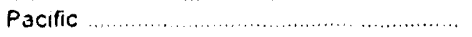 & 741 & 5,024 & W & 3,868 & 1734 & $w$ & 12.431 \\
\hline \multirow[t]{2}{*}{ U.S. Total } & 8,443 & 21,104 & 9,933 & 5,522 & 9,540 & 622 & 55,163 \\
\hline & \multicolumn{7}{|c|}{1991 ( 5 Megawatts or More) } \\
\hline 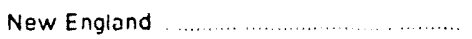 & 353 & 793 & 1.086 & 432 & 192 & $\cdots$ & 3,856 \\
\hline Middle Atlantic & 1328 & 1,053 & 1,636 & 239 & 684 & $m$ & 4.940 \\
\hline 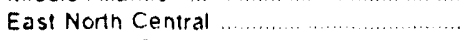 & 1.035 & 2810 & 523 & 59 & 577 & - & 5,033 \\
\hline 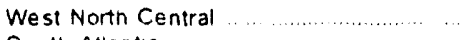 & W & $w$ & 84 & 55 & 104 & - & 1,103 \\
\hline South Allantic $\ldots \ldots \ldots \ldots$ & 2.114 & 632 & 1,165 & 155 & 2.809 & 388 & 7,263 \\
\hline East South Central & 276 & 239 & W & - & 874 & W & 1,489 \\
\hline 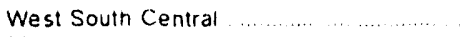 & $w$ & 9,244 & 806 & - & 1.157 & $w$ & 12,056 \\
\hline 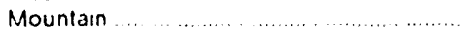 & 162 & 489 & $w$ & 363 & 159 & $w$ & 1292 \\
\hline 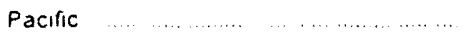 & $w$ & $W$ & 824 & 3.343 & 1,652 & 13 & 11.138 \\
\hline \multirow[t]{2}{*}{ 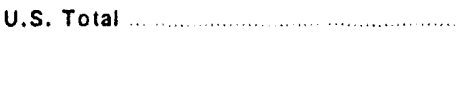 } & 7,291 & 20,259 & 6,256 & 4,647 & 9,207 & 510 & 48,171 \\
\hline & \multicolumn{7}{|c|}{1990 (5 Megawatts or More) } \\
\hline New England... & 358 & 218 & 1,052 & 418 & 1,171 & $\cdots$ & 3.218 \\
\hline 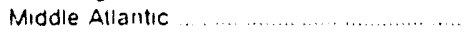 & 1.053 & 409 & 1,386 & 239 & 507 & - & 3.595 \\
\hline 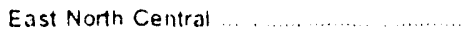 & 1,181 & 2.673 & 736 & 50 & 401 & - & 5.040 \\
\hline 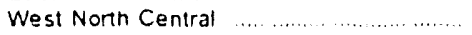 & 640 & W & $W$ & 55 & 122 & - & 869 \\
\hline South Aflantic & 1.733 & 621 & 953 & $w$ & 2.392 & w & 5,980 \\
\hline East South Central & 256 & $w$ & - & -. & 817 & W & 1.273 \\
\hline West South Central & 892 & 8.771 & 1.261 & $\cdots$ & 841 & -- & 11,765 \\
\hline Mountain $\ldots$ & $w$ & 347 & $W$ & 308 & 94 & W & 978 \\
\hline \multirow{3}{*}{$\begin{array}{l}\text { Pacific } \\
\text { U.S. Total }\end{array}$} & W & W & 1,489 & W & 1.670 & $\cdots$ & 10.150 \\
\hline & 6,712 & 16,682 & 6,978 & 4,274 & 8,016 & 206 & 42,869 \\
\hline & \multicolumn{7}{|c|}{1989 (5 Megawatts or More) } \\
\hline New England & $w$ & $w$ & 571 & 398 & 1,109 & - & 2.333 \\
\hline 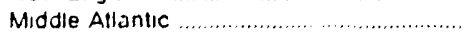 & 997 & 356 & 1.044 & 191 & 386 & -- & 2,974 \\
\hline 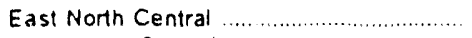 & 1,087 & 1,287 & 721 & 50 & 463 & $\cdots$ & 3,607 \\
\hline 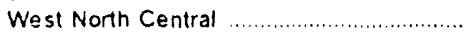 & 643 & $w$ & W & 55 & 122 & $\cdots$ & 872 \\
\hline South Atlantic & 1,805 & 328 & 425 & W & 1.996 & W & 4,824 \\
\hline 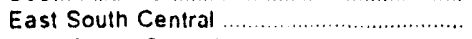 & 298 & $w$ & -- & $\ldots$ & 661 & $w$ & 1,123 \\
\hline 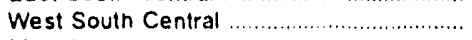 & 726 & 8,625 & 1,002 & $\ldots$ & 771 & - & 11,124 \\
\hline 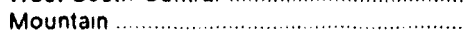 & $w$ & 263 & $W$ & 283 & 91 & W & 823 \\
\hline Pacific . . . . . . & $w$ & 3,001 & 1.490 & $w$ & 1.397 & - & 8.963 \\
\hline U.S. Tolal & 6,229 & 13,999 & 5,356 & 3,870 & 6,997 & 195 & 36,645 \\
\hline
\end{tabular}

- Includes coal, anthracite culm and coal waste

- Includes natural gas, butane, ethane, propane, waste heat and waste gases.

- Includes petroleum, petroleum coke, diesel, kerosene, and petroleum sludge and tar

- Includes petroleum used as a single energy source, and petroleum and natural gas used as a fuel combination by themselves and with other fuels

- Includes wood, wood waste, peat, wood liquors, railroad ties. pitch and wood sludge

- Includes municipal solid waste agricultural waste, straw, tires, landill gases, fish oils, and other waste

- Includes hydrogen. sulfur, batteries. chemicals, and spent suffite liquor Data prevously published for other energy sources have been reclassified and are included in the category that best reflects its characteristics $W=$ Withheld to avoid disclosure of indivinal company data. Notes. Data for 1992 are preilminary, data for prior years are final. - Totals may not equal sum of components because of independent rounding Source. Energy Information Administration, Form ElA-867. "Annual Nonutility Power Producer Report" 
Table 77. Installed Capacity at Nonutility Generating Facilities by Qualifying Facility Status and Census Division, 1989 Through 1992 (Megawatts)

\begin{tabular}{|c|c|c|c|c|c|c|}
\hline \multirow[b]{2}{*}{ Census Division } & \multicolumn{2}{|c|}{ QF Capacity } & \multicolumn{2}{|c|}{ Non-QF Capacity } & \multicolumn{2}{|c|}{ Total Capacity } \\
\hline & $\begin{array}{l}\text { No. of } \\
\text { Facilities }\end{array}$ & $\underset{\text { (megawatts) }}{\text { Capacity }}$ & $\begin{array}{l}\text { No. of } \\
\text { Facllities }\end{array}$ & $\underset{\text { (megawatts) }}{\text { Capacity }}$ & $\begin{array}{l}\text { No. of } \\
\text { Facilities }\end{array}$ & $\begin{array}{c}\text { Capacity } \\
\text { (megawatts) }\end{array}$ \\
\hline & \multicolumn{6}{|c|}{1992 (1 Megawatt or More) } \\
\hline 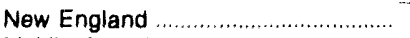 & 111 & 3,077 & 75 & 1,327 & 186 & 4,404 \\
\hline 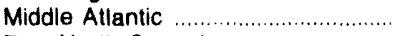 & 211 & 6.924 & 48 & 455 & 259 & 7,379 \\
\hline East North Centrai .............................. & 95 & 3,341 & 99 & 2,108 & 194 & 5,449 \\
\hline South Atlantic & 127 & 6,256 & 95 & 3,187 & 222 & 9,443 \\
\hline 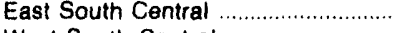 & 23 & 822 & 23 & 713 & 46 & 1,535 \\
\hline West South Central ............................... & 107 & 10,551 & 59 & 2,128 & 166 & 12,680 \\
\hline 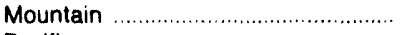 & 73 & 1.313 & 37 & 540 & 110 & 1,852 \\
\hline Pacific & 409 & 10,972 & 149 & 1,876 & 558 & 12,848 \\
\hline \multirow[t]{2}{*}{ U.S. Total } & 1,179 & 43,760 & 629 & 13,054 & 1,808 & 56,814 \\
\hline & \multicolumn{6}{|c|}{1992 (5 Megawatts or More) } \\
\hline 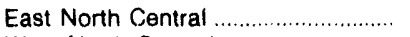 & 43 & 3,220 & 56 & 1,998 & 99 & 5,217 \\
\hline West North Central .............................. & 14 & 475 & 27 & 672 & 41 & 1,147 \\
\hline 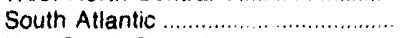 & 96 & 6,163 & 50 & 3.092 & 146 & 9,255 \\
\hline East South Central ............................... & 18 & 811 & 16 & 694 & 34 & 1,505 \\
\hline West South Central & 93 & 10,508 & 33 & 2,066 & 126 & 12,574 \\
\hline 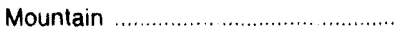 & 41 & 1,235 & 17 & 489 & 58 & 1.724 \\
\hline Pacific & 300 & 10,718 & 83 & 1,714 & 383 & 12,431 \\
\hline \multirow[t]{2}{*}{ U.S. Total } & B16 & 42,848 & 318 & 12,315 & 1,134 & 55,163 \\
\hline & \multicolumn{6}{|c|}{1991 (5 Megawatts or More) } \\
\hline 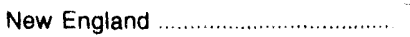 & 69 & 2,719 & 22 & 1.137 & 91 & 3,856 \\
\hline Middle Atlantic . .................................. & 105 & 4,474 & 17 & 467 & 122 & 4,940 \\
\hline 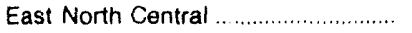 & 38 & 3,080 & 52 & 1,954 & 90 & 5,033 \\
\hline West North Central ............................. & 14 & 478 & 22 & 625 & 36 & 1,103 \\
\hline 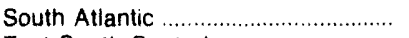 & 86 & 5,149 & 47 & 2,113 & 133 & 7,263 \\
\hline 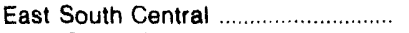 & 16 & 753 & 17 & 736 & 33 & 1,489 \\
\hline 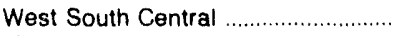 & 87 & 10,016 & 30 & 2,040 & 117 & 12,056 \\
\hline 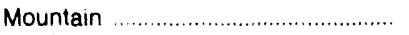 & 28 & 843 & 15 & 449 & 43 & 1,292 \\
\hline 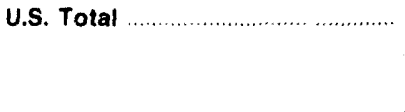 & \multicolumn{6}{|c|}{1990 (5 Megawatts or More) } \\
\hline 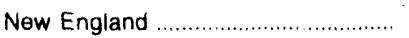 & 66 & 2,352 & 18 & 866 & 84 & 3.218 \\
\hline 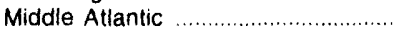 & 90 & 3,142 & 15 & 453 & 105 & 3,595 \\
\hline East North Central ................................ & 37 & 3,072 & 50 & 1,969 & 87 & 5,040 \\
\hline 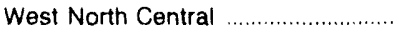 & 14 & 478 & 11 & 391 & 25 & 869 \\
\hline 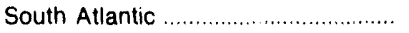 & 79 & 4.621 & 35 & 1,359 & 114 & 5,980 \\
\hline 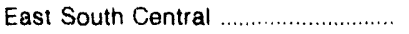 & 14 & 543 & 15 & 730 & 29 & 1,273 \\
\hline 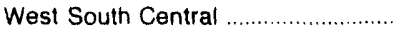 & 84 & 9,890 & 25 & 1,875 & 109 & 11,765 \\
\hline 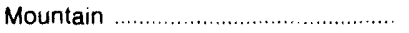 & 26 & 634 & 10 & 344 & 36 & 978 \\
\hline 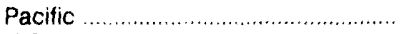 & 248 & 8,592 & 77 & 1,558 & 325 & 10.150 \\
\hline \multirow[t]{2}{*}{ U.S. Total } & 658 & 33,323 & 256 & 9,546 & 914 & 42,869 \\
\hline & \multicolumn{6}{|c|}{1989 (5 Megawatts or More) } \\
\hline 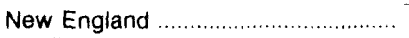 & 59 & 1,766 & 15 & 568 & 74 & 2,333 \\
\hline 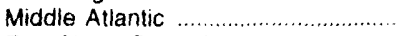 & 73 & 2,513 & 16 & 461 & 89 & 2,974 \\
\hline 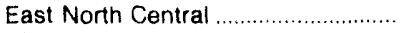 & 34 & 1,637 & 48 & 1,970 & 82 & 3,607 \\
\hline West North Central .............................. & 14 & 478 & 11 & 394 & 25 & 872 \\
\hline 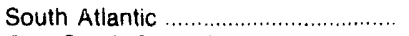 & 68 & 3,414 & 38 & 1,411 & 106 & 4,824 \\
\hline 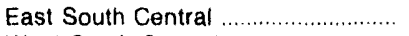 & 14 & 543 & 13 & 580 & 27 & 1,123 \\
\hline 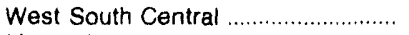 & 79 & 9,165 & 24 & 1,959 & 103 & 11,124 \\
\hline 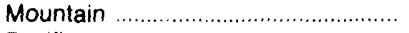 & 21 & 483 & 10 & 341 & 31 & 823 \\
\hline 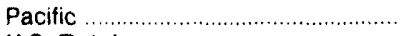 & 214 & 7,431 & 74 & 1,533 & 288 & 8,963 \\
\hline U.S. Total & 576 & 27,429 & 249 & 9,216 & 825 & 36,645 \\
\hline
\end{tabular}

QF :- Nonutility generating facilities that have obtained status as qualifying facilities under the Public Utility Regulatory Policies Act of 1978

Notes: - Data for 1992 are preliminary; data for prior years are final. The shift between the number of facilities previously published as qualifying and non-qualifying in 1989 and 1990 is due to changes in facility status. The number of facilities shown for 1992 includes operational facilities in 1991 and new facilities or planned facilities that became operational during that year. Potals may not equal sum of components because of independent rounding.

Source: Energy Information Administration, Form ElA-867, "Annual Nonutility Power Producer Report." 
Table 78. Installed Capacity at Nonutility Generating Facilities by Major Industry Group and Census Division, 1989 Through 1992

(Megawatts)

\begin{tabular}{|c|c|c|c|c|c|c|c|}
\hline Census Division & Manufacturing & $\left\{\begin{array}{c}\text { Transportation } \\
\text { and } \\
\text { Public Utilities }\end{array}\right.$ & Services & Mining & $\begin{array}{c}\text { Public } \\
\text { Administration }\end{array}$ & $\begin{array}{l}\text { Other } \\
\text { Industry } \\
\text { Groups }\end{array}$ & Total \\
\hline & \multicolumn{7}{|c|}{1992 (1 Megawalt or inore) } \\
\hline New England. & 2.120 & 2.167 & $w$ & $\cdots$ & $w$ & - & 4,404 \\
\hline Middle Atlantic $\ldots \ldots \ldots \ldots$ & 5,112 & 1.395 & 410 & W & $w$ & 162 & 7,379 \\
\hline 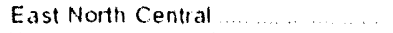 & 4.864 & 253 & 239 & $w$ & $w$ & W & 5,449 \\
\hline 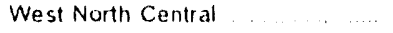 & 695 & W & 138 & W & $w$ & $w$ & 1,224 \\
\hline South Atlantic & 6.371 & 2.824 & 150 & w & $w$ & 61 & 9.443 \\
\hline East South Central & 1.497 & $w$ & $w$ & $w$ & W & $\ldots$ & 1,535 \\
\hline West South Central & 11,865 & 442 & 193 & 180 & $\cdots$ & $\cdots$ & 12,630 \\
\hline Mountain $\ldots$. & 746 & 474 & 157 & 197 & - & 278 & 1.852 \\
\hline Pacific $\quad \ldots \ldots \ldots$ & 4.342 & 6.200 & 239 & 1,500 & 326 & 182 & 12.8 .48 \\
\hline \multirow[t]{2}{*}{ U.S. Total } & 37,612 & 13,951 & 1,643 & 2,413 & 483 & 713 & 56,814 \\
\hline & \multicolumn{7}{|c|}{1992 (5 Megawatts or More) } \\
\hline New England & 2061 & 2.036 & 103 & $\cdots$ & $\cdots$ & $\ldots$ & 4200 \\
\hline Middle Atlantic & 5041 & 1.227 & 382 & W & W & 162 & 7,108 \\
\hline East North Central & 4749 & 185 & 197 & $w$ & $\ldots$ & $W$ & 5,217 \\
\hline West North Central & 650 & W & 131 & w & $\cdots$ & - & 1,147 \\
\hline South Allantic $\ldots$ & 6.29 & 2,752 & 130 & $\cdots$ & w & W & 9255 \\
\hline East South Centrat & 1.481 & $W$ & -- & $\cdots$ & $w$ & $-\infty$ & 1,505 \\
\hline West South Central .................... & 11.803 & 431 & 174 & 166 & $\cdots$ & $\cdots$ & 12.574 \\
\hline 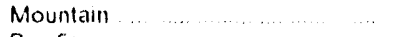 & 734 & 379 & 144 & 188 & $\cdots$ & $2 ? 8$ & 1724 \\
\hline Pacific $\ldots \ldots \ldots$ & 4.251 & 5.975 & 173 & 1.546 & 318 & 168 & 12431 \\
\hline \multirow[t]{3}{*}{ U.S. Total } & 37,066 & 13,163 & 1,434 & 2,361 & 455 & 685 & 55,163 \\
\hline & $\ldots \ldots$ & & $\cdots$ & & - & $\cdots$ & \\
\hline & \multicolumn{7}{|c|}{1991 (5 Megawatts or More) } \\
\hline New England & 1.925 & 1.898 & 33 & $\cdots$ & - & -- & 3356 \\
\hline Middle Allantic $\ldots . . . . . . . .$. & 3,326 & 984 & 184 & W & W & 162 & 4940 \\
\hline East North Central & 4.627 & 109 & 193 & w & - & W & 5033 \\
\hline West North Central & 607 & $N$ & 130 & W & $\cdots$ & $\ldots$ & 1.10 .3 \\
\hline South Allantic & 5,474 & $1,: 7$ & 124 & $\cdots$ & W & W & 7.26 .3 \\
\hline East South Central $\ldots$ & 1.466 & W & - & $\cdots$ & W & $\cdots$ & 1.489 \\
\hline West South Centrat ...... & 11.291 & 464 & W & W & $\cdots$ & - & 12056 \\
\hline Mountarn & 493 & 316 & W & $w$ & $\cdots$ & .268 & $1: 92$ \\
\hline Pacific & 3558 & $W$ & W & $w$ & $w$ & $W$ & 111,19 \\
\hline \multirow[t]{3}{*}{ U.S. Total } & 32,767 & 10,946 & 1,111 & 2,199 & 455 & 693 & 48,171 \\
\hline & & & & & $\ldots \ldots \ldots$ & & \\
\hline & \multicolumn{7}{|c|}{1990 (5 Meqawatts or More) } \\
\hline New England $\ldots \ldots \ldots$ & 1.558 & $w$ & $w$ & $\cdots$ & $\cdots$ & $\cdots$ & 3218 \\
\hline Middle Atlantic $\quad \ldots \ldots \ldots . . . . . . . . . .$. & 2.387 & 727 & 132 & W & W & 162 & 3.595 \\
\hline East North Central & 4.650 & 109 & 185 & $w$ & $\cdots$ & $w$ & 5040 \\
\hline West North Central & 551 & $w$ & $w$ & W & $\cdots$ & - & 869 \\
\hline 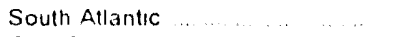 & 4.968 & 918 & W & $\cdots$ & $w$ & W & 5.980 \\
\hline East South Central & 1.250 & $w$ & $-\infty$ & - & $w$ & $\cdots$ & 1.273 \\
\hline West South Central & 10,990 & 464 & W & w & $\cdots$ & - & 11,765 \\
\hline Mountain $\ldots \ldots \ldots$ & 249 & 264 & $w$ & $w$ & - & 268 & 978 \\
\hline Pacific ... $\quad \ldots \quad \ldots \ldots$ & 3.382 & W & $W$ & W & 315 & $W$ & $10: 50$ \\
\hline \multirow[t]{2}{*}{ U.S. Total $\ldots$} & 29,985 & 8,937 & 869 & 1,955 & 452 & 670 & 42,869 \\
\hline & \multicolumn{7}{|c|}{1989 (5 Megawalts or More) } \\
\hline New England & 1,203 & $w$ & $w$ & - & $\cdots$ & $\cdots$ & 2,333 \\
\hline Middie Atlantic $\quad \ldots \ldots \ldots \ldots$ & 2.082 & 531 & 76 & w & w & W & 2,974 \\
\hline East North Central $\ldots \ldots \ldots$ & 3.220 & 109 & 182 & w & - & W & 3,607 \\
\hline 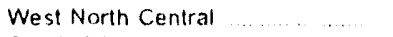 & 554 & $w$ & W & W & - & - & 872 \\
\hline South Atlantic & 4,263 & 468 & W & $\cdots$ & W & W & 4.824 \\
\hline East South Central $\ldots \ldots . . . .$. & 1,100 & $W$ & $\cdots$ & $\cdots$ & W & $\cdots$ & 1,123 \\
\hline 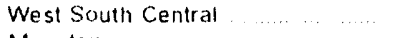 & 10,453 & 361 & W & W & - & $\cdots$ & 11124 \\
\hline 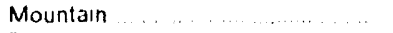 & 240 & 194 & $w$ & $w$ & - & W & 823 \\
\hline 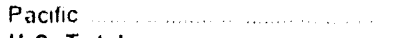 & 3.076 & W & $w$ & 1,125 & 315 & w & 8,963 \\
\hline U.S. Total $\ldots \ldots \ldots$ & 26,190 & 7,058 & 777 & 1,716 & 452 & 452 & 36,645 \\
\hline
\end{tabular}

$W=$ Witheld to avoid disclosure of individual company data

Notes. Data for 1992 are preliminary, data for prior years are final - See Techncal Notes for Standard Industrial Classifications for these industry groups - Totals may not equal sum of components because of independent rounding

Source: Energy Information Administration. Fom E1A-867. "Annual Nonutility Power Producer Report" 
Table 79. Gross Generation for NonutMity Power Producers by Energy Source and Census Division, 1989 Through 1992

(Million Kilowatthours)

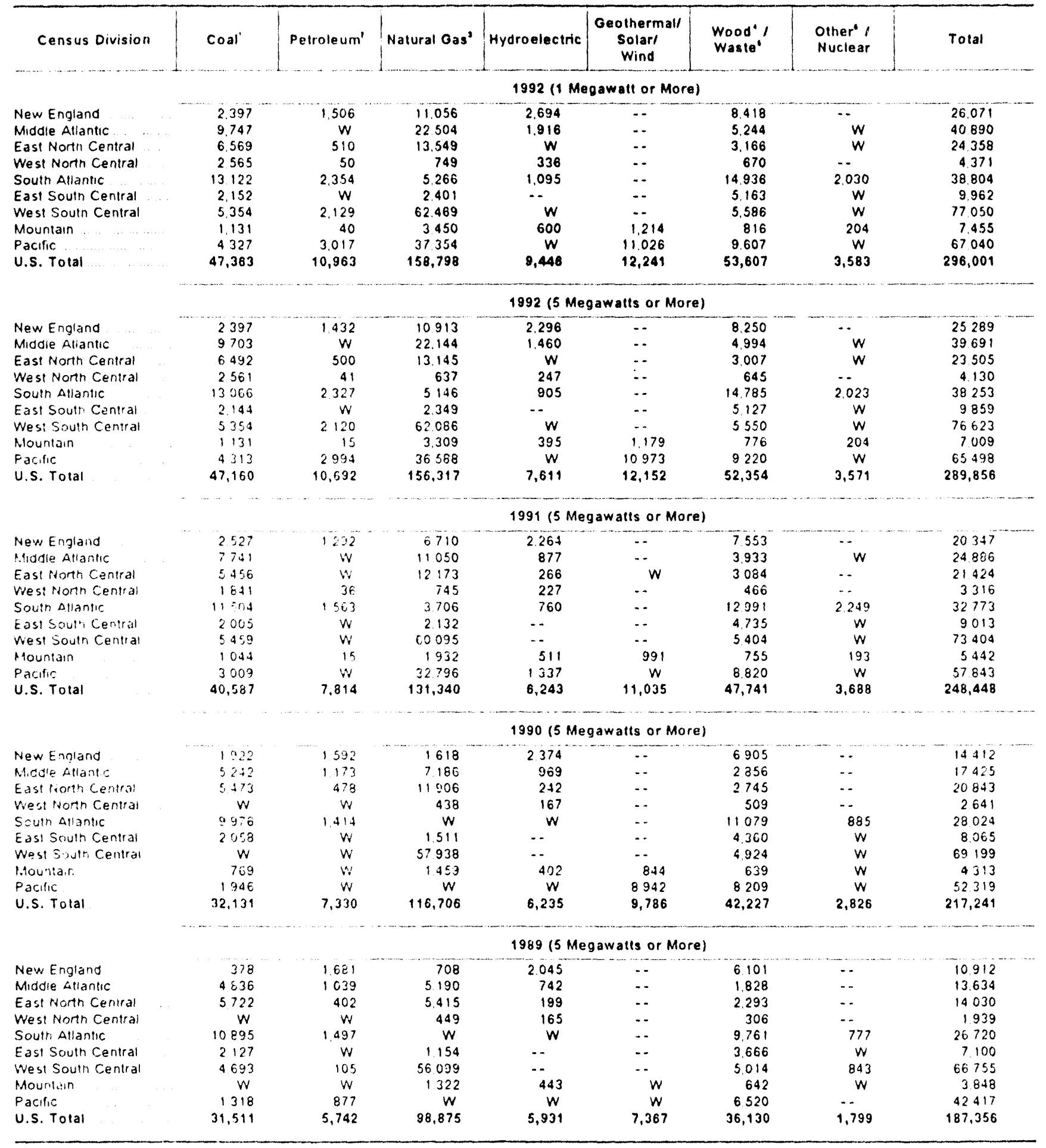

- Incluces coal antiracie culm and coal waste

- includes petroleum petroleum core diesel kerosene and petroleum sludge and tar

- Includes natural gas butane ethane propane waste heat and waste gases

- Includes wood wood waste peat wooj liquars faltrad ties pitch and wood sludge

- Includes municipal solid waste agricullural waste straw tires landfill gases fish oils. and other waste

- Irrtwdes hvdroger sultur batteries chemica's and spent suffite hquor Data prevously pudished for other energy sources have been reclassified and are tricluded in the categon, that best rellects its charactaristics $w=$ vill:held to arod discosure of individuat conosny data

Piotes - Data for 1992 are greilminary dala for pror years are final - Tolals may not equal sum of components because of independent rounding Source Energy Inicination Administration. Form Ela.867. Arinual Nonutility Power Producer Fepon." 
Table 80. Gross Generation at Nonutillty Generating Facillties by Qualifying Facility Status and Census Divislon, 1989 Through 1992

(Million Kilowatthours)

\begin{tabular}{|c|c|c|c|c|c|c|}
\hline \multirow[b]{2}{*}{ Census Divialon } & \multicolumn{2}{|c|}{ OF Generation } & \multicolumn{2}{|c|}{ Non-QF Ceneration } & \multicolumn{2}{|c|}{ Total Generation } \\
\hline & $\begin{array}{l}\text { No. of } \\
\text { Facilities }\end{array}$ & $\begin{array}{c}\text { Qeneration } \\
\text { (million } \\
\text { kllowatthours) }\end{array}$ & $\begin{array}{l}\text { No. of } \\
\text { Faclitiles }\end{array}$ & $\begin{array}{c}\text { Ceneration } \\
\text { (million } \\
\text { kllowatthours) }\end{array}$ & $\begin{array}{l}\text { No. of } \\
\text { Facilities }\end{array}$ & $\begin{array}{l}\text { Generation } \\
\text { (million } \\
\text { kllowatthours) }\end{array}$ \\
\hline & \multicolumn{6}{|c|}{1902 (1 Megawatt or More) } \\
\hline $\begin{array}{l}\text { New England } \\
\text { Middle Atlantic } \\
\text { East North Central } \\
\text { West North Central } \\
\text { South Atlantic } \\
\text { East South Central } \\
\text { West South Central } \\
\text { Mountain } \\
\text { Pacific } \\
\text { U.S. Total }\end{array}$ & $\begin{array}{r}111 \\
211 \\
95 \\
23 \\
127 \\
23 \\
107 \\
73 \\
409 \\
1,179\end{array}$ & $\begin{array}{r}18,717 \\
38,758 \\
15,683 \\
2,073 \\
28,916 \\
5,413 \\
65,080 \\
5,507 \\
60,979 \\
241,126\end{array}$ & $\begin{array}{r}75 \\
48 \\
99 \\
44 \\
95 \\
23 \\
59 \\
37 \\
149 \\
629\end{array}$ & $\begin{array}{r}7,354 \\
2,132 \\
8,675 \\
2,298 \\
9,888 \\
4,549 \\
11,970 \\
1,948 \\
6,061 \\
\mathbf{5 4 , 8 7 5}\end{array}$ & $\begin{array}{r}186 \\
259 \\
194 \\
67 \\
222 \\
46 \\
166 \\
110 \\
558 \\
1,808\end{array}$ & $\begin{array}{r}26,071 \\
40,890 \\
24,358 \\
4,371 \\
38,804 \\
9,962 \\
77,050 \\
7,455 \\
67,040 \\
298,001\end{array}$ \\
\hline & \multicolumn{6}{|c|}{1092 (5 Megawatts or More) } \\
\hline $\begin{array}{l}\text { New England } \\
\text { Middle Allantic } \\
\text { East North Central } \\
\text { West North Central } \\
\text { South Allantic } \\
\text { East South Central } \\
\text { West Sousth Central } \\
\text { Mountain } \\
\text { Pacific } \\
\text { U.S. Total }\end{array}$ & $\begin{array}{r}79 \\
132 \\
43 \\
14 \\
96 \\
18 \\
93 \\
41 \\
300 \\
816\end{array}$ & $\begin{array}{r}18,352 \\
37,900 \\
15,122 \\
1,949 \\
28,621 \\
5,367 \\
64,927 \\
5,223 \\
59,933 \\
237,394\end{array}$ & $\begin{array}{r}22 \\
14 \\
56 \\
27 \\
50 \\
16 \\
33 \\
17 \\
83 \\
318\end{array}$ & $\begin{array}{r}6,937 \\
1,791 \\
8,383 \\
2,180 \\
9,632 \\
4,492 \\
11,696 \\
1,785 \\
5,565 \\
52,461\end{array}$ & $\begin{array}{r}101 \\
146 \\
99 \\
41 \\
146 \\
34 \\
126 \\
58 \\
383 \\
1,134\end{array}$ & $\begin{array}{r}25,289 \\
39,691 \\
23,505 \\
4,130 \\
38,253 \\
9,859 \\
76,623 \\
7,009 \\
65,498 \\
289,856\end{array}$ \\
\hline
\end{tabular}

New England

Middle Atlantic

East North Central

West North Central

South Allantic

East South Central

West South Central

Mountain

Pacific

U.S. Total

$\begin{array}{rr}69 & 15,448 \\ 105 & 23,202 \\ 38 & 13,169 \\ 14 & 1,984 \\ 86 & 23,982 \\ 16 & 4,909 \\ 87 & 61,661 \\ 28 & 3,673 \\ 276 & 51,570 \\ 719 & 199,599\end{array}$

199,599

$\begin{array}{rr}66 & 11,776 \\ 90 & 15,748 \\ 37 & 12,394 \\ 14 & 2,002 \\ 79 & 21,129 \\ 14 & 3,713 \\ 84 & 58,348 \\ 26 & 3,046 \\ 248 & 46,710 \\ \mathbf{6 5 8} & 174,866\end{array}$

New England

Middle Atlantic

East North Central

West North Central

South Atlantic

East South Central

West South Central

Mounlain

Pacific

U.S. Total

$\begin{array}{rr}59 & 8,364 \\ 73 & 11,788 \\ 34 & 5,338 \\ 14 & 1,290 \\ 68 & 19,924 \\ 14 & 3,691 \\ 79 & 55,404 \\ 21 & 2,459 \\ 214 & 36,608 \\ \mathbf{5 7 6} & 144,867\end{array}$

1991 (5 Megawatte or More)

$\begin{array}{rrrr}22 & 4,899 & 91 & 20,347 \\ 17 & 1,684 & 122 & 24,886 \\ 52 & 8,255 & 90 & 21,424 \\ 22 & 1,331 & 36 & 3,316 \\ 47 & 8,791 & 133 & 32,773 \\ 17 & 4,104 & 33 & 9,013 \\ 30 & 11,743 & 117 & 73,404 \\ 15 & 1,769 & 43 & 5,442 \\ 86 & 6,273 & 362 & 57,843 \\ 308 & \mathbf{4 8 , 8 4 9} & 1,027 & \mathbf{2 4 8 , 4 4 8}\end{array}$

1990 (5 Megawatts or More)

$\begin{array}{rrrr}18 & 2,636 & 84 & 14,412 \\ 15 & 1,678 & 105 & 17,425 \\ 50 & 8,449 & 87 & 20,843 \\ 11 & 639 & 25 & 2,641 \\ 35 & 6,895 & 114 & 28,024 \\ 15 & 4,352 & 29 & 8,065 \\ 25 & 10,850 & 109 & 69,199 \\ 10 & 1,267 & 36 & 4,313 \\ 77 & 5,608 & 325 & 52,319 \\ \mathbf{2 5 6} & \mathbf{4 2 , 3 7 4} & \mathbf{9 1 4} & \mathbf{2 1 7 , 2 4 1}\end{array}$

1989 (5 Megawatts or More)

$\begin{array}{rrrr}15 & 2,548 & 74 & 10,912 \\ 16 & 1,847 & 89 & 13,634 \\ 48 & 8,692 & 82 & 14,030 \\ 11 & 649 & 25 & 1,939 \\ 38 & 6,796 & 106 & 26,720 \\ 13 & 3,409 & 27 & 7,100 \\ 24 & 11,350 & 103 & 66,755 \\ 10 & 1,389 & 31 & 3,848 \\ 74 & 5,809 & 288 & 42,417 \\ 249 & 42,489 & 825 & 187,356\end{array}$

OF : Nonutility generating facilities that have obtained status as qualifying facilities under the Public Utility Regulatory Policies Act of 1978

Notes. Data for 1992 are preliminary; data for prior years are final. The shift between the number of facilities previously published as qualifying and non-qualifying in 1989 and 1990 is due to changes in facility status. The number of facilities shown for 1992 includes operational lacilities in 1991 and new facilities or planned facilities that became operational during that year. - Totals may not equal sum of components because of independent roundirig

Source: Energy Information Administration. Form EIA-867. "Annual Nonutility Power Producer Report " 
Table 81. Gross Generation by Nonutility Power Producers by Major Industry Group and Census Division, 1989 Through 1992

(Million Kilowatthours)

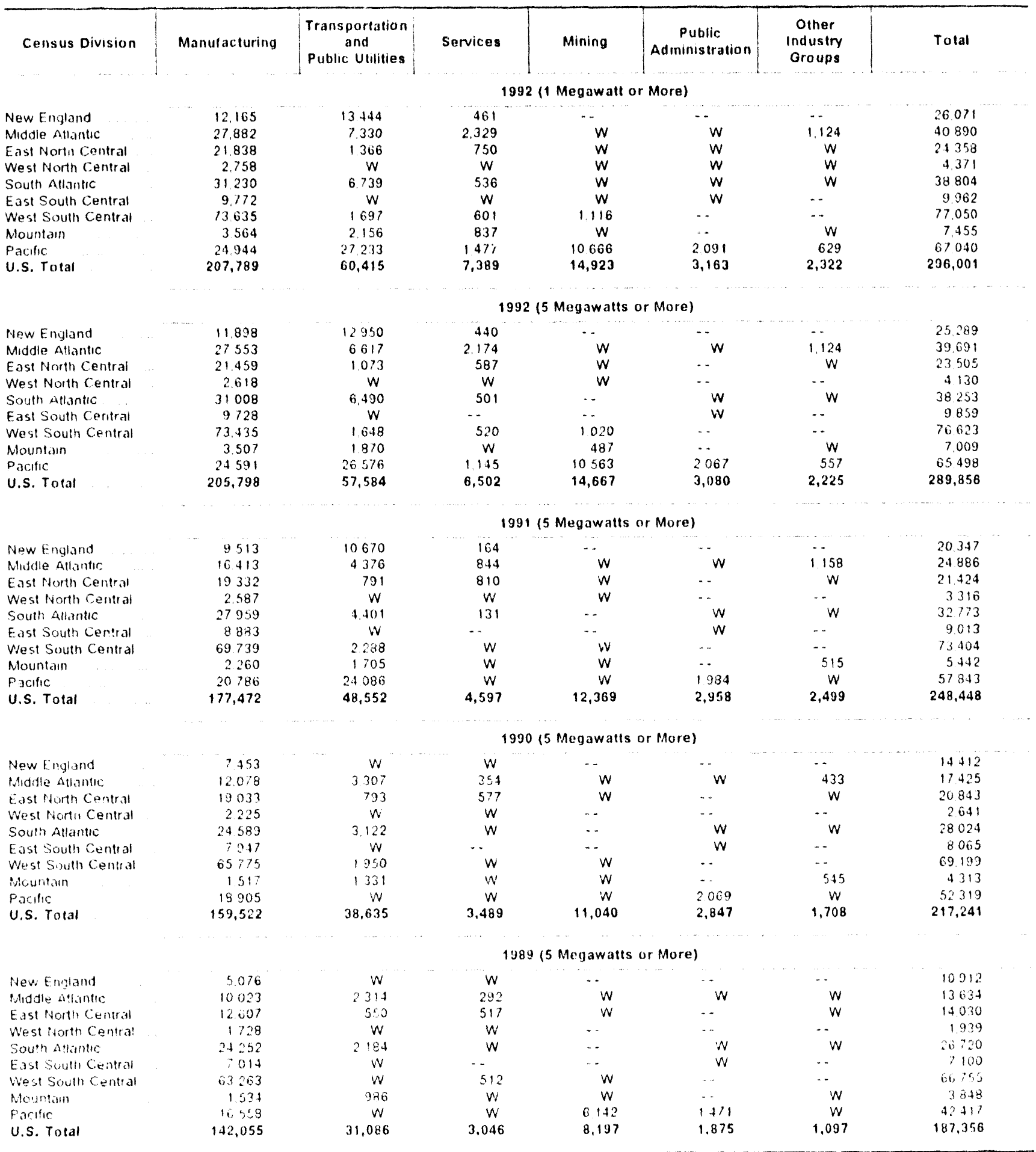

$W=$ Withnold to avold disclosure of individuat combanv data

Nutes. Data for 1932 are pietimnary data for pror yeirs are final e See Techncal Notes for Standard industral Classilications for these industry groubs - Tulals may not equal sum of componelles terasse of mdependent romeling

Source Energy hiformation Admustration. Form Ela-so7. Annual Nonutiaty Power froducer fieport 
Table 82. Nonutility Electricity Supply and Disposition for Facilities by Census Division and State, 1992

(Million Kilowatlhours)

\begin{tabular}{|c|c|c|c|c|c|c|c|c|}
\hline \multirow{2}{*}{$\begin{array}{c}\text { Census Division } \\
\text { and State }\end{array}$} & \multicolumn{2}{|c|}{$\begin{array}{c}\text { Gross } \\
\text { Generation }\end{array}$} & \multicolumn{2}{|c|}{ Receipts } & \multicolumn{2}{|c|}{ Delliveries' } & \multicolumn{2}{|c|}{$\begin{array}{c}\text { Facility } \\
\text { Use }\end{array}$} \\
\hline & $\begin{array}{l}1 \text { megawatt } \\
\text { or mote }\end{array}$ & $\begin{array}{l}5 \text { meqawatts } \\
\text { or more }\end{array}$ & $\begin{array}{l}1 \text { megawatt } \\
\text { or more }\end{array}$ & $\begin{array}{l}5 \text { megawatts } \\
\text { or more }\end{array}$ & $\begin{array}{l}1 \text { meqawalt } \\
\text { or mote }\end{array}$ & $\begin{array}{l}5 \text { megawatts } \\
\text { or more }\end{array}$ & $\begin{array}{l}1 \text { megawalt } \\
\text { or more }\end{array}$ & $\begin{array}{l}5 \text { mogawalts } \\
\text { or more }\end{array}$ \\
\hline New England & 26,071 & 25,289 & 2,878 & 2,503 & 20,687 & 20,095 & 8,262 & 7,696 \\
\hline Comnecticut & 4267 & 4.152 & W & $w$ & 3724 & 3638 & W & W \\
\hline Manne & 7634 & 7501 & 1947 & 1.9 .16 & $4+19$ & 4.312 & 5163 & $15: 75$ \\
\hline Massachusetts & 7406 & 7.320 & 409 & 273 & 6509 & 6419 & 1396 & 1144 \\
\hline New Hampshire & 1711 & 1407 & .82 & 95 & 1350 & 1031 & 593 & 1470 \\
\hline Fhode island & 4738 & 4751 & 83 & $w$ & 4556 & 4511 & 315 & $N$ \\
\hline Vermont & $1: 5$ & 158 & $w$ & w & 130 & 113 & w & I W \\
\hline Middle Allantic & 40,890 & 39,691 & 6.805 & 6,089 & 32,706 & 31,844 & 14,989 & 13,936 \\
\hline New Jensey & 12818 & 12618 & 571 & 355 & 11513 & 11.49 & 1876 & 1514 \\
\hline New Yotr. & 14138 & 13303 & 3139 & 3643 & $1: 487$ & 10 Bog & 6.439 & 6180 \\
\hline Pennsytiana & 13934 & $137: 0$ & 2445 & 2091 & 9705 & 9605 & 6674 & 0.06 \\
\hline East Nolth Central & 24.358 & 23,505 & 15,623 & 13,772 & 10,632 & 10,300 & 29.350 & 26,977 \\
\hline Illinots & 3539 & 32.27 & 4403 & 2.316 & 298 & 197 & 7704 & 6367 \\
\hline Indiana & $w$ & $w$ & 4416 & 4.098 & W & $w$ & 82.25 & 7832 \\
\hline Minhgan & 130.45 & 12.728 & $14 / 4$ & 998 & 9.360 & 9221 & 5159 & 4505 \\
\hline Ohio & 1433 & $W$ & 2773 & 2744 & 104 & $w$ & 4102 & 4048 \\
\hline Wisconsin & $w$ & $w$ & 2190 & 2.106 & $w$ & W & 4160 & 3725 \\
\hline West North Central & 4.371 & 4,130 & 4,395 & 4,149 & 1,096 & 1,009 & 7.670 & 7,270 \\
\hline lowa & W & $W$ & 991 & 9.39 & W & W & 1728 & 1666 \\
\hline Kansas & 322 & $w$ & $W$ & W & W & $\cdots$ & W & $w$ \\
\hline Minnesota & 2580 & 2486 & $?+45$ & 2323 & 729 & 671 & 1.205 & $A 138$ \\
\hline Missoun & w & $w$ & 187 & 177 & W & $W$ & 363 & 322 \\
\hline Nebraska & $w$ & $w$ & $W$ & W & -- & $-\cdot$ & $W$ & $w$ \\
\hline North Dituta & W & W & w & w & w & W & w & $w$ \\
\hline South Oak ota & $\cdots$ & $\ldots$ & $\cdots$ & - & - & $\cdots$ & $\ldots$ & $\cdots$ \\
\hline South Allantic & 38,804 & 38.253 & 15,833 & 14,331 & 16,315 & 16,102 & 38,321 & $: 6,482$ \\
\hline Delaware & ?01 & w & W & W & $w$ & $w$ & $w$ & $w$ \\
\hline Distenct of Columbia & $\cdots$ & $\cdots$ & $\therefore$ & $\cdots$ & $\cdots$ & $\cdots$ & $\cdots$ & -- \\
\hline Flonda & $10: 273$ & 10.137 & 2260 & 1077 & 3835 & 3,829 & 8.704 & 8285 \\
\hline Georgla & 5829 & 5.351 & 2599 & 1.907 & 106 & 86 & 8.322 & 7633 \\
\hline Maryland & 1647 & $w$ & $W$ & $w$ & $w$ & $w$ & W & $w$ \\
\hline North Corolina & 6872 & $6: 53$ & 2.905 & 2508 & $4+22$ & 4.401 & 5315 & 4857 \\
\hline South Calrolina & $2 E \cup 0$ & $2: 38$ & 1354 & 1338 & $M !$ & 716 & 34022 & 3360 \\
\hline Virguna & $7: 5$ & 7015 & 3197 & 3395 & 69 & 5751 & 5317 & 5247 \\
\hline West Virgma & $\{937$ & 2911 & 1606 & 1606 & 815 & 8.15 & 3759 & 3732 \\
\hline East South Centrat & 9,962 & 9.853 & 5,990 & 5.907 & 419 & 395 & 15,534 & 15,371 \\
\hline Adatioma & 4.41 & +76 & 2393 & $w$ & $1 / 6$ & $w$ & 6959 & 6906 \\
\hline Kenlucty & $\cdots$ & $-\cdots$ & & $\cdots$ & $\cdots$ & $\cdots$ & - & $\cdots$ \\
\hline Mesis-1inn & $2 \div 16$ & 270.4 & 523 & W & 99 & iN & 3172 & 3127 \\
\hline tenmessese & $2+5$ & $2+19$ & $30 \% 3$ & 3025 & 110 & 125 & 5400 & 3339 \\
\hline West south Central & 77,050 & 76,623 & 18,584 & 16,956 & $32,9: 4$ & 32,903 & 62,710 & 60,676 \\
\hline Ant insus & 2400 & $2+34$ & 781 & $W$ & 60 & W & 3208 & $312 ?$ \\
\hline Lowicana & 10703 & 10610 & 6532 & 5301 & 3.14 & 3594 & 21612 & 20918 \\
\hline Otingoma & 420.5 & $+1: 0$ & d $5 ?$ & W & $310 \%$ & $W$ & 1956 & 1875 \\
\hline Ifous & 51.68 & 5152 & $101: 6$ & 964 & $2016 ?$ & 20.112 & 35005 & 34.855 \\
\hline Mountain & 7,455 & 7,009 & 3.643 & 3,491 & 5,009 & 4,668 & 6.089 & 5,831 \\
\hline Arizond & $w$ & W & 121 & W & $w$ & $w$ & $w$ & W \\
\hline colorido & 1411 & 1200 & 253 & 181 & 100 & $9 n 9$ & 530 & 504 \\
\hline ldatio & 1304 & $1: 18$ & 936 & $93 \hat{0}$ & 138 & 1051 & 1.102 & 1.102 \\
\hline Montana & $4 C B$ & $w$ & $w$ & $w$ & $w$ & $w$ & W & $N$ \\
\hline Nevinda & $w$ & 2410 & $w$ & $(+)$ & $\therefore A 1$ & 2229 & 100 & 182 \\
\hline New Mexico & 301 & $W$ & $w$ & w & $w$ & $\cdots$ & 1252 & 1.98 \\
\hline Ulah & 128 & $W$ & $w$ & $w$ & 45 & $\cdots$ & W & $w$ \\
\hline Wyoming & 0.40 & 6.27 & w & $w$ & $W$ & $W$ & $w$ & $w$ \\
\hline Pacific & 67,040 & 65,498 & 9,670 & 8,999 & 55,373 & 54,520 & 21,337 & 19,978 \\
\hline Alask a & 1033 & 905 & $w$ & $w$ & $w$ & $w$ & 1042 & $97 ?$ \\
\hline Collerma & 59.90 & 99112 & 4391 & 3868 & 50,160 & $4094 ?$ & 13142 & 12038 \\
\hline Howal & 310 & 30.9 & 44 & $4 ?$ & $24: 9$ & 2369 & $71 i$ & 703 \\
\hline Orequn & 1159 & 1056 & $w$ & $w$ & W & $w$ & 1179 & 1.159 \\
\hline Washngton & 2450 & 2330 & 4.27 & 4203 & 1620 & 1529 & 5257 & 5106 \\
\hline U.S. Total & 296,001 & 289,856 & 83,421 & 76,198 & 175,160 & 171,836 & 204,261 & 194,218 \\
\hline
\end{tabular}

- Includes purchases interchanges and exchanges of electric enerly with uthties and other nomultities

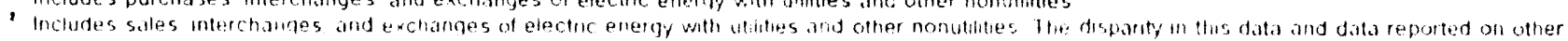

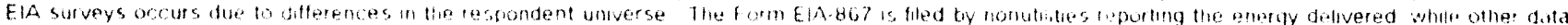

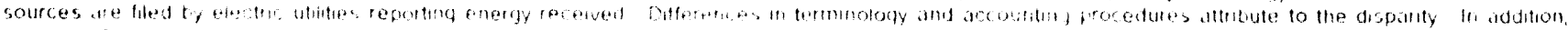

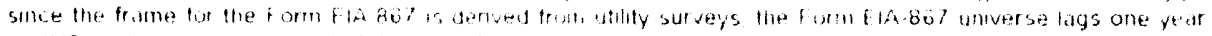

(*ionotes less thath one half the umt of metasure

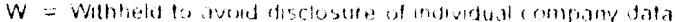

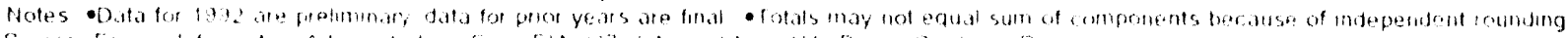

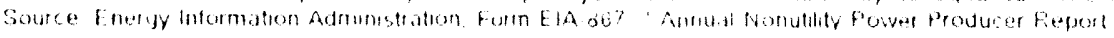


Table 83. Estimated Emissions from Nonutility Power Producers Facilities by Census Division, 1989 Through 1992 (Thousand Short Tons)

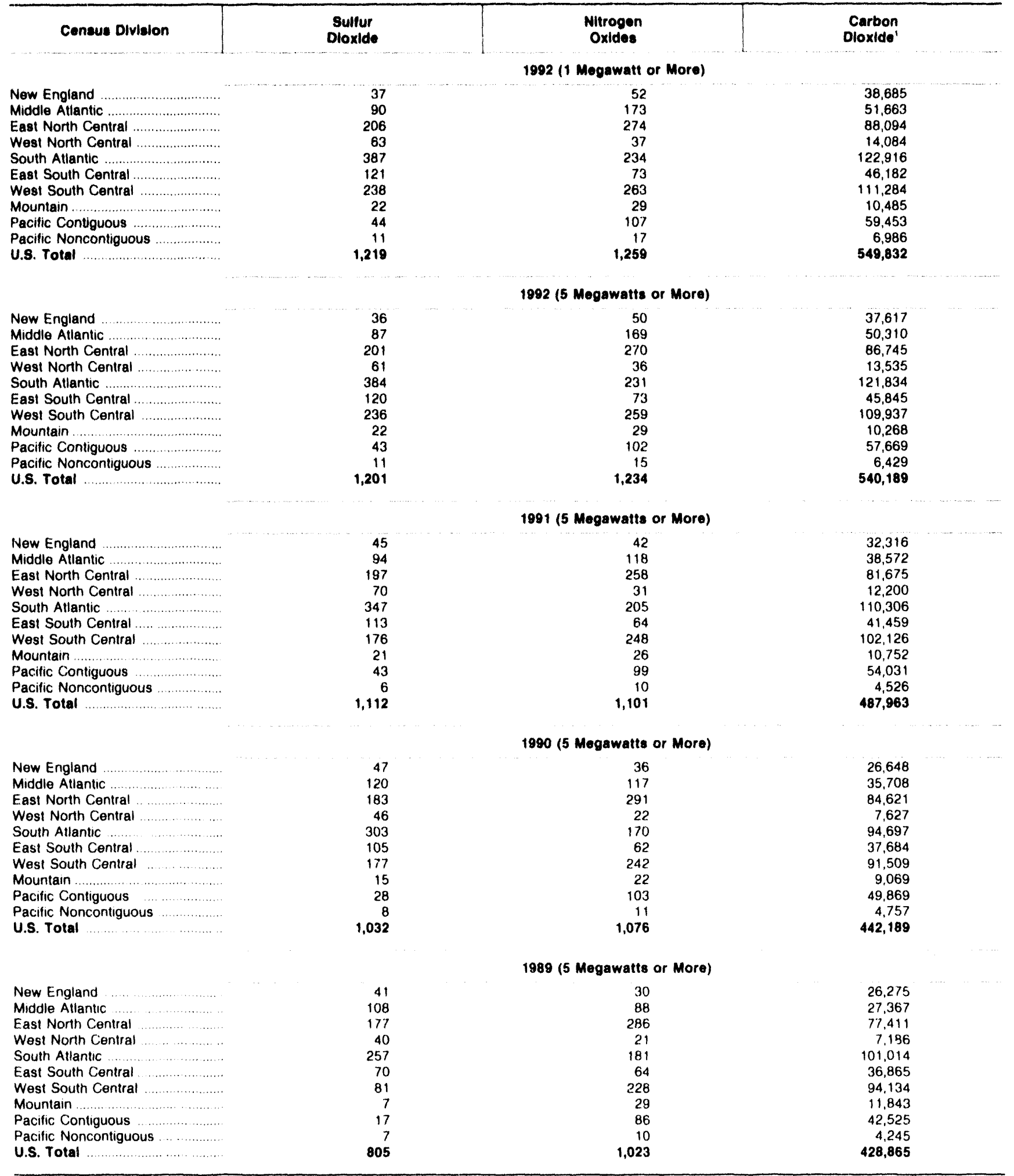

- As of 1992 data, emission factors for the calculation of carbon dioxide emissions and reductions from nitrogen oxide control technologies have been changed-historical estimates were revised to reflect that change.. See Technical Notes for more intormation.

Notes: Estimates for 1992 are preliminary; estimates for prior years are final. Historical data have been revised to reflect a change in methodology. see Technical Notes tor more intormation. - Totals may not equal sum of components because of independent rounding. •See Appendix $C$, "Technical Notes," for methodology

Source: Estimated using data from the Form EIA-867, "Annual Nonutility Power Producer Peport." 


\title{
Appendix A
}

\author{
Major \\ Disturbances and \\ Unusual \\ Occurrences in \\ U.S. Electric \\ Power Systems
}




\section{Appendix A}

\section{Major Disturbances and Unusual Occurrences in U.S. Electric Power Systems}

Electric power systems are subject to a variety of incidents that, to a smaller or greater degree, may adversely affect the delivery of electricity to consumers. Among these are natural phenomena (such as storms and earthquakes); failure of electric system components; accidental or purposeful activities inimical to continued safe operation of U.S. electric power systems; and difficulties associated with the normal operation of large, extremely complex, real-time systems.

Under current Federal regulations, some disturbances are reported to the Federal Government. The legal basis for the requirements and the specifications of in formation reported are detailed in Title 10, Part 205, Subpart W, of the Code of Federal Regulations, Sections 205.350 through 205.353, published in the Federal Register. October 31, 1986. Underlying the formulation of the reporting criteria, requirements and procedures was the need for the Federal Government to be aware of potentially dangerous situations, tempered by the desire to minimize burden on the reporting utilities. Another consideration in the development of the rules was the benefit gained from knowledge of the causes and effects of undesired events that may have been caused by unforeseen system defects or by purposeful adverse actions to system design and operation. The final rules reflect modification of the preliminary rules, as published in the Federal Register, based on comments from the electric power industry and the general public.

In general, the incidents to be reported are grouped into two categories: mandatory in all cases; and mandatory if the incident meets specified criteria. A report is mandatory in all cases when, for the purpose of maintaining the reliability of the bulk power supply system, a utility (1) initiates a system voltage reduction of 3 percent or more, (2) disconnects circuits supplying over 100 megawatts of firm customer load, or (3) issues an appeal to the public for a voluntary reduction in the use of electricity. A report is also mandatory in regard to any actual or suspected act of sabutage or terrorism directed at the bulk power supply system. For the second category of mandatory incidents, the electric utility involved is permitted to exercise some judgment as to whether the criteria requiring mandatory reporting have been met.

In general, reports are to be made by telephone to the Emergency Operating Center, Department of Energy, in Washington, DC, as soon as practicable for instances of load shedding or loss of service, and, at the latest, within 3 hours of the beginning of a service interruption. For other disturbances, the allowable reporting time ranges from 24 hours to days. Written reports may be required by the Director, Office of Energy Emergency Operations, if the circumstances so indicate.

The operation of the bulk power system in the United States should be as trouble-free as possible. To that end, information is collected, as discussed above, regarding major disturbances to the normal functioning of that system. Events, such as damage to some local distribution circuits by storms or other uncontrollable events, do not greatly affect the supply of bulk power to the system as a whole. These events are more properly the concern of local and State authorities.

\section{Data Sources}

The information contained in Table Al is based on data from the Form OE-417R, "Electric Power System Emergency Report." These data are collected by the Office of Emergency Planning and Operations. 
Table A1. Major Disturbances and Unusual Occurrences in U.S. Electric Power Systems, 1992

\begin{tabular}{|c|c|c|c|c|c|c|c|}
\hline Date & Time & Area & $\begin{array}{l}\text { Utillty/Power Pool } \\
\text { (NERC Councll) }\end{array}$ & $\begin{array}{c}\text { Type of } \\
\text { Disturbance }\end{array}$ & Loes & $\begin{array}{l}\text { Number of } \\
\text { Customers } \\
\text { Aftected }\end{array}$ & $\begin{array}{l}\text { Rectoration } \\
\text { Timu }\end{array}$ \\
\hline $1 / 06 / 92$ & 5:04 PM & $\begin{array}{l}\text { Washington, DC } \\
\text { Downtown area }\end{array}$ & $\begin{array}{l}\text { Potomac Electric } \\
\text { Power Company } \\
\text { (MAAC) }\end{array}$ & 'Equipment & 300 & 18,000 & $\begin{array}{l}\text { 7:34 PM } \\
\text { Same Day }\end{array}$ \\
\hline $1 / 21 / 92$ & $2.30 \mathrm{AM}$ & $\begin{array}{l}\text { Oklahoma City } \\
\text { Oklahoma }\end{array}$ & $\begin{array}{l}\text { Oklainoma Gas and } \\
\text { Electric Company } \\
\text { (SPP) }\end{array}$ & 'Rifle Fire & None & & $\begin{array}{c}\text { Not } \\
\text { Applicable }\end{array}$ \\
\hline $1 / 22 / 92$ & Morning & $\begin{array}{l}\text { Stillwater, } \\
\text { Oklanoma }\end{array}$ & $\begin{array}{l}\text { Stillwater Municipal } \\
\text { Electric Department } \\
\text { (SPP) }\end{array}$ & 'Rifle Fire & None & & $\begin{array}{c}\text { Not } \\
\text { Applicable }\end{array}$ \\
\hline $1 / 23 / 92$ & Morning & $\begin{array}{l}\text { Stillwater, } \\
\text { Oklahoma }\end{array}$ & $\begin{array}{l}\text { Stillwater Municipal } \\
\text { Electric Department } \\
\text { (SPP) }\end{array}$ & 'Rifle Fire & None & & $\begin{array}{c}\text { Not } \\
\text { Applicable }\end{array}$ \\
\hline $1 / 23 / 92$ & $2: 25 P M$ & $\begin{array}{l}\text { Livermore, } \\
\text { California }\end{array}$ & $\begin{array}{l}\text { Western Area Power } \\
\text { Administration } \\
\text { (WSCC) }\end{array}$ & ${ }^{4} F \circ g$ and $l_{c e}$ & 50 & One & $\begin{array}{c}\text { 2:47 PM } \\
\text { Same Day }\end{array}$ \\
\hline $1 / 30 / 92$ & 3:33 PM & Miami, Florida & $\begin{array}{l}\text { Florida Power and } \\
\text { Light Company } \\
\text { (SERC) }\end{array}$ & $\begin{array}{l}\text { "Relaying } \\
\text { Error }\end{array}$ & None & & $\begin{array}{c}\text { Not } \\
\text { Applicable }\end{array}$ \\
\hline $2 / 10 / 92$ & Evening & $\begin{array}{l}\text { Noble County } \\
\text { Oklahoma }\end{array}$ & $\begin{array}{l}\text { Oklahoma Gas and } \\
\text { Electric Company } \\
\text { (SPP) }\end{array}$ & 'Rifle Fire & 5 & NA & 4 hours \\
\hline $2 / 11 / 92$ & Evening & $\begin{array}{l}\text { Noble County } \\
\text { Okiahoma }\end{array}$ & $\begin{array}{l}\text { Oklahoma Gas and } \\
\text { Electric Company } \\
\text { (SPP) }\end{array}$ & "Rifle Fire & 5 & NA & 4 hours \\
\hline $2 / 20 / 92$ & $3: 31 \mathrm{PM}$ & $\begin{array}{l}\text { Noble County } \\
\text { Oklahoma }\end{array}$ & $\begin{array}{l}\text { Oklahoma Gas and } \\
\text { Electric Company } \\
\text { (SPP) }\end{array}$ & 'Aifle Fire & None & & $\begin{array}{l}5: 15 \text { AM } \\
2 / 21 / 92\end{array}$ \\
\hline $2 / 27 / 92$ & 3:08 PM & $\begin{array}{l}\text { East Central } \\
\text { Oklahoma }\end{array}$ & $\begin{array}{l}\text { Oklahoma Gas and Electric } \\
\text { Public Service of Oklahoma } \\
\text { (SPP) }\end{array}$ & "Rifle Fire & None & & Two days \\
\hline $3 / 08 / 92$ & 7:00 PM & Colorado & $\begin{array}{l}\text { Public Service Company } \\
\text { of Colorado } \\
\text { (WSCC) }\end{array}$ & 'Storm 1 & Minor & NA & Two days \\
\hline $3 / 26 / 92$ & $6: 35 \mathrm{AM}$ & $\begin{array}{l}\text { Town of } \\
\text { Windsor, NC }\end{array}$ & $\begin{array}{l}\text { Windsor Municipal } \\
\text { Electric System } \\
\text { (SERC) }\end{array}$ & ${ }^{10}$ Ligh 'ning & NA & 1,560 & $\begin{array}{l}\text { 10:58 AM } \\
\text { Same Day }\end{array}$ \\
\hline $4 / 13 / 92$ & $6: 00 \mathrm{AM}$ & $\begin{array}{l}\text { Chicago, lllinois } \\
\text { Business Area }\end{array}$ & $\begin{array}{l}\text { Commonwealth Edison } \\
\text { Company } \\
\text { (MAIN) }\end{array}$ & "Flood & NA & & $\begin{array}{l}5 / 4 / 9280 \% \\
5 / 19 / 92 \quad 100 \%\end{array}$ \\
\hline $4 / 27 / 92$ & 1:27 PM & Northern Utah & $\begin{array}{l}\text { Pacificorp } \\
\text { (WSCC) }\end{array}$ & $\begin{array}{l}\text { "Equipment } \\
\text { Failure }\end{array}$ & 418 & NA & $\begin{array}{l}\text { 1:38 PM } \\
\text { Same Day }\end{array}$ \\
\hline $4 / 29 / 92$ & 8:33 AM & $\begin{array}{l}\text { Los Angeles } \\
\text { California }\end{array}$ & $\begin{array}{l}\text { Los Angeles Department } \\
\text { of Water and Power } \\
\text { (WSCC) }\end{array}$ & ${ }^{12}$ Piots & 46 & 51,800 & $\begin{array}{l}4: 48 P M \\
5 / 4 / 92\end{array}$ \\
\hline $5 / 07 / y 2$ & $10: 40$ AM & New York City & $\begin{array}{l}\text { Consolidated Edison } \\
\text { Company } \\
\text { (NPCC) }\end{array}$ & ${ }^{14}$ Test & NA & & $\begin{array}{l}11: 49 \text { AM } \\
\text { Same Day }\end{array}$ \\
\hline $5 / 18 / 92$ & 6:29 PM & $\begin{array}{l}\text { Town of } \\
\text { Windsor, NC }\end{array}$ & $\begin{array}{l}\text { Windsor Municipal } \\
\text { Electric System } \\
\text { (SERC) }\end{array}$ & "Lightning & NA & 1,560 & $\begin{array}{l}\text { 9:52 PM } \\
\text { Same Day }\end{array}$ \\
\hline $6 / 17 / 92$ & $11: 00 \mathrm{AM}$ & Chicago, Illinois & $\begin{array}{l}\text { Commonwealth Edison } \\
\text { Company } \\
\text { (MAIN) }\end{array}$ & "Storm & NA & 230,000 & $\begin{array}{l}\text { Midnight } \\
6 / 19 / 92\end{array}$ \\
\hline
\end{tabular}

See endnotes on the next page. 
Table A1. Major Disturbances and Unusual Occurrences in U.S. Electric Power Systems, 1992-Continued

\begin{tabular}{|c|c|c|c|c|c|c|c|}
\hline Date & Time & Area & $\begin{array}{l}\text { Utility/Power Pool } \\
\text { (NERC Councll) }\end{array}$ & $\begin{array}{c}\text { Type of } \\
\text { Disturbance }\end{array}$ & $\begin{array}{c}\text { Loas } \\
\text { (megawatt) }\end{array}$ & $\begin{array}{l}\text { Number of } \\
\text { Customers } \\
\text { Affected }\end{array}$ & $\begin{array}{c}\text { Restoratton } \\
\text { Time }\end{array}$ \\
\hline $6 / 17 / 92$ & $11: 00$ AM & Northern Michigan & $\begin{array}{l}\text { Consumers Power } \\
\text { Company } \\
\text { (ECAR) }\end{array}$ & "Storm & 175 & 350,000 & $\begin{array}{l}\text { Noon } \\
6 / 22 / 92\end{array}$ \\
\hline $6 / 17 / 92$ & 1:00 PM & $\begin{array}{l}\text { Southern Michigan } \\
\text { Northern Indiana }\end{array}$ & $\begin{array}{l}\text { Indiana-Michigan } \\
\text { Power Company } \\
\text { (ECAR) }\end{array}$ & "Storm & NA & 93,000 & $\begin{array}{l}3: 32 P M \\
6 / 21 / 92\end{array}$ \\
\hline $6 / 17 / 92$ & 7:00 PM & Detroit Michigan & $\begin{array}{l}\text { Detroit Edison } \\
\text { Company } \\
\text { (ECAR) }\end{array}$ & "Storm & NA & 100,000 & $\begin{array}{l}\text { Noon } \\
6 / 18 / 92\end{array}$ \\
\hline $6 / 17 / 92$ & 11:00 PM & $\begin{array}{l}\text { Indianapolis } \\
\text { Indiana }\end{array}$ & $\begin{array}{l}\text { Indianapolis Power } \\
\text { and Light Company } \\
\text { (ECAR) }\end{array}$ & ${ }^{20}$ Storm & 268 & 155,000 & $\begin{array}{l}\text { Midnight } \\
6 / 22 / 92\end{array}$ \\
\hline $6 / 19 / 92$ & $3: 12$ PM & $\begin{array}{l}\text { Eastern and } \\
\text { S.W. Oklanoma }\end{array}$ & $\begin{array}{l}\text { Public Service Company } \\
\text { of Oklahoma } \\
\text { (SPP) }\end{array}$ & ${ }^{21}$ Storm & 75 & 100,000 & $\begin{array}{l}5: 00 P M \\
6 / 23 / 92\end{array}$ \\
\hline $6 / 24 / 92$ & 8:14 PM & $\begin{array}{l}\text { Town of } \\
\text { Windsor, NC }\end{array}$ & $\begin{array}{l}\text { Windsor Municipal } \\
\text { Electric System } \\
\text { (SERC) }\end{array}$ & ${ }^{22}$ Lightning & NA & 1,560 & $\begin{array}{l}9: 44 \text { PM } \\
\text { Same Day }\end{array}$ \\
\hline $7 / 01 / 92$ & 6:02 PM & $\begin{array}{l}\text { Corpus Christi } \\
\text { Rio Grande, Texas }\end{array}$ & $\begin{array}{l}\text { Central Power \& Light } \\
\text { Company } \\
\text { (ERCOT) }\end{array}$ & $\begin{array}{l}{ }^{23} \text { Equipment } \\
\text { Failure }\end{array}$ & 664 & 64,000 & $\begin{array}{l}\text { 7:40 PM } \\
\text { Same Day }\end{array}$ \\
\hline $7 / 02 / 92$ & 3:00 PM & Chicago, Illinois & $\begin{array}{l}\text { Commonweaith Edison } \\
\text { Company } \\
\text { (MAIN) }\end{array}$ & ${ }^{24}$ Storm & 700 & 210,000 & $\begin{array}{l}3: 00 \text { AM } \\
7 / 04 / 92\end{array}$ \\
\hline $7 / 08 / 92$ & $1: 00 \mathrm{AM}$ & Concordia, Kansas & $\begin{array}{l}\text { Centel Electric- } \\
\text { Kansas } \\
\text { (SPP) }\end{array}$ & ${ }^{26}$ Storm & NA & 7,800 & $\begin{array}{l}3: 00 \text { PM } \\
7 / 09 / 92\end{array}$ \\
\hline $7 / 22 / 92$ & 5:16 PM & $\begin{array}{l}\text { West Point } \\
\text { Jackson. } \\
\text { Mississippi }\end{array}$ & $\begin{array}{l}\text { Tennessee Valley } \\
\text { Authority } \\
\text { (SERC) }\end{array}$ & $\begin{array}{l}{ }^{27} \text { Equipment } \\
\text { Failure }\end{array}$ & 568 & 150,000 & $\begin{array}{l}\text { 5:48 PM } \\
\text { Same Day }\end{array}$ \\
\hline $8 / 10 / 92$ & $\begin{array}{l}8: 49 \text { AM } \\
\text { PAST }\end{array}$ & $\begin{array}{l}\text { Vancouver } \\
\text { British Columbia } \\
\text { Canada }\end{array}$ & $\begin{array}{l}\text { British Columbia Hydro } \\
\text { and Power Authority } \\
\text { (WSCC) }\end{array}$ & ${ }^{2}$ Line Fault & 380 & 50,000 & $\begin{array}{l}9: 19 \text { AM } \\
\text { PAST } \\
\text { Same Day }\end{array}$ \\
\hline $8 / 20 / 92$ & $\begin{array}{l}\text { 5:50 PM } \\
\text { PAST }\end{array}$ & Calif-Oregon & $\begin{array}{l}\text { Many systems } \\
\text { (WSCC) }\end{array}$ & $\begin{array}{l}{ }^{2} \text { Forest } \\
\text { Fire }\end{array}$ & 520 & NA & $\begin{array}{l}2: 00 \text { AM } \\
\text { PAST } \\
8 / 21 / 92\end{array}$ \\
\hline $8 / 21 / 92$ & $\begin{array}{l}3: 44 \text { PM } \\
\text { PAST }\end{array}$ & Calit-Oregon & $\begin{array}{l}\text { Many systems } \\
\text { (WSCC) }\end{array}$ & $\begin{array}{l}{ }^{30} \text { Forest } \\
\text { Fire }\end{array}$ & 400 & 165 & $\begin{array}{l}\text { 5:25 PM } \\
\text { PAST } \\
\text { Same Day }\end{array}$ \\
\hline $8 / 24 / 92$ & $4: 55 \mathrm{AM}$ & $\begin{array}{l}\text { East Coast of } \\
\text { South Florida }\end{array}$ & $\begin{array}{l}\text { Florida Power \& Light } \\
\text { Company } \\
\text { (GERC) }\end{array}$ & $\begin{array}{l}{ }^{31} \text { Hurricane } \\
\text { Andrew }\end{array}$ & 1,262 & $1,400,000$ & $\begin{array}{l}10: 00 \mathrm{AM} \\
9 / 27 / 92\end{array}$ \\
\hline $8 / 24 / 92$ & 8:00 AM & $\begin{array}{l}\text { Gulf Coast of } \\
\text { South Florida }\end{array}$ & $\begin{array}{l}\text { Lee County Electric } \\
\text { Cooperative } \\
\text { (SERC) }\end{array}$ & $\begin{array}{l}{ }^{32} \text { Hurricane } \\
\text { Andrew }\end{array}$ & NA & 37,938 & $\begin{array}{l}7: 00 \text { PM } \\
8 / 27 / 92\end{array}$ \\
\hline $8 / 24 / 92$ & $4: 55 \mathrm{AM}$ & $\begin{array}{l}\text { Key West } \\
\text { Florida }\end{array}$ & $\begin{array}{l}\text { Key West Utilities } \\
\text { Board } \\
\text { (SERC) }\end{array}$ & $\begin{array}{l}{ }^{33} \text { Hurricane } \\
\text { Andrew }\end{array}$ & 92 & 22,754 & $\begin{array}{l}\text { 11:00 PM } \\
\text { Same Day }\end{array}$ \\
\hline $8 / 24 / 92$ & $4: 55 \mathrm{AM}$ & $\begin{array}{l}\text { Florida Keys } \\
\text { Florida }\end{array}$ & $\begin{array}{l}\text { Florida Keys Electric } \\
\text { Cooperative } \\
\text { (SERC) }\end{array}$ & $\begin{array}{l}{ }^{34} \text { Hurricane } \\
\text { Andrew }\end{array}$ & 45 & 26,844 & $\begin{array}{c}10: 00 P M \\
9 / 04 / 92\end{array}$ \\
\hline
\end{tabular}

See endnotes on the next page. 
Table A1. Major Disturbances and Unusual Occurrences in U.S. Electric Power Systems, 1992-Continued

\begin{tabular}{|c|c|c|c|c|c|c|c|}
\hline Date & Time & Area & $\begin{array}{l}\text { Utillty/Power Pool } \\
\text { (NERC Councll) }\end{array}$ & $\begin{array}{c}\text { Type of } \\
\text { Disturbance }\end{array}$ & $\begin{array}{c}\text { Loss } \\
\text { (megawatt) }\end{array}$ & $\begin{array}{c}\text { Number of } \\
\text { Cuatomers } \\
\text { Affected }\end{array}$ & $\begin{array}{c}\text { Restoration } \\
\text { Time }\end{array}$ \\
\hline $8 / 25 / 92$ & Midnight & $\begin{array}{l}\text { St. Tammany and } \\
\text { other parishes }\end{array}$ & $\begin{array}{l}\text { Washington-St. Tammany } \\
\text { Electric Coop., LA. } \\
\text { (SPP) }\end{array}$ & $\begin{array}{l}{ }^{36} \text { Hurricane } \\
\text { Andrew }\end{array}$ & NA & 22,000 & $\begin{array}{l}4: 00 \text { PM } \\
8 / 29 / 92\end{array}$ \\
\hline $8 / 25 / 92$ & 7:15 PM & $\begin{array}{l}\text { Area around } \\
\text { E. Baton Rouge }\end{array}$ & $\begin{array}{l}\text { Dixie Elec Membership } \\
\text { Corp., La. } \\
\text { (SPP) }\end{array}$ & $\begin{array}{l}\text { Hurricane } \\
\text { Andrew }\end{array}$ & 225 & 57,018 & $\begin{array}{l}\text { Noon } \\
9 / 03 / 92\end{array}$ \\
\hline $8 / 25 / 92$ & 9:00 PM & $\begin{array}{l}\text { St. Mary and } \\
\text { other parishes }\end{array}$ & $\begin{array}{l}\text { So. LA. Electric Coop } \\
\text { Association } \\
\text { (SPP) }\end{array}$ & $\begin{array}{l}{ }^{37} \text { Hurricane } \\
\text { Andrew }\end{array}$ & 58 & 15,205 & $\begin{array}{c}10: 00 \text { AM } \\
8 / 29 / 92\end{array}$ \\
\hline $8 / 25 / 92$ & 9:00 PM & Southwest, MS & $\begin{array}{l}\text { Mississippi Power \& } \\
\text { Light Co } \\
\text { (SPP) }\end{array}$ & $\begin{array}{l}{ }^{30} \text { Hurricane } \\
\text { Andrew }\end{array}$ & 806 & 40,000 & $\begin{array}{l}4: 00 P M \\
8 / 29 / 92\end{array}$ \\
\hline $8 / 25 / 92$ & 11:00 PM & $\begin{array}{l}\text { City of } \\
\text { Morgan City, LA }\end{array}$ & $\begin{array}{l}\text { Morgan City, LA, Muni. } \\
\text { Power Plant } \\
\text { (SPP) }\end{array}$ & $\begin{array}{c}\text { Hurricane } \\
\text { Andrew }\end{array}$ & NA & 6,170 & $\begin{array}{l}8: 00 \text { AM } \\
9 / 09 / 92\end{array}$ \\
\hline $8 / 25 / 92$ & $11: 00 \mathrm{PM}$ & $\begin{array}{l}\text { St. Mary and } \\
\text { other parishes }\end{array}$ & $\begin{array}{l}\text { Teche Electric Coop., } \\
\text { Inc. LA } \\
\text { (SPP) }\end{array}$ & $\begin{array}{l}{ }^{10} \text { Hurricane } \\
\text { Andrew }\end{array}$ & 40 & 9,000 & $\begin{array}{l}\text { 5:00 PM } \\
9 / 09 / 92\end{array}$ \\
\hline $8 / 25 / 92$ & 9:00 AM & $\begin{array}{l}\text { Copiah \& } 10 \\
\text { other counties }\end{array}$ & $\begin{array}{l}\text { Southern Pine Electric } \\
\text { PWr, Assoc., MS } \\
\text { (SPP) }\end{array}$ & $\begin{array}{l}\text { "Hurricane } \\
\text { Andrew }\end{array}$ & NA & 26,500 & $\begin{array}{l}2: 00 P M \\
8 / 29 / 92\end{array}$ \\
\hline $8 / 25 / 92$ & 2:27 PM & $\begin{array}{l}\text { East Central } \\
\text { Mississippi }\end{array}$ & $\begin{array}{l}\text { Mississippi Power Co. } \\
\text { (SERC) }\end{array}$ & $\begin{array}{l}{ }^{42} \text { Hurricane } \\
\text { Andrew }\end{array}$ & & 12,000 & $\begin{array}{l}11: 00 \mathrm{AM} \\
8 / 31 / 92\end{array}$ \\
\hline $8 / 26 / 92$ & Midnight & $\begin{array}{l}\text { Attala and } 12 \\
\text { other courities }\end{array}$ & $\begin{array}{l}\text { Delta Electric Power } \\
\text { Association, MS } \\
\text { (SPP) }\end{array}$ & $\begin{array}{l}\text { Hurricane } \\
\text { Andrew }\end{array}$ & NA & 1,500 & $\begin{array}{l}\text { 7:00 PM } \\
8 / 28 / 92\end{array}$ \\
\hline $8 / 26 / 92$ & Midnight & $\begin{array}{l}\text { George and } 4 \\
\text { other counties }\end{array}$ & $\begin{array}{l}\text { Singing River Electric } \\
\text { Pwr. AsSOC, MS } \\
\text { (SPP) }\end{array}$ & $\begin{array}{l}\text { "Hurricane } \\
\text { Andrew }\end{array}$ & NA & 500 & $\begin{array}{l}\text { 8:00 AM } \\
8 / 27 / 92\end{array}$ \\
\hline $8 / 26 / 92$ & 12:10 AM & $\begin{array}{l}\text { South } \\
\text { Louisiana }\end{array}$ & $\begin{array}{l}\text { LA. P\&L \& New Orleans } \\
\text { Public Service } \\
\text { (SPP) }\end{array}$ & $\begin{array}{l}{ }^{45} \text { Hturricane } \\
\text { Andrew }\end{array}$ & 400 & 200,000 & $\begin{array}{l}\text { 8:00 AM } \\
9 / 01 / 92\end{array}$ \\
\hline $8 / 26 / 92$ & $1: 25 \mathrm{AM}$ & $\begin{array}{l}\text { Southwest } \\
\text { Louisiana }\end{array}$ & $\begin{array}{l}\text { Gulf States Utilities } \\
\text { Co. } \\
\text { (SPP) }\end{array}$ & $\begin{array}{l}\text { "Hurricane } \\
\text { Andrew }\end{array}$ & NA & 170,000 & $\begin{array}{l}\text { 5:00 PM } \\
9 / 02 / 92\end{array}$ \\
\hline $8 / 26 / 92$ & $1: 30 \mathrm{AM}$ & $\begin{array}{l}\text { City of } \\
\text { Houma, LA }\end{array}$ & $\begin{array}{l}\text { Houma, LA, Light \& } \\
\text { Water Dept. } \\
\text { (SPP) }\end{array}$ & $\begin{array}{l}\text { "Hurricane } \\
\text { Andrew }\end{array}$ & 20 & 6,000 & $\begin{array}{l}9: 00 \mathrm{AM} \\
8 / 28 / 92\end{array}$ \\
\hline $8 / 26 / 92$ & $2: 00 \mathrm{AM}$ & $\begin{array}{l}\text { Acadia and } \\
\text { other parishes }\end{array}$ & $\begin{array}{l}\text { Southwest. LA Elec. Mem. } \\
\text { Corp. } \\
\text { (SPP) }\end{array}$ & $\begin{array}{l}\text { Hurricane } \\
\text { Andrew }\end{array}$ & 60 & 42,000 & $\begin{array}{c}11: 00 \mathrm{AM} \\
9 / 02 / 92\end{array}$ \\
\hline $8 / 26 / 92$ & $2: 00 \mathrm{AM}$ & $\begin{array}{l}\text { City of St. } \\
\text { Martinville }\end{array}$ & $\begin{array}{l}\text { St. Martinville, LA, } \\
\text { Muni. Elec. Dept } \\
\text { (SPP) }\end{array}$ & $\begin{array}{l}{ }^{40} \text { Hurricane } \\
\text { Andrew }\end{array}$ & NA & 2,746 & $\begin{array}{l}\text { 5:00 PM } \\
8 / 30 / 92\end{array}$ \\
\hline $8 / 26 / 92$ & $2: 00 \mathrm{AM}$ & $\begin{array}{l}\text { South Central } \\
\text { Louisiana }\end{array}$ & $\begin{array}{l}\text { Central Louisiana } \\
\text { Electric Co. } \\
\text { (SPP) }\end{array}$ & $\begin{array}{l}{ }^{\circ} \text { Hurricane } \\
\text { Andrew }\end{array}$ & 250 to 350 & 36,264 & $\begin{array}{l}9: 00 \text { AM } \\
9 / 05 / 92\end{array}$ \\
\hline $8 / 26 / 92$ & $2: 15$ AM & $\begin{array}{l}\text { City of } \\
\text { Lafayette, LA }\end{array}$ & $\begin{array}{l}\text { Lafayette, LA, } \\
\text { Utilities System } \\
\text { (SPP) }\end{array}$ & $\begin{array}{l}\text { "Hurricane } \\
\text { Andrew }\end{array}$ & 167 & 26,000 & $\begin{array}{l}\text { Morning } \\
8 / 29 / 92\end{array}$ \\
\hline $8 / 26 / 92$ & $2: 20$ AM & $\begin{array}{l}\text { City of } \\
\text { Abbeyville, LA }\end{array}$ & $\begin{array}{l}\text { Abbeville, LA, Water \& } \\
\text { Light Plant } \\
\text { (SPP) }\end{array}$ & $\begin{array}{c}{ }^{52} \text { Hurricane } \\
\text { Andrew }\end{array}$ & 8 & 4,767 & $\begin{array}{l}9: 00 \text { PM } \\
8 / 29 / 92\end{array}$ \\
\hline
\end{tabular}

See endnotes on the next page. 
Table A1. Major Disturbances and Unusual Occurrences in U.S. Electric Power Systems, 1992-Continued

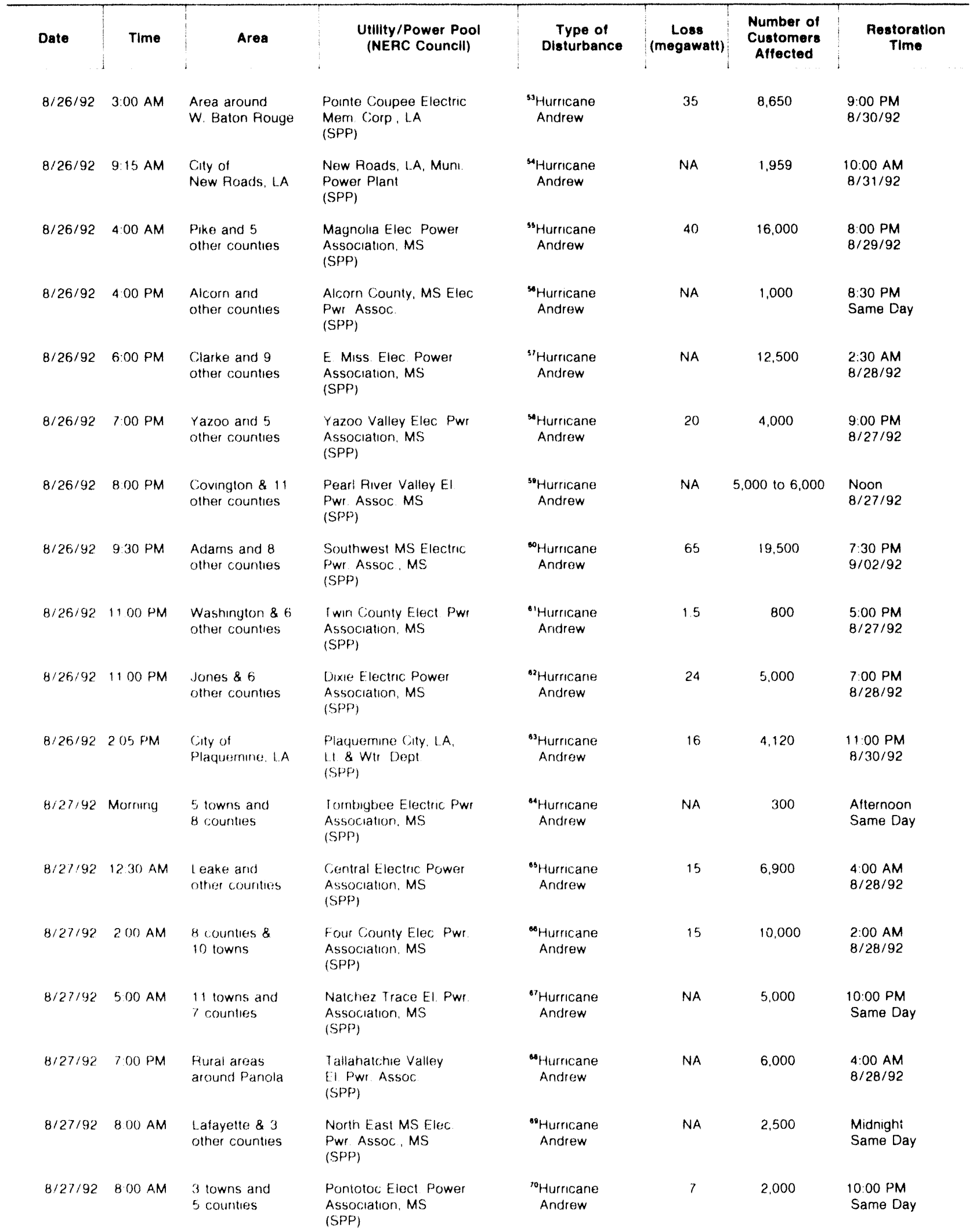

See endnotes on the next page 
Table A1. Major Disturbances and Unusual Occurrences in U.S. Electric Power Systems, 1992-Continued

\begin{tabular}{|c|c|c|c|c|c|c|c|}
\hline Date & Time & Area & $\begin{array}{l}\text { Utility/Power Pool } \\
\text { (NERC Council) }\end{array}$ & $\begin{array}{l}\text { Type of } \\
\text { Disturbance }\end{array}$ & $\begin{array}{c}\text { Loss } \\
\text { (megawatt) }\end{array}$ & $\begin{array}{l}\text { Number of } \\
\text { Customers } \\
\text { Affected }\end{array}$ & $\begin{array}{l}\text { Restoration } \\
\text { Time }\end{array}$ \\
\hline $8 / 27 / 92$ & 8:00 AM & $\begin{array}{l}\text { Monroe, Lowndes } \\
\text { \& Itawamba }\end{array}$ & $\begin{array}{l}\text { Monroe County Elec.Pwr } \\
\text { Association, MS } \\
\text { (SPP) }\end{array}$ & $\begin{array}{l}\text { "Hurricane } \\
\text { Andrew }\end{array}$ & NA & 1,300 & $\begin{array}{l}\text { 5:00 PM } \\
\text { Same Day }\end{array}$ \\
\hline $8 / 27 / 92$ & 10:00 AM & $\begin{array}{l}\text { Rural areas in } \\
\text { Miss. \& Tenn. }\end{array}$ & $\begin{array}{l}\text { Tippah Electric Power } \\
\text { Association, MS } \\
\text { (SPP) }\end{array}$ & $\begin{array}{l}\text { "2Hurricane } \\
\text { Andrew }\end{array}$ & NA & 150 & $\begin{array}{l}\text { 5:00 PM } \\
\text { Same Day }\end{array}$ \\
\hline $8 / 27 / 92$ & 12:30 PM & $\begin{array}{l}\text { Central } \\
\text { Alabama }\end{array}$ & $\begin{array}{l}\text { Alabama Power Co. } \\
\text { (SERC) }\end{array}$ & $\begin{array}{l}{ }^{73} \text { Hurricane } \\
\text { Andrew }\end{array}$ & 200 & 58,000 & $\begin{array}{l}1: 58 \mathrm{PM} \\
8 / 28 / 92\end{array}$ \\
\hline $8 / 28 / 92$ & $\begin{array}{l}\text { 5:00 PM } \\
\text { PAST }\end{array}$ & $\begin{array}{l}\text { Los Angeles, } \\
\text { Burbank, CA }\end{array}$ & $\begin{array}{l}\text { Los Angeles Dept. of } \\
\text { Water \& Power } \\
\text { (WSCC) }\end{array}$ & "Line Fault & 738 & 232.800 & $\begin{array}{l}\text { 5:37 PM } \\
\text { Same Day }\end{array}$ \\
\hline $9 / 11 / 92$ & 1:40 PM & $\begin{array}{l}\text { Island of } \\
\text { Kauai, } \mathrm{HI}\end{array}$ & $\begin{array}{l}\text { Citizens Utilities Company } \\
\text { Kauai Division }\end{array}$ & $\begin{array}{l}{ }^{19} \text { Hurricane } \\
\text { Iniki }\end{array}$ & NA & 24,700 & $\begin{array}{l}\text { Estimate } \\
2 \text { months }\end{array}$ \\
\hline $10 / 03 / 92$ & $6: 30 \mathrm{AM}$ & $\begin{array}{l}\text { Chiefland, FL } \\
\text { West Central, FL }\end{array}$ & $\begin{array}{l}\text { Central Florida Electric } \\
\text { Cooperative } \\
\text { (SERC) }\end{array}$ & "Tornado & NA & 32 & $\begin{array}{l}\text { 1:00 PM } \\
\text { Same Day }\end{array}$ \\
\hline $10 / 03 / 92$ & $10: 30 \mathrm{AM}$ & $\begin{array}{l}\text { St. Petersburg, } \\
\text { West Central. FL }\end{array}$ & $\begin{array}{l}\text { Florida Power } \\
\text { Corporation } \\
\text { (SERC) }\end{array}$ & "Tornado & NA & 30,000 & $\begin{array}{l}2: 00 \mathrm{AM} \\
10 / 5 / 92\end{array}$ \\
\hline $10 / 03 / 92$ & 12:30 PM & $\begin{array}{l}\text { Dade City. FL } \\
\text { West Central, FL }\end{array}$ & $\begin{array}{l}\text { Withlacoochee River } \\
\text { Electric Cooperative } \\
\text { (SERC) }\end{array}$ & "Tornado & NA & 3,600 & $\begin{array}{l}\text { 2:30 PM } \\
\text { Same Day }\end{array}$ \\
\hline $10 / 21 / 92$ & 5:00 PM & Guam & Guam Power Authority & ${ }^{10}$ Typhoon & NA & & NA \\
\hline $10 / 28 / 92$ & $\begin{array}{l}1: 29 \mathrm{PM} \\
\mathrm{CST}\end{array}$ & $\begin{array}{l}\text { New Mexico } \\
\text { West Texas }\end{array}$ & $\begin{array}{l}\text { Southwestern Public } \\
\text { Service Company } \\
\text { (SPP) }\end{array}$ & ${ }^{80}$ Misoperate & 236 & 17.199 & $\begin{array}{l}2: 24 \text { PM } \\
\text { Same Day }\end{array}$ \\
\hline $11 / 01 / 92$ & $11: 40 \mathrm{PM}$ & $\begin{array}{l}\text { Kewaunee Cty. } \\
\text { WI }\end{array}$ & $\begin{array}{l}\text { Wisconsin Public } \\
\text { Service Coporation } \\
\text { (MAIN) }\end{array}$ & "Seaweed & None & & $\begin{array}{l}10: 40 \text { AM } \\
11 / 3 / 92\end{array}$ \\
\hline $11 / 14 / 92$ & 10:12 AM & $\begin{array}{l}\text { OR, CA, CO, } \\
N V, \cup T, N M \\
A Z\end{array}$ & $\begin{array}{l}\text { Several systems in } \\
\text { (WSCC) }\end{array}$ & "Line Fault & None & & $\begin{array}{l}11: 49 \text { AM } \\
\text { Same Day }\end{array}$ \\
\hline $11 / 21 / 92$ & 3:35 PM & Houston, TX & $\begin{array}{l}\text { Houston Lughtning \& } \\
\text { Power Company } \\
\text { (ERCOT) }\end{array}$ & ${ }^{\text {*3 Tornado }}$ & 525 & 118,900 & $\begin{array}{l}\text { Midnight } \\
11 / 24 / 92\end{array}$ \\
\hline $11 / 23 / 92$ & $6: 29 \mathrm{AM}$ & $\begin{array}{l}\text { Town of } \\
\text { Windsor, NC }\end{array}$ & $\begin{array}{l}\text { Windsor Municipal } \\
\text { Electric System } \\
\text { (SERC) }\end{array}$ & "Tornado & NA & 1,560 & $\begin{array}{l}\text { 10:42 AM } \\
\text { Same Day }\end{array}$ \\
\hline $11 / 25 / 92$ & $9: 55 \mathrm{AM}$ & $\begin{array}{l}\text { Marin. Sonoma } \\
\text { Napa Counties }\end{array}$ & $\begin{array}{l}\text { Pacific Gas \& Electric Co. } \\
\text { California } \\
\text { (WSCC) }\end{array}$ & ${ }^{-5}$ Misoperate & 530 & 312,000 & $\begin{array}{l}\text { 10:30 AM } \\
\text { Same Day }\end{array}$ \\
\hline $12 / 11 / 92$ & $6: 00 \mathrm{AM}$ & I ong Island, NY & $\begin{array}{l}\text { Long Island Lighting } \\
\text { Company } \\
\text { (NPCC) }\end{array}$ & "Storm & 90 & 94,000 & $\begin{array}{l}10: 00 \mathrm{AM} \\
12 / 13 / 92\end{array}$ \\
\hline $12 / 12 / 92$ & 9:04 AM & $M A, R I, C T$ & $\begin{array}{l}\text { New England } \\
\text { Power Pool } \\
\text { (NPCC) }\end{array}$ & "Storm & 300 & 181,000 & $\begin{array}{l}5: 00 P M \\
12 / 14 / 92\end{array}$ \\
\hline $12 / 14 / 92$ & NA & $\begin{array}{l}\text { Near Santa } \\
\text { Rosa, CA }\end{array}$ & $\begin{array}{l}\text { Pacific Gas \& Electric } \\
\text { Company } \\
\text { (WSCC) }\end{array}$ & ${ }^{m}$ Sabotage & None & & NA \\
\hline
\end{tabular}

See endnotes on the next page. 
Table A1. Major Disturbances and Unusual Occurrences in U.S. Electric Power Systems, 1992-Continued

\begin{tabular}{|c|c|c|c|c|c|c|c|}
\hline Date & TIme & Area & $\begin{array}{l}\text { Utlltty/Power Pool } \\
\text { (NERC Counctl) }\end{array}$ & $\begin{array}{c}\text { Type of } \\
\text { Dleturbance }\end{array}$ & $\begin{array}{c}\text { Loss } \\
\text { (megawatt) }\end{array}$ & $\begin{array}{l}\text { Number of } \\
\text { Customers } \\
\text { Affected }\end{array}$ & $\begin{array}{c}\text { Restoration } \\
\text { Time }\end{array}$ \\
\hline $12 / 16 / 92$ & $4: 47 \mathrm{AM}$ & Southern, MD & $\begin{array}{l}\text { Southern Maryland } \\
\text { Electric Coop. } \\
\text { (MAAC) }\end{array}$ & "Misoperate & 85 & 41,000 & $\begin{array}{l}\text { 6:02 AM } \\
\text { Same Day }\end{array}$ \\
\hline $12 / 18 / 92$ & $5: 46$ AM & Las Vegas, NV & $\begin{array}{l}\text { Western Area Power } \\
\text { Administration } \\
\text { (WSCC) }\end{array}$ & ${ }^{m}$ Sabotage & 30 & NA & $\begin{array}{l}\text { 1:14 PM } \\
\text { Same Day }\end{array}$ \\
\hline $12 / 21 / 92$ & 3:15 PM & $\begin{array}{l}\text { Near Seattle } \\
\text { Washington }\end{array}$ & $\begin{array}{l}\text { Bonneville Power } \\
\text { Administration } \\
\text { (WSCC) }\end{array}$ & "Sabotage & None & & NA \\
\hline $12 / 28 / 92$ & $2: 40$ AM & Portola, CA & $\begin{array}{l}\text { Plumas-Sierra Rural } \\
\text { Electric Coop. } \\
\text { (WSCC) }\end{array}$ & ${ }^{\mathbf{n}}$ Line Fault & 16 & 5,492 & $\begin{array}{l}\text { 4:01 AM } \\
\text { Same Day }\end{array}$ \\
\hline $12 / 28 / 92$ & $11: 16$ AM & Portola, CA & $\begin{array}{l}\text { Plumas-Sierra Rural } \\
\text { Electric Coop. } \\
\text { (WSCC) }\end{array}$ & "SLine Fault & 16 & 5,492 & $\begin{array}{l}11: 39 \text { AM } \\
\text { Same Day }\end{array}$ \\
\hline $12 / 28 / 92$ & $9: 54 \mathrm{AM}$ & Portola, CA & $\begin{array}{l}\text { Plumas-Sierra Rural } \\
\text { Electric Coop. } \\
\text { (WSCC) }\end{array}$ & ${ }^{M}$ Line Fault & 16 & 5,492 & $\begin{array}{l}\text { 10:18 AM } \\
\text { Same Day }\end{array}$ \\
\hline $12 / 30 / 92$ & $3: 16$ AM & Portola, CA & $\begin{array}{l}\text { Plumas-Sierra Rural } \\
\text { Electric Coop } \\
\text { (WSCC) }\end{array}$ & "Line Fault & 16 & 5.492 & $\begin{array}{l}\text { 9:51 AM } \\
\text { Same Day }\end{array}$ \\
\hline $12 / 31 / 92$ & $9: 26$ AM & Portola, CA & $\begin{array}{l}\text { Plumas-Sierra Rural } \\
\text { Electric Coop. } \\
\text { (WSCC) }\end{array}$ & $\boldsymbol{\omega}_{\text {Line Fault }}$ & 16 & 5,492 & $\begin{array}{l}11: 27 \text { AM } \\
\text { Same Day }\end{array}$ \\
\hline $12 / 31 / 92$ & 7:03 PM & Portola, CA & $\begin{array}{l}\text { Plumas-Sierra Rural } \\
\text { Electric Coop. } \\
\text { (WSCC) }\end{array}$ & ${ }^{97}$ Line Fault & 16 & 5.492 & $\begin{array}{l}\text { 10:10 AM } \\
\text { Same Day }\end{array}$ \\
\hline
\end{tabular}

- During a normal switching operation, the switching device malfunctioned, initiating an arc between two 230 -kilovolt cables that connect PEPCO's Station $\mathrm{C}$ to the system. The station was thereby disconnected from the system, and its five generating units tripped, causing loss of all load supplied from that station. An emergency tie with Virginia Electric and Power Company was established to allow restoration of service to begin

2 One distribution transformer in each of the two different substations was damaged by rifle fire, one at 2:30 $4 \mathrm{M}$ and the other at an earlier time which could not be ascertained. Customer service was not affected.

3wo substation transformers (69-kilovolt/12.47-kilovolt) were damaged by rifle fire on $1 / 22$ and two more (69-kilovolt/12.47-kilovolt) were damaged by rifle fire on $1 / 23$. All four transformers were repaired and were re-energized by the morning of $1 / 25$. Customer service was not affected.

- The 230-kilovolt transmission line from Western Area Power Administration's Tracy substation to its Livermore substation tripped, causing loss of power to the DOE Lawrence Livermore National Laboratory Site No. 2 and the National Laboratory at Livermore, California. One of the two emergency generators at the Sandia tacility did not start; it was later discovered that a battery charger had been connected incorrectly. The other generator did start and provided power for critical loads. The cause of the 230-kilovolt line trip is believed to have been fog and icing in the Altamont Pass area. Service was restored via a 230-kilovolt line from Pacific Gas and Electric Company

- During test of a relaying system change, a tripping relay at Midway Substation was inadvertently operated, causing bus circuit breakers to open. At the same time a circuit breaker that should not have tripped did trip. Opening of the circuit breakers resulted in the op 230 -kilovolt lines from St. Lucie nuclear plant. This lett the two St. Lucie units feeding about 1,700 megawatts into one 230 -kilovolt line, which became overloaded by about 65 percent. The overload was removed in 4 minutes, 54 seconds. Customer service was not affected

- Rifle fire damaged insulators on one 138-kilovolt line and one 345-kilovolt line on February 10 and on two 138 -kilovolt lines on February 11 . The lines were tripped and locked out by protective relays. Three of the lines originate at the company's Sooner Generating Plant; dispatchers limited output from that plant until repairs were completed

7 Two 345-kilovolt lines were tripped by protective relays after being damaged by rifle fire. The lines originate at the company's Sooner Generating Plant, one going to the Northwest substation, one going to the Woodring substation. Power output at Sooner Unit 2 was reduced from 500 megawatts to 400 megawatts until repairs were completed and the lines were restored for service.

- Five 345-kilovolt lines tripped and were locked out by protective relays after insulators were damaged by rifle fire over a period of 2 hours and 54 minutes.

- A blizzard traversed the service area of Public Service of Colorado from about 7:00 PM on 3/08/92 to about 2:00 PM on 3/09/92. The PSC sys. tem temporarily lost ten 230-kilovolt lines, nine 115-kilovolt lines, a section of 44-kilovolt tine and two 345-kilovolt interconnections with Tri-State Gen eration \& Transmission Cooperative and Western Power Administration of Department of Energy. All lines except the 44-kilovolt were restored to service by 5:00 PM on 3/09/92; repairs were in progress on twelve wood pole structures of the 44-kilovolt line that had been damaged. The Fort St. Vrain substation lost one 230-kilovolt bus for a time due to tripping of a circuit breaker when a bushing flashed over. The Rocky Flats installation of DOE lost one of the two 115-kilovolt lines supplying utility power and used its emergency power facilities as backup.

10 Lightning burned a pole on US 13 bypass near Peanut Company. Power is purchased from North Carolina Power Company.

"Construction workers accidentally pierced the roof of a tunnel system under Chicago, allowing the Chicago River to flood the lunnels and the lower levels of buildings in the central business area. The presence of water in the buildings made it necessary to cut off power where there was danger of short circuits and damage to equipment. Restoration of service was dependent upon removal of water and debris, and restoration of safe condi- 
tons . . Customer premises that had been flooded.

12 An overhead static wire failed on a double-circuit transmission structure supporting the Gadsby-Terminal 138-kilovolt line and the Gadsby-Terminal 46-kilovolt line, causing a phase-lo-ground fault on both lines and then a multi-phase fault. Fault duration was about 20 cycles, during which the 138 . kilovolt bus voltage at Terminal dipped to 0.5 per unit. During the disturbance frequency fell to 59.987 cycles and then rose to 60.065 cycles before returning to normal. The 138-kilovolt line was restored to service in about 16 minutes, the 46-kilovolt line was left out of service pending repair of the static wire. The disturbance caused caused tripping of one 29 megawatt generating unit at a Kennecott Copper Company facility (restored within 17 minutes) and 5 megawatts of small hydro units. The load lost was 383 megawatts of firm load and 35 megawatts of interruptible

is Piots following the verdict in the Rodney King police brutality trial led to tripging of 375 -kilovolt disturbution circuits in the City of Los Angeles Festoration of service of delayed until the safety of utility personnel could be assured. There was no damage to distribution or transmission substa. tions or the bulk power system generally The maximum number of customers without power at any one time was 24,300 , the total number of cus tomers affected was 51,800

14 Test of the voltage reduction procedures. At 10:40 AM a voltage reduction of $8 \%$ was initiated; a $5 \%$ reduction was initiated at 10.58 AM and a

$3 \%$ reduction at 11:17 AM. Reset was begun at 11:24 AM; all voltages were normal by 11:49 AM

18 Lightning broke an insulator on the Roanoke 115-kilovolt tap Power is purchased from North Carolina Power Company

16 A storm caused distribution circuit damage. Generating plants and transmission lines were nol damaged

"A storm caused extensive distribution circuit damage. Sixty-five line crews were requested from out-ol-state utilities and contractor crews were reassigned from other duties, to restore service.

1. The storm caused many distribution circuit outages.

1" The storm caused many distribution circuit outages

to High winds toppled trees, damaging distribution conductors and breaking poles; lightning caused damage to distribution transformers. Three 138 kilovolt lines tripped when two steel towers fell and conductor support arms on other structures were damaged. Two of the lines were returned to service on June 22. Seventy-six line crews were sent in by other utilities, and 60 tree-trımming crews were also utilized

2) Winds in the 100 mile per hour range traversed the company's service area, causing distribution circult damage and tripping three 138 -kilovolt lines, two 345-kilovolt lines and one 345/138 kilovolt transtormer

22 Lightining struck a switch in the Everetts substations.

23 A 138-kilovolt lightning arrestor on Lon Hill Unit 3 (150 megawatt) main power transtormer lailed, causing a 3.phase on the CPL transmission sys tem. Unit 3 tripped Voltage levels in the Corpus Christi and Rio Grande areas dropped to $70 \%-85 \%$ or normal, and current in some distribution feeders rose $10170 \%$ to $300 \%$ of pre-fault values as motors stalled because of the low voltage. Over current relays tripped loads and voltage rose to $114 \%$ of nominal until capacitors could be removed Unit No 7 (48 megawatts) at La Palma Power Plant then tripperd on loss-of-excitation, and Bates Unit ? (107 megawatts) was tripped about 8 minutes later by operator control because of a high-combustible boiler alarm Load loss was as fol lows 380 megawatts industrial and 84 megawatts residential/commercial in the Corpus Christi area, 200 megawatts residential/commercial in the Rio Grande area 120 miles trum the location of the fault; and 42 megawatts tripped by under voltage relaying on the CFE system in Mexico

24 Falling trees damayed distribution circuits as a severe storm with high winds and lightning moved through the companys service area

28 Falling trees damaged distribution circuits as a storm with high winds and hail hit the service area

- High loads on the Allegheny Power System and neighboring utilities caused loads on the bulk power transmission system in the area to approach voltage stabitity limits Transfer of power from west to east through the Allegheny Power System were curtaled beginning at 800 AM on July 17 but power flow remained high as culs in contracted flows were replaced by other power flows looping through the APS system towards the P.JM service area A $5 \%$ voltage reduction was intrated at $3.17 \mathrm{PM}$ to reduce bulk transmission loading. APS aiso purchased energy so that some generators could be unloaded in ordet to reduce loading on critical lines

"A 1.200 MVA 500/161 kilovolt 3-phase transtormer bank was tripped by a sudden-pressure relay during a tap-changing-under-load operation un der supervisory control The bank is located in a substation at West Point. Mississippi Under-voltage relays shed 568 megawatts interrupting 150.000 customers in the West Point-Jackson area of Mississippi There was no damage evident to the transtormer structures. and differential relays did nol operate After preliminary inspection, the bank was returned to service at 6.53 PM the same day Lost load had been previously restored by switching operations

20 A single-line-to-ground fault occurred on the 138-kilovolt line between the Dunsmuir and John Hart substations on Vancouver Island in British Co lumbia. As operators atternpled to adjust generation to relleve loads on parallel lines, other lines tripped Some load was shed by under frequency re laying, some by low.voltage relaying. Some loads were restored within 15 minutes, some within 30 minutes. The 190 megawatt of pulp mill load that was shed required about 6 and 7 hours 10 clear the processing systems and return to full load even though electric service was avallable within half an hour. The US portion of the WSCC system was not affected Note. This event is included here because it occurred on the WSCC system, which ex. tends across the US Canadian border

* A lorest fire caused tripping of the 500-kilovolt Malın. Round Mountain transmission line No 2 The line reclosed and tripped again, the No 1 line of that circuit also tripped This caused operation of the WSCC Islanding Scheme, separating the WSCC system into a North Island and a South Is land and initiating operation of the Remedial Action Scheme inipoing some Northwest generating capacity in addition 225 megawatt of generation in Southern California tripped on under frequency. The fire also caused the toss of some 230 -kilovolt lransmission, resulting in the tripping of 450 megawat of generation in the Pit River watershed

* At 3.45 PM PAST a forest fire caused tripping of Malin. Round Mountain 500-kılovolt tranismussion lines No 1 and No 2 The WSCC islanding Scheme then separated the system into North and South islands South frequency dropped $105967 \mathrm{HZ}$ and North trequency rose to $60292 \mathrm{HZ}$. Fe. medial Action Scheme (RAS) tripped 400 megawatt of generation in the Northwest. Co (in the South Island) lost 400 megawatt of interruptible load. which tripped on under frequency. Both Malin-Pound Mountain lines were reclosed, and were again tripped by the fire at 4.03 PM PAST No further remedial actions took place because loading on the two lines was low The WSCC Open Loop procedure was implemented at at 421 PM

"Hurricane Andrew interrupted service to $1,400,000$ customers of Florida Power and Light Company, damaging the Cutier Power Plant itwo lossil urits) and the Turkey Point Power Plant (two nuclear and two fossil units) All eight iransmission ines connected to the Turkey Point Plant substained some damage, as did the switchyard and the two tossil units at Turkey Point The transmission line to Florida Keys Cooperative/Key West Utilities Board was blown down. There was much destruction of distribution facilities Restoration of service began shortly after the hurricane left the area By Seplember 23 service had been restored to all customers except 25,000, whose premises required major repairs betore electric power could be salely reconnected Cutler Unit 5 was returned to service on September 8 . Cutier Unit 6 returned to service on September 21 At the Turkey Point Plant, Unit 1 (fossil) may be back in service by April 1993 if rebulding of the demolished stack has been completed. Unit 2 (fossil) was returned to service a tull power on September 16. Unit 3 (nuclear) is out for refueling and may be retumed to service at full power on September 16, Unit 3 (nuclear) is out for refueling and may be returned to service in early December 1992. Unit 4 (nuclear) was re-started during the weekend of October $24 / 25$ and as of October 26 was operating at half power. All radial lines to substations had been repaired by September 3 and six of the eight $230-k i l o v o l t ~ l i n e s$ at Turkey Point were back in service as of September 4 The other 2 Turkey Point lines have not been reconnected because the system configuration will be changed. Many other lines that were te-established to temporary standards because of the need to restore service will be upgraded during 1993

"Distribution lines were knocked down by the hurricane

33 The hurricane destroyed about 13 miles of the 138-kilovolt interconnection between Key West Utilities Board, Flonida Keys Electric Cooperative and Florida Power and Light Corporation. interrupting all custorners on the Key West Utilties Board system The Key West System supplied limited power to its customers from its own generating laclities and requested customers to reduce loads until the interconnection was re-estabished. The Key West system also supplied some power to the Florida Keys Cooperative while the 138 -kilovolt line to Florida Power and Light was beirig rebuilt Full service was restored to both systems when the line was completed on S.jptember 8,1992

* Florida Keys Electric Cooperative lost all customers when the nurncane destroyed the interconnection 10 Flonda Power and Light Panial service to customers was restored by use of its own generation and power from the Key West utilties Board Customers were requested to reduce their use of power and restrictions on unessential use were entorced Fult power was restored when the interconnection 10 Florida Power and Light was re. stored to service on Septernber 8, 1992

36 The hurricarie knocked out many distribution circuits and service drops 10 customers All supply lines from Cajun Electric Cooperative were tripped Some customers were without service for 2.5 hours, some for 7 hours, others for longer 
- Distribution circuit damage was extensive. All power supply was lost when the seven supply lines from Cajun Electric Power Cooperative tripped Dixie has no generating plant; all power is purchased fram Cajun Dixie estimates that the cosi of restoring service after the hurricane was about \$2 5 million

"Distribution circuit damage was extensive Temporary repairs were made initially to restore service as soon possible; bringing all work un to sys. tem standards may take another six months. All power is purchased from Cajun Electric Power Cooperative and is delivered over 7 transmission lines and one small 13 8-kilovolt distribution circuit. Of the 7 transmission lines two (115.kilovolt) are owned by South Louisiana Cooperative, one (138.kilo volt) is owned by Central Louisıana Electric Company, and four (115-kilovolt) are owned by Lousiana Power and Light Company Early during the hurri. cane all supply lines were out of of service for a time

* The approximate cost of restoration work after the hurricance was $\$ 2.5$ million Three 115-kilovolt and one 230 -kilovolt transmission liries were down and much distribution circult work was needed

* The storm interrupted service to ail customers. About $70 \%$ of the customers had service restored by 5.00 PM on on $9 / 1 / 92$, drawing some 20 megawatts. The normally expected summer peak demand is 38 megawatts Load was being supplied by the interconnection with Louisiana Power and Light Company, pending reconstruction of the Central Loulsiana Electric Company 138 -kilovolt line which had 300 structures destroyed At the Morgan City Steam Plant, Units 1,2, and 3 are expected to be in service on the evening of September 1 Drying of Unit 4 switchgear is expected to take several days

- All power is purchased from Cajun Electric Power Cooperative. over 9 delivery points. 3 at 138-kilovolt and 6 at $345 \cdot k i l o v o l t$. All 9 delivery points tripped during the storm.

The Southern Pine Cooperative purchases its power from the South Mississippi Electric Power Association, over 26 delivery points: five of these tripped. Many of the customers affected had service restored before the final restoration time in the table above About 2,000 customers were out for the full duration of the incident. There is no record of the megawalt load lost, but the system has computed the energy loss as being 194892 megawatthours

4 The hurricane brushed the southern end of the company's area on $8 / 25$ with minimal damage, and returned on $8 / 26$, 11 was over by $8 / 27$ No damage was done to - - erating plants. Distribution circuits. 44-kilovolt lines and 115 -kilovolt lines were down on $8 / 25$ and $8 / 26$

4 Hurricane Andrew interrupted part of the purchased power supply to the system. which does not have a generating plant of its own Sorne distri bution circuits in the system were damaged

"4ower is purchased from South Mississippi Electric Power Associatıon. none of the supply lines Iripped Outages were caused by wind-driven con lacts between trees and distribution circuits

" High winds and torndoes resulting from Hurricane Andrew caused tripping of nıne 115-kılovolt and four 230-kilovolt transmissıon lines, causing outages of 15 major substations on the combined interconnected systems of Louisiana Power and Light Company and New Orleans Public Service Company. Distribution facilities were also damaged. No generation was lost during the storm.

* The hurricane caused tripping of transmission lines as follows. 24 138-kilovolt, 9230 -kilovolt and 2 500-kılovolt. Some tines reclosed after tripping. As of 4:30 PM on 8/26, 7 of the 230-kilovolt and 6 of the 138-kilovolt lines were back in service By $2: 00$ PM on 8/28, only $1230-k i l o v o l t ~ l i n e$. 5138 -kilovolt lines and one 500-kilovolt line were still out of service The 500-kilovolt line, from Webber to Willow Glen power plant, had 12 supporting structures down. It was expected that all the 138 -kilovolt lines would be back in service by Sep 10 . with the 500 -kilovolt line being restored by Sep 18 Many distribution circuits were down

"High winds caused many distribution circuit failures.

4 The system purchases its power from Cajun Electric Power Cooperative Delivery is made over 28 delivery points. sixteen point lost power during the hurricane beginning at 2.23 AM on 8/26/92 and continuing through $6.39 \mathrm{PM}$ on the same day. Outage times for the 16 points ranged from 2 min utes to 59 hours 27 minutes. The last restoration of service to a delivery point was made at $5: 03$ PM on $8 / 28 / 92$ Distribution circuit damage withir the system caused interruptions to begin before delivery point service was lost and continue after all delivery point power was restored

1- The entire city lost its power supply. Ahout $75 \%$ of the customers had power restored by 11:00 AM on $8 / 28$ The remainder had service re stored by 5:00 PM on 8/30 The city's consulting engineer estimates that the total revenue lost due to the hurricane was about $\$ 43,650$

so Transmission and distribution lines were damaged by the hurricane but the company did not report that any generating plants were damaged Ail 138-kilovolt lines south of Lafayette and New iberia were out of service, and $300 \mathrm{H}$-frame structures on 230-kilovolt lines were down As of September 3 service had been restored to about 20,800 customers

31 High winds caused faults that tripped 39 distribution circuit treakers (mostly at the 13.8 level) of the 63 on the system About 13,000 customers had service restored withın 24 hours By $8 / 28$ midday less than 500 custorners were without service About 35 crews including tree-trimmers worked on service restoration. The system used its own supplies for repairs. Insulators, conductors, transiormers Not many poles were broken

62 Some outages were reported about midnight on 8/25, additional outages were reported continuously after that time; the load at 220 AM was about 7.5 megawatts. The system was shut down at 3.30 AM when load had dropped to 5 megawatts to prevent damage by the many short circuits that occurred as falling tree branches and poles caused distribution lines to break Normal load at that time would have been about 125 megawatts.

b3 The 35 megawatts load loss endured for about an hour Power supply from Cajun Electric Cooperative was interrupted at all seven delivery points; 3 points were restored the same day. Service was restored to about $70 \%$ of the customers lost within 48 hours.

- The city's generating plant was not damaged but the line over which purchased power is supplied by the Louisiana Energy and Power Authority tripped. Distribution circuits were damaged

wower is purchased from South Mississippi Electuc Power Association and is delivered over the system of Mississippi Power \& Light Co Two of the supply lines tripped; in addition, distribution circuits within the system were damaged by the storm.

* Several distribution circuit poles were down, damage was minor. Most customers had service restored within 2 hours.

"Power is supplied to the system by Southeastern Power Administration over transmission lines Mississippi Power Company. TVA and Mississipp Power Company. One Mississippi Power Company line tripped

- The Yazoo system has 8 delivery points. at which it receives all its power The supplier is the South Mississippi Electric Power Association None of the delivery points lost power supply All customer outages were due to effects of the hurricane on distribution circuits.

- All power is purchased from South Mississippi Electric Power Association (SMEPA), and is delivered over several SMEPA 69.kilovolt lines One of the lines tripped during the storm; it was out of service for about 30 minutes. Customer outages weie due 10 windblown tree limbs contacting distrı bution circuits

- Almost the entire system was down due to distribution circuit faults and loss of three delivery points for 4 or 5 hours during the hurricane. Power is purchased for the cooperative by South Mississippt Electric Power Association and is delivered over the transmission system of Mississippi Power and Light $C_{0}$ at 11 delivery points. Transmission to the points that were interrupted was at 115-kilovolt.

- The effect of the hurricane was minor. None of the 10 delivery points over which power is received from South Mississippi Electric Power Asso ciation tripped

62 Power is purchased from South Mississippi Electric Power Association. There are 20 delivery points, nine of which tripped during the hurricane

* No details avarlable

-4 Outages were minor, caused by windblown tree limbs contacting distribution circuits Power is purchased from South Mississippi Electric Power Association; there are eight delivery points, none of which tripped during the storm

* Distribution circuits were out of service as 27 poles went down. The tolal cost of restoring the system to normal was about $\$ 65,000$

- Power supply, purchased from TVA, was not lost Outages were due to distribution system damage caused by the hurricane Service was re stored to many customers within 12 hours, but complete restoration was not accomplished urtil 2 AM on $8 / 28$

"Power is purchased from TVA. There was some intermittent tripping of the supply as tree limbs shorted transmission lines temporarily Cus tomer outages were due to tree limbs being blown into distribution circuits. The 5000 customer outages is the total that occurred during the storm. not the number out simultaneously

w Customer outages were due to the hurricane bringing trees into contact with distribution circuits and breaking some distribution circuit poles

About a dozen poles had to be replaced. Power is supplied to the cooperative from TVA at 8 delivery points; none of these tripped.

- Power is purchased trom TVA over 4 delivery points None of the delivery points tripped Damage was confined to distribution circuits

70 All power is purchased from TVA over 5 transmission lines: 1 at 46 -kilovolt, 1 at 69 -kilovolt and three at 161 -kilovolt; none of the lines tripped dur. ing the hurricane. Customer outages were due mainly to wind-blown tree limbs contacting distribution circuits 
"Power supply. purchased trom TVA, was not lost Oulages were due to distribution circuit damage caused by the storm

1 The hurricane had little effect on the system Power is purchased trom TVA, delivered over one ifit kilovoll line and one 46 kilovolt line ine power supply lines did not trip Customer outages were due to the effects of high winds on trees and distritution circults

"Hurricane Andrew caused tornadoes, high winds and lighining actoss central Alabama, damaging the subtransmission system and distribution cir cults There were no outages of the bulk power network

'4 A fault on an internal 230 kilovolt of Los Angeles Dept of Water and Power caused mis.operation of relays, opering curcuits to Iwo 230 kilovoll busses and cutting off power to the two 230/69-kilovolt transtormer banks that supply the Cily of Burthank lhere was tho darrage to system facilities

" Hurricane Iniki destroyed much of the transmission and distritsution system

- A lomado passed over Cantral Fiorida, darnaging distribution cilcuits

"The tornado in Central Flonda caused tripping of teeders

" The tomado in Central Flonda, caused falling trees and windblown debris to trip eleven distribution feeders and one fig kilovoll ling Generating plants were not damager The premises of some customers were damaged to the extent that service cotid not the restored until the premises were rebult

- Typhoon Brian crossed the southern tip of Guam about 5 PM Guam ume (3 AM ESI) The eye of the typhoon was some 8 lo 9 rilles wide winds were about $90 \mathrm{MPH}$. gusting to $110 \mathrm{MPH}$ The north end of the island received sustained winds of 45 MPH with gusts to 62 MPH Ihere were lirnited pockets of power oulages but no transmission lines falled Military bases have power No additional data were reported

- Protective relays at Jones Station operated to disconnect the plant from the system as a 345 kilovolt tratismission line was being relurried to service from a maintenarice outage Under trequency relays then operated. shedding 150 megawatts of the compariy's liem load (incsitly service to ru ral substations and Rural Electric Cooperatives) In addition. 86 megawatts of firm power sales over the DC he at Ariesia. NM. to EI Paso Electric Company and Texas. New Mexico Power Compariy was interrupted. Interruptible sales to Public Service Company of New Mexico and E. Paso fiectric

Company were also interrupted The areas affected were around Roswell. NM and the Texas cornmunities of Hereford Lutibock levelland and Tulia

"The Kewaunee nucleat generaling unit was shut down for about 35 hours when seaweed from lake Michigan clogged the scteens which filter the condenser cooling water No load was lost

"A lault on the 500 kilovolt line from Malın substation in Oregon to Found Mountain substation in northem Calitorna caused protective retays lo trip the line The Pacilic Interie (PAC) remedial action scheme then operated to send a separation signal to the Four Corners power plant iransmis sion lines tripped to separate WSCC into a Southern Istand and a Northern Island, and the frequency in the Northern Island rose to 60 ir hertz (cycles per second) No generating plants tripped and no customers were affected, 13 lines, operating at voltage levels trorn 55 kilovoll to 500 .kilovoli tripped

" A cold front moving through the Houston area caused tornadoes that disrupted service in all four zones of the company 5 service area Sorne sy distribution teeders were tripped and locked out due to broken poles downed conductors and windblown trees and deturis in addition five fig kituveit and eight 138-kilovolt transmission lines suffered outages as high winds damaged steel towers. wood poles. crossarms and insulators

* Tornado broke a pole supporting the supply line from North Carolina Power Company

os The No 1 and No 2230 -kilovolt busses at Ignacio Substation in Marn County were tripped by differential and breaker backup protective retays while a DC ground problem was being investigated Other lines and the Fulton Substation also tripped by action of under voltage and under frecuency relays Unit No 11 at the Geysers Geothermal Power Plant generating 89 megawalts, was tripped by under frequency and breaker backup over cur. rent relays The CCCPA No 2 unit. generatıng 70 megawatts, was Iripped by under voltage relays All the 115 kilovoll lines servirig Marin. Sonoma and Napa counties tripped

* The entite service area was affected by a storm with winds tanging between 50 and 75 miles per hout Sevelal lines at $33 . \mathrm{kitovoll}$ and $69 \mathrm{~g}$ kinovoll were tripped by storm effects Lines at 115 -kilovolt and higher voltages were not affected

"Storm caused tripping of three 345 . kilovoll transmission lines and eight 115 kilovolt lines

* One leg of a tower supporting a double circuit 115 -kilovolt transmission line appeared to have theen blowri off by a bornt: Ihe incident was dis covered during inspection after a customer noticed that the tower was titled There was no interruption to service

" While one of two 69-kilovolt lines supplying power to the cooperative was being switched improper operation of a protective telay taused the other line to trip. cutting off service to the cooperative. The relaying arrangements have been corrected

- DOE's Nevada Test Site is supplied by two 138-kilovolt transmission ines. one from Nevada Power Company (NPC) and one from Valiey flectric Power Assoctation (VEA) Al 100 AM the NPC line tripped It was later discovered that a line support structure (wishtuone pole) thad toppled after be ing sawed through at the base in lalling. the pole down an adjacent 3-pole H-frame structure At 1225 PM the VEA line topped due to fallure of a splice in one conductor and cesulting single phase operation it is assumed that the splice falled because of the stress caused by the falleri structures Tripping of the lines disrupted power supply from the Amargosa Substation of Western Area Power Adrnirustration lo toats of NPC VE A arid the lest

Site Emergency diesel generators at the Test Site started and supplied their loads until commercial was restored

"The Bonneville Power Adminstration Covington Substation operator tound what appeared to be an explosive device adjacent to the substation fence The device was removed, the power system was not affected

"Outage on Plumas Sierra system because of high winds in the area which caused an outage of the onty supply linf from pacitic lias, and flectric. Company

-3 Outage of the Pacific, Gas and Electric supply line caused loss of power to Plumas-Sierra

* Outage due to Pacific Gas and Electric transmission trouble

is Conductor down on Pacific Gas and Electric line to Plumas-Sierra

- Fault (short circuit) on Pacific Gas and Electric line Plumas. Sierra

" Tree tell into Pacific Gas and Electric. Ime to Plumas. Sierra

- A 500-klovolt circut breaker in the Sequoyah nuclear power plant switchyard was replaced by a new breaker Iwelve rruritetes alter the riew breaker was energized, a short circuit developed in Phase C. Protective relays tripped the faulty circult breaker and all the soo kilovoll breaks? in the switchyard as well as several 161-kilovolt circuit breakers Both generating units tripped resulting in a voltage dip and a decline un frecjueticy Ithe Raccoon Mountain pumped storage was brought on ine to supply the generation deficit and ine situation was stabilized in 11 minutes inere was rio loss of customers and the only of load was due to the short-term drop in voltage and frequency. this loss could not be measured

Notes -Under the Code of Federal Hegulations 110 CFR Part 205) and published in the Federal Register of (Octotem 31 1983 the: United States Department of Energy does not recerve reports of distribution system outages that are locat in nature and affert enty it sfriall intis ef at small number of customers the following abtreviations may be applicable

PAST Pacific Advanced Standard Time. EDT Eastern Daylight Time EST Eastem Standard lime

MAST Mountan Advanced Standard Time. CST Central Standard Time

Int Interruption of service

If Line fault (Accidental contact of energized conductors of of energized conductors with yrourd

LF Load Reduction.

LTNG Lightring Strike

MW Megawatts

NA Not Avallable

PA Public Appeal

EMC Electric Memuersho Corporation

UO Unusual Occurrence.

VR Voltage Reduction

LS Load Shedding.

LC Curtailment and interruptible customers were to drop some load

IPL Indianapolis Power and Light Company

PSt Pubic Service of indiana,

HE. Hoosier Energy Rural Electric Cooperative

IM indiana Michigan Power Company (Subsidiary of Arnerican Electric Power Compariyi

Source International Attars and Energy Emergenciess. Form OE $417 \mathrm{H}$. "Electric Power System tmengency Sempor! 
Appendix B

References 


\section{References}

1. Energy Information Administration, Office of Energy Markets and End Use, Monthly Energy Review, DOE/EIA- 0035(93/1-11) (Washington DC, 1993); DOE/EIA-0035(9/92) (Washington DC, 1992).

2. Energy Information Administration, Office of Coal, Nuclear, Electric and Alternate Fuels, Electric Power Monthly, DOE/EIA-(0226 (93/1-11) (Washington DC, 1993).

3. Energy Information Administration, Office of Energy Markets and End Use, Historical Monthly Energy Review, DOE/EIA-0035(73-88) (Washington DC, September 1991).

4. Energy Information Administration, Office of Coal, Nuclear, Electric and Alternate Fuels, Cost and Quality of Fuels for Electric Utility Plants, DOE/EIA-0191(92) (Washington DC, 1993).

5. Standard and Poor's Industry Survey, Natural Gas, Vol. 160, No. 47, November 19, 1992.

6. Energy Information Administration, Office of Coal, Nuclear, Electric and Alternate Fuels, Electric Power Annual 1991, DOE/EIA-0348(91) (Washington DC, 1992).

7. Energy Information Administration, Office of Coal, Nuclear, Electric and Alternate Fuels, Inventory of Power Plants in the United States, DOE/EIA-0095(92) (Washington DC, 1993); DOE/EIA-0095(91) (Washington DC, 1992).

8. Energy Information Administration, Office of Coal, Nuclear, Electric and Alternate Fuels, Electric Sales and Revenue, DOE/EIA-0540(91) (Washington DC, 1993).

9. Energy Information Administration, Office of Coal, Nuclear, Electric and Alternate Fuels, Financial Statistics of Major U.S. Investor-Owned Electric Utilities 1992, DOE/EIA- (1)437(92)/1 (Washington DC, 1993).

10. Energy Information Administration, Office of Coal, Nuclear, Electric and Alternate Fuels, Financial Statistics of Major U.S. Publicly Owned
Electric Utilities 1992, DOE/EIA- 0437(92)/2 (Washington DC, 1993).

11. Energy Information Administration, Office of Energy Markets and End Use, Annual Outlook for U.S. Electric Power 1985, DOE/EIA-0474(85) (Washington DC, 1985).

12. Energy Information Administration, Office of Energy Markets and End Use, Annual Energy Outlook 1993, DOE/EIA- 0383(93) (WashingIon DC, 1993).

13. Energy Information Administration, Office of Coal, Nuclear, Electric and Alternate Fuels, Electric Trade in the United States 1990, DOE/EIA-0531(90) (Washington DC, 1992).

14. Mitchell, Cynthia, "Integrated Resource Planning Survey: Where the States Stand," The Electricity Journal, (May 1992) pp. 10-15.

15. California Public Utilities Commission and California Energy Commission, Standard Practice Manual: Economic Analysis of Demand-Side Management Programs, (Sacramento CA, December 1987).

16. Baumol, William J. and Wallace E. Oates, The Theory of Environmental Policy, 2nd edition, (Cambridge University Press) (New York NY, 1989).

17. The Consumer Energy Council of America Research Foundation, Incorporating Environmental Externalities into Utility Planning, (Washington DC, 1993).

18. General Accounting Office, Electricity Supply, Demand-Side Management Programs Can Reduce Electricity Use, GAO/RCED-92-13 (Washington DC, October 1991).

19. Code of Federal Regulations, Title 18, Part 292, Subpart B. Federal Register, (Washington, DC, October 1992).

20. Prete, Larry and Betty Williams, "Nonutility Power Producers," Electric Power Monthly. (Washington DC, April 1992), pp 1-18. 
21. Code of Federal Regulations, Title 10, Part 205, Subpart W, Federal Register, (Washington DC, October 1902)

22. Energy Information Admmistration, office of Energy Markets and End Uac, Annual Energy Review 1902,1)(0):/ ilA - 0)384(92), Washington I) C. 199.3)

23. Finergy Information Administration, office of Statistical Standards, An Assessment of the Quality of Selected Ela Data Series: Electric Power Data, DOE/H:IA-(1292(87) (Washington I)C: $1989)$

24. Energy Information Administration, office of Filergy Markets and Find Use, Manufacturing Energy Consumption Survev: Consumption of Energy 1988. DOOE/FIA-1)512 (88) (Washington (): 1991)

25. Edison Electric Institute, Capacity and Generatlon of Non-Utility Sources of Energy. (11.93-14(92) (Washington DC. 1993).

26. Office of Management and Budget. Standard Classification Manual. 1972, (Washington DC: $1987)$

27. U.S. Department of Inergy, Assistant Secretary for Policy. Office of Emergency Planning, Electric Power Supply and Demand for the Contiguous United States 1989.1998. DOOE/IE:-0018(89.98) (Washinglon DC. 1990).

28. Fnergy Information Administration, "Policy on Disclonure of Individually Identifiable Energy Information in Possession of the EIA." 45 fed- eral Register $59812(1980)$.

29. U.S. Environmental Protection Agency, Office of Air and Radiation, Office of Air Quality Planning and Standards, Supplement A 10 Compilation of Air Pollutant Emission Factors, Vol. 1: Stationary Point and Area Sources, AP.42, Vol. 1. Supp. A, (Research Triangle Park NC. October 1986).

30. The Babcock and Wilcox Company, Steam. Its Generation and Use, (New York NY, 1978)

31. Energy Information Administration, Office of Energy Markets and End Use, Housing (haracteristics 1990, DOOE/EIA-(0314(90) (Washington DC, 1992)

32. Energy Information Administration, Office of Energy Markets and End Use, Household Energy Consumption and Expenditures 1990 , DOE: EIA-()321(90) (Washington I)C, February 1993)

33. Energy Information Administration, Office of Energy Markets and End Use, Commercial Building (haracteristics 1989. DOI:/LIA-0246(89) (Washington DC, June 19911

34. Energy Information Administration. Office of Energy Markets and End Use, Commercial Building Consumption and Expenditures 1989, DOE: EIA - () $318(89)$ (Washington DC. April 1992) 
Appendix C

Technical Notes 


\section{Appendix C}

\section{Technical Notes}

\section{Sources of Data}

The Electric Power Annual is prepared by the Survey Management Division; Office of Coal, Nuclear, Electric and Alternate Fuels; Energy Information Administration (EIA); U.S. Department of Energy (DOE). Data published in the Electric Power Annual are compiled from two statistical forms filed monthly and seven forms filed annually by electric utilities; and one form filed annually by nonutilities. Those forms are: the Form EIA-759, "Monthly Power Plant Report"; the FERC Form 423, "Monthly Report of Cost and Quality of Fuels for Electric Plants"; the Form EIA-861, "Annual Electric Utility Report"; the Form EIA-860, "Annual Electric Generator Report"; the Federal Energy Regulatory Commission (FERC) Form 1, "Annual Report of Major Electric Utilities, Licensees, and Others"; the Form EIA-412, "Annual Report of Public Electric Utilities"; the Form EIA-767, "Steam-Electric Plant Operation and Design Report"; the Form EIA-867, "Annual Nonutility Power Producer Report"; the Department of Energy, Emergency Planning and Operations Form OE-411, "Coordinated Bulk Power Supply Program"; and the Department of Energy, Office of Fuels Programs, Fossil Energy Form FE-781R, "Annual Report of International Electric Export/Import Data." The Electric Power Annual also includes data collected on the Form OE-417R, "Eles:tric Power System Emergency Report." Each form is summarized below.

\section{Form EIA-759}

The Form EIA-759 is a mandatory census of all operators of electric utility plants producing electric power for public use. The Form EIA-759 is used to collest monthly data on net generation, consumption of coal, petroleum, and natural gas; and end-of-the-month stocks of coal and petroleum for each plant by prime mover and fuel-type combination. Summary data from the Form EIA-759 are also published in the Electric Power Monthly (EPM), the Monthly Energy Review (MER), and the Annual Energy Review (AER). These reports present aggregated data for electric utilities at the U.S., Census division, and North American Electric Reliability Council Region (NERC) levels.
Instrument and Design History. Prior to 1936, the Bureau of the Census and the U.S. Geological Survey collected, compiled, and published data on the electric power industry. In 1936, the Federal Power Commission (FPC) assumed all data collection and prblication responsibilities for the electric power industr, and implemented the FPC Form 4. The Federal Power Act, Sections 311 and 312 , and FPC Order 141 define the legislative authority to collect power production data. The Form EIA-759 replaced the FPC Form 4 in January 1982.

Data Processing. The Form EIA-759, along with a return envelope, is mailed to respondents approximately 4 working days before the end of the month. The respondents names are obtained from a computerized mailing address file. The completed forms are to be returned to the EIA by the 10th working day after the end of the reporting month. After receipt, data from the completed forms are manually logged in and edited before being keypunched for automatic data processing. An edit program checks the data for errors not found during manual editing. The electric utility companies are telephoned to obtain data in cases of missing reports and to verify data when questions arise during editing. Following verification of the data, text and tables of aggregated data are produced for inclusion in the EPM. Following EIA approval of the $E P M$, the data are made available for public use, on a cost-recovery basis, through custom computer runs, data tapes, or in publications.

\section{FERC Form 423}

The FERC Form 423, a restricted census, is a monthly record of delivered-fuel purchases, submitted by approximately 230 electric utilities for each plant with a total steam-electric and combined-cycle nameplate capacity of 50 or more megawatts. Summary data from the FERC Form 423 are also published in the EPM, the MER, and the Cost and Quality of Fuels for Electric Utility Plants annual report. These reports present aggregated data on electric utilities at the U.S. and Census division level.

Instrument and Design History. On July 7, 1972, the FPC issued Order Number 453 enacting the New Code of Federal Regulations, Section 141.61, legally creating 
the Form 423. Originally, the form was used to collect data only on fossil-steam plants, but was amended in 1974 to include data on internal combustion and combustion turbines. The FERC Form 423 replaced the FPC Form 42.3 in January 1983. Peaking units were eliminated from the FERC Form 423. In addition, the nameplate capacity threshold was changed from 25 megawatts to 50 megawatts. This reduction in coverage eliminated approximately 50 utilities and 250 plants. All Form 423 historical data in this publication have been revised to reflect the new nameplate capacity threshold of 50 or more megawatts.

In 1991, the FERC Form 423 was amended to include combined-cycle generating units. This increase in coverage added 5 electric utilities and approximately 15 additional electric plants. Several plants, already reporting on the FERC Form 423, began including fuel receipts for combined-cycle units starting with 1991 data.

Data Processing. A computerized mailing-address file was used to send a 12-month supply of forms to respondents. Completed forms were to be returned to the EIA by the 45th day following the end of the reporting month. Data from the completed forms were manually logged in and edited before being keypunched for automatic data processing. The electric utility companies were telephoned to obtain data in cases of missing reports and to verify data when questions arose during editing. Following verification of the data, text and tables of aggregated data were produced for inclusion in the EPM. After the EPM received EIA approval, the data became available for public use, on a cost-recovery basis, through custom computer runs, data tapes, or in publications.

Starting with the January 1993 data, the FERC began collection of the data directly from the respondents. The FERC will process the data through edits and each month provide the EIA with a diskette containing the data. The EIA will review the data for accuracy. Publication schedules will not be effected.

\section{Form EIA-861}

The Form EIA-861 is a mandatory census of electric utilities in the United States, its territories, and Puerto Rico. The Form EIA-861 data contained in this publication are for the United States only. The survey is used to collect information on power production and sales of electricity from approximately 3,250 electric utilities. The data collected are used to update the electric utility frame data base maintained by the EIA. This data base supports queries from the Executive Branch, Congress, other public agencies, and the general public. Summary data from the Form EIA-861 are also contained in the EPM; the Electric Sales and Revenue; the Financial Statistics of U.S. Major InvestorOwned Electric Utilities; the Financial Statistics of Major U.S. Publicly Owned Electric Utilities; Annual Energy
Outlook; and the Electric Trade in the United States. These reports present aggregate totals for electric utilities on a national level, by State, and by ownership type.

Instrument and Design History. The Form EIA-861 was implemented in January 1985 to collect data as of year-end 1984. The Federal Administration Act of 1974 (Public Law 93-275) defines the legislative authority to collect these data.

Data Processing. The Form EIA-861 is mailed to the respondents in January to collect data as of the end of the preceding calendar year. The completed forms are to be returned to the EIA by May 1. The data are manually pre-edited before being entered into the interactive on-line system. Internal edit checks are performed to verify that current data total across and between schedules, and are comparable to data reported the previous year. Edit checks are also performed to compare data reported on the Form EIA-861 and similar data reported on the Forms EIA-826, "Monthly Electric Utility Sales and Revenue Report with State Distributions," the FERC Form 1, and the Form EIA-412, "Annual Report of Public Electric Utilities." These are utility-level checks. Respondents are telephoned to obtain clarification of reported data and to obtain missing data.

Detailed comparisons and descriptions of conceptual problems affecting the quality of the data are discussed in the report, An Aissessment of the Quality of Selected EIA Data Series: Electric Power Data. (See Appendix B, References.) One example of such a problem inherent in data on electricity sales is that the sectoral classification scheme can vary from utility to utility as influenced by the local public utility commission.

\section{Form EIA-860}

The Form EIA-860 is a mandatory census of electric utilities in the United States that operate power plants or plan to operate a power plant within 10 years of the reporting year. The survey is used to collect data on existing power plants from the electric utilities and their 10-year plans for constructing new plants, and modifying and retiring existing plants. Data on the survey are collected at the generating unit level. These data are then aggregated to provide totals by energy source (coal, petroleum, gas, water, uranium, other) and geographic area (State, NERC region, Federal region, Census division). Additionally, at the national level, data are aggregated to provide totals by prime mover. Data from the Form EIA-860 are also summarized in the Inventory of Power Plants in the United States, and are used as input to publications and studies by other offices in the DOE.

Instrument and Design History. The Form EIA-860 was implemented in January 1985 to collect data as of year-end 1984. The Federal Energy Administration 
Act of 1974 (Public Law 93-275) defines the legislative authority to collect these data.

Data Processing. The Form EIA-860 is mailed to approximately 900 respondents in December and the completed forms are to be returned to the EIA by February 15 containing data as of the end of the preceding calendar year. Data for each respondent are preprinted from the applicable data base. Respondents are instructed to verify all preprinted data and to supply missing data. The data are manually edited before being keyed for automatic data processing. Computer programs containing additional edit checks are run. Respondents are telephoned to obtain correction or clarification of reported data and to obtain missing data, as a result of the manual and automatic editing process.

\section{FERC Form 1}

The FERC Form 1 is a mandatory restricted-universe census of major investor-owned electric utilities in the United States having, in each of the last 3 consecutive years, sales or transmission service that exceeds one of the following: (1) 1 million megawatthours of total sales, (2) 100 megawatthours of sales for resale, (3) 500 megawatthours of power exchanges delivered, or (4) 500 megawatthours of wheeling for others (deliveries plus losses). All major U.S. investor-owned electric utilities, licensees, or others subject to the Federal Power Act of 1935 must submit this form annually to the FERC. Classification of such entities is provided in the FERC Uniform System of Accounts Prescribed for Public Utilities and Licensees Subject to the Provisions of the Federal Power Act. Approximately 180 electric utilities are classified as major. Excluded from the summary data are the independent power producers and cooperatives jurisdictional to the FERC. The FERC has determined that six independent power producers (IPP's): Catalyst Old River Hydroelectric Limited Partnership, Entergy Power Incorporated. Nevada Sun-Peak Limited Partnership, Ocean State Power, Ocean State Power II, and Terra Comfort Corporation are under FERC jurisdiction. These IPP'S must therefore submit the FERC Form 1 for 1992. The FERC has also determined that Golden Spread Electric Cooperative and Old Dominion Electric Cooperative should file a FERC Form 1 under Section 201 of the Federal Power Act. Data from these two entities were not included since they are classified as cooperative electric utilities on the Form ElA-861.

The FERC Form 1 is used to collect data on income and earnings, taxes, depreciation and amortization, distribution of salaries and wages, electric operating revenues, electric maintenance expenses, generating plant statistics, planned construction data, year-end balance sheets, and general corporate information. Respondents are required to report data on historical plant crist and power production expenses for their hydro. electric plants with a generator nameplate capacity of
10 or more megawatts; each steam-electric plant with a generator nameplate capacity of 25 or more megawatts; and each gas-turbine plant with a generator nameplate capacity of 10 or more megawatts. Less detailed data are required for other plants.

Instrument and Design History. The Federal Power Commission's (FPC) Form 1, the predecessor of the FERC Form 1, was implemented in 1935 by the FPC. When the FPC was merged with the DOE in October 1977, the processing of data on the survey became the responsibility of the EIA. In 1991, the collection responsibility reverted to the FERC. This mandatory survey is conducted in accordance with the FERC Uniform System of Accounts Prescribed for Private Utilities and Licensees.

Data Processing. The completed surveys are to be returned to the FERC on or before April 30, containing data for the preceding calendar year. A copy of each survey is forwarded to the EIA for processing. Manual editing of the reported data is completed prior to data entry. Additional edit checks of the data are performed through computer programs. The program edits include both deterministic checks, in which records are checked for the presence of data in required fields, and statistical checks, in which the data are checked against a range of values based on historical data values and for logical or mathematical consistency with data elements reported in the survey. Discrepancies found in the data, as a result of these checks, are resolved either by the processing office or by further information obtained from a telephone call to the respondent company.

\section{Form EIA-412}

The Form EIA-412 is a restricted-universe census used annually to collect accounting, financial, and operating data from major publicly owned electric utilities in the United States. Those publicly owned electric utilities engaged in the generation, transmission, or distribution of electricity which had 120,000$)$ megawathours of sales to ultimate consumers and/or 120,000) megawatthours of sales for resale for the 2 previous years, as reported on the Form EIA-861. "Annual Electric Utility Report," must submit the Form EIA-412. The criteria used 10 select the respondents for this survey results in approximately 450 publicly owned electric utilities.

Federal electric utilities are required to file the Form EIA-412. The financial data for the U.S. Army Corps of Engineers (except for Saint Mary's Falls at Sault St. Marie, Michigan): the U.S. International Boundary and Water Commission; and the U.S. Department of Interior, Bureau of Reclamation were collected on the Form EIA-412 from the Federal power marketing administrations. 
Instrument and Design History. The FPC created the FPC Form $1 \mathrm{M}$ in 1961 as a mandatory survey. It became the responsibility of the EIA in October 1977 when the FPC was merged with DOE. In 1979, the FPC Form 1M was superseded by the Economic Regulatory Administration (ERA) Form ERA-412, and in January 1980 by the Form EIA-412.

Data Processing. The processing of data reported on this survey is the responsibility of the Survey Management Division within the Office of Coal, Nuclear, Electric and Alternate Fuels. The completed surveys are due in this office on or before April 30. Nonresponse follow-up procedures are used to attain 100-percent response. Manual editing of the reported data is completed prior to data entry. Additional edit checks of the data are performed through computer programs. The program edits include both deterministic checks, in which records are checked for the presence of data in required fields, and statistical checks, in which the data are checked against a range of values based on historical data values and for logical or mathematical consistency with data elements reported in the survey. Discrepancies found in the data, as a result of these checks, are resolved either by the processing office or by further information obtained from a telephone call to the respondent company.

\section{Form EIA-767}

The Form EIA-767 is a mandatory restricted-universe census of all electric power plants with a total existing or planned organic- or nuclear-fueled steam-electric generator nameplate rating of 10 or more megawatts. The entire form is filed by approximately $7(0)$ power plants with a nameplate capacity of $1(0)$ or more megawatts. An additional 200 power plants with a nameplate capacity between 10 and 100 megawatts submit information only on fuel consumption/quality, boiler/ generator configuration, and flue-gas desulfurization equipment, if applicable. The Form EIA-767 is used to collect data annually on plant operations and equipment design (including boiler, generator, cooling system, flue gas desulfurization, flue gas particulate collectors, and stack data). Data from the Form E1A.767 are used for economic, regulatory, and environmental analyses conducted by the DOE, the FERC, the Environmental Protection Agency, and the Department of Commerce.

Instrument and Design History. The Federal Energy Administration Act of 1974 (Public Law 93.275) defines the legislative authority to collect these data. The predecessor form, FPC-67, "Steam-Electric Plant Air and Water Quality Control Data," was used to collect data from 1969 to 1980, when the form number was changed to Form EIA-767. In 1982, the form was completely redesigned and given the name Form EIA-767, "Steam-Electric Plant Operation and Design Report." In 1986, the respondent universe of 700 ) was increased to 900 to include plants with nameplate capacity from
10 megawatts to $1(0)$ megawatts. Respondents for these 200 additional plants complete only pages 1, 5, 6, and, if applicable, 13, and 14.

Data Processing. The Form EIA-767 is mailed to respondents in January to collect data as of the end of the preceding calendar year. The completed forms are to be returned to the EIA by May 1. Equipment design data for each respondent are preprinted from the applicable data base. Respondents are instructed to verify all preprinted data and to supply missing data. The data are manually reviewed before being keyed for automatic data processing. Computer programs containing additional edit checks are run. Respondents are telephoned to obtain correction or clarification of reported data and to obtain missing data, as a result of the manual and automatic editing process.

\section{Form EIA-867}

The Form EIA - 867 is a mandatory survey of all existing and planned nonutility electric generating facilities in the United States with a total generator nameplate capacity of 1 or more megawatts. In 1992, the reporting threshold of the Form EIA-867 was lowered to include all facilities with a combined nameplate capacily of 1 or more megawatts. Previously, data were collected every 3 years, from facilities with a nameplate capacity between 1 and 5 megawatts. Planned generators are defined as a proposal by a company to install electric generating equipment at an existing or planned facility. The proposal is hased on the owner having obtamed (1) all environmental and regulatory approvals, (2) a contract for the electric energy, or (3) financial closure on the facility. The Form consists of Schedules I. "Identificatum and Certufication;" Schedule II, "Facility Information"; Schedule III, "Standard Industrial Classification Code Designation": Schedule IVA, "Facility Fitel Information", Schedule IVB, "Facility Thermal and (ieneratum Information"; Schedule V, "Facility Environmental Information"; Schedule VI, "Electric Generator Information."

Submission of the Form EIA-867 is required from all facilities that have a combined facility nameplate capacity of 1 megawatt or more. Schedule $V$ "Facility Environmental Information" is only required of those facilites of 25 megawatts or more.

The form is used to collect data on the installed capacity, energy consumption, generation, and electric energy sales of electric utilities and other nonutilities by facility. Additionally, the form is used to collect data on the quality of fuels burned and the types of envi. ronmental equipment used by the respondent.

Instrument and Design History. The Form EIA-867 was implemented in December 1989 to collect data as of year-end 1989. The Federal Finergy Administration Act of 1984 (P'uhlic Law 93-275) defines the legislative authority to collect these data. 
Data Processing. The Form EIA-867 is mailed to the respondents in late January to collect data as of the end of the preceding calendar year. Static data for each respondent are preprinted from the previous year, and the respondents are instructed to verify all preprinted information and to supply the missing data. The completed forms are to be returned to the EIA by April 30. The response rate for all facilities that addresses were confirmed was 100 percent. The data are manually edited before being keyed for automatic data processing. Computer programs containing additional edit checks are run. Respondents are telephoned to obtain corrections or clarifications of reported data and to obtain missing data as a result of the manual and automated editing.

Data Quality. The Manufacturing Energy Consumption Survey (MECS) produces detailed estimates of manufacturing electricity generation by industry and Census Division on a triennial basis. The data are published in the Manufacturing Energy Consumption Survey, Consumption of Energy. Gross generation by nonutility power producers by major industry groups, and Census division, for 1989 through 1992 presented in this report, are reasonable given the growth in manufacturing on site generation that occurred between 1985 and 1988 as reported in MECS. As a historical reference, these tables are Table 9 in the 1985 MECS Consumption publication and Tables 14 through 17 and Tables 20 through 24 in the 1988 publication.

Data for the Form EIA-867 are collected from all existing and planned nonutility generating facilities in the United States with a total generator nameplate capacity of 1 or more megawatts. These data are aggregated to provide geographic totals for selected States and at the Census division and national levels. Since the Form EIA-867 data are considered confidential, suppression of some data is necessary to protect the confidentiality of the individual respondent data. See "Confidentiality of the Data" in this section for further information on the nondisclosure of data.

\section{Allocating Capacity}

The installed capacity for nonutility generating units is allocated to orie energy source using the following algorithms

- For generating units using a single fossil energy source, the capacity is allocated totally to that energy source.

- For generating units that use hydraulic, geothermal, solar, biomass, or wind energy, the capacity is allocated to that energy source.

- For generating units using a combination of fossil energy and renewable energy sources, capacity is characterized as fossil or renewable and allo- cated based on the greatest percentage of Btu consumed when summed for each.

- In addition, for capacity within the fossil energy and renewable energy sources, the single fuel within that energy source with the greatest percentage of Btu consumed is used to further allocate capacity.

\section{Allocating Generation}

The generation for nonutility facilities is allocated to one energy source using the following algorithms:

- For generating units that use energy sources that are not burned (hydraulic, geothermal, nuclear, solar, or wind energy), the generation is allocated to that energy source.

- For facilities having generating units using energy sources that are burned, the generation is allocated based on the percentage of Btu consumed. This algorithm assumes that unit efficiency is the same for all energy sources.

A comparison of installed capacity for facilities of 1 megawatts or more of EIA's data with data published by Edison Electric Institute (EEI) in Capacity and Generation of Non-Utility Sources of Energy shows a difference of approximately 1 percent.

Business Classification. The nonutility industry consists of all manufacturing, agricultural, forestry, transportation, finance, service and administrative industries, based on the Office of Management and Budget's Standard Industrial Classification (SIC) Manual. ${ }^{47}$ The following is a list from the Form EIA-867 of the main classifications and the category of primary business activity within each classification.

\section{Agriculture, Forestry, and Fishing}

01 Agriculture production-crops

02 Agriculture production, livestock and animal specialties

07 Agricultural services

08 Forestry

09 Fishing, hunting, and trapping

\author{
Mining \\ 10 Metal mining \\ 12 Coal mining \\ 13 Oil and gas extraction \\ 14 Mining and quarrying of nonmetallic minerals \\ except fuels
}

\section{Construction}

Manufacturing

20) Food and kindred products 
21 Tobacco products

22 Textile and mill products

23 Apparel and other finished products made from fabrics and similar materials

24 Lumber and wood products, except furniture 25 Furniture and fixtures

26 Paper and allied products (other than 2621 or 2631)

2621 Paper mills, except building paper 2631 Paperboard mills

27 Printing and publishing

28 Chemicals and allied products (other than $2819,2821,2869$, or 2873 )

2819 Industrial Inorganic Chemicals

2821 Plastics materials and resins

2869 Industrial organic chemicals

2873 Nitrogenous fertilizers

29 Petroleum refining and related industries (other than 2911)

\section{Petroleum refining}

30 Rubber and miscellaneous plastic products 31 Leather and leather products

32 Stone, clay, glass, and concrete products (other than 3241)

\section{Cement, hydraulic}

33 Primary metal industries (other than 3312 or 3334)

3312 Blast furnaces and steel mills

3334 Primary aluminum

34 Fabricated metal products, except machinery and transportation equipment

35 Industrial and commercial equipment and components except computer equipment

36 Electronic and other electrical equipment and components except computer equipment

37 Transportation equipment

38 Measuring, analyzing, and controlling instruments, photographic, medical, and optical goods, watches and clocks

39 Miscellaneous manufacturing industries

\section{Transportation and Public Utilities}

40 Railroad transportation

41 Local and suburban transit and interurban highway passenger transport

42 Motor freight transportation and warehousing 43 United States Postal Service

44 Water transportation

45 Transportation by air

46 Pipelines, except natural gas

47 Transportation services

48 Communications
49 Electric, gas, and sanitary services

50 to 51 Wholesale Trade

52 to 59 Retail Trade

Finance, Insurance, and Real Estate

60 Depository Institutions

61 Nondepository credit institutions

62 Security and commodity brokers, dealers, ex-

changes, and services

63 Insurance carriers

64 Insurance agents, brokers, and services

65 Real estate

67 Holding and other investment offices

Services

70 Hotels

72 Personal services

73 Business services

75 Automotive repair, services, and parking

76 Miscellaneous repair services

78 Motion pictures

79 Amusement and recreation services

80 Health services

81 Legal services

82 Education services

83 Social services

84 Museums, art galleries, and botanical and zoological gardens

86 Membership organizations

87 Engineering, accounting, research, management, and related services

88 Private households

89 Miscellaneous services

91 to 97 Public Administration

Other (explain):

\section{Form OE-411}

The Form OE-411 is filed annually as a voluntary report. The information reported includes: (1) actual energy and peak demand for the preceding year and 10 additional years; (2) existing and future generating capacity; (3) scheduled capacity transfers; (4) projections of capacity, demand, purchases, sales, and scheduled maintenance; (5) assessment of adequacy; (6) generating capacity unavailability; (7) bulk power system maps; (8) near term transmission adequacy; (9) future critical bulk power facilities that may not be in service when required; and, (10) system evaluation criteria. These data support queries from the executive branch, Congress, other public agencies, and the general public. These reports present various council aggregate totals for their member electric utilities, with some nonmember information included.

Instrument and Design History. The Form OE-411 program was initiated under the Federal Power Commission Docket $R-362$, reliability and adequacy of electric service, and Orders $383-2,383-3$, and 383-4. The 
Department of Energy, estahlished in October 1977, assumed the responsibility for this activity. This form is considered voluntary under the authority of the Federal Power Act (Public Law 88-280), The Federal Energy Administration Act of 1974 (Public Law 93-275), and the Department of Energy Organization Act (Public Law 95-91). The responsibility for collecting these data has been delegated to the Office of Emergency Planning and Operations within the Department of Energy.

Data Processing. The Form OE-411 is filed annually on April 1 by the ten North American Electric Reliability Councils. The forms are compiled from data furnished by electric utilities within the council areas. Data from the Form OE-411 are also summarized in the staff report Electric Power Supply and Demand for the Contiguous United States (DOE/OE-0013).

\section{Form OE-417R}

Electric utilities or other entities, subject to the provisions of Section 311 of the Federal Power Act (FPA), that are engaged in the generation, transmission, or distribution of electric energy for delivery and/or sale to the public are required to report expeditiously any 1) loss of firm system loads; 2) voltage reductions and public appeals; 3) vulnerabilities that could impact hulk electric power system adequacy or reliability; and, 4) fuel supply emergencies to the DOE.

In accordance with Section 202(a) of the Federal Power Act (FPA), the DOE is responsible for encouraging actions to assure an abundant supply of electric energy throughout the country. Under Section 311 of the FPA, the DOE is authorized and directed to collect information regarding the generation, transmission, and distribution of electric energy and to report the problems and developments of the electric utility industry to Congress. The Secretary of Energy has the Federal responsibility of receiving reports of major electric uthlity system emergencies. The Secretary has delegated that responsibility to the Office of Emergency Planning and (operations (OE) within the DOE.

Instrument and Design History. The collection of outage data was initiated by the FPC prior to the organization of the DOE. After Congress passed legislation creating the DOE, the collection of electric power system outage data became a function of the DOE. Currently the Office of Emergency Planning and Operations (OE) is the principal DOE office for this activity. Form OF 417 was activated after public comment on a rule-making procedure (FR 7/6/83). The form was revised to Form $\mathrm{OE}-417 \mathrm{R}$ after public comment under a later rule-making procedure (FR 10/31/86).

Data Processing. Reports of emergencies are usually received by the Alert Coordination Officer via telephone. The Director, Office of Emergency Operations, has the authority to require a full technical report (after notice in the Federal Register).

\section{Form FE-781R}

The Form FE-781R, "Annual Report of International Electrical Export/Import Data" is used to collect on an annual basis, monthly information on the gross amounts of electrical energy received and delivered and the costs and revenue associated with these transactions. The use of the format contained in Form FE-781R is optional for reporting purposes; however, submission of the data is mandatory.

Instrument and Design History. The authority to issue presidential permits pursuant to Executive Order Number 10485 was transferred to the Secretary of Energy by Executive Order Number 12038 (43 FR 4957 February 7,1987 ). This responsibility was delegated by the Secretary to the Economic Regulatory Administration (DOE Delegation Order Number 0204-04, October 1, 1977). The authority was redelegated (DOE Delegation Order Number 127) to the Office of Fuels Programs, Fossil Energy, (54 FR 11436 March 20, 1990). The survey universe is defined under Title 10 of the Code of Federal Regulations, Sections 205.308 and 205.325 to include all public utilities or other entities subject to the Department of Energy jurisdiction under Part 11 of the Federal Power Act engaged in the export of electric energy across the international borders of the United States with Canada and Mexico. It also includes those engaged in the transmission of electrical energy across these borders who hold a presidential permit.

Data Processing. The Form FE-781R is mailed to the respondents to collect annually, the monthly data for the preceding calendar year. The completed forms are to be returned to the DOE by February 15 . The receipts are manually edited and the data used for the Presidential Permit Program are entered into a machine readable format

\section{Quality of Data}

The Office of Coal, Nuclear, Electric and Alternate Fuels (CNEAF) is responsible for routine data improvement and quality assurance activities. All operations in this office are done in accordance with formal standards established by the EIA. These standards are the measuring rod necessary for quality statistics. Data improvement efforts include verification of data-keyed input by automatic computerized methods, editing by subject matter specialists, and follow up on nonrespondeits. The CNEAF office supports the quality assurance efforts of the data collectors by providing advisory reviews of the structure of information requirements, and of proposed designs for new and re- 
vised data collection forms and systems. Once implemented, the actual performance of working data collection systems is also validated. Computerized respondent data files are checked to identify those who fail to respond to the survey. By law, nonrespondents may be fined or otherwise penalized for not filing a mandatory EIA data form. Before invoking the law, the ElA tries to obtain the required information by encouraging cooperation of nonrespondents.

Completed forms received by the CNEAF office are sorted, screened for completeness of reported information, and keyed onto computer tapes for storage and transfer to random access data bases for computer processing. The information coded on the computer tapes is manually spot-checked against the forms to certify accuracy of the tapes. To ensure the quality standards established by the EIA, formulas that use the past history of data values in the data base have been designed and implemented to check data input for errors automatically. Data values that fall outside the ranges prescribed in the formulas are verified by telephoning respondents to resolve any discrepancies.

Conceptual problems affecting the quality of data are discussed in the report, An Assessment of the Quality of Selected EIA Data Series: Electric Power Data. This report is published by the Energy Information Administration (Office of Statistical Standards, see Appendix B)

\section{Data Editing System}

Data from the form surveys are edited using automated systems. The edit includes both deterministic checks, in which records are checked for the presence of required fields and their validity; and statistical checks, in which estimation techniques are used to validate data according to their behavior in the past and in comparison to other current fields.

\section{Confidentiality of the Data}

In general, the data collected on the forms used for input to this report are not confidential. However, data from the Form EIA-867, "Annual Nonutility Power Producer Report," are considered confidential and must adhere to EIA's "Policy on the Disclosure of Individually Identifiable Energy Information in the Possession of the EIA" (45 Federal Register 59812 (1980)). In order to protect the confidentiality of individual respondent's data, a procedure was developed to suppress the data for publication. The procedure is described as follows.

\section{Disclosure of Data}

Data reported on the Form EIA-867, "Annual Nonutility Power Producer Report," are confidential. In order to protect the confidentiality of data for an individual respondent, a policy was implemented to ensure that the reporting of survey data would not associate those data with a particular company. The final phase in the data quality assurance and control procedures is to determine which data must be suppressed (withheld) during publication to provide the necessary confidentiality for respondents that operate in small reporting areas. These procedures are performed as follows:

- Primary Withholding Based on the Number of Respondents in a Cell-.-All cells with three or fewer respondents are suppressed.

- Residual Withholding Dominance Rule--All cells containing four or more respondents are tested using a linear sensitivity rule

- Complementary Suppression--All tables are reviewed to identify cells that should have data withheld $(0)$ prevent disclosure of already suppressed cells. An example of this concept, when U.S. totals are available, would be the complementary suppression of a second State in order to prevent the derivation of an initially suppressed State.

The withholding/suppression of data is performed as an adjunct to Quality Assurance (QA) procedures. The work is performed by survey editors and the QA staff and is reviewed by the survey manager before being submitted to the division level QA review.

All sensitive cells identified in the withholding analysis are denoted with the symbol/letter "W." The use of the symbol/letter applies to primary, complementary and inter-table suppressions as well as all withheld data.

\section{Rounding Rules for Data}

Given a number with $r$ digits to the left of the decimal and $d+t$ digits in the fraction part, with $d$ being the place to which the number is to be rounded and $t$ being the remaining digits which will be truncated, this number is rounded to $r+d$ digits by adding 5 to the $(r+d+1)$ th digit when the number is positive or by subtracting 5 when the number is negative. The $t$ digits are then truncated at the $(r+d+1)$ th digit. The symbol for a rounded number truncated to zero is $\left(^{*}\right)$.

\section{CNEAF Data Revision and Policy}

The Office of Coal, Nuclear, Electric and Alternate Fuels has adopted the following policy with respect to the revision and correction of recurrent data in energy publications: 
1. Annual survey data collected by this office are published either as preliminary or final when first appearing in a data report. Data initially released as preliminary will be so noted in the report. These data will be revised, if necessary, and declared final in the next publication of the data.

2. All monthly and quarterly survey data collected by this office are published as preliminary. These data are revised only after the completion of the 12-month cycle of the data. No revisions are made to the published data before this.

3. The magnitude of changes due to revisions experienced in the past will be included in the data reports, so that the reader can assess the accuracy of the data.

4. After data are published as final, corrections will be made only in the event of a greater than one percent difference at the national level. Corrections for differences that are less than the beforementioned threshold are left to the discretion of the Office Director.

The Electric Power Annual (EPA) presents the most current annual data available to the ElA. The statistics may differ from those published previously in EIA publications due to corrections, revisions, or other adjustments 10 the data subsequent to its original release. On a chapter basis, the status (preliminary versus final) of the data contained in the EPA follows:

- Generating Capability at U.S. Electric Utilities Total net summer capability data for 1992 from the Form ElA-860) are final and unchanged from the preliminary data reported in the Inventory of Power Plants in the United States 1992, which was published in October 1993.

- Net Generation at U.S. Electric Utilities

All Form EIA-759 data are final. A comparison of preliminary versus final data for 1992 are provided in the Technical Notes of the Electric Power Monthly (EPM), July 1993.

- U.S. Electric Utility Fossil-Fuel Statistics All FERC Form 423 data are final. A comparison of preliminary versus final data for 1992 from the FERC Form 423 is provided in the Technical Notes of the EPM, July 1993.

- U.S. Electric Utility Retail Sales and Revenue

Data on sales, revenue, and average revenue per kilowatthour from the Form EIA-861 for 1992 are preliminary. The data are revised and declared final in the Electric Sales and Revenue 1992. A comparison of preliminary versus final annual data at the national level for 1992 will be provided in the Electric Power Annual (EPA) 1993.

\section{- U.S. Electric Utility Financial Statistics}

Financial data from the Federal Energy Regulatory Commission Form 1 and the Form ElA-412 for 1992 are final.

- U.S. Electric Utility Environmental Statistics

Data from the Form EIA-767 for 1991 are final. The methodology for calculating emissions of sulfur dioxides, nitrogen oxides, and carbon dioxide has been revised. As a result, final data for 1991 at the national level differ from the preliminary by 3.7 percent for sulfur dioxide, 2.6 percent for nitrogen oxides, and 6.6 percent for carbon dioxide. Data for 1992 are preliminary. A comparison of preliminary versus final data at the national level for 1992 will be provided in the EPA 1993.

\section{- U.S. Electric Power Transactions}

All data from the Forms OE-411 and FE-718R are final. Data from the Form EIA-861 for 1992 are preliminary; Form EIA-861 data for prior years are final. Data from the Form ElA-860 are final.

- U.S, Electric Utility Demand-Side Management Data on demand-side management from the Form EIA-861 for 1991 are final and unchanged from preliminary values. Data for 1992 are preliminary. A comparison of preliminary versus final data at the national level for 1992 will be provided in the EPA 1993.

- U.S. Nonutility Power Producers Data from the Form EIA-867 for 1991 are final and unchanged from preliminary data, with the exception of deliveries and facility use. Refinement of definitions for deliveries and facility use resulted in the reallocation of preliminary data between these two categories. The difference between preliminary and final values for both categories was a 9-percent change. Data for 1992 are preliminary. A comparison of preliminary versus final annual data for 1992 will be provided in the EPA 1993.

\section{- Appendix A}

All data from the Form OE-417R are final. 


\section{Formulas and Calculations}

\section{Average Heat Content}

In order to determine the Btu value per unit of consumption for each of the fossil fuels collected on the Form ElA-759, the heat content values contained on the FERC Form 423 were used. Data on the FERC Form 423 represent approximately 85 percent of the total generator nameplate capacity for all electric utilities.

\section{Percent Difference}

The following formula is used to calculate percent differences.

Percent Difference $=\left(\frac{x\left(t_{2}\right)-x\left(t_{1}\right)}{x\left(t_{1}\right)}\right) \times 100$,

where $x\left(t_{1}\right)$ and $x\left(t_{2}\right)$ denote the quantity at year $t_{1}$ and subsequent year $t_{2}$.

\section{Form EIA-759}

Data for the Form EIA-759 are collected at the plant level. These data are then aggregated to provide geographic totals at the State, Census division, and U.S. level, or totals by type of plant. Consumption of fuel(s) is converted from quantities (in short tons, barrels, or thousand cubic feet) to Btu at the plant level. Endof-month fuel stocks for a single generating plant may not equal beginning-of-the-month stocks, plus receipts, less consumption, for many reasons, including the fact that several plants may share the same fuel stock.

\section{FERC Form 423}

Data for the FERC Form 423 are collected at the plant level. These data are then used in the following formulas to produce aggregates and averages for each fuel type at the State, Census division, and U.S. level. For these formulas, receipts and average heat content are at the plant level. For each geographic region, the summation $\Sigma$ represents the sum of all plants in that geographic region. Additionally,

- For coal, units for receipts $(R)$ are in tons, units for average heat content $(A)$ are in Btu per pound, and the unit conversion $(U)$ is $2,00 x)$ pounds per ton;

- For petroleum, units for receipts $(R)$ are in barrels, units for average heat content $(A)$ are in Btu per gallon, and the unit conversion ( $U$ ) is 42 gallons per barrel;

- For gas, units for receipts $(R)$ are in thousand cubic feet (Mcf), average heat content (.4) are in Btu per cubic foot, and the unit conversion $(U)$ is 1,000 cubic feet per $\mathrm{Mct}$

Total Btu $=\sum\left(R_{i} \times A_{i} \times U\right)$

where $i$ denotes a plant; $R_{i}=$ receipts for plant $i$; $A_{i}=$ average heat content for receipts at plant $i$; and, $U=$ unit conversion;

Weighted Average Btu $\frac{\sum\left(R_{1} \times A_{1}\right)}{\sum R_{1}}$,

where $i$ denotes a plant: $R_{1}=$ receipts for plant $i$ : and, $A_{i}=$ average heat content for receipts at plant $i$.

The weighted average cost in cents (nominal dollars) per million Btu is calculated using the following formula:

Weighted Average $\operatorname{Cost}=\frac{\sum\left(R_{i} \times A_{1} \cdot U \cdot C_{i}\right)}{\sum\left(R_{1} \cdot A_{i}\right)}$,

where $i$ denotes a plant; $R_{i}=$ receipts for plant $i$ $\boldsymbol{A}_{i}=$ average heat content for receipts at plant $i$; and, $C_{i}=$ cost in cents per million Btu for plant,

The weighted average cost in dollars (nominal dollars) per unit is calculated using the following formula

Weighted Average Cost $=\frac{U \sum_{1}\left(R_{i}, A_{1}, C_{i}\right)}{\left(10^{8} \frac{\text { cents }}{\text { dollar }}\right) \sum_{1} R_{1}}$

where $i$ denotes a plant: $R_{1}=$ receipts for plant $i$; $A_{i}=$ average heat content for receipts at plant $i$;

$U=$ unit conversion; and, $C, \ldots$ cost in cents per million Btu for plant $i$.

Data on receipts of gas at combined-cycle gas turbines are not directly collected on the FFRC Form 423. They are estimated at the plant level by prorating based on Form EIA-759 gas consumption data as follows: (CCGT/(CCGT + CCST + ST)) times total receipts, where CCGT = combined-cycle gas turbines, CCST $=$ combined-cycle steam units, SI steam units, and receipts = plant level gas receipts.

\section{Form EIA-861}

Data for the Form EIA 861 are collected at the utility level from all electric utilities in the United States, its territories, and Puerto Rico. Form EIA 861 data in this publication are for the United states only. These 
data are then aggregated 10 provide geographic totals at the State, NERC region, Census division, and national level. Sources and disposition of data are also provided by utility class of ownership and retail consumer class of service. Average revenue (nominal dol. lars) per kilowatohour of electricity sold is calculated hy dividing total annual retail revenue (nominal dollars) by the fotal annual retail sales of electricity

Data for Demand-Side Management (DSM) activities are aggregated at the NERC region and consumer sector levels. In 1992, for the first time. EIA collected information on DSM activilies from all utilities with DSM programs. Utilities with sales 10 ultimate consumers or sales for resale greater than or equal to 120,000) megawalthours report their incremental peakload reductions and energy savings for the report. ing year (1992), annual peakloal reductions and energy savings for the reporting year and first-and fifthforecast years (1993 and 1997), and itemized direct and indirect utility costs and nomutility cost attributable to DSM programs for all 3 years. Annual and incremental effects for the reporting year are reported by consumer sector (residential, commercial, industrial, other) for each program category (energy efficiency, direct load control, interruptible load, other load management, other DSM programs, load building). Forecast peak reductions and energy savings are reported by program category with all consumer sectors combined. Utilities with sales to ultimate consumers and sales for resale less than 120,(XX) megawatthours report incremental peakload reductions and energy savings and total direct and indirect utility cost for the reporting year. In years prior to 1992, utilities with sales less than 120,(0)(o) megawatthours did not report on I)SM activities.

\section{Form EIA-860}

Data for the form IIA - 8 tol are submitled at the generating unt level and are then aggregated lo provide tolals by energy source and geographic area. In addition, at the national level, data are aggregaled by prime mover

Estimated values for net summer and nel winter capability for electric generating units were developed by use of a regression formula. Estimates of net summer capability and net winter capability are made for operable nonnuclear electric generating units with no reported capability and for all clectric generating units that are under construction or in the planning stage that are not nuclear-powered or coal-fired. The formula is based on reported values in the 1984 data file. The formula is used to estimate values for existing units where data are missing and for projected units. (When data are reported for existing units, the estimation formulas are not used. When data for existing units are not reported, the estimation formulas are used in all cases. The estimation formulas are not used for planned coal-fired or nuclear-powered units. However, the estimation formulas are used in all cases for all other planned units.) In all formulas, the symbol, *, is an operator meaning multiplied by: the symbol. **, is an operator meaning raised to the specitied power (exponent)

For nomnuclear units,

Net Summer Capability equals $e^{* *}$ (i plus ( In (generator Nameplate (apacity)*()), rounded to nearest megawatt,

where

- $c$, the base of natural logarithms $(\ln )$, is approximately 2.71828 .

- Generator Nameplate Capacily is expressed in megawatts.

- is the intercept, and c is the regression coefficient,

- i equals 0.02564, c equals 0.98423 , for steam units (Unit Type is Steam Turbine (ST), Atmospheric Fluidized Bed Combustion (AB), Pressurized Fluidized Bed Combustion (PB)),

- i equals -0.10255, c equals 0.97841 , for gas-lurbine units (Unit Types are Gas Turbine (GiT) and Jet Engine (JE)),

- i equals -(0.0(0)397, c equals 0.95914 , for combinedcycle units (Unit Types are Combined Cycle Steam Turbine with Supplemental Firing (CA), Combined Cycle - Single Shaft (CS), Combined Cycle Steam Turbine with Only Waste Heat Capability $(C W)$, Combined Cycle Combustion Turbine (CT), and Integrated Coal Gasification Combined-Cycle (IG)),

- i equals -0.08865, c equals 1.00966 , for internal combustion units (Unit Type is Internal combus. tion (diesel) (IC)),

- i equals -0.04963, c equals 1.03738 for conventional and pipeline hydroelectric units (Unit Types are Hydraulic Turbine - Conventional (HC) and Hydraulic Turbine - Pipeline (HI.)),

- i equals -0.(0922, c equals $1 .(00630$, for pumped storage hydroclectric units (Unit Type is Hydraulic Turbine - Reversible (pumped storage) (lHR)),

- i equals -0.02604, c equals 0.98289 , for all other units (Unit Types are Fuel Cell (FC), Steam Turbine - Geothermal (GE), ()cean Thermal Turbine (()C), Photovoltaic (SP), Steam Turbine - Solar (SS), and Wind Turbine (WT))

Net Winter Capability equals ( $\left.e^{* * i}\right)^{*}($ Generator Nameplate Capacity**().

where

- $e$, the base of natural logarithms $(\ln )$, is approximately 2.71828 , 
- Generator Nameplate Capacity is expressed in megawatts for conventional hydroelectric and pipeline hydroelectric units, and in kilowatts for all other unit types,

- $i$ is the intercept, and $c$ is the regression coefficient,

- i equals 0.1614, c equals 0.98373, for steam units (Unit Type is ST, AB, and PB),

- i equals 0.2249, c equals 0.97881 , for gas-turbine units (Unit Types are GT and JE),

- i equals 0.9626, c equals 0.90413, for combinedcycle units (Unit Types are CA, CS, CW, CT, and $I(B)$,

- i equals -0.1378, c equals 1.02501 , for internal combustion units (Unit Type is IC).

- i equals -0.0608, c equals 1.02560 , for conventional and pipeline hydroelectric units (Unit Types are $H C$ and $H L$,

- i equals -0.1167, c equals 1.08540, for pumped storage hydroelectric units (linit Type is HR),

" i equals 0.2859 , c equals $0{ }^{\circ} \quad 67$, for all other units (Unit Types are FC, GF .)C, SP, SS, and WT).

\section{FERC Form 1}

\section{Composite Financial Indicators for Major Investor-Owned Electric Utilities}

All financial monetary data in this report are expressed in nominal terms. The following formulas are used to calculate composite financial indicators

Electric Fixed Asset (Net Plant) Turnover =-

$$
\frac{\sum_{i}\left(E O R_{i}\right)}{\sum_{i}\left(U_{i}\right)}
$$

where $E O R_{\text {is }}$ is the Electric Operating Revenue for the $i^{\text {th }}$ major utility, and $U_{t}$ is the Electric Utility Plant

- Net for the $i^{\text {th }}$ major utility.

Total Asset Turnover :-

$$
\frac{\sum_{i}\left(O R_{i}\right)}{\sum_{i}\left(A_{i}\right)}
$$

where $O R$, is the Operating Revenue for the $i^{\text {th }}$ major utility, and $A_{i}$ are the Total Assets for the $i^{\text {th }}$ major utility.
Current Assets to Current Liabilities -

$$
\frac{\sum\left(C A A_{1}\right)}{\sum\left(C A L_{i}\right)}
$$

where CA.A, are the Current and Accrued Assets for the $i^{\text {th }}$ major utility, and $C .4 L$, are the Current and Accrued Liabilities for the $i^{\text {th }}$ major utility

Long-term Debt to Capitalization

$$
\frac{\sum\left(L . T D_{1}\right)}{\sum\left(C_{1}\right)} \cdot(x),
$$

where L.TD, is the Long-term Debt for the $i^{\text {th }}$ major utility, and $C_{1}$ is the Capitalization for the $i^{\text {th }}$ major utility.

\section{Preferred Stock to C'apitalization =}

$$
\frac{\sum\left(P S_{1}\right)}{\sum\left(C_{1}\right)} \cdot 100,
$$

where $P S_{1}$ is the Preferred Stock for the $i^{\text {th }}$ major utility, and $C_{1}$ is the Capitalization for the $i^{\text {th }}$ major utility.

\section{Common Stock Fquity to Capitalization}

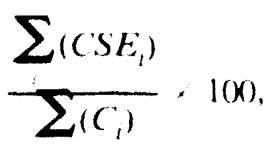

where CSE, is the Common Stock Equity of the $i^{\text {th }}$ major utility: and, $C_{1}$ is the Capitalization for the $i^{\text {th }}$ major utility.

Total Debt to Total Assets

$$
\frac{\sum\left(L T D_{i}+S T D_{l}\right)}{\sum\left(T A_{i}\right)} \times 100
$$

where $L T D$, is the Long-term Debt of the $i^{\text {th }}$ major utility; $S T D$, is the Short-term Debt of the $i^{\text {th }}$ major utility; and, $T A$ are the Total Assets of the $i^{\text {th }}$ major utility.

Common Stock Equity to Total Assets = 


$$
\frac{\sum_{i}\left(C S E_{i}\right)}{\sum_{i}\left(T A_{i}\right)} \times 100
$$

where $C S E_{i}$ is the Common Stock Equity of the $i^{\text {th }}$ major utility; and, $T A_{i}$ are the Total Assets of the $i^{\text {th }}$ major utility.

\section{Interest Coverage Before Taxes}

Without AFUDC =

$$
\frac{\sum_{1}\left(\begin{array}{c}
I B I_{i}+E I T_{i}+G I T_{i} \\
+O U I T_{i}+\text { OID }_{i}-A C_{i}
\end{array}\right)}{\sum_{i}\left(I E_{i}\right)}
$$

where $I B I_{i}$ is Total Income Before Interest Charges for the $i^{\text {th }}$ major utility; $E I T_{i}$ are the Electric Income Taxes for the $i^{\text {th }}$ major utility; $G I T_{i}$ are the Gas Income Taxes for the $i^{\text {th }}$ major utility; $O U I T_{i}$ are the Other Utility lncome Taxes for the $i^{\text {th }}$ major utility; TOIDare the Taxes for Other Income and Deductions for the $i^{\text {th }}$ major utility; $A C_{i}$ is the Allowance for Other Funds Used During Construction for the $i^{\text {th }}$ major utility; and, $I E_{i}$ is the Interest Expense for the $i^{i t h}$ major utility.

\section{Profit Margin =}

$$
\frac{\sum_{i}\left(N I_{i}\right)}{\sum_{i}\left(O R_{i}\right)} \times 100
$$

where $N I_{i}$ is the Net Income of the $i^{i h}$ major utility; and, $O R_{i}$ is the Operating Revenue for the $i^{\text {th }}$ major utility.

\section{Return on Average Common Stock Equity =:}

$$
\frac{\sum_{1}\left(N I_{i}\right)}{\left(\sum_{1}\left(C S E B_{i}\right)+\sum_{1}\left(\operatorname{CSEE_{i})}\right)\right.} / 2 \times 100
$$

where $N I_{1}$ is the Net Income of the $i^{\text {th }}$ major utility; $C S E B_{i}$ is the Common Stock Equity at Beginning of Year, for the $i^{\text {th }}$ major utility, and $C_{i} E E_{l}$ is the Common Stock Equity at End of Year for the $i^{\text {th }}$ major utility.

Return on Investment

$$
\frac{\sum_{i}\left(N I_{i}\right)}{\sum_{i}\left(T A_{i}\right)} \times 100
$$

where $N l_{i}$ is the Net Income of the $i^{\text {th }}$ major utility; and, $T A_{i}$ are the Total Assets of the $i^{\text {th }}$ major utility.

\section{Composite Financial Indicators for Major Publicly Owned Electric Utilities}

Electric Utility Plant per Dollar of Revenue $=$

$$
\frac{\sum_{i}\left(E U P_{i}\right)}{\sum_{i}\left(E O R_{i}\right)}
$$

Where EUP is the Electric Utility Plant for the the $i^{\text {th }}$ public utility; and, EOR is the Electric Operating Revenue for the $i^{\text {th }}$ public utility.

$$
\begin{aligned}
& \text { Current Assets to Current Liabilities }= \\
& \qquad \sum_{\sum_{i}^{1}\left(C A_{i}\right)},
\end{aligned}
$$

where $C A_{i}$ are the Current and Accrued Assets for the $i^{\text {th }}$ public utility; and, $C L_{i}$ are the Current and Accrued Liabilities for the $i^{\text {th }}$ public utility.

Electric Utility Plant as a Percent of Total Assets =

$$
\frac{\sum_{i}\left(E U P_{i}\right)}{\sum_{i}\left(T A_{i}\right)} \times 100
$$

where $E U P_{i}$ is the Electric Utility Plant for the $i^{\text {th }}$ public utility; and, $T A_{i}$ are the Total Assets for the $i^{\text {th }}$ public utility.

\section{Net Electric Utility Plant as a Percent of}

Total Assets =

$$
\frac{\sum_{1}\left(N E U P_{i}\right)}{\sum_{1}\left(T A_{i}\right)} \times 100
$$

where $N E U P_{i}$ is the Net Electric Utility Plant for the $i^{\text {th }}$ public utility; and, $T A_{i}$ is the Total Assets for the $i^{\text {th }}$ public utility.

Debt as a Percent of Total Liabilities :=

$$
\frac{\sum_{1}\left(D_{i}\right)}{\sum_{1}\left(T L_{i}\right)} \times 100
$$


where $D_{i}$ is the Debt for the $i^{\text {th }}$ public utility; and, $T L_{i}$ is the Total Liabilities for the $i^{\text {th }}$ public utility.

\section{Accumulated Provision for Depreciation as a Percent of Electric Utility Plant $=$}

$$
\frac{\sum_{i}\left(A P D_{i}\right)}{\sum_{i}\left(E U P_{i}\right)} \times 100
$$

where $A P D_{i}$ is the Accumulated Provision for Depreciation for the $i^{\text {th }}$ public utility; and, $E U P_{i}$ is the Electric Utility Plant for the $i^{\text {th }}$ public utility.

Electric Operation and Maintenance Expenses as a Percent of Electric Operating Revenue =

$$
\frac{\sum_{i}\left(E O M E_{l}\right)}{\sum_{1}\left(E O R_{i}\right)} \times 100
$$

where $E O M E_{i}$ is the Electric Operation and Maintenance Expenses for the $i^{\text {th }}$ public utility; and, $E O R_{i}$ is the Electric Operating Revenue for the $i^{\text {th }}$ public util. ity.

Electric Depreciation and Amortization as a Percent of Electric Operating Revenue $=$

$$
\frac{\sum_{i}\left(E D A_{i}\right)}{\sum_{i}\left(E O R_{i}\right)} \times 100
$$

where $E D A_{i}$ is Electric Depreciation and Amortization for the $i^{\text {th }}$ public utility; and, $E O R_{i}$ is the Electric Operating Revenue for the $i^{\text {th }}$ public utility

Taxes and Tax Equivalents as a Percent of Electric Operating Revenue

$$
\frac{\sum_{1}\left(T T E_{i}\right)}{\sum\left(E O R_{l}\right)} \times 100
$$

where $T T E$ are the Taxes and Tax Equivalents for the $i^{\text {th }}$ public utility: and, $E O R$, is the Electric Operating Revenue for the $i^{\text {th }}$ public utility.

Interest Expense as a Percent of Electric Operating Revenue -

$$
\frac{\sum\left(I E_{l}\right)}{\sum\left(E O R_{l}\right)} \times 10 x
$$

where $I E_{i}$ is the Interest Expense for the $i^{\text {th }}$ public utility; and, $E O R_{i}$ is the Electric Operating Revenue for the $i^{\text {th }}$ public utility.

\section{Net Income as a Percent of Electric Operating Revenues $=$

$$
\frac{\sum_{i}\left(N I_{i}\right)}{\sum_{i}\left(E O R_{i}\right)} \times 100,
$$

where $N I_{i}$ is the Net Income of the $i^{\text {th }}$ public utility; and, $E O R_{i}$ is the Electric Operating Revenue for the $i^{\text {th }}$ public utility.

\section{Air Emissions}

This section describes the methodology employed to calculate estimates of sulfur dioxide $\left(\mathrm{SO}_{2}\right)$, nitrogen oxides $\left(\mathrm{NO}_{x}\right)$, and carbon dioxide $\left(\mathrm{CO}_{2}\right)$ emissions from utility and nonutility electric generating plants.

\section{Utility Air Emissions}

The following describes the methodology employed to calculate estimates of $\mathrm{SO}_{2}, \mathrm{NO}_{x}$, and $\mathrm{CO}_{2}$ emissions from power plants operated by electric utilities. These air emissions are estimated using information contained on Form EIA-767, "Steam-Electric Plant Operation and Design Report." Form ElA-767 collects information annually for all U.S. power plants with a total existing or planned organic- or nuclear-fueled steamelectric generator nameplate rating of 10 megawatts (MW) or larger. Power plants with a total generator nameplate rating of $100 \mathrm{MW}$ or more must complete the entire form, providing, among other things, information about fuel consumption and quality, legal air emission limits, and flue gas desulfurization (FGD) efficiency. Power plants with a total generator nameplate rating from $10 \mathrm{MW}$ to less than $100 \mathrm{MW}$ complete only part of the form, including information on fuel consumption and FGD sulfur removal efficiency, if applicable.

Uncontrolled Air Pollutant Emissions. Uncontrolled air pollutant emissions are those emissions that would occur in the absence of any control equipment. Uncontrolled $\mathrm{SO}_{2}, \mathrm{NO}_{x}$, and $\mathrm{CO}_{2}$ emissions are determined by multiplying the quantity of fuel burned by an emission factor. An emission factor is the average quantity of a pollutant released from a boiler when a unit of fuel is burned.

The source of the $\mathrm{SO}_{2}$ and $\mathrm{NO}_{x}$ emission factors, when available, is the Environmental Protection Agency report AP-42, "Compilation of Air Pollutant Emission Factors" (Table C1). Environmental Protection Agency emission factors are based on boiler type, fir- 
ing configuration, and fuel burned. The methodology for determining emissions of $\mathrm{CO}_{2}$ has been revised since the 1991 publication. Emissions of carbon dioxide for prior years have been revised using the set of factors shown in Tables $\mathrm{Cl}$ and $\mathrm{C} 2$.

In 1992, a special study of the relationship between the heat and carbon content of coal was completed by the Energy Information Administration's Analysis and Systems Division of the Office of Coal, Nuclear, Electric and Alternate Fuels. The hypothesis underlying this study was that the ratio of carbon-to-heat content varies not only by coal rank (i.e., anthracite, bituminous, subbituminous, and lignite), but also by geographic location of the coal. In this study, the hypothesis was tested and the results of the analysis supported the hypothesis. That is, it was concluded from the analysis that coal rank and location of the coal are significant factors in the variation of the ratio of carbonto-heat content. After this determination, a set of conversion factors, by rank and State were derived on the basis of data contained in FilA's Coal Analysis File. ${ }^{44}$

In previous editions of this publication, separate conversion factors by coal rank were published and used to estimate emissions of $\mathrm{CO}_{2}$. The special study by ElA concluded that since geographic location of coal in addition to rank of coal is a significant factor in determining the carbon/heat content relationship, the use of emission factors that consider both of these elements may yield more accurate estimates of $\mathrm{CO}_{2}$ emissions. The emission factors for coal were developed in the units of pounds of $\mathrm{CO}_{2}$ per million Btu of coal.

The emission factors for $\mathrm{CO}_{2}(\mathrm{Table} \mathrm{C} 2$ ) from coal are applied by power plant, based on the rank, amount of coal received, and the State from which the coal originated, as reported in FERC Form 423, "Cost and Quality of Fuels for Electric Utility Plants." Thus, a weighted average emussions factor is obtained by plant and multiplied the quantity of coal consumed by plant, as reported on Form EIA-767, "Steam-Electric Plant Operation and Design Report," to determine the emissions of $\mathrm{CO}_{2}$. The emission factors for $\mathrm{CO}_{2}$ assume 100-percent combustion of the carbon in the fuel. Since a small percentage of the carbon in the coal is not converted to $\mathrm{CO}_{2}$, this publication assumes 99 percent combustion. The 1 percent of emissions is deducted at the State/National level. The emissions at the State level are based on the State in which the plant is located.

Uncontrolled emissions of $\mathrm{SO}_{2}$ and $\left.\mathrm{NO}\right)_{x}$ do not always accurately depict the quantity of emissions released into the atmosphere because they fail to reflect reductions from control equipment and/or operating technologies. Consequently, controlled emissions are cal- culated to provide a more accurate estimate of actual utility air emission.

Controlled Sulfur Dioxide Emissions. Because of environmental regulations controlling $\mathrm{S}_{2}$ emissions, many utilities are required to install $F(i D)$ units at their coal-fired plants." FGD units typically remove between 70 to 90 percent of $\mathrm{SO}_{2}$ from the hoiler flue gas although higher removal efficiencies can be achieved. Electric utilities report both sulfur removal efficiency (percent) and their most stringent $\mathrm{SO})_{2}$ emission limits on the Form EIA-767. To determine controlled $\mathrm{S}()_{2}$ emissions, the uncontrolled emissions are reduced by the annual average removal efficiencies reported on the Form EIA-767. This emission is the controlled emission. As a check, the controlled emission is compared with the most stringent legal limit reported on the Form EIA-767. The controlled emission should be less than the legal limit because research indicates that utilities routinely remove more $\mathrm{SO}_{2}$ than required to assure an operating margin of safety. If the controlled emission is not less than the most stringent legal limit, it implies that the utility is out of legal compliance and could be subject to fines and other penalties.

Utilities are permitted to take credit for sulfur that remains in bottom ash -- ash remaining in the bottom of the furnace after the coal is burned. For example, if a utility is required to remove 90 percent of the sulfur in the coal and 3 percent remains in the ash, it has to remove only 87 percent using scrubbers. This credit is included in emissions data in this report. It is likely, however, that in many cases the credit is not taken. In order to take the ash credit, utilities need to monitor the coal consumed on a daily basis; this is both timeconsuming and costly. To the extent that utilities do not take the ash credit, emissions might be slightly overstated.

Controlled Nitrogen Oxide Emissions. The controlled NO ${ }_{x}$ emission is calculated by applying the appropriate reduction factor in Table C3. For utility boilers with regulated nitrogen oxide emission limits, the annual controlled estimate used is the lesser of the controlled estimate or the annual limitation. When more than one control technology is reported, the highest single reduction factor is used to estimate the annual cont rolled NO emission

Carbon Dioxide Emissions. There are no Federal regulations that limit $\mathrm{CO}_{2}$ emissions. Information pertinem to the estimation of controlled $\mathrm{CO}_{2}$ emissions is not collected on the Form EIA-767; therefore, no estimates of controlled $\mathrm{CO}_{2}$ emissions are made.

\footnotetext{
44 "Supplement A to Complation of fir Pollutant Emessun Factors, Vol 1 Stationary Pout and Area Sources," Research I riangle Park. North Carcilina, October 1986

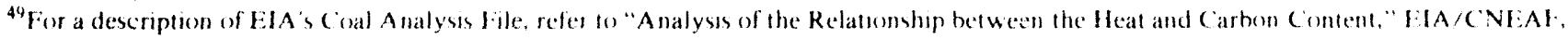
September 1992.

${ }^{30}$ Flue gas desulfurization units may also reduce sulfur dioxide emissions from plants that burn onl and petroleum cone.
} 
A degree of complexity is added to this approach, however, because air emission standards are not reported in consistent units. In some rare instances, emission standards are reported in units that cannot be directly compared with estimated uncontrolled emission rates. Examples of such standards are ones that specify the concentration of $\mathrm{NO}_{x}$ allowed in the flue gas or the ambient concentration of $\mathrm{NO}_{x}$ (parts per million). In cases where these types of standards are reported, the uncontrolled emission estimate is used. Such standards are uncommon, however, and do not significantly affect the results.

Air Emissions from Small Plants. The Form EIA-767 does not collect data for generators powered by internal combustion engines, gas turbines, combined cycle units (for example, gas turbines with waste heat boilers), and boilers at steam-electric plants with a total nameplate capacity of less than $10 \mathrm{MW}$. Accordingly, utility air emission from these generators are not estimated by the methodology. An estimate of air emissions from these generating units based on a similar methodology using 1991 fuel consumption data reported on the Form EIA-759, "Monthly Power Plant Report," was performed. Results of this effort indicate that emissions of $\mathrm{SO}_{2}, \mathrm{NO}_{x}$, and $\mathrm{CO}_{2}$ from utility sources not included on the Form EIA-767, are less than $0.1,1.2$, and 1.1 percent, respectively, of total utility air emissions.

\section{Nonutility Air Emissions}

The following describes the methodology employed to calculate estimates of $\mathrm{SO}_{2}, \mathrm{NO}_{x}$, and $\mathrm{CO}_{2}$ emissions from power plants operated by nonutilities. The emissions are estimated using information contained on Form EIA-867, "Annual Nonutility Power Froducer Report." Form EIA-867 collects information annually from all nonutility power producers with a total generator nameplate rating of 1 megawatt (MW) or more, including cogenerators, small power producers, and other nonutility electricity generators. Facilities with a total generator nameplate rating of $1 \mathrm{MW}$ or more must complete the entire form, providing, among other things, information about fuel consumption and quality. Facilities with a combined nameplate capacity of less than 25 megawatts are not required to complete Schedule V "Facility Environmental Information" of the Form EIA-867.

Uncontrolled Emissions. Uncontrolled air pollutant emissions are those emissions that would occur in the absence of any control equipment. Uncontrolled $\mathrm{SO}_{2}$, $\mathrm{NO}_{x}$, and $\mathrm{CO}_{2}$ emissions are determined by multiplying the quantity of fuel burned by an emission factor. An emission factor is the average quantity of a pollutant released from a boiler when a unit of fuel is burned. As with electric utilities, the source of both the $\mathrm{SO}_{2}$ and $\mathrm{NO}_{x}$ emission factors, when available, is the Environmental Protection Agency report AP-42, "Compilation of Air Pollutant Emission Factors." ${ }^{11}$ However, the boiler type and firing configuration are not reported on the Form EIA-867 so all boilers are assumed to be large boilers ${ }^{52}$ with pulverized coal firing and dry bottoms. For other types of prime movers (for example, gas turbines, combined cycle, and internal combustion engines) the same set of emission factors are used.

The methodology for determining emissions of $\mathrm{CO}_{2}$ from nonutility electric power plants has been revised. The new methodology uses the results of the coal study discussed under "Utility Air Emissions." Based on the coal rank, the quality of coal received and its State of origin, weighted average emission factors are determined by State for electric utility plants. It is assumed that nonutility plants located in the same State as utility plants obtain coal from the same State. The weighted emission factors by State for utility coal-fired plants are multiplied by the coal consumption reported Cor nonutility plants in the respective State on Form ElA-867.

Uncontrolled emissions of $\mathrm{SO}_{2}$ and $\mathrm{NO}_{x}$ do not always accurately depict the quantity of emissions released into the atmosphere because they fail to reflect reductions from control equipment and operating technologies. Consequently, controlled emissions are calculated to provide a more accurate estimate of actual nonutility air emissions.

Controlled Sulfur Dioxide Emissions. The Clean Air Act of 1971 established Federal emission limits for new fossil-fueled steam generators -- 1.2 pounds of $\mathrm{SO}_{2}$ per million Btu of solid fossil fuel consumed and 0.8 pounds for liquid fossil fuels. The Clean Air Act of 1978 established even more stringent sulfur dioxide emission limits. The revised law mandates the installation of flue gas desulfurization (FGD) equipment at some new industrial and commercial facilities built after June 19, 1984, and requires that these facilities remove 90 percent of the $\mathrm{SO}_{2}$ in the flue gases. Nonutilities report whether they have FGD equipment at their facilities and the date of first electrical generation on the Form EIA-867. Air emission limits are based on the date construction began. It is assumed that it takes two years from the start of construction to the date of first electrical generation as reported on the form.

Controlled $\mathrm{SO}_{2}$ emissions are calculated for respondents reporting FGD equipment or fluidized bed combustion. For facilities reporting first electrical generation before August 1973, no reductions are assumed.

\footnotetext{
51 "Supplement A to Compilation of Air Pollutant Emission Factors, Vol. I: Stationary Point and Area Sources," Research Triangle Park, North Carolina, October 1986

$\$_{2}$ Boilers with a gross heat rate of 100 million Btu per hour or greater
} 
For facilities reporting first electrical generation between August 1973 and June 1986, the controlled emission is estimated as the lesser of either: the uncontrolled emission, or a weighted average of 1.2 and 0.8 pounds of $\mathrm{SO}_{2}$ per million $\mathrm{Btu}$ of solid and liquid fossil fuel consumed, respectively. For facilities reporting first electrical generation after June 1986, the controlled emission is estimated as the lesser of either: the uncontrolled emission reduced by 90 percent, or a weighted average of 1.2 and 0.8 pounds of $\mathrm{SO}_{2}$ per million Btu of solid and liquid fossil fuel consumed, respectively.

Facilities with a total nameplate rating between $5 \mathrm{MW}$ and $25 \mathrm{MW}$ are not required to report whether they have FGD units. Controlled $\mathrm{SO}_{2}$ emissions for these facilities are calculated based on the year electricity was first generated at the facility as reported on the Form EIA-867. For facilities reporting electrical generation before August 1973, no control equipment is assumed and the controlled $\mathrm{SO}_{2}$ emission is equal to the uncontrolled emission as calculated above. For facilities reporting the date of their first electrical generation as between August 1973 and August 1980, the controlled $\mathrm{SO}_{2}$ emission is estimated as the lesser of either: the uncontrolled $\mathrm{SO}_{2}$ emission, or 1.2 pound of $\mathrm{SO}_{2}$ per million Btu of fuel consumed. For facilities reporting their first electrical generation after August 1980, the controlled $\mathrm{SO}_{2}$ emission is estimited as the lesser of either: the uncontrolled emission recluced by 80 percent, or 1.2 pounds of sulfur dioxide per million Btu of fuel consumed.

Controlled Nitrogen Oxide Emissions. Nonutilities with a total facility nameplate rating of $25 \mathrm{MW}$ or more are required to report on the Form ElA-867 whether they have any $\mathrm{NO}_{x}$ control equipment and its type. Controlled $\mathrm{NO}_{x}$ emissions estimates are based on assumed removal efficiencies for the different types of $\mathrm{NO}_{x}$ control equipment. The percent removal efficiencies of the $\mathrm{NO}_{x}$ control equipment and/or operating technologies are shown in Table $\mathrm{C} 4$

The controlled $\mathrm{NO}_{x}$ emission is calculated by reducing the uncontrolled emission by the appropriate reduction percentage based on the $\mathrm{NO}_{x}$ technology. In cases where more than one type of technology is reported, the highest single reduction percentage of the equipment reported is applied.

Facilities with a total nameplate rating between $5 \mathrm{MW}$ and $25 \mathrm{MW}$ are not required to report whether they have $\mathrm{NO}_{x}$ reduction equipment. However, the Clean Air Act limits $\mathrm{NO}_{x}$ emissions to 0.8 pounds per million Btu of fuel consumed. Controlled $\mathrm{NO}_{x}$ emissions for these facilities are calculated based on the year electricity was first generated at the facility as reported on the Form EIA-867. For facilities reporting electrical generation before August 1973, no control equipment is assumed and the controlled $\mathrm{NO}_{x}$ emission is estimated to be equal to the uncontrolled emission as calculated above. For facilities reporting the first date of electrical generation after August 1973, the controlled $\mathrm{NO}_{x}$ emission is estimated as the lesser of either: the uncontrolled NO $x$ emission, or 0.8 pounds of $\mathrm{NO}_{x}$ per million Btu of fuel consumed.

Controlled Carbon Dioxide Emissions. There are no Federal regulations that limit $\mathrm{CO}_{2}$ emissicns. Information pertinent to the estimation of controlled $\mathrm{CO}_{2}$ emissions is not collected on the Form ElA-867; therefore, no estimates of controlled $\mathrm{CO}_{2}$ emissions are provided.

\section{General Information}

\section{Use of the Glossary}

The terms in the glossary have been defined for general use. Restrictions on the definitions as used in these data collection systems are included in each definition when necessary to define the terms as they are used in this report.

\section{Obtaining Copies of Data}

These data are available on machine-readable tapes. Tapes may be purchased by using Visa, MasterCard, or American Express cards as well as money orders or checks payable to the National Technical Information Service (NTIS). Purchasers may also use NTIS and Government Printing Office depository accounts. To place an order, contact:

National Technical Information Service (NTIS)

Office of Data Base Services

U.S. Department of Commerce

5285 Port Royal Road

Springfield, Virginia 22161

(703) $487-4650$ 
Table C1. Sulfur Dioxide, Nitrogen Oxide, and Carbon Dioxide Emission Factors

\begin{tabular}{|c|c|c|c|c|}
\hline Fuel & $\begin{array}{l}\text { Boller Type/ } \\
\text { Firing } \\
\text { Conflguration }\end{array}$ & $\begin{array}{l}\text { Sulfur } \\
\text { Dloxide' }\end{array}$ & $\begin{array}{l}\text { Nitrogen } \\
\text { Oxides' }\end{array}$ & $\begin{array}{l}\text { Carbon } \\
\text { Dioxide' }\end{array}$ \\
\hline \multicolumn{5}{|l|}{ Utillty } \\
\hline Coal and Other Solld Fuels & & Ibs per ton & lbs per ton & Ibs per ton \\
\hline Bituminous' ${ }^{+} \ldots \ldots \ldots \ldots \ldots \ldots$ & $\begin{array}{l}\text { cyclone } \\
\text { fluidized bed } \\
\text { spreader stoker } \\
\text { tangential } \\
\text { all others }\end{array}$ & $\begin{array}{l}39.00 \times 5 \\
39.00 \times 5 \\
39.00 \times S \\
39.00 \times S \\
39.00 \times S\end{array}$ & $\begin{array}{ll}37 & (37) \\
21(34) \\
14(14) \\
15(15) \\
21(34)\end{array}$ & $\begin{array}{l}\text { See Table C2 } \\
\text { See Table C2 } \\
\text { See Table C2 } \\
\text { See Table C2 } \\
\text { See Table C2 }\end{array}$ \\
\hline Subbituminous & $\begin{array}{l}\text { cyclone } \\
\text { fluidized bed" } \\
\text { spreader stoker } \\
\text { tangential } \\
\text { all others }\end{array}$ & $\begin{array}{l}35.00 \times \mathrm{S} \\
35.00 \times \mathrm{S} \\
35.00 \times \mathrm{S} \\
35.00 \times \mathrm{S} \\
35.00 \times \mathrm{S}\end{array}$ & $\begin{array}{l}37(37) \\
21(34) \\
14(14) \\
15(15) \\
21(34)\end{array}$ & $\begin{array}{l}\text { See Table C2 } \\
\text { See Table C2 } \\
\text { See Table C2 } \\
\text { See Table C2 } \\
\text { See Table C2 }\end{array}$ \\
\hline Lignite ${ }^{4}$ & $\begin{array}{l}\text { cycione } \\
\text { fluidized bed } \\
\text { front/opposed } \\
\text { spreader stoker } \\
\text { tangential } \\
\text { all others }\end{array}$ & $\begin{array}{l}30.00 \times 5 \\
30.00 \times 5 \\
30.00 \times 5 \\
30.00 \times 5 \\
30.00 \times 5 \\
30.00 \times 5\end{array}$ & $\begin{array}{r}17.00 \\
12.00 \\
14.00 \\
6.00 \\
8.00 \\
12.00\end{array}$ & $\begin{array}{l}\text { See Table C2 } \\
\text { See Table C2 } \\
\text { See Table C2 } \\
\text { See Table C2 } \\
\text { See Table C2 } \\
\text { See Table C2 }\end{array}$ \\
\hline Petroleum Cok $\theta^{\circ}$ & $\begin{array}{l}\text { fluidized bed" } \\
\text { all others }\end{array}$ & $\begin{array}{l}39.00 \times S \\
39.00 \times S\end{array}$ & $\begin{array}{l}18.00 \\
18.00\end{array}$ & $\begin{array}{l}6,693 \\
6,693\end{array}$ \\
\hline Refuse & all types & 2.50 & 300 & 2,344 \\
\hline$\ldots$ & all types & 0.15 & 280 & 3.788 \\
\hline Petroleum and Other Liquid Fuels ....... & & Ibs per $10^{3} \mathrm{gal}$ & Ibs per $10^{3} \mathrm{gal}$ & lbe per $10^{\circ} \mathrm{gal}$ \\
\hline Residual $\mathrm{O}^{\prime}$. & $\begin{array}{l}\text { tangential } \\
\text { vertical } \\
\text { all others }\end{array}$ & $\begin{array}{l}159.90 \times S \\
159.90 \times S \\
159.90 \times S\end{array}$ & $\begin{array}{r}42.00 \\
10500 \\
67.00\end{array}$ & $\begin{array}{l}26,199 \\
26.199 \\
26,199\end{array}$ \\
\hline Distillate Oil & all types & $144.00 \times S$ & 2000 & 22,763 \\
\hline Methanol $\ldots \ldots \ldots \ldots$ & all types & 0.05 & 1240 & 7,603 \\
\hline Propane (liquid) & all types & 005 & 1240 & 12,617 \\
\hline Coal-Oll Mixture & all types & $185.00 \times 5$ & 50.00 & 22,368 \\
\hline \multicolumn{5}{|l|}{$\begin{array}{l}\text { Natural Gas and Other Gaseous } \\
\text { Fuels }\end{array}$} \\
\hline \multirow[t]{2}{*}{ Natural Gas } & tangential & 060 & 27500 & 124,127 \\
\hline & all others & 0.60 & 550.00 & 124,127 \\
\hline Blası Furnance Gas & all types & 060 & 55000 & 124,127 \\
\hline \multicolumn{5}{|l|}{ Nonutility } \\
\hline Coal and Other Solld Fuels & & Ibs per ton & Ibs per ton & Ibs per ton \\
\hline Anthracite Culm & all types & $3900 \times S$ & 1800 & See Table C2 \\
\hline Bituminous ${ }^{4}$ & all types & $39.00 \times 5$ & 2100 & See Table C2 \\
\hline Bituminous Gob & all types & $39.00 \times \mathrm{S}$ & 2100 & See Table C2 \\
\hline Subituminous & all types & $35.00 \times 5$ & 21.00 & See Table C2 \\
\hline Lignite $^{4}$ & all types & $3000 \times 5$ & 12.00 & See Table C2 \\
\hline Lignite Waste & all types & $30.00 \times 5$ & 12.00 & See Table C2 \\
\hline Peat & all types & $3000 \times 5$ & 1200 & See Table C2 \\
\hline Agricultural Waste & all types & $\begin{array}{l}0.15 \\
700\end{array}$ & $\begin{array}{l}2.80 \\
150\end{array}$ & $\begin{array}{l}1,714 \\
2725\end{array}$ \\
\hline Black Liquor & all types & 7.00 & 150 & 2,725 \\
\hline Chemicals ............... & all types & 700 & 150 & 2,725 \\
\hline Closed Loop Biomass & all types & 0.15 & 2.80 & 3,788 \\
\hline 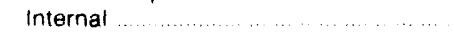 & all types & 0.15 & 280 & 3.788 \\
\hline
\end{tabular}

See footnotes at end of table. 
Table C1. Sulfur Dioxide, Nitrogen Oxide, and Carbon Dioxide Emission Factors-Continued

\begin{tabular}{|c|c|c|c|c|}
\hline \multirow[b]{2}{*}{ Fuel } & \multirow{2}{*}{$\begin{array}{l}\text { Boller Type/ } \\
\text { Firing } \\
\text { Conflguration }\end{array}$} & \multicolumn{3}{|c|}{ Emission Factors } \\
\hline & & $\begin{array}{c}\text { Sulfur } \\
\text { Dioxide }\end{array}$ & $\begin{array}{l}\text { Nitrogen } \\
\text { Oxides? }\end{array}$ & $\begin{array}{c}\text { Carbon } \\
\text { Dloxide }\end{array}$ \\
\hline & & Ibs per ton & Ibs per ton & Ibs per ton \\
\hline Liquid Acetonitrile Waste & all types & 7.00 & 1.50 & 2.725 \\
\hline Liquid Waste & all types & 7.00 & 1.50 & 2,725 \\
\hline Municipal Solid Waste & all types & 2.50 & 3.00 & 2,344 \\
\hline Petroleum Coke' ....... & all types & $39.00 \times 5$ & 18.00 & 6,693 \\
\hline Pitch ................ & all types & $30.00 \times 5$ & 12.00 & See Table $\mathrm{C}_{2}$ \\
\hline Railroad Ties & all types & 0.15 & 2.80 & 3,788 \\
\hline Red Liquor. & all types & 7.00 & 1.50 & 2,725 \\
\hline Sludge $\ldots \ldots \ldots$ & all types & 1.00 & 600 & 3.788 \\
\hline Sludge Waste & all types & 1.00 & 6.00 & 3,788 \\
\hline Sludge Wood & all types & 1.00 & 6.00 & 3,788 \\
\hline Spent Sulfite Liquor & all types & 7.00 & 150 & 2,725 \\
\hline Straw & all types & 0.15 & 2.80 & 3,788 \\
\hline$\ldots \ldots+\ldots$ & all types & 7.00 & 0.00 & 0 \\
\hline$\ldots \ldots \ldots$ & all types & $30.00 \times \mathrm{S}$ & 12.00 & See Table $\mathrm{C} 2$ \\
\hline (1) & all types & $39.00 \times 5$ & 21.00 & 5.715 \\
\hline Wasle Byproducts & all types & 2.50 & 3.00 & 2,344 \\
\hline Wasie Coal & all types & $39.00 \times S$ & 2100 & See Table C2 \\
\hline Wood/Wood Waste & all types & 0.15 & 280 & 3,788 \\
\hline Petroleum and Other Liquild Fuels & & Ibs per $10^{3} \mathrm{gal}$ & Ibs per $10^{3} \mathrm{gal}$ & Ibs per $10^{3} \mathrm{gal}$ \\
\hline Heavy OI' & all types & $159.90 \times \mathrm{S}$ & 67.00 & 26,199 \\
\hline 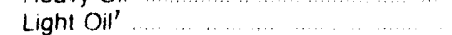 & all types & $144.00 \times 5$ & 2000 & 22,763 \\
\hline Diesel ...... & all types & $144.00 \times S$ & 20.00 & 22,763 \\
\hline ...................... & all types & $144.00 \times S$ & 2000 & 22,763 \\
\hline$\ldots \ldots \ldots \ldots \ldots$ & all types & 0.60 & 13.20 & 14,628 \\
\hline$\ldots \ldots \ldots+\ldots$ & all types & 0.50 & 1240 & 7.603 \\
\hline 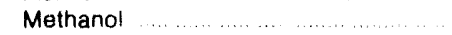 & all types & 0.50 & 12.40 & 7.603 \\
\hline 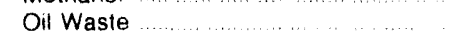 & all types & $151.50 \times \mathrm{S}$ & 37.50 & 24.481 \\
\hline Propane (llquid) & all types & 0.50 & 12.40 & 12.617 \\
\hline Sludge Oil & all types & $151.50 \times \mathrm{S}$ & 3750 & 24.481 \\
\hline Tar Oil . & all types & $159.00 \times 5$ & 55.00 & 26,199 \\
\hline Waste Alcohol $\ldots$ & all types & 0.50 & 1240 & 7,603 \\
\hline Natural Gas and Other Gaseous & & & & \\
\hline $\begin{array}{l}\text { Fuels } \\
\text { Fol }\end{array}$ & & Ibs per $10^{\circ} \mathrm{cf}$ & los per $10^{\circ} \mathrm{cf}$ & Ibs per $10^{\circ} \mathrm{cf}$ \\
\hline Natural Gas... & all types & 0.60 & 550.00 & 121,900 \\
\hline Butane (gas) & all types & 060 & 550.00 & 479,450 \\
\hline Hydroger & all types & 0.00 & 550.00 & 0 \\
\hline 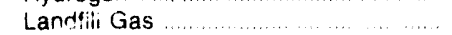 & all types & 0.60 & 550.00 & 121,900 \\
\hline 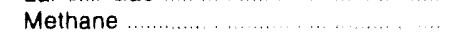 & all types & 0.60 & 550.00 & 116,436 \\
\hline 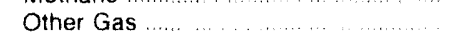 & all types & 0.60 & 550.00 & 121,900 \\
\hline Propane (gas) & all types & 0.60 & 55000 & 358,333 \\
\hline
\end{tabular}

' Uncontrolled sulfur dioxide emission factors. " $x$ S" indicates that the constant must be multiplied by the percentage (by weight) of sulfur in the fuel Sulfur dioxide emission estimates from facilities with flue gas desulfurization equipment are calculated by multiplying uncontrolled emission estimates by one minus the reported sulfur removal efficiencies. Sulfur dioxide emission factors also account for small quantities of sulfur trioxide and gaseous sulfates

2 Parenthetic values are for wet bottom boilers; otherwise dry bottom boilers. Emission factors are for boilers with a gross heat rate of 100 million Btu per hour or greater. See Table C3 for nitrogen oxide reduction factors used to calculate controlled nitrogen oxide emission estimates

3 Uncontrolied carbon dioxide emission estimates are reduced by 1 percent to account for unburned carbon.

4 Coal types are categorized by Btu content as follows: bituminous (greater than or equal to 9,750 Btu per pound), subbituminous (equal to 7,50$)$ to 9,750 Btu per pound), and lignite (less than 7.500 Btu per pound)

- Sulfur dioxide emission estimates from fluidized bed boilers assume a sulfur removal efficiency of 90 percent

- Emission factors for petroleum coke are assumed to be the same as those for anthracite. If the sulfur content of petroleum coke is unknown, a 6 percent sulfur content is assumed

'Oil types are categorized by Btu content as follows: heavy (greater than or equal to 144,190 Btu per gallon). and light (less than 144,190 Btu per gallon)

cf $\approx$ Cubic Feet

gal = U.S Galtons

ibs $=$ Pounds

Sources: •For sulfur dioxide and nitrogen oxide factors: Environrnental Protection Agency, "Compilation of Air Pollutant Emission Factors, Volume 1 Stationary Point and Area Sources." Research Triangle Park, North Carolina, October 1986. •For carbon dioxide factors: Department of Energy, "Carborı Dioxide Emıssions from Fossil Fuels: A Procedure for Estimation of Results, 1950-1981," June 1983. 
Table C2. Carbon Dioxide Emission Factors For Coal by Rank and State of Origin

\begin{tabular}{|c|c|c|}
\hline Rank & State of Origin & $\begin{array}{c}\text { Factors } \\
\text { (Pounds per Million Btu) }\end{array}$ \\
\hline Anthracite ............ & Pennsyivania & 227.38 \\
\hline Bituminous & Alabama & 205.46 \\
\hline Bituminous & Arizona & 209.68 \\
\hline Bituminous & Arkansas & 211.60 \\
\hline 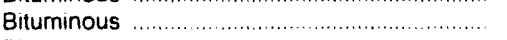 & Colorado & 206.21 \\
\hline Bituminous & llinois & 203.51 \\
\hline Bituminous & Indiana & 203.64 \\
\hline 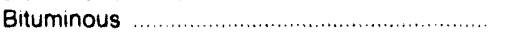 & lowa & 201.57 \\
\hline Bituminous & Kansas & 202.79 \\
\hline Bituminous & Kentucky: East & 204.80 \\
\hline Biturninous & Kentucky: West & 203.23 \\
\hline Bituminous & Maryland & 210.16 \\
\hline Bituminous & Missouri & 201.31 \\
\hline 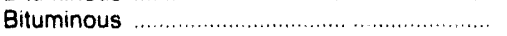 & Montana & 209.62 \\
\hline 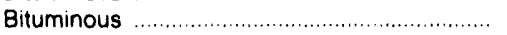 & New Mexico & 205.71 \\
\hline 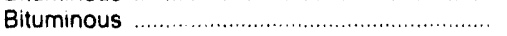 & Ohio & 202.84 \\
\hline 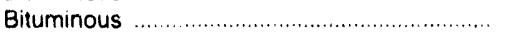 & Oklahoma & 205.93 \\
\hline 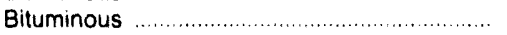 & Pennsylvania & 205.72 \\
\hline 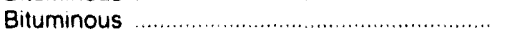 & Tennessee & 204.79 \\
\hline 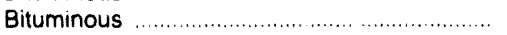 & Utah & 204.08 \\
\hline 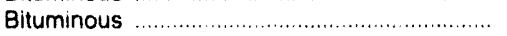 & Virginia & 206.23 \\
\hline 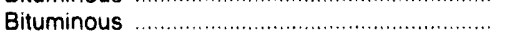 & Washington & 203.62 \\
\hline 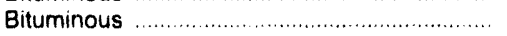 & West Virgınia & 207.10 \\
\hline 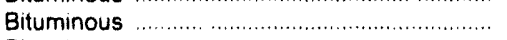 & Wyoming & 206.48 \\
\hline 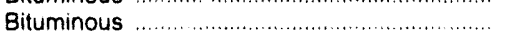 & Texas & 204.39 \\
\hline (2) & Alaska & 214.00 \\
\hline Subbituminous & Colorado & 212.72 \\
\hline Subbituminous & lowa & 200.79 \\
\hline Subbituminous & Missouri & 201.31 \\
\hline Subbituminous & Montana & 213.42 \\
\hline Subbituminous & New Mexico & 208.84 \\
\hline Subbituminous & Utah & 207.09 \\
\hline (2) & Washıngton & 208.69 \\
\hline 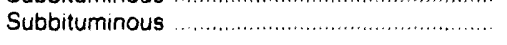 & Wyoming & 212.71 \\
\hline (2) & Arkansas & 213.54 \\
\hline Lignite & California & 216.31 \\
\hline 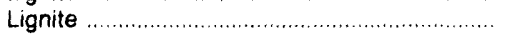 & Louisiana & 213.54 \\
\hline Lignite & Montana & 220.59 \\
\hline 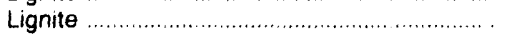 & North Dakota & 218.76 \\
\hline Lignite & South Dakota & 216.97 \\
\hline 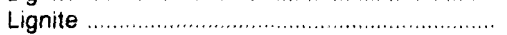 & Texas & 213.54 \\
\hline Lignite & Washington & 211.68 \\
\hline Lignite & Wyoming & 215.59 \\
\hline
\end{tabular}

Source: Energy Information Administration. 
Table C3. Nitrogen Oxide Reduction Factore

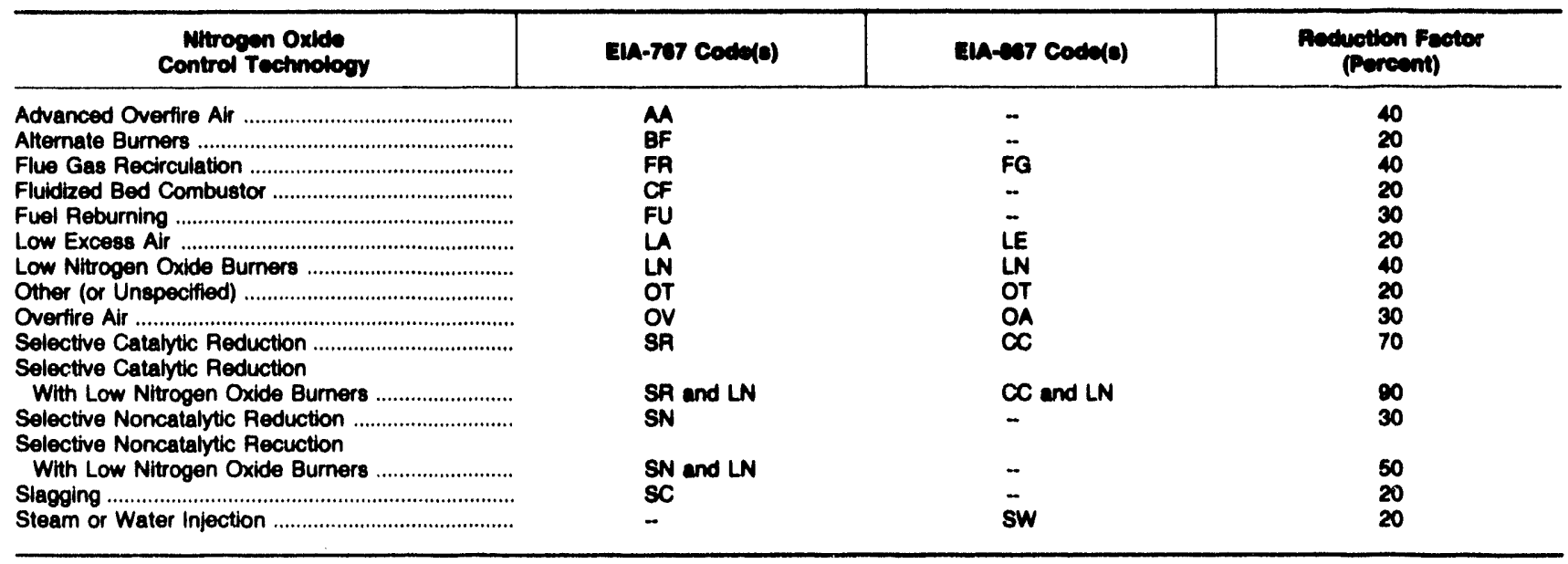

Source: Babcock and Wilcox, Steam: Its Generation and Use, 40th Edition, 1902.

Table C4. Unit-of-Measure Equivalents

\begin{tabular}{|c|c|c|c|}
\hline Unt & \multicolumn{3}{|c|}{ Equhrelent } \\
\hline $\begin{array}{l}\text { Kilowatt (kW) } \\
\text { Megawatt (MW) } \\
\text { Gigawatt }(\mathrm{SW}) \\
\text { Terawatt }(\mathrm{TW})\end{array}$ & $\begin{array}{r}1,000 \\
1,000,000 \\
1,000,000,000 \\
1,000,000,000,000\end{array}$ & $\begin{array}{l}\text { (One Thousand) } \\
\text { (One Million) } \\
\text { (On Bulion) } \\
\text { (One Trition) }\end{array}$ & $\begin{array}{l}\text { Watts } \\
\text { Watts } \\
\text { Watts } \\
\text { Watts }\end{array}$ \\
\hline Gigawatt & $\begin{array}{r}1,000,000 \\
1,000,000,000\end{array}$ & $\begin{array}{l}\text { (One Million) } \\
\text { (One Biltion) }\end{array}$ & $\begin{array}{l}\text { Killowatts } \\
\text { Kilowatts }\end{array}$ \\
\hline $\begin{array}{l}\text { Kilowatthours (kWh) } \\
\text { Megawatthours (MWh) } \\
\text { Gigawatthours (GWh) } \\
\text { Terawatthours (TWh) }\end{array}$ & $\begin{array}{r}1,000 \\
1,000,000 \\
1,000,000,000 \\
1,000,000,000,000\end{array}$ & $\begin{array}{l}\text { (One Thousand) } \\
\text { (One Million) } \\
\text { (One Billion) } \\
\text { (One Trillion) }\end{array}$ & $\begin{array}{l}\text { Watthours } \\
\text { Watthours } \\
\text { Watthours } \\
\text { Watthours }\end{array}$ \\
\hline $\begin{array}{l}\text { Gigawatthours } \\
\text { Thousand Gigawatthours }\end{array}$ & $\begin{array}{r}1,000,000 \\
1,000,000,000\end{array}$ & $\begin{array}{l}\text { (One Miltion) } \\
\text { (One Billion) }\end{array}$ & $\begin{array}{l}\text { Kllowatthours } \\
\text { Kllowatthours }\end{array}$ \\
\hline $\begin{array}{l}\text { U.S. Dollar . } \\
\text { U.S. Cont }\end{array}$ & $\begin{array}{c}1,000 \\
10\end{array}$ & \multicolumn{2}{|c|}{$\begin{array}{l}\text { (One Thousand) Mills } \\
\text { (Ten) MHts }\end{array}$} \\
\hline
\end{tabular}

Source: Energy Information Administration, Survey Managment Diviaion. 


\section{Glossary}

Acid Rain: Also called acid precipitation or acid deposition, acid rain is precipitation containing harmful amounts of nitric and sulfuric acids formed primarily by nitrogen oxides and sulfur oxides released into the atmosphere when fossil fuels are burned. It can be wet precipitation (rain, snow, or fog) or dry precipitation (absorbed gaseous and particulate matter, aerosol particles or dust). Acid rain has a $\mathrm{pH}$ below 5.6. Normal rain has a $\mathrm{pH}$ of about 5.6, which is slightly acidic. The term pH is a measure of acidity or alkalinity and ranges from 0 to 14 . A pH measurement of 7 is regarded as neutral. Measurements below 7 indicate increased acidity, while those above indicate increased alkalinity.

Actual Peak Reduction: The actual reduction in annual peak load (measured in kilowatts) achieved by consumers that participate in a utility DSM program. It reflects the changes in the demand for electricity resulting from a utility DSM program that is in effect at the same time the utility experiences its annual peak load, as opposed to the installed peak load reduction capability (i.e., Potential Peak Reduction). It should account for the reguiar cycling of energy efficient units during the period of annual peak load.

\section{Allowance for Funds Used During Construction} (AFUDC): A noncash item representing the estimated composite interest costs of debt and a return on equity funds used to finance construction. The allowance is capitalized in the property accounts and included in income.

Ampere: The unit of measurement of electrical current produced in a circuit by 1 volt acting through a resistance of $1 \mathrm{ohm}$.

Annual Effects: The total effects in energy use (measured in megawatthours) and peak load (measured in kilowatts) caused by all participants in the DSM programs that are in effect during a given year. It includes new and existing participants in existing programs (those implemented in prior years that are in place during the given year) and all participants in new programs (those implemented during the given year). The effects of new participants in existing programs and all participants in new programs should be based on their start-up dates (i.e., if participants enter a program in July, only the effects from July to December should bereported). If start-up dates are unknown and cannot be reasonably estimated, the effects can be annualized (i.e., assume the participants were initiated into the program on January 1 of the given year). The Annua! Effects should consider the useful life of efficiency measures, by accounting for building demolition, equipment degradation and attrition.

Anthracite: A hard, black lustrous coal, often referred to as hard coal, containing a high percentage of fixed carbon and a low percentage of volatile matter. Comprises three groups classified according to the following ASTM Specification D388-84, on a dry mineralmatter-free basis:

$\begin{array}{llllr} & \begin{array}{l}\text { Fixed } \\ \text { Carbon }\end{array} & \\ & \text { Volatile } \\ \text { Limits } & \text { Matter } \\ & \text { GE } & \text { LT } & \text { GT } & \text { LE } \\ \text { Meta-Anthracite } & 98 & - & - & 2 \\ \text { Anthracite } & 92 & 98 & 2 & 8 \\ \text { Semianthracite } & 86 & 92 & 8 & 14\end{array}$

Appliances: Energy Efficiency program promotion of high efficiency appliances such as dishwashers, ranges, refrigerators, and freezers in the residential, commercial, and industrial sectors. Includes programs aimed at improving the efficiency of refrigeration equipment and electrical cooking equipment, including replacement. It also includes the promotion and identification of high efficiency appliances in retail stores using a labeling system different from the federally-mandated Energy Guide. Energy Efficiency program promotion of high efficiency cooling and heating appliances are included under Cooling System and Heating System, respectively. 
Ash: Impurities consisting of silica, iron, alumina, and other noncombustible matter that are contained in coal. Ash increases the weight of coal, adds to the cost of handling, and can affect its burning characteristics. Ash content is measured as a percent by weight of coal on an "as received" or a "dry" (moisture-free, usually part of a laboratory analysis) basis.

Asset: An economic resource, tangible or intangible, which is expected to provide benefits to a business.

Available but not Needed Capability: Net capability of main generating units that are operable but not considered necessary to carry load, and cannot be connected to load within 30 minutes.

Average Revenue per Kilowatthour: The average revenue per kilowatthour of electricity sold by sector (residential, commercial, industrial, or other) and geographic area (State, Census division, and national), is calculated by dividing the total monthly revenue by the corresponding total monthly sales for each sector and geographic area.

Barrel: A volumetric unit of measure for crude oil and petroleum products equivalent to 42 U.S. gallons.

Base Bill: A charge calculated through multiplication of the rate from the appropriate electric rate schedule by the level of consumption.

Baseload: The minimum amount of electric power delivered or required over a given period of time at a steady rate.

Baseload Capacity: The generating equipment normally operated to serve loads on an around-the-clock basis.

Baseload Plant: A plant, usually housing highefficiency steam-electric units, which is normally operated to take all or part of the minimum load of a system, and which consequently produces electricity at an essentially constant rate and runs continuously. These units are operated to maximize system mechanical and thermal efficiency and minimize system operating costs.

Bbl: The abbreviation for barrel.
Bcf: The abbreviation for 1 billion cubic feet.

Bituminous Coal: The most common coal. It is dense and black (often with well-defined bands of bright and dull material). Its moisture content usually is less than 20 percent. It is used for generating electricity, making coke, and space heating. Comprises five groups classified according to the following ASTM Specification D388-84, on a dry mineral-matter-free (mmf) basis for fixed-carbon and volatile matter and a moist $\mathrm{mmf}$ basis for calorific value.

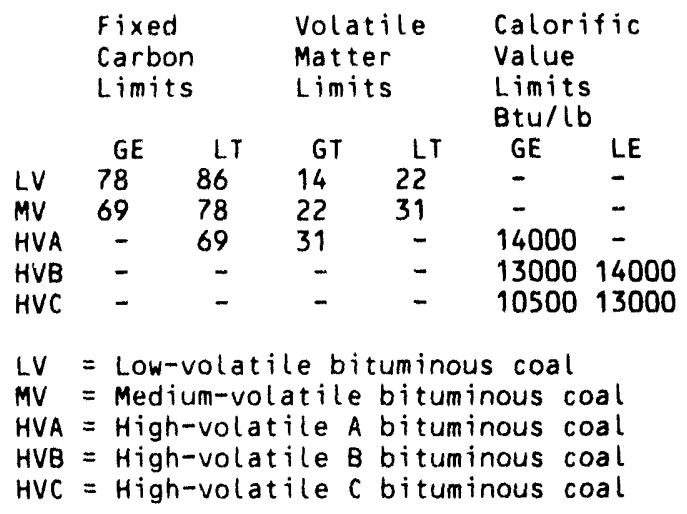

Boiler: A device for generating steam for power, processing, or heating purposes or for producing hot water for heating purposes or hot water supply. Heat from an external combustion source is transmitted to a fluid contained within the tubes in the boiler shell. This fluid is delivered to an end-use at a desired pressure, temperature, and quality.

Btu (British Thermal Unit): A standard unit for measuring the quantity of heat energy equal to the quantity of heat required to raise the temperature of 1 pound of water by 1 degree Fahrenheit.

Capability: The maximum load that a generating unit, generating station, or other electrical apparatus can carry under specified conditions for a given period of time without exceeding approved limits of temperature and stress.

Capacity: The amount of electric power delivered or required for which a generator, turbine, transformer, transmission circuit, station, or system is rated by the manufacturer. 
Capacity (Purchased): The amount of energy and capacity available for purchase from outside the systern.

Capacity Charge: An element in a two-part pricing method used in capacity transactions (energy charge is the other element). The capacity charge, sometimes called Demand Charge, is assessed on the amount of capacity being purchased.

Capital (Financial): The line items on the right side of a balance sheet, that include debt, preferred stock, and common equity. A net increase in assets must be financed by an increase in one or more forms of capital.

Census Divisions: The nine geographic divisions of the United States established by the Bureau of the Census, U.S. Department of Commerce, for the purpose of statistical analysis. The boundaries of Census divisions coincide with State boundaries. The Pacific Division is subdivided into the Pacific Contiguous and Pacific Noncontiguous areas.

Circuit: A conductor or a system of conductors through which electric current flows.

Coal: A black or brownish-black solid combustible substance formed by the partial decomposition of vegetable matter without access to air. The rank of coal, which includes anthracite, bituminous coal, subbituminous coal, and lignite, is based on fixed carbon, volatile matter, and heating value. Coal rank indicates the progressive alteration from lignite to anthracite. Lignite contains approximately 9 to $17 \mathrm{mil}$ lion Btu per ton. The contents of subbituminous and bituminous coal range from 16 to 24 million Btu per ton and from 19 to 30 million Btu per ton, respectively. Anthracite contains approximately 22 to 28 million Btu per ton.

Cogenerator: A generating facility that produces electricity and another form of useful thermal energy (such as heat or steam), used for industrial, commercial, heating, or cooling purposes. To receive status as a qualifying facility (QF) under the Public Utility Regulatory Policies Act (PURPA), the facility must produce electric energy and "another form of useful thermal energy through the sequential use of energy," and meet certain ownership, operating, and efficiency criteria established by the Federal Energy Regulatory Commission (FERC). (See the Code of Federal Regulations, Title 18, Part 292.)
Coincidental Demand: The sum of two or more demands that occur in the same time interval.

Coincidental Peak Load: The sum of two or more peakloads that occur in the same time interval.

Coke (Petroleum): A residue high in carbon content and low in hydrogen that is the final product of thermal decomposition in the condensation process in cracking. This product is reported as marketable coke or catalyst coke. The conversion factor is 5 barrels (42 U.S. gallons each) per short ton.

Combined Cycle: An electric generating technology in which electricity is produced from otherwise lost waste heat exiting from one or more gas (combustion) turbines. The exiting heat is routed to a conventional boiler or to a heat recovery steam generator for utilization by a steam turbine in the production of electricity. This process increases the efficiency of the electric generating unit.

Combined Cycle Unit: An electric generating unit that consists of one or more combustion turbines and one or more boilers with a portion of the required energy input to the boiler(s) provided by the exhaust gas of the combustion turbine(s).

Combined Pumped-Storage Plant: A pumped-storage hydroelectric power plant that uses both pumped water and natural streamflow to produce electricity.

Commercial: The commercial sector is generally defined as nonmanufacturing business establishments, including hotels, motels, restaurants, wholesale businesses, retail stores, and health, social, and educational institutions. The utility may classify commercial service as all consumers whose demand or annual use exceeds some specified limit. The limit may be set by the utility based on the rate schedule of the utility.

Commercial Operation: Commercial operation begins when control of the loading of the generator is turned over to the system dispatcher.

Connection: The physical connection (e.g. transmission lines, transformers, switch gear, etc.) between two electric systems permitting the transfer of electric energy in one or both directions. 
Conservation and Other DSM: This Demand-Side Management category represents the amount of consumer load reduction at the time of system peak due to utility programs that reduce consumer load during many hours of the year. Examples include utility rebate and shared savings activities for the installation of energy efficient appliances, lighting and electrical machinery, and weatherization materials. In addition, this category includes all other Demand-Side Management activities, such as thermal storage, time-of-use rates, fuel substitution, measurement and evaluation, and any other utility-administered Demand-Side Management activity designed to reduce demand and/or electricity use.

Construction Work In Progress (CWIP): The balance shown on a utility's balance sheet for construction work not yet completed but in process. This balance line item may or may not be included in the rate base.

Consumption (Fuel): The amount of fuel used for gross generation, providing standby service, start-up and/or flame stabilization.

Contract Price: Price of fuels marketed on a contract basis covering a period of 1 or more years. Contract prices reflect market conditions at the time the contract was negotiated and therefore remain constant throughout the life of the contract or are adjusted through escalation clauses. Generally, contract prices do not fluctuate widely.

Contract Receipts: Purchases based on a negotiated agreement that generally covers a period of 1 or more years.

Cooling System: Energy Efficiency program promotion aimed at improving the efficiency of the cooling delivery system, including replacement, in the residential, commercial, or industrial sectors.

Cooperative Electric Utility: An electric utility legally established to be owned by and operated for the benefit of those using its service. The utility company will generate, transmit, and/or distribute supplies of electric energy to a specified area not being serviced by another utility. Such ventures are generally exempt from Federal income tax laws. Most electric cooperatives have been initially financed by the Rural Electrification Administration, U.S. Department of Agriculture.
Cost: The amount paid to acquire resources, such as plant and equipment, fuel, or labor services.

Current (Electric): A flow of electrons in an electrical conductor. The strength or rate of movement of the electricity is measured in amperes.

Demand (Electric): The rate at which electric energy is delivered to or by a system, part of a system, or piece of equipment, at a given instant or averaget over any designated period of time.

Demand-Side Management: The planning, implementation, and monitoring of utility activities designed to encourage consumers to modify patterns of electricity usage, including the timing and level of electricity demand. It refers only to energy and load-shape modifying activities that are undertaken in response to utility-administered programs. It does not refer to energy and load-shape changes arising from the normal operation of the marketplace or from governmentmandated energy-efficiency standards. Demand-Side Management (DSM) covers the complete range of load-shape objectives, including strategic conservation and load management, as well as strategic load growth.

Demand-Side Management Expenditures: The expenditures incurred by the utility to achieve the capacity and energy savings from the Demand-Side Management Program. Expenditures incurred by consumers or third parties are to be excluded. The expenditures are to be reported in nominal dollars in the year in which they are incurred, regardless of when the savings occur. Program expenditures include expensed items incurred to implement the program, incentive payments provided to consumers to install DemandSide Management measures, and annual operation and maintenance expenses incurred during the year. Utility expenditures that are general, administrative, or not specific to a particular Demand-Side Management category are to be excluded.

Direct Load Control: Refers to program activities that can interrupt consumer load at the time of annual peak load by direct control of the utility system operator by interrupting power supply to individual appliances or equipment on consumer premises. This type of control usually involves residential consumers. Direct Load Control excludes Interruptible Load and Other Load Management effects. (Direct Load Control, as defined here, is synonymous with Direct Load Control Management reported to the North American Electric Reliability Council on the voluntary Office 
of Energy Emergency Operations Form OE-411, "Coordinated Regional Bulk Power Supply Program Report," with the exception that annual peakload effects are reported here and seasonal (i.e., summer and winter) peakload effects are reported on the OE-411.)

Direct Utility Cost: A utility cost that is identified with one of the DSM program categories (i.e. Energy Efficiency, Direct Load Control, Interruptible Load, Other Load Management, Other DSM Programs, Load Building).

Distillate Fuel Oil: A general classification for one of the petroleum fractions produced in conventional distillation operations. It is used primarily for space heating, on-and-off-highway diesel engine fuel (including railroad engine fuel and fuel for agriculture machinery), and electric power generation. Included are Fuel Oils No. 1, No. 2, and No. 4; and Diesel Fuels No. 1, No. 2, and No. 4 .

Distribution System: 'The portion of an electric system that is dedicated to delivering electric energy to an end user.

Diversity Exchange: An exchange of capacity or energy, or both, between systems whose peakloads occur at different times

Electric Plant (Physical): A facility containing prime movers, electric generators, and auxiliary equipment for converting mechanical, chemical, and/or fission energy into electric energy.

Electric Rate Schedule: A statement of the electric rate and the terms and conditions governing its application, including attendant contract terms and conditions that have been accepted by a regulatory body with appropriate oversite authority.

Electric Utility: A corporation, person, agency, authority, or other legal entity or instrumentality that owns and/or operates facilities within the United States, its territories, or Puerto Rico for the generation, transmission, distribution, or sale of electric energy primarily for use by the public and files forms listed in the Code of Federal Regulations, Title 18, Part 141. Facilities that qualify as cogenerators or small power producers under the Public Utility Regulatory Policies Act (PURPA) are not considered electric utilities.
Energy: The capacity for doing work as measured by the capability of doing work (potential energy) or the conversion of this capability to motion (kinetic energy). Energy has several forms, some of which are easily convertible and can be changed to another form useful for work. Most of the world's convertible energy comes from fossil fuels that are burned to produce heat that is then used as a Iransfer medium to mechanical or other means in order to accomplish tasks. Electrical energy is usually measured in kilowatthours, while heat energy is usually measured in British thermal units.

Energy Charge: That portion of the charge for electric service based upon the electric energy (kWh) consumed or billed.

Energy Deliveries: Energy generated by one electric utility system and delivered to another system through one or more transmission lines.

Energy Effects: The changes in aggregate electricity use (measured in megawatthours) for customers that participate in a utility DSM program. Energy Effects should represent changes at the consumer meter (i.e. exclude transmission and distribution effects) and reflect only activities that are undertaken specifically in response to utility-administered programs, including those activities implemented by third parties under contract to the utility. To the extent possible, Energy Effects should exclude non-program related effects such as changes in energy usage attributable to nonparticipants, government-mandated energy-efficiency standards that legislate improvements in building and appliance energy usage, changes in consumer behavior that result in greater energy use after initiation in a DSM program, the natural operations of the marketplace, and weather and business-cycle adjustments.

Energy Efficiency: Refers to programs that are aimed at reducing the energy used by specific end-use devices and systems, typically without affecting the services provided. These programs reduce overall electricity consumption (reported in megawatthours), often without explicit consideration for the timing of programinduced savings. Such savings are generally achieved by substituiing technically more advanced equipment to produce the same level of end-use services (e.g. lighting, heating, motor drive) with less electricity. Examples include high-efficiency appliances, efficient lighting programs, high-efficiency heating, ventilating and air conditioning (HVAC) systems or control modifications, efficient building design, advanced electric motor drives, and heat recovery systems. 
Energy Receipts: Energy generated by one electric utility system and received by another system through one or more transmission lines.

Energy Source: The primary source that provides the power that is converted to electricity through chemical, mechanical, or other means. Energy sources include coal, petroleum and petroleum products, gas, water, uranium, wind, sunlight, geothermal, and other sources.

Equity Capital: The sum of capital from retained earnings and the issuance of stocks.

Expenditure: The incurrence of a liability to obtain an asset or service.

Facility: An existing or planned location or site at which prime movers, electric generators, and/or equipment for converting mechanical, chemical, and/ or nuclear energy into electric energy are situated, or will be situated. A facility may contain more than one generator of either the same or different prime mover type. For a cogenerator, the facility includes the industrial or commercial process.

Federal Energy Regulatory Commission (FERC): A quasi-independent regulatory agency within the Department of Energy having jurisdiction over interstate electricity sales, wholesale electric rates, hydroelectric licensing, natural gas pricing, oil pipeline rates, and gas pipeline certification.

Federal Power Act: Enacted in 1920, and amended in 1935, the Act consists of three parts. The first part incorporated the Federal Water Power Act administered by the former Federal Power Commission, whose activities were confined almost entirely to licensing non-Federal hydroelectric projects. Parts 11 and III were added with the passage of the Public Utility Act. These parts extended the Act's jurisdiction to include regulating the interstate transmission of electrical energy and rates for its sale as wholesale in interstate commerce. The Federal Energy Regulatory Commission is now charged with the administration of this law.

Federal Power Commission: The predecessor agency of the Federal Energy Regulatory Commission. The Foderal Power Commission (FPC) was created by an Act of Congress under the Federal Water Power Act on June 10, 1920. It was charged originally with regulating the electric power and natural gas industries. The FPC was abolished on September 20, 1977, when the Department of Energy was created. The functions of the FPC were divided between the Department of Energy and the Federal Energy Regulatory Commission.

FERC: The Federal Energy Regulatory Commission.

Firm Gas: Gas sold on a continuous and generally long-term contract.

Firm Power: Power or power-producing capacity intended to be available at all times during the period covered by a guaranteed commitment to deliver, even under adverse conditions.

Flue Gas Desulfurization Unit (Scrubber): Equipment used to remove sulfur oxides from the combustion gases of a boiler plant before discharge to the atmosphere. Chemicals, such as lime, are used as the scrubbing media.

Flue Gas Particulate Collectors: Equipment used to remove fly ash from the combustion gases of a boiler plant before discharge to the atmosphere. Particulate collectors include electrostatic precipitators, mechanical collectors (cyclones), fabric filters (baghouses), and wet scrubbers.

Fly Ash: Particule matter from coal ash in which the particle diameter is less than $1 \times 10^{-1}$ meter. This is removed from the flue gas using flue gas particulate collectors such as fabric filters and electrostatic precipitators.

Forced Outage: The shutdown of a generating unit, transmission line or other facility, for emergency reasons or a condition in which the generating equipment is unavailable for load due to unanticipated breakdown.

Fossil Fuel: Any naturally occurring organic fuel, such as petroleum, coal, and natural gas.

Fossil-Fuel Plant: A plant using coal, petroleum, or gas as its source of energy. 
Fuel: Any substance that can be burned to produce heat; also, materials that can be fissioned in a chain reaction to produce heat.

Fuel Expenses: These costs include the fuel used in the production of steam or driving another prime mover for the generation of electricity. Other associated expenses include unloading the shipped fuel and all handling of the fuel up to the point where it enters the first bunker, hopper, bucket, tank, or holder in the boiler-house structure.

Full-Forced Outage: The net capability of main generating units that is unavailable for load for emergency reasons.

Gas: A fuel burned under boilers and by internal combustion engines for electric generation. These in. clude natural, manufactured and waste gas.

Gas Turbine Plant: A plant in which the prime mover is a gas turbine. A gas turbine consists typically of an axial-flow air compressor, one or more combustion chambers, where liquid or gaseous fuel is burned and the hot gases are passed to the turbine and where the hot gases expand to drive the generator and are then used to run the compressor.

Generating Unit: Any combination of physically connected generator(s), reactor(s), boiler(s), combustion turbine(s), or other prime mover(s) operated together to produce electric power.

Generation (Electricity): The process of producing electric energy by transforming other forms of energy; also, the amount of electric energy produced, expressed in watthciers (Wh).

Gross Generation: The total amount of electric energy produced by the generating units at a generating station or stations, measured at the generator terminals.

Net Generation: Gross generation less the electric energy consumed at the generating station for station use.

Generator: A machine that converts mechanical energy into electrical energy.

Generator Nameplate Capacity: The full-load continuous rating of a generator, prime mover, or other electric power production equipment under specific conditions as designated by the manufacturer. Installed generator nameplate rating is usually indicated on a nameplate physically attached to the generator.

Geothermal Plant: A plant in which the prime mover is a steam turbine. The turbine is driven either by steam produced from hot water or by natural steam that derives its energy from heat found in rocks or fluids at various depths beneath the surface of the earth. The energy is extracted by drilling and/or pumping.

Gigawatt (GW): One billion watts.

Gigawatthour (GWh): One billion watthours.

Greenhouse Effect: The increasing mean global surface temperature of the earth caused by gases in the atmosphere (including carbon dioxide, methane, nitrous oxide, ozone, and chlorofluorocarbon). The greenhouse effect allows solar radiation to penetrate but absorbs the infrared radiation returning to space.

Grid: The layout of an electrical distribution system.

Gross Generation: The total amount of electric energy produced by a generating facility, as measured at the generator terminals.

Heating System: Energy Efficiency program promotion aimed at improving the efficiency of the heating delivery system, including renlacement, in the residential, commercial, or industrial sectors.

Heavy Oil: The fuel oils remaining after the lighter oils have been distilled off during the refining process. Except for start-up and flame stabilization, virtually all petroleum used in steam plants is heavy oil.

Hydroelectric Plant: A plant in which the turbine generators are driven by falling water.

Incremental Effects: The annual effects in energy use (measured in megawatthours) and peakload (measured in kilowatts) caused by new participants in existing DSM programs and all participants in new DSM programs during a given year. Reported Incremental Effects should be annualized to indicate the program 
effects that would have occurred had these participants been initiated into the program on January 1 of the given year. Incremental effects are not simply the Annual Effects of a given year minus the Annual Effects of the prior year, since these net effects would fail to account for program attrition. degradation, demolition, and participant dropouts.

Indirect Utility Cost: A utility cost that may not be meaningfully identified with any particular DSM program category. Indirect costs could be attributable to one of several accounting cost categories (i.e., Administrative, Marketing, Monitoring \& Evaluation, UtilityEarned Incentives, Other). Accounting costs that are known DSM program costs should not be reported under Indirect Utility Cost, rather those costs should be reported as Direct Utility Costs under the appropriate DSM program category.

Industrial: The industrial sector is generally defined as manufacturing, construction, mining agriculture, fishing and forestry establishments Standard Industrial Classification (SIC) codes 01-39. The utility may classify industrial service using the SIC codes, or based on demand or annual usage exceeding some specified limit. The limit may be set by the utility based on the rate schedule of the utility.

Interdepartmental Service (Electric): Interdepartmental service includes amounts charged by the electric department at tariff or other specified rates for electricity supplied by it to other utility departments.

Intermediate Load (Electric System): The range from base load to a point between base load and peak. This point may be the midpoint, a percent of the peakload, or the load over a specified time period.

Internal Combustion Plant: A plant in which the prime mover is an internal combustion engine. An internal combustion engine has one or more cylinders in which the process of combustion lakes place, converting energy released frow the rapid burning of a fuel-air mixture into mechanical energy. Diesel or gasfired engines are the principal types used in electric plants. The plant is usually operated during periods of high demand for electricity.

Interruptible Gas: Gas sold to customers with a provision that permits curtailment or cessation of service at the discretion of the distributing company under certain circumstances, as specified in the service contract.

Interruptible Load: Refers to program activities that, in accordance with contractual arrangements, can in. terrupt consumer load at times of seasonal peak load by direct control of the utility system operator or by action of the consumer at the direct request of the system operator. It usually involves commercial and industrial consumers. In some instances the load reduction may be affected by direct action of the system operator (remote tripping) after notice to the consumer in accordance with contractual provisions. For example, loads that can be interrupted to fulfill planning or operation reserve requirements should be reported as Interruptible Load. Interruptible Load as defined here excludes Direct Load Control and Other Load Management. (Interruptible Load, as reported here, is synonymous with Interruptible Demand reported to the North American Electric Reliability Council on the voluntary Office of Energy Emergency Operations Form OE-411, "Coordinated Regional Bulk Power Supply Program Report," with the exception that annual peakload effects are reported on the Form ElA-861 and seasonal (i.e., summer and winter) peakload effects are reported on the OE-411)

Kilowatt (kW): One thousand watts.

Kilowatthour (kWh): One thousand watthours

Leverage Ratio: A measure that indicates the financial ability to meet debt service requirements and increase the value of the investment to the stockholders. (i.e. the ratio of total debt to total assets).

Liability: An amount payable in dollars or by future services to be rendered.

Light Oil: Lighter fuel oils distilled off during the refining process. Virtually all petroleum used in internal combustion and gas-turbine engines is light oil.

Lignite: A brownish-black coal of low rank with high inherent moisture and volatile matter (used almost exclusively for electric power generation). It is also referred to as brown coal. Comprises two groups classified according to the following ASTM Specification D388-84 for calorific values on a moist materialmatter-free basis: 
MMcf: One million cubic feet.

Limits Btu/lb.

$\begin{array}{llr} & \text { GE } & \text { LT } \\ \text { Lignite A } & 6300 & 8300\end{array}$

Lignite B - 6300

Load (Electric): The amount of electric power delivered or required at any specific point or points on a system. The requirement originates at the energyconsuming equipment of the consumers.

Load Building: Refers to programs that are aimed at increasing the usage of existing electric equipment or the addition of electric equipment. Examples include industrial technologies such as induction heating and melting, direct arc furnaces and infrared drying; cooking for commercial establishments; and heat $\operatorname{pur}_{{ }_{1}} \mathrm{~s}$ for residences. Load Building should include programs that promote electric fuel substitution. Load Building effects should be reported as a negative number, shown with a minus sign.

Marketing Cost: Expenses directly associated with the preparation and implementation of the strategies designed to encourage participation in a DSM program. The category excludes general market and load research costs.

Monitoring \& Evaluation Cost: Expenditures associated with the planning, collection, and analysis of data used to assess program operation and effects. It includes the activities such as load metering, customer surveys, new technology testing, and program evaluations that are intended to establish or improve the ability to monitor and evaluate the impacts of DSM programs, collectively or individually.

Maximum Demand: The greatest of all demands of the load that has occurred within a specified period of time.

Mcf: One thousand cubic feet.

Megawatt (MW): One million watts.

Megawatthour (MWh): Ons million watthours.
Natural Gas: A naturally occurring mixture of hydrocarbon and nonhydrocarbon gases found in porous geological formations beneath the earth's surface, often in association with petroleum. The principal constituent is methane.

Net Capability: The maximum load-carry:n of the equipment, exclusive of station use, $1=$ ified conditions for a given time interval, ind $e_{\boldsymbol{A}_{1}}$ of the characteristics of the load. (Capability is dete ${ }_{1}$ mined by design characteristics, physical conditions, adequacy of prime mover, energy supply, and operating limitations such as cooling and circulating water supply and temperature, headwater and tailwater elevations, and electrical use.)

Net Generation: Gross generation minus plant use from all electric utility owned plants. The energy required for pumping at a pumped-storage plant is regarded as plant use and must be deducted from the gross generation.

Net Summer Capability: The steady hourly output, which " ting equipment is expected to supply to syster lusive of auxiliary power, as demonstrate. at the time of summer peak demand.

Net Winter Capability: The steady hourly output which generating equipment is expected to supply to system load exclusive of auxiliary power, as demonstrated by tests at the time of winter peak demand.

New Construction: Energy-efficiency program promotion to encourage the building of new homes, buildings, and plants to exceed standard governmentmandated energy efficiency codes; it may include major renovations of existing facilities.

Noncoincidental Peak Load: The sum of two or more peakloads on individual systems that do not occur in the same time interval. Meaningful only when considering loads within a limited period of time, such as a day, week, month, a heating or cooling season, and usually for not more than 1 year.

Non-Firm Power: Power or power-preducing capacity supplied or available under a commitment having limited or no assured availability. 
Nonutility Power Producer: A corporation, person, agency, authority, or other legal entity or instrumentality that owns electric generating capacity and is not an electric utility. Nonutility power producers include qualifying cogenerators, qualifying small power producers, and other nonutility generators (including independent power producers) without a designated franchised service area, and which do not file forms listed in the Code of Federal Regulations, Title 18, Part 141.

North American Electric Reliability Council (NERC): A council formed in 1968 by the electric utility industry to promote the reliability and adequacy of bulk power supply in the electric utility systems of North America. NERC consists of nine regional reliability councils and encompasses essentially all the power regional of the contiguous United States, Canada, and Mexico. The NERC Regions are:

\section{ASCC - Alaskan System Coordination Council \\ ECAR - East Central Area Reliability Coordination Agreement}

ERCOT - Electric Reliability Council of Texas

MAIN - Mid-America Interconnected Network

MAAC - Mid-Atlantic Area Council

MAPP - Mid-Continent Area Power Pool

NPCC - Northeast Power Coordinating Council

SERC - Southeastern Electric Reliability Council

SPP - Southwest Power Pool

WSCC - Western Systems Coordinating Council

Nuclear Fuel: Fissionable materials that have been enriched to such a composition that, when placed in a nuclear reactor, will support a self-sustaining fission chain reaction, producing heat in a controlled manner for process use.

Nuclear Power Plant: A facility in which heat produced in a reactor by the fissioning of nuclear fuel is used to drive a steam turbine.

Off-Peak Gas: Gas that is to be delivered and taken on demand when demand is not at its peak.
Ohm: The unit of measurement of electrical resistance. The resistance of a circuit in which a potential difference of 1 volt produces a current of 1 ampere.

Operable Nuclear Unit: A nuclear unit is "operable" after it completes low-power testing and is granted authorization to operate at full power. This occurs when it receives its full power amendment to its operating license from the Nuclear Regulatory Commission.

Other Cost: A residual category to capture the Indirect Costs of DSM programs that cannot be meaningfully included in any of the other cost categories listed and defined herein. Included are costs such as those incurred in the research and development of DSM technologies.

Other DSM Programs: A residual category to capture the effects of DSM programs that cannot be meaningfully included in any of the prog $\mathrm{m}$ categories listed and defined herein. The energy effects attributable to this category should be the net effects of all the residual programs. Programs that promote consumer's substitution of electricity by other energy types should be included in Other DSM Programs. Also, selfgeneration should be included in Other DSM Programs to the extent that it is not accounted for as backup generation in Other Load Management or Interruptible Load categories.

Other Incentives: Energy Efficiency programs that offer cash or noncash awards to electric energy efficiency deliverers, such as appliance and equipment dealers, building contractors, and architectural and engineering firms, that encourage consumer participation in a DSM program and adoption of recommended measures.

Other Load Management: Refers to programs other than Direct Load Control and Interruptible Load that limit or shift peak load from on-peak to off-peak time periods. It includes technologies that primarily shift all or part of a load from one time-of-day to another and secondarily may have an impact on energy consumption. Examples include space heating and water heating storage systems, cool storage systems, and load limiting devices in energy management systems. This category also includes programs that aggressive promote time-of-use (TOU) rates and other innovative rates such as real time pricing. These rates are intended to reduce consumer bills and shift hours of operation 
of equipment from on-peak to off-peak periods through the application of time-differentiated rates.

Outage: The period during which a geterating unit, transmission line, or other facility is out of service.

Peak Demand: The maximum load during a specified period of time.

Peak Load Plant: A plant usually housing old, lowefficiency steam units; gas turbines; diesels; or pumpedstorage hydroelectric equipment normally used during the peak-load periods.

Peaking Capacity: Capacity of generating equipment normally reserved for operation during the hours of highest daily, weekly, or seasonal loads. Some generating equipment may be operated at certain times as peaking capacity and at other times to serve loads on an around-the-clock basis.

Percent Difference: The relative change in a quantity over a specified time period. It is calculated as follows: the current value has the previous value subtracted from it: this new number is divided by the absolute value of the previous value; then this new number is multiplied by 100

Petroleum: A nixture of hydrocarbons existing in the liquid state found in natural underground reservoirs, often associated with gas. Petroleum includes fuel oil No. 2, No. 4, No. 5, No. 6; topped crude; Kerosene; and jet fuel

Petroleum Coke: See Coke (Petroleum).

Petroleum (Crude Oil): A naturally occurring, oily, flammable liquid composed principally of hydrocarbons. Crude oil is occasionally found in springs or pools but usually is drilled from wells beneath the earth's surface.

Planned Generator: A proposal by a company to install electric generating equipment at an existing or planned facility or site. The proposal is based on the owner having obtained (1) all environmental and regulatory approvals, (2) a signed contract for the electric energy, or (3) financial closure for the facility.
Plant: A facility at which are located prime movers, electric generators, and auxiliary equipment for converting mechanical, chemical, and/or nuclear energy into electric energy. A plant may contain more than one type of prime mover. Electric utility plants exclude facilities that satisfy the definition of a qualifying facility under the Public Utility Regulatory Policies Act of 1978.

Plant Use: The electric energy used in the operation of a plant. Included in this definition is the energy required for pumping at pumped-storage plants.

Plant-Use Electricity: The electric energy used in the operation of a plant. This energy total is subtracted from the gross energy production of the plant; for reporting purposes the plant energy production is then reported as a net figure. The energy required for pumping at pumped-storage plants is, by definition, subtracted, and the energy production for these plants is then reported as a net figure.

Potential Peak Reduction: The potential annual peak load reduction (measured in kilowatts) that can be deployed from Direct Load Control, Interruptible Load, Other Load Management, and Other DSM Program activities. It represents the load that can be reduced either by the direct control of the utility system operator or by the cunsumer in response to a utility request to curtail load. It reflects the installed load reduction capability, as opposed to the Actual Peak Reduction achieved by participants, during the time of annual system peak load.

Power: The rate at which energy is transferred. Electrical energy is usually measured in watts. Also used for a measurernent of capacity.

Power Pool: An association of two or more interconnected electric systems having an agreement to coordinate operations and planning for improved reliability and efficiencies.

Price: The amount of money or consideration-in-kind for which a service is bought, sold, or offered for sale.

Prime Mover: The engine, turbine, water wheel, or similar machine that drives an electric generator; or, for reporting purposes, a device that converts energy to electricity directly (e.g., photovoltaic solar and fuel cell(s)). 
Process Heating: Energy Efficiency program promotion of increased electric energy efficiency applications in industrial process heating.

Profit: The income remaining after all business expenses are paid.

Public Authority Service to Public Authorities: Public authority service includes electricity supplied and services rendered to municipalities or divisions or agencies of State or Federal governments, under special contracts or agreements or service classifications applicable only to public authorities.

Public Street and Highway Lighting: Public street and highway lighting includes electricity supplied and services rendered for the purposes of lighting streets, highways, parks, and other public places; or for traffic or other signal system service, for municipalities, or other divisions or agencies of State or Federal governments.

Pumped-Storage Hydroelectric Plant: A plant that usually generates electric energy during peak-load periods by using water previously pumped into an elevated storage reservoir during off-peak periods when excess generating capacity is available to do so. When additional generating capacity is needed, the water can be released from the reservoir through a conduit to turbine generators located in a power plant at a lower level.

Purchased Power Adjustment: A clause in a rate schedule that provides for adjustments to the bill when energy from another electric system is acquired and it varies from a specified unit base amount.

Pure Pumped-Storage Hydroelectric Plant: A plant that produces power only from water that has previously been pumped to an upper reservoir

Qualifying Facility (QF): A cogeneration or small power production facility that meets certain ownership, onerating, and efficiency criteria established by the Federal Energy Regulatory Comimission (FERC) pursuant to the Public Utility Regulatory Policies Act (PURPA). (See the Code of Federal Regulations, Title 18, Part 292.) Part 292.
Railroad and Railway Services: Railroad and railway services include electricity supplied and services rendered to railroads and interurban and street railways, for general railroad use, including the propulsion of cars or locomotives, where such electricity is supplied under separate and distinct rate schedules.

Rate Base: The value of property upon which a utility is permitted to earn a specified rate of return as established by a regulatory authority. The rate base generally represents the value of property used by the utility in providing service and may be calculated by any one or a combination of the following accounting methods: fair value, prudent investment, reproduction cost, or original cost. Depending on which method is used, the rate base includes cash, working capital, materials and supplies, and deductions for accumulated provisions for depreciation, contributions in aid of construction, customer advances for construction, accumulated deferred income taxes, and accumulated deferred investment tax credits.

Ratemaking Authority: A utility commission's legal authority to fix, modify, approve, or disapprove rates, as determined by the powers given the commission by a State or Federal legislature.

Receipts: Purchases of fuel.

Regulation: The governmental function of controlling or directing economic entities through the process of rulemaking and adjudication.

Reserve Margin (Operating): The amount of unused available capability of an electric power system at peakload for a utility system as a percentage of total capability

Residential: The residential sector is defined as private household establishments which consume energy primarily for space heating, water heating, air conditioning, lighting, refrigeration. cooking and clothes drying. The classification of an individual consumer's account, where the use is both residential and commercial, is based on principal use. For the residential class, do not duplicate consumer accounts due to multiple metering for special services (water, heating, etc.). A partment houses are also included.

Residual Fuel Oil: The topped crude of refinery operation, includes No. 5 and No, 6 fuel oils as defined 
in ASTM Specification D396 and Federal Specification VV-F-815C; Navy Special fuel oil as defined in Military Specification MIL-F-859E including Amendment 2 (NATO Symbol F-77); and Bunker C fuel oil. Residual fuel oil is used for the production of electric power, space heating, vessel bunkering, and various industrial purposes. Imports of residual fuel oil include imported crude oil burned as fuel.

Restricted-Universe Census: This is the complete enumeration of data from a specifically defined subset of entities including, for example, those that exceed a given level of sales or generator nameplate capacity.

Retail: Sales covering electrical energy supplied for residential, commercial, and industrial end-use purposes. Other small classes, such as agriculture and street lighting, also are included in this category.

Revenue: The total amount of money received by a firm from sales of its products and/or services, gains from the sales or exchange of assets, interest and dividends earned on investments, and other increases in the owner's equity except those arising from capital adjustments.

Running and Quick-Start Capability: The net capability of generating units that carry load or have quickstart capability. In general, quick-start capability refers to generating units that can be available for load within a 30 -minute period.

Sales: The amount of kilowatthours sold in a given period of time; usually grouped by classts of service, such as residential, commercial, industrial, and other. Other sales include public street and highway lighting, other sales to public authorities and railways, and interdepartmental sales.

Sales for Resale: Energy supplied to other electric utilities, cooperatives, municipalities, and Federal and State electric agencies for resale to ultimate consumers.

Scheduled Outage: The shutdown of a generating unit, transmission line, or other facility, for inspection or maintenance, in accordance with an advance schedule.

Short Ton: A unit of weight equal to 2,000 pounds.
Small Power Producer (SPP): Under the Public Utility Regulatory Policies Act (PURPA), a small power production facility (or small power producer) generates electricity using waste, renewable (water, wind and solar), or geothermal energy as a primary energy source. Fossil fuels can be used, but renewable resource must provide at least 75 percent of the total energy input. (See Code of Federal Regulations, Title 18, Part 292.)

Spinning Reserve: That reserve generating capacity running at a zero load and synchronized to the electric system.

Spot Purchases: A single shipment of fuel or volumes of fuel, purchased for delivery within 1 year. Spot purchases are often made by a user to fulfill a certain portion of energy requirements, to meet unanticipated energy needs, or to take advantage of low-fuel prices.

Stability: The property of a system or element by virtue of which its output will ultimately attain a steady state. The amount of power that can be transferred from one machine to another following a disturbance. The stability of a power system is its ability to develop restoring forces equal to or greater than the disturbing forces so as to maintain a state of equilibrium.

Standard Industrial Classification (SIC): A set of codes developed by the Office of Management and Budget, which categorizes business into groups with similar economic activities.

Standby Facility: A facility that supports a utility system and is generally running under no-load. It is available to replace or supplement a facility normally in service.

Standby Service: Support service that is available, as needed, to supplement a consumer, a utility system, or to another utility if a schedule or an agreement authorizes the transaction. The service is not regularly used.

Steam-Electric Plant (Conventional): A plant in which the prime mover is a steam turbine. The steam used to drive the turbine is produced in a boiler where fossil fuels are burned. 
Stocks: A supply of fuel accumulated for future use. This includes coal and fuel oil stocks at the plant site, in coal cars, tanks, or barges at the plant site, or at separate storage sites.

Subbituminous Coal: Subbituminous coal, or black lignite, is dull black and generally contains 20 to 30 percent moisture. The heat content of subbituminous coal ranges from 16 to 24 million Btu per ton as received and averages about 18 million Btu per ton. Subbituminous coal, mined in the western coal fields, is used for generating electricity and space heating.

Substation: Facility equipment that switches, changes, or regulates electric voltage.

Sulfur: One of the elements present in varying quantities in coal which contributes to environmental degradation when coal is burned. In terms of sulfur content by weight, coal is generally classified as low (less than or equal to 1 percent), medium (greater than 1 percent and less than or equal to 3 percent), and high (greater than 3 percent). Sulfur content is measured as a percent by weight of coal on an "as received" or a "dry" (moisture-free, usually part of a laboratory analysis) basis.

Switching Station: Facility equipment used to tie together two or more electric circuits through switches. The switches are selectively arranged to permit a circuit to be disconnected, or to change the electric connection between the circuits.

System (Electric): Physically connected generation, transmission, and distribution facilities operated as an integrated unit under one central management, or operating supervision.

Total DSM Cost: Refers to the sum of total utility cost and nonutility cost.

Total DSM Programs: Refers to the total net effects of all the utility's DSM programs. For the purpose of this survey, it is the sum of the effects for Energy Efficiency, Direct Load Control, Interruptible Load, Other Load Management, Other DSM Programs, and Load Building. Net growth in energy or load effects shr !ld be reported as a negative number, shown with a . unus sign
Total Nonutility Cost: Refers to total cash expenditures incurred by consumers and trade allies that are associated with participation in a DSM program, but that are not reimbursed by the utility. The nonutility expenditures should include only those additional costs necessary to purchase or install an efficient measure relative to a less efficient one. Costs are to be reported in nominal dollars in the year in which they areincurred, regardless of when the actual effects occur. To the extent possible, provide the best estimate of nonutility costs if actual costs are unavailable.

Total Utility Cost: Refers to the sum of the total Direct and Indirect Utility Costs for the year. Utility costs should reflect the total cash expenditures for the year, reported in nominal dollars, that flowed out to support DSM programs. They should be reported in the year they are incurred, regardless of when the actual effects occur.

Transformer: An electrical device for changing the voltage of alternating current.

Transmission: The movement or transfer of electric energy over an interconnected group of lines and associated equipment between points of supply and points at which it is transformed for delivery to consumers, or is delivered to other electric systems. Transmission is considered to end when the energy is transformed for distribution to the consumer.

Transmission System (Electric): An interconnected group of electric transmission lines and associated equipment for moving or transferring electric energy in bulk between points of supply and points at which it is transformed for delivery over the distribution system lines to consumers, or is delivered to other electric systems.

Turbine: A machine for generating rotary mechanical power from the energy of a stream of fluid (such as water, steam, or hot gas). Turbines convert the kinetic energy of fluids to mechanical energy through the principles of impulse and reaction, or a mixture of the two.

Uniform System of Accounts: Prescribed financial rules and regulations established by the Federal Energy Regulatory Commission for utilities subject to its jurisdiction under the authority granted by the Federal Power Act. 
Useful Thermal Output: The thermal energy made available for use in any industrial or commercial process, or used in any heating or cooling application, i.e., total thermal energy made available for processes and applications other than electrical generation.

Utility-Earned Incentives: Costs in the form of incentives paid to the utility for achievement in consumer participation in DSM programs. These financial incentives are intended to influence the utility's consideration of DSM as a resource option by addressing cost recovery, lost revenue, and profitability.

Voltage Reduction: Any intentional reduction of system voltage by 3 percent or greater for reasons of maintaining the continuity of service of the bulk electric power supply system.

Water Heating: Energy Efficiency program promotion to increase efficiency in water heating, including low-flow shower heads and water heater insulation wraps. Could be applicable to residential, commercial, or industrial consumer sectors.

Watt: The electrical unit of power. The rate of energy transfer equivalent to 1 ampere flowing under a pressure of 1 volt at unity power factor.

Watthour (Wh): An electrical energy unit of measure equal to 1 watt of power supplied to, or taken from, an electric circuit steadily for 1 hour.

Wheeling Service: The movement of electricity from one system to another over transmission facilities of intervening systems. Wheeling service contracts can be established between two or more systems.

Wholesale Sales: Energy supplied to other electric utilities, cooperatives, municipals, and Federal and State electric agencies for resale to ultimate consumers. 

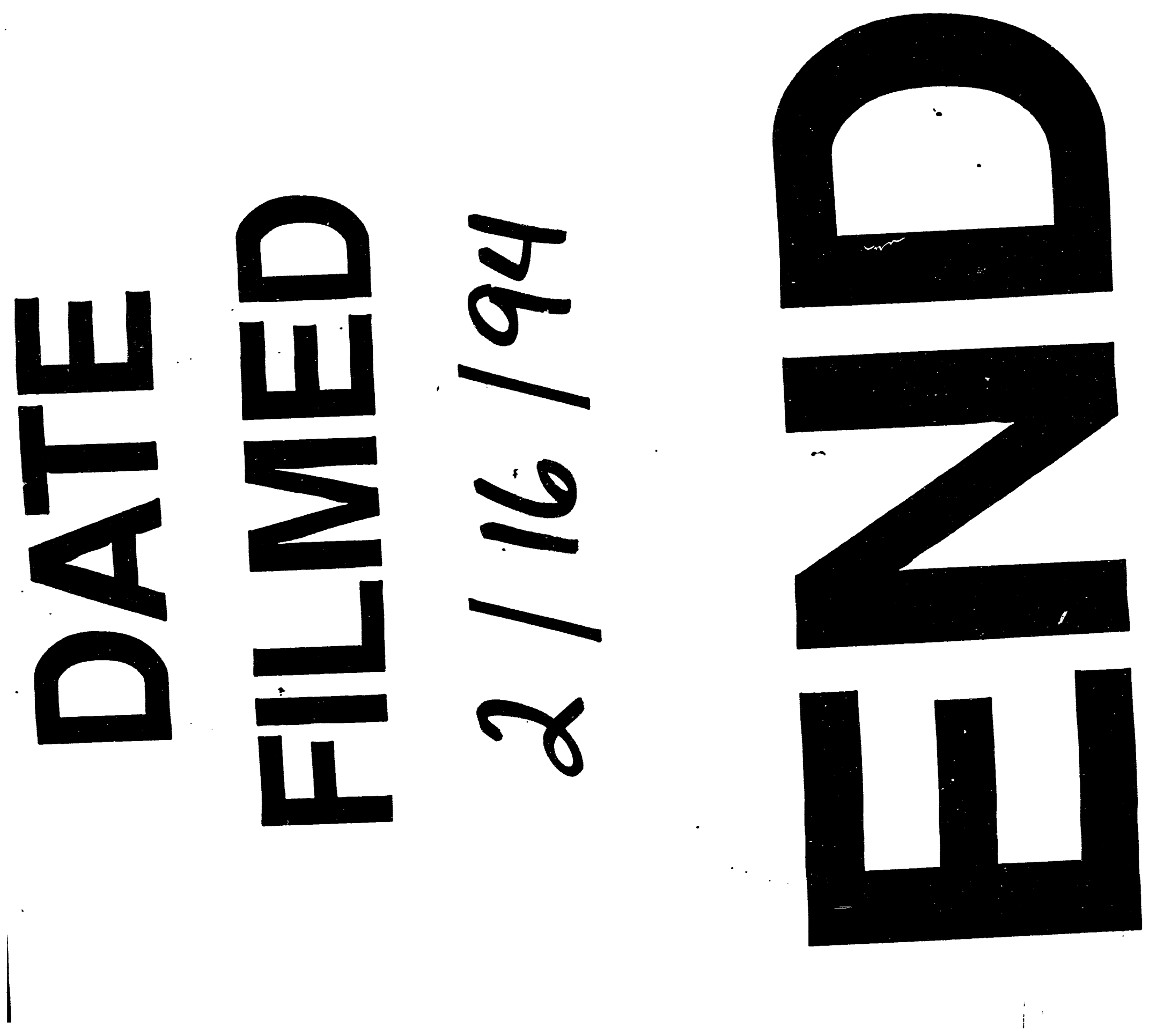
